\section{RUSSIAN JOURNAL OF AGRICULTURAL AND SOCIO- ECONOMIC SCIENCES}

ISSN 2226-1184

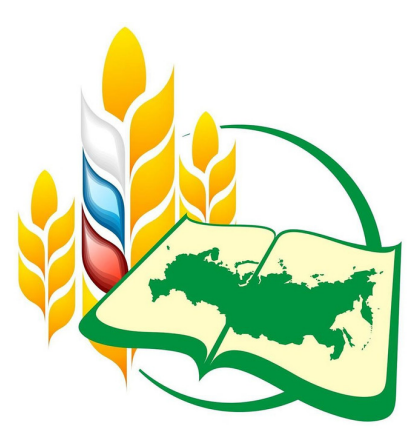

\title{
September 2017
}

"RJOAS is an interdisciplinary open accessjournal of agriculture and socioeconomic studies. The journal aims at establishing a bridge between theory and practice in the fields of agriculture and socio-economic research..." 
OPEN

ACCESS 


\section{TABLE OF CONTENT}

Korneyko O.V., Lyu I.

- COMPARATIVE ANALYSIS OF FREE ECONOMIC ZONES IN THE UNITED STATES OF AMERICA, CHINA AND RUSSIAN FEDERATION IN THE XXI CENTURY; pp. 5-16

- Crossref DOI: 10.18551/rjoas.2017-09.01

\section{Polukhin A.A.}

- ECONOMIC ANALYSIS OF THE TECHNICAL EQUIPMENT OF AGRICULTURE, THE CURRENT MECHANISMS FOR REGULATING THE AGRICULTURAL MACHINERY MARKET IN CANADA AND ASSESSING THE POSSIBILITY OF THEIR APPLICATION IN RUSSIA UNDER CONDITIONS OF IMPORT SUBSTITUTION; pp. 17-22

- Crossref DOI: 10.18551/rjoas.2017-09.02

Muliati, Pattawe A., Mile Y., Lucyani

- CORPORATE GOVERNANCE AND ENVIRONMENTAL PERFORMANCE IN THE CONTEXT OF ASEAN ECONOMIC COMMUNITY; pp. 23-33

- Crossref DOI: 10.18551/rjoas.2017-09.03

Astakhova E., Watson R.

- CURRENT TRENDS OF WORLD TRADE BY AGRICULTURAL PRODUCTS; pp. $34-40$

- $\quad$ Crossref DOI: 10.18551/rjoas.2017-09.04

Ignatova T.V., Polyanin A.V.

- MANAGEMENT OF THE DEVELOPMENT OF AGRO-INDUSTRIAL COMPLEX'S INNOVATIVE POTENTIAL IN THE CONTEXT OF IMPORT SUBSTITUTION POLICY; pp. 41-46

- Crossref DOI: 10.18551/rjoas.2017-09.05

Arisena G.M.K., Dewi N.L.P.K.

- THE STUDY OF AGRIBUSINESS WETLAND RICE FARMING SYSTEM IN AN ATTEMPT TO SYNERGIZE SUBAK WITH ECOTOURISM: A CASE IN SUBAK SEMBUNG, BALI PROVINCE OF INDONESIA; pp. 47-53

- Crossref DOI: 10.18551/rjoas.2017-09.06

Akpaeti A.J., Udo U.J., Bassey N.E.

- PROPER FUNDING AND MARKETING OF GREEN ECONOMY: A WAY OUT OF NIGERIA'S AGRICULTURAL WOES; pp. 54-62

- Crossref DOI: 10.18551/rjoas.2017-09.07

Hardanto H., Ismail M., Khusaini M.

- ANALYSIS OF THE EFFECTS OF ECONOMIC GROWTH, INVESTMENT, REGIONAL TAXES, AND CAPITAL EXPENDITURE TOWARD THE INCOME DISPARITY IN INDONESIA (2007-2013); pp. 63-70

- Crossref DOI: 10.18551/rjoas.2017-09.08

Yulianto $E$.

- ANALYSIS OF DISTRIBUTION CHALLENGES ON FOREIGN TOURIST IN INDONESIA: A STUDY ON DKI JAKARTA; pp. 71-76

- Crossref DOI: 10.18551/rjoas.2017-09.09

Adriani D., Wildayana E., Yulius, Alamsyah I., Hakim M.M.

- TECHNOLOGICAL INNOVATION AND BUSINESS DIVERSIFICATION: SUSTAINABILITY LIVELIHOODS IMPROVEMENT SCENARIO OF RICE FARMER HOUSEHOLD IN SUB-OPTIMAL LAND; pp. 77-88

- Crossref DOI: 10.18551/rjoas.2017-09.10 
Dyani D.A.M., Nuralam I.P.

- EVALUATION OF THE GOVERNANCE OF EXTERNAL SUPERVISORY INSTITUTIONS TOWARDS SOCIAL SECURITY AGENCY (BADAN PENYELENGGARA JAMINAN SOSIAL/BPJS) FOR HEALTHCARE; pp. 89-98

- Crossref DOI: 10.18551/rjoas.2017-09.11

Sabetova T.V., Zakharova N.A.

- STATE SUPPORT FOR INVESTMENT IN AGRICULTURE OF THE VORONEZH REGION; pp. 99-108

- Crossref DOI: 10.18551/rjoas.2017-09.12

\section{Zhurkina T.A.}

- OPERATIONAL COST ANALYSIS AND ITS USE IN AGRICULTURAL ENTERPRISES; pp. 109-113

- Crossref DOI: 10.18551/rjoas.2017-09.13

Kulikov S.

- POLITICAL AND ECONOMICAL SOCIALIZATION: MEANING AND RELEVANCE; pp. 114-117

- Crossref DOI: 10.18551/rjoas.2017-09.14

Nuralam I.P.

- ISLAMIC MARKETER ETHICS AND ITS IMPACT ON CUSTOMER SATISFACTION IN THE ISLAMIC BANKING INSTITUTION: A CASE STUDY OF BANK MUAMALAT INDONESIA; pp. 118-125

- Crossref DOI: 10.18551/rjoas.2017-09.15

Kuswantoro, Hidayat S., Santosa A.A.

- INVESTMENT FEASIBILITY ANALYSIS OF MAPPING SURVEY LABORATORY ESTABLISHMENT IN SAMARINDA CITY; pp. 126-133

- Crossref DOI: 10.18551/rjoas.2017-09.16

Komissarova V.V.

- LEASING AS EFFECTIVE INTERACTION MECHANISMS BETWEEN GOVERNMENT AND PRIVATE BUSINESS IN THE FIELD OF ROAD INFRASTRUCTURE IN RUSSIA; pp. 134-139

- Crossref DOI: 10.18551/rjoas.2017-09.17

Rio W.Y., Putranto E.H.D., Mulyadi L.

- MANAGEMENT OF ACCELERATION TIME BY USING TIME COST TRADE OFF METHOD ON CONSTRUCTION PROJECT OF INTEGRATED OFFICE OF SAMARINDA; pp. 140-146

- Crossref DOI: 10.18551/rjoas.2017-09.18

Rizaldi M.Y., Hidayat S., Santosa A.A.

- TIME AND COST EFFICIENCY ANALYSIS WITH FAST TRACK METHOD ON SAMARINDA-ANGGANA ROAD IMPROVEMENT PROJECT; pp. 147-154

- Crossref DOI: 10.18551/rjoas.2017-09.19

Syahrizal M., Hidayat S., Santosa A.

- COST, TIME, AND QUALITY ANALYSIS OF PRECAST CONCRETE CONSTRUCTION AND IN SITU CONCRETE AT MACRO CHANNEL IN CONTROL OF RUN-OFF: A CASE STUDY OF REGIONAL HARUN NAFSI STREET IN SAMARINDA; pp. 155-163

- Crossref DOI: 10.18551/rjoas.2017-09.20

Hadjaat M., Za S.Z., Wahyuni S.

- CAPABILITY ASSESSMENT OF SMALL AND MEDIUM ENTERPRISES IN KALIMANTAN TIMUR; pp. 164-176

- $\quad$ Crossref DOI: 10.18551/rjoas.2017-09.21 
Grafov A.V., Milovanov E.A., Nemirov V.N., Vinogradova E.A.

- MODERNIZATION ROLE OF WAGES IN ENTREPRENEURIAL ACTIVITY; pp. 177-181

- Crossref DOI: 10.18551/rjoas.2017-09.22

Herijanto P., Fiernaningsih N., Widjanarko

- PROFILE OF PLASTIC WATER BOTTLES WASTES PROCESSING BUSINESS UNIT FOR WASTE PICKERS; pp. 182-190

- Crossref DOI: 10.18551/rjoas.2017-09.23

Tallesang M., Rossanty N.P.E., Darman

- THE ROLE OF FINANCIAL LITERACY IN CREATIVE INDUSTRY GROWTH: WOMEN ENTREPRENEUR STUDY OF DONGGALA WOVEN FABRIC INDUSTRY; pp. 191-195

- Crossref DOI: 10.18551/rjoas.2017-09.24

Krasova E.V.

- PROBLEMS OF FORMATION OF LABOR POTENTIAL IN RUSSIAN SMALL TOWNS AND RURAL SETTLEMENTS: A STUDY ON THE EXAMPLE OF THE PRIMORSKY REGION, RUSSIA; pp. 196-200

- Crossref DOI: 10.18551/rjoas.2017-09.25

Mawardi R.

- EMPIRICAL ANALYSIS OF COMPANY SIZE, CORPORATE GOVERNANCE AND AUDIT QUALITY TO EARNING MANAGEMENT IN INDONESIA; pp. 201-214

- Crossref DOI: 10.18551/rjoas.2017-09.26

Iqbal M., Putra I.K., Arifin Z.

- OPENING UP FAMILY SUCCESSION AND BUSINESS CONTINUITY IN INDONESIA: THE CASE OF LOMBOK POST, INDONESIA; pp. 215-223

- Crossref DOI: 10.18551/rjoas.2017-09.27

Kuzubov A.A.

- DEVELOPMENT OF THE ORGANIZATIONAL AND ECONOMIC MECHANISM FOR THE REPRODUCTION OF PRODUCTIVE AND RESOURCE POTENTIAL OF THE AGRO-INDUSTRIAL COMPLEX'S ENTERPRISES; pp. 224-230

- Crossref DOI: 10.18551/rjoas.2017-09.28

Agustina F., Zahri I., Yazid M., Yunita

- DETERMINANT FACTORS OF AGRICULTURAL EXTENSION COMPETENCE IN THE IMPLEMENTATION OF GOOD AGRICULTURAL PRACTICES IN BANGKA, BELITUNG PROVINCE; pp. 231-238

- Crossref DOI: 10.18551/rjoas.2017-09.29

Shashlo N.V.

- EFFICIENCY VALUE THEORY AS A DIAGNOSTIC TOOL OF THE ECONOMIC STABILITY OF THE AGRO-INDUSTRIAL COMPLEX'S ENTERPRISES; pp. 239-246

- Crossref DOI: 10.18551/rjoas.2017-09.30

Loza A.A.

- EVALUATION OF THE EFFECTIVENESS OF NEW FOOD PRODUCTS TAKING INTO ACCOUNT THE USE OF INNOVATIONS; pp. 247-252

- Crossref DOI: 10.18551/rjoas.2017-09.31

Wati R.Y.E., Anindita R., Setiawan B.

- RICE PRICE VOLATILITY IN EAST JAVA; pp. 253-261

- Crossref DOI: 10.18551/rjoas.2017-09.32 


\section{Sudaryono T.}

- ASSESSMENT OF SEVERAL AMPHIBIAN RICE VARIETIES IN THE CENTER OF RICE PRODUCTION IN LAMONGAN REGENCY OF EAST JAVA PROVINCE; pp. 262-265

- Crossref DOI: 10.18551/rjoas.2017-09.33

Susilawati, Ammar M., Priadi D.P., Robiartini L., Irmawati, Fitra J.

- THE CORRELATION OF VEGETATIVE AND GENERATIVE CHARACTERS OF DUKU (LANSIUM DOMESTICUM CORR.) ACCESSION IN BANYUASIN REGENCY OF SOUTH SUMATRA; pp. 266-275

- Crossref DOI: 10.18551/rjoas.2017-09.34

Yani A.A., Hasbi, Priyanto G., Pambayun R., Wijaya A.

- CONTAMINATION OF COLIFORM, ESCHERICHIA COLI, AND LEAD IN VEGETABLES SOLD AT TRADITIONAL MARKET IN PALEMBANG CITY PROVINCE OF SOUTH SUMATRA; pp. 276-281

- Crossref DOI: 10.18551/rjoas.2017-09.35

Burlakov S.V., Kapustin A.V., Laishevtcev A.I.

- PECULIARITIES OF THE USE OF A PURULENT ERYTHROCYTE ANTIGEN: SPECIFICITY OF THE REACTION; pp. 282-287

- Crossref DOI: 10.18551/rjoas.2017-09.36

Dyatlova N.A., Salnikova N.B.

- EVALUATION OF THE SOYBEAN COLLECTION OF THE ALL RUSSIAN INSTITUTE OF CROP PLANTING NAMED AFTER N.I. VAVILOV IN CONDITIONS OF THE TULA REGION; pp. 288-293

- Crossref DOI: 10.18551/rjoas.2017-09.37

Prokhorov I.P., Pikul A.N.

- CHARACTERISTICS OF GROWTH AND DEVELOPMENT OF CALVES' CARCASSE MUSCLES OF BLACK-MOTLEY BREED AND ITS HYBRIDS WITH ABERDEENANGUS AND CHAROLAIS; pp. 294-301

- Crossref DOI: 10.18551/rjoas.2017-09.38

Vasilevich F.I., Bachinskaya V.M., Deltsov A.A.

- EFFECTIVENESS OF APPLICATION AND INFLUENCE OF PROTEIN HYDROLYSATE ON QUALITY OF THE RABBITS PRODUCTION; pp. 302-308

- Crossref DOI: 10.18551/rjoas.2017-09.39

Miru S., Suparman

- QUALITY LOSS ANALYSIS OF CAPTURE FISHERIES IN THE GULF OF TOMINI REGION, INDONESIA; pp. 309-314

- Crossref DOI: 10.18551/rjoas.2017-09.40

Widyasari F., Arafat G., Robiandi, Setiadi D., Rahmat S., Latulanit M.N., Fahlevi A.R., Arisandy K.R., Sayuti M.

- DISTRIBUTION, DENSITY AND IDENTIFICATION OF GIANT CLAMS IN COASTAL AREA OF NEGERI MORELLA (THE DISTRICT OF LEIHITU, CENTRAL MALUKU REGENCY, INDONESIA); pp. 315-322

- Crossref DOI: 10.18551/rjoas.2017-09.41 
DOI https://doi.org/10.18551/rjoas.2017-09.01

\title{
СРАВНИТЕЛЬНЫЙ АНАЛИЗ СВОБОДНЫХ ЭКОНОМИЧЕСКИХ ЗОН В США, КИТАЕ И РОССИИ В XXI ВЕКЕ \\ COMPARATIVE ANALYSIS OF FREE ECONOMIC ZONES IN THE UNITED STATES OF AMERICA, CHINA AND RUSSIAN FEDERATION IN THE XXI CENTURY
}

\author{
Корнейко О.В., кандидат экономических наук \\ Korneyko O.V., Candidate of Economic Sciences \\ Лю Ин, магистрант \\ Lyu In, Graduate student \\ Владивостокский государственный университет экономики и сервиса, \\ Владивосток, Россия \\ Vladivostok State University of Economics and Service, Vladivostok, Russia \\ E-mail: olga30300@mail.ru, 1392144194@qq.com
}

\begin{abstract}
АННОТАЦИЯ
Целью данной работы является проведение сравнительного анализа функционирования свободных экономических зон (СЭЗ) в российской, американской и китайской экономиках для выявления опыта, который Россия может перенять у США и Китая для оптимизации работы российских зон. Проведен комплексный сравнительный анализ функционирования СЭЗ в США, Китае и России. Дана сравнительная характеристика СЭЗ и кластеров, как особых экономических систем взаимосвязей фрирм, организаций и отраслей. На примере Китая представлен механизм взаимодействия СЭЗ и кластеров для формирования конкурентоспособности региона. Проанализированы возможности применимости американского и китайского опытов СЭЗ к российским условиям. Сформированы рекомендации по усовершенствованию функционирования СЭЗ в России. Теоретическая значимость результатов исследования заключается в представлении современного состояния свободных экономических зон в США, Китае и России и перспектив развития СЭЗ в России с учетом иностранного опыта.
\end{abstract}

\section{ABSTRACT}

The purpose of this paper is to conduct a comparative analysis of the functioning of free economic zones (FEZ) in the Russian, American and Chinese economies to identify the experience that Russia can adopt from the US and China to optimize the operation of Russian zones. A complex comparative analysis of the operation of FEZ in the United States, China and Russia has been carried out. Comparative characteristics of FEZ and clusters as special economic systems of interrelations of firms, organizations and industries are given. On the example of China, the mechanism of interaction between FEs and clusters is presented to form the region's competitiveness. The possibilities of applicability of American and Chinese FEZ experiments to Russian conditions are analyzed. The recommendations on improving the functioning of FEZ in Russia have been formulated. The theoretical significance of the research results lies in presenting the current state of free economic zones in the US, China and Russia and the prospects for the development of FEZ in Russia, taking into account foreign experience.

\section{КЛЮЧЕВЫЕ СЛОВА}

США, Китай, Россия, свободные экономические зоны, инструмент государственной политики, драйвер экономики, сравнительный анализ.

KEY WORDS

USA, China, Russia, free economic zones, state policy, economy, comparative analysis. 
В условиях глобализации рынков и растущей конкуренции правительства ведущих стран мира вынуждены использовать сложные организационноэкономические инструменты для поддержания экономики страны на хорошем уровне. Одним из таких инструментов является создание свободных экономических зон (СЭЗ), где присутствуют благоприятные условия для ведения бизнеса. За последние десятилетия можно было наблюдать процесс активизации использования механизма свободных экономических зон для развития экономики той или иной страны. Если в 1995 году в мире насчитывалось примерно 500 зон, то в настоящее время в более чем 130 странах действуют более 4300 зон, на которых занято более 68 тыс. рабочих. К тому же, мировая практика показала, что эффективная организация деятельности СЭЗ способна дать не только толчок в развитии экономики страны, но и вывести ее в мировые лидеры [1].

В данном аспекте особый интерес представляет опыт США и Китая, на территории которых функционирует наибольшее количество зон и аккумулируется передовой опыт их создания и организации. США первыми внедрили подобную практику для повышения конкурентоспособности национальной промышленности на мировом рынке. Правительство Китая, в свою очередь, вывело страну в мировые лидеры, освоив политику создания СЭЗ применительно к своей конкретной ситуации.

В последние два десятилетия в России происходит серьезное освоение территории и внедрение практики использования СЭЗ. Учитывая количество неудачных примеров их создания, цели которых не были достигнуты, целесообразно обратиться к мировому опыту, чтобы извлечь уроки, полезные для организации СЭЗ в России. Безусловно, необходимо учитывать специфику американской и китайской экономики, понимать различия.

Кроме того, в России необходимо серьёзное инфраструктурное обновление, способное дать предприятиям, созданным на территории страны, возможность конкурировать с иностранными фрирмами. В этом контексте портовые СЭЗ являются той составляющей, которая позволяет аккумулировать передовой мировой опыт и современные технологии для привлечения инвестиций и как следствие развития экономики страны. В частности, активизация использования такого института развития, как Свободный порт Владивосток, является инструментом повышения инвестиционной активности в регионе на основе улучшения состояния делового климата.

\section{ОБЗОР ЛИТЕРАТУРЫ}

На сегодняшний день существует целый ряд исследований, посвященных различным аспектам сущности и содержания СЭЗ, а также проблемам формирования, фрункционирования и развития свободных экономических зон. Эти направления нашли отражение в работах Бобровой В.В., Ковалевой Г.Д., Кравчук В. И., Перчинской Н.П., Русакович В.И., Шкваря Л.В., Шумского Н. [2-4].

Вопросы развития экономики Приморского края в целом и перспектив Свободного порта Владивосток в частности исследовались в работах Волкова Л.В., Ворожбит О.Ю., Даниловских Т. Е., Жук А. П., Коломейцевой Н. А., Корнейко О.В., Кузьмичевой И. А., Латкина А.П., Наливайко П. Н., Салтыкова М. А. [5].

Среди зарубежных ученых, исследующих деятельность свободных экономических зон, можно выделить, в частности Akinci G., Barbieri E., Bonnini S., Tiefenbrun S., Farole T., Kee G., Lee J., Marco R., Moberg L., Neveling P., Ota T., Rubini L., Sklair L., Xu C., Yeung Y., Zeng D. [6-13].

Однако, несмотря на многочисленность работ, посвященных данной проблематике, вопросы формирования, функционирования и развития территориально-организованных образований в виде свободных экономических зон в силу их многогранности и сложности следует признать недостаточно разработанными и остро дискуссионными. 


\section{ОБСУЖДЕНИЕ РЕЗУЛЬТАТОВ}

Свободные экономические зоны, как механизм свободной торговли, зародились после второй мировой войны. Политику внедрения зон инициировали США, создав первую экспортно-производственную зону (ЭПЗ) в Пуэрто-Рико в 1947 г. ЭПЗ представляют собой разновидность СЭЗ, где создаются налоговые и финансовые стимулы для зарубежных экспортно-ориентированных производств в целях расширения их сбыта на внешнем рынке. Соответственно они носят анклавный характер и мало связаны с национальной экономикой страны и региона.

Пуэрто-риканская схема получила глобальное распространение. Подобные зоны способствовали перемещению промышленного производства из одного района в другой. Перемещение было необходимо для ограничения положения рабочих на рынке труда в запущенных капиталистических районах, оно представляло собой инструмент получения контроля над странами третьего мира.

Несмотря на неоднозначный опыт появившихся после Второй мировой войны зон, в настоящее время практика создания СЭЗ представляет большой интерес во всем мире, т.к. механизм их действия постоянно развивается, они принимают все новые формы, преследуют новые цели в зависимости от уровня экономического развития страны-учредителя, научно-технического и экспортного потенциала того или иного региона, состояния отдельных отраслей, инфраструктуры, географических особенностей и других фракторов.

В силу вышесказанного существует множество формулировок СЭЗ в экономической литературе. В данной работе, говоря о СЭЗ, мы будем подразумевать ограниченные территории, находящиеся в пределах национальных границ той или иной страны, где правила бизнеса отличаются от тех, что преобладают на территории государства.

Стремительный экономический рост Китая в течение последних трех десятилетий является беспрецедентным «экономическим чудом» В истории человечества. СЭЗ и промышленные кластеры, возникшие как часть экономических реформ Китая, начавшихся в 1978 году, несомненно, являются двумя важными драйверами роста страны [14].

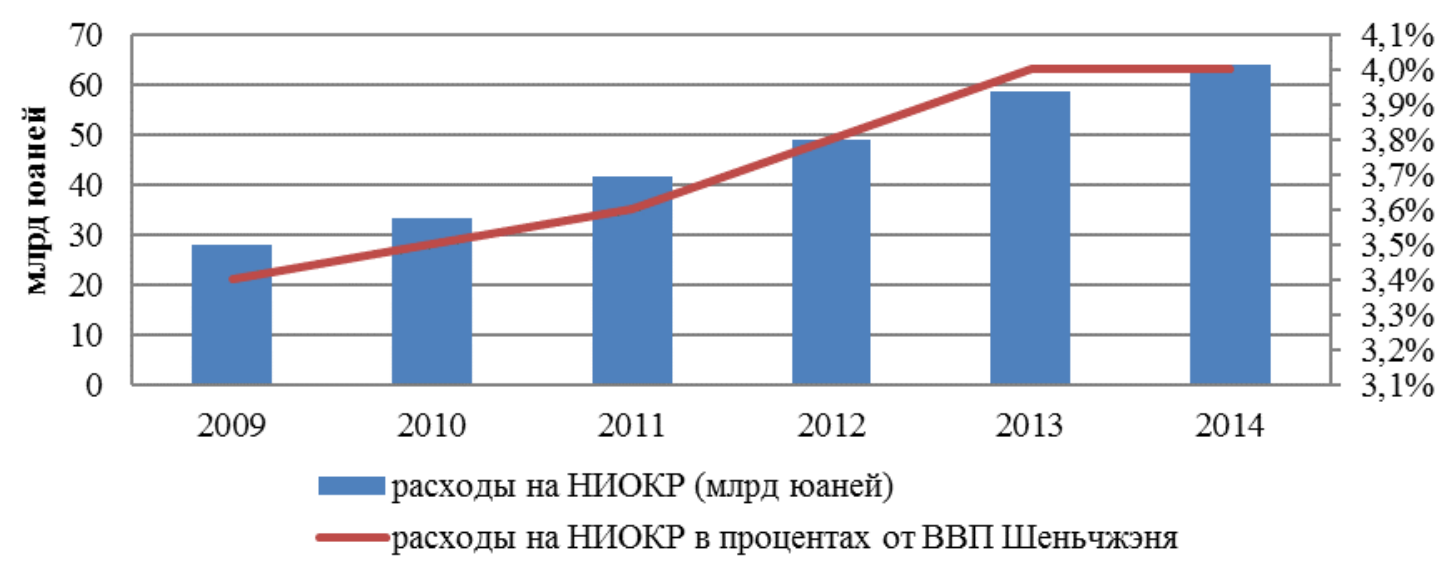

Рисунок 1 - Расходы на НИОКР в Шеньчжэне [15]

Опыт создания первой СЭЗ Китая - Шэньчжэнь - был настолько успешным, что он заслуживает особого внимания. В 1979 (всего за год до трансформации в СЭЗ) Шэньчжэнь представлял собой сельскохозяйственную деревню, с незначительным вкладом в ВВП Китая (менее 1\%) и ВВП на душу населения менее 90 долларов в год. Население составляло всего 20000 человек с низким уровнем образования и низким уровнем жизни. Производственный сектор практически отсутствовал. Единственным преимуществом области являлось расположение рядом с Гонконгом, Макао и 
Тайванем. С течением времени Шэньчжэнь продемонстрировал себя одним из наиболее быстро растущих городов в Китае, с годовым темпом роста 15\% в 2008 году. Спустя тридцать лет после основания СЭЗ, в 2010 году, журнал Форбс включил Шэньчжэнь в пятерку самых населенных городов мира.

Шэньчжэнь в настоящее время занимает второе место после Гуанчжоу по ВВП на душу населения: в 2014 г. он составил 149495 юаней. В Шэньчжэне наблюдается огромная концентрация деятельности в высокотехнологичных секторах. В 2014 году расходы на НИОКР в Шэньчжэне составили 64 млрд юаней, а это 4\% от его валового регионального продукта (рисунок 1).

Однако, ускоренный рост создал и ряд проблем, с которыми в настоящее время сталкиваются власти Китая. Среди них заторы, трафик, загрязнение окружающей среды, трудности с предоставлением услуг для всех на густонаселенной территории, и т.д.

В США в качестве объекта сравнения выступают зоны внешней торговли (ЗВТ). Они появились в США в 30-е годы XX века с целью повышения конкурентоспособности национальной промышленности на мировом рынке, и попутно снижения уровня безработицы и улучшения социально-экономического положения в стране после Великой Депрессии. Такие зоны являются торговыми или торгово-производственными, которые, оставаясь частью национальной территории, с точки зрения таможенного, бюджетно-налогового и финансового режимов рассматриваются как находящиеся за пределами государства.

География размещения зон внешней торговли свидетельствует о том, что наибольшая концентрация ЗВТ отмечается либо в штатах, имеющих выход к морю или океану (Техас - 32 зон, Нью-Йорк - 16, Флорида - 21, Калифорния - 17 зон), либо в штатах, не имеющих выхода к водным артериям, но располагающих крупными промышленными комплексами (Огайо - 9 зон, Индиана - 6, Иллинойс - 8, Аризона и Мичиган - по 7 зон).

Согласно существующему законодательству, зоны внешней торговли, действующие на территории США, подразделяются на зоны общего назначения и специализированные зоны (субзоны).

Сорера деятельности зон общего назначения охватывает складирование, сортировку, упаковку товаров без их дополнительной обработки. Важным условием создания этих зон является внесение ими вклада в хозяйственное развитие штата, в повышение уровня занятости, расширение торговли.

Специализированные зоны (субзоны) организуются В интересах крупных компаний, деятельность которых выходит за рамки зон общего назначения, и ориентированы только на одного пользователя. Такие зоны создаются решением руководства зон общего назначения для организации той или иной частной компанией сборочных заводов или различных промышленных производств. Статус субзоны является вторичным по отношению к статусу зоны общего назначения и, как правило, предоставляется уже существующим производствам. Субзоны технически являются частью зон общего назначения, но территориально могут быть значительно удалены от последних. Создание субзон преследует цели развития экспортного потенциала, налаживания импортозамещающих производств.

Впервые специализированные зоны возникли в 1952 г. после внесения в Закон 1934 года дополнения, разрешающего создавать в общих ЗВТ промышленные производства, и вначале стали временными площадками для проведения торговых ярмарок. В середине 80-х годов в субзонах было разрешено создавать предприятия по сборке различных узлов и блоков компьютеров, электронно-вычислительной техники, телефонных аппаратов, холодильных установок и автомобилей. Именно льготы, получаемые автомобильными компаниями в этой сфере бизнеса, способствовали дальнейшему росту числа специализированных зон.

Точкой отсчета существования особых экономических зон в нашей стране стоит считать 2005 г., то есть момент, когда был принят Федеральный закон от 22.07.2005 № 116-Ф3 «Об особых экономических зонах в Российской Федерации». На территории РФ 
официально функционирует 4 типа зон: технико-внедренческие (ОЭЗ ТВТ), промышленно-производственные (ОЭЗ ППТ), туристско-рекреационные (ОЭЗ ТРТ) и портовые (ПОЭЗ). По состоянию на 1 января 2017 года в Российской Федерации функционирует 26 особых экономических зон. из них 10 промышленнопроизводственного типа, 6 технико-внедренческого типа, 9 туристско-рекреационного типа и 1 портового типа (рисунок 2).

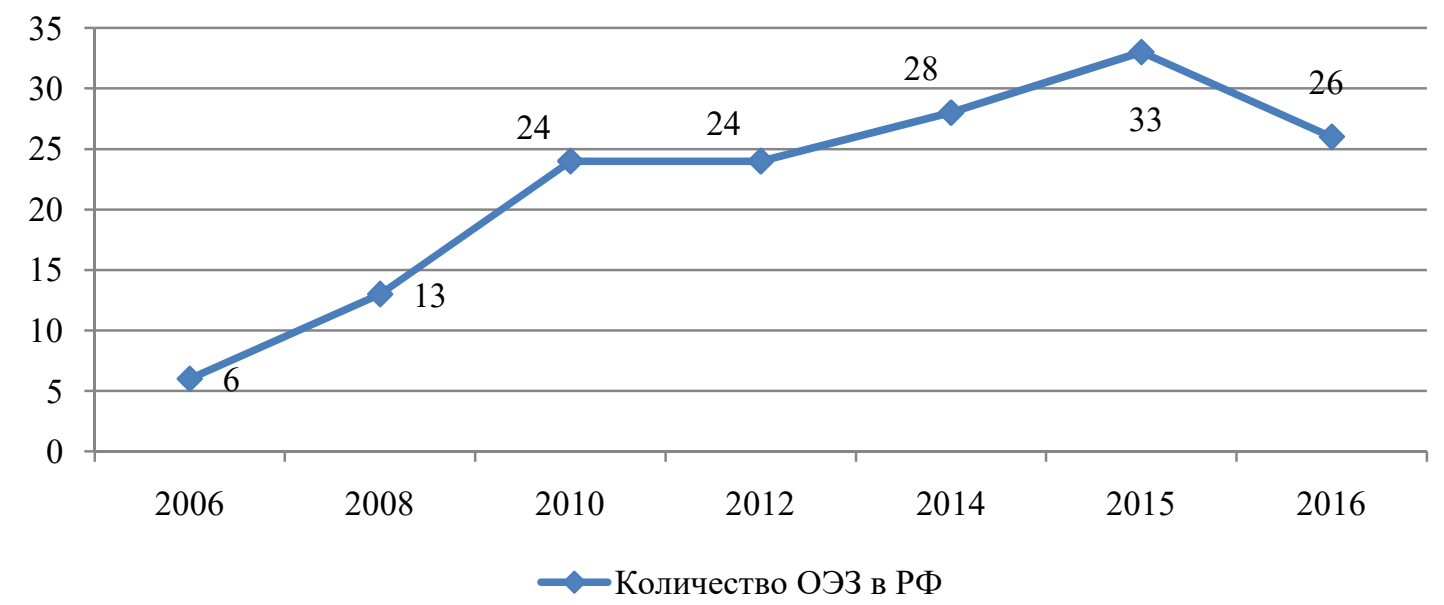

Рисунок 2 - Количественное распределение российских ОЭЗ в ретроспективе

Как продемонстрировано на рисунке 2, до 2017 года характерной тенденцией являлось увеличение количества ОЭЗ. Однако в 2016 году произошло значительное снижение их количества, и связано это с тем, что в настоящее время ОЭЗ РФ находятся под пристальным вниманием правительства.

Так, в начале 2016 года Коллегией Счетной Палаты РФ (СП РФ) была проведена экспертиза эфффективности ОЭЗ, которая основывалась на учете соотношения вложенных средств федерального бюджета, предоставленных налоговых и таможенных льгот к общему объему осуществленных резидентами инвестиций и уплаченных налогов и таможенных платежей на 1 января 2016 года [16].

По ее результатам было выявлено, что объем осуществленных резидентами инвестиций превысил объем вложенных средств федерального бюджета только по 6 ОЭЗ (ОЭЗ ППТ «Алабуга», ОЭЗ ППТ «Липецк», ОЭЗ ТВТ «Санкт-Петербург», ОЭЗ ППТ «Тольятти», ОЭЗ ППТ «Людиново» («Калуга»), ОЭЗ ТРТ «Ворота Байкала». Остальные ОЭЗ с учетом соотношения объема вложенных средств федерального бюджета и общего объема осуществленных инвестиций нельзя назвать эфффективными. Кроме того, из 15 существующих на 1 января 2016 г. ОЭЗ ТРТ фрункционируют 6. Из трех созданных ОЭЗ портового типа функционирует одна. По состоянию на 1 января 2016 года отсутствуют утвержденные перспективные планы развития по 16 из 33 ОЭЗ.

После проведения данной проверки были приняты следующие меры:

- утверждены новые критерии оценки эффрективности особых экономических зон (7 июля 2016 г.);

- досрочно ликвидированы 6 туристско-рекреационных ОЭЗ и 2 портовых ОЭЗ, на территории которых в течение трех лет с даты создания ОЭЗ не заключено ни одного соглашения о ведении деятельности и резидентами которых в течение трех лет подряд не ведется соответствующая деятельность;

- Минэкономразвития России заключены соглашения с органами исполнительной власти 17 регионов о передаче полномочий по управлению 20 ОЭ3;

- дополнены критерии создания особой экономической зоны (новые критерии предусматривают наличие оценки рентабельности, доходности, срока окупаемости предлагаемой к созданию ОЭЗ; проекта планировки территории; перспективного плана развития ОЭЗ; анализа экологических рисков; опыта будущей управляющей компании 
в создании подобной инфраструктуры).

Однако, по мнению экспертов СП РФ на сегодняшний день принятых мер недостаточно для более эффрективного функционирования ОЭЗ.

По состоянию на 1 января 2017 года относительно эфффективными можно признать только деятельность ОЭЗ, созданных на территориях Республики Татарстан («Алабуга»), Липецкой, Самарской областях и в г. Санкт-Петербурге. При этом следует отметить, что указанные ОЭЗ изначально создавались в регионах с благоприятным предпринимательским и инвестиционным климатом.

Несмотря на то, что в России созданы и постоянно совершенствуются условия для фуункционирования СЭЗ, не все из них в настоящее время развиваются эфффективно. Сравнительный анализ основных индикаторов функционирования СЭЗ в РФ, США и Китае, проведенный на основе данных, находящихся в открытом доступе, позволит наметить пути эффективного развития российских СЭЗ.

Объектами исследования выступают особые экономические зоны России и Китая, а также зоны внешней торговли США (таблица 1).

Таблица 1 - Определения зон в США, Китае и России

\begin{tabular}{|c|l|}
\hline Страна & \multicolumn{1}{|c|}{ Определение зоны } \\
\hline США & $\begin{array}{l}\text { Зоны внешней торговли (ЗВТ) - зоны, географрически расположенные на территории США, но } \\
\text { рассматриваемые законодательством как находящиеся за пределами таможенной территории } \\
\text { страны. }\end{array}$ \\
\hline Китай & $\begin{array}{l}\text { Особые экономические зоны Китая - это отдельные регионы, в которых действуют упрощенный } \\
\text { порядок регулирования внешнеэкономической деятельности. }\end{array}$ \\
\hline Россия & $\begin{array}{l}\text { В России особая экономическая зона - это часть территории РФ, на которой действует особый } \\
\text { режим осуществления предпринимательской и иной деятельности, а также может применяться } \\
\text { таможенная процедура свободной таможенной зоны. }\end{array}$ \\
\hline
\end{tabular}

Сравнивая свободные экономические зоны в США, Китае и России, обратим внимание на период и цели их создания (таблица 2).

Таблица 2 - Основные цели создания СЭЗ в США, Китае и России

\begin{tabular}{|c|l|}
\hline $\begin{array}{c}\text { Страна, год } \\
\text { основания } \\
\text { СЭ3 }\end{array}$ & \multicolumn{1}{|c|}{ Основные цели создания } \\
\hline \multirow{5}{*}{ США, 1934 } & $\begin{array}{l}\text { - повышение конкурентоспособности национальной промышленности на мировом рынке } \\
\text { путем расширения экономической активности на определенных территориях } \\
\text { (депрессивных старо-промышленных регионов, или отраслей промышленности, а в ряде } \\
\text { случаев конкретных предприятий); } \\
\text { - снижение уровня безработицы }\end{array}$ \\
\hline \multirow{5}{*}{ Китай, 1978 } & $\begin{array}{l}\text { - эксперименты с различными политическими методами; } \\
\text { - привлечение иностранного капитала, передовых технологий; } \\
\text { - увеличение экспортной валютной выручки; } \\
\text { - создание дополнительных рабочих мест; } \\
\text { - стимулирование конкуренции между регионами }\end{array}$ \\
\hline $\begin{array}{l}\text { - развитие обрабатывающих отраслей экономики, высокотехнологичных отраслей } \\
\text { экономики, развития туризма, санаторно-курортной сфреры, портовой и транспортной } \\
\text { инфраструктур; } \\
\text { - разработка технологий и коммерциализация их результатов; } \\
\text { - производство новых видов продукции }\end{array}$ \\
\hline
\end{tabular}

В США ЗТР зародились в период «великой депрессии», т.е. период упадка национальной экономики и всплеск безработицы. Соответственно, они преследовали цели укрепления экономики, основной целью было повышение конкурентоспособности национальной промышленности на мировом рынке, и попутно снижение уровня безработицы.

В Китае первые СЭЗ были разработаны в 1978 году в качестве «лабораторий» для экспериментов с ускоренным экономическим развитием и контролируемым импортом зарубежных технологий и капитала. В случае успеха предполагалось применить данный метод к остальной части страны. 
В России среди основных целей - развитие приоритетных для российской экономики отраслей. Анализируя эфффективность российских СЭЗ следует принимать во внимание, что по сравнению с китайскими и американскими, они находятся на начальной ступени развития, им чуть более 10 лет. К настоящему моменту зоны США и Китая уже доказали свою эффрективность, в то время как в РФ лишь часть зон (ОЭЗ ППТ и ОЭЗ ТВТ) считаются эфффективными.

Таблица 3 - Особые льготы и преимущества в зонах США, Китая и России

\begin{tabular}{|c|c|}
\hline Страна & Особые льготы и преимущества в зонах \\
\hline США & $\begin{array}{l}\text { - освобождение от «обратных» тарифов; } \\
\text { - освобождение от пошлин в случае реэкспорта продукции; } \\
\text { - освобождение от пошлин на отходы, лом и т.п.; } \\
\text { - еженедельная отчетность об отгрузках (в отличие от обычной системы, предполагающей } \\
\text { отчетность по каждой отгрузке продукции); } \\
\text { - отложенные во времени уплаты пошлины }\end{array}$ \\
\hline Китай & $\begin{array}{l}\text { - льготный налоговый режим, предоставляемый предприятиям с иностранными инвестициями } \\
\text { (возврат } 40 \% \text { налога на прибыль иностранным инвесторам, инвестирующим на срок не менее } 5 \\
\text { лет; освобождение от уплаты налога в случае инвестирования более } 5 \text { млн долл.); } \\
\text { - ставка подоходного налога для граждан снижена в четыре раза и составляет } 5 \% \text {; } \\
\text { - по земельному налогу пятилетние налоговые каникулы, а в дальнейшем } 50 \% \text { от действующей } \\
\text { ставки по налогу; } \\
\text { - большое количество дешевой рабочей силы }\end{array}$ \\
\hline Россия & $\begin{array}{l}\text { - режим свободной торговли (отсутствие таможенных пошлин и возврат НДС); } \\
\text { - специальный налоговый режим (снижение налогов на прибыль, имущество, транспортного и } \\
\text { земельного налогов на 5-10 лет) }\end{array}$ \\
\hline
\end{tabular}

Анализируя данные таблицы 3 отметим, что ЗВТ США вносят заметный вклад в социально-экономическое развитие страны. Это осуществляется, прежде всего, через стимулирование национальных компаний с помощью льготного налогового режима производства в самих США различных видов готовой продукции. Например, импортеры продукции ряда отраслей, как судостроение, автомобилестроение, производство промышленного оборудования, нефтепродуктов, а также продукции, собираемой или производимой в зонах внешней торговли, при ввозе конечного продукта на территорию США освобождаются от уплаты инверсированного (обратного) тарифа. Механизм установления данного тарифа предусматривает более высокие пошлины на узлы и отдельные блоки, чем на готовую продукцию с большей долей добавленной стоимости.

Привлекательность Китая в плане привлечения капитала определялась наличием дешевой рабочей силы, политической стабильностью в стране и достаточно льготным инвестиционным законодательством. При этом особый режим и льготные условия вовсе не являются главным условием прихода в ОЭЗ крупных транснациональных корпораций. В Китае используются такие же меры для стимулирования инвестиций, которые широко применяются и в других странах мира. Успех их применения в Китае заключается в последовательности, продуманности, рациональном поведении хозяйственных субъектов и государственной власти в целом.

На основе данных таблицы 4 можно выделить несколько отличий в функционировании СЭЗ в США, Китае и Российской Федерации. Так, в Китае нет полноценной законодательной базы, регулирующей деятельность СЭЗ, однако это не отразилось на функционировании зон, которые в полной мере доказали свою эфффективность. В то же время в США и в России существует нормативно-правовая база, отражающая различные аспекты создания и функционирования СЭЗ. В США закон о ЗВТ действует с 1934 года, в него неоднократно вносились существенные поправки, направленные на расширение и диверсифрикацию деятельности зон. В России закон об ОЭЗ вступил в силу в 2005 году, и за этот сравнительно небольшой период времени существенных поправок не наблюдалось.

Кроме того, в России наблюдается сложная система управления, что может приводить к непрозрачной схеме финансирования. 
Отметим, что в России хоть и делается акцент на привлечении иностранных инвестиций, но в основном создание инфрраструктуры ОЭЗ фринансируется из фредеральных средств, что изначально делает такой подход к формированию зон отличным от США. Американские ЗТР возникали на протяжении XX века стихийно, учитывая специфику штата и не навязываясь сверху, при этом в качестве основных инвесторов выступают частные резиденты самих штатов. Это приводит к более высокой эфффективности функционирования зон в США, нежели в России.

В фринансировании зон Китая, как и России, большой вклад принадлежит государству. Однако в Китае значительную роль сыграли инвестиции из Гонконга, Макао и Тайваня, рядом с которыми и были стратегически расположены первые зоны.

Таблица 4 - Модели функционирования ОЭЗ в США, Китае и России

\begin{tabular}{|c|c|c|c|}
\hline$\pi / \Pi$ & США & Китай & Россия \\
\hline $\begin{array}{l}\text { Нормативно- } \\
\text { правовая база }\end{array}$ & $\begin{array}{c}\text { Закон о ЗВТ } 1934 \text { года } \\
\text { (Foreign-Trade Zones Act } \\
\text { of 1934), } \\
\text { административные акты } \\
\text { Совета по ЗВТ, } \\
\text { Министерства торговли и } \\
\text { Таможенной службы } \\
\text { США }\end{array}$ & $\begin{array}{c}\text { нет единого законодательного } \\
\text { акта, регламентирующего } \\
\text { деятельность СЭЗ. Решения } \\
\text { о создании отдельных зон } \\
\text { принимаются Госсоветом } \\
\text { КНР. Конкретные положения о } \\
\text { зонах утверждаются } \\
\text { Народными собраниями } \\
\text { соответствующих субъектов } \\
\text { страны }\end{array}$ & $\begin{array}{c}\text { Федеральный закон от } \\
\text { 22.07.2005 № 116-Ф3 } \\
\text { «Об особых } \\
\text { экономических зонах в } \\
\text { Российской Федерации», } \\
\text { подзаконные } \\
\text { нормативно-правовые } \\
\text { акты; Соглашение по } \\
\text { вопросам СЭЗ на } \\
\text { таможенной территории } \\
\text { Таможенного союза и } \\
\text { таможенной процедуры } \\
\text { свободной таможенной } \\
\text { зоны от } 18 \text { июня } 2010 \\
\text { года и иные акты. }\end{array}$ \\
\hline $\begin{array}{c}\text { Организационные } \\
\text { структуры }\end{array}$ & $\begin{array}{c}\text { функционируют под } \\
\text { контролем специально } \\
\text { созданного } \\
\text { межведомственного } \\
\text { Совета. Кроме того, в } \\
\text { Министерстве торговли } \\
\text { США имеется } \\
\text { подразделение, } \\
\text { занимающееся } \\
\text { вопросами таких зон }\end{array}$ & $\begin{array}{c}\text { специальная } \\
\text { межведомственная комиссия, } \\
\text { которую возглавляет } \\
\text { представитель Госсовета КНР } \\
\text { в ранге вице-премьера. В } \\
\text { состав комиссии входят } \\
\text { представители Министерства } \\
\text { финансов, Министерства } \\
\text { строительства, Министерства } \\
\text { земельных ресурсов, } \\
\text { Главного таможенного } \\
\text { управления, Управления } \\
\text { валютного контроля, а также } \\
\text { силовых ведомств }\end{array}$ & $\begin{array}{c}\text { Министерство } \\
\text { экономического } \\
\text { развития, региональный } \\
\text { орган исполнительной } \\
\text { власти и управляющая } \\
\text { компания, учреждаемая } \\
\text { данным органом }\end{array}$ \\
\hline Финансирование & $\begin{array}{c}\text { преимущественно } \\
\text { частные денежные } \\
\text { средства американских } \\
\text { резидентов }\end{array}$ & $\begin{array}{c}\text { бюджетные средства и } \\
\text { внешние инвестиции } \\
\text { (преимущественно из } \\
\text { Гонконга, Макао и Тайваня, а } \\
\text { также инвестиции китайцев, } \\
\text { проживающих в других } \\
\text { странах) } \\
\end{array}$ & $\begin{array}{c}\text { бюджетные средства и } \\
\text { внешние инвестиции }\end{array}$ \\
\hline
\end{tabular}

Анализируя распределение зон по территории страны отметим, что в данное время в России ОЭЗ располагаются на территории 34\% субъектов (таблица 5). Кроме того, проследив конкретную локализацию ОЭЗ, можно прийти к выводу, что неэффективность ОЭЗ ТРТ и ПОЭЗ отчасти связана с их расположением в удаленных и недостаточно развитых регионах. В свою очередь ОЭЗ ППТ и ОЭЗ ТВТ, как уже было отмечено, считаются эффективными, при этом располагаются они преимущественно в развитых районах страны со сложившейся производственной и научно-технической специализацией.

В Китае 6 первоначальных специальных экономических зон занимают лишь 12\% территории Китая (таблица 5). Это обусловлено целями их создания, они являлись экспериментальной площадкой, анклавами внутри закрытой экономики Китая, для 
апробации новых методов по достижению ускоренного экономического развития. После того, как первые СЭЗ подтвердили эффрективность принятых мер, правительство Китая начало применять этот механизм и к остальной части страны, но вводя при этом те или иные поправки, ставя новые цели. Первые 6 СЭЗ остались уникальными в своем роде.

Таблица 5 - Количество СЭЗ в США, Китае и России и особенности их расположения на 2015 г.

\begin{tabular}{|c|c|c|c|}
\hline Характеристика & США & Китай & Россия \\
\hline $\begin{array}{c}\text { Количество зон на } \\
2015 \text { год, шт. } \\
\end{array}$ & 262 & 6 & 33 \\
\hline $\begin{array}{c}\text { Количество } \\
\text { территориально- } \\
\text { административных } \\
\text { единиц в стране на } \\
2015 \text { год, шт.: } \\
\end{array}$ & 51 & 34 & 85 \\
\hline $\begin{array}{c}\text { - из них, имеющих } \\
\text { зоны }\end{array}$ & 51 & 4 & 29 \\
\hline $\begin{array}{c}\text { \% территориально- } \\
\text { административных } \\
\text { единиц, имеющих } \\
\text { зоны } \\
\end{array}$ & $100 \%$ & $12 \%$ & $34 \%$ \\
\hline $\begin{array}{c}\text { Степень интеграции } \\
\text { в экономику }\end{array}$ & $\begin{array}{c}\text { высокая - глубоко } \\
\text { интегрированы в } \\
\text { экономику страны }\end{array}$ & $\begin{array}{c}\text { низкая - являются } \\
\text { экономическими } \\
\text { анклавами, фрактически } \\
\text { отделенными от } \\
\text { остальной территории } \\
\text { страны } \\
\end{array}$ & средняя \\
\hline Локализация & $\begin{array}{c}\text { наибольшая } \\
\text { концентрация ЗВТ } \\
\text { отмечается либо в } \\
\text { штатах, имеющих } \\
\text { выход к морю или } \\
\text { океану, либо в штатах, } \\
\text { располагающих } \\
\text { крупными } \\
\text { промышленными } \\
\text { комплексами. }\end{array}$ & $\begin{array}{c}\text { районы с } \\
\text { первоначально очень } \\
\text { низким уровнем жизни; } \\
\text { являлись издавна } \\
\text { сложившимися } \\
\text { торговыми центрами, } \\
\text { при этом расположены } \\
\text { близко к стратегическим } \\
\text { источникам } \\
\text { иностранного капитала - } \\
\text { Гонконгу, Макао и } \\
\text { Тайваню. }\end{array}$ & $\begin{array}{c}\text { для ОЭЗ ППТ и ОЭЗ ТВТ } \\
\text { характерны районы со } \\
\text { сложившейся } \\
\text { производственной и научно- } \\
\text { технической } \\
\text { специализацией, для ОЭЗ } \\
\text { ТРТ - живописные районы, } \\
\text { экономически неразвитые, } \\
\text { для ПОЭЗ - портовые } \\
\text { города, имеющие } \\
\text { преимущества } \\
\text { расположения, но } \\
\text { требующие комплексного } \\
\text { развития. }\end{array}$ \\
\hline
\end{tabular}

В США зоны внешней торговли охватывают всю территорию страны, т.е. в каждом штате находится как минимум одна зона. При этом наибольшее количество зон создано либо в штатах, имеющих выход к морю или океану, либо в штатах, не имеющих выхода к водным артериям, но располагающих крупными промышленными комплексами.

Сравнивая зоны по различным аспектам, целесообразно выделить и их проблемы, а также факторы успеха (таблица 6).

Как видим из таблицы 6, проблемы ОЭЗ России связаны с организационными моментами, что вполне логично, т.к. они находятся на начальной ступени своего развития, в отличие от США и Китая, где присутствуют аспекты негативного влияния СЭЗ на те или иные социально-экономические показатели.

В целом, формирование и развитие СЭЗ в США, Китае и России происходило в принципиально различных политических и экономических условиях, что является важнейшей причиной разного уровня развития СЭЗ и соответственно принципиально различной роли этих зон в хозяйственном развитии исследуемых стран.

Главными причинами низкой эффеективности деятельности ОЭЗ в России являются непоследовательная политика со стороны государства в этой области, отсутствие четкой концепции создания этих зон в контексте общенациональных 
программ развития, а также неблагоприятный инвестиционный климат и связанные с ним политические и экономические риски.

Для превращения ОЭЗ в реальный инструмент экономического развития России следует производить выбор средств и принципов их формирования исходя из задач конкретных регионов, причем не просто планов их хозяйственного подъема, а становления именно их конкурентоспособности.

Таблица 6 - Проблемы и фракторы успеха СЭЗ в США, Китае и России

\begin{tabular}{|c|c|c|}
\hline Страна & Проблемы особых экономических зон & Факторы успеха \\
\hline США & $\begin{array}{l}\text { недополучения в федеральный и } \\
\text { штатный бюджет; создание } \\
\text { неравномерных условий для } \\
\text { предприятий; образование перекосов в } \\
\text { экономике штатов; лазейки для } \\
\text { «отмывания» денег; экологический } \\
\text { урон }\end{array}$ & $\begin{array}{l}\text { - преимущества расположения; } \\
\text { - привлечение капиталов частных инвесторов- } \\
\text { резидентов штатов; } \\
\text { - гибкость программы: } \\
\text { 1950-1952 гг. - внесение в Закон дополнения, } \\
\text { разрешающего создавать в общих ЗВТ промышленные } \\
\text { производства, появление субзон; } \\
\text { 1980-1982 гг. - в субзонах было разрешено создавать } \\
\text { предприятия по сборке различных узлов и блоков } \\
\text { компьютеров, электронно-вычислительной техники, } \\
\text { автомобилей, предусматривая более высокие пошлины } \\
\text { на узлы и отдельные блоки, чем на готовую продукцию с } \\
\text { большей долей добавленной стоимости; } \\
\text { - льготы, стимулирующие производство на территории } \\
\text { зон; } \\
\text { - глубокая интеграция в экономику страны }\end{array}$ \\
\hline Китай & $\begin{array}{l}\text { экономический рост преимущественно } \\
\text { за счет экспорта; заторы, трафик, } \\
\text { загрязнение окружающей среды, } \\
\text { трудности с предоставлением услуг } \\
\text { для всех на густонаселенной } \\
\text { территории; отсутствие культурной } \\
\text { среды в зонах }\end{array}$ & $\begin{array}{l}\text { - льготная политика и институциональная автономия; } \\
\text { - сильная поддержка и дальновидное участие } \\
\text { правительств всех уровней; } \\
\text { - прямые иностранные инвестиции и китайская диаспора; } \\
\text { - изучение технологий, инновации, модернизация, а } \\
\text { также прочные связи с отечественной экономикой; } \\
\text { - инновационная культура; } \\
\text { - преимущества расположения; } \\
\text { - подход государственно-частных партнерств }\end{array}$ \\
\hline Россия & $\begin{array}{l}\text { проблемы административного } \\
\text { характера; коррупция и отсутствие } \\
\text { долгосрочных моделей развития; } \\
\text { недостаток контроля за расходованием } \\
\text { средств и реализацией проектов; } \\
\text { отсутствие санкцй для } \\
\text { распорядителей денежных средств; } \\
\text { проблемы инфраструктуры; проблемы } \\
\text { зонирования; политическая } \\
\text { нестабильность }\end{array}$ & $\begin{array}{l}\text { - преимущества расположения; } \\
\text { - развитая инфраструктура; } \\
\text { - эффрективное управление; } \\
\text { - заинтересованность властей региона в развитии ОЭЗ }\end{array}$ \\
\hline
\end{tabular}

Источник: $[11,12,13,15,17-21]$.

Подводя итог, отметим, что в связи с длительным сроком получения экономического эфффекта от деятельности СЭ3 (согласно мировой практике - 10-15 лет), следует предполагать, что особые экономические зоны России окажут более существенное влияние на экономику как отдельных регионов, так страны в целом, и именно они могут стать одним из моторов будущего роста.

Но для этого необходимо внести ряд корректив в практику их создания и функционирования:

- функционирование ОЭЗ должно осуществляться на основе перспективного плана развития конкретной ОЭЗ, без наличия утвержденного плана не следует проводить финансирование из бюджета;

- усовершенствовать законодательство в области регулирования ОЭЗ путем уточнения имеющихся законодательных актов и возможным введением новых;

- расширить налоговые, таможенные и административные преференции, в том числе за счет федеральных ресурсов; увеличить срок действия существующих налоговых льгот; 
- расширить перечень разрешенных видов деятельности, в том числе разрешить осуществление на территории отдельных видов ОЭЗ не только профильную, но и смежную деятельность;

- стимулировать предоставление дополнительных сервисов резидентам ОЭЗ (централизованный PR, консалтинговые, юридические, фринансовые услуги, образовательные услуги, аренда оборудования и т.д.);

- обеспечить существенную финансовую ответственность субъектов Федерации и управляющих компаний за невыполнение обязательств;

- ввести фринансовые поощрения местным руководителям по результатам экономического прогресса конкретного региона;

- обеспечить контроль за надлежащим расходованием бюджетных средств; прозрачность их использования;

- стимулировать не только определенные территории, но и выделять приоритетные отрасли при помощи особых льгот (например, установить дополнительные льготы для участников рыбохозяйственной деятельности в Приморском крае в условиях Свободного порта Владивосток).

Исходя из проведенного исследования, можно сделать вывод о том, что российские особые зоны имеют большой потенциал развития. К одной из таких перспективных зон следует отнести Свободный порт Владивосток (СПВ). В современных условиях Приморский край имеет явные преимущества на карте страны: благоприятные природно-климатические условия, географическая близость к государствам, не присоединившимся к санкциям, наличие режимов льготного администрирования.

\section{БИБЛИОГРАФИЯ}

1. Корнейко О.В. Опыт развития специальных экономических зон и промышленных кластеров в Китае / О.В. Корнейко, А.В. Пестерева // Вестник Удмуртского университета. Серия: Экономика и право. - 2016. - Т. 26. - № 6. - С. 34-40.

2. Кравчук В. И. Свободные экономические зоны: теоретические подходы к формированию и развитию в XXI веке [Электронный ресурс] / В.И. Кравчук // Региональная экономика. - 2015. - №7. - Режим доступа: http://www.uecs.ru/index.php?option=com_flexicontent\&view=items\&id=36303.

3. Ковалева Г.Д. СЭЗ: терять или приобретать? А может быть, последовать опыту соседей? / Г.Д. Ковалева // ЭКО. - 2014. - № 6. - С.124-141.

4. Русакович В.И. СЭЗ как фактор интеграции стран Азии в мировую экономику: реалии XXI века / В.И. Русакович // Глобализация: влияние на страны Азии. Ежегодник. - М.: РУДН, 2015.

5. Корнейко О. В. Перспективы развития рыбохозяйственной деятельности Приморья в условиях Свободного порта Владивостока / О. В. Корнейко, О. Ю. Ворожбит. - М.: БИБЛИО-ГЛОБУС, 2015. - 180 с.

6. Farole, T., Akinci, G. Special Economic Zones. Progress, Emerging Challenges, and Future Directions / T. Farole, G.Akinci. - Washington, DC: World Bank, 2011.

7. Moberg L. The political economy of special economic zones. Journal of Institutional Economics, vol. 11, no. 1, 2015. P. 167-190.

8. Tiefenbrun Susan U.S. Foreign Trade Zones, Tax-Free Trade Zones of the World, and Their Impact on the U.S. Economy// Hofstra International Law \& Business Journal, Vol. 13, 2013.

9. Neveling P. Free Trade Zones, Export Processing Zones, Special Economic Zones and Global Imperial Formations 200 BCE to 2015 CE / P. Neveling // The Palgrave Encyclopedia of Imperialism and Anti-imperialism. - Basingstoke: Palgrave Macmillan, 2015. - pp. 1007-16.

10. Rubini L., Di Tommaso M. R., Barbieri E. Special Economic Zones and Cluster Dynamics: China / L. Rubini, M. R. Di Tommaso, E. Barbieri // International Encyclopedia of the Social \& Behavioral Sciences. - Vol. 3. - 2015. - PP. 207-212. 
11. Zeng D. Z., How Do Special Economic Zones and Industrial Clusters Drive China's Rapid Development? / Douglas Zhihua Zeng // Journal of International Commerce, Economics and Policy (JICEP). - 2012. - Vol. 3, No. 3. - PP. 1-28.

12. Xu, Chenggang, The Fundamental Institutions of China's Reforms and Development / Chenggang Xu // Journal of Economic Literature. - Vol. 49, No. 4. - 2011. - PP. 10761151.

13. Sklair L. Problems of Socialist Development - The Significance of Shenzhen Special Economic Zone for China Open-Door Development Strategy / Leslie Sklair // International Journal of Urban and Regional Research. - Vol. 15, no 2. - 1991. - PP. 197-215.

14. Корнейко О.В. Кластерный подход в организации свободных экономических зон / О.В. Корнейко, А.В. Пестерева // Азимут научных исследований: экономика и управление. - 2017. - Т. 6. - № 1 (18). - С. 80-83.

15. 深圳统计年鉴. Shenzhen Statistical Yearbook [Электронный ресурс] // Официальный сайт правительства Шенчжень. - Режим доступа: http://www.sz.gov.cn/cn/xxgk/tjsj/ (accessed 10.04.2017).

16. Корнейко О.В. Критическая оценка действующих подходов к анализу эфффективности российских особых экономических зон / О.В. Корнейко, А.В. Пестерева, Л.Цян // Вектор науки Тольяттинского государственного университета. Серия: Экономика и управление. - 2016. - № 4 (27). - С. 49-54.

17. Annual Report of the Foreign-Trade Zones Board to the Congress of the United States [Electronic resources] // United States Department of Commerce. International Trade Administration. Enforcement and Compliance. - URL: http://enforcement.trade.gov/ftzpage/annual-report.html.

18. Информация о специальных экономических зонах США, КНР, РФ [Электронный ресурс] // Министерство экономического развития Российской Федерации: Портал внешнеэкономической информации. - Режим доступа: http://www.ved.gov.ru/exportcountries/us/about_us/laws_ved_us/special_area_us/.

19. A Brief History of the U.S. Foreign-Trade Zones Program [Electronic resources] // Foreign-Trade Zone Resource Center. - URL: http://www.foreign-tradezone.com/history.htm.

20. Online FTZ Information System [Electronic resources] // United States Department of Commerce. International Trade Administration. Enforcement and Compliance. - URL: http://ita-web.ita.doc.gov/FTZ/OFISLogin.nsf.

21. Benefits to a zone user [Electronic resources] // United States Department of Commerce. International Trade Administration. Enforcement and Compliance. - URL: http://enforcement.trade.gov/ftzpage/info/userbenefits.html

(C) 2017 by the authors. Licensee RJOAS, Orel, Russia. This article is an open access article distributed under the terms and conditions of the Creative Commons Attribution (CC BY) license: http://creativecommons.org/licenses/by/4.0/ 
DOI https://doi.org/10.18551/rjoas.2017-09.02

\title{
ЭКОНОМИЧЕСКИЙ АНАЛИЗ ТЕХНИЧЕСКОЙ ОСНАЩЕННОСТИ СЕЛЬСКОГО ХОЗЯЙСТВА, ДЕЙСТВУЮЩИХ МЕХАНИЗМОВ РЕГУЛИРОВАНИЯ РЫНКА СЕЛЬСКОХОЗЯЙСТВЕННОЙ ТЕХНИКИ КАНАДЫ, И ОЦЕНКА ВОЗМОЖНОСТИ ИХ ПРИМЕНЕНИЯ В РОССИИ В УСЛОВИЯХ ИМПОРТОЗАМЕЩЕНИЯ \\ ECONOMIC ANALYSIS OF THE TECHNICAL EQUIPMENT OF AGRICULTURE, THE CURRENT MECHANISMS FOR REGULATING THE AGRICULTURAL MACHINERY MARKET IN CANADA AND ASSESSING THE POSSIBILITY OF THEIR APPLICATION IN RUSSIA UNDER CONDITIONS OF IMPORT SUBSTITUTION
}

\author{
Полухин А.А., доктор экономических наук \\ Polukhin A.A., Doctor of Economic Sciences \\ Всероссийский научно-исследовательский институт сельского хозяйства, \\ Москва, Россия \\ All-Russian Research Institute of Agricultural Economics, Moscow, Russia \\ E-mail:polukhinogac@yandex.ru
}

\begin{abstract}
АННОТАЦИЯ
В статье проведена сравнительная оценка технической оснащенности сельского хозяйства Канады. Сравнение проведено со странами с сопоставимыми по размеру сельскохозяйственных угодий, климатическими условиями. Проанализировано изменение технической оснащенности сельского хозяйства Канады как в количественном, так и в стоимостном выражении. В статье дана структурный анализ машинотракторного парка сельского хозяйства Канады. В качестве источника эмпирического материала использованы данные офрициальной статистики Канады. На основе результатов экономической оценки технической оснащенности сельского хозяйства Канады сделаны выводы, которые можно использовать в качестве обоснований направлений развития сельского хозяйства как изучаемой страны, так их экстраполировать на страны со схожими условиями аграрного производства.
\end{abstract}

\section{ABSTRACT}

The article compares the technical equipment of the Canadian agriculture. The comparison was conducted with countries with comparable in size agricultural land, climatic conditions. The change in the technical equipment of Canada's agriculture, both quantitatively and in terms of value, is analyzed. The article gives a structural analysis of Canada's agricultural and tractor fleet. As a source of empirical material, the official statistics of Canada are used. On the basis of the results of the economic assessment of the technical equipment of agriculture in Canada, conclusions have been drawn that can be used as justifications for the development of agriculture as the country being studied, so they can be extrapolated to countries with similar conditions of agricultural production.

\section{КЛЮЧЕВЫЕ СЛОВА}

Экономика, сельское хозяйство, Канада, машинно-тракторный парк, техническая оснащенность, воспроизводство.

\section{KEY WORDS}

Economy, agriculture, Canada, machinery and tractors, equipment, reproduction.

Одной из самых развитых в аграрном отношении стран мира является Канада. Эта страна имеет природно-климатические условия аграрного производства максимально приближенные к российским. Демографическая ситуация в сельской местности Канады, отток молодежи из сельской местности, уровень безработицы на селе, уровень среднего семейного дохода по сравнению со средними показателями по стране также свидетельствуют об определенных сходных чертах между сельским 
хозяйством России и Канады. В тоже время отметим, что Канада - пятая по объему экспорта сельскохозяйственной продукции в мире. Сельскохозяйственное производство обеспечивает занятость более 2 миллионов канадцев и производит продукции более чем на 100 млрд. долларов, из них на экспорт идёт сельскохозяйственной продукции более чем на 40 млрд долларов.

Количественные и стоимостные показатели ресурсного потенциала сельскохозяйственных производителей Канады представлены в таблице 1.

Таблица 1 - Ресурсная оснащенность сельского хозяйства Канады ${ }^{1}$

\begin{tabular}{|l|c|c|c|c|}
\hline \multicolumn{1}{|c|}{ Показатель } & 2011 г. & 2016 г. & $\begin{array}{c}2016 \text { г. в \% } \\
\text { к 2011 г. }\end{array}$ & $\begin{array}{c}\text { Рост } \\
\text { снижение, +/- }\end{array}$ \\
\hline Количество сельскохозяйственных организация, ед & 205730 & 193492 & 94,1 & -12238 \\
\hline $\begin{array}{l}\text { Рыночная стоимость сельскохозяйственных } \\
\text { организаций, млрд. долларов }\end{array}$ & 330,8 & 509,7 & 154,1 & 178,9 \\
\hline Общая стоимость земли и зданий, млрд. долларов & 276,2 & 427,9 & 154,9 & 151,7 \\
\hline Из них арендованных, млрд. долларов & 73,1 & 120,5 & 164,8 & 47,4 \\
\hline $\begin{array}{l}\text { Стоимость всех сельскохозяйственных машин и } \\
\text { оборудования, млрд. долларов }\end{array}$ & 41,4 & 53,8 & 130,0 & 12,4 \\
\hline
\end{tabular}

Как видно из таблицы 1 в Канаде за последние 5 лет сократилось количество сельскохозяйственных производителей, однако стоимость их активов возросла более чем в 1,5 раза. Причем рост стоимости имущества наблюдается как по земле, зданиям, так и по технике. Это говорит о тенденции укрупнения агробизнеса в Канаде. Следует указать, что в Канаде достаточно высока централизация капитала в сельском хозяйстве, так 8\% сельскохозяйственных производителей владеют почти половиной земель сельскохозяйственного назначения, что позволяет им использовать энергонасыщенную технику с высоким уровнем загрузки. Укажем, что средняя обрабатываемая площадь одним фермером в Канаде составляет 250 га. Важно отметить, что 98\% всей товарной продукции фрермеров производится именно в крупных и средних хозяйствах.

Государство формирует векторы развития отрасли. Общефедеральная программа поддержки передовых и инновационных методов ведения аграрного сектора Канады включает следующие три общефедеральных аспекта:

1. Инновационные проекты касательно реальной интеграции аграрного сектора и перерабатывающей промышленности;

2. Научные разработки, позволяющие расширить сельскохозяйственный рынок, увеличить доступ к новым рынкам;

3. Дальнейшее развитие системы Экстеншн, а также проектов информационного характера, позволяющие придать новый динамизм развитию аграрного сектора.

Одной из особенностей аграрного производства Канады является ориентация на органическое земледелие и производство экологически чистой продукции. По этому направлению из 193,5 тыс. сельскохозяйственных производителей официальный сертификат производителя органической продукции имеют 1,5 тыс. фрермеров, плюс более 1 тыс. фрермеров заняты органическими технологиями в животноводстве. Под органическое земледелие используется более $1 \mathrm{Mлн.} \mathrm{га,} \mathrm{выращивание} \mathrm{экологически}$ чистой продукции занимает $1,34 \%$. В США эти показатели равны соответственно 0,9 млн. га, и 0,2\%. Канада занимает 2-е место после Австралии, США - Зе, по ареалу размещения органического земледелия. Это естественно влияет на формирование технической базы сельскохозяйственного производства.

Техническое оснащение сельского хозяйства Канады базируется на принципах экологизации: с учетом экологических аспектов севооборотов, почвозащитных технологии, элементами которых являются безотвальная вспашка, посадка лесополос, контурная обработка земель, ландшафртное землеустройство, террасирование,

\footnotetext{
${ }^{1}$ http://www.statcan.gc.ca/eng/ca2016 Table 004-0234 Census of Agriculture, farm capital (farm machinery and equipment, livestock and poultry, land and buildings)
} 
восстановление травяного покрова склонов водоканалов, вывод из активного сельскохозяйственного пользования эродированных земель, их трансформация, меры по восстановлению и ряд других крупномасштабных мероприятий, обеспечивающие достаточно солидный фон по выращиванию экологически чистых продуктов питания и становлению органического сельского хозяйства.

Министерство сельского хозяйства Канады разработало план ускорения темпов внедрения инноваций путем поддержки научно-исследовательской деятельности и внедрения технологий. В рамках программы предусмотрено фринансирование исследований в области сельского хозяйства и внедрение их в производство. Помимо этого, разработаны программы по основным сельскохозяйственным продуктам для управления спросом и предложением. ${ }^{2}$

В таблице 2 представлены данные об оснащенности сельского хозяйства Канады тракторами и навесным оборудованием.

Таблица 2 - Динамика оснащенности сельского хозяйства Канады тракторами и навесным оборудованием

\begin{tabular}{|l|c|c|c|c|}
\hline \multicolumn{1}{|c|}{ Показатель } & 2011 г. & 2016 г. & $\begin{array}{c}2016 \text { г. в \% } \\
\text { к 2011 г. }\end{array}$ & $\begin{array}{c}\text { Рост } \\
\text { снижение, +/- }\end{array}$ \\
\hline $\begin{array}{l}\text { Общее наличие тракторов (в том числе } \\
\text { арендованных), ед. }\end{array}$ & 685914 & 651266 & 94,9 & -34648 \\
\hline Общая стоимость тракторов, млрд. долларов & 14 & 18,6 & 132,9 & 4,6 \\
\hline $\begin{array}{l}\text { Количество тракторов (собственных и арендованных) } \\
\text { мощностью до 60 л.с. }\end{array}$ & 311782 & 290016 & 93,0 & -21766 \\
\hline $\begin{array}{l}\text { Общая стоимость тракторов мощностью до 60 л.с., } \\
\text { млрд. долларов }\end{array}$ & 1,9 & 2,1 & 110,5 & 0,2 \\
\hline $\begin{array}{l}\text { Количество тракторов (собственных и арендованных) } \\
\text { мощностью от 60 л.с.до 149 л.с. }\end{array}$ & 288451 & 256260 & 88,8 & -32191 \\
\hline $\begin{array}{l}\text { Общая стоимость тракторов мощностью от 60 л.с.до } \\
\text { 149 л.с., млрд. долларов }\end{array}$ & 6,6 & 7,1 & 107,6 & 0,5 \\
\hline $\begin{array}{l}\text { Количество тракторов (собственных и арендованных) } \\
\text { мощностью свыше 149 л.с. }\end{array}$ & 85681 & 104990 & 122,5 & 19309 \\
\hline $\begin{array}{l}\text { Общая стоимость тракторов мощностью свыше 149 } \\
\text { л.с., млрд. долларов }\end{array}$ & 5,5 & 9,4 & 170,9 & 3,9 \\
\hline $\begin{array}{l}\text { Плуги, культиваторы, посевное и посадочное } \\
\text { оборудование, ед. }\end{array}$ & 123526 & 111587 & 90,3 & -11939 \\
\hline $\begin{array}{l}\text { Общая стоимость плугов, культиваторов, посевного и } \\
\text { посадочного оборудования, млрд. долларов }\end{array}$ & 4,3 & 6,5 & 151,2 & 2,2 \\
\hline
\end{tabular}

В сельском хозяйстве Канады парк тракторов вырос с 635 тыс. штук в 1976 г. до 734 тыс. штук в 1991 г.; в 2011 г. количество тракторов составило 685,9 тыс. штук, а в 2016 г. количество снизилось до 651,3 тыс. штук. Укажем, что 45\% всех тракторов, используемых в сельском хозяйстве мощностью до 60 л.с. и лишь 16\% парка тракторов мощностью свыше 149 л.с. Отметим, что наблюдается на фоне снижения количества техники рост её стоимости.

В 2006 г. в структуре парка тракторы мощностью до 60 л.с. составляли 347,8 тыс. штук или 47,4 \%, от 60 до 149 л.с. - 307,2 тыс. штук или 42 \%, от и свыше 149 л.с. 78,2 тыс. штук или 10,6 \%; к 2016 году в структуре парка тракторов произошли следующие изменения: так количество тракторов мощностью менее 60 л.с. снизилось до 290 тыс. штук (доля составила 45\%), а количество тракторов мощностью свыше 149 л.с. увеличилось до 105 тыс. штук (доля составила 16\%).

Как видно на рис. 1 парк зерноуборочных комбайнов за период 1976 г. - 2016 г. сократился на 18\% с 163,6 тыс. штук до 134,6 тыс. штук. Это вполне естественная динамика парка техники, учитывая существенный рост производительности зерноуборочных комбайнов. Средняя остаточная стоимость зерноуборочных комбайнов работающих в Канаде 69,1 тыс. долларов. Техническая оснащенность

\footnotetext{
2 B.A. Зальцман // "Нивы России" №1 (134) январь-фревраль 2016

${ }^{3}$ http://www.statcan.gc.ca/eng/ca2016 Table 004-0234 Census of Agriculture, farm capital (farm machinery and equipment, livestock and poultry, land and buildings)
} 
кормопроизводства Канады характеризуется наличием кормоуборочных комбайнов, пресс-подборщиков, косилок-плющилок и т. д. в количестве 198453 единиц.

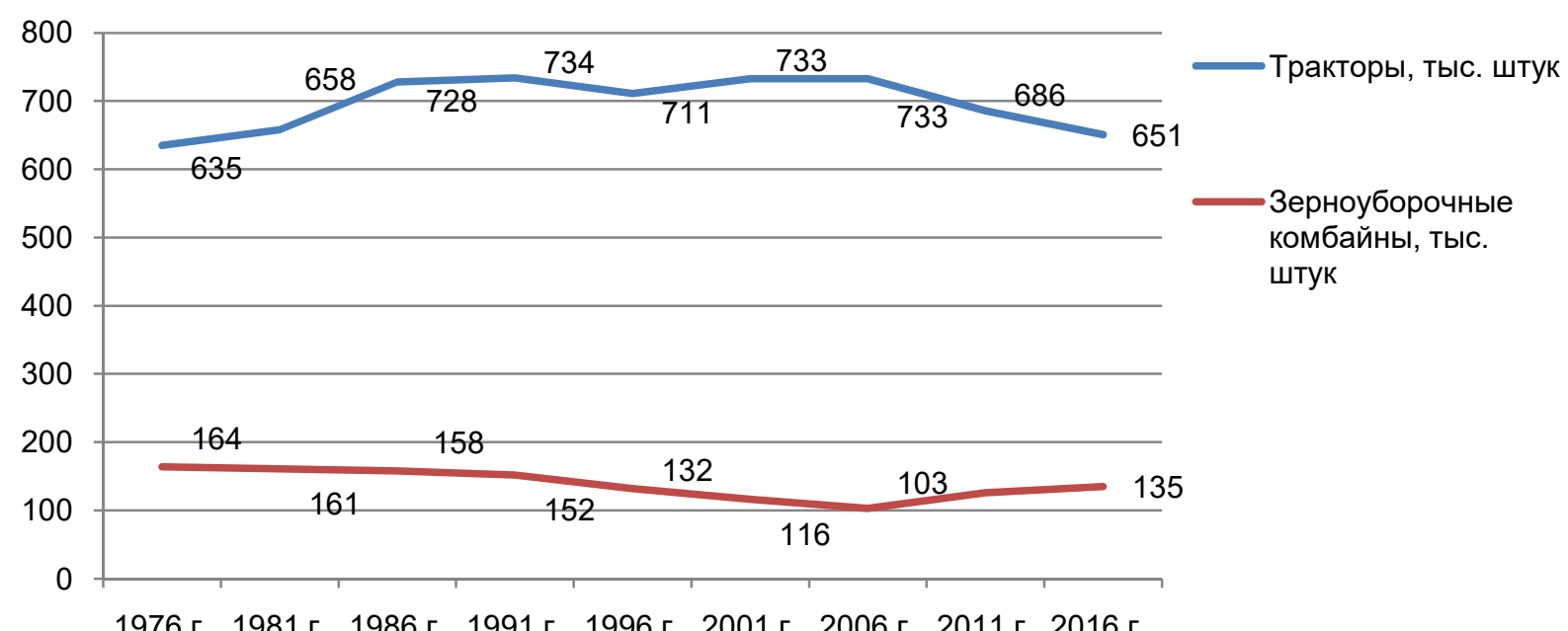

Рисунок 1 - Динамика обеспеченности сельского хозяйства Канады тракторами и зерноуборочными комбайнами, тыс. штук

2006 г.

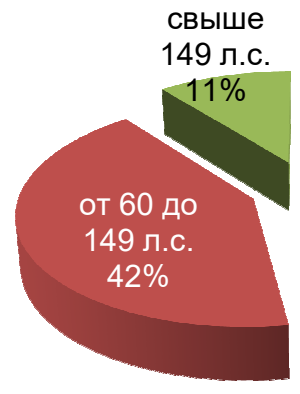

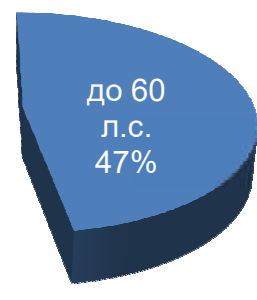

2016 г.

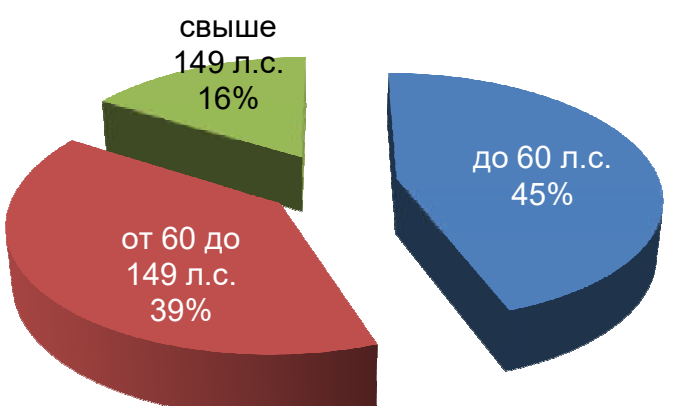

Рисунок 2 - Структура парка тракторов в сельском хозяйстве Канады ${ }^{4,5}$

Финансирование сельхозтоваропроизводителей помимо банков осуществляет Общегосударственная корпорация фрермерских кредитов (800 работников и 100 фрилиалов в провинциях). Корпорация работает на самообеспечении, она не конкурент банкам, но дополнительная альтернатива. Ее цель - кредитование под невысокие процентные ставки с учетом программы субсидирования.

В последнее время процентные ставки снизились до 6\%. Кроме чисто кредитных операций эта организация проводит аналитическую, консалтинговую работу и администрирует правительственные программы. Процент возврата кредитных ресурсов достаточно высок (на 14 тыс. фермерских хозяйств - один-два невозврата). В условиях такой конкуренции коммерческие банки вынуждены также уменьшать процентные ставки, развивать широкую сеть экономической и консалтинговой помощи фермерам на постоянной основе, а также привлекать специалистов для опроса фрермеров об их потребностях.

\footnotetext{
${ }^{4}$ Census Canada, 2006, табл. 1.36

${ }^{5}$ http://www.statcan.gc.ca/eng/ca2016 Table 004-0234 Census of Agriculture, farm capital (farm machinery and equipment, livestock and poultry, land and buildings
} 


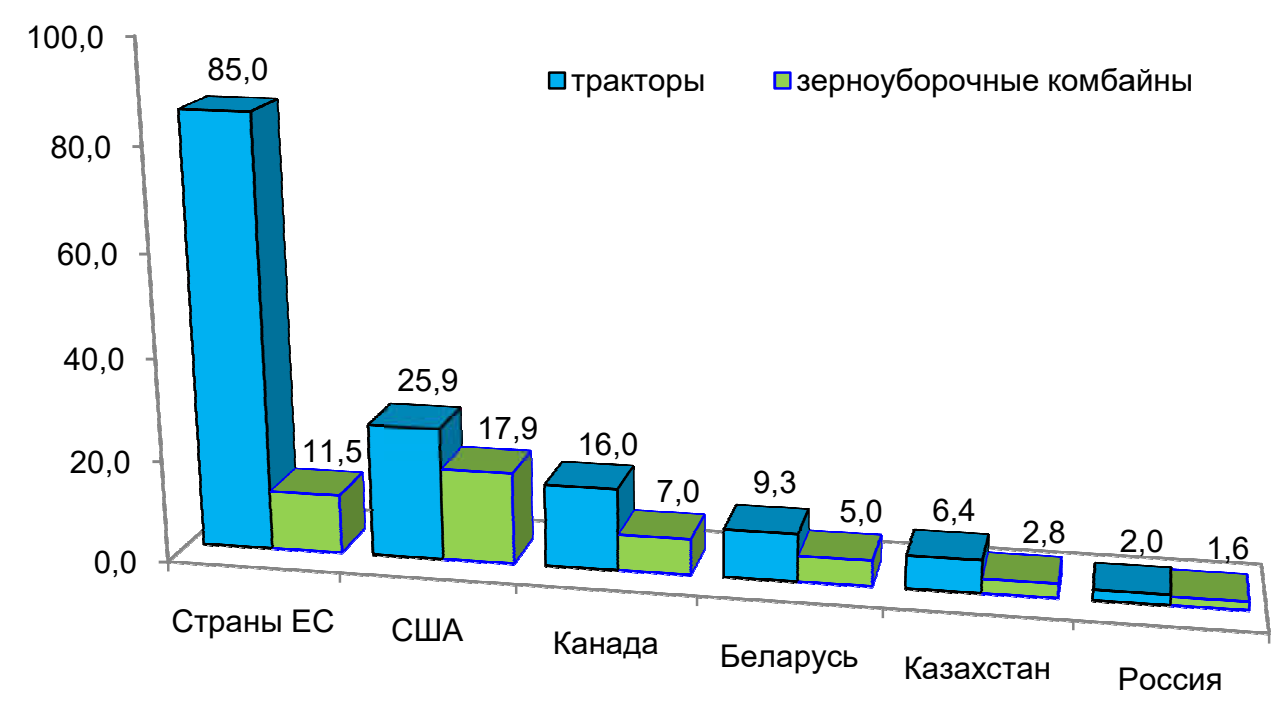

Рисунок 1 - Обеспеченность основными видами техники в ряде стран мира (тракторов на 1000 га пашни, комбайнов на 1000 га посевов)

Сельское хозяйство в Канаде отнюдь не воспринимается в качестве второстепенной отрасли экономики. По совместным программам федерального и провинциальных правительств (расходы на фринансирование распределены 50:50) принято и выполняются более 500 проектов по устойчивому развитию АПК. Производство продовольствия ежегодно растет, в сельское хозяйство внедряются передовые технологии и техника. Но в то же время отрасль все более монополизируется. Сельское хозяйство Канады получает значительную государственную поддержку в пределах 6-8 млрд. долл. (однако меньше, чем в странах ЕC). ${ }^{6}$

Условия сельскохозяйственного производства канады довольно схожи с российскими, поэтому считаем целесообразным использовать опыт этой страны при реализации мер по импортозамещению и обеспечению продовольственной безопасности. Как и в России в Канаде доминируют крупные производители: так только три компании контролируют рынок удобрений, лишь пять банков выдают подавляющее большинство сельскохозяйственных кредитов, а всего две фирмы управляют 70\% рынка мяса.

Ключевые направления технической модернизации сельского хозяйства Канады:

- большое значение в настоящее время уделяется освоению перспективных для экспорта направлений, поэтому именно по этим направлениям ведётся интенсивная модернизация парка;

- государство вкладывает большие средства в развитие аграрной науки и технико-технологическую модернизацию, поэтому ежегодно инвестирует сотни млн. долларов в различные исследования в области сельского хозяйства;

- в федеральном бюджете заложено, что в течение 2016-2021 гг. 500 млн долл. в расширение доступа к скоростному доступу к сети Интернет в отдаленных регионах страны, что необходимо для нормального функционирования современной сельхозтехники.

На современном этапе именно модернизация, экологизация, развитие технологий точного земледелия фрормируют перспективные направления технико-технологической модернизации сельского хозяйства Канады.

\footnotetext{
${ }^{6}$ https://www.agroxxi.ru/zhurnal-agroxxi/fakty-mnenija-kommentarii/mery-gosudarstvennoi-podderzhki-selskogo-hozjaistva-vagrarnyh-stranah-mira.html
} 


\section{БИБЛИОГРАФИЯ}

1. Алисов Н.В., Хорев Б.С.. Экономическая и социальная географрия мира (общий обзор): Учебник, 2003.

2. Зальцман В.А. // "Нивы России" №1 (134) январь-фревраль 2016.

3. Драгайцев В.И. Техническая оснащенность сельского хозяйства России, США, Канады и Германии/ В.И. Драгайцев // Сельскохозяйственные машины и технологии 2010. - № c. 21-26.

4. Захарова Е. Опыт государственной поддержки АПК за рубежом // Международный сельскохозяйственный журнал. - 2009. - № 1. - С. 15-16.

5. http://www.statcan.gc.ca/eng/ca2016 Table 004-0234 Census of Agriculture, farm capital (farm machinery and equipment, livestock and poultry, land and buildings).

6. Полухин А.А. Траектория развития рынка сельхозтехники стран - членов ЕАЭС/ Полухин А.А.// АПК: Экономика, управление. 2015. № 10. С. 80-84.

7. Санду И.С. Экономические аспекты технико-технологической модернизации сельского хозяйства в условиях интеграции в Евразийский экономический союз / И.С. Санду, П.И. Бурак, А.А. Полухин// Экономика сельского хозяйства России. 2015. - № 7. - С. 84-88.

8. Бурак П.И. Технико-технологическая модернизация сельского хозяйства: проблемы и решения/ И.С. Санду, П.И. Бурак, А.А. Полухин// АПК: Экономика, управление. 2014. - № 12. - С. 53-60.

(C) 2017 by the author. Licensee RJOAS, Orel, Russia. This article is an open access article distributed under the terms and conditions of the Creative Commons Attribution (CC BY) license: http://creativecommons.org/licenses/by/4.0/ 
DOI https://doi.org/10.18551/rjoas.2017-09.03

\title{
CORPORATE GOVERNANCE AND ENVIRONMENTAL PERFORMANCE IN THE CONTEXT OF ASEAN ECONOMIC COMMUNITY
}

\author{
Muliati ${ }^{*}$ Pattawe Abdul, Mile Yuldi, Lucyani \\ University of Tadulako, Indonesia \\ *E-mail: muli ak@yahoo.com
}

\begin{abstract}
ASEAN economic community is the opportunity for Indonesia to integrate the economy. This encourages Indonesian companies to have superiority to competing in the ASEAN. The objective of this study is to describe corporate governance and environmental performance in terms of AEC. This study used literature review as the research method. The data were collected from various references toward the practice of Asean Economic Community (AEC). The result shows that there is an increase of corporate governance index and the achievement of environmental performance rating from various companies assessed by Corporate Environmental Performance Ratings (PROPER) in 2014-2015 and Environmental Performance Index (EPI). This proves that Indonesian companies have been ready to face the AEC.
\end{abstract}

\section{KEY WORDS}

AEC, corporate governance, environmental performance.

Corporate governance is still a hotspot among shareholders, regulators, and the community and it significantly increases attention during the last decade (Smolo and Smajic, 2011). Good corporate governance will elevate the investor confidence, help small shareholders, and encourage good decision-making process. In addition, it also repairs the relationship between workers, creditors, and the other stakeholders (Yacob and Basiuni, 2014). According to Nurhaida (2015), corporate governance with the best standard will be one of the determinant factors for the issuer to face the AEC (www.ojk.go.id). AEC will be an opportunity and threat for companies in the ASEAN. Companies which have good governance will treat AEC as the opportunity, but those with poor governance will see it as a threat.

Public awareness of the importance of environmental management makes companies pay attention the corporate governance considering environmental issues. Information of environmental performance of ASEAN countries has been getting attention from researchers like Ab-Rahim (2014); Said (2014). Environment condition will affect investor to make a decision (Said et.al. 2014). Environmental information is useful for policy makers to repair their design of environmental policy and for long-terms sustainability of a nation. Ab-Rahim (2014) stated that countries with smaller economies like Laos, Cambodia, and Brunei are a country with efficient environmental management. In accordance with economic efficiency, countries with larger economies like Malaysia, Indonesia, Philippines, and Singapore is more efficient than the small countries (except Brunei).

This study will discuss the problem of corporate governance and environmental performance in the AEC.

\section{METHODS OF RESEARCH}

This study used literature review as the research method. The data were collected from various references related to the corporate governance, environmental performance, and Asean Economic Community. The time frame was in 2014-2015. The data collected would be analyzed descriptively to provide a view on the achievement of corporate governance and environmental performance in the AEC. 


\section{DISCUSSION OF RESULTS}

ASEAN Economic Community. Free trade era has been entering into force all over the world. This also encourages member states of ASEAN to initiate the program of AEC as the form of regional economic integration planned to achieve in 2015. Indonesian companies surely have to prepare to compete in the AEC.

The practice of AEC will be an opportunity and at the same time threat for Indonesia. An opportunity of goods exchanges among the countries will be created when there are only small obstacles to import or export them. The challenge faced by the member states of ASEAN is the homogeneity of circulating goods so that the products are demanded to have high quality to be marketable in this ASEAN free trade.

AEC will be a good opportunity for Indonesia as the trade obstacle decreases and event there is no again. This will affect the enhancement of export so that the wider the market area of Indonesian products, the higher the exchange resulted. On the other hand, another challenge is the problem of homogeneity of the commodity which is sold and bought so that there is a demand for a better quality to win the competition in the ASEAN.

The competition in the Asean Economic Community demands Indonesian companies to repair the business process to provide a product or service which have a competitive advantage. Due to the practice of AEC, companies around the state members of ASEAN will be a competitor of Indonesian companies. For that reason, considering matters which can support competitive advantage being the priority of Indonesian company is a must.

Competitive advantage can be achieved through the occurrence of a business process which conforms business regulations and those determined by the regulator. In this case, corporate governance as a regulation will be an important thing to achieve the sustainability of a company. Through the existence of good corporate governance, asset security will be achieved and the enhancement of long-terms shareholders value will occur (Effendi, 2009:1).

The regulation determined by the regulator is commonly in the form of responsibility and environment fulfillment. In particular, the implementation of good environmental business will get an attention from stakeholders. Companies which comply regulation required by the regulator will get a good rating. This surely will have an impact on the companies competitiveness. There have been many studies which prove that the establishment of good environmental business will enhance companies performance as the effect of the advantage gotten from the business performance which implies the regulation (Jo and Harjoto, 2011; Gunawan (2015).

ASEAN Corporate Governance. The Organization for Economic Co-operation and Development (OECD) states that "Corporate governance involves a set of relationships between a company's management, its board, its shareholders and other stakeholders. Corporate governance also provides the structure through which the objectives of the company are set, and the means of attaining those objectives and monitoring performance are determined." (OECD, 2004)

The existence of ASEAN integration and free investment environment makes corporate governance stand out as the main discriminating factor which influences the condition where the company can access capital market and the investor can participate to create company value. The standard of ASEAN corporate governance will remain as the main priority in an effort to strengthen ASEAN global competitiveness and to enhance the visibility of ASEAN.

The regulatory framework of corporate governance has to encourage transparency and efficient market, in accordance with law, and to clearly divide obligation and responsibility between the authority running the supervision function, regulation and law enforcement (OECG, 2004). This is the basis for determining a corporate governance framework in Indonesia by using the principles of transparency, accountability, responsibility, independence, and equity and fairness (KNKG, 2006).

ASEAN Capital Market Forum (ACMF) is an association of capital market regulator in the ASEAN. Agreement in ACMF implementation plan aims to realize ASEAN as the one and only economic community in 2015. 
ASEAN Corporate Governance (CG) Scorecard is the program initiated by ACMV; its members are the regulator of the capital market in the ASEAN. This scorecard also has been used to assess the practice of CG of open companies in other ASEAN countries, such as Philippines, Malaysia, Singapore, Thailand, and Vietnam.

Indonesia has shown its high commitment toward the improvement of corporate governance standard which is accordance with the aspiration of corporate governance of Asean capital Market forum (ACMF). Financial Services Authoritys (OJK) has strengthened the regulatory framework for the implementation of good corporate governance in Indonesia through the existence of regulation amendment and the introduction of new regulation.

There are four regulations of corporate governance to the companies listed in stock exchange (public company), namely:

- Financial Services Authoritys (OJK) regulation No.32/POJK/04/2014 on Shareholders General Meeting.

- Financial Services Authoritys (OJK) regulation No.33/PJOK.04/2014 on management and board of commissioners.

- Financial Services Authoritys (OJK) regulation No.34/PJOK.04/2014 on Nomination and Remuneration Committee.

- No.33/PJOK.04/2014 on the corporate secretary.

Those regulations were effectively entered into force on December 2014. Another initiative of road map corporate governance Indonesia is the existence of corporate governance regulation for the public company issued on June 2015. This promotes the adoption of best practices corporate governance among the Indonesian public companies.

The Indonesian Institute for Corporate Directorship (IICD) as the domestic rating agency pointed by OJK plays an important role to enhance the importance of GCG practice and to encourage public companies to adopt ASEAN CG Scored. Efforts performed by IICD are:

- Actively participating in the enhancement of road-map corporate governance Indonesia.

- Providing technical skill to declare regulation and corporate governance regulation for public companies.

- Continuously clarifying the practice of new regulation to the Indonesian public companies, and

- Providing training in ASEAN Corporate Governance Scorecard for Indonesian Public Companies.

The principle of corporate governance assessment of ASEAN Corporate Governance Scorecard is adopted from corporate principles developed by the Organization for Economic Co-operation and Development (OECD): Rights of shareholders, Equitable treatment of all shareholders, Stakeholders' role, Disclosure and Transparency, and board of commissioners and Board of director's responsibility (OECD, 2004).

Rights of Shareholders. Rights of shareholders both majority and minority in the corporate governance framework has to be reserved. Those rights comprised the right to get security guarantee of the method of ownership registration, to transfer and hand over the ownership of share, to get relevant information about the company periodically and regularly, to participate and give vote in the general meeting of shareholders, to select the members of board of commissioners and board of directors, to share the companies' profit.

Healthy corporate governance system makes shareholder actively participate and give an impact to the company decision-making process (Zhuang et al., 2000).

Equitable treatment of all shareholders. Corporate governance framework has to make sure the equitable treatment of all shareholders including those who are a minority and foreign ownership. Shareholders who have the same classification get fair treatment. Shareholders have to be protected from fraud, self-dealing, and insider trading conducted by the board of directors, manager, the main shareholders, or other parties who have information access. In addition, companies also have to transparently reveal the openness in terms of a transaction with conflicting interests. 
Shareholders have to be treated fairly in accordance with equity principle. For that matter, shareholders have to own a full right which is not violated to give one voice for every share. Companies have to provide information needed to the shareholders so that permitting the give of beneficial voice.

All shareholders have to get equitable treatment without considering the number of majorities or minority ownership, as do the openness of beneficial information providing and there is no allotment to share or stock sale by insider trading. This will be realized by issuing company's regulation that protects minority interest.

Stakeholders' Role. Corporate Governance framework has to give certainty that stakeholders and the community are protected by law and to encourage active cooperation between company and stakeholder to enhance welfare, prosperity, job vacancy and company's adequate financial ability. As a result, in the corporate governance, stakeholders' right is reserved and their interest is respected. When the stakeholders' interest reserved is violated by other sides, the stakeholders have to own fair problem solving; in addition, they have to be encouraged to participate in the company. The implementation of corporate governance has to acknowledge stakeholders' right fixed by law or through joint agreement and to encourage active cooperation between company and stakeholder to achieve wealth, job, and company financial sustainability.

According to OECD (2004), the key aspect of corporate governance is making sure the external stream capital for a company, both equity, and credit. Corporate governance also finds ways to encourage stakeholders within a company to economically perform optimal levels of specific resource investments and physical capital within a company. Competitiveness and the success of a company are the results of cooperation between investors, employees, creditors, and vendors who jointly give a contribution.

A company has to acknowledge that stakeholders' contribution is the precious resources to achieve goals. As a result, for long-terms interest, a company has to encourage cooperation to result in prosperity among stakeholders. Corporate governance framework has to acknowledge that company's interest is served by admitting stakeholder's interest and their contribution to the success of long-terms success.

Disclosure and Transparency. Corporate governance framework has to make sure the disclosure of accurate and just-in-time company's material information, among other things financial situation company performance, shareholders, and company management and risk factor might appear. Material information that needs to be disclosed includes financial result and company activities, controlling shareholders, members of the board of directors and executive, the risk might happen, company's structure and target which want to be achieved.

The information has to be disclosed and presented in accordance with the international or national standard which has high quality. In addition, annual company audit has to be performed by an independent auditor. A company also has to spread information fairly, timely, and affordable for users who want to access it.

The implementation of corporate governance has to make sure that the just-in-time and accurate disclosure was applied at all of the material things related to the company. Clear and just-in-time information provided to shareholders will give an effect on decision making both by shareholders themselves and investor candidates.

Shareholders have an important role within the company and active cooperation with stakeholder will result in a healthy company from the aspect of finance. These principles are realized with the consciousness that responsibility is a logical consequence of the existence of authorities, understanding that there is a social responsibility, avoiding the abuse of office, being a professional and respecting attitude, caring for the healthy business environment.

Board of commissioners or Board of Director's Responsibility. Board of directors has to effectively supervise the company and responsible to the shareholders. The members of the board of directors have to act transparently, to do something in good faith, to have performed due diligence and in the best method of their version. Board of directors responsible to accentuate the interest of shareholders and make sure that company performs its activities. In addition, board of directors also has to fulfill several functions of principle supervision, namely: 
- Studying company's strategy, principle action planning, risk policy of annual budget and business plan, stipulating goals, reviewing implementation and company performance and monitoring high income of company, acquisition, and investment.

- Selecting, giving compensation and monitoring if needed is able to change executives and monitoring substitution plan of company's executive.

- Monitoring and handling conflicting interests between the management of the board of directors' members and shareholders that might appear including abuse of transaction with an affiliated side.

- Monitoring the effectiveness of corporate governance implementation and doing some changes if needed.

- Board of directors considers the assignment given to executive officers in sufficient quantities or able to independently implement and stabilize conflicting interest might occur.

Assessment Analysis of Corporate Governance. Assessment Analysis of Corporate Governance decision-making by Indonesian Institute of Corporate Directorship. In 2014, the number of public companies assessed was 550 , it was $4 \%$ much more than assessed in 2013. The number of the public company assessed is not distributed proportionately since the lack of English version which causes Vietnam has less than 100 public companies assessed (Figure 1). The public companies assessed are those which adopt ASEAN Corporate Governance, consisting of ASEAN Corporate Governance Scorecard and ASEAN public companies assessment has shown significant enhancement in adopting best practice corporate governance. Public companies with good corporate governance have been collecting lots of share buyers which will decrease the market susceptibility to the financial crisis, strengthening the right to own, decreasing capital cost, and resulting in bigger capital market enhancement.

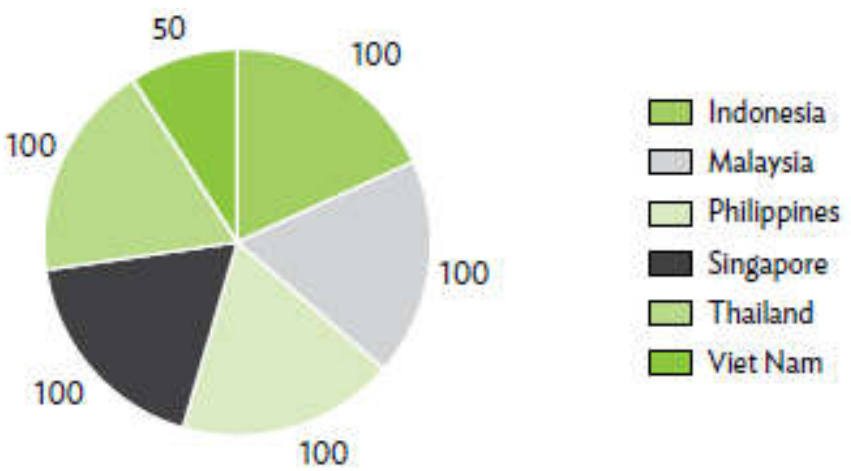

Figure 1 - The number of Public Companies Assessed in ASEAN Countries in 2014 Source: ACMF Working Group D Secretariat, 2014.

ASEAN Scorecard is continuously applied by ASEAN Public Companies as the diagnostic tool to overcome gaping in this practice; several regulators also have been considering the Scorecard to strengthen law or regulation on corporate governance. Figure 2 below will elaborate the average score of corporate governance of Indonesian public companies.

Figure 2 indicates an assessment from 2012; the progressive enhancement was displayed at all parts. From 2012 until 2014, rights of shareholders increase by $27.78 \%$; equitable treatment of all shareholders increases by $23.81 \%$; stakeholders' role increases by $28.30 \%$; disclosure and transparency increases by $6.56 \%$; and responsibility from the board of directors increases by $10.87 \%$. In 2014 , stakeholders' role got highest score (68) followed by disclosure and transparency (65). An item under the right of shareholders and responsibility of the board of directors get the lowest score.

There is score increase during the last three years on the rights of shareholders. In the 2014 assessment, Indonesian public companies reach an average of 4.95 points compared 
to 2013 by 4.15 points. Later on, it is important for Indonesian public companies to more strengthen an initiative to reserve the rights of shareholders.

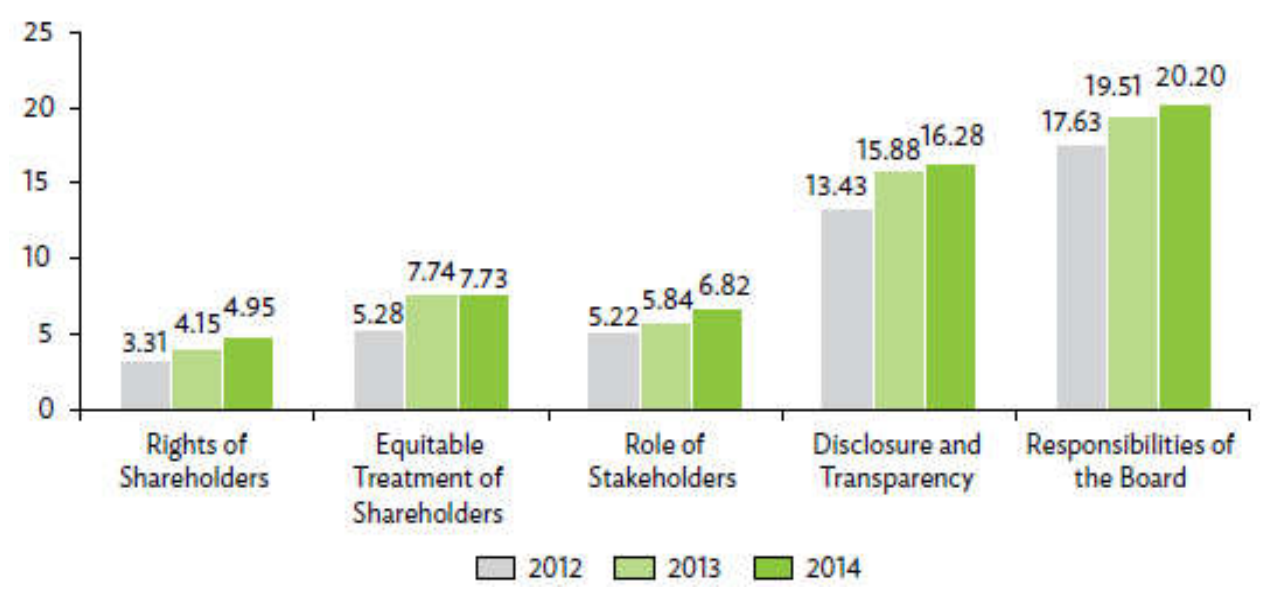

Figure 2 - The average score of Corporate Governance

The key factor of success that has given a contribution to the score enhancement of the rights of shareholders:

- Quality improvement of meeting summary;

- Publication of English version of information from shareholders general meeting;

- Strengthening regulatory framework to reserve the rights of shareholders.

The implementation of corporate governance to the Indonesian public companies shows the power of rights of shareholders. Rights of Shareholders are to participate in the policy that relates to the company and a basic change which is in accordance with:

- Amendment of company constitution;

- Authorization of additional shares;

- Transferring all or substantially the entire asset;

- Rights of shareholders to agree on the remuneration of the board of directors or board of commissioners;

- Shareholders general meeting is performed in an accessible location;

- Independent side is appointed by the board of directors or board of commissioners to evaluate the fairness of transaction cost of merger and acquisition.

Equitable treatment of all shareholders of public companies since 2012 shows a better score, the focus has to be put on:

- increasing the quality and information standard of shareholders general meeting;

- Notification issuance of shareholders general meeting in English;

- Strengthening regulatory framework and law enforcement.

Corporate governance performance for section "Equitable treatment of all shareholders shows a power on these matters:

- The existence of clear disclosure from voting rights for every class of share: amendment of company constitution; authorization of additional share; transferring all or substantially the entire asset;

- Availability of Proxy document;

- Availability of insider trading policy;

- Availability of transaction policy with related side.

Stakeholders' roles in the 2014 assessment reached $31 \%$ increase or 6.82 points from 2012. The role of stakeholders reaches the highest increase achieved year by year compared to other parts. Strengths in enhancing the role of stakeholders are characterized by:

- Availability of stakeholder interest policies in relation to: customer welfare; sustainable development; the rights of creditors; 
- Implementation of stakeholder policy is related to: welfare and customer health; sustainable development; the rights of creditors;

- Availability of company policy regarding: welfare, safety, and health of employees; employee development and training program.

The average score of Indonesian Public Companies disclosure is 16.28 points, with an increase of $2.51 \%$ compared to 2013 . Strengths in this area are marked by the enactment of OJK rules on transparency and disclosure. However, there are still some public companies that have not revealed some fundamental items for transparency and disclosure.

Supporting strengths in the area of disclosure and transparency are:

- Good corroboration disclosure structure;

- Good disclosure in terms of: the main risk; financial performance indicators; corporate objectives; training for director; the number of board meetings, including attending the board of commissioners meeting;

- Disclosure of related party transactions;

- Various modes of communication such as quarterly report and company website;

- Timeliness of the release of financial statements and annual reports.

Board of directors responsibility has an average score of 20.20 points, which has increased by 19.21 points compared to 2013. The board of directors' commitment to adopt corporate governance best practices is a major success factor in the upgrading of this area. The existing regulations play a role in ensuring that the board takes responsibility effectively and efficiently.

The achievement of corporate governance of Indonesian public companies in 2014 shows a smaller increase compared to 2013. Factors contributing to the low increase in 2014 can be attributed to the following:

- Low-level awareness for the ASEAN Corporate Governance Scorecard is especially small companies.

- Strong regulatory frameworks have not been implemented during the assessment period in 2014.

Environmental Performance. Environmental performance becomes an important thing in the AEC. The existence of free trade makes Indonesian companies able to defend their self against the foreign companies coming to Indonesia. In terms of environmental performance, environmental performing companies are of course will have an advantage than those who are not. Proper (2015) stated that if companies apply the system of good environmental management they will result in an efficiency. This will encourage companies to always create an innovation to result in their own values and make them become competitive advantage companies.

Adoption of the environmental issue in the management of the company will help to reduce the risk of the environment. It can be performed by applying eco-efficiency as being stated by Business Council for Sustainable development (WBCSD) that eco-efficiency helps to decrease the number of materials and energy, decrease pollution, and enlarge recycled materials, maximize the use of renewable natural resources, extend the lifetime of products and increase the intensity of service which is the key factor of eco-efficiency (ProLH, 2007). In order to establish a new market by embracing environmental issue, a company can apply Eco-design, Eco-sales, and marketing (Proper, 2015).

Environmental performance achievement as the result of company business activity will be reflected from environmental performance achieved by a company. The measure of environmental performance is different as depends on the institution or a country conducting a research. In Indonesia, a performance measure of environment applied by the ministry of environment is based on the PROPER.

The implementation of PROPER encourages the world of business to be consistent with the environment, applies the efficiency of resources usage and empowers the community and makes an innovation to manage the environment. Due to the fact that the company will be assessed for its performance based on efficiency in resource use, through the criteria of efficiency, emission reduction, conservation and reduction of water pollution 
load, 3R (reduce, reuse, and recycle) B3 waste and non-B3 solid waste and biodiversity protection, then it by itself makes the company more efficient in resource utilization so that the company puts some of that resources aside for the surrounding community with community empowerment programs.

The size of Proper is identical to the Green Economy, which according to the United Nation of Environment Program (UNEP) is a reconfiguration of businesses and infrastructure to generate better returns from natural resource, human being, economic capital while reducing greenhouse gas emissions, reducing waste, reducing extraction of natural resources and reducing social inequality (www.unep.org).

Table 1 indicates the assessment of the environmental performance of Indonesian public companies during the period of 2012 - 2015 showing an increase both in terms of the number of Public Companies assessed and environmental performance achievement which increases.

Table 1 - Indonesian Public Companies Environmental Performance Achievement

(Source: Proper, 2005)

\begin{tabular}{|c|r|r|r|r|r|r|}
\hline \multicolumn{1}{|c|}{ YEAR } & \multicolumn{1}{l|}{ BLACK } & \multicolumn{1}{l|}{ REUE } & GREEN & \multicolumn{1}{c|}{ GOLD } & \multicolumn{1}{c|}{ TOTAL } \\
\hline $2002-2003$ & 2 & 20 & 52 & 8 & 0 & 82 \\
\hline $2003-2004$ & 22 & 64 & 99 & 9 & 0 & 194 \\
\hline $2008-2009$ & 41 & 116 & 182 & 21 & 0 & 360 \\
\hline $2008-2009$ & 9 & 73 & 305 & 45 & 0 & 432 \\
\hline $2008-2009$ & 32 & 118 & 385 & 40 & 1 & 576 \\
\hline $2009-2010$ & 47 & 154 & 433 & 54 & 2 & 690 \\
\hline $2010-2011$ & 48 & 233 & 603 & 106 & 5 & 995 \\
\hline $2011-2012$ & 79 & 295 & 805 & 119 & 12 & 1,310 \\
\hline $2012-2013$ & 17 & 551 & 1,099 & 113 & 12 & 1,792 \\
\hline $2013-2014$ & 21 & 516 & 1,224 & 121 & 9 & 1,891 \\
\hline $2014-2015$ & 21 & 529 & 1,406 & 108 & 12 & 2,076 \\
\hline
\end{tabular}

The increase in the number of public companies that follow the environmental performance assessment program from year to year increases. This is in line with the increase in the number of companies that meet the compliance criteria in the applicable regulations. This demonstrates the increase of Public Company awareness to run a business that is not only pursuing profit but also paying attention to environmental management as required.

The number of companies which its environmental performance gets bigger assessed from the achievement of the Blue criteria in 2012 to 2013 has increased sharply. This is due to the efforts of the company in complying with the rules, besides the expansion of the scope of the companies that participated in the rating program conducted by the Ministry of Environment.

The achievement of green criteria is an effort made by the company by undertaking environmental management beyond compliance through the implementation of environmental management systems and utilizing resources efficiently and performing social responsibility well (www.menlh.go.id/proper). Compared to the achievement of the blue criteria, the number of companies performing under the green criteria is smaller, let alone companies that get gold ratings. 
The achievement of green and gold criteria in 2010 to 2015 was not too significant. This illustration shows that in general the environmental performance achievement of public companies is still on the blue criterion or meets the required regulations only.

Environmental performance achievement is the result of implementing voluntary initiatives to integrate social and environmental issues in today's business, in the hope of sustainability. Companies with good environmental performance will certainly support sustainable development. For that matter, sustainability will be increasingly important so that this has changed the direction of business (UNGC, 2010).

As sustainability is being recognized as a source of competitive advantage, organizations seek to achieve economic sustainable performance, social and environmental, although economic growth remains at the core of business (Hart and Milstein, 2003; Porter and Kramer, 2006). Thus, business sustainability efforts are mainly directed to expand the market and keep business as usual. The implementation of MEA in 2015 became a place to expand the market of Indonesian companies.

Other environmental performance measures besides PROPER are those issued by Yale University known as the Environmental Performance Index (EPI). It is grouped into 9 categories of issues: health impact, air quality, water and sanitation, water resources, agriculture, forests, fisheries, habitats and biodiversity, and climate and energy, with a total of 20 indicators. (www.epi.yale.edu).

Table 2 indicates environmental performance achievements of ASEAN countries from 2014 to 2016.

Table 2 - Environmental Performance Index of ASEAN Countries

\begin{tabular}{|l|c|c|c|c|c|}
\hline \multirow{2}{*}{ COUNTRY } & \multicolumn{2}{|c|}{ EPI 2016 } & \multicolumn{2}{c|}{ EPI 2014 } & \multirow{2}{*}{ RATING CHANGES } \\
\cline { 2 - 5 } & RATING & SCORE & RATING & SCORE & -10 \\
\hline Singapore & 14 & 87.04 & 4 & 81.78 & -12 \\
\hline Malaysia & 63 & 74.23 & 51 & 59.31 & 48 \\
\hline Philippines & 66 & 73.70 & 114 & 44.02 & -13 \\
\hline Thailand & 91 & 69.54 & 78 & 52.83 & -61 \\
\hline Brunei Darussalam & 98 & 67.86 & 37 & 66.49 & 5 \\
\hline Indonesia & 107 & 65.85 & 112 & 44.36 & 5 \\
\hline Vietnam & 131 & 58.50 & 136 & 38.17 & -1 \\
\hline Cambodia & 146 & 51.24 & 145 & 35.44 & -21 \\
\hline Laos & 148 & 50.29 & 127 & 40.37 & 11 \\
\hline Myanmar & 153 & 48.98 & 164 & 27,44 & \\
\hline
\end{tabular}

Table 3 - Score Indicator of Indonesia EPI

\begin{tabular}{|l|c|c|}
\hline \multicolumn{1}{|c|}{ Indicator of EPI } & 2016 & 2014 \\
\hline Rank & 107 & 112 \\
\hline Score of EPI & 65.85 & 44.36 \\
\hline EH - Health Impacts & 75.43 & 67.55 \\
\hline EH - Air Quality & 80.36 & 75.31 \\
\hline EH -Water and Sanitation & 7466 & 2429 \\
\hline EV - Water Resources & 12.69 & 0.02 \\
\hline EV - Agriculture & 84.31 & 51.85 \\
\hline EV - Forests & 12.96 & 7.75 \\
\hline EV - Fisheries & 23.59 & 25.8 \\
\hline EV- Biodiversity and Habitat & 81.62 & 78.08 \\
\hline EV - Climate and Energy & 81.59 & 45.25 \\
\hline
\end{tabular}


The rating changes of environmental performance achievement show the existence of changeover in the environmental management. There are four countries which undergo rating enhancement; Philippines, Indonesia, Vietnam, and Myanmar. Indonesia has been experiencing EPI rating enhancement from 112 with the score of 44.36 in 2014 and 107 with the score of 65.85 in 2016. This change in rating indicates an improvement in the environmental performance index achieved by up 5 ranks in 2016.

Table 3 indicates score achievement of each indicator of Indonesia Environmental Performance Indicators (EPI).

The increase of EPl's score and rating shows the existence of effort to repair environmental management from 2014 to 2016. Each of EPI indicators in 2014 compared to 2016 shows an enhancement so that the general score also increases. This shows that there is a betterment effort of environmental performance in the Asean Economic Community.

\section{CONCLUSION}

Based on the discussion above, several conclusions can be made as follows: corporate governance of Indonesian public companies shows an increase during the observation so that can be concluded that public companies are ready to face the AEC; environmental performance of Indonesian public companies measured by PROPER and EPI shows an improvement during the observation period so that can be concluded that those companies are ready to face the AEC.

\section{REFERENCES}

1. Ab-Rahim, Rossazana. 2014 Environmental Performance of ASEAN Countries: A Data Envelopment Analysis Approach. Journal of Economic Policy \& Research. Vol. 10 Issue 1, pp. 98-108.

2. Albelda, E. 2011. The role of management accounting practices as facilitators of the environmental management Evidence from EMAS organisations. Sustainability Accounting, Management and Policy Journal Vol. 2 No. 1, 2011 pp. 76-100.

3. Effendi, M. Arief. 2009. Good Corporate Governance; Teori dan Implikasinya. Jakarta; Salemba Empat.

4. Gunawan, J. 2015. Corporate Social Disclosure in Indonesia; Stakeholders influence and motivation, Social Responcibility Journal, VI.11. No.3.

5. Hart, S.L. and Milstein, M.B. 2003. Creating sustainable value. Academy of Management Executive, Vol. 17 No. 2, pp. 56-67.

6. OECD Report, 2004. The OECD Principle of Corporate Governance. The Organization for Economic Cooperation and Development, Paris.

7. ProLH, GTZ, Panduan Penerapan Eko-efisiensi Usaha Kecil dan Menengah Sektor Batik. Jakarta: Kementrian Negara Lingkungan Hidup Republik Indonesia, 2007.

8. Said, M.R. Sulaiman, M. and Ahmad N. 2014. Environmental information usefulness to Stakeholders: Empirical Evidence from Malaysia. Social Responsibility Journal. Vol. 10 No. 2, 2014, pp. 348-363.

9. Smolo and Smajic, 2011. Recent fiasco in Qatar: the need for good governance. ISRA Bulletin, Vol. 8, pp. 3-4.

10. The ASEAN Secretariat Jakarta. 2015. A Blueprint for Growth ASEAN Economic Community 2015: Progress and Key Achievements.

11. Yacoob, $\mathrm{H}$ and Basiuni, J. 2014. Corporate governance model of a state-owned enterprise: evidence from an Asian emerging market. Corporate Governance . Vol. 14 No. 4, 2014, pp. 504-514.

12. www.asean.org. Asean corporate governance scorecard; country report and assessment 2014. Retrieved on 24 Agustus 2016.

13. www.asean.org. Asean corporate governance scorecard; country report and assessment 2015. Retrieved on 24 Agustus 2016. 
14. www.asean.org. A Blueprint for Growth ASEAN Economic Community 2015: Progress and Key Achievements. Retrieved on 24 Agustus 2016.

15. www.ojk.go.id. Roadmap tata kelola perusahaan Indonesia. Retrieved on 24 Agustus 2016.

16. www.menlh.go.id/proper/ Publikasi Proper 2015. Retrieved on 23 November 2016

17. www.epi.yale.edu. 2016 Report - Environmental Performance Index - Yale University. Retrieved on 28 Desember 2016. 
DOI https://doi.org/10.18551/rjoas.2017-09.04

\title{
СОВРЕМЕННЫЕ ТЕНДЕНЦИИ МИРОВОЙ ТОРГОВЛИ СЕЛЬСКОХОЗЯЙСТВЕННОЙ ПРОДУКЦИЕЙ CURRENT TRENDS OF WORLD TRADE BY AGRICULTURAL PRODUCTS
}

\author{
Астахова E.B. ${ }^{*}$, кандидат экономических наук \\ Astakhova E.V., Candidate of Economic Sciences \\ Владивостокский государственный университет экономики и сервиса, \\ Владивосток, Россия \\ Vladivostok State University of Economics and Service, Vladivostok, Russia \\ Уотсон Р., координатор образовательных программа обучения учителей \\ Watson R., Special Education Coordinator \\ Университет Клермонт, США \\ Claremont Graduate University, USA \\ *E-mail: evastahova1@yandex.ru
}

\begin{abstract}
АННОТАЦИЯ
Сельскохозяйственный комплекс мировой экономики представляет собой один из наиболее важных секторов мирового хозяйства, без которого было б невозможным само существование человечества. От наличия и качества продуктов питания, в первую очередь, зависит фризическое существование и здоровье миллиардов людей. Агропромышленный комплекс включает различные отрасли и предприятия: сельскохозяйственное машиностроение, переработка продукции агросектора, сельскохозяйственные, торговые, транспортные и т.п., прямо или косвенно вовлечены в процессы создания и распределения продуктов питания и продукции промышленного назначения, получаемых в результате переработки сельскохозяйственного сырья.
\end{abstract}

\section{ABSTRACT}

The agricultural complex of the world economy is one of the most important sectors of the world economy, without it would be impossible for the very existence of mankind. From the availability and quality of food, in the first place, depends on the physical existence and health of billions of people. The agricultural complex includes various industries and enterprises: agricultural machinery, processing of agricultural products, agricultural, trade, transport, etc, that are directly or indirectly involved in the processes of creating and distributing food products and industrial products obtained as a result of processing agricultural raw materials.

\section{КЛЮЧЕВЫЕ СЛОВА}

Агропромышленный комплекс, сельское хозяйство, мировая экономика, мировая торговля.

\section{KEY WORDS}

Agro-industrial complex, agriculture, world economy, world trade.

Развитие мировой торговли сельскохозяйственной продукцией происходит под воздействием кардинальных изменений на международной арене вследствие глобализации хозяйственной деятельности. Наряду с ростом интернационализации хозяйственной жизни и увеличением взаимозависимости национальных экономик, продолжается острая конкуренция между поставщиками сельскохозяйственного сырья и продовольствия на международные рынки. На пути к единой глобальной экономике происходит дальнейшее обособление больших групп государств в три-четыре региональных мегарынка (европейский, североамериканский, азиатский, а также 
латиноамериканский), которые соперничают между собой за лидерство в ключевых секторах экономики, в том числе на рынке сельскохозяйственной продукции.

Целью статья является анализ тенденций и особенностей развития мировой торговли аграрной продукцией и определения места и роли РФ в указанных процессах. Объектом исследования служит мировая торговля аграрной продукцией как важный элемент глобальной торговой системы. Предметом исследования являются современные тенденции в мировом развитии агропромышленного комплекса, торговле сельскохозяйственной продукцией. Основными методами исследования в процессе выполнения работы являются следующие: сравнение, обобщение, статистического и экономического анализа, графический метод, анализ рядов динамики и другие. Информационную базу исследования составляют статистические отчеты и официальные аналитические материалы Всемирной организации торговли, Организации Объединенных Наций, Федеральной службы государственной статистики Российской Федерации, профильных организаций.

В прошлом веке был достигнут огромный прогресс. Во всем мире произошло улучшение благосостояния человека благодаря технологиям в производственной сфере, инновациям, быстрой урбанизации. Однако, в условиях сегодняшнего мира миллиарды людей по-прежнему сталкиваются с повсеместной нищетой, неравенством, безработицей, деградацией окружающей среды, болезнями и лишениями. В области устойчивого развития на период до 2030 года одной из основных целей системы Организации Объединенных Наций является ликвидация голода на глобальном уровне. По мере дальнейшего развития структуры потребления и производства все более важную роль в удовлетворении растущих потребностей стран с дефицитом продовольствия будет играть торговля сельскохозяйственной и продовольственной продукцией. В последние десятилетия объемы торговли сельскохозяйственной и продовольственной продукции в мире росли быстрыми темпами при активном вовлечении в эту торговлю стран в качестве экспортеров или импортеров.

Важно выделить участие ряда экспертов из научно-исследовательских институтов, международных неправительственных организаций и межправительственных организаций в области исследований состояния рынков сельскохозяйственной продукции А. Бахалима, Ж. Балие, Э. Бьянки, К. Бонекампа, С. Брегдон, Л. Бринка, П. Брауна, Э. Чапото, У. Фостера, Т. Джордано, а также отечественных исследователей в вопросах развития АПК на международном и национальном уровнях: В. Андрийчука, В. Агаева, П. Абалкина А.Бабенка, В. Богачова, И. Богданова, О. Бужина, А. Гойчук, В Ильяшенко, З.Ильину, О. Кочеткова, Б. Кумахова, Н. Скидана, В. Суперсона, В. Ткаченко, В.П.Щербаня, В.В.Юрчишина и др.

За последнее десятилетие объемы мировой торговли продовольственной продукции выросли почти втрое при прогнозируемом дальнейшем увеличении темпов роста. Мировая торговля продовольственной продукцией продолжает развиваться быстрыми темпами, однако различия в организации и структуре торговли в зависимости от товара и региона остаются значительными. По оценкам продовольственной и сельскохозяйственной ассоциации Великобритании, население мира увеличится на 47\%, до 8,9 млрд., к 2050 году. Практически весь прирост населения придется на долю развивающихся стран. Урбанизация будет расти ускоренными темпами, около $70 \%$ населения мира, как ожидается, будет городским (по сравнению с 49\% на сегодняшний день) (рис.1).

Для того чтобы обеспечить продовольствием растущее, в большей степени городское и потенциально более благополучное население, к 2050 году потребуется увеличить объемы производства продуктов питания с исходного уровня 2005-2007 годов на $60 \%$. Средний годовой объем чистых инвестиций в сельское хозяйство развивающихся стран, необходимый для обеспечения такого роста производства, оценивается в 83 млрд долл. США. [2]

В этом контексте следует говорить об обострении глобальной продовольственной проблемы, которая заключается в опережающем росте численности населения в сравнении с ростом производства продуктов питания. В 
результате этого в мире происходит увеличение численности недоедающих и голодающих.

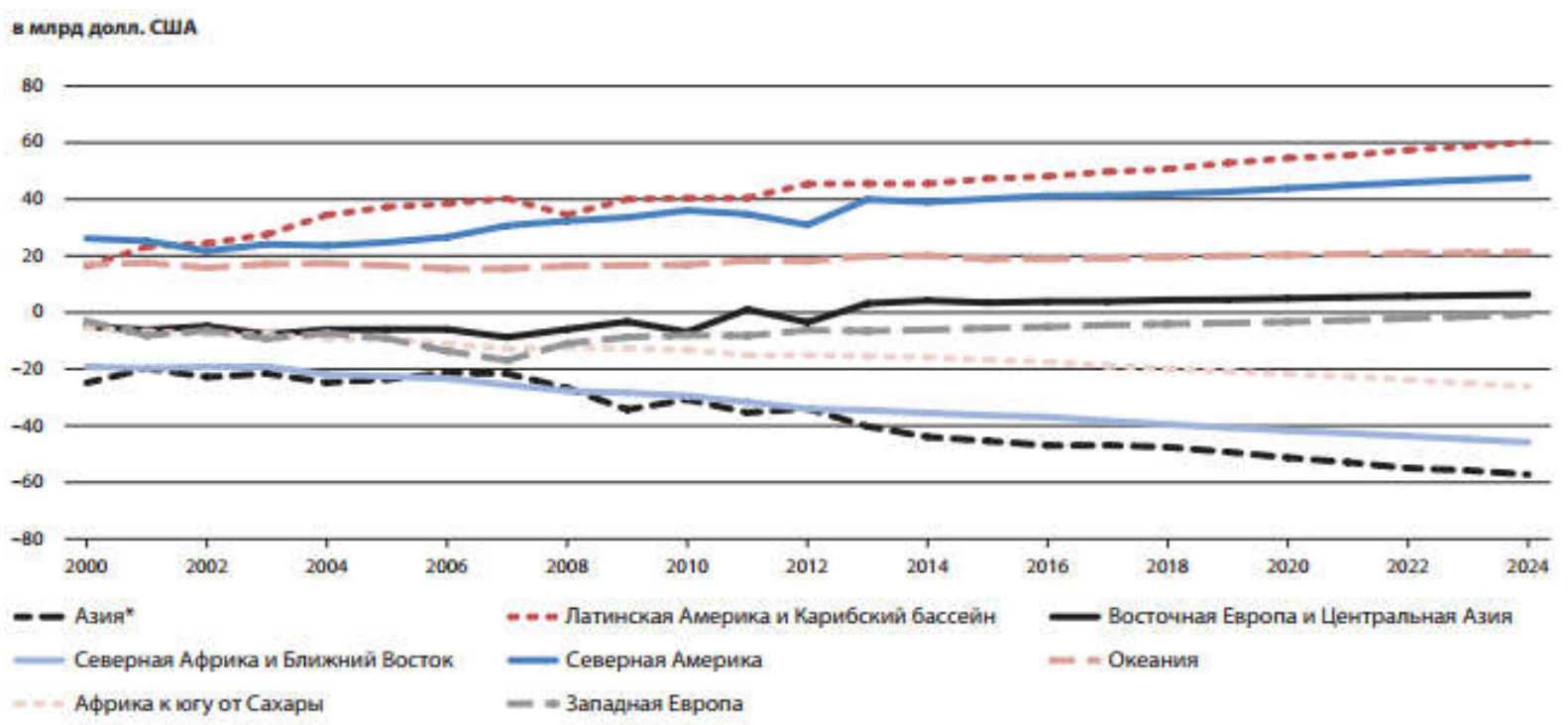

Рисунок 1 - Динамика торговли сельскохозяйственной продукцией по регионам, 2000-2024 годы [1]

На современном глобальном рынке сельскохозяйственной продукции выделяют две главные качественные тенденции. Первая из них заключается в том, что обострение проблемы голода дало толчок для активизации производства генетически модифицированной сельскохозяйственной продукции потребляется на национальном рынке отдельных стран и реализуется на международном уровне. Прослеживается переход от полного и категорического отказа стран производить и потреблять генномодифицированную продукцию до законного утверждения допустимых пределов выращивания определенных видов сельскохозяйственной продукции и расширении научных исследований в данном направлении.

Таким образом, эти две тенденции на международном рынке сельскохозяйственной продукции можно объяснить одновременным существованием спроса на качественную и безопасную продовольственную продукцию со стороны развитых стран и необходимостью преодоления голода в развивающихся странах, за счет потребления генетически модифицированной продукции.

Ключевыми импортерами сельскохозяйственной и продовольственной продукции являются страны EC, США, Китай и Япония. Наряду с тем, что главными импортерами сельского хозяйства и продовольственной продукции в мире преимущественно высокоразвитые страны, лидерами по ее закупки с точки зрения доли в структуре национального импорта являются развивающиеся страны.

Самым быстрорастущим чистым импортером является Азия. Крупнейшим чистым экспортером продовольствия стала Латинская Америка, где существенный рост производства опережает устойчивый рост потребления. Вторым по значимости чистым экспортером является Северная Америка, однако это, скорее, следствие стагнации потребления в регионе, чем роста производства. Восточная Европа и Центральная Азия находятся в процессе перехода из чистых импортеров в чистые экспортеры. В то же время растут показатели чистого импорта стран Африики к югу от Сахары, в основном вследствие увеличения численности населения, тогда как Ближний Восток и Северная Африка быстро превращаются в регион чистого импорта, поскольку производство продуктов питания не успевает за ростом спроса.

Большинство стран рассматривают расширение участия в мировой торговле как обязательный элемент своей национальной стратегии в области торговли. Однако для того чтобы торговая деятельность способствовала укреплению продовольственной 
безопасности, потребуется обеспечить надлежащее регулирование процесса повышения открытости экономики для торговли. Торговля оказывает влияние на все четыре измерения продовольственной безопасности: наличие, доступ, использование и стабильность. Взаимосвязь торговли с этими измерениями носит сложный характер и обусловлена целым рядом глубинных фракторов, что объясняет большую разницу в опыте разных стран и ограничивает возможности для выявления поддающихся обобщению взаимосвязей.

Соотношение между степенью вовлеченности в торговую деятельность и продовольственной безопасностью зависит от того, как работают продовольственные рынки, от способности и готовности производителей реагировать на изменение стимулов, порождаемых развитием торговли, и от территории, затронутых проблемой отсутствия сельскохозяйственной продукции (рис. 2).

\begin{tabular}{|c|c|c|c|c|c|c|c|}
\hline & $\begin{array}{c}\text { Азиатско- } \\
\text { Тикоокеанский } \\
\text { регион }\end{array}$ & Африкка & Espona & $\begin{array}{c}\text { Латинская } \\
\text { Америка й } \\
\text { Каршбский } \\
\text { бассейн }\end{array}$ & $\begin{array}{c}\text { Ocтальные } \\
\text { развитые } \\
\text { страны }\end{array}$ & $\begin{array}{l}\text { Северная } \\
\text { Америка }\end{array}$ & $\begin{array}{c}\text { Развитивые } \\
\text { страны } \\
\text { Океании }\end{array}$ \\
\hline \multicolumn{8}{|c|}{ D6bem 4ucmoro skenopma, mbic. motity } \\
\hline Пишеницца & -49963 & -44987 & 45788 & -7074 & -8299 & 46206 & 18329 \\
\hline Puc & 21083 & -18052 & -1368 & -1192 & -2637 & 2419 & 299 \\
\hline Кормовые зерновые & -63999 & -22851 & 30402 & 21795 & -19595 & 53574 & 4154 \\
\hline Масличные культуры & -98449 & -3494 & -11469 & 57748 & -5185 & 58323 & 2921 \\
\hline Шpor & -27206 & -4461 & -19586 & 49715 & -4912 & B 963 & -2669 \\
\hline Говкаинна & -2105 & -877 & -1110 & 3341 & -1147 & 42 & 2224 \\
\hline Свинина & -2625 & -714 & 1715 & -376 & -1280 & 3621 & -362 \\
\hline Баранина & -790 & 53 & -140 & 9 & -40 & -71 & 1032 \\
\hline Птица & -5234 & -2192 & 877 & 3677 & -1729 & 4710 & 57 \\
\hline Pы6а & 9625 & -3323 & -1822 & 2015 & -2769 & -3406 & -220 \\
\hline Рыбная мука & -1418 & 43 & -7 & 1398 & -112 & 125 & -28 \\
\hline Рыбий жир & -124 & 56 & -189 & 296 & -30 & 4 & -12 \\
\hline Сливомное масло & -413 & -161 & 80 & -22 & -39 & 98 & 476 \\
\hline Сыры & -633 & -219 & 879 & -284 & -365 & 318 & 518 \\
\hline $\begin{array}{l}\text { Oбезжиренныс сужое } \\
\text { мопоко }\end{array}$ & -1241 & -387 & 640 & -367 & -95 & 826 & 642 \\
\hline Lеentioe cyxoe manoko & -1372 & -618 & 379 & -46 & -21 & 4 & 1656 \\
\hline Pactutenbrite macna & 5447 & -8775 & -2366 & 8362 & -2279 & 235 & -386 \\
\hline Caxap & -17342 & -11684 & -591 & 38337 & -4475 & -4511 & 3636 \\
\hline Хлопок & -7164 & 1620 & 48 & 927 & 741 & 2562 & 1035 \\
\hline
\end{tabular}

Memoyнuк: no материалам FAO and OECD. 2015. OECD-FAO Agricultural Outiook 2014-2023, Table 1.1. Paris, OECD Publishing.

Рисунок 2 - Объемы чистого экспорта в мире, тыс.тонн

Последнее несколько лет наблюдается повышение мировых цен на продовольствие резкими скачками, которое следует рассматривать в контексте более долгосрочной тенденции снижения реальных цен. Значение скачков цен на продовольствие связано с их потенциально неблагоприятным воздействием на продовольственную безопасность и питание, и даже в том случае, если они носят эпизодический характер, их необходимо учитывать в процессе принятия долгосрочных решений в сфрере регулирования торговли продовольствием и сельскохозяйственными продуктами.

Геополитические и метеорологические фракторы неопределенности могут привести к усугублению проблемы эпизодических скачков цен на продовольствие в будущем, что может повысить вероятность и частоту перебоев в торговых потоках. 
Общемировые тенденции и перспективы в области сырьевых товаров свидетельствуют о резких колебаниях.

На рынках зерна цены с 2012 года испытывали тенденцию к понижению в результате хороших урожаев, что позволило пополнить запасы. Далее наблюдался непродолжительный всплеск цен на зерно из-за опасений по поводу погодных условий в странах - крупнейших производителях сельскохозяйственных пищевых продуктов, таких как Соединенные Штаты и Бразилия, и напряженности в черноморском регионе [5].

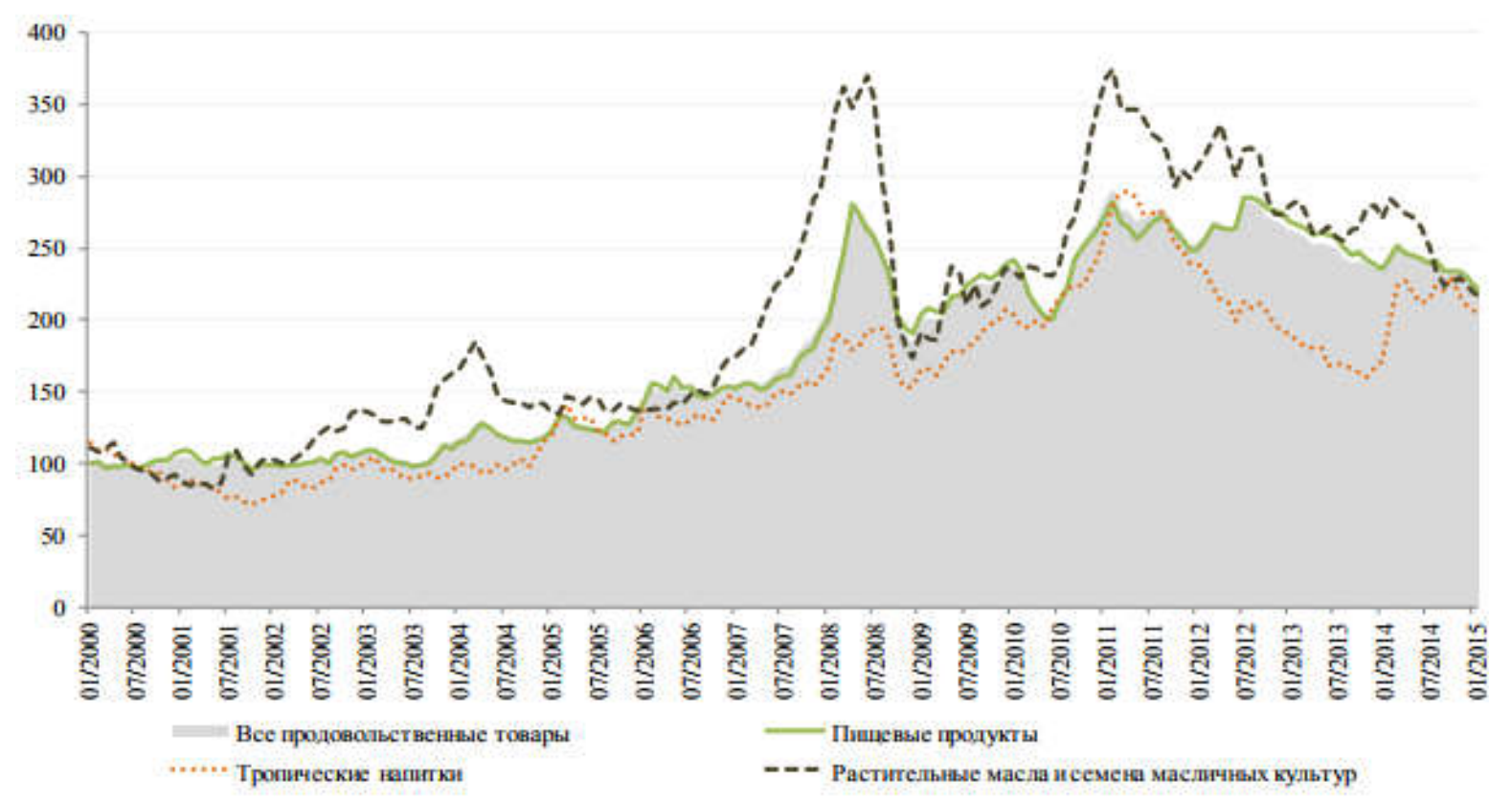

Рисунок 3 - Динамика индекса цен на отдельные группы сельскохозяйственных товаров $[3,4]$

Цены на пшеницу и кукурузу подвержены аналогичной динамике. Цены на зерно упали, поскольку условия для сбора урожая улучшились, что способствовало увеличению объемов производства, достигнув самых низких значений. Согласно прогнозам, на рынках пшеницы и кукурузы не ожидается резких изменений конъюнктуры, что объясняется сохранением стабильного предложения, если только основные районы произрастания зерновых культур не пострадают в результате неблагоприятных погодных условий. На рынках риса цена за тонну таиландского риса, являющегося эталонным сортом для Азии, несмотря на краткосрочные колебания, испытывала тенденцию к понижению. Позднее неблагоприятные погодные условия в Таиланде в сочетании с решением фермеров этой страны ограничить посадки риса вследствие прекращения действия программы государственного субсидирования оказали повышательное давление на цены. Затем, когда правительство Таиланда продолжило распродажу запасов, цены на рис продолжили неуклонное снижение. Если эта понижательная динамика сохранится, то фермеры, занимающиеся выращиванием риса в странах - крупнейших производителях, вероятно, переключатся на выращивание более выгодных культур, что вызывает опасения в отношении объемов будущего производства. На рынках сахара цены также испытывают общую тенденцию к понижению, хотя при этом и подвержены краткосрочным колебаниям. Понижение цен на сахар объяснялось главным образом большими урожаями, что позволило накопить значительные общемировые резервы [6].

Большое влияние оказало также замедление роста в Китае и странах с развивающейся экономикой. Что касается предложения, то на ряде отдельных рынков минерального сырья и сохраняется высокий уровень предложения вследствие их 
интенсивного производства, являющегося результатом крупных инвестиций в недорогостоящую продукцию.

Эмбарго западных стран, направленное на ограничение ввоза определенных продовольственных товаров из стран - участников санкций в отношении России, повлекло за собой сокращение объемов импорта данной категории товаров. В стоимостном объеме импорта произошло снижение поставок продовольственных товаров.

Подобная ситуация способствует стимулированию развития внутреннего производства, но реализация программы поддержки отечественного производства происходит лишь в некоторых сегментах продовольственных товаров. Движение в поддержку продовольственного суверенитета выступает за снижение зависимости от импорта продуктов питания $и$ за укрепление национальных $и$ местных продовольственных систем. Этот подход предполагает, что значительная доля национального потребления удовлетворяется за счет внутренних запасов, а не благодаря импорту пищевых продуктов. Однако производство достаточных объемов продовольствия для удовлетворения национального спроса не обязательно означает, что все домохозяйства страны имеют равный доступ к необходимым им пищевым продуктам или что такой подход к обеспечению продовольствием отличается большей стабильностью или более доступными ценами по сравнению с импортом.

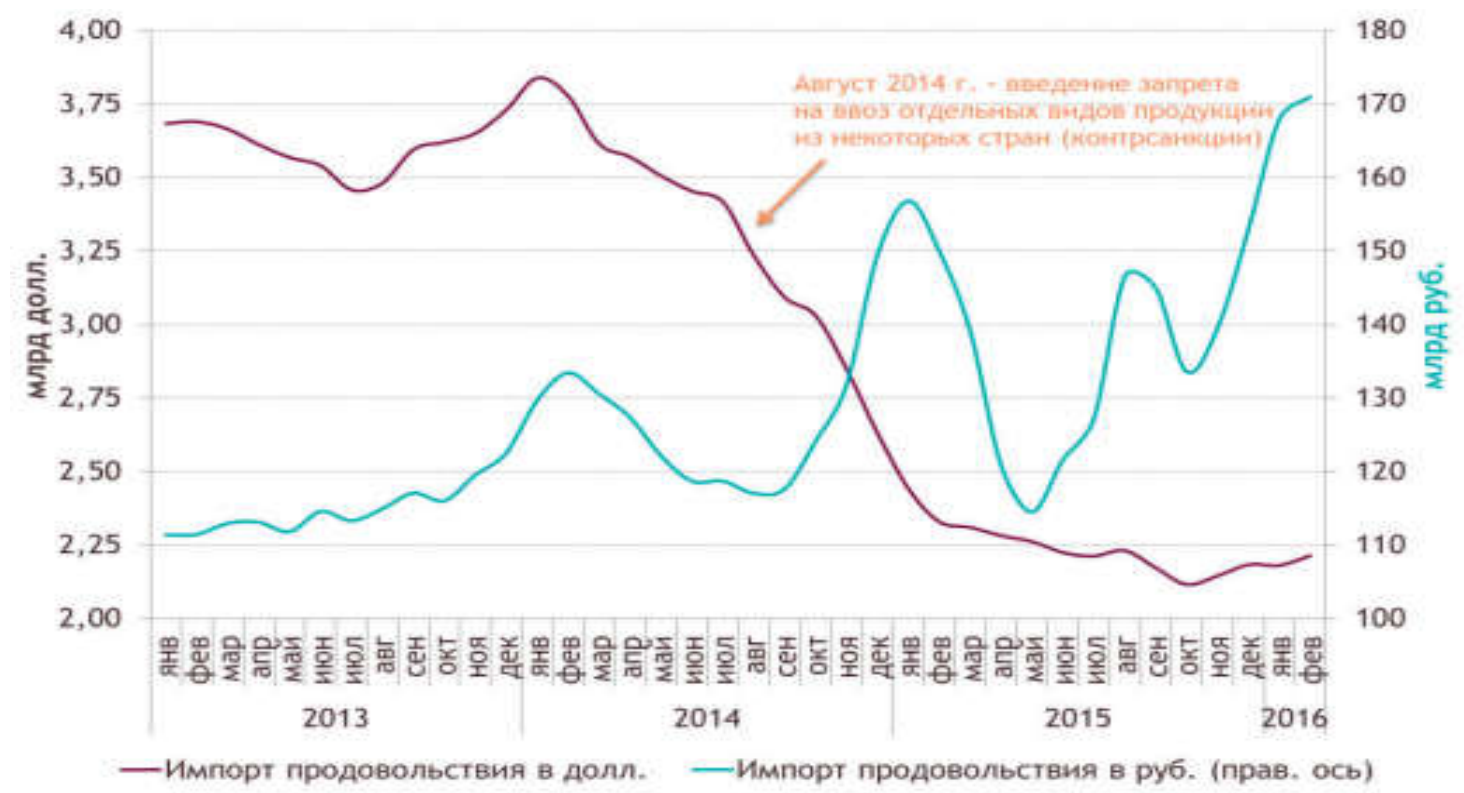

Рисунок 4 - Динамика импорта продовольственных товаров в РФ [5]

Снижение импорта продовольственной продукции стимулирует развитие мелкого сельскохозяйственного производства, которое представлено 257 тыс. субъектами малого предпринимательства, включая 223,2 тыс. крестьянских (фермерских) хозяйств и индивидуальных 37 предпринимателей. Несмотря на это, доля занятых в основных отраслях сельской экономики России (сельское хозяйство, охота, лесное хозяйство, рыболовство, рыбоводство) с 2000 по 2013 год сократилась с 49 процентов до 23 процентов общего числа занятых в сельской местности. Производится 50,5 процента зерновых и зернобобовых культур, 57,9 процента подсолнечника, 94 процента картофеля, 88,7 процента овощей и 65,4 процента молока [7].

Таким образом, этот сектор играет важную роль не только в обеспечении занятости сельского населения, но и продовольственной безопасности страны.

Базовые индикаторы достижения основных целей к 2030 году отражены в Стратегии устойчивого развития сельских территорий Российской Федерации на период до 2030 года: увеличение в 2,5 раза оборота малых и средних предприятий в постоянных ценах по отношению к 2014 году (в реальном выражении); увеличение в 2 
раза производительности труда в секторе малого и среднего предпринимательства в постоянных ценах по отношению к 2014 году (в реальном выражении); увеличение доли обрабатывающей промышленности в обороте сектора малого и среднего предпринимательства (без учета индивидуальных предпринимателей) до 20 процентов; увеличение доли занятого населения в секторе малого и среднего предпринимательства в общей численности занятого населения до 35 процентов [7].

Стратегическим ориентиром является увеличение доли малых и средних предприятий в валовом внутреннем продукте в 2 раза (с 20 до 40 процентов), что будет соответствовать уровню развитых стран. Ежегодный прирост указанной доли должен составлять 1 процент и более. Это, в свою очередь, требует значительного расширения инвестиционного потенциала сектора малого и среднего предпринимательства, привлечения инвестиций домохозяйств, крупного бизнеса, институтов развития в объеме, достаточном для обеспечения выполнения указанного ориентира [8].

Торговля влияет на сельскохозяйственное производство и производство продуктов питания и, соответственно, на наличие продовольствия на национальном уровне. В развивающихся странах в целом производится больше продуктов питания и осуществляется больше торговых операций. В тех случаях, когда на аграрный сектор приходится существенная доля ВВП, и еще более значительная доля рабочих мест, повышение производительности сельского хозяйства крайне необходимо, поскольку, во-первых, позволяет стимулировать инвестиции в самом сельском хозяйстве, а вовторых, ведет к высвобождению избыточного капитала и трудовых ресурсов, которые могут быть использованы в других секторах экономики.

\section{БИБЛИОГРАФИЯ}

1. Торговля и продовольственная безопасность: достижение оптимального баланса между национальными приоритетами и общим благом - [Электронный ресурс] Режим доступа: http://www.fao.org/3/a-i5090r.pdf

2. Тенденции развития агропромышленного комплекса России в контексте импортозамещения - [Электронный ресурс] - Режим доступа: https://cyberleninka.ru/article/n/tendentsii-razvitiya-agropromyshlennogo-kompleksarossii-v-kontekste-importozamescheniya

3. Общемировые тенденции и перспективы в области сырьевых товаров [Электронный ресурс] - Режим доступа: http://unctad.org/meetings/en/SessionalDocuments/a70d184_ru.pdf

4. Бюллетень социально-экономического кризиса в России.18 бюллетень социально экономического кризиса в России выпуск № 12, апрель 2016 объемах [Электронный ресурс] - Режим доступа: http://ac.gov.ru/files/publication/a/8884.pdf

5. Agricultural Statistics. US Department of Agriculture Washington- [Электронный ресурс] - Режим доступа: https://www.princeton.edu/ ota/disk2/1986/8623/862305.PDF

6. Agricultural Trends and the Future of Technology - [Электронный ресурс] - Режим доступа :http://ieassa.org/en/agricultural-trends-and-the-future-of-technology/

7. Никонова А.А. Научно-технологические основы АПК: проблемы и перспективы, М.2016- $378 \mathrm{c}$.

8. Стратегии устойчивого развития сельских территорий Российской Федерации на период до 2030 года - [Электронный ресурс] - Режим доступа: Гарант.ру: http://www.garant.ru/products/ipo/prime/doc/70761426/\#ixzz4psHsYgmm

(C) 2017 by the authors. Licensee RJOAS, Orel, Russia. This article is an open access article distributed under the terms and conditions of the Creative Commons Attribution (CC BY) license: http://creativecommons.org/licenses/by/4.0/ 
DOI https://doi.org/10.18551/rjoas.2017-09.05

\title{
УПРАВЛЕНИЕ РАЗВИТИЕМ ИННОВАЦИОННОГО ПОТЕНЦИАЛА АГРОПРОМЫШЛЕННОГО КОМПЛЕКСА В КОНТЕКСТЕ ПОЛИТИКИ ИМПОРТОЗАМЕЩЕНИЯ \\ MANAGEMENT OF THE DEVELOPMENT OF AGRO-INDUSTRIAL COMPLEX'S INNOVATIVE POTENTIAL IN THE CONTEXT OF IMPORT SUBSTITUTION POLICY
}

Игнатова Т.В., доктор экономических наук, профессор

Ignatova T.V., Doctor of Economic Sciences, Professor

Южно-Российский институт управления, Российская академия народного хозяйства и государственной службы при Президенте России, Ростов-на-Дону, Россия

South-Russia Management Institute, Russian Academy of National Economy and Public Administration under the President of Russia, Rostov-on-Don City, Russia

Полянин А.B. ${ }^{*}$, доктор экономических наук, профессор

Polyanin A.V., Doctor of Economic Sciences, Professor

Среднерусский институт управления, Российская академия народного хозяйства и государственной службы при Президенте России, Орёл, Россия

Central Russian Management Institute, Russian Academy of National Economy and Public Administration under the President of Russia, Orel City, Russia

\section{*E-mail: polyanin.andrei@yandex.ru}

\begin{abstract}
АННОТАЦИЯ
В статье показаны основные тенденции развития инновационного потенциала АПК на различных уровнях его структуры: национальном, региональном, предприятий. Определены направления импортозамещения в АПК в сферах сельского хозяйства и сельскохозяйственного машиностроения, которые позволят обеспечить реализацию инновационного потенциала каждого из уровней в целях повышения продовольственной безопасности регионов РФ.
\end{abstract}

\section{ABSTRACT}

The article describes main tendencies of development of agro-industrial complex innovation potential import at the different levels of it's' structure. Directions of substitution in agroindustrial complex in the spheres of agriculture and agricultural machinery building are determined that could provide innovation potential development of each level of agroindustrial complex and strengthen food security of Russian regions.

\section{КЛЮЧЕВЫЕ СЛОВА}

Импортозамещение, инновационный потенциал, АПК, сельское хозяйство, сельскохозяйственное машиностроение.

\section{KEY WORDS}

Import substitution, innovation potential, agro-industrial complex, agriculture, agricultural machinery building.

Инновационный потенциал АПК как объект системного анализа предполагает проведение исследований его генезиса и логики развития, структуры потенциала и динамики его функций. Разнообразие подходов к определению сущности инновационного потенциала АПК, его источников и форм реализации отражает мультиуровневый характер самого инновационного потенциала АПК, который рассматривается как инновационный потенциал АПК страны в целом в целом, 
инновационный потенциал подотраслей АПК, инновационный потенциал предприятий и организаций АПК, инновационный потенциал регионального АПК.

В настоящее время интерес к проблематике развития инновационного потенциала АПК усиливается под влиянием импортозамещения в России, которое наиболее ярко отражается на сфере сельского хозяйства и производства продуктов питания. Оно призвано защитить внутренний рынок от резкого подорожания продовольственной корзины из-за цен импортируемых продуктов. В России увеличилось производство сыра, фруктов, овощей, свинины, мяса кур, индейки, что позволило не допустить резкого сокращения поставки продовольственных товаров в розничную сеть, а также по государственному заказу. Управление данным процессом должно не только обеспечить защиту внутреннего рынка от резкого подорожания продуктов питания и сельскохозяйственного сырья, но и создать возможности реализации накопленных инноваций макро-, мезо- и микроуровня в АПК.

В научной литературе отмечается, что инновационный потенциал сельскохозяйственных предприятий (в нашем понимании микроуровень инновационного потенциала), «являясь ведущим элементом в развитии инновационных процессов отрасли, в настоящее время проходит начальную стадию становления. Оценка инновационного потенциала сельскохозяйственных организаций предполагает использование и сравнение большого количества показателей, измеряющихся в различных, зачастую сложно сопоставимых величинах, а также учет и анализ существующих между ними взаимосвязей» [19]. С данным тезисом трудно согласиться полностью: признавая действительно ведущую роль инновационного потенциала именно микроуровня, на наш взгляд, не следует считать, что он находится на начальной стадии развития, т.к. процессы создания и имплементации инноваций в сельском хозяйстве протекают на протяжении столетий.

Широкое понимание инноваций позволяет проследить их развертывание в сельском хозяйстве от перехода к двуполью и триполью до индустриализации АПК, внедрения современных природосберегающих технологий, генномодифрицированной продукции и целого ряда других инноваций XX-XXI вв., которые объективны, но получают противоположные субъективные оценки результатов их внедрения. Инновации в АПК не распространяются повсеместно на все предприятия одновременно, они внедряются первоначально на отдельных крупных или средних, даже малых предприятиях, а затем уже могут приобретать региональный, национальный или глобальный размах.

Инновационный потенциал АПК имеет не только привычное технологическое измерение, но не менее важное институциональное. Институциональные макроинновации рыночных реформ существенно повлияли на развитие российского АПК в последние десятилетия. «Современное развитие кредитных отношений и лизинга, упрочение положения малых сельскохозяйственных предприятий как сектора, занимающего ведущее место в животноводстве, стало возможным после проведенной приватизации земли и реорганизации колхозов и совхозов» [5].

Вместе с тем понимание инноваций в узком смысле слова, как преимущественно технологических, имеет большее распространение в современных исследованиях. «Имеющийся инновационный потенциал агропромышленного комплекса используется в пределах 4-5 \%. Среди сельскохозяйственных товаропроизводителей лишь небольшой удельный вес занимают хозяйства, производство которых основано на инновациях и относится к пятому технологическому укладу. В основном это предприятия свиноводческого, птицеводческого направления, овощеводства закрытого грунта. На другом полюсе - личные подсобные хозяйства и мелкие фермерские хозяйства, использующие в основном ручной труд, примитивные отсталые технологии и не вышедшие еще из второго уклада. Между ними - многообразные сельскохозяйственные организации и крупные крестьянские (фрермерские) хозяйства, относящиеся в основном к третьим - четвертым укладам, требующие модернизации» [13]. Именно преимущественно технологический подход к оценке спектра инноваций определяет, таким образом, экспертные оценки распространения инноваций на 
сельскохозяйственных предприятиях, которые обычно свидетельствуют об их скромных величинах. Недостатками процесса внедрения инноваций, перехода на ресурсосберегающие технологии объясняют и низкую производительность труда в сельском хозяйстве РФ, в 4-10 раз меньшую в зависимости от подотрасли по сравнению с ситуацией в АПК различных развитых стран [6].

Реализация инновационного потенциала предприятий АПК и отрасли в целом зависит от квалификационного уровня работников данной сферы, обеспеченности трудовыми ресурсами. Поэтому региональным органам власти и управления следует разработать ряд мер, направленных на «повышение миграционной привлекательности сельских территорий региона на основе формирования новых стандартов среды проживания в сельской местности, сохранения ее уникальности и социокультурного наследия, что позволит привлечь квалифицированные кадры» [8]. Инновационный потенциал регионального АПК во многом определяется усилиями региональных органов власти и управления по его развитию, обеспечению благоприятного инвестиционного и социального климата.

Импортозамещение в сельском хозяйстве позволит устранить явные преференциальные перекосы, приводящие к нарушению принципов государственного регулирования внешнеторговой деятельности, содержащихся в соответствующем законе РФ, в частности принципа равенства прав участников внешнеторговой деятельности. Так, ранее в России «для западных экспортеров были созданы чрезвычайно благоприятные условия. Например, в 2005 году по льготной таможенной пошлине ввозилось 1090,4 тыс.т мяса птицы, 430 тыс.т - говядины и 467,4 тыс.т свинины. Помимо этого было принято соглашение с США, названное «сделкой века», которое предусматривало увеличение до 2009 года квот на мясо всех видов более чем на 200 тысяч тонн. Сверх этого объема разрешалось беспрепятственно импортировать мясную продукцию по более высокой пошлине. Причем льготный налоговый режим должен был расширяться, а со временем льготы распространяться на весь импорт. В Россию животноводческую продукцию поставляли более 11 тыс. предприятий со всего мира, в том числе из Европейского сообщества - 4096. Российский же производитель практически не допускался на мировой рынок. Лишь 12 предприятий были аттестованы на право поставок продукции животноводства, в т.ч. 9 молокозаводов и 3 мясокомбината, перерабатывающие в основном оленину» [9].

Однако в этом секторе есть не только позитивные подвижки, что обусловлено высокой зависимостью российского сельского хозяйства от зарубежного семенного материала в сфере овощеводства и производства фруктов, длительным циклом выращивания крупного рогатого скота и производства говядины. Продовольственная инфляция наблюдается постоянно, хотя и не в таких масштабах, какой могла бы быть в отсутствие российских санкций.

Следует поддержать позицию Шагайда Н., что «сохраняющийся высокий уровень продовольственной инфляции обусловлен преимущественно макроэкономическими фракторами: девальвация рубля, с одной стороны, сократила издержки сельхозпроизводителей и пищевой промышленности, а с другой - привела к подорожанию импортных ресурсов для сельскохозяйственного и пищевого производства, а также повысила рентабельность экспорта продовольствия. Кроме того, замена поставщиков и импортозамещение, связанные с ограничением ввоза продовольствия из ряда стран, далеко не всегда ведут к снижению цен на соответствующую продукцию. Ослабление конкуренции со стороны импорта также не способствует стабилизации цен. При этом следует иметь в виду, что, за исключением отдельных секторов, российское сельскохозяйственное производство является конкурентной отраслью, а доля сырья, в том числе сельскохозяйственного, в структуре розничных цен продовольственных продуктов редко превышает 50\%» [18].

В современных условиях импортозамещение в сельском хозяйстве Ростовской области как конкурентной отрасли требует ориентации на лучшие практики других регионов, в частности, ближайшего региона-конкурента - Краснодарского края. Подобный бенчмаркинг необходим в поиске рациональных путей обновления основных 
фондов, разработке мероприятий областных властей по поддержке сельхозпроизводителя в условиях сокращающихся бюджетных возможностей через системы гарантий и страхования.

Рассмотрение современного импортозамещения в Российской Федерации частично подтверждает вывод Титова А.В. о сомнительности того, что вынужденное импортозамещение в результате объявленных экономических санкций станет эфрфективным и масштабным. «Для достижения значительного эфффекта снижения зависимости от импорта необходима активная государственная деятельность по планомерному осуществлению импортозамещения за счет фрормирования прогрессивной технологической структуры отечественной экономики и внедрения инноваций. При этом необходимо максимально использовать возникшие в результате введения экономических санкций дополнительные возможности и учитывать существующие ограничения»[16].

Частично мы признаем данный вывод потому, что эффрективным импортозамещение действительно назвать нельзя с учетом его преимущественно устаревшей технологической базы, но масштабным, особенно в сфере сельского хозяйства, - можно. В данном случае мы наблюдаем краткосрочные и долгосрочные эффекты, причем с точки зрения восполнения и насыщения рынка, даже ныне разворачивающееся импортзамещение можно признать и эффрективным. Хотя бы с количественных позиций, но не с качественных.

Импортозамещение, вызванное санкциями, также сильно повлияло на структуру российского экспорта. Так, «доля сырья в структуре российского экспорта за 2015 г. снизилась с 72 до 62\%. Ключевая для конкурентоспособности экономики доля в экспорте машин и оборудования выросла с 3,7 до 6\%. Объем поставок этой группы в долларах увеличился на 12,9\%. У значительной части промышленной продукции велика доля импортных комплектующих, поэтому реакция производителей на слабый рубль оказалась неравномерной. Воспользоваться сложившейся конъюнктурой смогли лишь предприятия, чья продукция и раньше была востребована за рубежом» [2]. Однако, следует учитывать, что улучшение структуры экспорта, рост сельскохозяйственного экспорта проходит на фоне резкого сокращения его объемов.

Проведенный анализ причин импортозамещения В АПК, характерного очередному кризисному этапу развития российской экономики, позволяет предложить прогноз его развертывания как реактивного преимущественно процесса в направлении переноса центра тяжести от сферы сельского хозяйства к сфрере переработки и сельхозмашиностроения при условии долгосрочного сохранения международных санкций, что должно резко активизтровать процесс внедрения и коммерциализации инноваций в АПК. Снятие санкций либо их поэтапное сокращение существенно затормозит объективно необходимый процесс импортозамещения.

Организационной формой реализации инновационного потенциала регионального АПК могут выступать инновационные кластеры, создание которых позволяет достичь ряда эфффектов. Это «внутренние и внешние кластерные эффректы, приводящие к двум интегральным преимуществам: увеличению конкурентоспособности экономики и эффективному использованию реальных механизмов согласования интересов власти и бизнеса при реализации стратегии инвестиционно-инновационного развития в сельском хозяйстве» [14]. И.С.Санду и Л.А. Семиной также определены основные составляющие их эффрективного фрункционирования: наличие лидирующих предприятий АПК, выпускающих конкурентоспособную продукцию, а также развитой сети обслуживающих организаций, благоприятный бизнес-климат, включающий в себя высокое качество трудовых ресурсов, возможность доступа к инвестиционным потокам, высокий уровень развития инфрраструктуры в кластере, развитый научно-исследовательский потенциал.

Инновационный потенциал АПК мезоуровня, его оценка, стимулирование развития, государственная поддержка фрорм реализации особенно важны для регионов Юга России и Северного Кавказа, которые являются аграрно-индустриальными, и в условиях современной промышленной стагнации именно экономический рост в 
сельском хозяйстве позволяет данным регионам надеяться на положительную динамику экономического развития. Разрабатываются в регионах соответствующие стратегии, например, Гурфова С.А. и др. полагают, что «важнейшими задачами инновационной стратегии развития АПК Кабардино-Балкарской Республики являются разработка и практическая реализация ведомственных инновационных и научнотехнических программ, стимулирование инвестиционной активности населения, однако решение этих задач требует пересмотра существующей государственной системы управления инновационно-индустриального развития. Для эфрфективной реализации указанных мероприятий необходимо создание новых структур, а именно: инвестиционного фоонда Кабардино-Балкарской Республики, Банка развития Кабардино-Балкарской Республики и регионального инновационного фронда» [3]. На наш взгляд, необходимо, чтобы подобные институты поддержки инновационноиндустриального развития создавались на началах государственно-частного партнерства с обязательным привлечением ответственных крупных частных инвесторов под предоставление гарантий. В дотационных республиках Северного Кавказа невозможно совершить качественный прорыв в инновационном развитии АПК исключительно за счет средств региональных властей и регионального бизнеса.

Таким образом, системно-структурный подход в методологии развития инновационного потенциала АПК позволяет разграничить содержательно уровни инновационного потенциала для выбора соответствующих способов его оценки, мер по его наращиванию и реализации, отвечающих императивам политики импортозамещения.

\section{БИБЛИОГРАФИЯ}

1. Гончаров П.В. Аналитические возможности бухгалтерской (финансовой) отчетности в управлении инновационно-инвестиционной деятельностью предприятий АПК / Гончаров П.В., Лытнева Н.А. // Фундаментальные исследования. 2015. №2-5. C. $1017-1022$.

2. Горшков В.Г. Современные вызовы российской экономике: кризис и санкции (взгляд на проблему / Горшков В.Г., Денисов М.С., Колыханов Д.А. // Вестник Алтайской академии экономики и права. 2016. №1 (43). С. 64-68.

3. Гурфова С.А. Инновационно-индустриальная стратегия развития регионального АПК (на примере Кабардино-Балкарской республики) / Гурфова С.А., Багова О.И., Маржохов 3.С. // Национальные интересы: приоритеты и безопасность. 2014. №42 (279). C. 55-63.

4. Докукина И.А. Перспективные направления развития человеческого потенциала в условиях инновационной активности региона / Докукина И.А., Ловчикова Е.И. // В сборнике: Проблемы развития отраслей АПК: тенденции и перспективы 2012. С. 130-134.

5. Игнатова Т.В. Государственная политика либерализации аграрных отношений как предпосылка развития государственно-частного партнерства в АПК / Игнатова Т.В. // Роль бизнеса и власти в развитии агропромышленного комплекса: материалы XV Международной научно-практической конференции. Барнаул, 14-15 сентября 2016 г. / Алтайская лаборатория СибНИИЭСХ СФНЦА РАН; под науч. ред. проф. Г.М. Гриценко. - Барнаул: Алтайский дом печати, 2016. С.58-59.

6. Косякова Л.Н. Анализ состояния инновационного потенциала сельского хозяйства РФ / Косякова Л.Н. //Известия Санкт-Петербургского государственного аграрного университета. 2016. №43. С. 206-211.

7. Макарова Ю.Л. Государственное регулирование развития материальнотехнической базы растениеводства / Макарова Ю.Л. // Аграрная наука. 2014. №1. С. 6-7.

8. Матвеева Л.Г. Конкурентное импортозамещение как императив развития АПК в условиях экономических санкций / Матвеева Л.Г., Чернова О.А. //Региональная экономика. Юг России. 2016 . №1 (11). С. 59-67. 
9. Милосердов В.В. Санкции, эмбарго продовольствия, импортозамещение / Милосердов В.В. //Экономика сельского хозяйства России. 2014. №11. С. 13-20.

10. Павлова А.В. Современные проблемы фоормирования учетно-информационного обеспечения инновационной деятельности организаций АПК / Павлова А.В., Проняева Л.И. // Известия Международной академии аграрного образования. 2013. №17. C. 253-257.

11. Парушина Н.В. Предпринимательская деятельность по хранению и доработке зерна: анализ фринансовых показателей / Парушина Н.В., Сучкова Н.A., Федотенкова О.А. // Экономика. Предпринимательство. Окружающая среда. 2009. Т. 40. №4. С. 74-80.

12. Проняева Л.И. Состояние и проблемы инновационного развития процесса воспроизводства основного капитала в АПК / Проняева Л.И. // Вестник Орловского государственного аграрного университета. 2012. Т. 38. №5. С. 21-25.

13. Рыженкова Н.Е. Развитие инновационного потенциала АПК: проблемы, направления / Рыженкова Н.Е., Чепик Д.А. //Экономика сельского хозяйства России. 2014. №6. C. 53-57.

14. Семина Л.А. Инновационный кластер - основа развития инвестиционноинновационной деятельности в сельском хозяйстве / Семина Л.А., Санду И.С. // Вестник Алтайского государственного аграрного университета. 2013. №6 (104). С. 137-140.

15. Сухорукова Н.В. Зарубежный опыт государственного регулирования аграрного сектора / Сухорукова Н.В., Цвырко А.А. // Теоретические и прикладные вопросы экономики и сфреры услуг. 2015. №1. С. 125-127.

16. Титов А.В. Импортозамещение в условиях действия международных фринансовоэкономических санкций: история вопроса и современное состояние проблемы / Титов А.В. //Экономические науки в России и за рубежом. 2014. №XV. С. 52-55.

17. Цвырко А.А. Направления государственной поддержки аграрного производства региона / Цвырко А.А., Иващенко Т.Н. // Вестник Орловского государственного аграрного университета. 2011. Т. 31. №4. С. 82-84.

18. Шагайда Н. Продовольственная инфляция: основные фракторы и особенности / Шагайда Н. // Экономическое развитие России. 2015. Т. 22. №2. С. 24-28.

19. Шурыгина Е.С. Методические подходы к оценке уровня инновационного потенциала АПК / Шурыгина Е.С. // Наука XXI века: актуальные направления развития. 2016. №1-1. C. 629-631. 
DOI https://doi.org/10.18551/rjoas.2017-09.06

\title{
THE STUDY OF AGRIBUSINESS WETLAND RICE FARMING SYSTEM IN AN ATTEMPT TO SYNERGIZE SUBAK WITH ECOTOURISM: A CASE IN SUBAK SEMBUNG, BALI PROVINCE OF INDONESIA
}

\author{
Arisena Gede Mekse Korri*, Dewi Ni Luh Prima Kemala \\ Agribusiness Study Program, Agriculture Faculty, Udayana University, Bali, Indonesia \\ *E-mail: arisenakorri@yahoo.co.id
}

\begin{abstract}
The rapid development of tourism in the Bali Province led to the conversion of agricultural land into a settlement and tourism support facilities are growing rapidly occurred in Denpasar City. This causes the decline in the area of rice fields and increasingly threatened the existence of subak (Balinese cultural base irrigation system for paddy fields) in Denpasar City. By making the paddy field become a tourism object based on the principles of ecotourism, is expected to maintain the existence of subak in Denpasar City. This study examines the benefits and feasibility of wetland paddy farming, economic efficiency of the use of production factors of wetland paddy farming, environmentally friendly production pattern of wetland paddy farming, the potential of subak sembung area as the attraction of ecotourism, performance of agribusiness system of wetland paddy farming and create a synergy model between subak and ecotourism based on agribusiness. The results obtained can be concluded that the commodity rice paddy worth to be used as farming in Subak Sembung, rice farmers in Subak Sembung classified as efficient in using production factors but has not achieved optimal efficiency, production patterns in Subak Sembung still using chemicals (not yet environmentally friendly) and Subak Sembung has a very noble agrarian cultural value that can be used as tourism assets.
\end{abstract}

\section{KEY WORDS}

Agribusiness, tourism, sustainable agriculture, conversion of agricultural land, agrarian cultures.

The Bali Island with an area of $5,632.86 \mathrm{~km}^{2}$ has a population of 4.15 million people, have only limited environmental resources. This large population utilizes a large enough land therefore it is estimated that land conversion will take place of 380 to 500 ha per year. In addition to population growth, the growth of the tourism support sector also contributes to the acceleration of land conversion. The most dominant sectors experiencing pressure from tourism growth are the agricultural sector (wetland and moorland).

The impact of the rapid transfer of land functions on Bali Island is the threat of food security and subak sustainability due to the increasing number of rice fields lost due to switching functions for non-agricultural use. If this does not receive serious attention from the government in the form of subsidies or protection, the destruction of the agricultural sector will lead to the destruction of the subak system which is one of the cultural heritage resources of Balinese society in the form of social institutions. Without rice fields, subak cannot exist, and without subak, the preservation of Balinese culture will be threatened. Thus the rice fields and their organizations must be conserved with various efforts.

One of the efforts that can be done to create a sustainable and firm subak in supporting the sustainable development of agriculture is to make the paddy field become tourism object based on the principles of ecotourism and supported by environmentally friendly production pattern in running rice farming.

Satria (2009), ecotourism is a concept of sustainable tourism development that aims to support the efforts of environmental conservation (nature and culture) and increase community participation in its management. Ecotourism is a tourist trip to a natural environment both natural and artificial and existing culture that is informative and participatory which aims to ensure the conservation of the natural and socio-cultural. 
Ecotourism focuses on three main things: natural or ecological sustainability, provide economic benefits, and psychologically acceptable in the social life of society. Thus, ecotourism activities directly provide access to everyone to see, to know, and enjoy the experience of nature, intellectual and local culture.

Based on the above problems it is very interesting to be studied about the utilization of subak area that conduct wetland paddy farming. This study aims to support the success of sustainable food security program and to find out how far the synergy between subak and ecotourism based on agribusiness in Denpasar City.

\section{METHODS OF RESEARCH}

Location Subak Sembung selected because Subak Sembung is a subak that still survive in the middle of Denpasar City. Population in this research is farmer/member who manage Subak Sembung in Denpasar City which amount 200 people. The sample size is $20 \%$ of the total population or about 40 people.

In this study, data collection through observation and interview. The researcher as a data collector participates in the activities that are the source of the observation. The data collected in this study is data related to farmers' income, feasibility of rice field farming, factors of production used, environmentally friendly production patterns, the potential of Subak Sembung as an attraction for ecotourism and performance of agribusiness system in Subak Sembung.

In addition to analyse descriptively, the data is processed with several variations of statistical analysis. For more detailed analysis of each of these objectives are detailed as follows. The first objective analyses the advantages and feasibility of rice farming in Subak Sembung. This objective is analysed descriptively quantitative with the calculation of cost analysis and farming income as well as the ratio analysis of revenue and cost ( $R / C$ ratio).

The second objective is to analyse the economic efficiency of the use of production factor of rice farming in Subak Sembung. To explain the amount of production and input used in the production process which is then used as the basis for calculating the efficiency of the use of production factors using the Cobb-Douglas production functionas a Frontier production function (Cobb-Douglas Production Frontier). Estimation or modelling of production function to be performed using the program of FRONTIER Version 4.1c. The Cobb-Douglas frontier stochastic production function specification is as follows.

$$
\operatorname{LnY}=\beta_{0}+\beta_{1} L n X_{1}+\beta_{2} L n X_{2}+\beta_{3} L n X_{3}+\beta_{4} L n X_{4}+\beta_{5} L n X_{5}+\beta_{6} L n X_{6}+\beta_{7} L n X_{7}+v_{i}-u_{i}
$$

Where $Y$ : rice production $(\mathrm{kg}) ; \mathrm{X}_{1}$ : land area (ha); $\mathrm{X}_{2}$ : the amount of seeds $(\mathrm{kg}) ; \mathrm{X}_{3}$ : the amount of NPK Phonska Fertilizer $(\mathrm{kg})$; $\mathrm{X}_{4}$ : the amount of Urea Fertilizer $(\mathrm{kg})$; $\mathrm{X}_{5}$ : the amount of Insecticide (g); $X_{6}$ : the amount of Herbicide $(g) ; X_{7}$ : the amount of labor (man days); $v_{i}-u_{i}$ : error term $\left(u_{i}\right)$ Effect of technical efficiency in the model, error term $\left(v_{i}\right)=$ noise of the expected coefficient value is $\beta_{1}-\beta_{5}>0$.

The third objective is to analyse the pattern of environmentally friendly production of wetland rice farming in Subak Sembung. This third objective is analysed descriptively qualitative to know the production pattern used is already in line with the concept of environmentally friendly. The patterns of production in this case are: the use of fertilizers, the use of pesticides and production management.

The fourth objective is to analyse the potential of Subak Sembung area as an ecotourism attraction. This fourth objective is analysed descriptively by describing condition and state of Subak Sembung. Supported with the data in the form of documentation Subak Sembung photo as authentic data. Potential Subak Sembung area should also be supported by potential data of flora, fauna, culture and human resources.

The fifth objective is to examine the performance of agribusiness system of rice farming in Subak Sembung. This objective is analysed descriptively qualitative to know the performance of agribusiness system of rice farming in Subak Sembung. The performance of agribusiness system in this case includes subsystem of supply of production facilities farming 
subsystem, marketing subsystem of agricultural products as well as price changes and external factors.

The sixth objective is to create a synergy model between subak and ecotourism based on agribusiness. In this purpose, a qualitative descriptive analysis is based on the results of one, two, three, four and five objective analysis. The sixth objective is expected to have been able to build a synergy model between subak and ecotourism based on agribusiness.

\section{RESULTS AND DISCUSSION}

According to data from farmers respondents, the amount of cash cost compared to the cost to be accounted in the activities of rice farming, because most farmers allocate costs for the payment of wages to labor outside the family which includes labor in plowing and planting activities with wholesale systems amounting to IDR1,556,393.94 man days/ha or with a percentage of $41.90 \%$. The amount of costs that must be incurred for these activities because most farmers have an advanced age,thus requires the labor to work on the land they own (Table 1).

In this research, the income on total cost is the profit obtained from rice farming in Subak Sembung. Income on total farming costs is derived from reductions in total revenues with total farming costs, thus the average income earned on total cost or average profit of IDR6,996.784.20/ha. The high income on the total cost obtained from the rice farming is because the farmers get the seed subsidyand fertilizers and farmers are not charged the tax cost for land by the government due to Subak Sembung into a green area, thus farmers are able to minimize the costs incurred in rice farming activities. Therefore, rice farming run by farmers in Subak Sembung can be said to gain profit in the growing season of July-October 2016 (Table 1).

Table 1 - Average Cost and Income of Rice Farming of Subak Sembung per Hectare per Planting Season July - October 2016

\begin{tabular}{|c|c|c|c|}
\hline Descriptions & Component of Cost & Value (IDR/Ha) & Percentage (\%) \\
\hline A. & Total Revenue & $10,711,363.64$ & - \\
\hline \multicolumn{4}{|l|}{$\begin{array}{l}\text { Cash cost } \\
\text { B. }\end{array}$} \\
\hline & - Dues for Subak & $76,909.09$ & 2.07 \\
\hline & $\begin{array}{l}\text { Sub total } \\
\text { Variable Cost }\end{array}$ & $76,909.09$ & 2.07 \\
\hline & - Seed & $29,272.73$ & 0.79 \\
\hline & - $\quad$ Fertilizer & $468,492.42$ & 12.61 \\
\hline & - Pesticide & $86,130.30$ & 2.32 \\
\hline & - Labor outside the family & $1,556,393.94$ & 41.90 \\
\hline & Sub total & $2,140,289.39$ & 57.62 \\
\hline & Total Cash Cost & $2,217,198.48$ & 59.69 \\
\hline \multicolumn{4}{|c|}{ Cost to be accounted } \\
\hline C. & Fixed Cost & & \\
\hline & - Depreciation of farming tools & $80,638.53$ & 2.17 \\
\hline & $\begin{array}{l}\text { Sub total } \\
\text { Variable Cost }\end{array}$ & $80,638.53$ & 2.17 \\
\hline & Labor in the family & $1,006,060.61$ & 27.08 \\
\hline & - Ceremony & $410,681.82$ & 11.06 \\
\hline & Sub total & $1,416,742.42$ & 38.14 \\
\hline & Total Cost Accounted & $1,497,380.95$ & 40.31 \\
\hline D. & Total Cost $(B+C)$ & $3,714,597.44$ & 100.00 \\
\hline $\mathrm{E}$. & Income over total costs (A-D) & $6,996,784.20$ & - \\
\hline
\end{tabular}

Wetland rice farming in Subak Sembung has an average revenue of IDR10,711,363.64/ha with a total average cost of IDR3,714,597,441/ha, then after the average revenue divided by the average total cost then it is known $R / C$ ratio on the total cost of 2.88 which means that each one rupiah(IDR1) the total cost incurred by farmers will receive revenue of IDR2.88.Thus, it can be seen that the results of $R / C$ ratio analysisof rice 
farming in Subak Sembung said feasible to be implemented in the future. The result of R/C ratio analysis of rice farming of Subak Sembung per hectare for planting season from July to October 2016 can be seen in Table 2.

Table 2 - R/C Ratio Analysis of Rice Farming of Subak Sembung per Hectare per Planting Season July - October 2016

\begin{tabular}{lll}
\hline No & Descriptions & Total (IDR/Ha) \\
\hline 1. & Revenue & $10,711,363.64$ \\
2. & Cash Cost & $2,217,198.48$ \\
3. & Cost to be accounted & $1,497,380.95$ \\
4. & Total Cost & $3,714,597.44$ \\
5. & R/C Ratioover total cost & 2.88 \\
\hline
\end{tabular}

The highest allocative efficiency value achieved by rice farmers in Subak Sembung is 1.2232 with an average of 1.0489. Farmers can be said to be efficient if they have a rating of $\geq 0.7$. The average value of the allocative efficiency indicates that rice farmers in Subak Sembung are at a price efficiency (cut-off value $\geq 0.7$ ) and farmers' opportunity to achieve the highest price efficiency was $14.25 \%$ (Table 3 ).

Farmers in Subak Sembung are on productive efficiency (technical efficiency, price efficiency, and economic efficiency) with cut-off value $\geq 0,7$; which illustrates that rice farmers are categorized as capable of utilizing production factors well, although not exactly in the frontier position (optimal production). This phenomenon occurs probably because of the subsidy from the government and channelled to Subak Sembung in the form of seed and fertilizer subsidy, thus the subsidy obtained can help in lowering farmer production costs. In addition, because Subak Sembung once won the application of rice technology, it is likely that rice paddy farmers in the area have understood how rice farming can increase production through applied technology (Table 3).

Table 3 - Efficiency Level (TE, AE, and EE)

\begin{tabular}{lllll}
\hline Efficiency Level & $\mathrm{N}$ & Minimum & Maximum & Mean \\
\hline TE & 66 & 0,8113 & 0,9997 & 0,9450 \\
AE & 66 & 0,9920 & 1,2232 & 1,0489 \\
EE & 66 & 0,9078 & 0,9994 & 0,9887 \\
\hline Valid N (list wise) & 66 & & & \\
\hline
\end{tabular}

Based on Table 4, it is concluded that all rice farmers are in technical, allocative and economic efficiency with a cut-off value of efficiency of $\geq 0.7$. Seeing from statement of Darmawan (2016) about four ways of describing the relative success of a company which in this case is the relative success of rice farmers in Subak Sembung is in the first category that is in technical and allocative efficiency.

Table 4 - Distribution of Technical, Allocative, and Economical Efficiency Levels

\begin{tabular}{llll}
\hline Efficiency Level & TE & AE & EE \\
\hline$<0,7$ & 0 & 0 & 0 \\
$\geq 0,7$ & 66 & 66 & 66 \\
\hline Total & 66 & 66 & 66 \\
\hline
\end{tabular}

Currently farmers in the Subak Sembung area is still difficult to use $100 \%$ organic fertilizer because of the dependence of farmers is still large on chemical fertilizers such as Urea, ZA, and $\mathrm{KCl}$.It takes time to convince farmers to switch to using organic fertilizer.Farmers use chemical fertilizers in excess without being balanced with other fertilizers, such as organic fertilizer.The use of chemical fertilizers and pesticides makes soil fertility reduced so that every growing season comes, the need for fertilizers and pesticides to be met by farmers continues to increase.The increasing need for fertilizers and chemical pesticides causes the farmers to incur greater costs, thus the income received by farmers is decrease. This increase in cost is not only due to the increasing amount of use, but also due 
to the increasingly expensive price of fertilizers and chemical pesticidesand more difficult to obtain. This condition can threaten the continuity of farming.

Subak Sembung as ecotourism area, causing farming in Subak Sembung has selling value as a tourist attraction for the visitors. The establishment of ecotourism area is useful to increase the economic value for the parties involved in the management,and add environmental value to conserve the Subak Sembung area in order to remain sustainable.In achieving the objectives of the development of Subak Sembung ecotourism, ecotourism managers certainly involve the parties who are in the ecotourism area. Parties referred to in this case are the people who are in Peguyangan Village, as well as farmers who run the farm in Subak Sembung area.The involvement in this regard is to make them as partners in the effort of developing ecotourism area. In the implementation of programs that have been packaged in the form of tour packages, the manager of ecotourism will involve the community around the subak area and the farmers who run the farm in Subak Sembung.

Subak Sembung as an ecotourism area is also rich with agricultural culture.But the agricultural potential has not been maximally worked out to be a tourism product.Because the true life of agriculture has enriched the culture that is now sold as a tourist product.However, agricultural culture has not become a superior product that is marketed to tourists. In some places have been able to create attractions based on agriculture (agrotourism), or ecotourism.As in Subak Jati Luwih, Tabanan, subak area is able to become a tourist attraction.

In the upstream agro-industry subsystem on rice farming in Subak Sembung, according to farmer respondents, the procurement of seed production facilities for rice farming in Subak Sembung obtained through preparationof The List of Proposed Purchase Subsidized Seeds (DUPBB) according to the needs of the seeds of each farmer. Preparation of DUPBB aims to reduce the production costs incurred by farmers in rice farming activities through seed subsidy fromDepartment of Agriculture Food Crops and Horticulture Denpasar City. In rice farming in Subak Sembung, the assistance of the subsidized seeds is not given fully to the farmers because there is free seed assistance to be given to farmers by the Department of Agriculture Food Crops and Horticulture Denpasar City. The goal is to break the chain of pests and diseases that generally attack rice plants, in order to maintain the amount of rice production obtained by farmers.

Downstream agro-industry subsystem is an activity in the farm which includes postharvest processing as well as marketing of production. Based on the respondents of farmers in Subak Sembung, they do not do post-harvest processing on the crop. This is because farmers already sell paddy with slash system, thus in the subsystem of downstream agroindustry only discussed about marketing channel from paddy that produced at its farm in Subak Sembung.

Each type of agricultural commodity has different marketing channels between each other. All respondents of rice farmers in Subak Sembung, amounting to 66 people selling their products using slash system. The slash system actor usually goes directly to the farmers on the paddy fields they own. The slash system used by farmers in wetland rice marketing is caused by farmers having difficulty in finding labor in Denpasar City area for harvesting of production,considering the majority of rice farmers in Subak Sembung already in the elderly. In addition, farmers use the system because they want to be more practical to take care of the crop that is generally time consumingand requires a large place to dry the crop. Usually with this slash system, it can be settled quickly so that the farmer's land can be replanted immediately.

In this slashsystem, of course there are advantages and disadvantages received by farmers. The advantages of slash system for farmers in Subak Sembung are farmers become easier in harvesting and marketing their production, while the Idisadvantages are the farmers do not know the maximum revenue obtained from the production of rice each season planting.

Based on the observations and has been described previously built a model of synergy between subak and ecotourism based on agribusiness. The development of ecotourism in Subak Sembung is one of the efforts to increase the natural resources potential,environment 
and uniqueness of nature and culture that will later become one of the leading sectors of the region that has not been developed optimally. Where ecotourism is a natural tourism activity with attention to elements of education, understanding and support for natural resource conservation efforts. With the principle of conservation development that protects, preserves and utilizes sustainably existing natural resources and does not escape from economic value, educationas well as community participation in the planning, utilization and control of ecotourism with socio-cultural values.

In accordance with the objectives of this research are to support the success of sustainable food security program and create synergy between subak and ecotourism based on agribusiness, then formed a model of synergy between subak and ecotourism based on agribusiness.

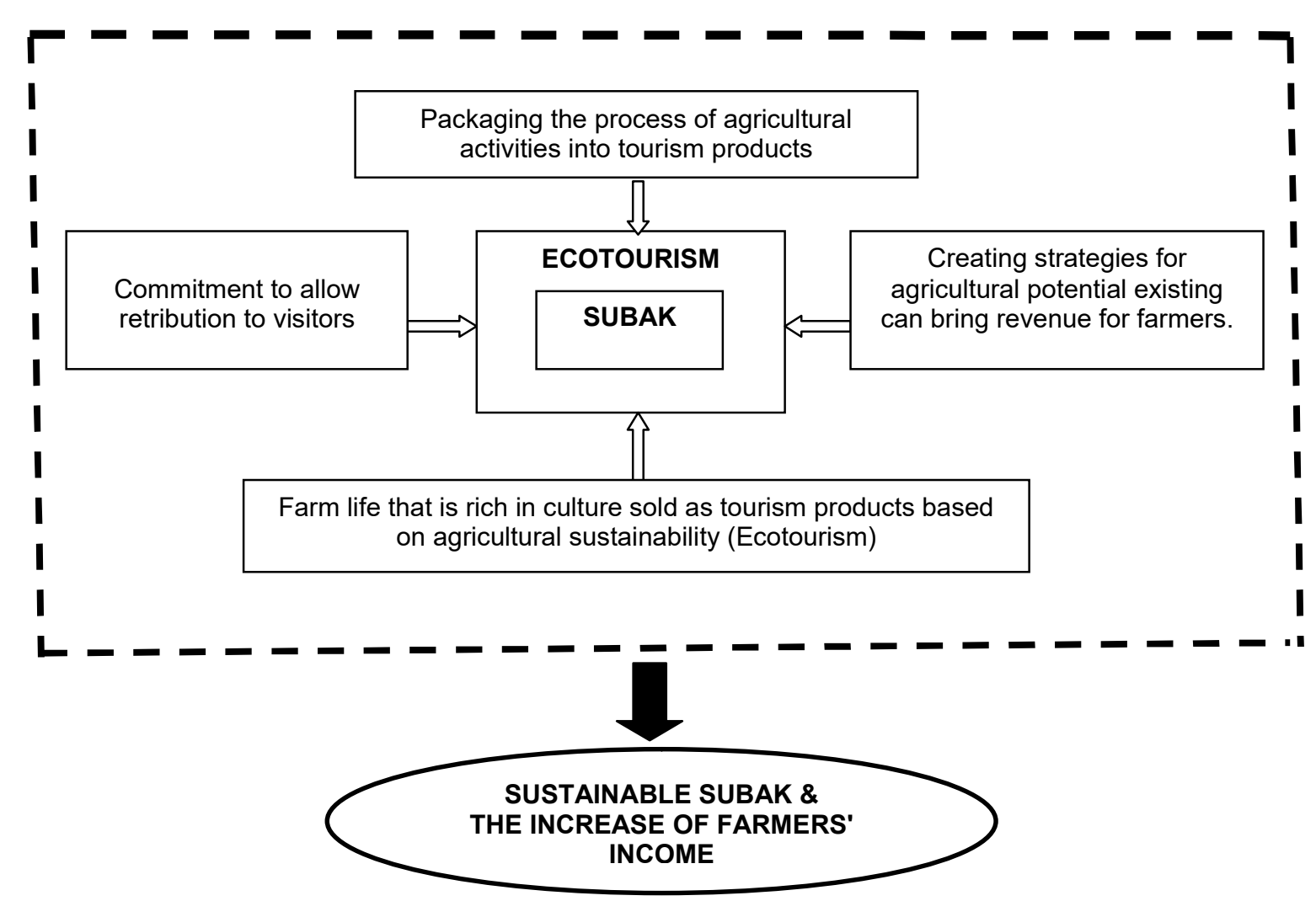

Figure 1 - Synergy Model between Subak and Ecotourism Based on Agribusiness

The development of alternative tourism objects such as ecotourism requires a touch of creativity and a new breakthrough, thus its presence can draw from existing objects so far. The development of alternative tourism objects such as ecotourism should remain based on local culture.Rice fields and farmers become one of tourism assets. From agriculture life has born the values of agrarian culture which very noble and can be used as tourism assets.Local wisdom that becomes the power of subak has a basic nature of socioculturaland unique socio-religious.

Subak that have various intelligences that are part of the local culture based on the concept of Tri Hita Karanaand received a universal appreciation associated with the philosophical content of the cosmos. The essence of local wisdom is a high commitment to the sustainability of nature, human subjectivity, religious sense and construction of reasoning that empathize with the offerings, togetherness, harmony and the balance of sustainable universe.

Integrating the agricultural sector with tourism will have a broad impact that increases farmers' income. Preserve the culture of agriculture, providing an alternative tourism object that may never be found in other countries.In terms of agricultural empowerment to support 
the tourism sector is very strategic. From the agricultural production side, the process of agricultural activities can also be packaged into tourism products. Then the agricultural ritual is also very rich and interesting for tourism. But it needs to be packaged and need strategies thus agricultural potential it can bring in income.

\section{CONCLUSION}

Between the upstream agro-industry subsystem, farming subsystem, subsystems of downstream and agro-industries subsystems of supporting institutions have been running quite well, but still needs further improvement. Subak Sembung has a very noble agrarian cultural value that can be used as tourism assets. Related to the ecotourism area in Subak Sembung there is a special support institution in the form of ecotourism management. Development of ecotourism in Subak Sembung shows that the results obtained from the involvement of farmers in ecotourism activities cannot be felt directly but enter into a typical organization of Subak Sembung, even though the paddy farmers are still benefiting.

\section{REFERENCES}

1. Adiyoga, Witono. 1999. Beberapa Alternatif Pendekatan untuk Mengukur Efisiensi atau In-Efisiensi dalam Usahatani. http://www.litbang.pertanian.go.id/warta-ip/pdffile/witono.pdf. Diunduh pada tanggal 3 Januari 2017

2. Badan Pusat Statistik Propinsi Bali. 2016. Propinsi Bali Dalam Angka. Bali Province in Figures 2016. CV. Bhinneka: Denpasar.

3. Darmawan, Dwi Putra. 2016. Pengukuran Efisiensi Produktif Menggunakan Pendekatan Stochastic Frontier. New Elmatera Publisher : Yogyakarta

4. Desa Peguyangan. 2015. Profil dan Potensi Desa Peguyangan. Tidak diterbitkan: Denpasar.

5. Fandeli, Chafid. 2000. Pengertian dan Konsep Ekowisata. Jurnal. Fakultas Kehutanan. Universitas Gadjah Mada: Yogyakarta.http://saveforest.webs.com/konsep_ekowisata.pdf. Diakses pada tanggal 21 November 2016.

6. Hadi, S. P. 2007. Pariwisata Berkelanjutan (Sustainable Tourism). Makalah Seminar Sosialisasi Sadar Wisata Edukasi Sadar Wisata bagi Masyarakat di Semarang.

7. Pitana, Gde dan Setiawan AP., Gede. 2004. Revitalisasi Subak dalam Memasuki Era Globalisasi. Andi: Yogyakarta.

8. Satria, D.2009. Strategi Pengembangan Ekowisata Berbasis Ekonomi Lokal Dalam Rangka Program Pengentasan Kemiskinan Di Wilayah Kabupaten Malang. Journal of Indonesian Applied Economics. Vol. 3 No. 1: 37-47

9. Sumiyati, Sutiarso,L., Windia,W., Sudira,P. 2011. Evaluasi Kinerja Fisik Sistem Subakyang Berorientasi Agroekowisata Menggunakan Pendekatan Logika Fuzzy. Jurnal Teknik Industri, Vol. 12, No. 2, Agustus 2011: 147-155.

10. Sutawan, N. 2001. Eksistensi Subak di Bali:Mampukah bertahan Menghadapi Berbagai Tantangan. Jurusan Sosial Ekonomi Pertanian Fakultas Pertanian Udayana. Denpasar.

11. Suyastiri, N.M.2012. Pemberdayaan Subak Melalui "Green Tourism" Mendukung Keberlanjutan Pembangunan Pertanian Di Bali. Journal SEPA : Vol. 8 No. 2 Pebruari 2012: $51-182$

12. Widowati, S.2012. Kajian Potensi dan Evaluasi Penerapan Prinsip - Prinsip dan Kriteria Ekowisata di Kawasan Taman Wisata Alam Kawah ljen, Desa Taman Sari, Kabupaten Banyuwangi. Tesis. Program Pascasarjana Universitas Udayana Denpasar

13. Windia, Wayan. 2006. Transformasi Sistem Irigasi Subak yang Berlandaskan Konsep Tri Hita Karana. PT. Offset BP Denpasar: Jakarta. 
DOI https://doi.org/10.18551/rjoas.2017-09.07

\title{
PROPER FUNDING AND MARKETING OF GREEN ECONOMY: A WAY OUT OF NIGERIA'S AGRICULTURAL WOES
}

\author{
Akpaeti A.J.*, Udo U.J., Bassey N.E. \\ Department of Agricultural Economics and Extension, Akwa Ibom State University, Nigeria \\ *E-mail: anigreat04@yahoo.comm
}

\begin{abstract}
Agricultural policy papers have highlighted the critical role of agriculture to economic prosperity and development. In spite of the numerous agricultural policies, the Nigerian agricultural sector has performed so poorly in terms of its contribution to the country's GDP. Undoubtedly, green economy offers an alternative vision for correcting this dismal performance of the sector. To achieve this feat, proper funding and marketing becomes indispensable. Hence, this paper assesses the impact of proper funding and marketing on agricultural productivity through the development of green economy in Nigeria. Secondary data sourced from Central Bank of Nigeria; food and agricultural organization covering 19702010 were analyzed using co-integration, error correction and Granger Causality test techniques, the study found a positive and significant long run relationship between agricultural productivity (ARGDP), commercial bank credit to agriculture (CBA), total government expenditure on agriculture (TEA), consumer price index (CPI) and agriculture population (APOP) as well as a uni-Granger causality from TEA to ARGDP, CBA to TEA, $\mathrm{CPI}$ to APOP and TEA to APOP. It is recommended that concerted effort by all stakeholders are required to steer green agriculture on a sustainable production and productivity pathway through mobilization of funds and provision of an environmentally friendly alternative for Nigeria's transition from a mono economy to a diversified green economy for effective and efficient use of resources by present and future generations for sustainable development.
\end{abstract}

\section{KEY WORDS}

Agricultural productivity, funding, marketing, green economy, inorganic fertilizer.

Nigeria's domestic economy is partly determined by agriculture which has experienced a rapid growth in recent times with recorded growth rate well above $5 \%$ compared with the less than $2 \%$ growth of early 80 's (Falusi, 2008). In 2005 , agriculture contributed $6.8 \%$ out of the $8.2 \%$ growth rate recorded by the entire non-oil sector (NEEDS, 2008) while in 2007, the sector also employed about 65 million persons and contributed about $41 \%$ of the Gross Domestic Product (GDP). Of this, the crop subsector contributed $85 \%$, Livestock $(10 \%)$ and Forestry (1\%) (National Bureau of Statistics, 2007). Despite this growth rate, the Nigerian National planning Commission (NPC), (2004) citing the United Nations Food and Agriculture Organization (FAO) reported that productivity of Nigeria's farmland is low but has the potentials to improve if properly manage. Jeter (2004) submitted that there is a serious declined in agricultural productivity over the past two decades which has resulted in severe rural poverty. Undoubtedly these are the periods our farmers relied on inorganic fertilizer as the only major soil nutrient supplier. Much still need to be done to regain our agricultural lost glory of the early 1970 as a major driver of the Nigeria's economy. The performance of Nigeria's agriculture is poor when we assess the current food import bill, rate and degree of rural poverty and rural-urban drift. The World bank data cited by Chigbu (2005) shows that more than $70 \%$ of Nigerians live below the poverty line (which is less than a dollar/day) implying that there has been an astronomical growth in the levels of poverty of Nigerians most of whom are engaged in agriculture from independence till today.

This low productivity calls for serious concern owing to the fact that the country is the largest in the region representing an average of 45 percent of total fertilizer consumption (in nutrients base) in the Economic Community of West African States (ECOWAS), followed by Burkina Faso, Côte d'Ivoire, Ghana and Mali for the years 2005-2009 (FAOSTAT, 2011), In 
addition to its vast natural and human resources, Nigeria has perhaps, the largest National Agricultural Research and Extension System (NARES) in Sub-Saharan Africa today, made up of: 17 Commodity-based Research Institutes, a specialized National Agricultural Extension Institute, 18 Faculties of Agriculture in regular Federal Universities; 3 specialized Universities of Agriculture and one International Agricultural Research Centre (IARC = IITA) (Arokoyo 1998), A most pertinent question today therefore is: why has Nigeria's awesome natural, human and huge investment on fertilizer subsidy and extension service not been able to deliver the much needed agricultural growth and development. The reason for this is because more than $90 \%$ of the agricultural output is accounted for by small-scale farmers who depend on inorganic fertilizers with less than two hectares under cropping while out of about $75 \%$ (68 million ha) of estimated potential total Nigeria land for agricultural activities only about 33 million hectare is under cultivation (Chigbu 2005). These situations have caused food production in Nigeria to fail to keep space with the increasing population thereby making Nigeria a net importer of food (Daramola, Ehui, Ukeje \& McIntire 2007). Therefore, the need to give agricultural productivity the greatest priority if the incidence of poverty is to be reduced in the economy with special attention on less carbon emissions and its negative impacts on the environment as this will ultimately reverse the present condition and leads to income growth justifies the quest for green economy.

Green economy is "one that results in improved human well-being and social equity, while significantly reducing environmental risks and ecological scarcities" (United Nations Environment Programme [UNEP] 2010). It is aimed at sustainable development without degrading the environment while emphasizing production and consumption modes that are environmentally and socially sustainable. By sustaining natural resources and ecosystem services, it protects the global commons allowing current and future generations to meet their needs. And by promoting social inclusiveness it generates jobs for the poor and enhances their access to basic services (UNCTAD 2011). A transition to a green economy involves expanding green production and markets; reducing depletion of natural resources and degradation of ecosystems caused by economic activity; and increasing reliance on lowcarbon energy supply to mitigate climate change. The transition is not automatic though; it needs to be supported by development-led policies and concerted actions to ensure that outcomes are inclusive across and within countries (UNCTAD 2011). This would help in reviewing the production and postharvest constraints affecting agricultural productivity in Nigeria as an important step in formulating policies to reverse these trends in the future.

Over the years, Nigerian government has almost been the sole provider of financial and other capital resources to support agriculture. She has attempted to increase expenditure on agriculture through budgetary allocation and through the provision of cheap and readily available credit facilities (Nwosu 2004). This implies that the government budgeting allocation has become an important determinant of agricultural output in Nigeria (Nwosu 1995). Yet, government budgetary allocation to agriculture is not without limitations. The first is the relatively low allocation to the agricultural sector. The second is the actual expenditure which often falls short of budgeted expenditure and the high rate of under spending which is usually higher for agriculture than for other economic sectors. The third is the vast proportion of the funds allocated to agriculture which does not go directly to farmers (Nwosu \& Akpokodje 1993; Omanukwu, 2005). Balogun (2007) posited that despite the rapid increase in financial lending to the economy by financial institutions, a significant proportion of the production loans go to manufacturing, probably to finance imports of raw materials, machineries and component assembly activities and to agriculture. This further suggests that financial institutions like commercial banks have always found an alternative portfolio investment more lucrative than lending to the agricultural sector. Apart from direct funding, government has also been involved in input procurement and distribution. Thus, government effort towards improving soil nutrients in the past had been focused on inorganic fertilizer procurement, distribution and use.

Apart from funding, efficient marketing system is desirable for the attainment of increased agricultural productivity; especially in developing countries that are characterized by high post harvest loses due to poor marketing infrastructures. Efficient food marketing 
system have been documented to reduce post harvest loses, ensure adequate returns to farmer's investment and stimulate expansion in food production thereby enhancing the level of food security in the country (Ladele \& Ayoola 1997). Other studies such as Bassey, Okon \& Ibok (2013), Oladopo (2007) \& Tura (2010) all lend credence to the importance of efficient marketing system in promoting economic development. However, efficient marketing system should incorporate both environmental and social sustainability as high incidence of post harvest loses could diminish the capacity of the rural farmers. Therefore, in attaining green economy in agricultural sector, proper funding of the sector, development of efficient marketing system as well as encouraging the use of organic manure becomes imperative. This is a sure way of ensuring sustainable development that is capable of reducing poverty and enhancing the much advocated national capacity building strategy. Against this backdrop, the study reviews the past government efforts and policies towards inorganic fertilizer procurement and distribution and also examines the impact of proper funding and marketing of green economy in enhancing agricultural productivity in Nigeria

Review of Past Government Effort towards Funding Inorganic Fertilizer. Nigerian Government has been involved in fertilizer procurement, distribution, and subsidizing of fertilizer at various times. The fertilizer distribution system prior to 1996 operated virtually as a government monopoly. Within this period, several variants of the procurements and distribution arrangements between the Federal government of Nigeria and its States were experimented with. This has been aptly reviewed and critiqued by IFDC (1994), Ogunfowora (2000) \& Kwa (2002) and abridge thus:

Prior to 1976: State governments procured fertilizer independently and distributed the fertilizer through sales agents and the extension system. Fertilizer was subsidized at about $95 \%$.

1976 to 1986: Procurement and distribution of fertilizer was centralized by FGN through the Fertilizer Procurement Distribution Division (FPDD).

1987 to 1991: The physical transport from Port and Federal Superphosphate Fertilizer Company (FSFC) became the responsibility of the states but FGN reimbursed transport costs.

1992 to 1994: The depot system was abandoned. FPDD was given responsibility to distribute imported fertilizer only while NAFCON distributed locally produced fertilizer. State agricultural ministries and/or Agricultural Development Projects (ADPs) distributed the fertilizer.

1995 to 1996: FGN stopped importing fertilizer in 1995, and fertilizer was imported by the private sector. NAFCON and blending plants became agencies for distributing locally produced fertilizer. States collected their fertilizer allocation from the fertilizer plants to be reimbursed for transport by FGN later (similar to the 1989-1991 policy). Task forces were set up to monitor distribution.

1997-2002: FGN discontinued the fertilizer subsidy and distribution programs in 1997 and adopted a complete privatization/liberalization of the fertilizer sector. Subsidies were abolished and the import tariff reduced from $10 \%$ to $5 \%$. However, this policy was largely ineffective because the ground work had not been properly laid for the private sector to take over. Fertilizer use declined sharply and the FGN reintroduced a fertilizer subsidy of $25 \%$ in May 1999.

Evidence as shown above indicate the huge investment and attention to fertilizer industry through fertilizer import, subsidy and the establishment of fertilizer production and blending industries aim at improving agricultural productivity. From the above review, Nigerian government has seriously downplayed on the support for green economy.

In addition to the above policy actions, government has also established about thirty two (32) fertilizer companies in different locations across the country between 1976 and 2003. As evidence in Table 1, of the thirty two (32) fertilizer production plants established by the government, only one was for organic manure. This is an indication that government funding in the organic manure subsector has not been encouraging and has undermined the quest for the attainment of a green economy. 
Table 1 - Installed Fertilizer Production Units in Nigeria from 1973-2003

\begin{tabular}{|c|c|c|c|c|c|}
\hline $\mathrm{S} / \mathrm{N}$ & Fertilizer Production Units & $\begin{array}{c}\text { Year of } \\
\text { Establishment }\end{array}$ & Products & $\begin{array}{l}\text { Installed } \\
\text { Capacity }\end{array}$ & Location \\
\hline 1. & $\begin{array}{l}\text { Federal Superphosphate Fertilizer } \\
\text { (FSFC) }\end{array}$ & 1973 & NPK & 100000 & Kaduna \\
\hline 2. & $\begin{array}{l}\text { Notore, Formely called National } \\
\text { Fertilizer Company of Nigeria } \\
\text { (NAFCON) }\end{array}$ & 1981 & $\begin{array}{l}\text { Ammonia } \\
\text { Urea } \\
\text { NPK }\end{array}$ & $\begin{array}{l}200000 \\
550000 \\
250000\end{array}$ & $\begin{array}{l}\text { Onne, Port } \\
\text { Harcourt }\end{array}$ \\
\hline 3 & Cybernetics Nigeria Ltd & 1986 & Micronutrients & - & Kaduna \\
\hline 4. & Fertilizer \& Chemical Co. & - & NPK & 200000 & Kaduna \\
\hline 5. & Morris Nigeria Ltd & 1989 & NPK & 200000 & Minna \\
\hline 6. & Afro-Nutrients \& Chemical Co. Ltd & 1993 & NPK & 300000 & Kano \\
\hline 7. & $\begin{array}{l}\text { Kano Agricultural Supply Co. } \\
\text { (KASCO) }\end{array}$ & 1993 & NPK & 100000 & Kano \\
\hline 8. & Golden Fertilizer Company Ltd & 1993 & NPK & 200000 & Lagos \\
\hline 9. & Zunguru Fertilizer Company Ltd & 1997 & NPK & 200000 & Niger State \\
\hline 10 & Zamfara Blending Plant & 1998 & NPK & 84000 & Gasau \\
\hline 11. & Funtua Fertilizer Company Ltd & - & - & 100000 & Katsina \\
\hline 12. & Bauchi Fertilizer Company Ltd & 1998 & - & 121000 & Bauchi \\
\hline 13. & Gombe Fertilizer Company Ltd & 1999 & NPK & 96000 & Gombe \\
\hline 14. & Bor----no Fertilizer Company Ltd & 1999 & - & 120000 & Borno \\
\hline 15. & Bauchi Kaolin Industry & 1999 & - & - & Bauchi \\
\hline 16. & Gaskiya Fertilizers & 1999 & - & 54000 & Kano \\
\hline 17. & Sasisa Fertilizer Co. & 1999 & NPK & 20000 & Kano \\
\hline 18. & Edo Blending Plant & 2001 & - & 40000 & Edo \\
\hline 19. & Samrock Blending Plant & 2000 & - & - & Sokoto \\
\hline 20. & Kebbi Blending Plant & - & - & 30000 & Kebbi \\
\hline 21. & Adamawa Blending Plant & - & - & - & Yola \\
\hline 22. & Crystal Fertilizer Blending Plant & - & - & 100000 & Kagara \\
\hline 23. & Scentum Al Fertilizers & - & - & - & Enugu \\
\hline 24. & Morgan Int. Ltd & - & NPK & 60000 & Lagos \\
\hline 25. & Jimco Nigeria Co. & - & NPK & 60000 & Lagos \\
\hline 26. & Yobe Fertilizer Co. & 2002 & - & - & Damatoru \\
\hline 27. & $\begin{array}{l}\text { Pacesetter Organic Fertilizers Co. } \\
\text { Ltd. }\end{array}$ & - & $\begin{array}{l}\text { Organic } \\
\text { Fertilizer }\end{array}$ & - & Ibadan \\
\hline 28. & $\begin{array}{l}\text { Albarka Agro Allied \& Chemical } \\
\text { Nigeria Ltd }\end{array}$ & - & - & - & Kano \\
\hline 29. & Plateau Fertilizer \& Chemicals Co. & 2002 & - & - & Jos/Bocos \\
\hline 30. & $\begin{array}{l}\text { Ebonyi State Fertilizer \& Chemicals } \\
\text { Co. } \\
\end{array}$ & 2002 & - & - & Abakaliki \\
\hline 31. & Aweba Fertilizer Co. & 2003 & - & - & Nasarawa \\
\hline 32. & West African Fertilizer Co. & - & - & - & Okpella \\
\hline \multicolumn{2}{|r|}{ Total Installed (Potential) Capacity } & - & - & 2945800 & \\
\hline
\end{tabular}

Source: Federal Fertilizer Department (FFD) and International Fertilizer Development Center (IFDC) cited in IFDC Internal Draft Reporting Assessment of Nigeria and Fertilizer Market (2012).

\section{METHODS OF RESEARCH}

Theoretical Framework and Model Specification. The study use the neoclassical growth model often referred to as growth accounting framework to explain the channel of growth in an economy by examining the impact of proper funding and marketing of green economy in enhancing agricultural productivity in Nigeria. The latter model is used in conjunction with Cobb-Douglas production function which is consistent with the supply theory that underlies the specification of the supply-side of agricultural output (Koskela 2000). The Cobb-Douglas production function is specified as:

$$
Y=f(A, L, K)=A L
$$

Where: $Y=$ Output; $A=$ Efficiency of labour or total factor productivity, $L=$ Labour, $\mathrm{K}=$ Capital stock, $\mathrm{T}=$ Time dimension. 
Several studies have attempted to integrate exogenous variables with endogenous variables in explaining growth in output. Hence, this empirical study adopts neoclassical production function employed by Odusola (1998), Iganiga \& Unemhilin (2011) as follows:

$$
Y_{t}=A_{t} L^{\beta}{ }_{1} K^{\beta}{ }_{2} P^{\beta}{ }_{3}
$$

Where: $Y=$ output; $P=$ Additional Input; $\beta_{1}+\beta_{2}+\beta_{3}=1$ (assuming constant returns to scale).

The log linear form of equation 2 taking the natural logarithm of both sides is:

$$
\ln Y=\beta+\beta_{1} \operatorname{lnL}+\beta_{2} \operatorname{lnk}+\beta_{3} \ln P
$$

It is assumed in this study that government expenditure is the being the main determinant of agricultural output.

$$
\begin{gathered}
\operatorname{In} A R G D P=\beta_{0}+\beta_{1} \operatorname{lnTGEA} \\
\ln A R G D P=\beta_{0}+\beta_{1} \ln T G E A+\beta_{2} \ln C B A+\beta_{3} \ln C P I+\beta_{4} A P O P+U_{t}
\end{gathered}
$$

Where: ARGDP = Agricultural Real Gross Domestic Product (\#M); TGEA = Total Government Recurrent Expenditure on agriculture sector ( $\mathrm{AM})$; $\mathrm{CPI}=$ Composite consumer

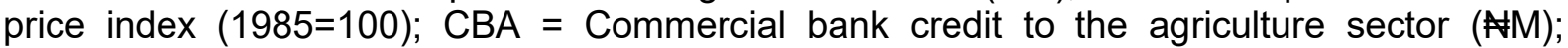
APOP = Agricultural Population.

$\beta_{0}$ is the intercept while $\beta_{1}, \beta_{2}, \beta_{3}, \beta_{4}$ are parameter estimate of the linear equation. $U_{t}$ is the error term which captures all other variables not explicit captured in the model and is expected to be independently distributed.

Data Collection. Secondary data were used for the study. Time-series annual data covering 1970-2010 from publication of the Central Bank of Nigeria Statistical Bulletin, Annual Report and Statements of Account of Central Bank of Nigeria (CBN), Food and Agriculture Organization (FAO) online data base were employed.

Estimation Procedure. Analysis was carried out using Econometric View (E-View 7.1). Four estimation procedures were employed as follows:

Unit root test. This was done to solve the problem of spurious regression arising from the time series properties of the data set used in estimation of equation 5 . The Augmented Dickey-Fuller (ADF) unit root test was employed for this purpose to test the integration level and the possible co-integration among the variables. The model is written as:

$$
\Delta y_{t}=\alpha_{0}+Y y_{t} 1+\alpha_{2} t+\Sigma \beta j \Delta D y_{t}-1+e_{t}
$$

Where: $y$ is the series $t$ is (trend factor); $\alpha_{0}$ is the constant term; $e_{t}$ is the stochastic error term $b$ is the lag length.

Co-integration. If the data set indicates integration property of the order 1(1) for the employed variable, co-integration test among the variables using Johansen (1988 1991) will be employed.

Error correction Model (ECM). If the variables tested are co-integrated, then ECM will be estimated to test for the short-run dynamics of the model. Thus:

$$
\begin{aligned}
& Y_{t}=\alpha+\beta_{y t}+\xi_{t} \\
& \Delta y_{t}=U_{t-1}+\Sigma \beta \Delta x_{t-1}+\Sigma \alpha_{t} \Delta y_{t-1}+\varepsilon
\end{aligned}
$$

$\mathrm{U}_{\mathrm{t}-1}$ is the one period lagged value of the error from cointegrating regression while $\Delta$ denotes the first differences operator.

Granger causality technique. This was used to examine the direction of causality between variables. 


\section{RESULTS AND DISCUSSION}

ADF Unit Root Test. The time series behavior of each of the series is represented in Table 2. The result of the ADF test conducted at both levels and first difference revealed that variables were homogenous of order one. Thus, variables became stationary at first difference prior to subsequent estimations to avoid spurious regressions.

Table 2 - ADF Unit Root Test

\begin{tabular}{|c|c|c|c|}
\hline Variable & Level Intercept & 1st Difference Intercept & Conclusion \\
\hline LNARGDP & -1.7138 & $-6.0123^{* * *}$ & $1(1)$ \\
\hline LNTGEA & -0.6870 & $-10.2762^{* * *}$ & $1(1)$ \\
\hline LNCBA & -2.1412 & $-11.1470^{* * *}$ & $1(1)$ \\
\hline LNCPI & 0.6662 & $-6.6267^{* * *}$ & $1(1)$ \\
\hline APOP & -2.8742 & $-6.0002^{\star * *}$ & $1(1)$ \\
\hline
\end{tabular}

Source: Computed by Author, 2014.

Co-integration Test. Tables 3 and 4 show the results of Johansen cointegration tests indicating the presence of two (Trace) and one (Maximum Eigen value) cointegrating vectors respectively. With the fact that almost all the variables were stationary at the first differencing, it was necessary to carry out another test to assess if the non-stationary variables were co-integrated. In essence, the hypotheses were tested to affirm the rank of the cointegrating relationships that existed among the variables at 5 percent level of significance. This indicates that there was evidence of the existence of a long-run relationship among the variables. Therefore, applying the error correction model (VECM) would enable us to track the long-run relationship between the variables and tie it to deviation that may occur in the short-run (Lorde, Jackson \& Thomas 2009).

Table 3 - Johansen Cointegration Trace Test

\begin{tabular}{|c|c|c|c|}
\hline Null Hypothesis & Alternative Hypothesis & Test Statistic & Critical Value (0.05) \\
\hline$r=0$ & $r=<1$ & 81.74684 & $69.81889^{* *}$ \\
\hline$r=1$ & $r=<2$ & 43.45620 & 47.85613 \\
\hline$r=2$ & $r=<3$ & 19.66315 & 29.79707 \\
\hline$r=3$ & $r=<4$ & 6.857417 & 15.49471 \\
\hline$r=4$ & $r=<5$ & 1.983648 & 3.841466 \\
\hline
\end{tabular}

Source: Computed by Author, 2014. Notes: $r$ indicates the number of co-integrating vector. ${ }^{* *}$ is the significance level at 5\%. P-values are obtained using response surfaces in MacKinnon, Haug \& Michelis (1999).

Table 4 - Johansen Cointegration Maximum Eigenvalue Test

\begin{tabular}{|c|c|c|c|}
\hline Null Hypothesis & Alternative Hypothesis & Test Statistic & Critical Value 0.05 \\
\hline$r=0$ & $r=1$ & 38.29063 & $33.87687^{\star *}$ \\
\hline$r=1$ & $r=2$ & 23.79306 & 27.58434 \\
\hline$r=2$ & $r=3$ & 12.80573 & 21.13162 \\
\hline$r=3$ & $r=4$ & 4.873769 & 14.26460 \\
\hline$r=4$ & $r=5$ & 1.983648 & 3.841466 \\
\hline
\end{tabular}

Source: Computed by Author, 2014. Notes: $r$ indicates the number of co-integrating vector. ${ }^{* *}$ is the significance level at 1\%. P-values are obtained using response surfaces in MacKinnon, Haug \& Michelis (1999).

Error Correction Model. To examine if a significant short-run relationship existed between variables used in the study, an error correction modeling (ECM) analysis was employed as presented in Table 5. The parsimonious error correction model with a twoperiod lagged values of the explanatory variables and one lagged value of the error term (ECM) estimate showed that $R^{2}$ value of 0.77 indicates the variables explained about 77 percent of agricultural output. F-statistic of $11.01(\mathrm{P}<0.01)$ reveals that they are jointly significant and the Durbin Watson Statistic value of 2.08 implies that the model does not suffer from autocorrelation problem but has a very good fit. The error correction term with a value of -0.1045 approximately is appropriately signed but not significant. This implies that 
financing and marketing of green economy had no impact on agricultural productivity in the short-run but in the long-run. However, the ECM value provides an insight on the speed of adjustment of the model from its long run equilibrium on account of any short run shock. Thus, the value of -0.1045 indicates that a short run disequilibrium in the long run financing and marketing of green economy relationship will be corrected at a speed of 10.45 percent per annum and it would take nine years and five months for full restoration back to the equilibrium after a short-run distortion. Therefore, correcting any deviations from the long-run equilibrium.

Table 5 - Parsimonious Error Correction Model for Short-run Impact

\begin{tabular}{|c|c|c|c|c|}
\hline Variable & Coefficient & Std. Error & t-Statistic & Prob. \\
\hline $\mathrm{C}$ & 0.078090 & 0.057359 & 1.361414 & 0.1842 \\
\hline D(LNARGDP(-1)) & 0.555906 & 0.149662 & 3.714415 & 0.0009 \\
\hline D(LNARGDP(-2)) & -0.095670 & 0.089788 & -1.065513 & 0.2957 \\
\hline $\mathrm{D}($ LNAPOP $(-1))$ & -10.75602 & 1.194855 & -9.001948 & 0.0000 \\
\hline $\mathrm{D}(\mathrm{LNAPOP}(-2))$ & 8.375462 & 1.931414 & 4.336441 & 0.0002 \\
\hline $\mathrm{D}(\mathrm{LNCBA}(-1))$ & 0.046584 & 0.045513 & 1.023537 & 0.3148 \\
\hline $\mathrm{D}(\mathrm{LNCPI})$ & -0.070670 & 0.090156 & -0.783866 & 0.4397 \\
\hline $\mathrm{D}(\mathrm{LNCPI}(-2))$ & -0.047946 & 0.096320 & -0.497784 & 0.6225 \\
\hline $\mathrm{D}$ (LNTGEA) & 0.039740 & 0.045683 & 0.869895 & 0.3918 \\
\hline $\operatorname{ECM}(-1)$ & -0.104518 & 0.153656 & -0.680208 & 0.5020 \\
\hline R-squared & 0.779686 & \multicolumn{2}{|c|}{ Mean dependent var } & 0.133892 \\
\hline Adjusted R-squared & 0.708871 & \multicolumn{2}{|c|}{ S.D. dependent var } & 0.384908 \\
\hline S.E. of regression & 0.207682 & \multicolumn{2}{|c|}{ Akaike info criterion } & -0.084681 \\
\hline Sum squared resid & 1.207694 & \multicolumn{2}{|c|}{ Schwarz criterion } & 0.346263 \\
\hline Log likelihood & 11.60893 & \multicolumn{2}{|c|}{ Hannan-Quinn criter. } & 0.068646 \\
\hline F-statistic & 11.01016 & \multicolumn{2}{|c|}{ Durbin-Watson stat } & 2.081627 \\
\hline \multicolumn{2}{|c|}{ Prob(F-statistic) } & \multicolumn{3}{|c|}{0.000000} \\
\hline
\end{tabular}

Source: Computed by Author, 2014.

Granger Causality Test. Granger causality test was used to examine the direction of causality between two variables (Granger 1969) with a maximum lag of two (2) on the first difference of the log transforms of the variables as presented in Table 6.

Table 6 - Pairwise Granger Causality Tests

\begin{tabular}{|c|c|c|c|}
\hline Null Hypothesis: & Obs & F-Statistic & Probability \\
\hline LNCBA does not Granger Cause LNARGDP & 39 & 2.33115 & 0.11253 \\
\hline \multicolumn{2}{|l|}{ LNARGDP does not Granger Cause LNCBA } & 1.07336 & 0.35316 \\
\hline LNCPI does not Granger Cause LNARGDP & 39 & 0.49608 & 0.61325 \\
\hline \multicolumn{2}{|l|}{ LNARGDP does not Granger Cause LNCPI } & 0.40468 & 0.67036 \\
\hline LNTGEA does not Granger Cause LNARGDP & 39 & 2.80676 & 0.07444 \\
\hline \multicolumn{2}{|l|}{ LNARGDP does not Granger Cause LNTGEA } & 1.02488 & 0.36966 \\
\hline LNAPOP does not Granger Cause LNARGDP & 39 & 67.3989 & $1.5 \mathrm{E}-12$ \\
\hline \multicolumn{2}{|l|}{ LNARGDP does not Granger Cause LNAPOP } & 1.59790 & 0.21714 \\
\hline LNCPI does not Granger Cause LNCBA & 39 & 0.61609 & 0.54597 \\
\hline \multicolumn{2}{|l|}{ LNCBA does not Granger Cause LNCPI } & 0.84108 & 0.44002 \\
\hline LNTGEA does not Granger Cause LNCBA & 39 & 0.68020 & 0.51327 \\
\hline \multicolumn{2}{|l|}{ LNCBA does not Granger Cause LNTGEA } & 4.19355 & 0.02356 \\
\hline LNAPOP does not Granger Cause LNCBA & 39 & 0.11552 & 0.89125 \\
\hline \multicolumn{2}{|l|}{ LNCBA does not Granger Cause LNAPOP } & 2.23345 & 0.12265 \\
\hline LNTEA does not Granger Cause LNCPI & 39 & 1.48505 & 0.24081 \\
\hline \multicolumn{2}{|l|}{ LNCPI does not Granger Cause LNTGEA } & 1.44354 & 0.25020 \\
\hline LNAPOP does not Granger Cause LNCPI & 39 & 0.04534 & 0.95573 \\
\hline \multicolumn{2}{|l|}{ LNCPI does not Granger Cause LNAPOP } & 2.64678 & 0.08544 \\
\hline LNAPOP does not Granger Cause LNTGEA & 39 & 1.42134 & 0.25537 \\
\hline \multicolumn{2}{|l|}{ LNTGEA does not Granger Cause LNAPOP } & 6.01277 & 0.00581 \\
\hline
\end{tabular}

Source: Computed by Author, 2014. 
The empirical results of the Granger causality test showed that Granger causality runs uni-directionally from Total Government Recurrent Expenditure on agricultural sector (LNTGEA) to Agricultural Real GDP (ARGDP), Commercial bank credit to the agriculture sector (LNCBA) to Total Government Recurrent Expenditure on agriculture sector (LNTGEA), Composite consumer price index (LNCPI) to Agriculture Population (LNAPOP) and Total Government Recurrent Expenditure on agriculture sector (LNTGEA) to Agriculture Population (LNAPOP).

\section{CONCLUSION AND RECOMMENDATIONS}

The role of finance cannot be over-emphasized since no tangible investment can be done without funds. The outcome of the review shows that government funding of the organic subsector has not been encouraging and has undermined the attainment of a green economy. Findings also revealed that government is the prime mover of funds to agriculture. This is evidence with the uni-direction of government funds to agricultural output and agricultural population. Also, the uni-direction of consumer price index to agricultural population is an indication that proper marketing of green economy to the populace by all stakeholders in the business coupled with proper financing both by the government and financial institutions would boost agricultural productivity in the country. It is therefore recommended that concerted efforts by all stakeholders are required to steer green agriculture on a sustainable production and productivity pathways. Funds used for inorganic fertilizer procurement and subsidy should be re-directed to organic manure. This is a sure way towards Nigeria's transition from inorganic based economy to a diversified green economy for sustainable development as well as reducing poverty and heightened National capacity building strategy.

\section{REFERENCES}

1. Balogun, ED 2007, 'A review of Soludo's Perspective of Banking Sector Reforms in Nigeria', MPRA Paper, No. 3803. pp. 3-5, 7-8, 12-14.

2. Bassey, NE, Okon, UE \& Ibok, OW 2013, 'Inter-market performance and Pricing Efficiency of Imported Rice marketing in South- South Nigeria: the case of Akwa lbom State Traders', Agricultural Science, vol. 1, no.2, pp. 49-52.

3. Chigbu, UE 2005, Agriculture as the only saviour to Nigeria dyeing economy retrieved on12th July 2005, <http://www.nigerianvillagesquare.com/articles/guest/2005/03/agric-asonly-saviour-to.html>

4. Daramola, A, Ehui, S, Ukeje, E \& McIntire, J 2007, Agricultural Export Potential in Nigeria Economic Policy Options for a Prosperous Nigeria, Palgrave Macmillian, London.

5. Falusi, AO 2008, 'Sustainable Agriculture in Sub-Saharan Africa: A critical look into the constraints and prospects', paper presented at IARSAF conference IITA, Ibadan.

6. FMAWR, 2008, Federal Ministry of Agriculture and Water Resources National Programme for Food Security.

7. Fuentes, P A, Bumb, B \& Johnson, M 2012, Improving Fertilizer Markets in West Africa: The Fertilizer Supply Chain in Nigeria. International Fertilizer Development Center (IFDC) \& International Food Policy Institute (IFPRI).

8. Jeter, HF 2004 'How to revive Nigeria's agricultural sector' The vanguard Lagos. Retrieved on 22nd July 2004 <http://africa.com/stories/200403040476.html>

9. Igaaniga, BO \& Unemhilin, DO 2011, 'The Impact of Federal Government Agricultural Expenditure on Agricultural Output in Nigeria', J. Economics, vol.2, no. 2, pp. 81-88.

10. Koskela, L 2000, 'An Exploration towards Production: Theory and its Application to Construction' VIT Publications, pp. 408.

11. Kwa, A. R. 2002. 'Policy Initiatives Relating to Fertilizer Production and Marketing (Including Fertilizer Regulations) in Nigeria', Paper presented at the National Workshop for Fertilizer Blending Plants in Nigeria, organized by the IFDC DAIMINA Project, Abuja, Nigeria, June, 25-26. 
12. Ladele, AA \& Ayoola, GB 1997, 'Food marketing and its roles in Food Security in Nigeria': In Shaib B; Adedipe NO; Aliyu A and Jir MM. (eds): Integrated Agricultural Production in Nigeria; strategies and Mechanisms for Food Security. Proceedings of the National Workshop on Nigeria position at the World Food Summit, Abuja, Nigeria. pp. 88.

13. Lorde, T, Jackson, M \& Thomas, C 2009, 'The Macroeconomic Effects on a Price Fluctuations on a Small Open Oil-Producing Country: The Case of Trinidad and Tobago', Energy Policy, vol.37, no.7, pp. 2708-2716.

14. MacKinnon, JG, Haug, AA \& Michelis, L 1999, 'Numerical distribution functions of likelihood ratio tests for cointegration', Journal of Applied Econometrics, vol 14, pp. 56377.

15. McCalla, AF \& Josling, TE, 1985, Agricultural Policies and World Markets, MacMillan Publishing Company, New York, NY, U.S.A.

16. National Bureau of Statistics (NBS) 2005, Poverty profile for Nigeria. Federal Republic of

17. Nigeria.

18. NBS 2007, National Bureau of Statistics: Agricultural survey Report 1994/95 - 2005/06.

19. NEEDS 2008, National Economic Empowerment and Development Strategy (20082011): The seven point Agenda.

20. Nigerian National planning Commission 2004, Meeting Everyone's Needs- National Economic Empowerment and Development Strategy Nigerian National Planning Commission, Abuja, 2004.

21. Nwosu, AC 1995, 'The Determinants of Government Agricultural Expenditure in Nigeria', IRP no. 4, Nigerian Institute of Social and Economic Reearch, Ibadan. Nwosu, AC \& Akpokodje G 1993. Planning for the Rural Poor: Trends and options in the Development Plans of Nigeria. Review of Government and Society.

22. Nwosu, AC 2004, 'Private Sector Initiative in Agricultural Development in Nigeria' Central Bank of Nigeria Publication'. Proceedings of the 13th Annual Conference of the Regional Research Unit. University of Ibadan, August 6 to 8, 2004.

23. Ocampo, JA 2014, 'The Transition to a Green Economy: Benefits, Challenges and Risks from a Sustainable Development Perspective Summary of Background Papers' http://www.unep.org/greeneconomy/Portals/88/documents/research_products/UNDESA, \%20UNCTAD\%20Transition\%20GE.pdf-8/12/2014

24. Odusola, AE 1998, 'Rekindling Investment Economic Development in Nigeria'. NES Selected Paper for the 1998 Annual Conference, University of Lagos June, 22 - 24, 1998.

25. Ogunfowora, O 2000. 'The Travails of Nigerian Agricultural Inputs Supply System: Which Way Forward?', ACS ABISE Consulting System (NIG) Ltd., 5th Tai Solarin Memorial Lecture,Mayflower School, Ikenne, Nigeria.

26. Oladapo, MO, Momoh S, Yusuf S \& Awoyinka, Y 2007,' Marketing Margin and Spatial Pricing Efficiency of Pineapple in Nigeria' Asian Journal of Marketing, vol.1, no.1, pp. 1422.

27. Ogunfowora, O. 2000, 'The Travails of Nigerian Agricultural Inputs Supply System: Which Way Forward?' ACS ABISE Consulting System (NIG) Ltd., 5th Tai Solarin Memorial Lecture, Mayflower School, Ikenne, Nigeria.

28. Tura VB, Johnathan, A, \& Lawa, H 2010, 'Structural Analysis of paddy rice markets in Southern Part of Taraba State, Nigeria' J. of agriculture and Social Sciences. vol. 6, no. 4, pp. $110-112$.

29. UNCTAD, 2011. Building a Development-Led Green Economy.

30. UNEP (United Nations Environmental Programme) 2010, 'Green Economy: A Brief for Policymakers on the Green Economy and Millennium Development Goals', Document prepared for the UN Summit on MDGs, September, 2010.

(C) 2017 by the authors. Licensee RJOAS, Orel, Russia. This article is an open access article distributed under the terms and conditions of the Creative Commons Attribution (CC BY) license: http://creativecommons.org/licenses/by/4.0/ 
DOI https://doi.org/10.18551/rjoas.2017-09.08

\title{
ANALYSIS OF THE EFFECTS OF ECONOMIC GROWTH, INVESTMENT, REGIONAL TAXES, AND CAPITAL EXPENDITURE TOWARD THE INCOME DISPARITY IN INDONESIA (2007-2013)
}

\author{
Hardanto $H_{.}^{*}$, Ismail M., Khusaini M. \\ Faculty of Economics and Business, University of Brawijaya, Indonesia \\ *E-mail: heruhard@yahoo.co.id
}

\begin{abstract}
This research is aimed to examine the effects of economic growth, Foreign Direct Investment, regional taxes, and provincial regional capital expenditure toward the income disparity in Indonesia from 2007-2013. This research utilized panel data composed from 33 provinces in Indonesia from 2007-2013 (231 observations). The method used in this research was regression analysis of panel data using Fixed Effect Model. Research results showed that economic growth and regional taxes had a positive influence toward the income disparity. Capital expenditure affected the income disparity negatively. Meanwhile, foreign direct investment had no effect on the income disparity.
\end{abstract}

\section{KEY WORDS}

Income disparity, economic growth, FDI, regional taxes, capital expenditure.

Economic growth is one of the indicators of development success, in addition to the other indicator of income distribution. From the standpoint of economic growth, Indonesia continues to experience an increase in per capita output per year, which is shown by the increase in gross national per capita income. According to World Bank data, the gross national per capita income of Indonesia increased from US\$ 560 in 2000 to US\$ 3.630 in 2014. Even though there was an increase of per capita output, the income disparity in Indonesia as measured by the Gini Coefficient (Gini Index) instead tends to experience an increase. Based on data from the Central Statistics Agency (Badan Pusat Statistik, BPS), the Gini Coefficient of Indonesia has risen from 0.36 in 2006 to 0.41 in 2013.

The Gini Coefficient of Indonesia since 2011 has exceeded 0,40, which is the international warning level for a dangerous disparity level. Globally, since 2011 Indonesia could be categorized as a country with a low income and a high income disparity, shifting from a low-income country with a low income disparity in the previous decade (Yusuf, 2014).

Much attention has been given on how the income disparity appears in the time of economic growth. According to Galbraith and Kum (2012), the relationship between income disparity and economic growth began to receive attention when Simon Kuznets explained his hypothesis. According to Kuznets, in the early stage of development, initially the income distribution becomes more uneven, but income distribution will become more even after reaching a certain level of development. Several studies and their findings confirm the view of Kuznets, among them including Park and Shin (2015) and Cevik and Caro (2015). However, several studies also did not support the view, an example being the study carried out by Khasru and Jalil (2004). Several studies showed that economic growth did not affect the income disparity (Schultz (1998), Deininger and Squire (1998), Ravalion and Chen (1996).

Because of these differences in study results regarding the effect of economic growth on the income disparity, there needs to be research on whether economic growth in various provinces in Indonesia is able to reduce the income disparity or instead make the income disparity deeper and even worse.

Based on the results of other studies, there is another factor that may also encourage economic development and affect income disparity, and that is investment. Investment plays important roles in encouraging development in a country, and thus this is often called as an "engine of growth" by economists. According to Mundell (1957) and Bhandari (2007), an 
increase in the flow of investment will reduce the disparity in the distribution of income. Conversely, according to Freeman (2010), Mah (2002), and Lipsey and Sjoholm (2001), the entry of investment, in particular foreign direct investment (FDI), causes an increase of the income disparity. Yet the results of studies by Mah (2003) and Sylwester (2005) show that FDI did not have an effect on income distribution.

Based on data from the Central Statistics Agency, the realization of foreign direct investment (FDI) in Indonesia in 2007 was US\$ 10,341.4 and in 2013 this increased to US\$ 28,617.5. Thus in the time frame within 2007-2013 there was an increase of investment by US\$ 18,276.1. Seeing the magnitude of foreign investment, research then needs to be conducted on whether foreign investment has been able to encourage development and overcome the income disparity.

Yet another factor that may affect the distribution of income is government policies. According to Todaro (2011), the government may perform intervention through government policies to change the distribution of income. This form of government intervention is through the application of government budget expenditure and taxation policies. Since entering the era of regional autonomy in 1999, the Indonesian government has provided greater authority to regional governments in regulating, taking advantage of, and uncovering potential sources in each region. One of the forms of this authority is that regional governments can determine regional tax and budget expenditure policies. One of the goals of this decentralization of authority is to equalize regional development. Regional autonomy has been implemented for over a decade, and therefore it is necessary to see whether government policies through the application of regional taxes and government expenditure has been able to increase the equalization of income distribution or to overcome the income disparity.

Considering that research that discusses discrepancies using provinces as the unit of analysis has been limited, this research was conducted. The objective of this research is to analyze the effects of economic growth, foreign direct investment, regional taxes, and capital expenditure toward the income disparity in Indonesia.

\section{LITERATURE REVIEW}

The relationship between economic growth and disparity began to surface when the economist Simon Kuznets put forth his upside-down $U$ hypothesis (Galbraith and Kum, 2012). According to Kuznets, income distribution at an early stage tends to worsen, but in the following stages, the distribution will improve. Because the shape of the curve of changing tendencies of income distribution (Gini Coefficient) and the per capita Gross Domestic Product growth appears to resemble appears to resemble the shape of an upside-down letter " $U$ ", this hypothesis is known as the upside-down $U$ hypothesis of Kuznets. Income distribution, according to Kuznets, will increase along with economic growth (Todaro, 2000).

Neoclassical economists explain that while still at an early stage, economic growth will tend to reduce the disparity of income and poverty. Meanwhile, Karl Marx (in Irawan 2012) had the opinion that at an early stage of development, economic growth will cause demand for labor to increase. The increasing rate of wages of laborers will affect the increase of capital risk for laborers, which will cause a decrease in the demand for labor. This situation will create a problem of unemployment and income disparity. Thus, it is only at the early stage that economic growth tends to be able to reduce poverty and the income disparity; in the next stage, the opposite will occur.

Results of research by Park and Shin (2015) showed that financial and per capita income growth in several developed countries affected the income disparity at certain levels of per capita income accordingly to the upside-down $U$ curve hypothesis of Kuznets. In contrast, the opposite was found by Khasru and Jalil (2004) from their research with time

series data and panel data from 24 countries, where results indicated that the effect of economic growth did not conform to the upside-down $U$ curve pattern by Kuznets.

Lin (2003) conducted research on the effect of economic growth on the income disparity and reduction of poverty in the People's Republic of China within the years of 19852001. The result was that economic growth negatively affected poverty but positively 
influenced the income disparity. Meanwhile, Kang (2015) found that economic growth correlated negatively toward income disparity. Similar results were obtained by Psacharopoulos et al. (1995) with research of Latin American countries that showed that economic growth negatively affected the income disparity.

Deininger and Squire (1998) found that economic growth did not affect the income disparity significantly. Similar findings were obtained by Ravalion and Chen (1996) where the aggregate income increase in several developing countries did not significantly affect the reduction of the income disparity.

Foreign Direct Investment (FDI) becomes one of the important sources of funding for a developing country. According to Mundell (1957), an increase in the flow of Foreign Direct Investment (FDI) in a developing country will reduce the disparity in income distribution. The increase of FDI flows from developed countries to developing countries through the increase of available capital will result in the marginal increase of physical product from laborers. This will in turn increase nominal wages as well as real wages, reducing the income disparity.

Feenstra and Hanson (1997) have the view that capital flows from developed countries to developing countries will cause an increase in the demand for skilled labor (seen from the view of developing countries). This will increase the relative wages for those laborers. As such, wages will improve for skilled laborers and conversely for unskilled laborers, wages do not improve. Thus the primary consequence of FDI flows to developing is the increase of the disparity on income distribution.

Research results by Bhandari (2007) indicated that investment negatively affects the income disparity. Dabla-Norris et al. (2015) found that investment will have a positive influence in increasing the disparity in developed countries. Meanwhile in developing countries, foreign direct investment does not have an influence on the disparity.

Figini and Gorg (2006) found that FDI had a different influence on the income disparity. In developing countries, investment will first have a positive influence on the income disparity, and then in later times will influence the income disparity negatively. Meanwhile in developed countries, investment will have a negative influence on the income disparity. Also, Mihaylova (2015) found that the influence of FDI on the disparity can vary depending on the levels of development, education, and economy in the countries targeted for investment.

Mah (2002) and Lipsey and Sjoholm (2001) found that FDI caused the increase of the income disparity. Yet Mahler et al. (1999), Sylwester (2005), and Mah (2003) found that the expansion of FDI does not significantly affect the disparity of income distribution in developing countries.

In relation to the influence of taxes on the income disparity, llaboya (2013) found that tax revenue negatively affected the income disparity. As well, Martinez-Vazquez et al. (2014) found that the share of individual progressive income tax on the GDP had a positive influence on the distribution of income or in other words reduce the income disparity. On the other hand, consumptive taxes, excise taxes, and import duties instead increased the income disparity. A greater share of social prosperity expenditure on the GDP was able to reduce the income disparity.

Musgrave and Rostow in Mangkoesoebroto (1998) created a development model that related development from government expenditures with the stages of state economic developmental growth. In the early stage of economic development, there needs to be major state expenditures for investment, in particular to provide infrastructure. In the middle stages of economic development, government investment is still needed for economic growth, but at this stage investment from the private sector has begun to develop. In the advanced stages of economic development, government expenditures are still necessary, in particular to increase the welfare of the people.

One of the government expenditures to increase the welfare of the people is capital expenditure. One of the uses of capital expenditure is for the construction of public infrastructure that the people need. According to Estache (2003), infrastructure can aid impoverished people and those living in backward regions to become connected with important economic activities, which allow the people to obtain additional productive opportunities. 
Holzner (2011) found that government expenditures correlated negatively toward the income disparity. Conversely, Sabir et al. (2015) found that government expenditures had a positive influence on the income disparity.

\section{METHODS OF RESEARCH}

In this research, the utilized type of data was secondary data. The utilized data was in the form of panel data, which combines the two types of time series and cross section data. This research combines time series data of a time frame of seven years from 2007-2013 as well as cross section observations of 33 provinces in Indonesia (231 observations). Analysis using panel data has the advantage of allowing the researcher to examine deeper the economic effects that cannot be obtained if the researcher only uses either time series or cross section data. Several of the methods used in performing estimations with panel data regression are the Common Effect (CE) Model, Fixed Effect (FE) Model, and Random Effect (RE) Model. The Chow and Hausman tests are used to determine the most appropriate regression estimation. Analysis of panel data in this research uses the Eviews 7 program.

Mathematically, the form of the regression equations for the panel data in this research can be formulated as:

$$
\text { GINlit }=\beta 0+\beta 1 \text { GROWit }+\beta 2 \text { FDlit }+\beta 3 \text { TAXit }+\beta 4 \text { SPCAPit }+\varepsilon i t
$$

Where: GINI is the income disparity (Gini Ratio); GROW is economic growth (as a percent); FDI is foreign direct investment; TAX is the regional tax of the provincial government; SPCAP is the capital expenditure of the provincial government; and $\varepsilon$ is error.

To avoid incorrect understandings and to narrow down the coverage of the problems in this research, the following are the operational definitions of each research variable:

Income disparity in this research is the income disparity that is measured using the Gini Index in each province in Indonesia. The Gini Index was taken from the Central Statistics Agency (Badan Pusat Statistik, BPS).

Economic growth is the growth in per capita gross regional domestic product (GRDP) from the constant price base in the year 2000 in each province (as a percent). The per capita GRDP growth data from the constant price base in 2000 was taken from the Central Statistics Agency.

Foreign direct investment is the ratio of foreign direct investment toward the GRDP in each province in the time frame of 2007-2013 (as a percent). Data of foreign direct investment (FDI) realization was taken from the Investment Coordinating Board (Badan Koordinasi Penanaman Modal, BKPM) and GRDP data was taken from the Central Statistics Agency. The value of FDI realization ratio is calculated by dividing the FDI realization value by the GRDP. Because the FDI value is in US dollars and the GRDP is in rupiahs, to calculate the ratio of FDI to GRDP, unit conversion is performed on the GRDP from rupiahs to US dollars by dividing the GRDP of each year by the yearly average exchange value of the rupiah to the US dollar. Data of the yearly average exchange value was taken from Bank Indonesia.

Regional tax of the provincial government is the ratio of realization of provincial tax revenue toward the GRDP of each province in the time frame of 2007-2013 (as a percent). Data of the realization of provincial tax revenue and the GRDP were taken from the Central Statistics Agency. The ratio of realization of provincial tax revenue is obtained by dividing the realization of tax revenue by the GRDP value of the same year.

Capital expenditure of provincial governments is the ratio of realization of capital expenditure of provincial governments toward the GRDP of each province in the time frame of 2007-2013 (as a percent). Data of the realization of capital expenditure and the GRDP were taken from the Central Statistics Agency. The ratio of realization of capital expenditure of provincial governments is obtained by dividing the realization of capital expenditure by the GRDP value of the same year. 


\section{RESULTS AND DISCUSSION}

In the analysis of panel data with the bound variable of income disparity (GINI) and free variables of economic growth (GROW), investment (FDI), regional taxes (TAX), and capital expenditure (SPCAP), the Chow Test and Hausman Test were performed to obtain the most appropriate regression model.

Based on the results of the Chow Test with Eviews, a Chi-square probability value of 0.0000 was obtained, less than the significance value $\alpha$ of $0.05(\alpha=5 \%)$. This shows that the fixed effect model was better compared to the common effect model (pooled least square). The results of the Hausman Test showed a Chi-square probability value (Prob.) of 0.0005 , less than the value of $\alpha$ of $0.05(\alpha=5 \%)$. This shows that the fixed effect model was better compared to the random effect model. Thus, the best model used to estimate the regression of panel data in this research was the fixed effect (FE) model.

Using the fixed effect (FE) model for analysis of panel data, these estimation results were obtained:

Table 1 - Regression Results

\begin{tabular}{|c|c|c|c|}
\hline Variable & Coefficient & $t$-Statistic & Probability \\
\hline Constant (C) & 0.273525 & 22.51559 & $0.0000^{*}$ \\
\hline Economic Growth ( GROW) & 0.001480 & 2.026599 & $0.0441^{*}$ \\
\hline Foreign Direct Investment (FDI) & 0.000386 & 0.863960 & $0.3887^{*}$ \\
\hline Regional Tax (TAX) & 0.081643 & 7.482308 & $0.0000^{\star}$ \\
\hline Capital Expenditure(SPCAP) & -0.010536 & -2.771299 & $0.0061^{*}$ \\
\hline
\end{tabular}

$R$-squared: 0.652748

Adjusted R-squared: 0.588310

F-statistic: 10.12979

Prob. (F-statistic): 0.000000

Note: $\left(^{*}\right)$ significant for $\alpha=5 \%$

Based on the results of regression above, it can be seen that economic growth (GROW) had a positive influence toward changes in the variable of income disparity (GINI). This means that as economic growth (growth in per capita GRDP) escalates, this will also increase income disparity.

As such, economic growth will instead worsen the income disparity. Referring to the view of Kuznets, the stages of development in provinces in Indonesia could still be at the early stage of development, where economic growth worsens the income disparity instead. This may be because of the still-unequal opportunities and access toward economic resources for all people or economic actors in various provinces.

The results of this research supports the research of Lin (2003) who found that economic growth positively affected the income disparity and negatively affected the poverty rate. Meanwhile, the group of Neo-Marxist economists have the view that economic growth will cause the disparity between rich people and poor people to widen further. In contrast, the results of this research do not reflect the views of Neoclassical economists, that economic growth will reduce the income disparity (negative effect to the disparity) even in the early stages of economic development.

Meanwhile, based on the results of the above regression, the variable of foreign direct investment (FDI) has a $\mathrm{t}$ statistical probability value of 0.3887 ; hence foreign direct investment did not significantly affect the income disparity. These results do not reflect the theory of Mundell (1957), who stated that an increase in Foreign Direct Investment (FDI) flow in developing countries will reduce the disparity in the distribution of income.

The variable of regional tax (TAX) based on the results of the regression had a $t$ statistical probability value less than the value of $\alpha=0.05$. With this, regional taxes will have a positive influence on the income disparity. This means that every increase in regional taxes will increase the income disparity. 
According to Law No. 28 of 2009, regional provincial taxes are composed of the Motor Vehicle Tax, Motor Vehicle Transfer Fee, Motor Vehicle Fuel Tax, Surface Water Tax, and Cigarette Tax. These five regional taxes above are included as consumption taxes. The Surface Water Tax, Cigarette Tax, and Motor Vehicle Fuel Tax are indirect taxes on consumption. From the above fact, it can be seen that regional taxes and in particular provincial taxes are more dominated by indirect taxes. This result is also supported by the research of Chu (2000), where it was stated that the structure of taxes in developing countries are dominated by indirect taxes with a limited portion of capital taxes and income taxes.

There is the tendency that these indirect taxes on consumption in regional taxation are more regressive than progressive in nature. According to de Wulf in Chu (2000), research in developing countries show that it is difficult to not conclude that the taxation system in developing countries are surely regressive. The basis of this rationale is the relative dominance of consumptive taxes, which are assumed to be mostly regressive in nature. These research results are supported by the research of Martinez-Vazquez et al. (2014), where the application of taxes on consumption will increase the income disparity.

Meanwhile, the variable of capital expenditure (SPCAP) based on the results of the regression had a t statistical probability value of less than the value of $\alpha=0.05$. Thus capital expenditure will negatively and significantly affect the income disparity. This means that each time capital expenditure increases, this will reduce the income disparity.

According to Todaro (2011), increasing the distribution of income (reduce the income disparity) at the lowest level (impoverished people) can be done using the budget expenditure of the government. One way of doing this is by increasing the income of impoverished people indirectly through the construction of infrastructure that is funded by government spending. For the case of Indonesia, the government budget expenditure that is most frequently utilized for the construction of public infrastructure is capital expenditure.

The construction of infrastructure can provide a positive effect on the income of impoverished people. Conceptually, infrastructure can aid impoverished people and backward regions to become connected with important economic activities that enable them to obtain additional productive opportunities (Estache, 2003). Construction of infrastructure in backward regions also reduces production and transaction costs (Gannon and Liu, 1997). Calderon and Serven (2004) who researched the influence of infrastructure on the level of economic growth and income disparity in developed and developing countries found that quantity and quality of infrastructure negatively affects the disparity of income.

\section{CONCLUSION}

This research using panel data from 33 provinces in Indonesia within 2007-2013 examined the effects of economic growth, investment, regional taxes, and capital expenditure toward the income disparity. From the results of this research four conclusions can be obtained. First, economic growth has a positive influence toward the income disparity in Indonesia. Second, investment (FDI) does not significantly affect the disparity of income. Third, regional taxes have a positive influence on the income disparity. This occurs because the structure of regional taxes which are primarily in the form of indirect taxes on consumption, which tends to worsen the income disparity. Fourth, capital expenditure has a negative influence on the disparity of income. The utilization of capital expenditure in particular for the provision of public infrastructure allows the people to obtain additional productive opportunities to increase their income.

\section{REFERENCES}

1. 2008. Statistik Indonesia 2008. Jakarta: BPS

2. 2009. Statistik Indonesia 2009. Jakarta: BPS

3. 2010. Statistik Indonesia 2010. Jakarta: BPS 
4. 2011. Statistik Indonesia 2011. Jakarta: BPS

5. 2012. Statistik Indonesia 2012. Jakarta: BPS

6. 2013. Statistik Indonesia 2013. Jakarta: BPS

7. 2014. Statistik Indonesia 2014. Jakarta: BPS

8. 2011. Pembangunan Ekonomi jilid 1 edisi kesebelas. Jakarta: Erlangga

9. 2011. Statistik Keuangan Pemerintah Provinsi 2007-2010. Jakarta: BPS

10. 2012. Statistik Keuangan Pemerintah Provinsi 2008-2011. Jakarta: BPS

11. 2014. Statistik Keuangan Pemerintah Provinsi 2010-2013. Jakarta: BPS

12. 2016. Statistik Keuangan Pemerintah Provinsi 2012-2015. Jakarta: BPS

13. Badan Pusat Statistik. 2007. Statistik Indonesia 2007. Jakarta: BPS

14. Bhandari, Bornali. 2007. Effect of Inward Foreign Direct Investment on Income Inequality in Transition Countries. Journal of Economics Integration 22(4), December 2007;888-928

15. Calderon, C., and Serven, L. 2004. The Effect of Infrastructure Development on Growth and Income Distribution, vol 3400, World Bank Policy Research Working Paper. Washington, DC: The World Bank

16. Cevik, S. and Caro. C. 2015. Growing (Un)equal: Fiscal Policy and Income Inequality in China and BRIC+. IMF Working Paper No. 68

17. Chu, Ke-young., H. Davoodi, and S. Gupta. 2000. Income Distribution and Tax, and Government Social Spending Policies in Developing Countries. IMF Working Papers WP/00/62, Washington DC

18. Deininger, K. and Squire, L. 1998. New ways of Looking at Old Issues: Inequality and Growth. Journal of Development Economics, 57(2), 259-287

19. Estache, A. 2003. "On Latin America's Infrastructure Privatization and its Distributional Effects." Washington, DC: The World Bank, Mimeo

20. Feenstra, R. and Gordon Hanson. 1997. Foreign Direct Investment and Relative Wages: Evidence from Mexico's Maquiladoras. Journal of International Economics 42, 371-393

21. Figini, P., dan Holger Gorg. 2006. Does Foreign Direct Investment Affect Wage Inequality? An Empirical Investigation. IZA Discussion Paper No.2336, September 2006

22. Freeman, R. 2010. "Does Inequality Increase Economic Output?" In Controversies about Inequality. Stanford, CA: Stanford University Press

23. Galbraith, J. K., and Hyunsub Kum. 2012. Inequality and Economic Growth: Data Comparations and Econometric Tests. UTIP Working Paper Number 21

24. Ganon, C.and Liu, Z. 1997. "Poverty and Transport." Washington, DC: The World Bank, Mimeo

25. Holzner, M. 2011. Inequality, Growth and Public Spending in Central, East and Southeast Europe. Working Paper, 221.

26. Ilaboya, O.J., and N. Ohonba. (2013). Direct Versus Indirect Taxation and Income Inequality. European Journal of Accounting Auditing and Finance Research, Vol.1 No.1, March 2013, pp.1-15

27. Irawan, M. Suparmoko. 2002. Ekonomika Pembangunan Edisi ke 6. Yogyakarta: BFE

28. Kang, J.W. 2015. Interrelation Between Growth and Inequality. ADB Economics Working Paper Series No. 447

29. Khasru, S.M. and Jalil, M.M. 2004. Revisiting Kuznets Hypothesis; An Analysis with Time Series and Panel Data. The Bangladesh Development Studies vol. xxx, SeptemberDecember 2004, No. 3 \& 4

30. Kuncoro, Mudrajad 2004. Ekonomi Pembangunan: Teori Masalah dan Kebijakan, UPPAMP YKPN, Yogyakarta.

31. Kuznets, S. 1955. Economics Growth and Income Inequality. An American Economic Review, Vol. No. 45, 1-28

32. Lin, B.Q. 2003. Economic Growth, Income Inequality, and Poverty Reduction in People's Republic of China. Asian Development Review 20: 105-124

33. Lipsey, R. and Sjoholm, F. 2001. Foreign Direct Investment and Wages in Indonesian Manufacturing. National Bureau of Economics Reseach (NBER). Working Paper. No.1925 
34. Mah, J.S. 2002. The Impact of Globalization on Incom Distribution: The Korean Experience. Applied Economics Letters. 9 (15). Pp. 1007-1009

35. Mah, J.S. 2003. A Note on Globalisation and Income Distribution - The Case of Korea, 1975-1995. Journal of Asian Economics 14, 157-164

36. Mahler, A., Jesuit, K., Roscoe, D. 1999. Expolring the Impact of Trade and Investment on Income Inequality. Comparative Political Studies 32, 3, 363-395

37. Mangkoesoebroto, Gurit. 1998. Kebijakan Ekonomi Publik di Indonesia: Substansi dan Urgensi. Jakarta: Gramedia Pustaka Umum

38. Martinez-Vazquez, J., Vulovic, V. and Dodson, B.M. (2014). The Impact of Tax and Expenditure Policies on Income Distribution: Evidence from a Large Panel Countries. Hacienda Publica Espanola / Review of Public Economies, 200-(4/2012): 95-130

39. Mihaylova, Svilena. 2015. Foreign Direct Investment and Income Inequality in Central and Eastern Europe. Theoretical and Applied Economics Vol. XXII (2015), Summer, pp.23-42

40. Mundell, R. 1957. International Trade and Factor Mobility. The American Economic Review 47, 3, 321-335

41. Park, D. and Shin, K. 2015. Economics Growth, Financial Development, and Income Inequality. ADB Economics Working Paper Series No. 441

42. Psacharopoulos, G. Morley, S., Fiszbein, A. Lee, H. and Wood, W. 1995. Poverty and income inequality in Latin America during the 1980s, Review of Income and Wealth, series 41, No. 3, pp. 245-64, Sep. 1995

43. Ravallion, M. and Chen, S. 1996. What can new survey data tells us about recent changes in distribution and poverty? The World Bank Economic Review, 11 (1), 345-361

44. Sabir, Ahmad Erani Yustika, Susilo, Ghozali Maskie. 2015. Local Government Expenditure, Economic Growth and Income Inequality in South Sulawesi Province. Economic Department Hasanuddin University

45. Schultz, T.P. 1998. Inequality in the Distribution of Personal Income in the World: How It Is Changing and Why. Journal of Population Economics, August 1998, v. 11, iss. 3, pp. 307-44

46. Sukirno, S. 1996. Pengantar Teori Makroekonomi. Jakarta: Raja Grafindo Persada

47. Sylwester, K. 2005. Foreign Direct Investment, Growth and Income Inequality in Less Developed Countries. International Review of Applied Economics 19, 3, 289-300

48. Todaro, M.P. dan Smith, Stephen. 2000. Pembangunan Ekonomi di Dunia Ketiga. Jakarta: Erlangga

49. Yusuf, Arief Anshory. 2014. Trend of Inequality in Indonesia. Keynote address delivered in a workshop on, "Mapping the Impact of inequality in Indonesia. SMERU research Institute, Jakarta. 
DOI https://doi.org/10.18551/rjoas.2017-09.09

\title{
ANALYSIS OF DISTRIBUTION CHALLENGES ON FOREIGN TOURIST IN INDONESIA: A STUDY ON DKI JAKARTA
}

\author{
Yulianto Edy \\ Business Administration Department, Faculty of Administrative Science, \\ University of Brawijaya, Indonesia \\ E-mail: edy y fia@ub.ac.id
}

\begin{abstract}
Tourism industry is one of the available solutions in facing economic problems in Indonesia and is one source of foreign exchange. Tourism sector created foreign exchange up to US\$ 12.5 billion or equivalent to IDR 163 trillions in 2015. It is ranked 4th in Indonesia's foreign exchange earnings under other business lines, such as palm oil, coal, and natural gas. There are various entrances of foreign tourists to Indonesia. There are 3 (three) largest entrance to foreign tourists. Those are Bali, Jakarta Capital City Special Region (DKI Jakarta), and Batam. According to BPS in November 2016, the number of foreign tourists visiting Bali was 396,150 visits, DKI Jakarta 219,246 visits, and Batam 106,953 visits. The study aims to determine, describe and analyze the distribution channels of foreign tourists that occurred in DKI Jakarta, which gains the second largest number of foreign tourist arrival after Bali. This research was conducted to determine the reason behind DKI Jakarta ranks 2nd in Indonesia compared to other tourist cities in Indonesia.
\end{abstract}

\section{KEY WORDS}

Tourism, foreign tourist, foreign currency, tourist entrance.

Tourism is one of the new types of industries capable of accelerating economic growth, employment, income generation, living standards and stimulate other productive sectors. Traveling is a process of one leaving their residence to another location, which is conducted for at least 24 hours or more. The reasons for conducting tourism activities are economic, social, cultural, political, religious, health reasons or conducting study and gaining experience (Pendit, 2005: 32; Suwantoro, 2004: 3; Yoeti, 2003: 47).

Tourism industry has been included as a solution in facing economic problems in Indonesia. Economic problems caused by declining sectors, rising imports and slow development are deemed to be overcome by the tourism industry in Indonesia because the tourism industry can create jobs vacancy and gain foreign exchange for the country. The tourism industry is also a means to safeguard and encourage economic development. For Indonesia, tourism can enhance mutual respect and international tolerance (Suwantoro: 2004: 37).

Tourism is one source of foreign exchange. The tourism sector created foreign exchange up to US\$12.5 billion or equivalent to Rp163 trillion in 2015. It ranked 4th in Indonesia's foreign exchange earnings compared to other business lines, under palm oil, coal, and natural gas.

Table 1 describes Indonesian foreign exchange earnings and projection of foreign exchange earnings from the main sectors of the Indonesian economy taken from the Central Bureau of Statistics (BPS) and Pusat Data Informasi or Central Information Data (Pusdatin).

Table 1 exhibits foreign exchange earnings from tourism field in 2013 to 2015 which continue to increase. In contrast to other business fields that tend to decrease or unstabl. The projection charts made by Kemenpar exhibits foreign exchange earnings from tourism sector will rank first in comparison with other sectors by 2019 (Pusdatin, Kemenpar, 2014)

There are various entrances of foreign tourists to Indonesia. There are 3 (three) largest entrance to foreign tourists. Those are Bali, DKI Jakarta, and Batam. According to BPS, total visitors in Bali on November 2016 were 396,150. On the other hand, DKI Jakarta 219,246 visits and Batam 106,953 visits. However, there's a huge gap between the three cities and 
other cities in Indonesia. Most visitors other cities received was 20,000 in November 2016, which occurs in cities such as Medan and Surabaya. The condition exhibits a gap in the foreign tourist's distribution channel. Foreign tourist visits are concentrated in certain cities, especially DKI Jakarta, despite Indonesia possessing a number of a tourist destination. DKI Jakarta is included in 2 (two) major as the entrance of foreign tourists to Indonesia. DKI Jakarta is the capital city of the Republic of Indonesia which is also the only city in Indonesia which has a provincial level status with an area of $661.52 \mathrm{~km}^{2}$. DKI Jakarta as the capital of the Republic of Indonesia becomes the center of government, trade and economy activities.

The high number of foreign tourist arrivals to Jakarta every month compared to other cities exhibits a contrast inequality for tourism in Indonesia. Foreign tourists are focused on 3 (three) main destinations such as Bali, Jakarta, and Batam. Good distribution channels to foreign tourists are required in order to introduce Indonesia's tourism potential. For it has various tourist destinations not sought after by the majority of foreign tourists.

Table 1 - Indonesian Foreign Currency Earnings According to Business Field

\begin{tabular}{|c|c|c|c|c|c|c|}
\hline \multirow{2}{*}{ No. } & \multicolumn{2}{|c|}{2013} & \multicolumn{2}{c|}{2014} & \multicolumn{2}{c|}{2015} \\
\cline { 2 - 7 } & Commodity Type & $\begin{array}{c}\text { Value } \\
\text { (Billion US\$) }\end{array}$ & Commodity Type & $\begin{array}{c}\text { Value } \\
\text { (Billion US\$) }\end{array}$ & Commodity Type & $\begin{array}{c}\text { Value } \\
\text { (Billion US\$) }\end{array}$ \\
\hline 1 & Oil \& Gas & $32.633,2$ & Oil \& Gas & $30.318,8$ & Oil \& Gas & $18.906,7$ \\
\hline 2 & Coal & $24.501,4$ & Coal & $20.819,3$ & Coal & $16.359,6$ \\
\hline 3 & Palm Oil & $15.839,1$ & Palm Oil & $17.464,9$ & Palm Oil & $15.485,0$ \\
\hline 4 & Tourism & $10.0541,1$ & Tourism & $11.166,3$ & Tourism & $12.578,6$ \\
\hline 5 & $\begin{array}{c}\text { Processed } \\
\text { Rubber }\end{array}$ & $9.316,6$ & $\begin{array}{c}\text { Processed } \\
\text { Rubber }\end{array}$ & $7.450,9$ & $\begin{array}{c}\text { Processed } \\
\text { Rubber }\end{array}$ & $7.340,5$ \\
\hline 6 & Clothing & $7.501,0$ & Clothing & $7.021,7$ & Clothing & $6.351,2$ \\
\hline 7 & $\begin{array}{c}\text { Electric } \\
\text { Equipments }\end{array}$ & $6.418,6$ & $\begin{array}{c}\text { Electric } \\
\text { Equipments }\end{array}$ & $6.486,8$ & $\begin{array}{c}\text { Electric } \\
\text { Equipments }\end{array}$ & $5.997,4$ \\
\hline 8 & Processed Food & $5.434,8$ & Processed Food & $6.259,1$ & Processed Food & $5.713,3$ \\
\hline 9 & Textile & 5.293 .6 & Textile & $5.379,7$ & Textile & $5.048,8$ \\
\hline 10 & $\begin{array}{c}\text { Paper and paper } \\
\text { goods }\end{array}$ & $3.802,2$ & $\begin{array}{c}\text { Paper and paper } \\
\text { goods }\end{array}$ & $3.914,1$ & $\begin{array}{c}\text { Paper and paper } \\
\text { goods }\end{array}$ & $3.647,5$ \\
\hline
\end{tabular}

Source: BPS and Pusdatin Ministry of Tourism of Indonesia (Kemenpar), 2015.

\section{LITERATURE REVIEW}

Tjiptono and Chandra (2012: 393) "The program of distribution and sales can be defined as a program consisting of various marketing activities seeking to facilitate goods and services distribution from producers to consumers, to ensure usage is in accordance with requirement (type, quantity, price, place, and time required) ". Channel Members (Anggota Saluran) function according to Kotler and Keller's research (2008: 112) is to gather information about potential customers and current customers, competitors, and other actors and forces in marketing environment; develop and perform persuasive communication to encourage purchases; reaching price agreements and other terms so ownership transfer can be influenced; placing orders to producers; obtain funding to finance inventories at various levels within the marketing channel; assume risks associated with the implementation of channel work; provide storage and movement of physical products seamlessly; providing bills for buyer payments through banks and other financial institutions; overseeing the actual transfer of ownership from one organization or person to another organization or person. The marketing channel is not just limited to the distribution of physical goods. Services and ideas are a "product" which is invisible but possess benefits for humans and are consumed by humans in certain activities. The production may and may not be tied to a product.

Schulalard (in Yoeti, 1982: 105) provides a tourism limitation which is stated as the following: "Tourism is the sum of operations, mainly of an economic nature, which is directly related to the entry, stay and movement of the foreign inside a certain country, city or region". It indicates that tourism is a number of activities, especially economic ones, which are directly connected with entry, settling and transfer of foreigners in a certain country, city or region. 
Freuler (in Yoeti 1982: 105-106) defines the notion of tourism in the modern sense as a phenomenon of the present age based on health and atmosphere change need, conscious and cultivating (Citra) appreciation of nature's beauty in particular due to the increased people association and human society classes as a result of commerce, industry, trade and transportation refinement development. Hunzieker and Krapf (1942) as stated in Yoeti (1982: 106) described "Tourism is totally of the relationship and phenomena arising from the travel and stay strangers (Ortsfremde), provide the stay does not imply the establishment of a permanent resident".

The Tourism Committee of the Organization for Economic Cooperation and Development in 1970 provided restrictions on tourist definition. "A person becomes a tourist if he visits a place at least 24 hours; if for a shorter period, i.g. under 24 hours, he is counted as an excursionist ". Furthermore, for the benefit of marketing in tourism promotion, Schmoll (Yoeti, 1982: 127) provides the following limits: "Tourist: individuals or groups of individuals who, considering their purchasing power available for vacation and recreational travel, interest in and motivation for travel in general, past travel behaviour, existing knowledge, interest and awareness concerning the services or destinations concerned, are likely to prospects for a future visit".

According to Burkart and Medlik, in Ross (Ross, 1998: 4-5), tourists possess three main characteristics. These three features are:

- Tourists are people who travel to and live in various destinations;

- Tourist destinations are different from their respective origin and residence; as tourist activity differs from locals who live and work in tourist destinations;

- Tourists intend to return home after a few days or months; therefore the journey is temporary and short-term.

\section{METHODS OF RESEARCH}

This research is a qualitative research utilizing descriptive approach, as descriptive method describes an event obtained by researchers related to the distribution channel of foreign tourists in DKI Jakarta. Researchers used this type of qualitative research as an attempt to describe the events according to data and facts obtained through existing research in the field.

The research was conducted in DKI Jakarta, as it becomes the entry point for the 2nd largest foreign tourist after Bali. The research was undertaken in Department of Tourism DKI Jakarta, the distributor of foreign tourists (travel agent), Indo Citra Tamasya Travel Agent Company and foreign tourists. These sites were selected existing data and information which are accurate and relevant to analyze the distribution channel of foreign tourists centered in DKI Jakarta.

Primary data sources are data obtained directly from field research. The source is obtained from the relevant parties as informants in research object. Data obtained from the interviews result between researchers and related parties. In this case, the informants are:

- The Jakarta Tourism Office, the Head of Data \& Information Division;

- Party Travel Agent / Travel Agent ie, Finance Director Indo Citra Tamasya;

- Foreign tourists: Vojtech Bazant (Czech Republic), Kieran (England) and Naomi (England).

The secondary data source is data obtained indirectly from source, but collected by other party and secondary data in this research. Those secondary data are:

- Foreign tourist data entering DKI Jakarta;

- Data of foreign tourist visit to museum in DKI Jakarta.

\section{RESULTS AND DISCUSSION}

DKI Jakarta ranks 2nd in the number of foreign tourists arriving in Indonesia after Bali. Based on the results of interviews with the Jakarta Tourism Office, foreign tourists who come 
to DKI Jakarta mostly conduct MICE tourism (Meeting, Incentive, Convention, and Event). In addition to MICE tours, foreign tourists mostly shops. The statement was also reinforced and complemented by private parties or travel agents stating that a high number of foreign tourists visiting DKI Jakarta does not fully wish travel in DKI Jakarta region. Instead, they use it as a transit area before continuing to other areas in Indonesia. It exhibits foreign tourists visiting Jakarta joins a type of convention tour. According to the private sector in general, access to Indonesia is centralized in DKI Jakarta, because foreign airlines transit in DKI Jakarta, the cooperation of airlines affects the high number of foreign tourists who come to DKI Jakarta. The readiness of the region/city or airport is also reinforced by the result of the interview from the Jakarta Tourism Department which states that DKI Jakarta was ready sooner compared to other cities, therefore there is existing gap of foreign tourists entering DKI Jakarta.

The interview exhibits a high number of foreign tourists visiting Jakarta has a positive impact. The gap of total tourist compared to other cities is affected by the readiness of the region and the airport respectively. The impact of the phenomenon is also maintained by the government and the private sector in advancing DKI Jakarta economy. Based on interviews with foreign tourists Vojtech Bazant (Czech Republic) and Kieran Rieley (UK) from their perspective as tourists, they do not know the sights in DKI Jakarta. They commented on lack of tourism activity in Jakarta, the lack of maps for international tourists, lack of places to visit, a bustling city, very difficult mobility, therefore, causing difficulty in traversing the city and other places. Foreign tourists' comments on lack of Indonesian tourism promotion. European tourist stated that the government should optimise promotion on Indonesia. The Jakarta Tourism Department stated that the government has conducted promotional tips and the private sector follows the government's policy in relation to promoting Indonesian tourism. Private parties commented that the government's promotional policy never sells DKI Jakarta as a tourist destination and focuses on other regions in Indonesia. Indo Citra Tamasya believes that the high number of foreign tourists does not make DKI Jakarta as their final destination, but the condition of the airport and airline that requires them to come to Jakarta for transit plane then continue the trip to other destinations in Indonesia.

Foreign Tourist Distribution Channel. Based on distribution channel, DKI Jakarta ranks second in foreign tourist arrival. Jakarta Tourism Department stated that there is no special attention, system or strategy for the distribution channel of foreign tourists to DKI Jakarta. This is due to the readiness of DKI Jakarta airport which has cooperated with international airlines to channel tourists. DKI Jakarta Tourism Office focuses more on MICE tourism, due to the available infrastructure. Tourism products in DKI Jakarta cater to MICE tour, whereas tourism products in Bali focused on nature tourism. Tourism Department also explained that the imbalance is only a matter of access to other areas due to limited direct flight (direct flight).

The Jakarta Tourism Department stated that the inequality merely the fact that airlines lands in DKI Jakarta. Nevertheless, foreign tourists are distributed to other areas which do not possess direct flight from their respective country of origin. Bali itself has built an international airport ready to accommodate international airlines to directly land forgoing transit.

The frequency of international flights to Jakarta is very high that makes foreign tourists in Jakarta also high. Travel agents also argue that the high number of foreign tourists in DKI Jakarta is not necessarily tourists visiting DKI Jakarta, because when they arrived in DKI Jakarta, they will be listed as tourists of DKI Jakarta, but they can only transit and continue to other cities in Indonesia but recorded in airport immigration is as a foreign tourist of DKI Jakarta. This is caused by foreign tourists requirement to transit in DKI Jakarta.

The condition of tourism in DKI Jakarta which ranks 2 nd in the number of foreign tourist arrivals to Indonesia. DKI Jakarta, which ranks 2 nd in the number of foreign tourist arrivals argue that in this case there are many factors in which one of the factors of infrastructure availability that affect the arrival of foreign tourists to DKI Jakarta. The government and the private sector argued about the visit of foreign tourists to DKI Jakarta is a MICE tour (Meeting, Incentive, Convention, and Exhibition). It is recognized by the government and 
private parties who play a role in the distribution channels of foreign tourists to DKI Jakarta because the infrastructure in Jakarta is adequate for the needs of conventions such as the Jakarta Convention Center, Senayan Convention Hall and so forth. It is inversely related to tourism in Bali which tourism products are nature tourism because DKI Jakarta is a rapidly developing megapolitan city regarding infrastructure development.

Types of Tourists. The types of tourists visiting DKI Jakarta varies. The private sector argues that the high number of foreign tourist arrivals in Jakarta does not determine that their final destination is DKI Jakarta. Foreign tourists transit at the airport before proceeding to another area. As IUOTO (International Union of Official Travel Organization) stated in Pitana et al (2005: 43), foreign tourists are included in the category of travelers/visitors (excursionist), i.e those who live in tourist destinations less than 24 hours, because they only transit in DKI Jakarta before continuing their journey to other areas in Indonesia.

The private sector also argues that foreign tourists are not using their services to travel in Jakarta, in addition, there is lack of city tour for foreign tourists. Foreign tourists merely purchase airplane tickets, hotel reservations or transportation purposes, but for their own travel arrangements. According to Cohen (1972, in Pitana et al, 2005: 53-54) clarified Explorer as tourists who travel by arranging their own journey, and seeking uncommon matter (off the beaten track). Tourists, such are these are willing to take advantage of facilities with local standards and interact with locals.

The condition is also supported by the statements of foreign tourists who have been interviewed researchers, Vojtech Bazant and Kieran Rieley. They acknowledge that they do not use the services of private parties during their visits to DKI Jakarta. They merely their own air ticket to DKI Jakarta and seek the nearest hotel without telling their travel arrangements to travel agents.

Types of Distribution Channel. According to Tan (2010: 142), there are 3 categories tourism distribution channels: Tour Operator, Broker, and Travel Agent. Indo Citra Tamasya as a private company engaged in tourism is included in the category of Tour Operator. Indo Citra Tamasya provides outbound tour packages (abroad) known as holiday package. Related to the distribution channel of foreign tourists in DKI Jakarta, ICT (Indo Citra Tamasya) do not provide tour packages for DKI Jakarta. Even after 8 years of company history, ICT does not provide tour packages for DKI Jakarta region.

DKI Jakarta as a metropolitan city makes it an extremely bustling city. DKI Jakarta as the capital city of Indonesia has crowded population. The rapid development of infrastructure makes DKI Jakarta disturbed because of the density and congestion that makes mobility inhibited. ICT also states although many foreign tourists arriving at DKI Jakarta, they do not require city tour or guide. Foreign tourists can book direct flights to DKI Jakarta, hotel reservations, and transportation without the help of travel agents.

\section{CONCLUSION AND SUGGESTIONS}

Based on research result of Distribution Channel Analysis of Foreign Tourist in Indonesia ( A study on DKI Jakarta), the researchers concluded:

The condition of tourism in DKI Jakarta which ranks 2 nd in the number of foreign tourists arrival is described as follows:

a) The gap of foreign tourists in Indonesia is influenced by the readiness of the region and the airport respectively. DKI Jakarta possesses infrastructure, especially in accommodating international airlines for direct flights to DKI Jakarta.

b) Foreign tourists arriving in DKI Jakarta outline possess 3 motives: MICE tourism (Meeting, Incentive, Convention, and Event) due to many multinational companies that set up its branch in Jakarta, therefore, a huge number of foreigners visit Indonesia for corporate meetings. The second purpose is shopping, and lastly is to transiting in DKI Jakarta before continuing the trip to other areas in Indonesia (tourists excursionist / stop under 24h).

c) In general, access to Indonesia is still dominated by DKI Jakarta, due to the readiness of DKI Jakarta airport, the cooperation of international airlines that provide direct 
flights from abroad to DKI Jakarta, it is influential in the distribution channels of foreign tourists in DKI Jakarta.

Based on research result and discussion, there are suggestions that can be used for the parties concerned. The suggestion is intended to provide benefits to the parties concerned. The suggestions are described as follows:

1. The government and private parties ought to work together to facilitate a short city tour in DKI Jakarta, especially for foreign tourists who are in transit. It is to provide tours to tourist waiting for transit in airports, foreign tourists can spend their money to buy consumption, or souvenirs in Jakarta before resuming their flight to other areas

2. Maximizing the infrastructure and access to tourist attractions or museums in DKI Jakarta to attract foreign tourists to visit.

3. International promotion could be provided via the internet, by showing history and culture. Exhibiting unique selling points that can be offered to foreign tourists to visit Indonesia. In general, foreign tourists generally visit a place based on history, culture, and business factors. Should DKI Jakarta succeeds in creating businesses, it will create jobs vacancies and attract foreign tourists to come and build the tourism industry to flourish.

\section{REFERENCES}

1. Fandeli, C. 2001. Dasar-Dasar Manajemen Kepariwisataan Alam. Yogyakarta: Liberty.

2. Foster, D.L. 2000. Fisrt Class An Introduction To Travel and Tourism. Jakarta: Raja Grafindo Persada.

3. Khuong, M.N. \& Ha, H.T.T. 2014. The Influences of Push and Pull Factors on The International Leisure Tourists' Return Intention to Ho Chi Minh City, Vietnam - A Meditation Analysis of Destination Satisfaction. International Journal of Trade, Economics, and Finance, 5(6). 490 - 496.

4. Pendit, N.S. 2006. Ilmu Pariwisata Sebuah Pengantar Perdana. Jakarta: PT Pradnya Paramita.

5. Pitana, I.G. \& Gayatri, P.G. 2005. Sosiologi Pariwisata: Kajian Sosiologis terhadapStruktur, Sistem dan Dampak-Dampak Pariwisata.Yogyakarta: Andi.

6. Sugiyono. 2015. Metode Penelitian Kuantitatif dan Kualitatif dan R\&D. Bandung: Alfabeta.

7. Suwantoro, G. 2004. Dasar-DasarPariwisata. Yogyakarta: Andi.

8. Tan, R.B.P. 2010. Kunci Sukses Memasarkan Jasa Pariwisata. Jakarta: Erlangga.

9. Wardiyanta. 2006. Metode Penelitian Pariwisata. Yogyakarta: Andi.

10. Yiamjanya, S. \& Wongleedee, K. 2014. International Tourists' Travel Motivation by PushPull: Factors and the Decision Making for Selecting Thailand as Destination Choice. World Academy of Science, Engineering, and Technology: International Journal of Social, Behavioral, Educational, Economic, Business and Industrial Engineering, 8(5).1348 1353.

11. Yoeti, O.A. 2002. Perencanaan Strategis Pemasaran Daerah Tujuan Wisata. Jakarta: Pradnya Paramita.

12. Yoeti, O.A. 2003. Tours and Travel Marketing. Jakarta: Pradnya Paramita.

13. Yoeti, O.A. 2008. Ekonomi Pariwisata: Introduksi, Informasi dan Aplikasi. Jakarta: Kompas.

14. Yoeti, O.A. 2013. Pemasaran Pariwisata. Bandung: Angkasa.

(C) 2017 by the author. Licensee RJOAS, Orel, Russia. This article is an open access article distributed under the terms and conditions of the Creative Commons Attribution (CC BY) license: http://creativecommons.org/licenses/by/4.0/ 
DOI https://doi.org/10.18551/rjoas.2017-09.10

\title{
TECHNOLOGICAL INNOVATION AND BUSINESS DIVERSIFICATION: SUSTAINABILITY LIVELIHOODS IMPROVEMENT SCENARIO OF RICE FARMER HOUSEHOLD IN SUB-OPTIMAL LAND
}

\author{
Adriani Dessy ${ }^{1,2 *}$, Wildayana Elisa ${ }^{1}$, Yulius $^{1}$, Alamsyah Idham ${ }^{1}$, Hakim Maryati Mustofa ${ }^{1}$ \\ ${ }^{1}$ University of Sriwijaya, Palembang, Indonesia \\ ${ }^{2}$ Center of Excellence Peatland Conservation and Productivity Improvement (CoE PLACE), \\ University of Sriwijaya, Palembang, Indonesia \\ *E-mail: dessyadriani@fp.unsri.ac.id
}

\begin{abstract}
The increased role of the sub-optimal land to support food security continue to be encouraged in Indonesia, given the more limited expansion for potential land. But until recently, development of sub-optimal land becomes not an easy thing. Ecological and technical barriers became the main issue. A series of these issues resulted in a high number of underemproleymeny and poverty in agriculture region. Technological inovation of agriculture and the business diversification can be seen be the solution to those issues. This research aims to analyze the impact of the technological innovation and business diversification on underemployment, working time, household income and also sustainable livelihoods of farmers on the sub-optimal land. The research was carried out in Pemulutan District, Ogan Ilir Regency, South Sumatra Province, Indonesia. The objects of research are farmers which adopter and non adopter technological innovation, and also work outside of paddy farming (business diversification). The research method is the survey. Method of sampling is stratified random sampling. Data obtained in the field analyses using descriptive statistics and inferesia. The results showed there are positive impact of technological innovation on the allocation of working time farmer households, the numbers underemployment, household income and livelihood sustainability. Determinant factors for farmers in applying technology and business diversification are paddy farming income, offfarm income, and age. The use of technology and business diversification proves to be one of the positive scenarios for sustainable livelihood of farmers in sub-optimal land.
\end{abstract}

\section{KEY WORDS}

Underemployment, diversification, technology, livelihoods, sustainability, sub-optimal land.

The agricultural sector in Indonesia is largely built by farmers. Thus, the welfare of farmers should be a concern. The increased role of the sub-optimal land to support food security continue to be encouraged in Indonesia, given the more limited expansion for potential land in food production. But until recently, development of sub-optimal land becomes not an easy thing. The efforts of agricultural development in sub-optimal land extremely complex from upstream (production) to downstream (post harvest). The complexity of the issue also involved multi-stakeholders with their each interest that are interlinked with each other (interdependent) in one system. The above problems togethered with the low productivity of the sub-optimal land, the limitations of labour, low levels of knowledge of farmers, agricultural custom subsystems, limitations of capital, infrastructure sub-optimal irrigation limited, as well as high levels of pests-diseases in plants, also caused a sub-optmal land to be difficult managed (Riyani, 2013; Panggabean, E.W., and B.Y. Angunniko, 2014; Alwi, 2014).

With the variety of problems facing by farmers in the household, so that the farmers majority in sub-optimal land trapped in poverty. Poverty reduction strategies based on the argument that with high economic growth, poverty will be reduced through the mechanism of a trickle down effect have yet to deliver maximum results in the region. One thing that needs to be understood that factors social, economic and culture is often seen as an important 
element that determines the resolution of various issues above.

Benjamin, L., and N. Gofar (2013), the development of the sub-optimal land need to be prioritized in the technological development of that are technically relevant to the respective characteristics of the suboptimal land, economically affordable by local farmers, as well as expected also in tune with the preferences and socio-cultural community. To realize the sustainability of suboptimal land management, then all the technical and technological efforts undertaken should also consider the possibility of impact ecologisnya, sosioculturale compliance with the local community, in addition to the obviously economically profitable for farmers as the main producer in food production.

Technological innovation is a term that has been used widely in many fields, both agricultural and non agricultural. Adams (1988); Simamora (2003); and Kotler (2003) states, technological innovation is an idea, practice, or new products that are considered by the individual or group that is relevant. Musyafak and Ibrahi (2005) states one of the factors that affect the acceleration of the adoption of technological innovations is the nature of the innovation itself. Innovations introduced must have a lot of conformity (adaptive power) against the conditions of the biophysical, social, economic, and culture that exists on the farmers. So that, the innovation offered to swamps land farmers should be appropriate innovations.

South Sumatra (Sumatra) is a one of main area for rice production in Indonesia, the sixth in Indonesia or the third in outsite of Javanese after South Sulawesi and North Sumatra. The trend of harvesting, production, and productivity of rice in South Sumatra from 1991 until the year 2014 shows increasing. This is supported by the availability of potential land resources are quite varied, ranging from wetland irrigation, rainwater, tidal marshes, lebak, and dry land. Rice paddy field South Sumatra in 2012 is about 443,199 hectares and with the application of technological innovation to the planting area of rice then South Sumatra could reach 800,615 hectares by the year 2014 . The swamps land which has been used for rice cultivation in South Sumatra, about 304,563 hectares or approximately 38 per cent of padi land South Sumatra.

The swamps land is one of the sub-optimal land potential to be developed. Ogan Ilir Regency is one of regencies in South Sumatra which is the center of swamp land in Soutn Sumatera. Ogan Ilir Regency is a region with the second largest of Swamp land in South Sumatra. This area has the potential land covering an area of swamp land 63,503 hectares, cultivated area for once per year was hectare 49,092 hectares, while not cultivated area of 7,617 hectares of land, and only an area of 137 hectares are planted with two times per year. If we refer to the data, there is still the potential for land use in the Ogan llir swamp land, where just 137 acres was done twice planting. For such purposes, of course needed any agriculture innovations.

Freeman (2005) stated the implementation of an innovation is one of the main keys in the utilization of limited resources condition in each region; as well as in the sub-optimal land. The ecological problems faced by farmers is the availability of water at any given time, so that in this region most farmers could only plant 1 time a year (Cropping Index 100). In contrast to the area of iirigated land, for example, can plant rice up to three times a year (Cropping Index 300). For increased, cropping index in the sub-optimal land, then the technology is a must. Beginning in 2015, the government has launched various packages of technology that have an impact on the increase of the cropping index be 200 in sub-optimal land. Technology package are water treatment and agricultural integrated plant technology. With this package of technology, then the beginning of land can only be cultivated one time increased to twice. Not only that, the application of innovations in the cropping pattern that can actually increase utilization of swapt land

In addition, besides to the cropping index is still low, the issue of sub-optimal land are also related to the high underemployment, due to the limited selection of work that can be done. Some of the last results shows, the increasing of underemployment in the agricultural sector. Adriani (2015), there are 627.67 hours for labor potential times available in household. With the allocation of working time on the farming of rice of 55.85 hour, and 571.82 hours for underemployment. This is supposed to be a covert underemployment 
allocated on other productive sectors in on-farm (soybeans, corn and beans, etc) and offfarm (labour, stalls, merchants, and so on). With underemployment condition, farmers rationally and economically used their time for diversify the structure of the work (business diversification). Work time allocation covers how the behavior of households in adjusting on the constraints of existing employment opportunities and with the resources that belong to fullfill his needs. According to Becker (1965); Gronau (1976); Nakajima (1986); and Fabrerro and Schwartz (2000), the allocation of working time explained that the individual economically allocate his time in the labour market, to get a reward and satisfaction of the allocation of time to work outside of wages. Thus, farmers do diversify of bussiness to improve his livelihoods. Business diversification is an important decision and very rational to be taken by the farmer's household, although in fact not all farmer households unable or unwilling to execute it. With limited resources, owned then the vulnerable households or who have yet to choose alternative income household Precision farmers in taking decisions in conditions of risk will largely determine the sustainability of penghidupannya.

Based on the results of the above description, it is noted that the research on technological innovation in technics and Economics and relation to other businesses outside of the diversification of rice have already been done, but its impact on the increase in work time, the reduction of underemployment, income, and sustainability of livelihoods have not been much researched. Therefore, this study aimed to analyze the specific impact of the application of technological innovations and businesses diversification on the allocation of working time, the reduction of underemployment, income and sustainability of livelihoods, as well as the factors that influence the allocation of working time. The results of this study are expected to provide input for the improvement of the income of farmers so that the farmers ' welfare can be achieved.

The objectives of research are:

1. To analyze the impact of technological innovation and business diversification on the allocation of household working time, underemployment, income and livelihood sustainability.

2. Analyze the factors that influence the allocation of working time household farmers who use technological innovation and do business diversification on the land sub-optimal.

Hypothesis:

1. Expected that there are positif impact of technological innovation and business diversification on the allocation of working time, underemployment, income and livelihood sustainability of adopter farmer household in sub-optimal land.

2. Expected that age of farmers, on-farm income (rice and non rice farming income) and off-farm income influenced positive significantly, while the members number of the family and the educational factors influenced negative significantly to the allocation of working time adopter farmer household in sub-optimal land.

\section{METHODS OF RESEARCH}

This research was carried out in Pemulutan District Ogan Ilir Regency. This research was carried out in February 2017. The research method was survey methods, in which the sample are (1) farmers who does not adopt the technology (IP-100) and (2) farmers who adopt technological innovation (IP 200) and also done business diversification. Sampling methods were disproportionate stratified random sampling. Data collection is done through interviews using questionnaire method. In total, 120 farmers were selected at two category from these areas. Data obtained in the field processed in tabulations, calculated mathematically and descriptive quantitatively. To calculate the allocation of working time households, calculated the average amount of time each activity for one year and then explained in the descriptive. To answer the first purpose and hypothesis about the existence of the difference of the technological innovation of farming on the allocation of household work time, underemployment, income, and livelihoods sustainability of farmer households conducted in tabulative, followed by t-testing. To answer the second hypothesis about the purposes and the factors those influence the allocation of working time household farmer innovation and also done business diversification done by multiple linear regression method. 


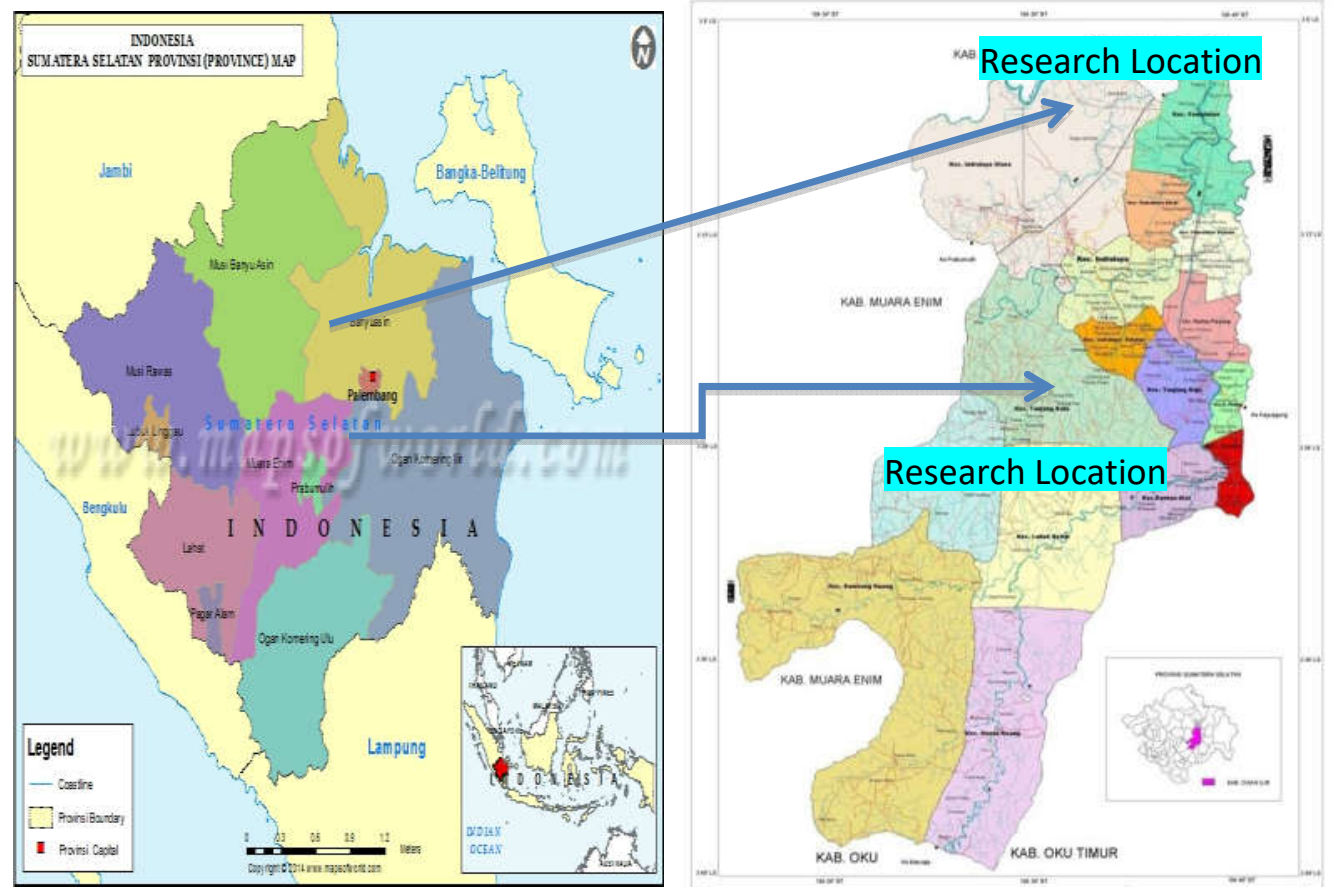

Figure 1 - Research Location

Definitions:

1. Non-adopter is farmers household that didn't apply technological innovation (using cropping index 100).

2. Adopter is farmers households that apply technological innovation (using cropping index 200).

3. The potensial working time allocation is the total working time of farmer households in normal condition, that is 300 for man and 226 for woman.

4. The actual working time allocation is the actual working time that is used by farmer household comes from within the family in activities of on-farm (both rice farming and non-rice farming) and off-farm.

5. Underemployment is the difference between the potensial working time and the actual working time allocation

6. Bussiness diversification is the bussiness of farmers household comes from on-farm and off-income activities.

7. On-farm income activities from (1) rice farming income and (2) non rice farming income such as corn, longleans, soybeans, and livestocks.

8. Off-farm income activities outsite of farming that is laborers, traders, drivers, and so on.

\section{RESULTS AND DISCUSSION}

The Impact of Technological Innovation and Bussiness Diversification to Underemployment and Working Time Allocation of Sub-optimal Land Farmer Household. Detection of underemployment in the sub-optimality land is performed by calculating in advance the potential work force and the allocation of working time in the household for (1) non adopter and (2) adopter farmer who also done business diversification. The allocation of actual working time is the working time that is used by farmers comes from within the family in activities of on-farm (both rice farming and non-rice farming) and off-farm. Rice farming for non adopter farmer households are conducted once in a year, carried out in the month of April until the month of August. Table 1 presents working time for non adopter is 10.39 workingday/households/year, will undergo underemployment amounting to 687.74 workingday/household/year or $98.51 \%$ of a their total potential working time. 
Table 1 - The Potential Working Time, Actual Working Time and Underemployement for Non Adopter Rice Farmer Households in Sub-optimal Land, 2017

\begin{tabular}{cccc}
\hline No. & Description & $\begin{array}{c}\text { Working Time Allocation } \\
\text { (workingday/ household/year) }\end{array}$ & Percentage (\%) \\
\hline 1 & Actual Working Time & 10.39 & 1.49 \\
2 & Underemployment & 687.74 & 98.51 \\
\hline & Potential Working time & 698.13 & 100.00 \\
\hline
\end{tabular}

But if the farmer is adopter of technological innovation (with Cropping index 200), then the case of underemployment decrease to become 672.61 workingday/household/year. Rice farming with technological innovation is able to absorb into the work potential of 3.66 percent available, from previously only 1.49 percent. With the application of technology, there is an increase in working time of 2.17 percent followed by the reduction of underemployment by the same percentage (Table 2).

Table 2 - The potential, working time Farmers and unemployed Veiled on farmers Land in Technology Practitioners Sub Optimal, 2017

\begin{tabular}{cccc}
\hline No. & Description & $\begin{array}{c}\text { Working Time Allocation } \\
\text { (workingday / household/year) }\end{array}$ & Percentage (\%) \\
\hline 1 & Actual Working Time & 25.53 & 3.66 \\
2 & Underemployment & 672.61 & 96.34 \\
\hline & Potential Working time & 698.13 & 100.00 \\
\hline
\end{tabular}

Thus, without technological innovation, the incidence of underemployment will be higher. Furthermore, in order to resolve underemployment, households of farmers also diversified structure of the bussiness. A selection of the work being done is on-farm (rice and non-rice) and off-farm (Labour, drivers, trader, and so on).

Table 3 - Work time allocation of household for Adopter with Business Diversification in Sub-optimal Land, 2017

\begin{tabular}{cccc}
\hline No. & Bussiness Diversification & Working Time & Percentage (\%) \\
\hline 1 & On Farm-Rice & (Working Day /Household/Year) & 20.56 \\
2 & On Farm-Non Rice (Corn, longbeans, soybean, livestock) & 34.53 & 27.63 \\
3 & Off-farm (laborer,traders,drivers) & 64.33 & 51.81 \\
\hline & Total & 124.16 & 100.00 \\
\hline
\end{tabular}

Allocation of working time in off farm activities is 64.33 workingday/household/year, then on farm-rice 25.53 workingday/household/year dan on farm-non rice 34.30 workingday/household/year (Table 3 and Figure 2). Thus, bussiness diversification can improve the allocation of working time farmer households from 25.53 workingday/household/year to 124.16 workingday/household/year (Table 4).

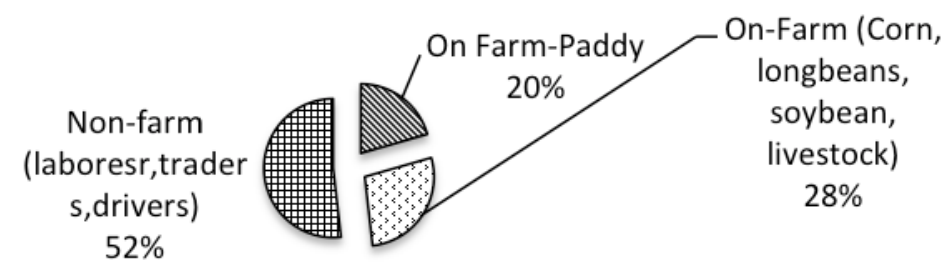

Figure 2 - Work time allocation for Adopter with Bussiness Diversification in Sub-optimal Land, 2017

Analysis results in Table 4 indicates that business diversification on activities of onfarm and off farming impact on increasing work time allocation amounting to 124.16 workingday/households/year or increased by 386.39 percent. Diversification also encouraged a decrease in underemployment 98.64 workingday/households/year (-14.66\%). 
Table 4 - Change Working time farmers and Covert Unemployment in Households with Diversified Innovation Practitioners Work in Sub-Optimal, 2017

\begin{tabular}{cccccccc}
\hline & & \multicolumn{2}{c}{$\begin{array}{c}\text { Adopter Without } \\
\text { Diversification }\end{array}$} & \multicolumn{2}{c}{ Adopter With Diversification } & \multicolumn{2}{c}{ Change } \\
\cline { 3 - 8 } No. Description & $\begin{array}{c}\text { Working Time } \\
\text { (Working Day } \\
\text { /Household/Year) }\end{array}$ & $\begin{array}{c}\text { Percentage } \\
(\%)\end{array}$ & $\begin{array}{c}\text { Working Time } \\
\text { (Working Day } \\
\text { /Household/Year) }\end{array}$ & $\begin{array}{c}\text { Percentage } \\
(\%)\end{array}$ & $\begin{array}{c}\text { Working Time } \\
\text { (Working Day } \\
\text { /Household/Year) }\end{array}$ & $\begin{array}{c}\text { Percentage } \\
(\%)\end{array}$ \\
\hline 1 & $\begin{array}{c}\text { Actual Working } \\
\text { Time }\end{array}$ & 25.53 & 3.66 & 124.16 & 17.79 & 98.64 & 386.39 \\
2 & Underemployment & 672.61 & 96.34 & 573.97 & 82.21 & -98.64 & -14.66 \\
\hline $\begin{array}{c}\text { Potential Working } \\
\text { time }\end{array}$ & 698.13 & 100.00 & 698.13 & 100.00 & & \\
\hline
\end{tabular}

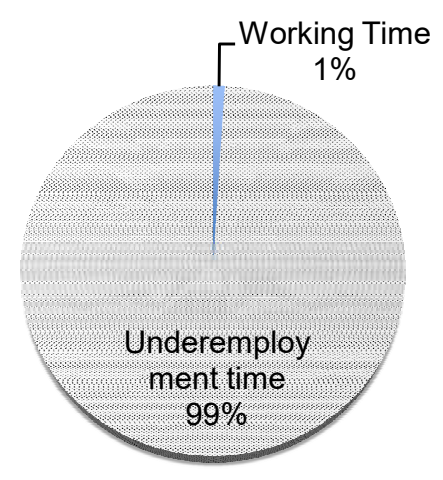

Without Technology

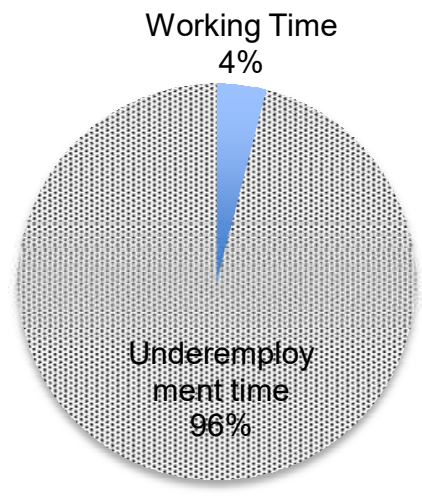

With Technology, Without Bussiness Diversification

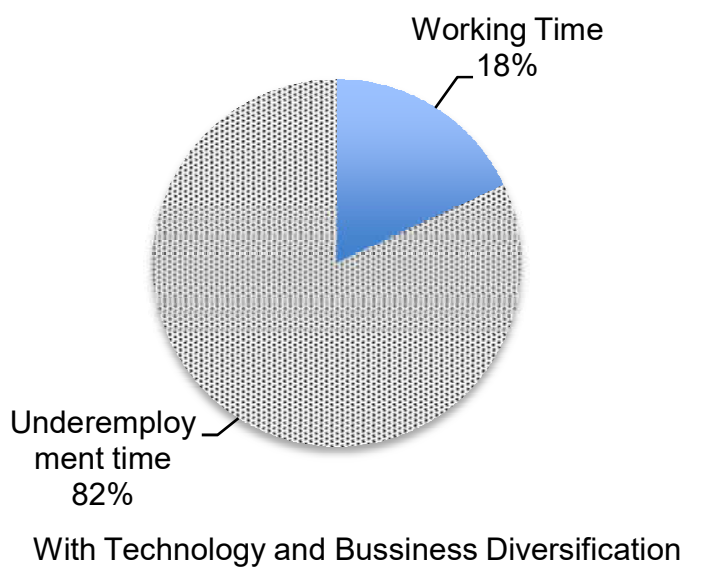

Figure 3 - Comparison of the allocation of working time and unemployment is veiled for farmers instead of technology practitioners, practitioners of technology with and without the Diversification Effort 
Furthermore Figure 3 presents a comparison of the allocation of working time and underemployment for non adopter farmers and adopter farmers with and without the bussiness diversification. It can be concluded that technological innovation and bussiness diversification can improve the allocation of time and reduce underemployment.

The t-test shows the same result. The t-value is 5.669 with df 58 and $\alpha=0.05$. The value of tabel in df 58 with $\alpha=0.05$ is 1.671 so the obtained conclusions based on t-test value $>$ t-test tabel $(5.669>1.671)$ reject $\mathrm{H}_{0}$, meaning that the allocation of time to work for adopter with business diversification is much larger than non adopter farmers. In other words, technological innovation can significantly reduce underemployment in a significant way.

But the results of this research strengthen new facts, that the choice of a job that can be done by farmers are very limited in rural area. Thus, even though farmers have been doing a lot of things to optimize the allocation of time, yet the percentage of underemployment in the region remains high. Therefore, the policy of the government is required relate to the creation of new employment opportunities in rural areas. Employment opportunities are not only related to the addition of a number of job opportunities, but also increasing productivity coupled with farmers. Industrial agriculture also remains necessary to encourage the development of the creation of employment opportunities.

The results of this study are contrary to many previous research results that reveal the negative impact of the use of technology in the agricultural sector as has been revealed by Acemoglu, D. (2002) and Bartelsman et al., (2010), the use of technology in the field of agriculture gave rise to many problems. The use of technology does not necessarily increase productivity significantly. Another issue that arises is related to a decrease in the use of labour, the loss of the job for as the poor population who do not have land, reinforcing inequality, monopoly to the forefront for the owner of the technology, and the potential conflicts in society.

The results of this study at least suggest that the use of technology in a way that is appropriate and wise thus provide a positive impact for the community. The use of technology in the agricultural sector is a must for the progress of the agricultural sector. Thus, it should think about is the increased of technological innovation is accompanied by an increase in employment opportunities. One of them through an increase in the productivity of farmers, not only in on farm but also in off the farm.

The Impact of Technological Innovation and Businesses Diversification on Income and Livelihood Sustainability of Farmer Households in Suboptimal Land. The increase of income is the farmers expected by applicated of technological innovations and bussiness diversification. The results of this research show that technological innovation in the suboptimal land can increase the income of farmers. Technological innovation not only has an impact on the allocation of working time farmers, but also on the rice farming income as presented in Figure 5.

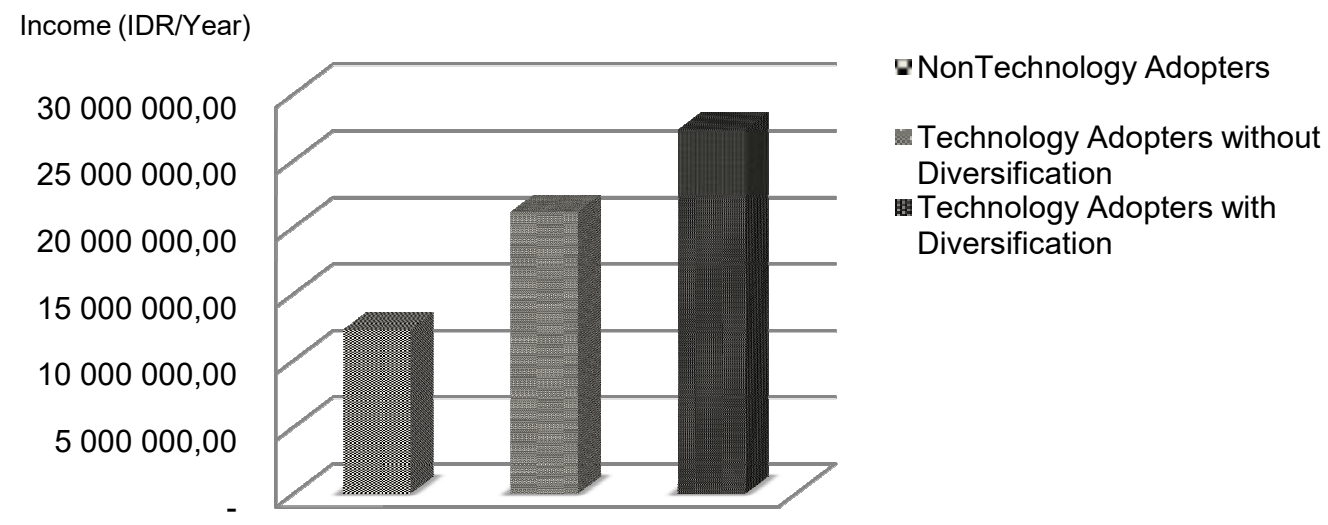

Figure 4 - Comparison of Income between Farmers Household for Non Technology Adopters, Technology Adopters with and without Diversification, 
$\mathrm{t}$-Test results indicates that the t-value is 8.323 with $58 \mathrm{df} 8.323$ and $\alpha=0.05$. The value of t-tabel in df 58 with $\alpha=0.05$ is 1.671 so the obtained conclusions based on t-test thitung $>$ value is ttabel $(8.323>1.671)$ reject $\mathrm{H}_{0}$, this indicates the income of adopter farmers is larger than non adopters farmers who do not use the innovation of farming. This shows that the first hypothesis is suspected the existence of a positive impact of technolocigal innovation and business diversification on the allocation of household work time and income.

If then, analysis of farmers ' income was more focused on technology adopters and also diversify, then Table 5 presents the total household income earned amounting to $\mathrm{Rp}$ $27,335,452.00 / y e a r$. When compared to the farmers instead of technology adopters, then an increase in income of $121.86 \%$.

Table 5 - Total household income for Technology Adopters with Business Diversification, 2017

\begin{tabular}{lll}
\hline \multicolumn{1}{c}{ Income Diversification } & Income (IDR/Year) & Percentage (\%) \\
\hline On Farm-Paddy & $21,162,119.00$ & 77.42 \\
On-Farm (Corn, longbeans, soybean, livestock) & $1,863,333.00$ & 6.82 \\
Non-farm (laboresr,traders,drivers) & $4,310,000.00$ & 15.77 \\
\hline Total & $27,335,452.00$ & 100.00 \\
\hline
\end{tabular}

Figure 6 presents that income from rice farming contributed most $(77 \%)$ to the total household income of farmers, followed by income from off the farm of $16 \%$. In choosing good alternative livelihoods to its addition in order to enlarge the owned assets or because of having to cover the needs of the family, then the most noteworthy consideration is whether household farmers still able to undertake such activities. It is given the circumstances of physical ability and limited capital as well as requiring mastery of innovation and adequate information.

Based on the structure of jobs, jobs as merchants are found in all areas of research. Likewise, the livestock business. While trade and building materials more concentrated in certain regions. An important aspect in the development of diversified business was the availability of leisure time of the family member. From Table 4, clearly that free time for off farm activities is still available potentially for $573.97 \mathrm{HOK} /$ household/year $(82.21 \%)$. If the household uses only time it works is less than 30 percent a year, then it seems that underemployment has occurred in the suboptimal area.

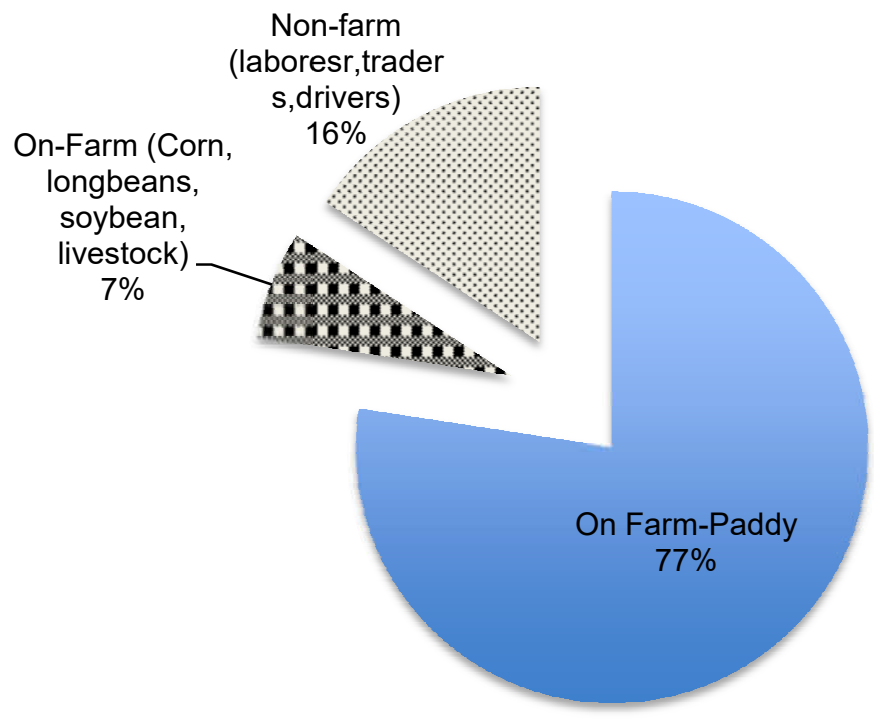

Figure 6 - Share of Total household income for Technology Adopters with Business Diversification

Doing some alternative livelihood options in terms of household livelihood sustainability while protecting the assets of households is something a wise decision. Household decisions 
in the business diversification will be more precise if alternative livelihoods or businesses contribute increasingly to the total household income. According to Ellis (200), farmer households have 5 kinds of assets that greatly affect the economic activities of households i.e. natural capital (land and potential on it), the physical form of road access and proximity, humans as a source of manpower, financial investment and capital as a force of social activities collectively accelerate mutual. In that condition, the economic activities in the household does not only consist of production, consumption and labor supply, but there are also investment activity that play a role in enhancing the capabilities of sustainable household livelihoods.

The strategy of diversification of household business relies on the ability of households in responding to the diverse livelihood as a business opportunity is accompanied and it should be in line with the program implemented by the Government. With the condition of household economic constraints, regardless of choice of alternative businesses outside the farming still need the support from parties, because in fact all such endeavor requires capital does little to its sustainability.

This research result shows that technological innovation and business diversification give opportunities for farmers' household in increasing livelihoods sustainability.

The Determinant Factor in Allocation of Working Time of Adopter Farmer with Business Diversification. Factors that influence the allocation of working time in applying technological innovation with business diversification consists of economic factors and social factors. Prediction value of the parameters in the equations used multiple linear regression analysis by using applications SPSS 17.0. The results of estimation present factors namely on farm income (rice and non rice), off farm income farm income, education, age and number of family members influenced the allocation of working time of farmer household in technological innovation with business diversification as can be seen on table 6 .

The value of the coefficient determination $\left(R^{2}\right)$ of 0.439 which means that on farm income (rice and non rice), off farm income farm income, education, age and number of family members and the rest of 56.10 percent is explained by other variables that are not included in the model.

The value of F-statistics (Fhitung) obtained from the regression result is 3.000 where $\mathrm{F}$ value greater than F-tabel with $\alpha=0.05$ i.e. 2.53 , so hypothesis nol $\left(\mathrm{H}_{0}\right)$ is rejected and accepted the alternative hypothesis $\left(\mathrm{H}_{\mathrm{a}}\right)$. This indicates on farm income (rice and non rice), off farm income farm income, education, age and number of family members influenced on the allocation of working time farmer households on $\alpha=0.05$.

Economically, the estimation are good when the five of the six sign of regression coefficients are obtained from the results is in compliance with economic theory. Variables which have the positive sign is on farm income (rice and non rice), off farm income, education, age, while variables with a negative sign is the number of family members.

Table 6 - The results of estimation for the allocation of working time farmers household equation in Sub-optimal Land, 2017

\begin{tabular}{|c|c|c|c|c|c|c|}
\hline \multicolumn{7}{|c|}{ Estimation Result } \\
\hline Independent Variable & $\begin{array}{c}\text { Regression } \\
\text { Coefficient }\end{array}$ & t-hitung & Prob-t & Tolerance & VIF & Note \\
\hline Constanta & $-50,094$ & $-1,748$ & 094 & & & \\
\hline Rice on Farm Income & 7,891E-7 & 2,103 & 047 & ,790 & 1,266 & * \\
\hline Non-Rice on Farm Income & $6,495 \mathrm{E}-7$ & 678 &, 505 & 813 & 1,230 & - \\
\hline Off Farm Income & $1,286 \mathrm{E}-6$ & 1,622 & 018 & ,700 & 1,429 & * \\
\hline Age & 1,018 & 2,235 & ,035 &, 504 & 1,985 & * \\
\hline Education & 1,928 & 1.052 & ,304 & ,430 & 2,327 & - \\
\hline $\begin{array}{c}\text { Number of Family } \\
\text { Members }\end{array}$ & $-2,440$ &,- 980 & ,337 & ,879 & 1,137 & - \\
\hline
\end{tabular}

$R^{2}=0,439$ F-hitung $=3,000$

In econometrics, the regression equation estimated that they would not be analyzed the problem of autocorrelation. Durbin Watson value obtained is amounting to 1.377 . If tested 
with a test using the Durbin Watson (DW) obtained results $\mathrm{dl}=0.9256$ and $\mathrm{du}=2.0343$, where DW is located between the dl and du, then retrieved the results $0.9256<2.0343<$ meaning 1.377 such values are inconclusive as to whether the positive autocorrelation occurred, or not going negative autocorrelation autocorrelation. But according to Pindyck, $r$. s. and d. I. Rubienfeld (1991) autocorrelation problem only affects efficiency prediction and does not affect to prediction bias. One thing that is most important and became the main orientation of this research are all signs of the estimated parameter in the model correspond to the expectations based on theory as well as economic logic. The regression equation that analyzed, also doesn't indicate the multikolinierity problem. Relation between two variables independent is free because the value of variance inflation factor (VIF) is not more than 10 . The results of the scatter plot in SPSS output does not indicate the existence of a certain pattern so that it can be concluded that no also occurrence of heteroskedastisitas on the regression equations.

A significant level of test-t is used to see the influence of each free variable i.e. on farm income (rice and non rice), off farm income farm income, education, age and number of family members who have an effect on the allocation of working time farmer households. Free variables that affect the allocation of working time economically positive and significant in statistics is on farm income (rice), off farm income farm income, and age, whereas a non influential variables are not real other on farm income (rice), education, and the number of family members.

Rice on-farming income has a positive affect to the allocation of working times farmer household in sub-optimal, whereby any income increase of rice farming at Rp 1.00 , then it would cause an increase in the amount of household work time allocation of $7.891 \times 10-7$ HOK. The higher income gained by farmers adopter farming in sub-optimal land, then the allocation of working time that household used by farmers in are also higher due to the more land area owned, then the number of capital that are used are also high because the time allotted is not much anyway. This will affect the income of rice farming rice and the amount of work time allocation used by farmers in the land. To that end, rice farming income gained by farmers is positive towards the allocation of working time farmer households.

The regression coefficient values for off farmi income has a positive affect toward the allocation of working time households farmer which means any addition of other farming

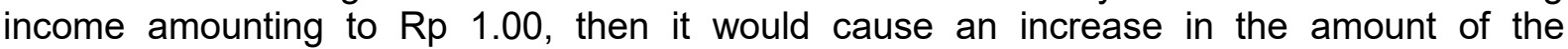
allocation of working time farmer households of $6.495 \times 10-7 \mathrm{HOK}$. It is also evidenced in the field that in other farming activities such as raising fish, chicken, or duck, farmers use of labor in the family i.e. husband and wife so that the income earned by farmers in other farming activity increased.

Variable for the age of farmer also had a positive influence to the allocation of working time farmer households. The fact that the average age of farmers is 45 years old. The more the increasing age of the farmers, then the allocation of working time used will also increase until eventually the farmers have entered old age and do not have a physical and strong power again to do the farming of rice, and finally more use outside of the family labor (labor wages) for rice farming activities.

The results of the analysis with multiple linear regression model shows that the factors that influence positively to the allocation of working time farmer household is rice on farm income, off income, and age. Almost all the income variables examined the real effect to the allocation of working time. This means that the acquisition of income remains a major factor of farmers to work. almost The influencing of all of the income variable indicates that income is an important thing that makes farmers decide to add their hours of work. In other words, economic motives still continues to be the reason for farmers to work. These results are in line with research Adriani (2015) which states that the farmers have rationality in social and economic activities of farming. This study shows that the use of technology and business diversification proves to be one of the positive scenarios for sustainable livelihood of farmers in sub-optimal land. 


\section{CONCLUSION}

Existence of the positive impact of the use of technological innovation of farming and business diversification efforts to increased allocation of working time, to decrease underemployment, income generating and livelihood of rice farmers ' households in sub optimal land. Factors that effect positive and significantly to the allocation of working time farmers household who use technology and also to diversify is rice on-farm income, off-farm income, and age. And so that, the use of technology and business diversification proves to be one of the positive scenarios for sustainable livelihood of farmers in sub-optimal land.

\section{ACKNOWLEDGEMENT}

This paper is part of the Grant Competitive Universitas Sriwijaya Research in 2017, which has been funded this research complies with the letter of Agreement Assignment of Competitive Grants Research Universitas Sriwijaya in 2017.

\section{REFERENCES}

1. Acemoglu, D. 2002. Technical Change, Inequality and the Labor Market. Journal of Economic Literature 40: 7-72.

2. Adams, M.E. 1988. Agricultural Extension in Developing Countries. First Edition. Longman Singapore Publisher Pte Ltd. Singapore.

3. Adriani, Dessy. 2015. Rasionalitas Sosial Ekonomi Dalam Penyelesaian Pengangguran Terselubung Petani Padi Sawah Tadah Hujan . MASYARAKAT: Jurnal Sosiologi 20 (1): 43-58.

4. Agus, F. dan Irawan. 2007. Agricultural land conversion as a threat to food security and environmental quality. Jurnal Penelitian dan Pengembangan Pertanian 25(3):90-98.

5. Ali, Muhammad. 2014. Prospek Lahan Rawa Pasang Surut Untuk Tanaman Padi. Prosiding Seminar Nasional Inovasi Teknologi Pertanian Spesifik Lokasi. Banjarbaru: Balai Penelitian Pertanian Lahan Rawa.

6. Becker, Garry S. 1965. A Teory of the Allocation of Time. Economic Jurnal. 75(299).

7. Bennett, N. (2010). Sustainable livelihoods from theory to conservation practice: An extended annotated bibliography for prospective application of livelihoods approaches in protected area community research, 55. Retrieved from http://dspace.library.uvic.ca:8080/handle/1828/4461

8. Bartelsman, Eric J., Gautier P. A., dan J. de Wind. 2010. Employment Protection, Technology Choice, and Worker Allocation. The Institute for the Study of Labor (IZA). IZA DP No. 4895. April 2010.

9. Ilis, F. (1999). Rural Livelihood Diversity in Developing Countries: Evidence and Policy Implications. ODI Natural Resource Perspectives, 40(40), 1-10. https://doi.org/xx

10. Fabrero, R., and P.S. Schwatrz. 2000. The Essence of Becker. Hoover Institution Press. Stanford University. California.

11. Granou, R. 1976. Leisure, Home Production and Work. The Theory of The Alocation of Time Revised. Journal of Political Economy 86 (6): 1099-1124.

12. Grist. D.H. 1960. Rice. Formerly Agricultural Economist, Colonial Agricultural Service, Malaya. London: Longmans, Green and Co Ltd.

13. Gujarati, D. 1993. Ekonometrika Dasar. Cetakan ketiga. Jakarta: Erlangga.

14. Musyafak, Akhmad Dan T. M. Ibrahim. 2005. Strategi Percepatan Adopsi Dan Difusi Inovasi Pertanian Mendukung Prima Tani. Analisis Kebijakan Pertanian. Volume 3 No. 1, Maret 2005: 20-37.

15. Nakajima, C. (1986). Subjective Equilibrium Theory of The Farm Household. Elsevier Science Publisher. Amsterdam.ISBN:0-444-42646-9.

16. Norsida Man, \& Sami Ismaila Sadiya. (2009). Off-Farm Employment Participation Among Paddy Farmers in the Muda Agricultural Development Autority and Kemasin Semerak 
Ganary Areas of Malaysia. Asia-Pasific Development Journal, 16(2), 141-154. https://doi.org/10.18356/be439b1f-en.

17. Panggabean, E.W., Dan B.Y. Angguniko. 2014. Kebijakan Pengembangan Irigasi Rawa Pasang Surut Dengan Pendekatan Sistem Dinamik. Puslitbang Kebijakan Dan Penerapan Teknologi. Balitbang Kementerian Pekerjaan Umum Dan Perumahan Rakyat. Jakarta.

18. Pindyck, R. S. and D. L. Rubinfeld. 1991. Econometries Models, and Economies Forecast. 3rd. ed. McGraw-Hill Edition. Singapore.

19. Riyani, Rita. Radian, Setia Budi. 2013. Pengaruh Berbagai Pupuk Organik Terhadap Pertumbuhan Dan Hasil Padi Di Lahan Pasang Surut. Jurnal Sains Mahasiswa Pertanian 2 (2). Untan.

20. Simamora, Bilson. 2003. Membongkar Kotak Hitam Konsumen. PT. Gramedia. Jakarta. 
DOI https://doi.org/10.18551/rjoas.2017-09.11

\title{
EVALUATION OF THE GOVERNANCE OF EXTERNAL SUPERVISORY INSTITUTIONS TOWARDS SOCIAL SECURITY AGENCY (BADAN PENYELENGGARA JAMINAN SOSIAL/BPJS) FOR HEALTHCARE
}

\author{
Dyani Dindha Ayu Mitra, Nuralam Inggang Perwangsa* \\ Faculty of Administrative Science, Universitas Brawijaya, Indonesia \\ *E-mail: ing.nuralam@ub.ac.id
}

\begin{abstract}
Since the formation of the Social Security Agency (Badan Penyelenggara Jaminan Sosial/BPJS) for Healthcare has found the public spotlight rising with its management; including the regulatory body BPJS for Healthcare activities. BPJS for Healthcare external supervisors such as DJSN, OJK, BPK are entities established according to the Law of the Republic of Indonesia 24 Year 2011. However, there are views on neutrality, independence, and supervisor capability. By using Soft System Methodology, this research invites us to understand the problem situation and what efforts should be taken in managing the complexity. This paper will analyze the co-operation with collaborative governance perspective as a cooperative approach in overseeing BPJS for Healthcare. The focus of this paper is in the stage of identifying a series of factors that are crucial within the collaborative process itself, which includes shared understanding as stated by Ansel \& Gash (2008) and Emerson \& Nabatchi (2015).
\end{abstract}

\section{KEY WORDS}

Soft system methodology, collaborative governance, external supervisors.

The Government of Indonesia seeks to improve health services for Indonesians, as evidenced by Law of Republic of Indonesia No. 24 of 2011 on Social Security Agency (Badan Penyelenggara Jaminan Sosial/BPJS) for Healthcare. Various challenges began to accompany the birth of Law No. 24 of 2011 , so that social security can be immediately felt by all the people. Based on observations on the implementation of BPJS for Healthcare, the Health Insurance policy in Indonesia faces problems that can be mapped using three levels of policy level (Bromley, 1989); policy level, the organizational level; and operational level.

In Organizational Level, there is factual problem ie the absence of regulation instrument formation of external BPJS for Healthcare Supervisory Board (DJSN, OJK, BPK) as mandated by the Law of Republic of Indonesia No. 24 Year 2011 regarding BPJS Article 39 paragraph (3). In the theory of collaborative governance, the absence of an ideal organizational setting is highlighted as a problem. This is because the organization BPJS is an entity in which all stakeholders in a state involved. Thus, stakeholders in other ways can also formulate, support, and become objects of strategic value management, corporate management, corporate goals (Freeman \& Reed, 1983); and be the responsibility of the company for the achievement of their satisfaction (Nuralam, 2016).

Collaborative Governance is the governance between institutions both state and nonstate agencies. This concept is born out of a society's view that the government has failed to represent the interests of society, and ultimately society has a bad view on the public sector and the legitimacy of the government (Hetherington, 2006). Osborne and Gaebler (1992) reveals the reason for the emergence of "reinvention" that transforms the "classical" bureaucracies that adopt organizations in the private and business sectors, so that it can change the response of the "classic" style of bureaucracy tends to be slow and unable to cope with competitive pressures

\section{LITERATURE REVIEW}

Public Policy and Its Formulation. Some scholars define Public Policy as a system 
consisting of measures, measurable regulations, laws, and financing priorities that focus on a particular topic by government agencies or their representatives. Public policy is generally embedded in constitutional board, legislative acts, and judicial decisions (Schuster II, 2008). Dye (1987) defines public policy as what the government does, how to do it, why it needs to be done and what difference it makes. Changes in public policy thus are dynamic in keeping with changes that are driven by changes in the environment outside and within the public organization.

Public policy making can be characterized as a dynamic, complex, and interactive system in which common problems are identified and resisted by creating new public policies or by reforming existing public policies (John, 1998). Common problems affecting public policy making can be from the economic, social, and political realms (Hill, 2005).

Policy formulation can not be separated from the management function inherent in the organization. Bromley (1989) captures this phenomenon by presenting a hierarchical policy theory that indicates the difference of content and policy context at each level within an organization. There are 3 (three) policy levels related to the hierarchy of policy making process, namely policy level, organizational level, and operational level.

Bromley's policy hierarchy is predominantly included in the context of public sector organizations. At the level of a country, Bromley's policy hierarchy provides a pretty clear picture of the policy level at each agency or institution in government. Applications of this theory can be adapted to the context of a policy and those with authority over the policy, whether at national, sectoral, or autonomous levels.

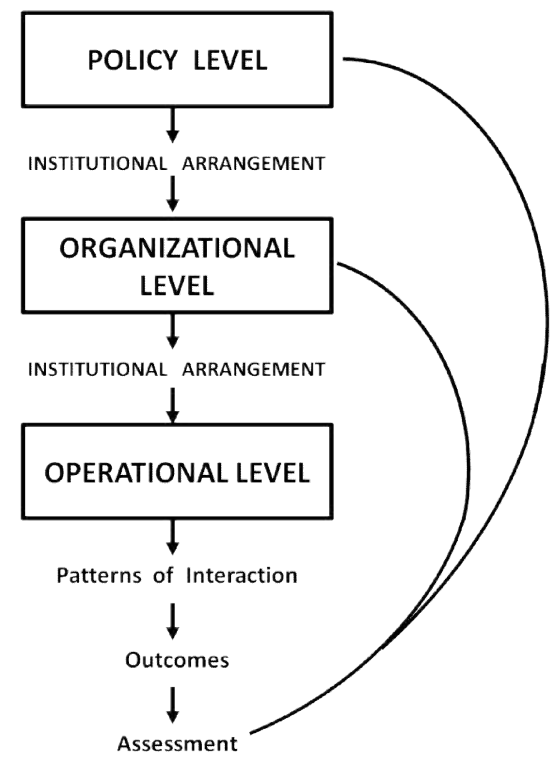

Figure 1 - Hierarchy of Policy Formulation Source: Bromley (1989)

Governance. The World Bank (1992) defines governance as a way in which power in economic development. Moreover, Neo and Chen (2007) define governance as the relationship between government and society that allows public policies and programs to be formulated, implemented and evaluated. By Hufty (2011) governance is the interaction and decision processes among actors involved in collective issues that lead to, strengthen, or build social norms and institutions. While Bevir (2013) defines it as all processes in government, whether committed by governments, markets or networks, whether within families, tribes, formal or informal organizations or territories and whether through organized laws, norms, powers or languages of society. In business and outsourcing relationships, governanc frameworks are built into relational contracts that foster long-term collaboration and innovation. Poor governance can lead to contract failure (Vitasek, 2011). Bouckaert and Pollit (2011) describe the concept of dangerous government, because it is considered only to 
overcome and contradict before, as well as public / private, or market bureaucracy. Osborne (2010) states governance needs to shift from traditional hierarchical organizational forms to network structures. In this sense requires a revision of relations between state and civil society in a more participatory direction.

Collaborative Governance. Collaborative governance was born out of a view from society that the government has failed to represent the interests of society, and ultimately the public has a bad view on the public sector and the legitimacy of the government (Hetherington, 2006). The concept of collaborative governance is possible because of dissatisfaction from the public regarding the performance of government organizations. The practice of collaborative governance is not only happening in the United States, but it has begun to be practiced in other countries (Freeman and Peck, 2006; Lee and Hague, 2006; Noble and Jones, 2006). The following are examples of collaborative governance practices in the United States: a) water resources management (Innes and Boher, 2003; Blomquist, et al., 2004); b) conservation of rare animals (Sabatier et al., 2005; Thomas, 2003).

Furthermore, Donahue (2004) considers that effective collaborative governance should provide new mechanisms for collaborative action determined by collaborative partners in line with their explicit and implied theory of theory to achieve the desired outcomes. The study conducted by Donahue and Zeckhauser (2011) reveals the role of government too often struggling with its inability to competence, will, and capacity in carrying out its mission. This is evidenced by the number of weak infrastructure, health services that are not balanced income and distribution, as well as tax leakage. Thus, Collaborative Governance becomes the main bargaining option to solve the problem by showing how governments at all levels can combine with the private sector in achieving public goals effectively.

The main purpose of the collaborative governance approach is to bring together several stakeholders together with the public agency and to engage in a deeper cooperation where there is a division of tasks and functions of each part with the same goals and ideology (shared vision among stakeholders, community and public agent) (Ansell and Gash, 2008). Emerson et al. (2012) have developed a less normative and less restrictive definition, as the processes and structures of the public policy of the decision making and management of public relations, the levels of government, and the public, private and civic spheres in order to carry out accomplished.

\section{METHODS OF RESEARCH}

Systems Thinking as an Approach. The purpose of the systems approach is to simplify our processes of thinking and managing complex facts (Senge, 1990). Systems thinking provides a selective way of dealing with the details that make possible complex thinking on the subject of transparency. Systems thinking guides understanding by looking at the relationship between elements to see the world (and make sense of it). The system approach begins with complex and uncertain situations. System language is about 'problem situation' rather than 'problem', and resolution (fixing situation) rather than solution (problem solving). Soft systems methodology (SSM) action research is in the position that the system is the epistemological construct of the real-world entities (Checkland, 1978). Given the background of SSM, Checkland and Poulter (2006) suggest that SSM developed is aptly used as an alternative study model, the social assessment model at the level of a group or organizational situation, ie action research.

Much of the literature on action research defines action research in the context of the learning process while doing something (learning by doing) and primarily for problem-solving purposes (Hardjosoekarto, 2012). According to O'Brien (1998), the problem-solving process with action research can be distinguished from the problem-solving process in the everyday sense, namely in its emphasis on scientific studies.

Soft System Methodology (SSM). This reasearch is using the Soft System Methodology (SSM) approach as a model to understand the problem situation and fixing the situation holistically. Soft Systems Methodology is a methodology based systems thinking 
and system concept that deals only with the human activity system (Hardjosoekarto, 2012) which consists of seven stages:

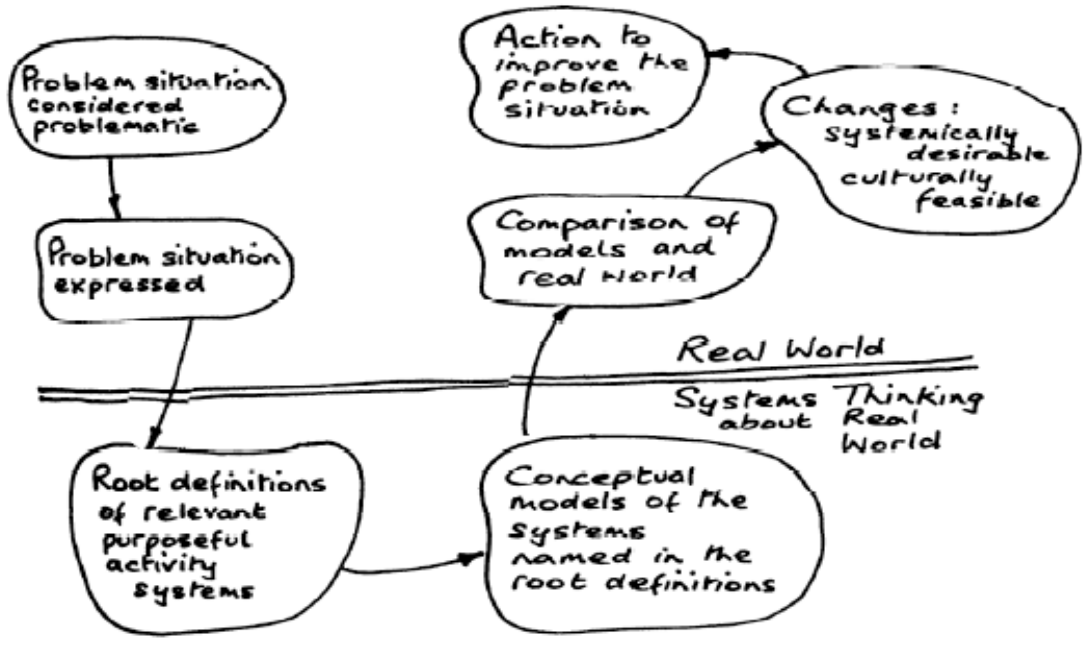

Figure 2 - Seven-Stage Model of SSM Source: Checkland and Scholes, 1990

This method consists of two parts of activity, namely 'real-world' and 'systems thinking', and seven stages, namely (1) problem situation considered problematic, (2) problem situation expressed, (3) root definition of relevant purposeful activity, (4) change systematically desireable, culturally feasible, and (7) action to improve the situation. Stages $1,2,5,6$ and 7 are real-world activities that contain problem situations, while stages 3 and 4 are systems thinking that may be involved in the situation of the problem, depending on the individual conducting the research.

\section{RESULTS AND DISCUSSION}

Stage 1 SSM: Problem Situation Considered Problematic. The BPJS Law states that BPJS is directly under the presidency and external supervision is conducted indirectly by BPK, DPR, and OJK and the National Social Security Council (DJSN) with all its limitations. On the other hand, the existence of DJSN assisting the president in the formulation of general policy is only to monitor and evaluate and synchronize the implementation of the National Social Security System (SJSN), conduct study and propose investment policy plus propose budget for beneficiaries. As an external supervisor, the DJSN has not performed its function effectively so it needs to be more empowered. The above explanation illustrates the vulnerability of direct supervision, requiring the management of BPJS to be performed by professionals with high integrity and proven "track record" of both the supervisory board and its directors. Such a large managed fund with much greater potential in the future may create a great temptation to deviate. Corruption can be done as easily as turning a hand without strict supervision by both internal (supervisory board and internal control unit) or external supervisor. Thus, the focus on integrity is mandatory and should be a major consideration. It is not just a matter of honesty to abstain from corruption, irregularities, and the like that must be prioritized, but also a commitment to efficiency and prohibited to disburse funds in accordance with one of the principles of social security.

The possibility of irregularities encountered by BPJS is quite diverse and vulnerable, so there needs to be a "good government" implementation which is periodically assessed by an independent consultant. It is therefore necessary that the supervisory board be proven to have practical experience in supervision, in addition to the integrity requirements. The representation of the tripartite element in the composition of the supervisory board is a "fatal weakness" in the provisions of the Act. Other considerations that govern BPJS well, rightly 
and rightly are the compliance with legislation and best practices in the provision of social security.

Stage 2 SSM: Problem Situation Expressed. Characteristics of SSM users, users will be observed through images and diagrams, known as rich picture - as well as making notes and writing narratives. Checkland (1990) states, this is because human events show the pageant of relationships, and images will better record relationships and connections than prose. Next, the researchers structured the problem that is linked to form the problem situation structure mapped in the form of rich picture. Rich picture will help researchers in doing research (Checkland and Poulter, 2006).

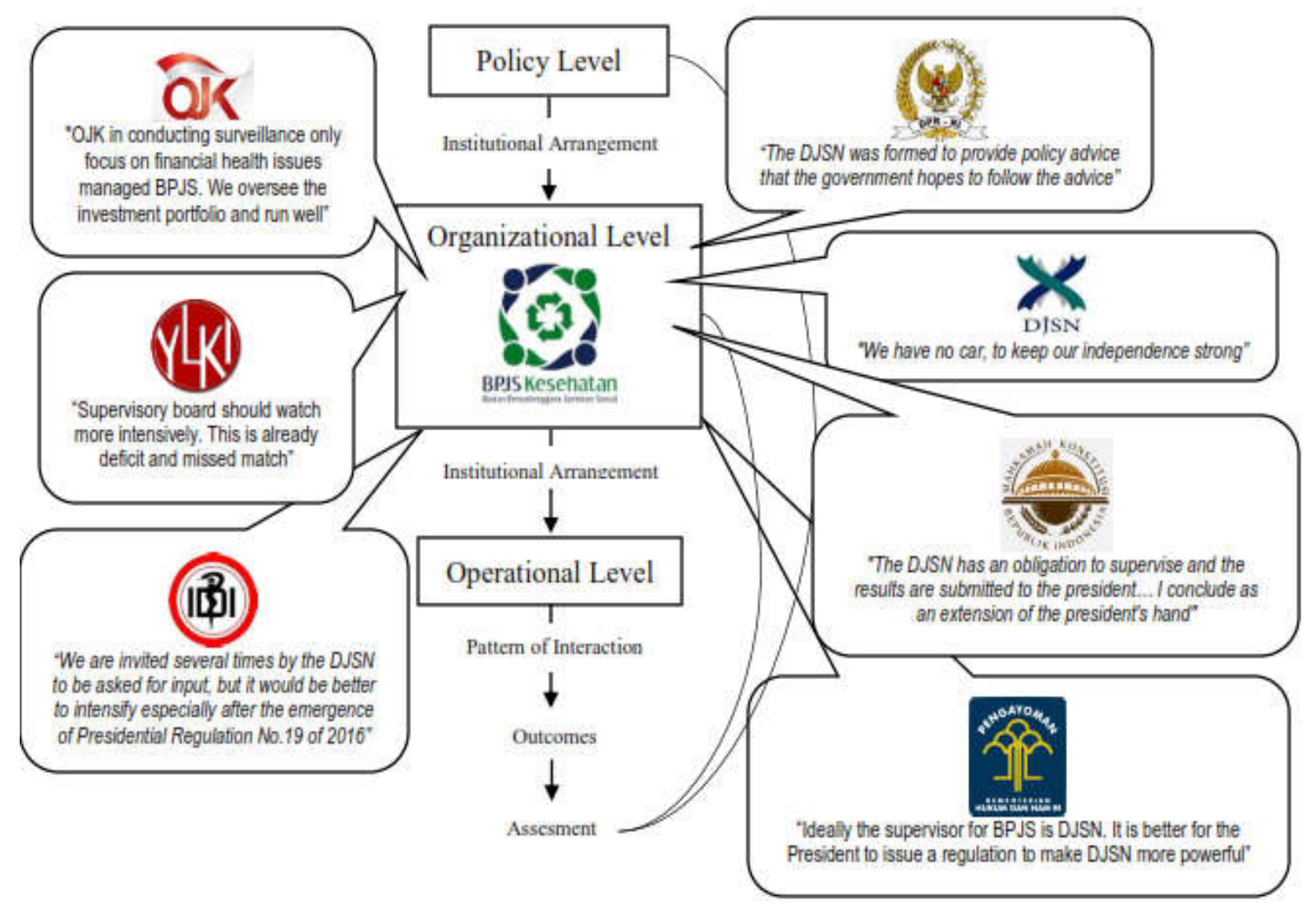

Figure 3 - Rich Picture in Organizational Level Source: Primary Data

Table 1 - CATWOE on RD

\begin{tabular}{cl}
\hline Customers & $\begin{array}{l}\text { President, House of Representatives, Regional Representative Council, Ministry of } \\
\text { Health, Ministry of Justice and Human Rights, Ministry of Finance, BPJS for Healthcare, } \\
\text { BPJS for Employment. }\end{array}$ \\
\hline Actors & DJSN, BPK, OJK \\
\hline Transformation & $\begin{array}{l}\text { Creating the External Monitoring Instrument BPJS for Healthcare Instrument (DJSN, OJK, } \\
\text { BPK); from the previous one that does not exist. } \\
\text { The establishment of the External Monitoring Instruments BPJS for Healthcare (DJSN, } \\
\text { OJK, BPK) is expected to clarify the authority of DJSN, OJK and BPK as external } \\
\text { Worldview } \\
\text { supervisors in assisting the President to formulate general policy and synchronize the } \\
\text { implementation of JKN system. }\end{array}$ \\
\hline Owner (s) & $\begin{array}{l}\text { BPJS for Healthcare, BPJS for Employment, DJSN, OJK, BPK } \\
\text { Environment }\end{array}$ \\
$\begin{array}{l}\text { Parties who do not want the occurrence of formal law and informal conventions in the } \\
\text { improvement of the Health Insurance System Policy }\end{array}$ \\
\hline
\end{tabular}

Stage 3 SSM: Root Definition (RD) of Relevant Purposeful Activity. RD is a relevant system concerning the system of problems studied. RD can also be interpreted as a brief verbal definition expression of the nature of the system deemed relevant to explore the 
problem situation. RD in this research contains the meaning of "System owned by External Supervisor of BPJS for Healthcare in formulating Regulation of Supervision through formal law in formulation of policies on BPJS Health External Governance Monitoring Instrument (DJSN, OJK, BPK) in order to guarantee achievement of collaborative governance of Indonesia's Health Insurance System".

Stage 4 SSM: Conceptual Models of the Systems Named in the Root Definition. In making the $\mathrm{CM}$ in each $\mathrm{RD}$ activity, it is analyzed using the elements of collaborative governance found in Emerson \& Nabatchi (2015).

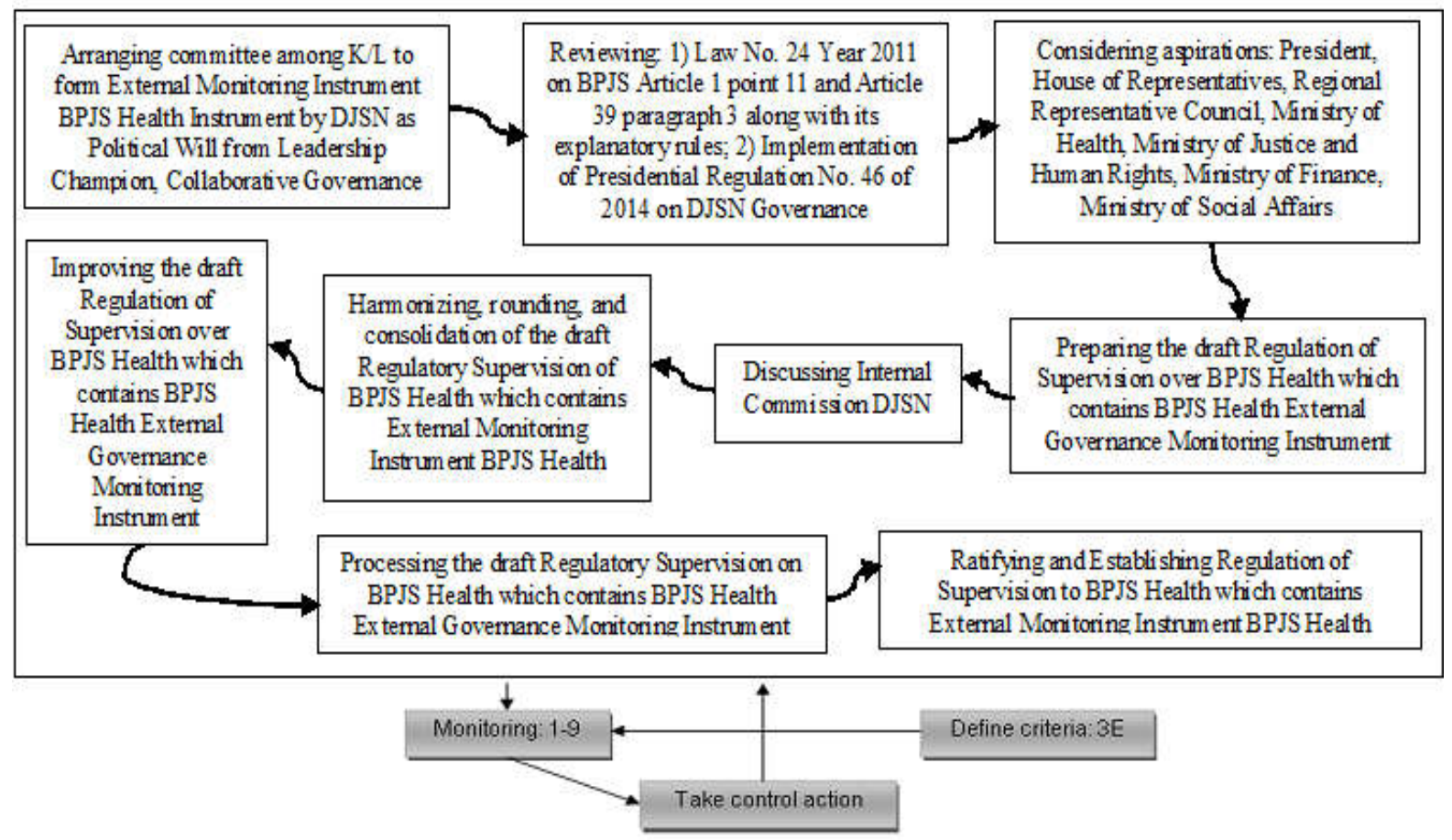

Figure 4 - Conceptual model at Organizational Level Effective.

The success of CM can be measured through three criteria: Efication, Efficiency, and

\begin{tabular}{cl}
\hline \multirow{2}{*}{ Efication } & $\begin{array}{l}\text { The existence of formal law and informal convention in forming Regulation of Supervision to } \\
\text { BPJS for Healthcare which contains External Monitoring Instrument BPJS for Healthcare } \\
\text { (DJSN, OJK, BPK) as mandated by Law of Republic of Indonesia Number } 24 \text { Year } 2011 \\
\text { regarding BPJS. }\end{array}$ \\
\hline Efficiency & Use the minimum resources (financial and time) \\
\hline \multirow{3}{*}{ Effective } & $\begin{array}{l}\text { Establishment of Supervision Regulation on BPJS for Healthcare which contains External } \\
\text { Monitoring Instrument BPJS for Healthcare (DJSN, OJK, BPK) as mandated by the Law of the } \\
\text { Republic of Indonesia Number 24 Year 2011 on BPJS. }\end{array}$ \\
\hline
\end{tabular}

Stage 5 SSM: Comparison of Models and Real World. This activity aims to answer the question of whether the model as an intellectual tool is relevant to the real research problem (Checkland, 1999); by means of Informal Discussion, Formal Discussion, Screenplay Writing, Real World Model Modeling Checkland and Poulter (2006) and Checkland (1999).

Stage 6 SSM: Systematically Desirable and Culturally Feasible. After conducting discussions and researches to compare conceptual models with perceived reality, the next step is to formulate recommendations for any changes or actions needed to address the problems. The recommendations are usually described as "systematically desirable" and "culturally feasible" (culturally feasible to do in the real world) to support the desired change of theoretical research practice or research interest. So that in the end will be gained knowledge (understanding) about Collaborative Governance best practice in JKN program become lesson learned. 
Table 2 - Comparison Conceptual Model with Real World

\begin{tabular}{|c|c|c|c|c|c|}
\hline No. & Activity in the Model & Exists? & Who? & $\begin{array}{l}\text { Good } \\
\text { / bad? }\end{array}$ & Alternatives? \\
\hline 1 & $\begin{array}{l}\text { Arranging committee among Ministry / } \\
\text { Institution to form External Monitoring } \\
\text { Instrument BPJS for Healthcare } \\
\text { Instrument by DJSN as Political Will from } \\
\text { Leadership Champion, Collaborative } \\
\text { Governance }\end{array}$ & No & DJSN & Good & $\begin{array}{l}\text { Collaboration with DPR RI, DPD } \\
\text { RI, and Ministry of Health }\end{array}$ \\
\hline 2 & $\begin{array}{l}\text { Reviewing: 1) Law No. } 24 \text { Year } 2011 \text { on } \\
\text { BPJS Article } 1 \text { point } 11 \text { and Article } 39 \\
\text { paragraph } 3 \text { along with its explanatory } \\
\text { rules; 2) Implementation of Presidential } \\
\text { Regulation No. } 46 \text { of } 2014 \text { on DJSN } \\
\text { Governance }\end{array}$ & No & DJSN & Good & $\begin{array}{l}\text { Collaboration with Ministry of } \\
\text { Labor, Ministry of PAN-RB, } \\
\text { Labor Practitioner, Researcher, } \\
\text { and Academician }\end{array}$ \\
\hline 3 & $\begin{array}{l}\text { Considering aspirations: President, House } \\
\text { of Representatives, Regional } \\
\text { Representative Council, Ministry of } \\
\text { Health, Ministry of Justice and Human } \\
\text { Rights, Ministry of Finance, Ministry of } \\
\text { Social Affairs }\end{array}$ & No & $\begin{array}{l}\text { DJSN } \\
\text { and } \\
\text { BPJS }\end{array}$ & Good & $\begin{array}{l}\text { Collaboration with Ministry of } \\
\text { Labor, Ministry of PAN-RB, } \\
\text { Labor Practitioner, Researcher, } \\
\text { and Academician }\end{array}$ \\
\hline 4 & $\begin{array}{l}\text { Preparing the draft Regulation of } \\
\text { Supervision over BPJS for Healthcare } \\
\text { which contains BPJS for Healthcare } \\
\text { External Governance } \\
\text { Instrument }\end{array}$ & No & DJSN & Good & $\begin{array}{l}\text { Collaboration with House of } \\
\text { Representatives, Regional } \\
\text { Representative Council, Ministry } \\
\text { of Health, and BPJS, } \\
\text { Researcher, and Academics }\end{array}$ \\
\hline 5 & Discussing Internal Commission DJSN & No & DJSN & Good & $\begin{array}{l}\text { Collaboration with House of } \\
\text { Representatives, Regional } \\
\text { Representative Council, Ministry } \\
\text { of Health, and BPJS, } \\
\text { Researcher, and Academics }\end{array}$ \\
\hline 6 & $\begin{array}{l}\text { Harmonizing, rounding, and consolidation } \\
\text { of the draft Regulatory Supervision of } \\
\text { BPJS for Healthcare which contains } \\
\text { External Monitoring Instrument BPJS for } \\
\text { Healthcare }\end{array}$ & No & DJSN & Good & $\begin{array}{l}\text { Consultation with House of } \\
\text { Representatives, } \\
\text { Representative Council, Ministry } \\
\text { of Justice and Human Rights }\end{array}$ \\
\hline 7 & $\begin{array}{l}\text { Improving the draft Regulation of } \\
\text { Supervision over BPJS for Healthcare } \\
\text { which contains BPJS for Healthcare } \\
\text { External Governance } \\
\text { Instrument }\end{array}$ & No & DJSN & Good & $\begin{array}{l}\text { Consultation with House of } \\
\text { Representatives, } \\
\text { Representative Council, Ministry } \\
\text { of Justice and Human Rights }\end{array}$ \\
\hline 8 & 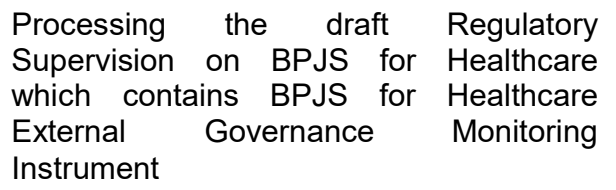 & No & DJSN & Good & $\begin{array}{l}\text { Consultation with House of } \\
\text { Representatives, } \\
\text { Representative Council, Ministry } \\
\text { of Justice and Human Rights, } \\
\text { BPJS }\end{array}$ \\
\hline 9 & $\begin{array}{l}\text { Ratifying and Establishing Regulation of } \\
\text { Supervision to BPJS for Healthcare which } \\
\text { contains External Monitoring Instrument } \\
\text { BPJS for Healthcare }\end{array}$ & No & DJSN & Good & $\begin{array}{l}\text { Socialization by House of } \\
\text { Representatives, Ministry of } \\
\text { Health, Ministry of Manpower }\end{array}$ \\
\hline
\end{tabular}

Source: Adapted from Checkland and Scholes (1990).

Table 3 - System Changes

\begin{tabular}{|c|c|c|}
\hline Name of RD & Systematically Desirable? & Culturally Feasible? \\
\hline The Establish an external & Yes, through the preparation of external BPJS & representing \\
\hline BPJS for Healthcare & Healthcare Monitoring Supervisory & accommodation \\
\hline Monitoring Agency (DJSN, & instruments (DJSN, OJK, BPK) supplen & interests of \\
\hline OJK, BPK) instrument in & supervisory procedures that have been & Healthcare External \\
\hline accordance with the Law & out so far, it is expected to clarify the a & Governance \\
\hline of the Republic of & of BPJS for Healthcare external & accordance with the mandate of the \\
\hline Indonesia Number 24 Year & (DJSN, OJK, BPK) as external supervision in & Law of the Republic of Indonesia \\
\hline 2011 regarding BPJS & assisting President to formulate general & Number 24 Year 2011 on BPJS \\
\hline Article 39 paragraph (3) & $\begin{array}{l}\text { policies and synchronize the implementation of } \\
\text { the national social security system }\end{array}$ & Article 39 paragraph (3) \\
\hline
\end{tabular}

Source: Adoption of Checkland and Scholes, 1990. 
Stage 7 SSM: Action to Improve the Situation. The action to improve the situation stage is an action to improve, refine, and change the problematic situation. This stage is the "end" stage of SSM. Given that since the beginning of the SSM process has involved both Clients and Owners (of the issues addressed), and considering that the process is a learning system (learning systems), then by itself there is no resistance to take action based on the proposed action steps that have been formulated (Hardjosoekarto 2012). This stage also asks whether posible action can be done in this research to change the system.

Table 4 - Possible Action on the system

Possible Action

Yes, by representing an accommodation of the different interests of stakeholders on BPJS for Healthcare external Monitoring instruments, so BPJS for Healthcare can organize a national social security system based on the following principles: a. mutual cooperation; b. non-profit; c. openness; d. caution; e. accountability; f. portability; g. membership is mandatory; h. trust fund; and i. the results of the management of the Social Security Fund shall be used wholly for the development of the program and for the greatest interest of the Participant; as mandated by the Law of the Republic of Indonesia Number 24 Year 2011 on BPJS Article 39 paragraph (3)

\section{CONCLUSION}

BPJS for Healthcare management is still seen partially and non-holistic. It was caught the problems in the management of BPJS for Healthcare especially external supervision as a systemic problem and needed to be solved in a non-linear way. Studies conducted at the organizational level (DJSN, Supervisory Board, and BPJS for Healthcare using collaborative governance theory emphasizes the collaboration made by the government with other governmental or non-governmental organizations for the success of the program being run. In general, the research conclusions focus on collaborative governance interwoven among government agencies; and also involves non-governmental organizations acting as overseers of BPJS for Healthcare organizations.

In Organizational Level JKN's policy practice in Indonesia using collaborative governance approach, managed by BPJS for Healthcare is still far from ideal value. This can be seen from the lack of Principled Engagement and Joint Capacity for Action among stakeholders. Strengthening external and internal BPJS for Healthcare supervisory rules is required to perform program control functions; and the success of the JKN program.

By system, the improvement of BPJS for Healthcare management especially external supervision can be done through several steps so that action implementation can be done well. In principle, there needs to be a system that governs the establishment of BPJS for Healthcare external regulatory instruments, so that BPJS for Healthcare can organize a national social security system.

It is concluded that there is one value that is not owned in the theory of collaborative governance, namely political will. After deepening the problems SJSN, JKN, Operations BPJS for Healthcare, and Jamkesmas; found that leadership champion will not develop without political will. It is interpreted as a dynamic or dynamic process of collaboration in implementing the JKN program at every level of policy (Bromley, 1989) conducted between government organizations, or government organizations with the community.

\section{ACKNOWLEDGMENTS}

This research is conducted by a joint research team organized by Faculty of Administrative Science (FIA) and Research Institutions and Community Service (LPPM), Universitas Brawijaya. Members of the team are Inggang Perwangsa Nuralam (Faculty of Administrative Science) and Dindha Ayu Mitra Dyani (Faculty of Administrative Science). The research team expresses their gratitude to the Director of Research Institutions and Community Service (LPPM), Universitas Brawijaya who grants a collaborative Research Grant for budget year 2017. 


\section{REFERENCES}

1. Ansell, Chris \&, Alison Gash. (2008). "Collaborative Governance in Theory and Practice". Journal of Public Administration Research and Theory. 18 (4): 544.

2. Bevir, Mark. (2013). Governance: A very short introduction. Oxford, UK: Oxford University Press.

3. Blomquist, W., E. Schlager and T. Heikkila. (2004). Common Waters, Diverging Streams: Linking Institutions and Water Management in Arizona, California, and Colorado. Washington, DC: Resources for the Future.

4. Bouckaert, Geert and Christhoper Pollit. (2011). Public Management Reform Oxford University Press

5. Bromley, Daniel W. (1989). Economic Interest and Institutions: The Conceptual Foundations of Public Policy. New York: Basil Blackwell.

6. Checkland, P. (1978). "The Origins and Nature of 'Hard' Systems Thinking." Journal of Applied Systems Analysis 5: 99-110.

7. Checkland, P. (1999). Systems thinking. Rethinking management information systems, 45-56.

8. Checkland, Peter, \& John Poulter. (2006). Learning for Action: A Short Definitive Account of Soft Systems Methodology and its use for Practitioners, Teachers, and Students. England: John Wiley \& Sons Ltd.

9. Checkland, Peter, \& Scholes. (1990). Soft Systems Methodology in Action. England: John Wiley \& Sons Ltd.

10. Donahue, John D., and Richard J. Zeckhauser. (2011). Collaborative Governance: private roles for public goals in turbulent times. United Kingdom: Princeton University Press.

11. Donahue, John. (2004). On collaborative governance. Working Paper \#2. CSRI. http://www.hks.harvard.edu/mrcbg/CSRI/publications/workingpaper_2_donahue.pdf.

12. Dye, Thomas R. (1987). Understanding Public Policy. Prentice Hall Inc., New Jersey.

13. Emerson, Kirk, Tina Nabatchi, Stephen Balogh. (2012). "An Integrative Framework for Collaborative Governance". Journal of Public Administration Research and Theory. 22 (1): 1-29.

14. Emerson, Kirk., and Tina Nabatchi. (2015). Collaborative Governance Regimes. Washington DC: Georgetown University Press.

15. Freeman, R. E., \& Reed, D. L. (1983). Stockholders and stakeholders: A new perspective on corporate governance. California management review, 25(3), 88-106.

16. Freeman, Tim., and Edward Peck. (2006). Evaluating partnerships: a case study of integrated specialist mental health services. Health \& Social Care in the Community. Volume 14, Issue 5, pages 408-417, September 2006

17. Hardjosoekarto, Sudarsono. (2012). Soft System Methodology (Metode Serba Sistem Lunak). UI Press, Jakarta

18. Hetherington, M. J. (2006). Why Trust Matters: Declining Political Trust and the Demise of American Liberalism. Princeton, NJ: Princeton University Press.

19. Hill, Michael. (2005). Public Policy Process. London: Pearson.

20. Hufty, Marc (2011). "Investigating Policy Processes: The Governance Analytical Framework (GAF). In: Wiesmann, U., Hurni, H., et al. eds. Research for Sustainable Development: Foundations, Experiences, and Perspectives.". Bern: Geographica Bernensia: 403-424.

21. Innes, J. E. and D. E. Boher. (2003). Collaborative policymaking: governance through dialogue. In Deliberative Policy Analysis: Understanding Governance in the Network Society. Edited by M. Hajer and H. Wagenaar. New York, NY: Cambridge University Press.

22. John, Peter. (1998). Analysing Public Policy. London: Routledge.

23. Lee, E. W. Y. and M. S. Haque. (2006). The New Public Management Reform and Governance in Asian NICs: A Comparison of Hong Kong and Singapore. Governance, 19(4): 531-698. 
24. Neo, Boon Siong and Geraldine Chen. (2007). Dynamic Governance; Embedding Culture, Capabilities and Change in Singapore. Singapore: World Scientific Publishing Co. Pte. Ltd

25. Noble, G. and R. Jones. (2006). The Role of Boundary Spanning Managers in the Establishment of Public-Private Partnerships. Public Administration 84(4): 817-1122.

26. O'Brien, Rory. (1998). An Overview of the Methodological Approach of Action Research. http://www.web.ca/-robien/papers/artifinal.html

27. Osborne, David., and Ted Gaebler. (1992). How the Entrepreneurial Spirit is Transforming the Public Sector. Reading, MA: Addison-Wesley.

28. Osborne, Stephen P. (2010). The New Public Governance?: Emerging Perspectives on the Theory and Practice of Public Governance. UK: Routledge.

29. Nuralam, I. P. (2016). Creating Customer Relationship Management Based On Islamic Values: A Case Study Of Pt. Bank Muamalat Indonesia Tbk. Russian Journal of Agricultural and Socio-Economic Sciences, 58(10).

30. Sabatier, P. A., W. Focht, M. Lubell, Z. Trachtenberg, A. Vedlitz and M. Matlock. (2005). Swimming Upstream: Collaborative Approaches to Watershed Management. Cambridge, MA: The MIT Press.

31. Schuster II, W. Michael. (2008). For the Greater Good: The Use of Public Policy Considerations in Confirming Chapter 11 Plans of Reorganization. Houston Law Review, Vol. 46, p. 467, 2009

32. Senge, Peter. M. (1990). The Fifth Discipline: The Art and Practice of The Learning Organization. New York: Divison of Bantam Doubleday Dell Publishing Group.Inc

33. Thomas, C. W. (2003). Bureaucratic Landscapes: Interagency Cooperation and the Preservation of Biodiversity. Cambridge, MA: MIT Press.

34. Vitasek, Kate; et al. (2011). The Vested Outsourcing Manual (1st ed.). New York: Palgrave Macmillan. ISBN 0230112684.

35. World Bank. (1992). Governance and development. Washington, DC: The World Bank.

(c) 2017 by the authors. Licensee RJOAS, Orel, Russia. This article is an open access article distributed under the terms and conditions of the Creative Commons Attribution (CC BY) license: http://creativecommons.org/licenses/by/4.0/ 
DOI https://doi.org/10.18551/rjoas.2017-09.12

\title{
ГОСУДАРСТВЕННАЯ ПОДДЕРЖКА ИНВЕСТИЦИЙ В СЕЛЬСКОЕ ХОЗЯЙСТВО ВОРОНЕЖСКОЙ ОБЛАСТИ \\ STATE SUPPORT FOR INVESTMENT IN AGRICULTURE OF THE VORONEZH REGION
}

\author{
Сабетова Т.В. ${ }^{*}$ Захарова Н.А., кандидаты экономических наук \\ Sabetova T.V., Zakharova N.A., Candidates of Economic Sciences \\ Воронежский государственный аграрный университет, Воронеж, Россия \\ Voronezh State Agrarian University, Voronezh, Russia \\ ${ }^{*}$ E-mail: tsabetova@mail.ru
}

\begin{abstract}
АННОТАЦИЯ
Статья посвящена проблеме государственной поддержки инвестиционной деятельности в сельском хозяйстве. Воронежская область является индустриальноаграрным регионом, доля сельского хозяйства в создании валового регионального продукта Воронежской области устойчиво растет и в 2015 году составила 15,3\%. Между тем, концентрация основных фондов в данной отрасли ниже - лишь 8,8\%, а в сумме инвестиций в основной капитал на долю сельского хозяйства региона приходится 9,7\%. Инвестиционные процессы в сельском хозяйстве области отличаются некоторыми особенностями, их состояние далеко от удовлетворительного. По наблюдениям автора, стоимость основных средств за последние 5 лет росла наиболее интенсивными темпами по тем их группам, которые получали государственную поддержку. Автор делает вывод о том, что увеличения притока инвестиций в сельское хозяйство можно ожидать лишь в случае реализации масштабной государственной поддержки. Часть мер государственной поддержки аграрных предприятий, реализуемых в Воронежской области, направлена именно на инвестиционную составляющую, например, часть мероприятий по поддержке отраслей растениеводства и животноводства, техническая и технологическая модернизация, инновационное развитие, возмещение части процентной ставки по кредитам и займам.
\end{abstract}

\section{ABSTRACT}

The article concerns the problem of governmental support of investment activity in agriculture. Voronezh region is an industrial-agrarian area, the share of agriculture in the gross regional product creation is steadily growing and reached $15,3 \%$ in 2015 . Meanwhile, the concentration of the fixed assets in this branch is considerably lower - only $8,8 \%$; agriculture has $9,7 \%$ on the total investments into the fixed capital of the region. Investment processes in agriculture are marked with specific features and their state is far from satisfactory. According to the author's observations, the amount of the fixed capital during the last 5 years was growing most intensively for those groups of them which received governmental support. The authors conclude that one may only expect the increase of the investment inflow in the agriculture in case of implementation of large-scale governmental support. Several means of governmental support for agricultural enterprises implemented in the Voronezh region is aimed specifically at the investment component, for example, some measures to support the crop and livestock sectors, technical and technological modernization, innovative development, reimbursement of interest rates on loans and borrowings.

\section{КЛЮЧЕВЫЕ СЛОВА}

Сельское хозяйство, государственная поддержка, инвестиции, источники фринансирования, сельскохозяйственная техника, внеоборотные активы.

\section{KEY WORDS}

Agriculture, governmental support, investments, sources of financing, agricultural machinery, fixed assets. 
Исследование проблем инвестиций всегда находилось в центре внимания экономической науки, поскольку они затрагивают основы хозяйственной деятельности, определяя процесс расширенного воспроизводства и экономического роста в целом. Что же касается инвестиций в сельское хозяйство, то эти вопросы выходят далеко за рамки отраслевых проблем. Динамично растущие инвестиции, трансформирующиеся в инновации, в новые конкурентоспособные производства, повышают количественные и качественные показатели хозяйственной деятельности сельскохозяйственных организаций, всего аграрного комплекса в целом, решают вопросы продовольственной безопасности страны [10].

Роль инвестиций как на уровне всего народнохозяйственного комплекса, так и на уровне отдельных субъектов хозяйствования весьма значительна. Что касается отдельных видов деятельности, то здесь имеются свои особенности. Например, в сельском хозяйстве в условиях формирования социально-ориентированной рыночной экономики центральное место должно отводиться человеку с его потребностями при одновременном сохранении и увеличении производительных свойств земли.

Постановка проблемы. Государственная поддержка инвестиционной деятельности может проводиться путем использования различных регуляторов субсидирования процентной ставки по инвестиционным кредитам; возмещения части инвестиционных затрат; стимулирования привлечения средств частных инвесторов введением для них льготных условий деятельности; несвязанной поддержки всех инвестиций, включая собственные; проектного управления и финансирования.

В настоящее время механизм инвестиционной поддержки развития сельского хозяйства в рамках реализации Государственной программы характеризуется:

1) Изменением структуры субсидирования по используемым фрормам господдержки. В прошедшем году особенно значительной трансформации подверглась поддержка региональных экономически значимых программ. Так, если в предшествующий период в их состав были включены развитие молочного и мясного скотоводства, производство овощей и картофеля, свеклосахарное производство и др., то в 2015 г. - лишь развитие льноводства, рисоводства и мясного скотоводства. Минсельхозом РФ рассматривался вопрос о включении в 2015 г. в состав экономически значимых программ таких новых направлений, как развитие коноплеводства, производства хлопка, хмеля, а также конкурентоспособной продукции овцеводства (шерсть). В соответствии с указанным прогнозом будет осуществляться снижение уровня кредитной поддержки (доля субсидирования процентной ставки по кредитам составит к 2020 г. менее 30\% против 50\% в 2012 г.) в пользу финансирования прозрачных и легко администрируемых инструментов.

2) Совершенствованием действующих форм инвестиционного субсидирования в направлении повышения эффеективности их применения с позиции окупаемости бюджетных средств, упрощения механизма, оптимизации сроков получения господдержки сельхозтоваропроизводителем и др. Например, переход к так называемому авансированию товаропроизводителя в рамках используемой меры субсидирования процентных ставок по инвестиционным кредитам и др.

3) Введением новых государственных регуляторов инвестиционной деятельности в АПК, таких как субсидирование на возмещение части прямых понесенных затрат на создание и модернизацию объектов агропромышленного комплекса, проектное фринансирование наиболее крупных инвестиционных проектов. Развитие проектного фринансирования предусмотрено планом Правительства РФ по повышению производительности труда и стимулированию развития экономики. В рамках программы проектного фринансирования в 2015 г. (по состоянию на июнь 2015 г.) в состав отобранных 13 проектов были включены шесть проектов АПК на общую сумму кредитов 30,4 млрд. рублей, в том числе по птицеводству, свиноводству, молочному скотоводству и производству сахара. Кроме того, для рассмотрения в межведомственную комиссию направлено два новых проекта по тепличному овощеводству. 
Обсуждение результатов. На рисунке 1 представлены объем и доля инвестиций в основной капитал в сельском хозяйстве Воронежской области. Здесь мы не наблюдаем столь устойчивой тенденции к росту, как в целом по объему инвестиций в областной экономике.

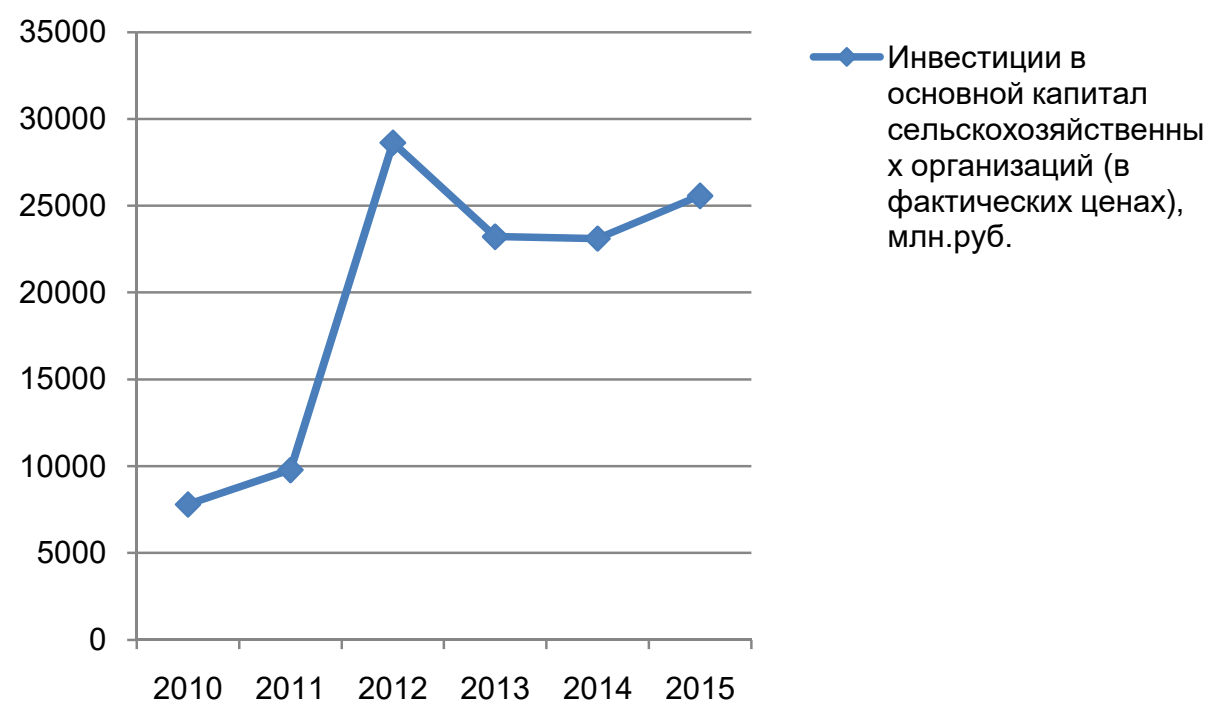

Рисунок 1 - Инвестиции в основной капитал по сельскому хозяйству

Оценить состояние инвестиционных процессов в сельском хозяйстве Воронежской области позволят следующие аспекты:

1. Объем и динамика внеоборотных активов на балансе аграрных предприятий области. лишь основные средства аграрных предприятий области демонстрируют устойчивый рост. Следует отметить, что ежегодный рост достаточно существенен, и хотя мы оценивали все значения в текущих ценах, можно предположить, что в постоянных ценах динамика также была бы положительной.

С другой стороны, мы видим, что другие группы внеоборотных активов демонстрируют неустойчивую динамику, причем никак не коррелирующую с кризисными явлениями 2014-2016 гг. Снижение стоимости нематериальных активов на балансе началось уже в 2013 году, а доходных вложений - лишь в 2015 году. Если же рассматривать динамику фринансовых вложений, то они, напротив, росли ежегодно, начиная с 2013 года.

2. Динамика основных средств в разрезе их видов. За последние пять лет суммарная стоимость основных средств в сельскохозяйственных организациях Воронежской области возросла почти на 89\%, хотя рост этот неравномерно распределялся по отдельным группам основных средств.

Так, стоимость зданий и сооружений за рассматриваемый период выросла на $161 \%$, машин и оборудования - на $117 \%$. С другой стороны, стоимость транспортных средств увеличилась менее значительно, лишь на $72 \%$, производственного и хозяйственного инвентаря - на $69 \%$, рабочего скота - всего на $62 \%$, хотя последнее вполне объяснимо в точки зрения замены использования гужевого транспорта и других способов использования животных машинами, которые, очевидно, стали несколько более доступными для предприятий. В наибольшей степени за период увеличилась стоимость продуктивного скота - на $290 \%$ и многолетних насаждений - на $300 \%$, т.е. практически в 4 раза. Эти фракты связаны с государственной поддержкой соответствующих отраслей сельского хозяйства, возможностями компенсации расходом на приобретение или создание именно этих групп основных средств.

3. Источники фринансирования инвестиций в сельскохозяйственных организациях области [1]. 
Таблица 1 - Региональные программы поддержки сельского хозяйства в Воронежской области

\begin{tabular}{|c|c|c|c|}
\hline Год & Направление / программа & $\begin{array}{l}\text { Объем } \\
\text { фринансирования, } \\
\text { тыс. руб. }\end{array}$ & $\begin{array}{l}\text { В т.ч. из } \\
\text { регионального } \\
\text { бюджета }\end{array}$ \\
\hline \multirow{6}{*}{2012} & $\begin{array}{l}\text { Субсидии на возмещение части затрат на уплату } \\
\text { процентов по кредитам и займам }\end{array}$ & 2822222 & 484352 \\
\hline & Господдержка отраслей животноводства & 1222970 & 1077600 \\
\hline & Господдержка отраслей растениеводства & 720867 & 68839 \\
\hline & $\begin{array}{l}\text { Субсидии на компенсацию части затрат по } \\
\text { страхованию урожая с/х культур, урожая и посадок } \\
\text { многолетних насаждений }\end{array}$ & 282000 & 14100 \\
\hline & $\begin{array}{l}\text { Господдержка экономически значимых региональных } \\
\text { программ }\end{array}$ & 743783 & 282000 \\
\hline & Bсего & 6209275 & 2085736 \\
\hline \multirow{7}{*}{2013} & Возмещение части затрат на уплату страховой премии & 148768 & 12859 \\
\hline & $\begin{array}{l}\text { Оказание несвязанной поддержки с/х } \\
\text { товаропроизводителям в области растениеводства }\end{array}$ & 1098650 & 197962 \\
\hline & $\begin{array}{l}\text { Возмещение части процентной ставки по кредитам и } \\
\text { займам }\end{array}$ & 4354292 & 595740 \\
\hline & Господдержка отраслей животноводства & 1299557 & 434662 \\
\hline & Господдержка отраслей растениеводства & 68623 & 5359 \\
\hline & $\begin{array}{l}\text { Господдержка экономически значимых региональных } \\
\text { программ (развитие растениеводства, } \\
\text { животноводства, в т.ч. мясного скотоводства) }\end{array}$ & 1600659 & 663769 \\
\hline & Всего & 9002224 & 2129511 \\
\hline \multirow{7}{*}{2014} & $\begin{array}{l}\text { Оказание несвязанной поддержки с/х товаро- } \\
\text { производителям в области растениеводства }\end{array}$ & 1153353 & 424000 \\
\hline & Возмещение части затрат на уплату страховой премии & 393193 & 68476 \\
\hline & $\begin{array}{l}\text { Возмещение части процентной ставки по кредитам и } \\
\text { займам }\end{array}$ & 6281844 & 1197990 \\
\hline & Господдержка отраслей животноводства & 969016 & 551055 \\
\hline & Господдержка отраслей растениеводства & 73139 & 12765 \\
\hline & $\begin{array}{l}\text { Господдержка экономически значимых региональных } \\
\text { программ (развитие животноводства, в т.ч. мясного } \\
\text { скотоводства) }\end{array}$ & 126342 & 78068 \\
\hline & Всего & 9436663 & 2575961 \\
\hline \multirow{8}{*}{2015} & Возмещение части затрат на уплату страховой премии & 219251 & 15565 \\
\hline & $\begin{array}{l}\text { Оказание несвязанной поддержки с/х товаро- } \\
\text { производителям в области растениеводства }\end{array}$ & 1017268 & 154970 \\
\hline & $\begin{array}{l}\text { Возмещение части процентной ставки по кредитам и } \\
\text { займам }\end{array}$ & 6267784 & 1058301 \\
\hline & $\begin{array}{l}\text { Техническая и технологическая модернизация, } \\
\text { инновационное развитие }\end{array}$ & 136930 & 6847 \\
\hline & Господдержка отраслей животноводства & 521242 & 85445 \\
\hline & Господдержка отраслей растениеводства & 261498 & 38964 \\
\hline & $\begin{array}{l}\text { Господдержка экономически значимых региональных } \\
\text { программ (развитие животноводства, в т.ч. мясного } \\
\text { скотоводства) }\end{array}$ & 327555 & 70010 \\
\hline & Всего & 9337594 & 1683690 \\
\hline \multirow{8}{*}{2016} & $\begin{array}{l}\text { Оказание несвязанной поддержки с/х товаро- } \\
\text { производителям в области растениеводства }\end{array}$ & 1014418 & 139100 \\
\hline & Возмещение части затрат на уплату страховой премии & 227706 & 13399 \\
\hline & $\begin{array}{l}\text { Возмещение части процентной ставки по кредитам и } \\
\text { займам }\end{array}$ & 5076107 & 1159625 \\
\hline & Господдержка отраслей животноводства & 766368 & 292741 \\
\hline & Господдержка отраслей растениеводства & 313202 & 44086 \\
\hline & $\begin{array}{l}\text { Господдержка экономически значимых региональных } \\
\text { программ (развитие животноводства, в т.ч. мясного } \\
\text { скотоводства) }\end{array}$ & 626672 & 73600 \\
\hline & $\begin{array}{l}\text { Возмещение части прямых понесенных затрат на } \\
\text { создание и модернизацию объектов АПК }\end{array}$ & 699742 & 36065 \\
\hline & Всего & 9219241 & 1969239 \\
\hline
\end{tabular}


Конкретно в Воронежской области на настоящий момент (2017 год) действуют следующие программы, предполагающие финансовую поддержку сельского хозяйства:

1. Направление «Развитие отраслей АПК»: оказание несвязанной поддержки сельскохозяйственным товаропроизводителям в области растениеводства; повышение продуктивности в молочном скотоводстве; содействие достижению целевых показателей региональных программ развития агропромышленного комплекса («Единая субсидия»).

2. Направление «Стимулирование инвестиционной деятельности»: поддержка инвестиционного кредитования в агропромышленном комплексе; компенсация прямых понесенных затрат на создание и модернизацию объектов агропромышленного комплекса, а также на приобретение техники и оборудования.

3. Федеральная целевая программа «Развитие мелиорации земель сельскохозяйственного назначения России на 2014-2020 годы».

4. Федеральная целевая программа «Устойчивое развитие сельских территорий на 2014-2017 годы и на период до 2020 года»

Однако перечень данных программ и направлений весьма существенно варьирует по годам. Рассмотрим основные региональные программы, реализация которых финансировалась за последние 5 лет (табл. 1).

Как видим из таблицы 1, часть мер государственной поддержки аграрных предприятий направлена именно на инвестиционную составляющую, например, часть мероприятий по поддержке отраслей растениеводства и животноводства, техническая и технологическая модернизация, инновационное развитие, возмещение части процентной ставки по кредитам и займам. Важно подчеркнуть, что общие суммы фринансирования не столь сильно колебались в течение последних 4 лет.

Порядок получения субсидий един для всей страны и включает следующие действия и этапы:

1. Сельскохозяйственные товаропроизводители выбирают необходимую им субсидию и оценивают условия ее получения.

2. Сельскохозяйственные товаропроизводители подготавливают заявку $и$ документы, необходимые для получения субсидии, и предоставляют их в региональный орган управления АПК согласно утвержденным нормативно-правовым актам.

3. После предоставления сельскохозяйственными товаропроизводителями заявки и документов региональный орган управления АПК рассматривает предоставленные документы в течении установленного нормативно-правовыми актами времени.

4. После рассмотрения документов региональный орган управления АПК принимает решение о предоставлении субсидии или отказе от предоставления субсидии и сообщает сельскохозяйственному товаропроизводителю о принятом решении.

5. При принятии региональным органом управления АПК решения о предоставлении субсидии сельскохозяйственным товаропроизводителям перечисляются средства, предусмотренные на оказание государственной поддержки.

6. На всех уровнях предоставления государственной поддержки осуществляется контроль за выполнением условий и требований, установленных при предоставлении субсидий, а также за целевым использованием субсидии.

В целом мы уже отметили, что структура расходования средств государственной поддержки существенно влияет на направления инвестиционной деятельности сельскохозяйственных организаций. Несмотря на то, что далеко не все средства государственного фринансирования напрямую или косвенно используются для развития инвестиционной деятельности, все же наблюдается и существенная корреляция между объемом выделенного государственного финансирования и объемом инвестированных средств.

В частности, мы можем указать, что за период с 2012 по 2015 годы совокупный объем государственного фринансирования составил 33985756 тыс. рублей. За тот же 
период совокупная стоимость основных средств в собственности сельскохозяйственных организаций Воронежской области возросла на 44582286 тыс.рублей. Причем с момента начала сокращения объемов поддержки в 2014 году произошел перелом и в динамике стоимости основных средств.

В результате инвестиционной активности предприятий, в частности, сложилась динамика количества техники в сельскохозяйственных организациях, представленная в таблице 2.

Таблица 2 - Наличие техники в сельскохозяйственных предприятиях (без КФХ) Воронежской области, всего, на конец года, ед.

\begin{tabular}{|l|c|c|c|c|c|c|}
\hline \multirow{2}{*}{ Показатели } & \multicolumn{3}{c|}{ Годы } & \multirow{2}{*}{ Баз. темп роста, \% } \\
\cline { 2 - 7 } & 2011 & 2012 & 2013 & 2014 & 2015 & \\
\hline Тракторы всех марок & 8864 & 9109 & 8571 & 8828 & 8658 & 97,7 \\
\hline Тракторные прицепы & 2425 & 2515 & 2513 & 2625 & 2540 & 104,7 \\
\hline Сеялки и посевные комплексы & 4341 & 4261 & 3866 & 3999 & 3912 & 90,1 \\
\hline Сенокосилки тракторные & 913 & 970 & 923 & 1000 & 1009 & 110,5 \\
\hline Комбайны всего & 2904 & 2881 & 2668 & 2739 & 2648 & 91,2 \\
\hline Дождевальные и поливальные машины & 136 & 158 & 260 & 269 & 275 & 202,2 \\
\hline Жатки & 897 & 824 & 751 & 906 & 948 & 105,7 \\
\hline Доильные установки и агрегаты & 687 & 679 & 619 & 706 & 738 & 107,4 \\
\hline Кормораздатчики и смесители всего & 480 & 519 & 571 & 614 & 548 & 114,2 \\
\hline Транспортеры для уборки навоза & 1038 & 1092 & 969 & 963 & 933 & 89,9 \\
\hline Автомобили грузоперевозящие & 5239 & 5382 & 20161 & 23187 & 4867 & 92,9 \\
\hline
\end{tabular}

Данные таблицы 2 демонстрируют неоднозначные тенденции. Так, за рассматриваемый период в хозяйствах области возросло количество такой техники, как: тракторные прицепы - на 4,7\%; сенокосилки тракторные - на 10,5\%; жатки - на $5,7 \%$; доильные установки и агрегаты - на 7,4\%; кормораздатчики - на $14,2 \%$; дождевальные и поливальные машины - на целых 102,2\%.

С другой стороны, одновременно сократилась численность основных наименований техники хозяйств: тракторов всех марок - на 2,3\%; сеялок - на 8,9\%; комбайнов - на 8,8\%; грузовых автомобилей - на 7,1\%.

Отчасти такая замена связана с более рациональным использованием техники, ее заменой на более производительные экземпляры, что следует признать позитивной тенденцией. Однако если бы данный фактор отвечал за всю имеющуюся динамику, она была бы стабильно понижающейся, а подходящего тренда нет, пожалуй, ни по одной из названных групп.

Только по тракторам всех марок наблюдается тенденция, объяснимая с этой точки зрения: хозяйства приобретают новую технику, испытывают ее, наблюдают ее повышенную производительность, затем списывают старую технику, ставшую просто лишней. Результат - волнообразные колебания.

По всем остальным группам, где наблюдается общее снижение, очевидно, действуют и другие, неблагоприятные фракторы.

Невозможность обеспечения сельскохозяйственных предприятий необходимой сельскохозяйственной техникой обусловлена двумя причинами: недостатком собственных финансовых ресурсов; труднодоступностью заемных средств.

В этих условиях, по мнению некоторых исследователей, одним из важнейших направлений решения проблемы оснащения предприятий сельскохозяйственной техникой является лизинг.

В сельском хозяйстве лизинг осуществляется в основном с участием государства. Указанный вид лизинга характеризуется тем, что лизингодателем является специализированная лизинговая компания, которой на осуществление лизинга сельхозтехники и племенного скота ежегодно выделяются средства из фредерального бюджета. Номенклатура продукции, закупаемой этой компанией для передачи в лизинг, ежегодно утверждается Министерством сельского хозяйства РФ. Сельскохозяйственным лизингом в России занимается одна государственная компания 
ОАО «Росагролизинг» и несколько самостоятельных компаний. Доля на рынке компании «Росагролизинг» за последние годы колеблется на уровне свыше $90 \%$.

Согласно данным 2013-14 гг., по лизингу в АПК в целом по России поступало лишь 22-32 процента от общего количества приобретаемой сельскохозяйственной техники, племенного скота и животноводческого оборудования. В 2015 году произошел ощутимый спад рынка лизинга, который коснулся и сельского хозяйства, и в 2016 году рынок не отыграл позиций. О лизинговом буме 2010-2011 годов сейчас практически ничто не напоминает. Несмотря на рост государственной поддержки сельхозтоваропроизводителей, лизинг как инструмент для обновления техники и оборудования используется слабо.

Государственная политика в области лизинга стимулирует использование высокопроизводительной техники и оборудования. Суть большинства госпрограмм заключается в том, что сельхозпроизводители получают технику или оборудование по договору лизинга с определенной скидкой, которая потом субсидируется государством.

Наши наблюдения по развитию лизинга в сельском хозяйстве Воронежской области позволили нам сделать достаточно пессимистичные выводы (табл. 3).

Таблица 3 - Параметры развития лизинга в аграрной сфере Воронежской области

\begin{tabular}{|l|c|c|c|c|c|}
\hline \multicolumn{1}{|c|}{ Показатель } & \multicolumn{3}{c|}{ Годы } \\
\cline { 2 - 6 } & 2011 & 2012 & 2013 & 2014 & 2015 \\
\hline Поступило тракторов всех марок, всего, шт. & 866 & 1020 & 845 & 829 & 626 \\
\hline - в т.ч. по лизингу, шт. & 17 & 26 & 62 & 43 & 16 \\
\hline - в т.ч. по лизингу, \% & 2,0 & 2,5 & 7,3 & 5,2 & 2,6 \\
\hline Поступило комбайнов всего, шт. & 321 & 281 & 359 & 349 & 250 \\
\hline - в т.ч. по лизингу, шт. & 12 & 9 & 27 & 19 & 10 \\
\hline - в т.ч. по лизингу, \% & 3,7 & 3,2 & 7,5 & 5,4 & 4,0 \\
\hline Поступило автомобилей грузоперевозящих всего, шт. & 433 & 383 & 408 & 3279 & 319 \\
\hline - в т.ч. по лизингу, шт. & 29 & 8 & 12 & 24 & 14 \\
\hline - в т.ч. по лизингу, \% & 6,7 & 2,1 & 2,9 & 0,1 & 4,4 \\
\hline
\end{tabular}

В целом по области следует отметить не только крайне небольшой объем поступления основных видов сельскохозяйственной техники за счет лизинга (всего порядка $5 \%$ единиц приобретаемой техники для отрасли растениеводства), но и неустойчивость этой доли. Колебания по годам за последние пять лет были очень сильными.

Основным источником фринансирования инвестиций в сельском хозяйстве региона, как и страны в целом, остаются собственные средства компаний, складывающиеся из накопленной амортизации (теоретически предназначенной лишь для простого воспроизводства основных средств) и нераспределенной прибыли.

Основные источники фринансирования инвестиций в сельскохозяйственных организациях Воронежской области рассмотрены в таблице 4.

Таблица 4 - Источники финансирования инвестиций, сельскохозяйственные предприятия (без КФХ) Воронежской области, всего, на конец года, тыс. рублей

\begin{tabular}{|c|c|c|c|c|c|}
\hline \multirow{2}{*}{ Показатели } & \multicolumn{5}{|c|}{ Годы } \\
\hline & 2011 & 2012 & 2013 & 2014 & 2015 \\
\hline Уставный капитал & 11547981 & 10452754 & 9631439 & 9689483 & 10298925 \\
\hline Резервный капитал & 803870 & 1174348 & 1235300 & 1284312 & 1509837 \\
\hline Итого привлеченные & 12351851 & 11627102 & 10866739 & 10973795 & 11808762 \\
\hline Нераспределенная прибыль & 15917476 & 21243710 & 22951280 & 32482422 & 47806291 \\
\hline Накопленная амортизация на конец года & 13319788 & 16379069 & 21681020 & 28222982 & 35131012 \\
\hline Итого собственные & 29237264 & 37622779 & 44632300 & 60705404 & 82937303 \\
\hline Долгосрочные заемные средства & 31415919 & 43468912 & 46161654 & 49925819 & 53685222 \\
\hline Итого & 73005034 & 92718793 & 101660693 & 121605018 & 148431287 \\
\hline
\end{tabular}

Таким образом, данные таблицы 4 позволяют нам заключить, что источники фринансирования деятельности, в том числе инвестиционной, сельскохозяйственных организаций Воронежской области прирастают существенными темпами, причем 
лидирующие позиции здесь занимают собственные источники. За пятилетний период объем собственных источников увеличился почти в три раза, долгосрочных заемных на $71 \%$, а привлеченных - на $96 \%$.

Роль собственных средств в финансировании инвестиций оказывается все выше, так как краткосрочные займы и кредиторскую задолженность невозможно напрямую использовать для финансирования инвестиций, например, в средства производства, долгосрочных по самой своей природе.

Однако средства, находящиеся в краткосрочном пользовании компании, или, напротив, в пользовании других участников рынка в обмен на долговые обязательства, могут быть преобразованы в иные формы и таким образом инвестированы. Примером такой трансформации могут служить фракторинговые операции. Факторинг представляет собой разновидность торгово-комиссионной операции, связанной с кредитованием оборотных средств. Факторинговые компании покупают у продавца платежные документы со скидкой 2-4\% от их номинала, обеспечивая его таким образом «реальными» деньгами. Кроме того, они обычно предоставляют целый комплекс финансовых услуг: гарантийных, учетных и др.

С другой стороны, в России, и в Воронежской области в частности, факторинг пока не получил достаточного распространения из-за высоких рисков в финансовой сфрере и высокой цены. Также имеются другие варианты фринансирования инвестиционной деятельности, недостаточно или вовсе не используемые в отраслях сельского хозяйства Воронежской области:

1. Форфейтинг - представляет собой кредитование продавца путем покупки векселей, акцептованных покупателем.

2. Проектное фринансирование - это фрорма долгосрочного кредитования, при котором сам проект является способом обслуживания долговых обязательств, то есть за финансирование предоставляется право на участие в разделе резервов реализации проекта.

3. Инвестиционный налоговый кредит представляет собой такое изменение срока уплаты налога, при котором организации при наличии соответствующих оснований предоставляется возможность в течение определенного срока и в определенных пределах снизить свои платежи по налогу с последующей поэтапной уплатой суммы кредита и начисленных процентов.

4. Государственное фонансирование инвестиций в инновации может осуществляться на возвратной, безвозвратной или смешанной основе.

В целом мы не можем указать на высокий уровень развития инвестиционной активности в сельское хозяйство Воронежской области, что связано, с одной стороны, со спецификой данной отрасли, а с другой - с особенностями сложившегося инвестиционного климата в регионе.

\section{ЗАКЛЮЧЕНИЕ}

По данным Министерства сельского хозяйства Российской Федерации Воронежская область заняла второе место по объему инвестиций в основной капитал в аграрном секторе по итогам 2015 года с объемом частных вложений в 17,4 млрд. рублей, уступив только Краснодарскому краю, в АПК которого было вложено 21,1 млрд. рублей. В тройке лидеров также Тамбовская область с показателем в 15,8 млрд. рублей. В первом полугодии 2016 года инвестиции в сельское хозяйство Воронежской области уже составили 12 млрд. рублей, что позволяет судить об увеличении инвестиционной привлекательности и о благоприятном инвестиционном климате в регионе в целом.

Администрацией Воронежской области поставлены следующие задачи для привлечения инвестиций в формирование конкурентоспособных кластеров в АПК:

- содействовать увеличению объемов привлекаемых фринансовых ресурсов коммерческих банков, лизинговых компаний к инвестированию в модернизацию существующих предприятий АПК области; 
- привлекать инвестиционные ресурсы с целью модернизации, реконструкции, а также создания новых предприятий в областном АПК, предоставлять инвесторам максимально возможный комплекс мер господдержки;

- обеспечивать создание необходимой инженерной и бизнес-инфраструктуры для предприятий АПК области.

Целью инвестиционной политики нашего региона является кратное увеличение объема инвестиций В экономику Воронежской области для обеспечения пропорционального ускоренного роста ВРП до 2020 года.

Одной из задач инвестиционной стратегии Воронежской области является обеспечение привлечения инвестиционных ресурсов для развития агропромышленных производств и предоставление инвесторам максимально широкого спектра мер государственной поддержки.

\section{БИБЛИОГРАФИЯ}

1. Алехина А.Ю., Федулова И.Ю. Сущность и значение инвестиций в основной капитал предприятия и отдельные его элементы // Социально-экономическое обеспечение развития хозяйственных формирований. Воронеж, 2016. С. 28-31.

2. Asmara R., Hanani N., Fahriyah F. Farmers' Welfare Level Based On Farmer's Terms Of Trade (FTT) Index // Russian Journal of Agricultural and Socio-Economic Sciences. 2016. №12. C. 33-38.

3. Avrashkov L.Y., Grafov A.V., Grafova G.F. Innovative Entrepreneurship And Assessment Of The Effectiveness Of Investments In Innovations // Russian Journal of Agricultural and Socio-Economic Sciences. 2016. №12. C. 91-99.

4. Волкова А.Г., Сабетова Т.В. Формирование кластеров на субрегиональном уровне как инструмент преодоления кризиса на территории // Стратегическое развитие АПК и сельских территорий РФ в современных международных условиях: Материалы Международной научно-практической конференции, посвящённой 70летию Победы в Великой Отечественной войне 1941-1945 гг. 2015. С. 184-187.

5. Danilov K.D. Economic Growth And Welfare Of The Population In Russia: Historical Overview And Management Solutions // Russian Journal of Agricultural and SocioEconomic Sciences. 2016. №12. C. 39-46.

6. Efimov A.B., Sabetova T.V. Economic And Social Issues Of Achieving Food Security Of Russia // Russian Journal of Agricultural and Socio-Economic Sciences. 2016. №11. C. 10-17.

7. Iskenderov R., Gulaliyev M., Nasirova O. Assessment Of Major Factors Of Food Security // Russian Journal of Agricultural and Socio-Economic Sciences. 2016. №10. C. 128-138.

8. Лебедев А.В., Сабетова Т.В. Некоторые особенности конкуренции в сельском хозяйстве // Институциональные и инфраструктурные аспекты развития различных экономических систем: Сборник статей Международной научно-практической конференции. 2015. С. 258-261.

9. Moiseev V.V., Ogneva V.V., Polyanin A.V. Government Policy Of Import Substitution As A Factor Of Russian Economy Development // Russian Journal of Agricultural and SocioEconomic Sciences. 2016. №10. C. 36-44.

10. Novikova I.I. The Investment Activity State In The Voronezh Regional Agriculture // Russian Journal of Agricultural and Socio-Economic Sciences. 2016. №11. C. 185-191.

11. Otinova M.E. Theoretical And Methodological Aspects Of The Interaction Of Agrarian Business And The State // Russian Journal of Agricultural and Socio-Economic Sciences. 2016. №11. C. 30-37.

12. Сабетова Т.В. Диверсификация экономики сельских территорий и ее обеспечение ресурсами // Актуальные проблемы социально-экономического развития региона: сборник научных трудов по материалам Всероссийской научно-практической конференции. 2016. С. 191-195.

13. Сабетова Т.В. Оценка эфффективности государственной поддержки сельского хозяйства и устойчивого развития сельских территорий // Совершенствование 
учета, анализа и контроля как механизмов информационного обеспечения устойчивого развития экономики. 2016. №2. С. 280-286.

14. Федулова И.Ю., Шевцова Н.М. Лизинг как инструмент обновления парка сельскохозяйственной техники // Сельскохозяйственные науки и агропромышленный комплекс на рубеже веков. 2016. №13. С. 187-192.

15. Шевцова Н.М., Федулова И.Ю. Конкурентоспособность областей Центральночерноземного региона РФ // Экономика и предпринимательство. 2016. №2-1 (67-1). C. $265-268$.

16. Шевцова Н.М., Федулова И.Ю. Экономическая оценка конкурентоспособности областей ЦЧР // Политэкономические проблемы развития современных агроэкономических систем: Материалы международной научно-практической конференции, посвященной 100-летию со дня образования кафедры экономической теории и мировой экономики. 2014. С. 73-77.

17. Шевцова Н.М., Сабетова Т.В. Comparison of central black-soil area regions in terms of competitiveness // Институциональные и инфраструктурные аспекты развития экономических наук: Сборник статей Международной научно-практической конференции. - Уфа, 2015. С. 217-220.

18. Zagvozkin M.V., Sabetova T.V. Consideration of the Price Fluctuations In Companies' Planning And Public Control Of The Agricultural Product Market // Russian Journal of Agricultural and Socio-Economic Sciences. 2016. №9. C. 58-66. 
DOI https://doi.org/10.18551/rjoas.2017-09.13

\title{
ОПЕРАЦИОННЫЙ АНАЛИЗ ЗАТРАТ И ЕГО ИСПОЛЬЗОВАНИЕ В СЕЛЬСКОХОЗЯЙСТВЕННЫХ ПРЕДПРИЯТИЯХ OPERATIONAL COST ANALYSIS AND ITS USE IN AGRICULTURAL ENTERPRISES
}

\author{
Журкина Т.А., кандидат экономических наук \\ Zhurkina T.A., Candidate of Economic Sciences \\ Воронежский государственный аграрный университет, Воронеж, Россия \\ Voronezh State Agrarian University, Voronezh, Russia \\ E-mail: zhutat@yandex.ru
}

\begin{abstract}
АННОТАЦИЯ
Одним из современных инструментов комплексного экономического анализа является операционный анализ, который позволяет проанализировать структуру производственных затрат предприятия и выявить ее влияние на изменение уровня рентабельности. Система управления затратами стала ключевым рычагом стабилизации неустойчивого фринансового состояния предприятия. Операционный леверидж и его особенности необходимо учитывать при использовании операционного анализа затрат в производственной деятельности любого предприятия в том числе и сельскохозяйственного.
\end{abstract}

\section{ABSTRACT}

One of the modern tools for integrated economic analysis is operational analysis, which allows you to analyze the structure of the production costs of an enterprise and to identify its impact on the change in the level of profitability. The cost management system has become a key lever to stabilize the unsustainable financial condition of the enterprise. Operational leverage and its features should be taken into account when using the operational cost analysis in the production activities of any enterprise, including agricultural.

\section{КЛЮЧЕВЫЕ СЛОВА}

Операционный анализ, постоянные затраты, переменные затраты, валовая маржа, точка безубыточности, запас финансовой прочности.

\section{KEY WORDS}

Operational analysis, fixed costs, variable costs, gross margin, break-even point, financial strength margin.

С целью повышения своей конкурентоспособности и оптимизации производственного процесса на сельхозпредприятиях в последнее время все чаще стал использоваться операционный анализ затрат. При этом часто возникает проблема, связанная с дефицитом информации, так как нет даже приблизительной информации о величине постоянных и переменных затрат. Особенно остро эта проблема стоит у внешних фринансовых аналитиков, не имеющих доступа к первичным и сводным данным бухгалтерского учета. С этой же проблемой сталкиваются специалисты малых и средних предприятий, в которых управленческий учет затрат не организован, но руководство при этом интересуется информацией о размере безубыточной выручки и запасе фринансовой прочности.

Мы считаем, что в случае анализа безубыточности наиболее часто используется оперативный анализ затрат. При этом структура затрат тщательно анализируется с точки зрения ее влияния на рентабельность продукции или предприятия в целом. Цель операционного анализа - найти оптимальное сочетание переменных и постоянных затрат, цены и объема продаж. Применение операционного анализа дает возможность решать разнообразные задачи, связанные с оценкой эфффективности производства продукции. На основе его использования можно дать оценку организационной 
структуре управления и методам производства. Операционный анализ позволяет количественно оценить изменение прибыли в зависимости от объема производства и реализации продукции. Действие этого механизма связано с тем, что постоянные затраты включенные в состав операционных затрат, позволяют прибыли предприятия расти более высокими темпами, чем растете объем производства и реализации продукции.

Операционный анализ используется как средство планирования и прогнозирования деятельности предприятия, он может быть использован в ценообразовании.

Эффрективность использования операционного анализа для принятия оперативных управленческих решений определяется тем, что такой анализ сводит в единое целое маркетинговые исследования, учет затрат, фринансовый анализ и производственное планирование. Большинство этих вопросов на предприятии решается на основе применения системы управления затратами, которая включает в себя следующие элементы: анализ динамики и структуры затрат предприятия в целом и по отдельным отраслям; изучение фракторов и закономерностей их влияния на производственный процесс; выявление возможностей для экономии затрат; разработка комплекса мер для улучшения структуры издержек предприятия на основе их анализа.

Операционный анализ - один из наиболее эффективных способов измерения и анализа затрат, позволяющий подобрать наиболее выгодное соотношение между переменными и постоянными затратами, ценой продукции и объемом производства.

Анализируя основные показатели, можно экономически грамотно использовать ставки маржинальной прибыли, оптимизируя ассортимент выпускаемой продукции, принимать следующие решения в сфере ценообразования (ориентируясь на конкурентов), замене оборудования, производству всего необходимого у себя или закупать со стороны, о возможности и целесообразности принять заказ на выпуск дополнительного количества продукции. Операционный анализ работает с такими параметрами деятельности предприятия, как затраты, объем реализации и прибыль, при этом важное значение имеет разделение затрат на постоянные и переменные.

В ходе операционного анализа выявляется сила операционного левериджа, которая определяется как отношение валовой маржи к прибыли после уплаты процентов, но до уплаты налога на прибыль. Она показывает, на сколько процентов изменится прибыль при изменении выручки на один процент. Эфрфект операционного левериджа заключается в том, что изменение выручки от реализации (выраженное в процентах) всегда приводит к более сильному изменению прибыли (выраженному в процентах).

Сила воздействия операционного левериджа отражает величину предпринимательского риска, то есть риска, связанного с деятельностью предприятием. Операционный анализ позволяет оценить устойчивость предпринимательской деятельности компании и величину предпринимательского риска.

Производственный рычаг является обобщающим показателем, представляющий управленцам информацию о выборе оптимальной стратегии предприятия в сфере управления затратами с целью максимизации прибыли. Величина производственного рычаг может изменяться под влиянием: цены и объема продаж, переменных и постоянных затрат; либо комбинации этих фракторов.

Изменение эффеекта производственного рычаг связано с изменением удельного веса постоянных затрат в общей величине затрат предприятия. При этом необходимо помнить, что чувствительность прибыли к изменению объема продаж может быть неоднозначной на предприятиях, имеющих различное соотношение постоянных и переменных затрат. Чем ниже удельный вес постоянных затрат в общей сумме затрат предприятия, тем в большей степени изменяется величина прибыли по отношению к темпам изменения выручки от реализации продукции. 
В конкретных производственных ситуациях использование механизма производственного левириджа имеет ряд особенностей, которые необходимо тщательно учитывать при его использовании.

1. Положительное воздействие производственного рычаг проявляться после того, как предприятие преодолело точку безубыточности по каждому виду продукции.

2. По мере дальнейшего увеличения объема продаж и удаления от точки безубыточности эфффект производственного рычага начинает снижаться. При этом каждый последующий процент прироста объема продаж будет приводить к все большему темпу прироста величины прибыли.

3. Механизм производственного левериджа имеет и обратную направленность при любом снижении объема продаж в еще большей степени будет уменьшаться размер прибыли предприятия.

4. Производственным леверидж и прибыль предприятия связаны, причем между ними существует обратно пропорциональная зависимость, что позволяет сделать вывод о том, что производственный леверидж является инструментом, уравнивающим соотношение уровня доходности и уровня риска в процессе осуществления производственной деятельности.

5. Эфрфект производственного левериджа проявляется только в коротком периоде, так как постоянные затраты предприятия остаются на одном уровне лишь на протяжении короткого отрезка времени.

Нами проведен операционный анализ затрат на примере ФГУП им. А.Л. Мазлумова Рамонского района Воронежской области. Анализируемое предприятие является мелким предприятием района, так как стоимость его валовой продукции в 2 раза ниже среднерайонного уровня. Специализация производства зерно-молочная, причем в динамике з 2013-2015 году снижается удельный вес зерна и молока в структуре выручки. ФГУП им. А.Л. Мазлумова ведет свою деятельность неинтенсивно, рентабельность по хозяйству в целом в 2015 году составила $0,1 \%$, что на 25 процентных пунктов выше, чем в прошлом году. Анализируемое предприятие имеет неустойчивое фринансовое положение, является неплатежеспособным.

Не по всем видам продукции растениеводства анализируемое предприятие получает маржинальный доход. Так, заметно отрицательное значение маржинального дохода на 1 ц продукции - по гороху - 257,06 руб., по сое - 1355,09 руб., по мясу КРС 4212,82 руб. Максимально выгодной является реализация подсолнечника и молока, так как маржинальный доход на 1 ц продукции составил 1319,15 рублей и 639,63 рубля соответственно.

Найденные значения удельных маржинальных доходов для каждого конкретного вида продукции важны для менеджера. Если данный показатель отрицателен (что в анализируемом предприятии наблюдается по гороху, coe и мясу КРС), это свидетельствует о том, что выручка от реализации продукта не покрывает даже переменных затрат. Каждая последующая произведенная единица данного вида продукции будет увеличивать общий убыток организации, следовательно не рекомендуется увеличивать объем ее производства.

Наши расчет показали рост суммы маржинальной прибыли по сравнению с прошлым годом по пшенице на 4,8 млн. руб. и по молоку на 2,4 млн. руб. На рост маржинальной прибыли по пшенице положительно повлияли рост количества реализованной продукции ее цены и величины постоянных затрат на 1 ц продукции. На рост маржинальной прибыли по молоку положительно повлияли рост количества реализованной продукции, ее цена и величина переменных затрат на 1 ц продукции.

Некоторое снижение маржинальной прибыли по молоку связано со снижением постоянных затрат на 1 ц продукции, а по пшенице - со снижением переменных затрат на 1 ц продукции.

С целью максимизации прибыли рекомендуется реализовывать минимум 5465 ц пшеницы, 1207 ц подсолнечника, 10257 ц молока. При этом минимальная выручка от реализации пшеницы может составить 5819 тыс. руб., от реализации подсолнечника 2361 тыс. руб., от реализации молока - 19686 тыс. руб. Если выручка будет меньше, то 
предприятие будет получать убытки и могут возникнуть фринансовые проблемы. Следует отметить, что порог рентабельности превышен по всем анализируемым культурам, так по пшенице прибыль составила 4812 тыс. руб., по подсолнечнику - 8109 тыс. руб., по молоку - 1096 тыс. руб.

Наши расчеты показали, что маржинальная рентабельность максимальная по подсолнечнику - 67,4\%, несколько ниже данный показатель по пшенице и молоку $55,6 \%$ и $33,3 \%$ соответственно.

Такие расчеты весьма полезны для управленцев, так как они позволяют повысить степень управляемости предприятия из-за принятия эффеективных своевременных управленческих решений. Однако широкому применению мешает специфика сельскохозяйственного производства, так как не представляется возможным свободно регулировать объемы и структуру производства и реализации продукции. Это связано с особенностями производственного цикла, с необходимостью соблюдения севооборотов.

Для того чтобы поднять значение коэфффициента прочности предприятия необходимо провести следующие мероприятия: повысить суммарную выручку от продаж: увеличить количество проданной продукции, повысить цену продаж, повысить одновременно количество и цены продаж; понизить величины в точке безубыточности: повысить цены продаж, улучшить структуру оборота за счет интенсивного продвижения продукции, которая имеет большую удельную сумму покрытия в процентах от цены; снизить затраты: уменьшить переменные затраты, уменьшить постоянные затраты, уменьшить и постоянные и переменные затраты одновременно; заменить постоянные затраты на переменные, например, при переходе к закупкам со стороны от своего собственного производства. Принимать такое решение на основе тщательного анализа.

\section{БИБЛИОГРАФИЯ}

1. Журкина Т.А. Учет и анализ затрат в отрасли растениеводства / Т.А. Журкина, Н.Н. Межерицкая // В сборнике: Вопросы образования и науки: теоретический и методический аспекты сборник научных трудов по материалам Международной научно-практической конфреренции. 2015. С. 65-68.

2. Журкина Т.А. Анализ фринансовых результатов деятельности предприятия / Т.А. Журкина, В.П. Коротеев // Российское предпринимательство. 2015. Т. 16. №18. C. 3023-3028.

3. Журкина Т.А. Пути снижения затрат в молочном скотоводстве / Т.А. Журкина, Э.Р. Мустафаева // В сборнике: Наука и образование проблемы и перспективы развития: сборник научных трудов. 2014. С. 63-65.

4. Журкина Т.А. Маржинальный анализ прибыли и рентабельности / Т.А. Журкина, Т.Н. Лихачева, А.И. Потокин // В сборнике: Научное и кадровое обеспечение развития агропродовольственного комплекса материалы Всероссийской научнопрактической конференции, посвященной 65-летию подготовки экономических и управленческих кадров для АПК в Воронежском ГАУ. 2016. С. 300-304.

5. Фомкина М.Ю. Анализ себестоимости продукции растениеводства и пути ее снижения / М.Ю. Фомкина, Т.А. Журкина // Актуальные вопросы экономических наук. 2016. №49. С. 205-210.

6. Грибанов А.А. Адаптация системы «директ-костинг» в сельскохозяйственных организациях в отрасли растениеводства / А.А. Грибанов, М.В. Кудинова // В сборнике: Инновационные технологии и технические средства для АПК. 2014. C. $119-125$.

7. Грибанов А.А. Совершенствование методики определения порога рентабельности продукции растениеводства в сельскохозяйственных организациях / А.А. Грибанов, М.В. Кудинова // Управленческий учет. 2014. №1. С. 69-76.

8. Грибанова А.А. Методические аспекты расчета порога рентабельности продукции растениеводства на основе функционально-стоимостного калькулирования / 
А.А. Грибанов, Н.Н. Волкова, М.В. Кудинова // Международный бухгалтерский учет. 2013. №48. С. 17-25.

9. Грибанов А.А. Адаптация системы «директ-костинг» в растениеводстве в условиях автоматизации управленческого учета / А.А. Грибанов, М.В. Кудинова // Економічний форум. 2013. №1. С. 416-422.

10. Грибанов А.А. Учет косвенных затрат в условиях применения системы «директкостинг» в растениеводстве / А.А. Грибанов, М.В. Кудинова // Экономический анализ: теория и практика. 2012. №6. С. 26-31.

11. Шатохина Л.А. Проблемы внедрения системы «директ-костинг на предприятия АПК / Л.А. Шатохина, М.А. Объедкова, Е.В. Кретинина // В сборнике: Социальноэкономические проблемы инновационного развития материалы VI Международной научно-практической конференции преподавателей, научных работников и специалистов. 2015. С. 522-529.

12. Шатохина Л.А. Традиционные и современные методыучета производственных затрат и калькуляция себестоимости продукции / Л.А. Шатохина, И.М. Верболович // В сборнике: Социально-экономические проблемы инновационного развития. 2014. C. 421-427.

13. Шатохина Л.А. Амортизация основных средств в системе управленческого учета «директ-костинг» / Л.А. Шатохина, Г.И. Хаустова, О.И. Шатохина // В сборнике: Стратегические вопросы мира науки. 2014. С. 63-66.

14. Хаустова Г.И. Повышение эфффекта операционного рычага при производстве зерна / Г.И. Хаустова, О.И. Шатохина // Финансовый вестник. 2004. №12. С. 84-86.

(C) 2017 by the author. Licensee RJOAS, Orel, Russia. This article is an open access article distributed under the terms and conditions of the Creative Commons Attribution (CC BY) license: http://creativecommons.org/licenses/by/4.0/ 
DOI https://doi.org/10.18551/rjoas.2017-09.14

\title{
POLITICAL AND ECONOMICAL SOCIALIZATION: MEANING AND RELEVANCE
}

\author{
Kulikov Sergey, Candidate of Sociological Sciences \\ Department of Public Administration and Social Technologies, Moscow Aviation Institute \\ (National Research University), Moscow, Russia \\ E-mail: ncsrm@mail.ru
}

\begin{abstract}
The meaning and relevance of political socialization in the context of contemporary economic state are discussed in the article. The main conceptual directions of the study on political socialization are presented. Relevant conclusions were suggested with regard to the relevance of the issues raised.
\end{abstract}

\section{KEY WORDS}

Relevance, socialization, society, individual, political culture, political and economic socialization.

The term "political socialization" makes it possible to link the following concepts: Political culture, behaviour, participation, activities describing the behaviour of the individual in the political arena. In general, political socialization is viewed through the prism of the impact of political life of the society on the individual. The result of this impact is a certain way of political behaviour that reflects the norms of the political culture of society Imposed on the individual from the outside and became habitual to him. The outcomes of political socialization are political system stability and continuity of social development, which can be attributed in many ways to the increased interest of political scientists in this phenomenon.

The consideration of political socialization has rather deep methodological roots. The following four directions of the most significant conceptual fields of political socialization research can be distinguished: Political behaviorism (b. Skinner), Social Action (T. Parsons), role-related behavior adoption (C.Verba and N. Nai) and a psychodynamic understanding of political socialization (S. Freud).

Political behaviorism observes political socialization as individual's reaction to the effects of the social environment (incentives) adopted in the process of learning. Behaviorism representatives succeeded in converting the problem of political socialization into practice, that is to address the issue of the possibility of a factual influence on the political behaviour of the individual. In the works of B. Skinner and his succeeders, socialization is seen in analogy with the biological processes of adapting the organism to the environment. Adaptation to it is essentially a synonym for socialization. Man do not affect the world but the world affects man. Skinner considers socialization as controlled process in which the proportion of penalties and rewards, i.e. incentives that provide the desired response, must be carefully weighed. The control of the behavior for Skinner is not imposed on a man by civilization, but natural [4]. Without it, the integration into society and, ultimately, the personality becoming are impossible. Without social control, a person remains only a biological, feral creature. At all stages of evolution, nature has exercised strict control over the behaviour of all living beings, so that the ability to obey control is biologically embedded in a human being. Skinner finds practical, useful aspects of the problem of control in maintaining the stability of society by changing the psychology of its members in the right direction. The solution to this problem is the detailed development of a system of "reinforcement" of behaviour, i.e. "modification" of political behaviour through metered rewards. The problem of behaviour in the socialization process has been described by behaviorists as the teaching of certain patterns of behaviour under the influence of responses (incentives) from the external environment to human actions. Political scientists R. Sears, F. Greenstein, R. Lane transferred this vision to the political process. They described political socialization as the teaching of certain forms of political behaviour in the relevant political environment [9]. By studying the experience of 
socialization, political behaviorists are trying to understand the causes of wars, revolutions, conflicts and rebellions. They link these reasons to psychological dissatisfaction from dissatisfaction of some essential human needs that lead to aggressive behaviour. The most successful approach has proved to be the study of electoral behaviour, political participation and the psychological characteristics of political behaviour (attitudes, beliefs and other personal factors). In conventional behaviorism, it is possible to highlight the common concept of the American political scientist, G.Lasswell, who proposed a contextual approach to the analysis of political socialization. According to G.Lasswell, the political environment affects the individual, not directly, but through the system of public institutions and values. He presented the process as a formula: Its participants strive to values: Power, well-being, love, respect, through institutions: the state, the army, and the police that own and distribute the resources. Lasswell divide all participants of the process into socializing agents and agents socialised-these terms describe the political activity of the actors. Socializing agents are adopting and implementing important political decisions, and the status of "agents socialized" refers to social-political immaturity, which makes a person a passive participant in the political process. The notion of immature or mature participants is a value proposition and is not related to social experience or to the age limits. American psychologists A. Bandura and R. Walters, adherents of the concept of "social learning", analysed the mechanism for converting of the norms and values of society into personal beliefs by the subject [9]. They supplemented the classic linear formula of behaviorism (S-R), with intermediate mediator (S$\mathrm{J}-\mathrm{R}$ ) that allows to understand why the same stimulus for different influences causes different reactions. This model of behaviour is widely used by modern political researchers in the area of electoral behaviour. The mediator allows to take into account the individual characteristics of the subject: views, attitudes, beliefs. Political orientations allow to consider the public opinion that directly influences the outcome of the election, and the process of forming political orientations, allows to control electoral behaviour. Political orientations are displayed subject to their intensity in: attitude, beliefs and behaviour becoming the source of political activity.

Social action studies political socialization as a process and result of numerous interactions among people, which is determined by relatively sustainable and stable society political system elements. Lawrence Kohlberg's understanding of control stages of man's social behavior (stages of moral development) can be regarded as a basis for this concept. The first stage is pre-conventional based on a control and punishment system. According to Kohlberg, this stage is comprised of $70 \%$ of children under the age of seven, $30 \%$ of tenyear-olds and $10 \%$ of adolescents aged $13-16$. The second stage is conventional, controlling behavior by way of imitating the behavior of the reference group. Most children reach this stage by the age of 13 . The third stage is post-conventional, characterized by an independent morals development. Behavior is controlled by way of man's inner regulations and his/her own self-awareness. Only $10 \%$ of adolescents reach this stage. It is noteworthy that not all adults reach this stage during their lifetime [8]. It is, however, the social point of reference. Parsons was able to create a general analytical and deductive system that encompasses human reality in all its diversity, and it allows for the consideration of social human action as a self-organizing system, whose specific character is defined by its symbolism, i.e. by the existence of symbolic regulatory mechanisms (language and values); and standardization, i.e. how an individual act depends on societal norms as well as by its voluntarism, i.e. irrationality and independence from the environment and at the same time, depending on subjective "interpretations of the situation". The basic concepts of this theory are "[social] actor", "intuition", "actor's commitment to the situation". Parsons created a comprehensive, formalized model of the system of action that includes cultural, social, personal and organic subsystems, which are in constant interaction and interchange. Parsons's system of social action is based on the principle of systematic society arrangement, he lists four functions necessary for the system to survive: adaptation, goal attainment, integration and latency (or latent pattern maintenance). Adaptation is regarded as an individual's adjustment to a particular situation as well as to the general environmental changes [2]. Goal attainment considers system's objectives and ways of fulfilling them. 
Integration describes how the system relates all its components and ensures their normal operation. Latency gives an idea as to how the system creates, maintains, improves and updates the motivation of the included individuals, behavior patterns and cultural principles. According to this theory, in the course of socialization a person is taught social stereotypes and by learning them he/she is included in a particular social and political system. The existence of the system is conditioned by the existence of norms and values in the mind of the individual. Socialization is an ongoing process of man's adaptation to a society's behavior patterns based on the value system. Parsons developed an understanding of socialization being an interalization process of norms and values in a personal system, which ensures a successful integration of an individual into a society [3].

Role behavior considers political socialization to be a process of social role adoption, characterized by dynamism of its meanings (symbols), which has a secondary impact on the objective socialization environment. An individual is considered through a set of functions that are determined by a total of the social roles performed by the individual in the society. The role set shows the degree of political socialization of an individual. As the roles relate to the person being part of a social group(s), the political socialization of the individual is derived from a total of the social groups to which the individual is included. By passing political socialization, the individual is learning the characteristics of role behavior, $\mathrm{n}$ ways to perform roles, and thus becomes a person. These concepts have been widely applied in various aspects of management, as reflected in practical recommendations to develop the role of a leader (including political). American political experts S.Verba ans N.Nie complemented the model of political socialization. It is based on the basic principles of the individual, which determine the choice of a political role and serve as indicators of the citizen's inclusion in political activity [9]. It is a psychological involvement in politics, measured by interest and attention to public affairs; Political participation, measured by the intensity of party identification; a sense of political involvement, measured by the respondent's belief that he is contributing to the affairs of his community. Role theory considers the possible causes of failures in political mechanisms in the inconformity of role expectations in a society and the implementation of an individual's role. Process of political socialization is to synchronize the expectations and role execution which is regarded as a training of political role execution. In examining the relationship between the political system and the individual, western researchers have drawn attention to the fact that psychological factors have a complex impact on politics. The combination of psychological conditions (attitudes, opinions, customs, traditions, values, etc.) within which the political system operates, has been marked by the term "political culture". The main conceptual views of political culture were developed by G. Almond, S. Verba, R. Tucker and others, mainly by American researchers [1]. Political socialization in their conceptions was portrayed as a process of transmitting cultural heritage, the result of which is a person mastering a political culture. Political socialization here is an automatic process in which the individual as "tabula rasa" perceives culture in his/her individual development.

Political freudianism defines political socialization as a socially controlled process of assimilation of peremptory political norms and ideologies that restrict asocial human nature. The psychodynamic model of political socialization is connected with the basic idea of classical freudianism: People are born with motives that are inherently selfish, and are designed only to meet their own needs and are, consequently, asocial. At the heart of the Freudian understanding of political socialization lies the human topology model developed by S. Freud. Its main structures are: "Id", "Ego" and "Super-ego", between which there is a constant exchange of energy that ensures the supremacy of a structure [5]. Traditionally, the most energy-strong structure is considered "Id", which gives rise to the claim of rule unconscious motives to ensure the asocial nature of a human being. The threefold Model of Personality has the interplay of the principles of pleasure and reality in its very core. The central motive of the unconscious mind is pleasure, but due to the deterring influence of social situational awareness, a clash with reality, social behavior is shaped. Consequently, socialization in general, and political socialization in particular, is a personal drama for an 
individual and his social and economic problems, in which the society "pares them down" according to its own models [9].

The problem of socialization consists in the "taming" and controlling the destructive instincts of the unconscious mind. Psychotherapy has drawn the attention of researchers to socialization and the need to control of the society over natural instincts.

Thus, political socialization is a gradual addiction to social control when its rules are assimilated into basic structures of the individual, becoming accustomed. This process is closely linked to the transfer of cultural heritage, the mastery of the culture of society as a whole and social and economic conditions.

\section{REFERENCES}

1. The coordinate system of the action and the general theory of the action systems. Functional theory of change. The concept of society//American Sociological thought. Moscow: Ed. International University of Business and Management, 1996. Pp. 462-525.

2. Sedov L. A. Parsons, Tolkott//modern Western sociology: Dictionary. Moscow: Politizdat, 1990. Pp. 257-260.

3. Kovalev A. D. Formation of an action theory of Tolkott Parsons//History of Theoretical sociology. In 4 volumes. T.Z. Moscow: Kanon, 1997, Pp. 150-179.

4. Skinner B. Was ist Behaviorismus Reinbek bei Hamburg: Rohwolt, 1978. Pp. 9-11

5. Zeigarnik B.V. Theory of Personality in foreign psychology. Moscow: MSU, 1982.

6. Parsons T. Concept of society: Components and their relationship//American sociological thought. Moscow, 1996.

7. Sorokin P.A. Social and cultural dynamics and Evolutionism//American sociological thought. Moscow, 1996.

8. Spasibenko S.G. A lifelong road: Adult Socialization//social and humanitarian knowledge. 2002. -No. 6. Pp. 83-103.

9. Shestopal E.B. Personality and politics: A critical essay of contemporary western concepts of political socialization. Moscow, 1988. Pp. 24-25.

10. Novikov S.V. The national economy is a large-scale organizational socio-economic system. "Vestnik Universiteta" (State University of Public administration). 2014. No. 6. Pp. 125-132.

11. Kulikov S.P. Methodological Problems in the study of patriotism in Russian society from a generational perspective. Social and humanitarian knowledge. 2016 No. 7. Pp. 227-235.

12. Novikov S.V., Meshankov D.V. Present-day personnel policy implementation in Russia: challenges and threats. Competitiveness in a globalized world: economics, science, technology. 2017. No. 3-3 (34). Pp. 113-115.

13. Nikolaev A.V., Tikhonov A.I., Novikov S.V. Civil statesmen professional activity efficiency assessment. Russian technology journal. 2014. No.4 (5). Pp. 284-295.

14. Sorokin A.E., Novikov S.V., Zamkovoy A.A. Innovative and technological management in organization of science-intensive production. Innovations. 2016. No.10 (216). Pp. 132136.

15. Tikhonov A.I. Institutional aspects of state personnel policy in Russia. Management and business administration. 2017. №2. Pp. 25-32. 
DOI https://doi.org/10.18551/rjoas.2017-09.15

\title{
ISLAMIC MARKETER ETHICS AND ITS IMPACT ON CUSTOMER SATISFACTION IN THE ISLAMIC BANKING INSTITUTION: A CASE STUDY OF BANK MUAMALAT INDONESIA
}

\author{
Nuralam Inggang Perwangsa \\ Faculty of Administrative Science, University of Brawijaya, Indonesia \\ E-mail : ing.nuralam@ub.ac.id
}

\begin{abstract}
The aim of this study is to know the influence of Islamic marketer ethics to customers' satisfaction of Bank Muamalat Indonesia (BMI). These ethics principally concern on Qur'an and Hadith which are the basic foundation of Islamic values in Islam. Through this study we also can use another perspective of giving customer satisfaction in Islamic way and find out that there is a causal relation between Islamic marketer ethics and customer satisfaction. The research method used is survey method with sampling method using purposive sampling. Data analysis using multiple linear regression. From the results, it is found that Islamic marketer ethics as independent variables simultaneously effect on customer satisfaction, while partially some of variables refuse the hypothesis
\end{abstract}

\section{KEY WORDS}

Islamic marketer ethics, Islamic values, customer satisfaction.

Islamic banking is banking activity that complies with sharia (Islamic law) and its practical application through the development of Islamic economics. Sharia prohibits riba, or usury, defined as interest paid on all loans of money (Farooq, 2009; Khan 2013). Investment in businesses that provide goods or services considered contrary to Islamic principles (e.g. pork or alcohol) is also haraam ("sinful and prohibited").In the late 20th century as part of the revival of Islamic identity (Usmani, 1998), a number of Islamic banks formed to apply these principles to private or semi-private commercial institutions within the Muslim community (Rammal and Zurbruegg, 2007; Saeed, 1996). In 2009, at least more than 300 banks dan 250 mutual funds around the world complying with Islamic principles (The Economist, 2009) and around $\$ 2$ trillion were sharia-compliant by 2014 (The Economist, 2014).

Although the notion of Islamic banking is relatively new, which is no more than two decades, it still attracts the attention of many investors around the world. From a strategic point of view, this novelty is profitable and unfortunate at the same time. Thus, on the positive side, being a new idea, sharia banking has the potential to attract new customers and consequently, increasing market share of banks (Hassan et al., 2008). Siddiqi (1980) and Shahul (2001) say that sharia banks as business institutions running on the basis of Islamic principles should not be directed to generate maximum profit. As a business institution Islamic banks should be directed to achieve success in the world and in the afterlife (Siddiqi, 1980, and Shahul, 2001). Sadeque (1980) defines a Sharia bank as a financial institution operating on the basis of Shariah principles and does not always use the instrument of interest in receiving funds or providing financing to third parties. Therefore, according to Suleiman (2000), Sharia banks must operate on the basis of Sharia principles in every activity and transactions conducted.

A study conducted by Turen (1996) on bank performance shows that sharia banks perform better than non-Islamic banks. Samad and Hassan (2009) found that sharia banks are more liquid and less risky than conventional banks. The results are different from Rashid and Nishat (2009) who found poor performance of sharia banks in the field of investor management, profit maximization and operating efficiency. However, Sumachdar \& Hasbi (2011) and Jaffar \& Manarvi (2011) both found that sharia banks performed better than conventional banks. Hasbi and Haruman (2011) also found that Sharia Banking performed well; reflect CAMEL on the Deposit Fund. Kuppusamy et al., (2010) using financial indicators 
and indicators of sharia profitability, found that Islamic banks have maintained a very good position and have become benchmark institutions. While Masruki et al. (2011) found that the profitability of conventional banks is higher than that of sharia banks, but Islamic banks are more liquid than conventional banks. Widagdo and lka (2008) used inter-temporal comparisons and interbank ratios to test bank performance and the results found no major differences between sharia banks and conventional banks.

\section{LITERATURE REVIEW}

The major of the marketing literatures generally agrees on the benefits derived by product or service providers, policy makers, social activists or even consumers. Most of the priorities are advantages for product or service providers or marketers (Walters, 1974; Mowen, 1995; Hoyer and Maclnnis, 2001; Schiffman and Kanuk, 2004; Suprapti, 2010). This is because the ultimate goal of any marketing activity is consumer satisfaction as well as the benefits gained (marketer); including in sharia marketing.

Sharia marketing is a business process and a way to market its process that puts forward values that glorify justice and honesty (Kartajaya and Sula, 2006). With sharia marketing, the whole process should not be in conflict with Islamic principles. Sharia marketing is also followed by its ethics. These ethics are the principle for a Shariah marketer in carrying out marketing functions. Saeed et al. (2001) argue that ethical based on Islamic values requires marketers in no circumstances to exploit customers or to be dishonest and deceptive. Ethics are the conventional rules of individual behavior in a civilized society, formal or civic order of birth to govern interpersonal relationships, in accordance with their respective social status (Ya'qub, 1985; Spence and Heekeren, 2005; Faisal, 2007). Schlegelmilch (1998) further argues that ethics is difficult to define because the fact that it cannot be measured directly and derives from many influences such as the influence of internal and external environments.

Marketing based on Islamic perspective can be defined as a process and strategy (hikmah) to meet the need through the halal products and services (tayyibat) by mutual consent and welfare (Falah) of both parties of buyer and seller to achieve material and the spiritual wealth in the world and the hereafter (Alom and Haque, 2011).

Kartajaya and Sula (2006) reveal 9 (nine) marketer's ethics, which will become the principles for Shariah marketers in carrying out marketing functions: 1) Have a spiritual personality (Takwa). Religious values are present in the midst of us when doing business transactions; 2) Be kind and sympathetic (Shidq). A Shariah marketer must behave; Very sympathetic, sweet-spoken, humble words; 3) Applies fairly in business (Al-'Adl). In modern business, fairness must be portrayed for all stakeholders, all must feel justice; 4) Be serving and humble (Khidmah). Service is the most important factor in a business. Whatever the core of our business, stakeholders must always be aware that their business is a service business; 5) Keeping promises and not cheating. A Shariah marketer, must be able to maintain the trust given to him as a representative of the company in marketing and promoting products to customers; 6) Honest and reliable (Al-Amanah). Sharia business does seem to be hard for those who are accustomed to cheating, but it is light for those who rarely cheat, as well as for professionals who commonly uphold moral values; 7) Do not negative (Su'uzh-zhann). No one entrepreneur should vilify other entrepreneurs, only motivate business competition; 8) Do not backbiting (Ghibah). For sharia marketers, ghibah is a futile act, and a waste of time. It would be better for him to spill all his time to work professionally; 9) Do not bribe (Risywah). In shariah, bribe is haraam, and bribe is included in the category of eating other people's treasures by vanity.

As the empirical study has been conducted by raising the issue of Islamic financial institutions (Omer, 1992, Rosly, 2005); Islamic marketing (Arham, 2010; Kalthom \& Ahmad, 2010; Sandikci, 2011); Islamic ethics (Hanafy and Salam, 1988; Metawa \& Almossawi, 1998); Ethical Marketing of Sharia (Saeed et al., 2001; Hassan et al., 2008); Consumer Satisfaction in Sharia Banks (Naser et al., 1999; Lone and Rehman, 2017; Lone et al., 2017); 
Customer Relationship Management (Nuralam, 2016) this study also rely on the ethics of Sharia marketers associated with customer satisfaction.

Crosby et al. (1990) says that contact between the marketer and the consumer is the foundation in a consumer's purchase decision. Theorists such as Shepherd (1999) add that companies should emphasize the process of such relationships as critical points in business. Furthermore, in a study conducted by Hassan et al. (2008) mentions the term Customer Relationship Advisor (CRA) as a representation of bank institutions associated with the consumer.

\section{METHODS OF RESEARCH}

The study used a quantitative research methods since the purpose is to explain the correlation among variables syariah marketer ethics (Kartajaya and Sula, 2006) on customer satisfaction. The objective of quantitative research is to develop and employ mathematical models, theories and hypotheses pertaining to phenomena (Given, 2008). The variables syariah marketer ethics are have a spiritual personality (Takwa), be kind and sympathetic (Shidq), Applies fairly in business (Al-'Adl), Be serving and humble (Khidmah), Keeping promises and not cheating, Honest and reliable (Al-Amanah), Do not negative (Su'uzhzhann), Do not backbiting (Ghibah), Do not bribe (Risywah).

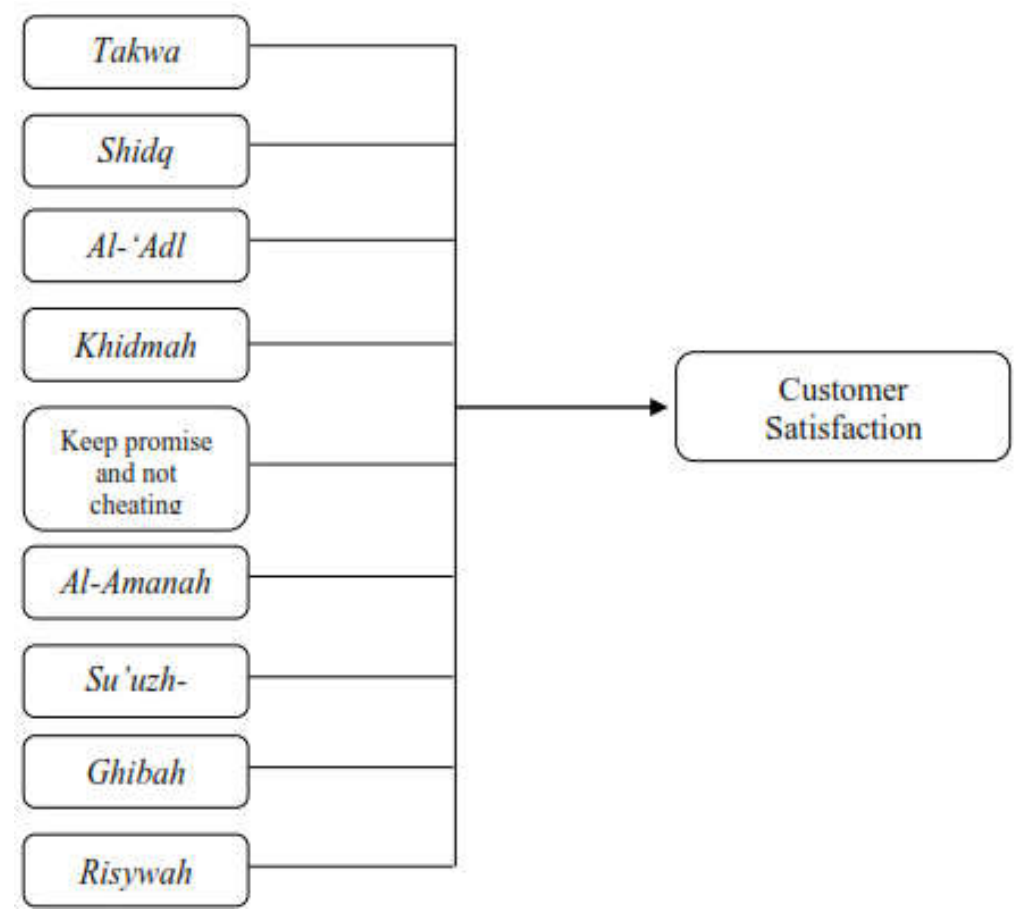

Figure 1 - Research Framework Source: (Adopted by Author, 2017)

The location of this research at Bank Muamalat Indonesia (BMI) Malang Branch, Jawa Timur. To look for these influences, there is a hypothesis to be tested. The hypothesis testing is done to test the influence of Shariah Marketer Ethics to the satisfaction (Kartajaya and Sula, 2006). To examine the relationship between these variables, regression analysis was used. The research framework is presented in Fig 1.

\section{RESULTS AND DISCUSSION}

This survey method conducted in the environment of Bank Muamalat Indonesia (BMI) Malang Branch. The sampling technique used is Purposive Sampling (Sekaran \& Bougie, 2016), which is the selection of the sample based on certain characteristics considered to be 
related to the previously known characteristic of the popover. According to Hoeber et al. (2017) purposive sampling is a sampling technique used in researches that prioritize the purpose of research rather than the nature of the population in determining the sample research. Then the respondents selected in this study is with the characteristics of 1) Has been use the products for approximately 6 months; 2) Has been use one of Bank Muamalat Indonesia's products. The sample used in this study was 136 respondents, referring to the population and purposive sampling.

The data used in this regression analysis is data obtained based on the results of questionnaires distributed to customers of Bank Muamalat Indonesia (BMI) Malang Branch with services perceived by customers or the reality encountered in the field. Based on the regression analysis, get the equation:

\begin{tabular}{|c|c|c|c|c|c|}
\hline No. & Independent Variable & $\begin{array}{c}\text { F test } \\
\text { (Overall } \\
\text { test) } \\
\text { Sig. F }\end{array}$ & Alpha & $\begin{array}{c}\text { Influence on Customer } \\
\text { Satisfaction }(Y) \\
\text { Sig. } \mathrm{F}<\text { Alpha }\end{array}$ & Hypothesis \\
\hline 1 & Independent Variable (X1-X9) & 0.000 & 0.05 & Significant & Supported \\
\hline No. & Independent Variable & $\begin{array}{c}\text { T test } \\
\text { (Partial } \\
\text { test) } \\
\text { Sig. }\end{array}$ & Alpha & $\begin{array}{c}\text { Influence on Customer } \\
\text { Satisfaction }(Y) \\
\text { Sig. < Alpha }\end{array}$ & Hypothesis \\
\hline 1 & $\begin{array}{c}\text { Have a spiritual personality } \\
(\text { Takwa })\left(\mathrm{X}_{1}\right)\end{array}$ & 0.021 & 0.05 & Significant & Supported \\
\hline 2 & $\begin{array}{c}\text { Be kind and sympathetic (Shidq) } \\
\left(\mathrm{X}_{2}\right)\end{array}$ & 0.000 & 0.05 & Significant & Supported \\
\hline 3 & $\begin{array}{l}\text { Applies fairly in business }\left(A l^{\prime} A d l\right. \\
)\left(X_{3}\right)\end{array}$ & 0.828 & 0.05 & Significant & $\begin{array}{c}\text { Not } \\
\text { Supported }\end{array}$ \\
\hline 4 & $\begin{array}{c}\text { Be serving and humble } \\
(\text { Khidmah })\left(\mathrm{X}_{4}\right)\end{array}$ & 0.001 & 0.05 & Significant & Supported \\
\hline 5 & $\begin{array}{c}\text { Keeping promises and not } \\
\text { cheating }\left(\mathrm{X}_{5}\right)\end{array}$ & 0.148 & 0.05 & Significant & $\begin{array}{c}\text { Not } \\
\text { Supported }\end{array}$ \\
\hline 6 & $\begin{array}{c}\text { Honest and reliable (Al-Amana) } \\
\left(\mathrm{X}_{6}\right)\end{array}$ & 0.019 & 0.05 & Significant & Supported \\
\hline 7 & $\begin{array}{c}\text { Do not negative (Su'uzh-zhann } \\
\qquad\left(\mathrm{X}_{7}\right)\end{array}$ & 0.193 & 0.05 & Significant & $\begin{array}{c}\text { Not } \\
\text { Supported }\end{array}$ \\
\hline 8 & $\begin{array}{c}\text { Do not backbiting (Ghibah } \\
)\left(\mathrm{X}_{8}\right)\end{array}$ & 0.749 & 0.05 & Significant & $\begin{array}{c}\text { Not } \\
\text { Supported }\end{array}$ \\
\hline 9 & $\begin{array}{c}\text { Do not bribe (Risywah } \\
\qquad\left(\mathrm{X}_{9}\right)\end{array}$ & 0.090 & 0.05 & Significant & $\begin{array}{c}\text { Not } \\
\text { Supported }\end{array}$ \\
\hline
\end{tabular}

Source: Adopted by Author, 2017.

Based on the equation of regression analysis result, the interpretation obtained:

1. The higher value on the variables $X_{2}, X_{3}, X_{4}, X_{6}$, and $X_{9}$, the higher the Satisfaction (Y) felt by the customers of Bank Muamalat Indonesia (BMI) Branch Malang. In other words, the relationship of these variables is positive and unidirectional.

2. Otherwise the higher value on the variables $X_{1}, X_{5}, X_{7}$, and $X_{8}$, the lower the Satisfaction (Y) felt by the customers of Bank Muamalat Indonesia (BMI) Malang Branch. In other words, the relationship of these variables is negative and contradictory.

3. Coeffisient of determination (Adjusted $R$ Square) of 0.469 which means the variable $\mathrm{X}_{1}$ $\mathrm{X}_{9}$ able to explain the model of $46.9 \%$ while the rest $(53.1 \%)$ is explained by other variables that are not contained in this regression model.

4. F-test (overall test). It is known that the significance level of 0.000 and smaller than 0.05 $(0.000<0.05)$, it can be concluded that the independent variables $\left(X_{1}-X_{9}\right)$ simultaneously affect the dependent variable $(Y)$. The relationship between $\mathrm{X}_{1}-\mathrm{X}_{9}$ and $\mathrm{Y}$ variables can be seen on the correlation coefficient (R), which is positive is 0.710 which means the relationship of the variable is unidirectional and strong. Where the higher the ethics of sharia market, the higher the level of satisfaction.

5. T-test (partial test). Based on the number of significance can be seen that there are independent variables that partially significant effect on satisfaction, if significance $<0.05$, 
but there is also a partial no significant effect on satisfaction, if significance $>0.05$.

6. The rejection of the hypothesis is based on the lack of perceived variables by the customer. Although the performance of these variables is good enough, but customers can not feel the impact directly. This is due to the lack of customer understanding about the ethics of sharia marketers run by Bank Muamalat Indonesia (BMI) Malang Branch. What has been felt directly by customers of Bank Muamalat Indonesia (BMI) Malang Branch is the services provided by the bank, so that the ethics of sharia marketers with respect to services that is Variable $X_{2}$ (behave kindly and sympathetic) Sharia is a very perceived syariah marketer By the customer directly.

\section{RESEARCH LIMITATION}

The existence of an opportunity error of the use of a particular indicator to measure the variables concerned because of the difficulty of drawing firm limits between variables with each other. This research is only conducted limited to the Bank Muamalat Indonesia (BMI) Branch Malang, so it needs to expand the larger scope of research to get A better picture. The nine ethics of sharia marketers used in this study are only able to explain the model of $46.9 \%$ which means that the rest are explained other variables not included in the study.

\section{CONCLUSION AND RECOMMENDATION}

It is concluded that Shariah Marketer Ethics such as have a spiritual personality (Takwa) $\left(\mathrm{X}_{1}\right)$, be kind and sympathetic (Shidq) $\left(\mathrm{X}_{2}\right)$, Applies fairly in business (Al-'Adl) $\left(\mathrm{X}_{3}\right)$, Be serving and humble (Khidmah) $\left(\mathrm{X}_{4}\right)$, Keeping promises and not cheating $\left(\mathrm{X}_{5}\right)$, Honest and reliable (Al-Amanah) $\left(\mathrm{X}_{6}\right)$, Do not negative (Su'uzh-zhann) $\left(\mathrm{X}_{7}\right)$, Do not backbiting (Ghibah) $\left(\mathrm{X}_{8}\right)$, Do not bribe (Risywah) $\left(\mathrm{X}_{9}\right)$ simultaneously affect the satisfaction of customers of Bank Muamalat Indonesia Malang Branch $(Y)$. Then, variable of have a spiritual personality (Takwa) $\left(\mathrm{X}_{1}\right)$, be kind and sympathetic (Shidq) $\left(\mathrm{X}_{2}\right)$, Be serving and humble (Khidmah) $\left(\mathrm{X}_{4}\right)$, Honest and reliable (Al-Amanah) $\left(\mathrm{X}_{6}\right)$ Partially significant effect on customer satisfaction of Bank Muamalat Indonesia (BMI) Malang Branch. Variable Shariah Marketer Ethics "be kind and sympathetic (Shidq) $\left(\mathrm{X}_{2}\right)$ ") is the dominant influence Customer satisfaction of Bank Muamalat Indonesia (BMI) Malang Branch (Y).

In our discussion this ethical behavior of Islam will have a major impact on the development and scheduling of buyer-marketer relationships. Therefore, Islamic banks that value the importance of long-term relationships with their customers, must reach an environment where the potential for unethical behavior is minimal. Thus, management should follow-up on the following: (1) The need to create, communicate and apply the ethical code of sharia. Employees should know whether it is necessary. When it happens, it is very important to be informed of the punitive action taken against the offender; (2) Sharia ethics code should be the basis of ongoing training related to ethical dilemmas. Sharia bank management needs to be updated on sales training programs where sales managers can present salespeople with several different ethical scenarios and ask each of them; (3) Sharia bank managers should try to communicate with the marketing of their products / services, assist and guide them to specifically view their daily sales activities from the perspective of sharia ethics and its various activities, not just the results achieved (sales volume).

From this Islamic banks in an ethical manner guided by the value of Islam (sharia) as the main reference source, there is gun to the records of local Islamic banks still cannot achieve the goals of society and the environment. Some community groups as consumers, are expecting the quality of sharia banks can increase. This is evident from the empirical studies expressed in this book that highlight such as 1) speed and perception over time; 2) Best practices in use (professionalism / corporate governance); 3) Transparency of transactions and financial reporting; needs to be improved so that consumers as customers feel satisfied with the sharia banking system. 


\section{ACKNOWLEDGMENTS}

This research is conducted by a joint research team organized by Faculty of Administrative Science (FIA) and Research Institutions and Community Service (BPP-FIA), Universitas Brawijaya. Members of the team are Inggang Perwangsa Nuralam (Faculty of Administrative Science) and Students of the Faculty of Administrative Science. The research team expresses their gratitude to the Director of Research Institutions and Community Service (BPP-FIA), Universitas Brawijaya who grants a collaborative Research Grant for budget year 2017.

\section{REFERENCES}

1. Alom, M. M., \& Haque, M. S. (2011). Marketing: an Islamic perspective. World Journal of Social Sciences, 1(3), 71-81.

2. Arham, M. (2010). Islamic perspectives on marketing. Journal of Islamic Marketing, 1(2), 149-164.

3. Cooper, R.W. and Frank, G.L. (2002) "Ethical Challenges in the Two Main Segments of the Insurance Industry: Key Considerations in the Evolving Financial Services Marketplace", Journal of Business Ethics, 36: 5-20.

4. Crosby, L. A., Evans, K. R., \& Cowles, D. (1990). Relationship quality in services selling: an interpersonal influence perspective. The journal of marketing, 68-81.

5. Faisal. (2007). Tekanan Pengaruh Sosial dalam menjelaskan Hubungan dalam Moral Reasoning terhadap keputusan Auditor. Jurnal Akuntansi dan Keuangan Negara, Vol 4(1) Juni: 25-46.

6. Farooq, Mohammad Omar. (2009). The Riba-Interest Equation and Islam: Reexamination of the Traditional Arguments. Global Journal of Finance and Economics, Vol. 6, No. 2, pp. 99-111

7. Given, Lisa M. (2008). The Sage encyclopedia of qualitative research methods. Los Angeles, Calif.: Sage Publications. ISBN 1-4129-4163-6.

8. Hanafy, A. A. \& Salam, H. (1988). Business ethics: an Islamic perspective. Proceeding of the Seminar on Islamic Principles of Organizational Behaviour, IIIT, Herndon, USA

9. Hasbi, H., and Haruman, T. (2011). Banking: According to Isalmic Sharīah Concepts and its performance in Indonesia. International Review of Business Research Papers, 7 (1), 60-76.

10. Hassan, Abul., Abdelkader Chachi., and Salma Abdul Latiff. (2008). Islamic Marketing Ethics and Its Impact on Customer Satisfaction in the Islamic Banking Industry. JKAU: Islamic Econ., Vol. 21 No. 1, pp: 27-46.

11. Hoeber, O., Hoeber, L., Snelgrove, R., \& Wood, L. (2017). Interactively Producing Purposive Samples for Qualitative Research using Exploratory Search. In SCST@ CHIIR (pp. 18-20).

12. Hoyer, W. D. \&MacInnis, D. J. (2001). Consumer behaviour (2nd ed.). New York: Houghton Mifflin.

13. Jaffar, M., and Manarvi, I. (2011). Performance comparison of Islamic and conventional banks in Pakistan. Global Journal of Management and Business Research, 2 (1), 60-66.

14. Kalthom, Abdullah \& Mohd Ismail Ahmad. (2010). Compliance to Islamic marketing practices among businesses in Malaysia. Journal of Islamic Marketing, 1(3), 286-297.

15. Kartajaya, Hermawan., M. Syakir Sula. (2006). Syariah Marketing. Bandung: PT Mizan Pustaka.

16. Khan, Muhammad Akram (2013). What Is Wrong with Islamic Economics?: Analysing the Present State and Future Agenda. Edward Elgar Publishing. ISBN 9781782544159

17. Kuppusamy, M., Salman, A., and Samudhram, A. (2010). Measurement of Islamic banks performance using a Sharīah Conformity and Profitability Model. International Association for Islamic Economics, 13 (2), 35-48. 
18. Lone, Fayaz Ahmad and Rehman, Awais Ur. (2017). Customer Satisfaction in FullFledged Islamic Banks and Islamic Banking Windows: A Comparative Study. Journal of Internet Banking and Commerce, Jan 2017, vol. 22, no. S7.

19. Lone, Fayaz Ahmad.; Ebraheem Mohamad Aldawood.; Ulfat Rashid Bhat (2017). Comparative Analysis of Customer Satisfaction Towards Islamic and Conventional Banking: An Empirical Study from Saudi Arabia. International Review of Management and Marketing, 2017, 7(1), 273-280.

20. Masruki, R., Ibrahim, N., Osman, E., and Wahab, H. A. (2011). Financial performance of Malaysian Founder Islamic Banks versus Conventional Banks. Journal of Business and Policy Research, 6 (2), 67-79

21. Metawa, S. A. \& Almossawi, M. (1998). Banking behaviour of Islamic bank customers: Perspectives and implications. International Journal of Bank Marketing, 16(7), 299-313.

22. Mowen, J. C., \& Minor, M. (1995). Consumer Behavior. 4-th ed. Jersey: Prentice Hall.

23. Naser, K., Jamal, A. \& Al-Khatib, L. (1999). Islamic banking: A study of customer satisfaction and preferences in Jordan. International Journal of Bank Marketing, 17(3), 135-150.

24. Omer, H. S. H. (1992). The implications of Islamic beliefs and practice on the Islamic financial institutions in the UK: Case study of Albaraka International Bank UK. Unpublished Doctoral Thesis, Loughborough University.

25. Nuralam, I. P. (2016). Creating Customer Relationship Management Based On Islamic Values: A Case Study Of Pt. Bank Muamalat Indonesia Tbk. Russian Journal of Agricultural and Socio-Economic Sciences, 58(10).

26. Rammal, H. G., \& Zurbruegg, R. (2007). Awareness of Islamic banking products among Muslims: The case of Australia. Journal of Financial Services Marketing, 12(1), 65-74.

27. Rashid, M., and Nishat, A. (2009). Disparity of performance indicators of Islamic banks: study on Bangladesh. International Journal of Business and Management, Vol.4.No.8, 52-72.

28. Rosly, Saiful Azhar. (2005). Critical issues on Islamic banking and financial markets. Kuala Lumpur: Dinamas.

29. Sadeque, M. (1980). Components of Islamic Banking. Ins, Thought of Islamic Banks. Dhaka. Bangladesh

30. Saeed, A. (1996). Islamic Banking and Interest: A Study of the Prohibition of Riba and its Contemporary Interpretation. Leiden, Netherlands: E.J.Brill.

31. Saeed, M., Ahmed, Z. U., \& Mukhtar, S. M. (2001). International marketing ethics from an Islamic perspective: A value-maximization approach. Journal of Business Ethics, 32(2), 127-142.

32. Samad, A. and Hassan, K. (2009). The Performance of Malaysian Islamic Bank during 1984-1997: an exploratory research. International Journal of Islamic Financial Service $1(3)$.

33. Sampurno, 2011. Manajemen Pemasaran Farmasi, Yogyakarta: Gadjah Mada University Press.

34. Sandikci, O. (2011). Researching Islamic marketing: Past and future perspectives, Journal of Islamic Marketing, 2(3), 246-258.

35. Schiffman, L. G. \& Kanuk, L. L. (2004). Consumer behaviour (8th ed.). New Jersey: Prentice Hall.

36. Schlegelmilch, B. B. (1998). Marketing Ethics: An International Perspective. London: International THomson Business Press.

37. Sekaran, U., \& Bougie, R. (2016). Research methods for business: A skill building approach. John Wiley \& Sons.

38. Shahul, H.M.I. (2001). Different Worldview Needs Different Accounting. Paper presented at IIUM International Conference of Accounting I, Kota Bahru, Kelantan, Malaysia.

39. Shepherd, P. R., \& Kahn, B. B. (1999). Glucose transporters and insulin actionimplications for insulin resistance and diabetes mellitus. New England Journal of Medicine, 341(4), 248-257.

40. Siddiqi, N. (1980). The Issues of Islamic Economics. Lahore, Pakistan 
41. Spence, E. H., \& Heekeren, B. V. (2005). Advertising Ethics. New Jersey: Pearson Education, Inc.

42. Suleiman, N. (2000). Corporate Governance of Islamic Bank. At http://www.nzibo.com/lB2/nmsuleiman.pdf. Retrieved at 5th Agust 2017.

43. Sumachdar, Endang dan Hariandy Hasbi. 2010. Financial Performance Analysis for Islamic Rural Bank to Third Party Funds and The Comparation with onventional Rural bank in Indonesia. International Conference on Business and Economics research Vol. 1 (2011).

Suprapti, N. W. S. (2010). Perilaku konsumen [Malay manuscript]. Bali: Udayana University Press.

44. The Economist. (2009). "Sharia calling". The Economist. The Economist Newspaper Limited 2009-11-12. http://www.economist.com/node/14859353. Retrieved 15 September 2017.

45. The Economist. (2014). "Islamic finance: Big interest, no interest". The Economist. The Economist Newspaper Limited. Sep 13, 2014. https://www.economist.com/news/financeand-economics/21617014-market-islamic-financial-products-growing-fast-big-interest-nointerest. Retrieved 15 September 2017.

46. Turen, S. (1996). Performance and risk analysis of the Islamic Banks: The case of Bahrain Islamic bank. J.KAU: Islamic Economics, 8, 3-14.

47. Usmani, M. T. (1998). An Introduction to Islamic Finance. Karachi: Idaratual Maarif.

48. Walters, C. G. (1974). Organizational behaviour: Human behaviour at work (9th ed.). New Delhi: Tata McGraw Hill.

49. Widagdo, A. K., \& Ika, S. R. (2008). Analisis Perbandingan Kinerja Keuangan Bank Syariah dengan Bank Konvensional. Jurnal Ekonomi dan Bisnis, UNS.

50. Ya'qub, D. H. (1985). Etika Islam: Pembinaan Akhlaqulkarimah (Suatu Pengantar) (3 ed.). Bandung: CV. Diponegoro. 
DOI https://doi.org/10.18551/rjoas.2017-09.16

\title{
INVESTMENT FEASIBILITY ANALYSIS OF MAPPING SURVEY LABORATORY ESTABLISHMENT IN SAMARINDA CITY
}

\author{
Kuswantoro*, Hidayat Sutanto, Santosa Andrianus Agus \\ Study Program of Civil Engineering, Concentration of Construction Management, \\ National Institute of Technology, Malang, Indonesia \\ *E-mail: boengkhoez@gmail.com
}

\begin{abstract}
The rapid growth of construction works in East Kalimantan Province, especially in Samarinda, will also increase the needs of mapping survey equipment availability. The availability of the mapping survey laboratory facility as a supporting facility is expected to accelerate the implementation of a project development in Samarinda and is expected to increase the contribution for the improvement of economic growth in East Kalimantan, especially the capital city of Samarinda, so it is necessary to conduct Investment Feasibility Analysis of Mapping Survey Laboratory Establishment in Samarinda City. The type of research used in this research is qualitative with case study approach because its research produces descriptive data which discuss about investment feasibility assessment by using Net Present Value (NPV) method, Internal Rate Return (IRR), Benefit Cost Ratio (BCR), and Pay Back Period (PBP). The results showed that the investment value of Mapping Survey Laboratory establishment in Samarinda City is Rp.11,619,400,000.00 done in 1 year that is in year of 2016. In the calculation, it obtained total cost and benefits as follows: a) total Cost of Investment + Operational Cost + Credit Bank (Principal Loans + Interest Bank) until 2026 is Rp.20.392.566.497,20, b) benefit from the price of the service until 2026 is Rp.31.574.759.134,50. Mapping Survey Laboratory Establishment is economically feasible to build, with economic analysis as follows: a) Net Present Value Value $>0$ is Rp 1.964.475,890, b) Internal Rate of Return $>12 \%$ is $13,37 \%$, c) Benefit Cost Ratio $>1$ is 1.962 , d) Pay Back Period (PBP) is 4 Years 8 Months.
\end{abstract}

\section{KEY WORDS}

Investment, feasibility, laboratory, mapping, survey.

Acceleration of development in East Kalimantan Province must be supported by the availability of infrastructure or the availability of adequate supporting facilities. The availability of the construction industry as a tool of development, as well as a means of meeting the needs of development itself. Samarinda as the capital city of East Kalimantan Province, geographically, is very strategic, because it becomes the node point of the surrounding city or regency, namely: Tenggarong, Bontang, and Sangata. Samarinda becomes the central point of the land, sea, and air transportation routes making Samarinda as a service city, trade industry, and environmentally settlement.

In the stages of construction work, both in the planning stage and the implementation stage, it requires equipment that supports for data accuracy, (Buchholz et al, 1996). The needed equipment is in line with the needs of the construction itself where the equipment used as needed both from manual model and digital model. The medium of supporting equipment for construction works is still inadequate, such as a mapping survey laboratory which is an important part of the field data of construction work. Complete mapping survey service providers can be an alternative for users who want to use mapping survey services for both consultants and contractors in East Kalimantan Province.

The establishment of mapping survey laboratory in Samarinda City to support construction work in East Kalimantan Province which of course needs high enough cost, so that feasibility study analysis needs to be done for the development of mapping survey laboratory in Samarinda City. The establishment of mapping survey laboratory in Samarinda city as supporting facility for work construction is expected to serve with the fast timing of 
survey mapping service needs in East Kalimantan. In investment activities, it must pay attention on some business supporting aspects to gain maximal profit and to know whether the business is feasible or not, such as: market aspect; if the market or the consumers enjoying this product service is not that many, then this business market is not feasible, (Brook, 2016). The second is management aspect: who undergoes those aspects; social aspect: how is the implication for people surrounding the project; and the finance aspect.

The establishment of a mapping survey laboratory is considered as a supporting facility for construction works. Problems to be reviewed in this research include: 1) how much investment cost of mapping survey laboratory establishment needed in Samarinda City?, 2) how much cost and benefit of mapping survey laboratory establishment in Samarinda City?, 3 ) is the mapping survey laboratory establishment feasible in Samarinda City?.

From the problems above, this research has objectives such as: 1) Analyzing the investment cost of mapping survey laboratory establishment in Samarinda City, 2) Analyzing the cost and benefit value of mapping survey laboratory establishment in Samarinda City, 3) Analyzing whether it is feasible or not to establish a mapping survey laboratory in Samarinda City.

\section{LITERATURE REVIEW}

Definition of Feasibility Study. Every proposal or project plan must firstly be evaluated for feasibility in various aspects including technical feasibility, operational feasibility, economic feasibility, and so forth. The project feasibility study is a study of whether a project (usually an investment) is able to be conducted successfully or not. This notion of success may be interpreted in a more limited sense, also interpreted more broadly. In a more limited sense, it is especially used by private parties who are more interested in the economic benefits of an investment. Whereas, from the government, or nonprofit, being profitable meaning can be in a more relative sense. It may be considered various factors such as benefits for the wider community that could be the employment, the abundant resource utilization in the place, and so on. It can also be associated with, for example, savings in foreign exchange or additional foreign exchange needed by the government, (Effendi, 2009). In general, a project feasibility study will involve three aspects:

- The project economic benefits are for the project itself (financial benefits). It means that whether the project is viewed quite profitable when compared to project risk;

- The project economic benefits are for the country where the project is implemented (national economic benefits). It shows the benefits of the project for a country's macro economy;

- The project social benefits are for the communities surrounding the project.

Definition of Investment. Investment is the attribution of sources in long term to gain profits in the future (Mulyadi, 2001). Investment can also be defined as capital investing or ownership of long-term sources that will be profitable in some future accounting periods (Supriyono, 1987). Besides, investment can also be defined as the placement of the current amount of funds in the hope of making a profit in the future (Halim, 2005). According to Husnan and Suwarsono (2008), investment is to maximize the values of market and capital themselves. The capital owners themselves are the companies that should attempt to improve their welfare. Many advantages that can be obtained from investment activities, such as: employment, resulted output increase, exchange saving or exchange addition. Basically, the increase of investment activities can trigger and motivate the economic activities in a country. Absolutely, the intended investment activities are the investment activities that invite loss for associated parties in the future.

Definition of Mapping Survey Laboratory. Laboratory (abbreviated as lab) is where scientific research, experiment, measurement or scientific training is done. Laboratory is typically built to enable the conduct of these activities in a controlled manner. Meanwhile, according to Emha (2002), the laboratory is defined as a place to conduct experiments, investigations, and so on that relate to physics, chemistry, and biology or other fields. Another definition is sounded by Sukarso (2005), the laboratory is a place where work 
activities to produce something. This place can be a closed room, room, or open space, such as gardens, and so forth.

Based on the afore-mentioned definitions, a laboratory is a place used for experiments or training related to physics, biology, and chemistry or other fields of science, which is a closed room, room, or open space like gardens and others.

Survey or surveying is defined as collecting data related to earth surface measurements and illustrated by map or digital. While the measurement is defined as equipment and methods related to the continuity of the survey. So, surveying is everything related to data collection. It is started from the measurement of the earth's surface to the depiction of the earth's shape. Besides, a measurement is everything related to the use of tools ranging from measuring tapes to distance measurements with electromagnetic methods.

Survey is generally done on a flat field, which is by not taking into account the curvature of the earth. In a surveying project, the curvature of the earth is small, so the effect can be neglected by using calculations which its formulas are simplified. On the other hand, a project that has a long distance, the curvature of the earth cannot be neglected because this situation includes geodesy surveying.

The Mapping Survey is defined as a science, arts, and technology to determine relative positions, upper points, or beneath the surface of the earth. In a more general sense, survey (geomatics) can be defined; a discipline that encompasses all methods of measuring and collecting information about the earth's physical and the environment; processing information, and disseminating various products produced for various needs, (Nihtinen et al, 2007).

At the moment, the role of our environmental measurements and monitoring is becoming increasingly important, due to the increase of human population, the rising prices of land, the diminishing of our natural resources, and the human activity that causes our soil, water, and air quality decline. In modern age like nowadays, with the help of computer and satellite surveyor technology, the earth and natural resources globally can be measured and monitored. Much information has been available like; Making planning decisions, and formulating policies in various land use resource development, and environmental conservation applications.

\section{METHODS OF RESEARCH}

The type of research used in this research is qualitative with case study approach because its research produces descriptive data which discuss about investment feasibility assessment using Net Present Value (NPV) method, Internal Rate Return (IRR), Benefit Cost Ratio (BCR), and Pay Back Period (PBP). The data used in the analysis, aiming to be able to make a conclusion in this study, consist of primary data and secondary data. Primary data is data obtained directly from the source, observed and recorded for the first time. Secondary data is the data collected by researchers themselves. Secondary data used in this research is data of the number of project, which is the amount of survey service use assumption at infrastructure project activity in East Kalimantan 2015 on General Plan of Procurement at Department of Public Works of East Kalimantan Province. In this study, primary data collection is obtained by conducting questions and answers to the concerned parties. While, the secondary data is obtained through literature or literature study which is by reading and studying books related to this writing and through the documentary which is by reading the reports issued by relevant agencies. The data has been collected and then moved into the work table to facilitate the classification and data code and to facilitate the stages of data analysis.

\section{RESULTS OF STUDY}

Investment. Total Investment Cost for Mapping Survey Laboratory Establishment is Rp. $11,619,400,000.00$. For more details, it can be seen in the following table: 
Table 1 - Investment Cost of Mapping Survey Laboratory Establishment

\begin{tabular}{|c|l|c|c|c|c|}
\hline No. & \multicolumn{1}{|c|}{ Type of Investment } & Unit & Quantity & Unit price (Rp) & Price (Rp) \\
\hline 1 & Land Procurement & $\mathrm{M}^{2}$ & 300 & $3,500,000.00$ & $1,050,000,000.00$ \\
\hline 2 & Construction of a 3-storey Lab & $\mathrm{M}^{2}$ & 600 & $5,000,000.00$ & $3,000,000,000.00$ \\
\hline 3 & Office Equipment and Furniture & Set & 1 & $250,000,000.00$ & $250,000,000.00$ \\
\hline 4 & Mapping Survey Equipment & Set & 1 & $6,000,000,000.00$ & $6,000,000,000.00$ \\
\hline 5 & Operational car & Nos & 2 & $450,000,000.00$ & $900,000,000.00$ \\
\hline 6 & Generator (10 KVA) & Nos & 1 & $70,000,000.00$ & $70,000,000.00$ \\
\hline 7 & Motorcycle & Nos & 3 & $22,000,000.00$ & $66,000,000.00$ \\
\hline 8 & Other cost 2.5\% & - & - & $283,400,000.00$ \\
\hline \multicolumn{4}{|c|}{ Total } \\
\hline
\end{tabular}

Analysis of Net Present Value (NPV). Analysis in the use of Net Present Value (NPV) method obtains a value of Rp. 1,964,475,890, so that the establishment of a mapping survey laboratory is feasible. The calculation of investment feasibility analysis is by using Net Present Value (NPV) method with interest rate of $12 \%$ by calculating investment age of 10 years. This information can be seen in detail in the following table.

Table 2 - Calculation of Net Present Value (NPV) Method

\begin{tabular}{|c|c|c|c|}
\hline Years & Net Benefit (Rp.) & DF 12\% & Present Value (Rp.) \\
\hline 2016 & $-11,619,400,000$ & 1.0000 & $-11,619,400,000$ \\
\hline 2017 & $1,071,725,203$ & 0.8929 & $956,897,503$ \\
\hline 2018 & $1,094,146,203$ & 0.7972 & $872,246,654$ \\
\hline 2019 & $1,336,302,203$ & 0.7118 & $951,153,513$ \\
\hline 2020 & $1,569,620,453$ & 0.6355 & $997,522,174$ \\
\hline 2021 & $1,945,388,422$ & 0.5674 & $1,103,865,635$ \\
\hline 2022 & $2,005,353,113$ & 0.5066 & $1,015,974,296$ \\
\hline 2023 & $2,684,014,004$ & 0.4523 & $1,214,111,629$ \\
\hline 2024 & $3,048,775,084$ & 0.4039 & $1,365,349,122$ \\
\hline 2025 & $3,785,626,694$ & 0.3606 & $3,875,620,427$ \\
\hline 2026 & $12,037,088,758$ & 0.3220 & $1,964,475,890$ \\
\hline \multicolumn{2}{|r|}{} \\
\hline
\end{tabular}

Analysis of Internal Rate Return (IRR). Internal Rate Return Criteria (IRR) in the establishment of this mapping survey laboratory obtains interest rate of $13.37 \%$ which is higher than $12 \%$ discount factor, so it is feasible to be conducted.

Table 3 - Calculation of Internal Rate Return Method

\begin{tabular}{|c|c|c|c|c|c|}
\hline Years & Net Benefit (Rp.) & DF 12\% & Present Value (Rp.) & DF 14\% & Present Value (Rp.) \\
\hline 2016 & $-11,619,400,000$ & 1.0000 & $-11,619,400,000$ & 1.0000 & $-11,619,400,000$ \\
\hline 2017 & $1,071,725,203$ & 0.8929 & $956,897,503$ & 0.8772 & $940,109,827$ \\
\hline 2018 & $1,094,146,203$ & 0.7972 & $872,246,654$ & 0.7695 & $841,909,975$ \\
\hline 2019 & $1,336,302,203$ & 0.7118 & $951,153,513$ & 0.6750 & $901,965,924$ \\
\hline 2020 & $1,569,620,453$ & 0.6355 & $997,522,174$ & 0.5921 & $929,341,313$ \\
\hline 2021 & $1,945,388,422$ & 0.5674 & $1,103,865,635$ & 0.5194 & $1,010,373,786$ \\
\hline 2022 & $2,005,353,113$ & 0.5066 & $1,015,974,296$ & 0.4556 & $913,611,902$ \\
\hline 2023 & $2,684,014,004$ & 0.4523 & $1,214,111,629$ & 0.3996 & $1,072,632,170$ \\
\hline 2024 & $3,048,775,084$ & 0.4039 & $1,231,349,122$ & 0.3506 & $1,068,775,712$ \\
\hline 2025 & $3,785,626,694$ & 0.3606 & $1,365,134,937$ & 0.3075 & $1,164,110,277$ \\
\hline 2026 & $12,037,088,758$ & 0.3220 & $3,875,620,427$ & 0.2697 & $3,246,930,177$ \\
\hline \multicolumn{7}{|r}{} & $=$ & $1,964,475,890$ & & $470,361,063$ \\
\hline
\end{tabular}

$$
\begin{gathered}
\mathrm{IRR}=\mathrm{DF} 1+\frac{\mathrm{NPV} 1}{\mathrm{NPV} 1-\mathrm{NPV} 2} \times(\mathrm{DF} 2-\mathrm{DF} 1)=12 \%+\frac{1,964,475,890}{1.964 .475,890-470,361,063} \times(14 \%-12 \%) \\
=12 \%+\frac{1,964,475,890}{1,494,114,827} \times 2 \%=12 \%+1,37 \%=13.37 \% / \text { Year }
\end{gathered}
$$


Analysis of Benefit Cost Ratio (BCR). In the calculation of Benefit Cost Ratio (BCR), it obtained value of 1.962 which is more than 1 , then the establishment of this mapping survey laboratory is feasible.

Table 4 - Calculation of Benefit Cost Ratio (BCR) Method

\begin{tabular}{|c|c|c|c|c|c|c|c|}
\hline Years & Investment & $\begin{array}{l}\text { Operational } \\
\text { costs (Rp.) }\end{array}$ & Benefit (Rp.) & DF $12 \%$ & I. (Rp.) & OM (Rp.) & B (Rp.) \\
\hline 2016 & $11,619,400,000$ & 0 & 0 & 1 & $11,619,400,000$ & 0 & 0 \\
\hline 2017 & 0 & $1,071,825,000$ & $4,200,000,000$ & 0.8929 & 0 & $956,986,607$ & $3,750,000,000$ \\
\hline 2018 & 0 & $1,259,404,000$ & $4,410,000,000$ & 0.7972 & 0 & $1,003,989,158$ & $3,515,625,000$ \\
\hline 2019 & 0 & $1,347,998,000$ & $4,740,750,000$ & 0.7118 & 0 & $959,478,350$ & $3,374,372,210$ \\
\hline 2020 & 0 & $1,470,236,000$ & $5,096,306,250$ & 0.6355 & 0 & $934,361,558$ & $3,238,794,755$ \\
\hline 2021 & 0 & $1,476,691,000$ & $5,478,529,219$ & 0.5674 & 0 & $837,914,131$ & $3,108,664,609$ \\
\hline 2022 & 0 & $1,827,616,000$ & $5,889,418,910$ & 0.5066 & 0 & $925,927,143$ & $2,983,762,906$ \\
\hline 2023 & 0 & $1,737,897,000$ & $6,478,360,801$ & 0.4523 & 0 & $786,136,344$ & $2,930,481,425$ \\
\hline 2024 & 0 & $2,020,972,000$ & $7,126,196,881$ & 0.4039 & 0 & $816,236,695$ & $2,878,151,400$ \\
\hline 2025 & 0 & $2,174,895,000$ & $8,016,971,491$ & 0.3606 & 0 & $784,288,940$ & $2,891,000,290$ \\
\hline 2026 & 0 & $2,384,818,000$ & $9,019,092,928$ & 0.3220 & 0 & $767,847,570$ & $2,903,906,541$ \\
\hline \multicolumn{5}{|c|}{ Total } & $11,619,400,000$ & $8,773,166,497$ & $31,574,759,134$ \\
\hline
\end{tabular}

The calculation of Benefit Value minus by the value of Operations and Maintenance is as below:

$$
\mathrm{BCR}=\frac{\mathrm{PV} \text { Benefit }}{\mathrm{PV} \text { Cost }}=\frac{\text { Total Benefit }- \text { Total Operational Maintenance }}{\text { Investment }}=\frac{31,574,759,134-8,773,166,497}{11,619,400,000}=1.962
$$

Analysis of Pay Back Period (PBP). With the calculation of Pay Back Period (PBP), the establishment of this mapping survey laboratory resulted 4 Years 8 Months relatively nearly half of the investment period of 10 years.

$$
\mathrm{PBP}=T_{p-1}+\frac{\sum_{i=1}^{n} I_{i}-\sum_{i=1}^{n} B_{i c p-1}}{B_{p}}=4+\frac{1,595,42,309}{67532,669-1,595,42,30}=4+0.70=4+8 \text { months }
$$

Table 5 - Calculation of Pay Back Period (PBP) Method

\begin{tabular}{|c|c|c|c|c|c|}
\hline Years & I. (Rp.) & OM (Rp.) & B (Rp.) & Net Benefit (Rp.) & Cumulative Benefit (Rp.) \\
\hline 2016 & $11,619,400,000$ & 0.0000 & 0 & $-11,619,400,000$ & $-11,619,400,000$ \\
\hline 2017 & 0 & $956,986,607$ & $3,750,000,000$ & $2,793,013,393$ & $-8,826,386,607$ \\
\hline 2018 & 0 & $1,003,989,158$ & $3,515,625,000$ & $2,511,635,842$ & $-6,314,750,765$ \\
\hline 2019 & 0 & $959,478,350$ & $3,374,372,210$ & $2,414,893,859$ & $-3,899,856,906$ \\
\hline 2020 & 0 & $934,361,558$ & $3,238,794,755$ & $2,304,433,197$ & $-1,595,423,709$ \\
\hline 2021 & 0 & $837,914,131$ & $3,108,664,609$ & $2,270,750,478$ & $675,326,769$ \\
\hline 2022 & 0 & $925,927,143$ & $2,983,762,906$ & $2,057,835,762$ & $2,733,162,531$ \\
\hline 2023 & 0 & $786,136,344$ & $2,930,481,425$ & $2,144,345,081$ & $4,877,507,612$ \\
\hline 2024 & 0 & $816,236,695$ & $2,878,151,400$ & $2,061,914,705$ & $6,939,422,317$ \\
\hline 2025 & 0 & $784,288,940$ & $2,891,000,290$ & $2,106,711,350$ & $9,046,133,666$ \\
\hline 2026 & 0 & $767,847,570$ & $2,903,906,541$ & $2,136,058,971$ & $11,182,192,637$ \\
\hline & $11,619,400,000$ & $8,773,166,497$ & $31,574,759,134$ & $11,182,192,637$ & $3,197,927,546$ \\
\hline
\end{tabular}

\section{DISCUSSION OF RESULTS}

Investment of this mapping survey laboratory establishment used is sourced from bank loan funds amounting to Rp.11,619,400,000.00. The discussion of this investment cost assumption that will be explicated is related to the elements in the calculation of mapping survey laboratory establishment in Samarinda. It can be seen in the table of Investment Cost of Mapping Survey Laboratory Establishment.

Land Procurement Cost. In this investment, the alternative of location that will established is a strategic location, so that the users of mapping survey services in the field of construction can easily get to the location of the mapping survey laboratory. Based on the market price of land located in the site, it is between $3-3.5$ million rupiah/M2, then it is 
assumed that the highest value is taken with consideration to obtain the strategic location. With a land area of $300 \mathrm{M} 2$, then the cost of land procurement is Rp. 1.050.000.000,-.

Establishment of Mapping Survey Laboratory. The investment of this mapping survey laboratory establishment is made with the assumption that the building will be occupied to be built itself which its construction is given by the contractors at a cost of Rp. 3.000.000.000,-It is as in the table below which is a recapitulation of Cost Budget Plan of Mapping Survey Laboratory Establishment.

Office Equipment and Furniture. With the establishment of this mapping survey laboratory, then office equipment and furniture are also required to support the laboratory activities. The purchase of office equipment and furniture is Rp.250.000.000,- which is counted as a set for the whole building.

Mapping Survey Equipment. The equipment needed in the establishment of this mapping survey laboratory is the main element because the existing equipment must support the services provided to the consumers, with various types of equipment such as manual type, semi digital type and full digital type and all equipment is the latest equipment in the aspect of technology, so that consumers are expected to have construction services that will ultimately provide a great income. The price for the purchase of equipment of all types needed is Rp. 6.000.000.000,--.

Operational Car. In supporting the activities of outside mapping survey laboratory, then vehicle that can be used in all fields is needed, therefore the selected vehicle is Double Cabin Car which is assumed to price of Rp.450.000.000,- per unit and the total purchase for 2 vehicles is $\mathrm{Rp}$. 900.000.000,-

Generator. Circumstances in the city of Samarinda which is often occurring a power outage is the reason for the purchase of a unit of generator with a capacity of 10 KVA for activity in Mapping Survey Laboratory keeps running, so that the service to consumers is not disturbed. Purchase of one unit generator with the price of Rp.70.000.000, -

Motorcycle. To support the activity in the mapping survey laboratory, two-wheeled vehicles are needed for the benefit of relatively close employee mobility and no need to use the car. The purchase price of 3 units of two-wheeled vehicles is Rp. 66.000.000,-

Other Costs. In this investment cost, it is needed funds that may not be known yet the amount of the price, then $2.5 \%$ is taken from Investment Cost as other costs, thus it is obtained Rp. 283.400.000,--.

Calculation of Cost and Benefit. Total Cost of Investment + Operational Cost + Bank Loan (Principal Loans + Bank Interest) from 2016 to 2026 is Rp.20.392.566.497,20. Annual operational costs are calculated with several approaches, including:

Operational Cost of Mapping Survey Laboratory, covering fuel cost of operational vehicle and generator of Rp. 9.990.000,00/month.

Personnel costs, including personnel costs are burdened by employee salary of Rp 31.250.000,00/month and by Laboratory fixed employees salary of Rp.24.000.000,00/month. While, for some components related to employee activities, it is assumed as follows: Employee overtime of $2.5 \%$ from employee's salary; Holiday allowance of 1 month from employee's salary; Employee bonus of $1.5 \%$ from employee's salary;Welfare and other employee expenses of $1 \%$ for each employee's salary.

Maintenance costs in operational laboratory consisting of laboratory equipment maintenance, operational vehicle maintenance amounting to Rp.242.995.000/year.

General administrative costs, including in office stationery, office household needs, photocopy and printed materials, correspondence, electricity and telephone amounting to Rp. 5.900.000,00/month.

From the above details, the operational cost of the project in 2017 is Rp. 1.071.825.000,00/year.

In the calculation of this expenditure costs, it also calculates the increase of each year, such as: Assumption of Fuel Increase $=2 \%$ per Year; Assumption of Increase Spare parts = $2 \%$ per Year; Assumption of Employee Salary Increase $=10 \%$ per Year; Assumption of Maintenance Increase $=5 \%$ per year; Assumption of Other Increases $=2 \%$ per Year. 
The profit of this mapping survey laboratory establishment is by calculating net benefit obtained from Benefit minus Investment Cost and Operational Cost + Maintenance, then it is obtained the calculation as in the following table.

Table 6 - Calculation of Profitability Ratio

\begin{tabular}{|c|c|c|c|c|c|}
\hline Years & Investment & $\begin{array}{c}\text { Operational } \\
\text { Maintenance }\end{array}$ & Benefit & Net Benefit & Cumulative Benefit \\
\hline 2016 & $11,619,400,000.00$ & 0.00 & 0.00 & $-11,619,400,000.00$ & $-11,619,400,000.00$ \\
\hline 2017 & 0.00 & $956,986,607.14$ & $3,750,000,000.00$ & $2,793,013,392.86$ & $-8,826,386,607.14$ \\
\hline 2018 & 0.00 & $1,003,989,158.16$ & $3,515,625,000.00$ & $2,511,635,841.84$ & $-6,314,750,765.31$ \\
\hline 2019 & 0.00 & $959,478,350.49$ & $3,374,372,209.82$ & $2,414,893,859.33$ & $-3,899,856,905.98$ \\
\hline 2020 & 0.00 & $934,361,557.52$ & $3,238,794,754.96$ & $2,304,433,197.44$ & $-1,595,423,708.54$ \\
\hline 2021 & 0.00 & $837,914,131.00$ & $3,108,664,608.56$ & $2,270,750,477.56$ & $675,326,769.02$ \\
\hline 2022 & 0.00 & $925,927,143.16$ & $2,983,762,905.54$ & $2,057,835,762.37$ & $2,733,162,531.40$ \\
\hline 2023 & 0.00 & $786,136,344.29$ & $2,930,481,425.08$ & $2,144,345,080.79$ & $4,877,507,612.19$ \\
\hline 2024 & 0.00 & $816,236,695.02$ & $2,878,151,399.63$ & $2,061,914,704.62$ & $6,939,422,316.81$ \\
\hline 2025 & 0.00 & $784,288,940.28$ & $2,891,000,289.81$ & $2,106,711,349.53$ & $9,046,133,666.33$ \\
\hline 2026 & 0.00 & $767,847,570.14$ & $2,903,906,541.10$ & $2,136,058,970.96$ & $11,182,192,637.30$ \\
\hline Total & $11,619,400,000$ & $8,773,166,497$ & $31,574,759,134$ & $11,182,192,637.30$ & $3,197,927,546.09$ \\
\hline
\end{tabular}

All in Rupiah.

Data Source: Analysis Results.

The average benefit calculation per year is Rp. 2,280,159,263.73 by not included in the first year. At Cumulative Profit Value, then it is got Rp. 3,197,927,546.09 until the end of investment. The residual value of the land and buildings and equipment is 7.459.263.627,38 which is also included in the calculation of the total profit, so that the profit value of Benefit from Selling Price + Residual Value to 2026 is Rp. 18.641.456.264,67.

Investment Feasibility of Mapping Survey Laboratory Establishment. The calculation of financial aspect in analyzing investment feasibility of this Mapping Survey Laboratory Establishment is summarized as shown in the table below

Table 7 - NPV, IRR, BCR, PBP

\begin{tabular}{|c|c|}
\hline NPV & Rp. 1964475890 \\
\hline IRR & $13.37 \%$ \\
\hline BCR & 1,962 \\
\hline PBP & 4 Years 8 Months \\
\hline
\end{tabular}

NPV Net Present Value Method. Net Present Value (NPV) Method with interest rate of $12 \%$ with 10 years investment obtained NPV calculations which its results are positive amounting to $1,964,475,890$, thus the establishment of mapping survey laboratory is feasible to do.

IRR Internal Rate Return Method. Calculation by IRR Internal Rate Return method that obtains $13.37 \%$ higher than discount factor level which is $12 \%$, then Establishment of Mapping Survey Laboratory is feasible.

$B C R$ Benefit Cost Ratio Method. In the calculation of BCR, it obtained value of 1.962 higher than 1, then the establishment of Mapping Survey Laboratory Establishment is feasible.

PBP Pay Back Period Method. In the calculation of PBP, it results 4 Years 8 Months which is relatively close to half the age of the investment which is 10 Years, then the establishment of Mapping Survey Laboratory is feasible.

\section{CONCLUSION}

The investment value of Mapping Survey Laboratory Establishment in Samarinda City is Rp. $11,619,400,000.00$ done in 1 year that is in year of 2016. In the calculation, it is obtained total cost and benefits as follows: a) total Cost of Investment + Operational Cost + 
Bank Credit (Principal Loans + Interest Bank) until 2026 is Rp. 20.392.566.497,20, b) benefit from the price of the service until 2026 is Rp.31.574.759.134,50. The Establishment of Mapping Survey Laboratory is economically feasible to build, with economic analysis as follows: a) Net Present Value Value> 0 is Rp. 1.964.475,890, b) Internal Rate of Return> $12 \%$ is $13,37 \%$, c) Benefit Cost Ratio $>1$ is 1.962 , d) Pay Back Period (PBP) is 4 Years 8 Months.

\section{REFERECES}

1. Abdul Halim, (2005). Analisis Investasi, Edisi Ke-2. Salemba Empat, Jakarta.

2. Brook, M. (2016). Estimating and tendering for construction work. Taylor \& Francis.

3. Buchholz, B., Paquet, V., Punnett, L., Lee, D., \& Moir, S. (1996). PATH: a work samplingbased approach to ergonomic job analysis for construction and other non-repetitive work. Applied ergonomics, 27(3), 177-187.

4. Effendi, H, (2009). Analisis Kelayakan pembangunan Asphalt Mixing Plant (AMP) di Pulau Kangean Kabupaten Sumenep, Tesis, UNTAG Surabaya.

5. Emha, H. (2002). Pedoman Penggunaan Laboratorium Sekolah. PT Remaja Roesda Karya, Bandung.

6. Husnan, S. dan Suwarsono, M. 2008. Studi Kelayakan Proyek,UPP AMP YKPN. Yogyakarta.

7. Mulyadi, (2001). Akuntansi Manajemen: Konsep, Manfaat dan Rekayasa, Edisi. Ketiga. Salemba Empat. Jakarta.

8. Nihtinen, A., Anttila, V. J., Richardson, M., Meri, T., Volin, L., \& Ruutu, T. (2007). The utility of intensified environmental surveillance for pathogenic moulds in a stem cell transplantation ward during construction work to monitor the efficacy of HEPA filtration. Bone marrow transplantation, 40(5), 457.

9. Sukarso, 2005, Pengertian dan Fungsi Laboratorium. Online http://wanmustafa.wordpress.com/2011/06/12/pengertian-danfungsi-laboratorium/

10. Supriyono, 1987, Akuntansi Biaya: Pengumpulan Biaya dan Penentuan Harga. Pokok Produk. Edisi Kedua.BPFE Universitas Gajah Mada, Yogyakarta. 


\title{
LEASING AS EFFECTIVE INTERACTION MECHANISMS BETWEEN GOVERNMENT AND PRIVATE BUSINESS IN THE FIELD OF ROAD INFRASTRUCTURE IN RUSSIA
}

\author{
Komissarova V.V., Lecturer \\ Vladivostok State University of Economics and Service, Vladivostok, Russia \\ E-mail: valeriya.komissarova@vvsu.ru
}

\begin{abstract}
Subject of the article is devoted to the development of cooperation between government agencies and business according to the principles of public-private partnership. Today one of the most important conditions for optimizing the federal budget is the introduction of effective scientific developments in the road sector. For the past several years the problem is posed to achieve not only sufficient amount, but also to improve financing and management mechanisms in the road sector. The experience of developed and developing countries has shown that the impossibility of such industries as a road and utilities, rail and pipeline transport, electricity, ports, airports privatization by virtue of their strategic, social and sociopolitical significance and lack of funds in state budgets for future development formed the basis for creating and implementing the concept of public-private partnership in business practices. Applying of leasing as one of the PPP forms is regarded as the most favorable way of national economy development in Russia. Despite the growing interest of scientists in this issue, many problems have been identified, but not resolved. The issues connected with the formation of systemic notions about the essence, functional and procedural content of publicprivate partnership, the principles and mechanism of its organization, as well as the prospects for development require detailed elaboration.
\end{abstract}

\section{KEY WORDS}

Public-private partnership, roads, transport infrastructure, innovation, concessions, leasing, credit.

Roads constitute the most extensive part of the transport infrastructure. This performs a variety of tasks from the maintenance of international and interregional traffic to ensure entrance to facilities, enterprises, institutions, to the citizens' homes. A significant part of small and medium-sized businesses, which primarily transport small quantities of products or operate in the service sector, tend to use motor vehicles. According to the Federal statistical observation, the public road network in the Russian Federation as of January 1, 2016 has a total length of $1,479.9$ thousand $\mathrm{km}$, of which 51.9 thousand $\mathrm{km}$ are federal roads, 515.8 thousand $\mathrm{km}$ are regional roads, 912.2 thousand $\mathrm{km}$ are local roads. The fact that $36.4 \%$ of the length of highways of federal significance, $61.9 \%$ of the total length of regional highways and $44.8 \%$ of the length of highways of local significance do not meet the regulatory requirements [1].

Analyzing the experience of developed and rapidly developing countries, the changes can be traced in such industries as road and utilities, rail and pipeline transport, electricity, ports, airports, previously completely state-owned and evaluated as a cardinal. The reason for these changes is, on the one hand, the fact that a lack of funds was appeared in the state budgets not only for further development, but also for simple maintenance of effective functioning of these industries and, on the other hand, the impossibility of privatization because of their strategic, social and socio-political significance. This contradiction served as the basis for creating and implementing the concept of public-private partnership (PPP) in business practice.

Various aspects of public-private partnerships formation and functioning are reflected in the research of such scientists as V.G. Varnavsky, V.A. Kabashkin, A.V. Belitskaya, R.M. Japaridze, V.V. Maksimov, , A.A. Alpatov, A.V. Klimenko, A.A. Pushkin, A. Smith, M.I. TuganBaranovsky, Chonka, D. Amunts and others. 
Smith $A$. in his works pointed out that the state should "create and maintain some public enterprises that can never be created by an individual or a group, because profits will never cover costs» [2].The first time projects based on private public partnership (private partnership projects) were implemented in England in the early nineties. It is in the early nineties in England a special law was passed that allowed investors to build the infrastructural facilities with the state on equal footing. Since then, similar laws have started to operate in 40 countries.

Abroad, public-private partnership includes the very wide range of business models and relationships. In the most general sense, the term is applied in any use of private sector resources to meet social needs. Spheres of application of public-private partnerships in foreign countries are very varied. Collaboration between partners can be held in the various legislative bodies, with a diverse range of tasks and competencies.

An international practice of partnership creation shows that they can be implemented in a variety of industries:

Transport - construction, operation, maintenance, traffic management systems implementation and many other projects in various sectors of transport, including urban transport.

Housing and communal services - public services, maintenance of utilities (water, sewerage); street cleaning, removal and disposal of garbage.

Ecology - the creation, maintenance and development of urban and suburban parks with the right of exploitation of natural resources and revenues from the organization of ecotourism.

Real estate - construction and maintenance of public buildings and municipal housing in exchange for the right of development and participation in commercial projects.

Public order and safety - ensuring order in transportation and in public places served by private companies, organization and maintenance of parking lots.

Telecommunications - creation of telecom infrastructure and services for consumers.

Financial sector - involvement of private insurance and asset management companies in the sphere of compulsory social insurance and public pensions.

Education - construction and equipping of schools and other institutions by the private companies that received the right to build and develop adjacent territories [3].

Forms, which public-private partnerships is implemented in have different levels of responsibility of state or the private sector takes over the operation and maintenance, capital investment and ongoing funding, commercial risk, as well as those who own assets and lasting cooperation. The main forms of partnerships are: service contracts, management contracts, leasing, contracts for the construction, operation and transfer (BOT) and their variants; concession. In practice, combinations of these forms are used in foreign countries commonly.

World leaders in the field of public-private partnership the United States and Great Britain, France, Germany are recognized.

To date, the PPP, on the one hand, is regarded as a form of indirect privatization. This is associated with the transfer of broad powers relating to the ownership, operation, construction and financing facilities (the experience of developed countries) by state to private business. On the other hand, PPP is as alternative to privatization, which allows to realize the potential of private capital and retain control functions of the state in significant public sectors of economy that are strategically important.

The main common features defining PPP are: firstly, the purpose of PPP is the realization of both national and international social projects in various fields in the interaction of state and business structures in the long term and, second, the principle of public-private partnership is based on pooling resources and sharing risks between the parties [4].

Using the mechanisms of public-private partnership (PPP) is widely spreading in the Russian Federation now.

Despite the fact that today in Russia, public-private partnership, from a legal point of view, can only be exercised on the basis of the law on concessions, this kind of partnership may act in such forms as governmental contracts, rent, financial rent (leasing), public-private 
ventures, production sharing agreements and concession agreements [3].

PPP includes a number cooperation forms, allowing the state and the private sector to derive mutual benefit, referring to the innovative methods used by the public sector to contract with the private sector, that use their own capital and management capacity in implementing projects in accordance with established timeframes and budgets. The public sector retains the responsibility for the provision of these services by profitable way and has a positive impact on economic development and improvement life's quality.

PPP is regarded like the specific projects being implemented by public authorities and private companies for objects of federal, regional and municipal property jointly.

During the years of reform, Russia's economy has undergone a series of structural reforms that resulted in a reduction of the public sector and transfer of management functions in critical infrastructure in the hands of private business. Under the circumstances, it is essential to move to a strategic partnership with the private sector, to create such system of relations that would provide a rational combination of free competition and measures of state regulation in order to serve the public interest.

In this regard, the attention is increasingly focused on public-private partnership as one of the most important mechanisms to attract private capital for the solving of socio-economic problems in Russia. Such an alliance is advantageous for private companies because of a simple reason - to receive the income from investments, and the state - because of budget savings during the implementation of socially significant investment projects [5].

Leasing, which is a procedure of borrowing in the form of long-term loan provided in natural form and repaid in installments, has established itself as an effective mechanism for attracting investment in road construction and service sectors of road facilities, utilities and passenger traffic [6].

As a vivid example of the collaboration of businesses and government the creation of aviation leasing company «llyushin Finance Co» can be demonstrated, a company that for several years has created a portfolio of orders for billions of dollars, thus creating a favorable environment for the development of the national aircraft industry, and the money invested by the state in this project, returned to the budget in taxes.

Now, as a few years ago, leasing is a very promising direction. Analysts have found several reasons for the rapid development of the leasing of construction and road machinery in Russia. The most important reason is increasing the volume of construction - average annual growth rate is $10-15 \%$. High deprecation rate of available technology plays a significant role of in enterprises. Due to the fact that the development of construction is still going on, in the coming years high rates growth can be observed in the leasing market [7].

Today, a significant portion of all leasing deals in Russia are deals on road transport, railway transport, road construction equipment, aircraft equipment, power equipment, as well as equipment designed for the extraction of minerals (is presented in Figure 1).

Issues of the road network development are currently among the top priority for Russia. Creating a modern road transport network is one of the factors ensuring steady economic growth, execution of social programs and improving the quality of life. Transportation is an industry where various forms of public-private partnership have to be successfully implemented, as it is considered as one of the most important sectors that can enhance the competitiveness of the Russian economy.

The choice of public-private partnership in road construction is determined by two factors: transport is not an end in itself but a mean for implementing economic activities and social life. In this sense, the majority of transportation projects are of great socio-economic value that does not cause a large interest among potential investors; transport infrastructure is the capital-intensive industry, so funding for the initial phase results in a fairly significant amount.

Today, park equipment of road sector is characterized by high deprecation and a relatively small amount of modern machinery and equipment that can provide qualitative indicators of construction, repair and maintenance of roads, which depend on the technical level of most equipment and its degree of automation. 


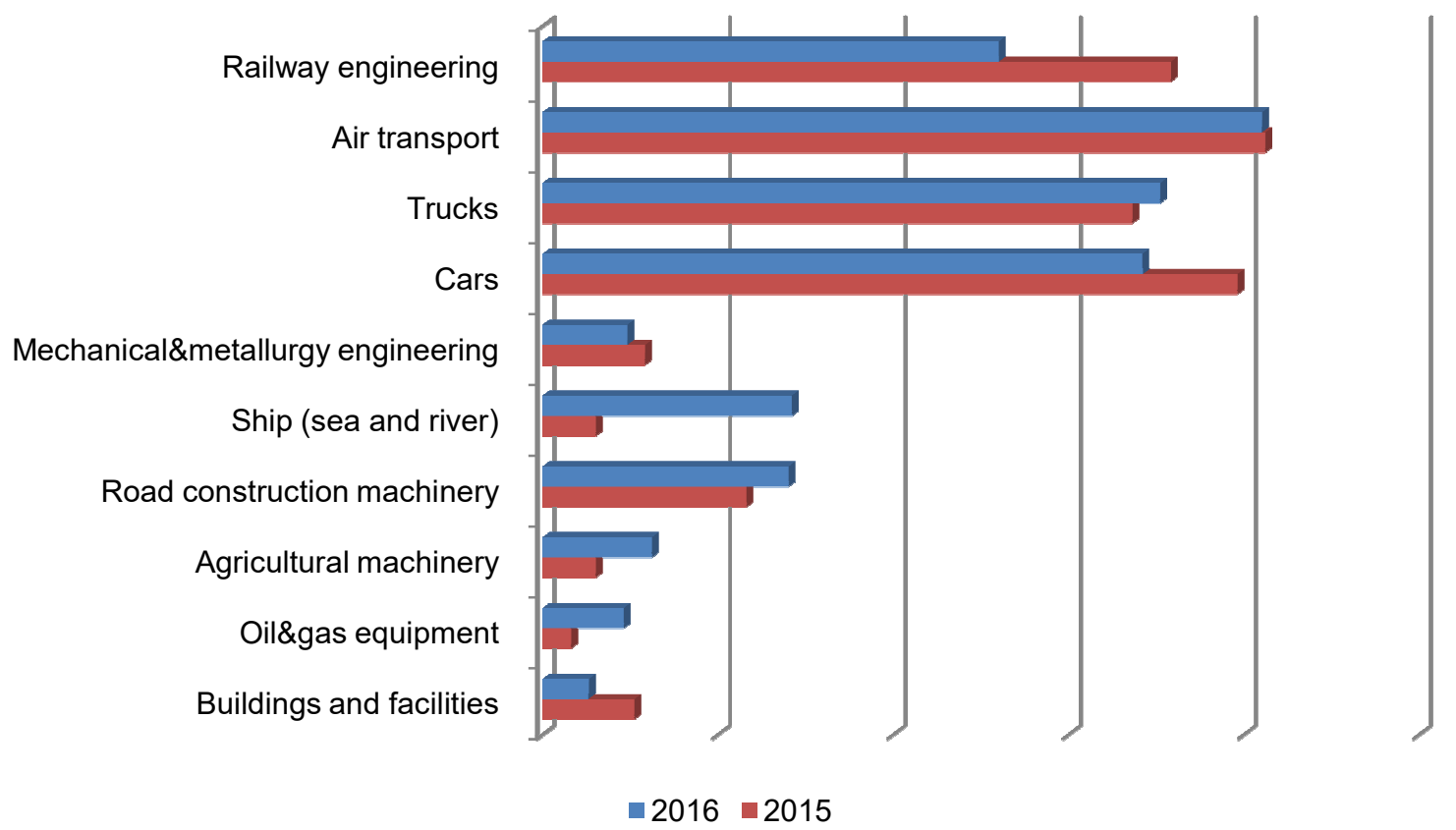

Figure 1 - Key market segments share in the new business [8] Source: compiled by the author according to «Expert RA»

Given the size of the country and, consequently, the necessity for construction and repair of roads, the development of industry and quality assurance of roadworks issues require a new approach in investing with the purpose of technical re-equipment of the road sector. Use of public-private partnership in the road sector can be seen from the viewpoint of innovation, which can provide budget savings at the various stages of road works by reducing the cost of the works themselves, increasing the maintenance period, bringing the technical capacity of the industry to a level that meets the needs of the country in freight and passenger transportation.

The use of leasing as a form of public-private partnership is one of the most appropriate instruments to attract investment in the road sector [7].

For road businesses attractiveness of leasing arrangements can be explained by the fact that the acquisition of machinery and equipment reduces the need for proper start-up capital - it means that lump sum is not required to pay for necessary equipment that frees up user's liquidity, increases the working capital to expand production without drastic financial stress allows to update the fixed assets.

The advantages of purchasing equipment under leasing contracts are:

1. Assignment of lease payments at the cost of production and jobs that reduces the tax base (income tax).

2. The use of accelerated depreciation, which increases the possibility of rapid updating of obsolete equipment and technical upgrading of production. The period of the lease agreement is much less than the statutory age of the property and the customer does not pay full property tax due to accelerated depreciation.

3. The amount of VAT on the lease agreement in its entirety is placed to offset.

4. The flexibility of lease payments is provided by: the grace period is possible, a gradual increase or decrease benefits, orientation for seasonal work that is important enough for the road sector enterprises.

5. Leasing contracts are cheaper than credit.

6. The risk for the development of innovative products is insignificant: in case of insufficient demand there is an opportunity to return the property to lessor [9].

To substantiate the benefits of leasing schemes represent a simple comparative analysis of the acquisition of road equipment by credit or leasing. 
The structure of lease payments compensation is included for the property tax of leasing company in the project framework taking into account accelerated depreciation for the period of the lease agreement. Advanced payment on a lease agreement is not provided.

Table 1 - Comparison of costs of the enterprise acquiring equipment through the credits in commercial bank and leasing scheme

\begin{tabular}{|c|c|c|}
\hline 1 & The cost of the equipment including VAT, rub. & 5000000 \\
\hline 2 & Advanced payment & $0 \%$ \\
\hline 3 & The amount of down payment, VAT included, rub. & - \\
\hline 4 & Transportation tax, registration with the traffic police and customs fees (if applicable), rub. & - \\
\hline \multicolumn{3}{|c|}{ CREDIT SCHEME } \\
\hline 5 & Loan amount, rub. $(1-3+4)$ & 5000000 \\
\hline 6 & The term of the loan, months. & 36 \\
\hline 7 & Interest on bank loan, \% & 16 \\
\hline 8 & Accrued interest (accruing on the balance), rub. & 1233485,54 \\
\hline 9 & Total: $(5+8)$ & 6233485,54 \\
\hline 10 & VAT to offset (purchase of equipment), rub. & 762711,86 \\
\hline 11 & The tax on assets of the company, rub. & 244882,66 \\
\hline 12 & Accumulated depreciation during the period (excluding accelerated depreciation), rub. & 1271186,44 \\
\hline 13 & The amount of reduction of the tax base for income tax, rub. $(8+11+12)$ & 2749554,64 \\
\hline 14 & Income tax saving, now. $(13 \times 0.24)$ & 659893,11 \\
\hline 15 & The amount that reduces the costs of the company on taxes, rub. $(10+14)$ & 1422604,97 \\
\hline 16 & Total cost of the enterprise under a credit scheme, rub. $(3+9+11-15)$ & 5055763,23 \\
\hline \multicolumn{3}{|c|}{ LEASING SCHEME } \\
\hline 17 & The sum of all payments under the lease agreement, rub. & 7257299,85 \\
\hline 18 & VAT to offset (amounts of the lease payments), rub. & 1107045,74 \\
\hline 19 & The amount of reduction of the tax base for income tax, rub. $(17-18)$ & 6150254,11 \\
\hline 20 & Income tax savings, rub. $(19 \times 0.24)$ & 1476060,99 \\
\hline 21 & The amount that reduces the costs of the company on taxes, rub. $(18+20)$ & 2583106,73 \\
\hline 22 & Total costs for the company leasing scheme, rub. $(17-21)$ & 4674193,12 \\
\hline 23 & $\begin{array}{l}\text { Leasing scheme savings, rub. }(16-22) \\
\text { Leasing scheme savings in } \% \\
\text { Rate loan, giving the same effect }\end{array}$ & $\begin{array}{c}381570,11 \\
7,631 \% \\
7,75 \%\end{array}$ \\
\hline
\end{tabular}

These calculations reflect the following costs of the enterprise.

Credit (study period - 3 years):

- Repayment of the loan principal: 5000000 rubles.

- Accrued interest: 1233 485, 54 rubles.

- Tax on enterprise property during the analyzed period: 244882,66 rubles.

- During the study period, the amount of accumulated depreciation will be: 1271 186,44 rubles.

So, we see, that accrued interest on the loan, accrued property tax on businesses and accumulated depreciation for the equipment is deductible for income tax and is as follows: 2 749554,64 rubles. Thus, income tax savings will be 659893,11 rubles, and in the amount of VAT is equal to 762711,86 rubles, formed with the purchase of equipment, gives the enterprise tax savings in the amount of 1422604,97 rubles.

Costs of the company under a credit scheme is the sum of the advance payment from its own resources (in our example 0), the amount of the loan principal and accrued interest of the loan life period, the property tax business during the analyzed period, less the value of saving the company taxes. The credit scheme cost will be 5055763,23 rubles.

Leasing:

The total amount of lease payments during the lease agreement term on a standard calculation is 7257299,85 rubles. Due to the fact that the accrual of the total lease payments of VAT equal to 1107045,74 rubles, the company aims to offset, the amount of reduction of the tax base for income tax will be 6150254,11 rubles.

Thus, income tax savings will be 1476060,99 rubles, and in the amount of charging VAT on the full amount of lease payments, provides cost savings for the company tax rate in sum of 2583106,73 rubles. 
Costs of the leasing scheme are the sum of all lease payments for the term of the lease agreement minus the value company's taxes savings. Leasing scheme costs will be 4674 193, 12 rubles.

It's clear, that the difference in real spending in the enterprise of leasing and loan company provides cost savings when leasing scheme at a rate of 381570,11 rubles, which amounts to $7,631 \%$ of the purchase price of equipment.

To draw an analogy to a bank loan, the cost of enterprise leasing scheme provided the acquisition of fixed assets would be similar costs for bank credit, which was taken at a rate of $7,75 \%$ per annum.

Conclusion. Advantages of using forms of PPP are obvious, so Russian government need to accelerate the creation of a legal framework for the wider use of leasing and other forms of public-private partnership in which the partnership with the private sector can bring greater benefits through effective quality of service, while at the same time, let the legislative authorities allocation of rights, responsibilities and risks between the state and investors in the implementation of various transportation projects.

Public-private partnership has become one of the main instruments of government management in the world. Events of the past fifteen years clearly showed that, for addressing the complex socio-economic, structural, and technological and other strategic development objectives of Russia for realizing its national interests and providing a supportive living environment, there is a need do exist for integration of private enterprise economic potential and the capabilities of the state.

\section{REFERENCES}

1. Information and analytical materials for the meeting of the Public Council under the Ministry of Transport of the Russian Federation on the issue «The state and prospects of the public net-work roads development» [Electronic resource] / Ministry of Transport of the Russian Federation, 2010.

2. Smith A. Research on the nature and causes of the nation's wealth. - M.-L., 1935 - P.32

3. Amunts D.M. «Public-private partnerships. The concession model in the joint participation of public and private sector in implementing financial sector-capacity projects» / / Directory cultural institution. - 2005. - №12.

4. Chonka A. «Public-private partnership: the symbiosis of government and business» [Electronic resource] / Law Portal «Akron», 2010. - Mode of access: http://arkongroup.ru/see.php?see $=56$

5. Varnavsky V.G., Klimenko A.V. Public-private partnership: theory and practice // State University - Higher School of Economics. - Moscow: University of Higher School of Economics, 2010. - p. 119-125

6. Alpatov A.A. et al. Public-Private Partnership: Implementation Mechanisms // LLC "Alpina", 2011. - Mode of access: http://thelib.ru/books/a_v_pushkin/

7. "About strengthening of the tenants' influence on the development of leasing construction machinery in Russia» [Electronic resource] / Portal on the special road and construction equipment «ADC Engineering», 2011. - Mode of access: http://www.adctehnika.ru/content/review/4145/Lizing-vzyalsya-za-novoe/

8. R. Romanovsky «The leasing market for the 2016» [Electronic resource] / Rating agency Expert RA, 2016. - Mode of access: https://raexpert.ru/researches/leasing/2016/part1

9. Moskvin "Leasing - the best way to update the fixed assets» [Electronic resource] / Online magazine «Fixed assets», 2006. - Mode of access: http://www.os1.ru/article/business/2006_06_A_2006_11_03-17_47_43/ 
DOI https://doi.org/10.18551/rjoas.2017-09.18

\title{
MANAGEMENT OF ACCELERATION TIME BY USING TIME COST TRADE OFF METHOD ON CONSTRUCTION PROJECT OF INTEGRATED OFFICE OF SAMARINDA
}

\author{
Rio Wahyu Yusuf*, Putranto Edi Hargono Dwi, Mulyadi Lalu \\ Study Program of Civil Engineering, Concentration on Construction Management, \\ National Institute of Technology, Malang, Indonesia \\ *E-mail: wahyusufrio@gmail.com
}

\begin{abstract}
Time and cost analyzes were conducted in this research; which were required in the application of Time Cost Trade Off (TCTO) in finishing construction project of Samarinda Integrated Office. In order to realize the picture of the acceleration, it began with the creation of Critical Path Method (CPM) network to know the existence of critical path. Moreover, the application of TCTO method was conducted to find the cost slope value from each of these critical activities. In order to realize the acceleration, the compression on critical work items was conducted starting from the lowest cost slope value. The result of this research produces two alternatives. Alternative I obtained the overtime over one activity from 1 hour to 4 hours, the time and cost were found in the 2-hour-overtime alternative to ACP plank list job, it obtained the time for 408 days from the normal amount for 410 days. Meanwhile, for the cost, it obtained IDR 41.356.071.000,00 from the total normal cost of IDR 40.623.401.000,00 or there was additional cost of IDR 732.670.000,00. Whereas in alternative II, it was obtained overtime of some activities from 1 hour to 4 hours overtime, time and cost were obtained in 1-hour overtime on ground foundation work, the ground work of the sand under the foundation, ACP plank list, window door, and dry hand, with 398 days and a fee of IDR 41.440.678.000,00 (there was additional fee of IDR 817.277.000,00).
\end{abstract}

\section{KEY WORDS}

Planning, scheduling, financing, crashing, time cost trade off.

The present development of construction services in Indonesia is rapidly progressing with the large number of projects are undertaken on a large scale, whether it is built by the government, the private sector, or a combination of both. By the growing development in Indonesia, especially in the area of Samarinda, competition among contractors who are engaged in the construction world becomes more competitive, so that time factor is very important in addition to cost factor in a project completion, (Sheremata, 2000). Discrepancy frequently occurs in the implementation of construction projects between the time schedule and the realization in the field, so that it may cause delays, (Feng et al, 1997). The delays are caused by lack of discipline of human resources, lack of equipment, delays in material delivery and delays in the costs of construction implementation, (El-Rayes and Kandil, 2005). Some ways are made to overcome the delays, such as holding a shift job, extending the work time (overtime), using more productive tools, increasing the number of labor, using materials that can make the work faster, all of which are intended to speed up the duration of project implementation, (Cohen et al, 1996). Among these alternative acceleration, overtime alternative is better to be applied, because extending work time may help in reducing the overall time of an activity, it can reduce the duration of an activity by $33 \%$ (Ward and Chapman, 2003).

The research of this case is the construction project of Integrated Office of Samarinda. This project was implemented with implementation time of 410 days of the calendar, and the budget was Rp. 40,623,400,000.00 (forty billion six hundred twenty three million and four hundred thousand rupiah). This project was planned from October 24, 2014 and completed on December 7, 2016, but in its implementation the project was experiencing delays. On October 24, 2014 the project should be workable, but in its implementation, the project could 
be conducted on November 1, 2014. This was due to the late availability of the Spun Pile D 45 foundation, so it caused delay to other activities.

According to the regulation of project delay fines, Article 120 of Presidential Decree No. 70 of 2012, concerning the delay sanction, it says that the provider of goods/services who are late in completing the work within the time stipulated in the contract due to the mistake of the provider of goods/services, shall be liable to a fine of 1/1000 (one thousandth) of the contract value or the contractual portion value for each day of delay.

According to the matter, to restore the level of progress of the project to the original time schedule, it would require an effort of acceleration, although it will cause the rising cost of the project, (Tavana et al, 2014). Such efforts can be analyzed by exchanging cost against time by using Time Cost Trade Off (TCTO) method. The TCTO method aims to make an attempt for an acceleration of an activity duration, by conducting tests for all critical activities, so that the acceleration is followed by an increase in the total project cost, which is kept as minimum as possible.

\section{LITERATURE REVIEW}

Network Planning. Suharto (2001) stated that principally, network planning is a dependency relationship between the parts of the work that is illustrated in the network diagram, so that it is known which parts of work should take precedence and which work should wait for the completion of another work.

CPM Calculation Procedure. Suharto (2001) mentioned that Critical Path Method (CPM) uses counting forward and counting backward. Counting forward is intended to find out the earliest time to start and end each work without delay. While counting backward is intended to determine the time or the latest date to start and end of each work, without delaying the overall project completion time, which have been resulted from the counting forward, (Robertson and Ulrich, 1998).

Float and Critical Track. Suharto (2001) argued that float is the allowed time where the works can be delayed. In the CPM method, there are three types of floats; they are Total Float (TF), Free Float (FF), and Interferent Float (IF).

Project Costs. American Association of Cost Engineering (1992) stated that there are several types of costs related to the cost of construction project (Hegazy, 1999), they can be divided into two types, as follows:

- Indirect costs

Indirect costs are costs that are indirectly related to the construction, but it must exist and can not be separated from the project. Indirect costs include overhead costs, profit, unexpected costs, and value added tax (VAT).

- Direct costs

Direct costs are costs that are incurred and directly related to ongoing project activities. Direct costs include material costs, labor costs, and tool costs.

Time Cost Trade Off. Time cost trade off is a deliberate, systematic and analytical process by doing testing of all works in a project that focus on the work that is on the critical track, (Roemer et al, 2000). Suharto (2001) argued that the total project cost is the sum of both direct and indirect costs. The amount of this cost depends on the duration of the project completion. Both of them change according to the time and progress of the project. Further analysis of the relationship between time and cost of a work are mentioned below.

- Normal Duration (ND);

- Crash Duration (CD);

- Normal Cost (NC);

- Crash Cost (CC).

Compression of Time Cost Trade Off. Soeharto (2001) argued that in accelerating the completion of a project by compressing the duration of activities, efforts are made to make the additional costs as minimum as possible. Control of the cost that is conducted is direct costs, because this cost will increase if the duration is decreased. Compression is only 
conducted on activities that are on the critical track. If compression is conducted on activities that are not on the critical path, the overall project completion time will remain the same. Compression is conducted firstly to the activity that has the lowest cost slope and is on the critical track.

\section{METHODS OF RESEARCH}

This research is a quantitative research that was conducted on construction project of an Integrated Office. This project had a budget of IDR 40.623.400.000,00 with normal implementation time for 410 days of the calendar. This research uses primary and secondary data. Primary data includes data that were obtained from the main source or from the project. The primary data sources are from the employees of the company and construction project of Integrated Office. The primary data are obtained by observation and interviews with the head of the project about the overhead cost. To support the primary data and become input and research reference, secondary data are obtained through working drawings, network planning, Budget Plan (RAB), S curve (Schedule), core personnel data, and Samarinda City Map.

Data are collected through the interviews to the head of the project that is directly involved in project implementation. The collected data are processed, related to the identification of critical track and project cost that include direct costs and indirect costs, before analyzing TCTO on the construction project of Integrated Office Samarinda. Data analysis technique were used in this study includes the calculation of the number of activities that are on the critical track in the network planning, direct costs and indirect costs, and the setting of the scenario analysis of TCTO method. In the implementation of this scenario, TCTO used the alternative of work time.

Acceleration of Network Planning. After compression of overtime 1 hour to 4 hours, one of the acceleration of overtime alternative is advantageous in terms of time and cost. In terms of time, the fastest and the most effective cost will be made again in the acceleration of network planning, (Haga and Marold, 2004). The steps in preparing the CPM network planning are as follows:

- Collect secondary data from the project in the form of curve $S$ so that it is the reference material of duration.

- Identify the scope of the project and break it down into components of activity.

- Compile the components of activities on the project in the order of dependence logic into network planning.

- Provides an approximate time curve according to the duration of the project for each job.

- Identify the critical track, float, and duration of the project.

\section{RESULTS AND DISCUSSION}

Identify the Critical Track. Construction project of Integrated Office of Samarinda consisted of four main works. Each part as composed of more specific work items. In scheduling the project, time schedule was used (curve S). The project was scheduled for completion in 410 days of calendar, starting from October 24, 2014 until December 7, 2016, but in its implementation, the project was delayed. On October 24, 2014 the project should had been workable but it was started on November 1, 2014.

Identification of Project Costs. In construction project of Integrated Office of Samarinda, the contract value is IDR $40.623 .401 .000,00$. In this case, analyzing the acceleration of the project time may affect the cost of the project itself, then project costs will first be detailed with indirect and direct costs, as a follow up of the TCTO method.

Indirect Costs. Indirect costs are costs that are not directly related to construction, but it must exist and can not be separated from the project. Indirect costs include overhead costs, profit, unexpected costs and value added tax (VAT) which can be explained as follows. 
Overhead Costs. Overhead costs are the salaries of project staff and the cost of field facilities. The overhead cost that has been identified in the construction project of Integrated Office of Samarinda is IDR $890.000,00$.

Table 1 - Total Overhead

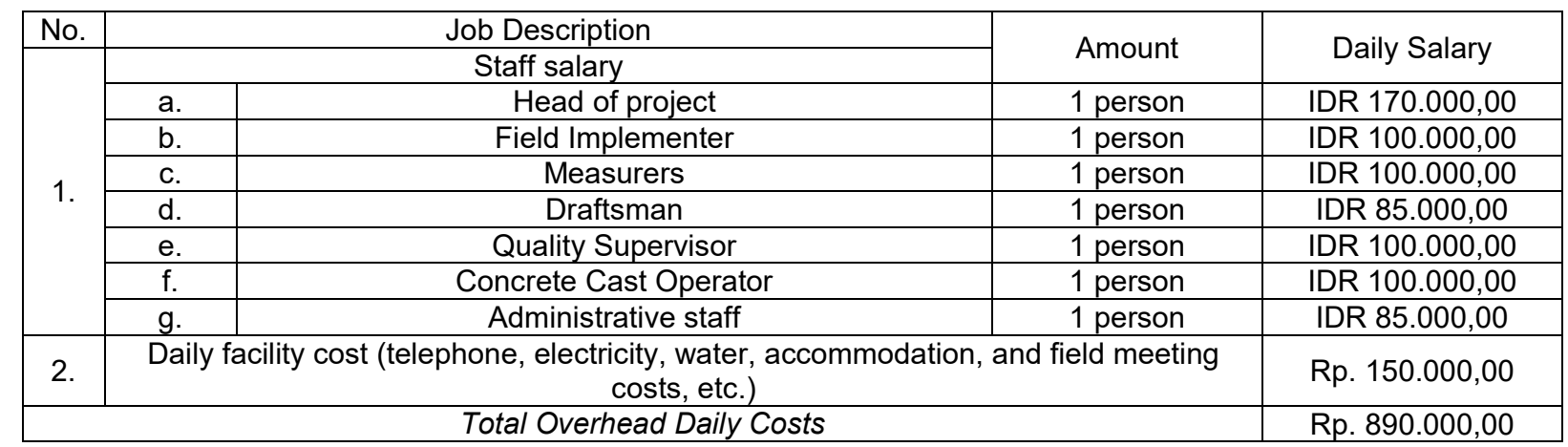

Staffs, who are directly involved in overtime work at the project site are field implementers and quality supervisors.

Details of overtime costs for staffs in the field are as follows:

Total of staff salary per day $=$ Salary of the implementers + quality supervisors $=$ Rp. $200.000,00$

$$
\text { Total of staff salary per hour }=\frac{\text { Total salary per hour }}{\text { Normal worktime }}=\frac{\text { IDR 200.000,00 }}{7 \text { Hours }}=\text { IDR 28.571,43 }
$$

So, the total overtime salary of the staff per day from 1 hour to 4 hours is as follows:

Total 1 hour overtime salary of the staff $=\left(J k_{1} \times 1.5 \times\right.$ total salary per hour $)$ $=(1$ hour $\times 1.5 \times$ IDR 28.571,43) $=$ IDR 42.857,14

Total 2 hours overtime salary of the staff $=\left(J k_{1} \times 1.5 \times\right.$ total salary per hour $)+\left(J k l_{1} \times 2 \times\right.$ total salary per hour $)$ $=(1$ hour $\times 1.5 \times$ IDR 28.571,43) + (1 hour $\times 2 \times$ IDR 28.571,43) $=$ IDR 100.000,00

Total 3 hours overtime salary of the staff $=\left(J k_{1} \times 1.5 \times\right.$ total salary per hour $)+\left(J k l_{2} \times 2 \times\right.$ total salary per hour $)$ $=(1$ hour $\times 1.5 \times$ IDR 28.571,43) + (2 hours $\times 2 \times$ IDR 28.571,43) $=$ IDR 157.142,86

Total 4 hours overtime salary of the staff $=\left(J k_{1} \times 1.5 \times\right.$ total salary per hour $)+\left(J k l_{3} \times 2 \times\right.$ total salary per hour $)$ $=(1$ hour $\times 1.5 \times$ IDR 28.571,43) + (3 hours $\times 2 \times$ IDR 28.571,43) $=$ IDR 214.285, 71

Advantages. Contractor profit is profit earned on a project that has the difference between the Budget Plan with the Budget Implementation Plan, (Dickinson et al, 2001). Profit is divided into two kinds: gross profit and net profit. The gross profit is $10 \%$ of the real cost, which includes the overhead cost that is borne by the contractor.

Table 2 - Real Cost

\begin{tabular}{|c|c|c|c|}
\hline No. & Job Description & \multicolumn{2}{|c|}{ Total price } \\
\hline 1. & Preparatory Work & IDR & $77.990 .750,00$ \\
\hline 2. & Structural Work & IDR & $18.021 .465 .129,90$ \\
\hline 3. & Architectural Work & IDR & $6.631 .945 .075,55$ \\
\hline 4. & Mechanical and Electrical Work & IDR & $12.198 .963 .200,00$ \\
\hline \multicolumn{2}{|r|}{} \\
\hline
\end{tabular}

Here is the calculation of the gross profit and net profit on the project below:

Gross profit $=$ Real cost $\times 10 \%=I D R 36.930 .364 .155,45 \times 10 \%=I D R 3.693 .036 .415,55$

Net profit $=$ Gross profit - (Overhead cost per day $x$ Implementation time)

$=I D R$ 3.693.036.415,55 $-(I D R 890.000,00 \times 410)=I D R 3.328 .136 .415,55$ 
Unexpected costs. Based on the letter of chartering agreements (contracts), the amount of unexpected costs are $2 \%$ of the real cost. The calculation of the unexpected cost of the project is as follows:

$$
\begin{gathered}
\text { Unexpected costs }=\text { Real cost } \times 2 \%=I D R 36.930 .364 .155,45 \times 2 \%=I D R 738.607 .283,11 \\
\text { Unexpected costs per day }=\frac{\text { Unexpected Cost }}{\text { Time Implementation }}=\frac{I D R 738.607 .283,11}{410 \text { days }}=I D R 1.801 .481,18
\end{gathered}
$$

Value Added Tax (VAT). Based on the letter of chartering agreements (contracts) of the cost of the Value Added Tax (VAT) is $10 \%$ of the real cost that is borne by the contractor. The calculation of the amount of VAT cost on the project is as follows:

Value Added Tax $($ VAT $)=$ Real cost $\times 10 \%=$ IDR 36.930.364.155,45 x 10\% = IDR 3.693.036.415,55 as follows:

So the indirect costs of the construction project of Integrated Office of Samarinda are Indirect costs $=($ implementation time $x($ overhead costs per day + unexpected costs per day $))+$ net profit + VAT
$=(410$ days $x($ IDR 890.000,00 + IDR 1.801.481,18) $)+$ IDR 3.328.136.415,55 + IDR 3.693.036.415,55
$=$ IDR 8.124.680.115,20

Direct Cost. Direct costs are costs that are directly related to project work in the field. The direct costs in this project are the cost of workers' salary and material costs.

$$
\begin{gathered}
\text { Direct cost }=\text { Real cost }- \text { gross profit }- \text { unexpected costs of } 2 \% \\
=I D R 36.930 .364 .155,45-I D R 3.693 .036 .415,55-I D R 738.607 .283,11=I D R 33.237 .291 .710,28
\end{gathered}
$$

The Implementation of Time Cost Trade Off Method. The steps of applying TCTO method on alternative calculation of overtime changes, which are to be tested from 1 hour to 4 hours of maximum limit, will be given examples for excavation work of foundation ground in the calculation of 2 hours overtime as follows:

Normal duration is the period of time that is required to complete the work normally. Crash duration or the shortened period is the shortest time to complete a job that is technically still allowed to be accelerated. After the daily productivity after the crash increases, the time that is required to complete a job will be increased. Here is the calculation of crash duration for some work.

$$
\text { Crash Duration of foundation soil excavation }=\frac{\text { Volume }}{\text { Daily productivity after crash }}=\frac{468,90 \mathrm{~m}^{3}}{1.201,11 \mathrm{~m}^{3} / \mathrm{day}}=0.39 \text { day }
$$

Normal cost is the cost required to complete the work at the normal time period. The following is a normal cost calculation for some work, as follows:

$$
\begin{aligned}
& \text { Normal Cost of foundation soil excavation }=\text { ND } \times \text { Normal Cost of worker per day } \\
& =0.48 \text { day } \times \text { IDR } 62.325 .183,21=I D R 29.892 .375,00
\end{aligned}
$$

Crash Cost or cost for a shortened time is the amount of costs / salary of workers that are required to complete a work with an accelerated time period (Crash Duration). Here's a crash cost calculation of some works:

$$
\begin{gathered}
\text { Crash Cost of foundation soil excavation }=\text { Crash Cost of worker per day } \times \text { Crash Duration (CD) } \\
=I D R 93.487 .774,82 \times 0.39 \text { day }=I D R 36.496 .504,36
\end{gathered}
$$

Cost Slope is the increase of the direct costs to speed up an activity per unit of time. The following is the calculation of Cost Slope for some works, as follows:

$$
\text { Cost Slope (CS) of foundation soil excavation }=\frac{\text { Crash Cost }- \text { Normal Cost }}{\text { Normal Duration }- \text { Crash Duration }}=I D R \text { 74.011.155,07 }
$$


In the CPM method there are two estimates of time and cost for each activity in the network planning. Both of these estimates are approximate completion time and costs that are normal (normal estimate) and the estimated time of completion and costs that are accelerated (crashes estimate).

In the process of speeding up the project completion time by emphasizing the duration (compression), it is strived for additional costs to be as minimum as possible. Compression is conducted on all works that are on the critical track and are started from the works that have the lowest value of cost slope. From the steps of the compression, it will be sought for the fastest time of completion of the total project cost to be as minimum as possible.

The analysis of normal step:

1. Age of the project $=410$ days

2. Direct cost $=$ IDR $32.237 .291 .710,28$

3. Indirect costs $=$ IDR 8.124.680.114,20

4. Total cost $=$ Direct Cost + Indirect Cost $=$ IDR 40.623.400.000,00

The analysis of compression step I:

1. Cost Slope $=$ IDR 74.011.155,07

2. Normal Duration $=0.48$ day

3. Crash Duration $=0.39$ days

4. Total $\mathrm{Crash}=$ Normal Duration - Crash Duration $=0.09$ day

5. Total duration of the project $=$ Age of the project - Total Crash $=409.91$ day

6. Additional fee $=$ Cost Slope $\times$ Total Crash $=$ IDR 6.604.129,36

7. Direct cost $=$ Normal direct cost + Additional cost $=R p 33 \cdot 242 \cdot 130 \cdot 388,08$

8. Additional staff overtime charge $=$ Overtime Cost for staff $/$ day $\times$ Crash Duration $=$ IDR $39.038,80$

9. Indirect costs $=($ Total project duration $x$ (Daily overhead cost + Unexpected daily cost $))+$ Net profit + VAT + Additional overtime staff costs = IDR 8.124.478.987,99

10. Total Cost $=$ Direct Cost + Indirect Costs $=$ IDR 41.366.609.000,00

11. Added Cost $=$ Total accelerated costs - Total normal costs $=$ IDR $743.208 .000,00$

Accelerated Adjustment to Target. In this case, a very advantageous step in terms of time is on alternative II, it is to have for 7 activities for 1 hour. The critical activity that has overtime for over 1 hour is the board works, spun pile stakes, sand excavation under the foundation, plank list works, installation of $9 \mathrm{~mm}$ gypsum ceiling, window doors, and dry hand. The cost is IDR 41.440.678.000,00 from the total normal cost of IDR $40.623 .401 .000,00$ or the additional cost of IDR $817.277 .000,00$. After that, it looks for suitable schedule with 8 days of delays, and then it looks for acceleration for 8 days. It is conducted with the addition of 1 hour of overtime work. It is not having overtime work for the installation of $9 \mathrm{~mm}$ gypsum plafond and dry hand activities.

Table 3 - Recapitulation of Overtime Alternative

\begin{tabular}{|c|c|c|c|c|c|c|}
\hline No. & & vertime & Time & Acceleration & Total Cost & Additional Cost \\
\hline 1 & & Normal & 410 & - & IDR 40.623.401.000,00 & - \\
\hline 2 & \multicolumn{6}{|c|}{ Alternative I } \\
\hline & $a$ & 1 Hour & 408 & 2 & IDR 41.356.736.000,00 & IDR 733.335.000,00 \\
\hline & $\mathrm{b}$ & 2 Hours & 407 & 3 & IDR 41.356.071.000,00 & IDR 732.670.000,00 \\
\hline & $\mathrm{C}$ & 3 Hours & 407 & 3 & IDR 41.357.156.000,00 & IDR 733.755.000,00 \\
\hline & $d$ & 4 Hours & 406 & 4 & IDR 41.359.782.000,00 & IDR 736.381.000,00 \\
\hline 3 & \multicolumn{6}{|c|}{ Alternative II } \\
\hline & $a$ & 1 Hour & 398 & 12 & IDR 41.440.678.000,00 & IDR 817.277.000,00 \\
\hline & $\mathrm{b}$ & 2 Hours & 390 & 20 & IDR 42.380.342.000,00 & IDR 1.756.941.000,00 \\
\hline & $\mathrm{C}$ & 3 Hours & 385 & 26 & IDR 44.315.223.000,00 & IDR 3.691.822.000,00 \\
\hline & $d$ & 4 Hours & 382 & 29 & IDR 47.170.344.000,00 & IDR 6.546.943.000,00 \\
\hline
\end{tabular}

After conducting acceleration by the addition of overtime hours of 1 hour up to 4 hours, acceleration by the addition of 1 hour worktime was chosen with the total cost of IDR 41.440.677.900.01. Then from the acceleration of 1 hour overtime, acceleration is tried again to get the results of 8 days acceleration that aims for the on time implementation of activities according to the time schedule. 
From the 8 days acceleration, it is obtained values for total cost of IDR 41.449.583.302,64 which has a greater value than 12 days of acceleration. So 12 days acceleration is chosen to avoid the amount of additional costs due to the acceleration from IDR 826.182.000,00 to IDR 817.277.000,00. Thus, the project completion time of 398 days can be rescheduled (rescheduling) by using network planning.

\section{CONCLUSION AND RECOMMENDATIONS}

With the addition of 1 hour overtime, the acceleration time for completion of the construction project is 12 days. Or the project completion duration is 398 days from the remaining 402 days of completion target: total cost needed after the acceleration by using TCTO is IDR 41.440.678.000.00 of the total normal cost of IDR 40.623.401.000,00; additional cost is IDR 817.277.000,00.

For the construction entrepreneur party, if the project certainly will not experience delay of a predetermined schedule on specific contractual agreements, but if accelerated step is conducted, then in the implementation of TCTO method, only one of the critical activities can have the overtime. It is because, in addition to completing the project faster, in terms of the cost of acceleration, it will require a little additional cost.

When delay is occuring by pursuing a predetermined schedule of contractual agreements, it is advisable to apply TCTO methods to some critical activities. This is because in addition to completing the project on time or faster, the required cost for the acceleration can be clearly identified through the TCTO method approach.

For the next researcher, it is suggested that the research can do the optimization of time and cost and development of another acceleration method, and using the latest SNI for its resource requirement.

\section{REFERENCES}

1. AACE (1992). Skills and Knowledge of Cost Enggineering, 3rd Ed., ACE, West Virginia.

2. Cohen, M. A., Eliasberg, J., \& Ho, T. H. (1996). New product development: The performance and time-to-market tradeoff. Management Science, 42(2), 173-186.

3. Dickinson, M. W. (2001). Technology portfolio management. IEEE Transactions on engineering management, 48(4), 518-527.

4. El-Rayes, K., \& Kandil, A. (2005). Time-cost-quality trade-off analysis for highway construction. Journal of construction Engineering and Management, 131(4), 477-486.

5. Ervianto, WI 2004, Teori Aplikasi Manajemen Proyek Konstruksi, Andi, Yogyakarta.

6. Feng, C. W., Liu, L., \& Burns, S. A. (1997). Using genetic algorithms to solve construction time-cost trade-off problems. Journal of computing in civil engineering, 11(3), 184-189.

7. Haga, W. A., \& Marold, K. (2004, June). A simulation approach to the PERT/CPM timecost trade-off problem. Project Management Institute.

8. Hegazy, T. (1999). Optimization of construction time-cost trade-off analysis using genetic algorithms. Canadian Journal of Civil Engineering, 26(6), 685-697.

9. Robertson, D. (1998). Planning for product platforms. Sloan management review, 39(4), 19.

10. Roemer, T. A., Ahmadi, R., \& Wang, R. H. (2000). Time-cost trade-offs in overlapped product development. Operations Research, 48(6), 858-865.

11. Sheremata, W. A. (2000). Centrifugal and centripetal forces in radical new product development under time pressure. Academy of management review, 25(2), 389-408.

12. Soeharto, I 2001. Manajemen Proyek - Dari Konseptual Sampai Operasional, Jakarta.

13. Tavana, M. (2014). A new multi-objective multi-mode model for solving preemptive tradeoff project scheduling problems. Expert Systems with Applications, 41(4), 1830-1846.

14. Ward, S., \& Chapman, C. (2003). Transforming project risk management into project uncertainty management. International journal of project management, 21(2), 97-105. 
DOI https://doi.org/10.18551/rjoas.2017-09.19

\title{
TIME AND COST EFFICIENCY ANALYSIS WITH FAST TRACK METHOD ON SAMARINDA-ANGGANA ROAD IMPROVEMENT PROJECT
}

\author{
Rizaldi Muhammad Yusuf*, Hidayat Sutanto, Santosa Andrianus Agus \\ Study Program of Civil Engineering, Concentration on Construction Management \\ National Institute of Technology Malang, Indonesia \\ *E-mail: myrizaldii@gmail.com
}

\begin{abstract}
On Samarinda-Anggana Road Improvement Project, in estimating the time and cost of a project, an acceleration process is needed. Acceleration is usually done to optimize the duration of existing activities and to minimize risk but it still gets optimal results. One of the ways to achieve time and cost efficiency is by using the method of "Fast Track" with modification of CPM model scheduling on the activities of the critical path. The objectives of this research are: 1) Determining the optimal result with the Fast Track process on the project, 2) Determining the cost plan for the time acceleration, 3) Calculating the amount of time difference of optimum acceleration in the completion of road improvement project and cost caused by acceleration. This research uses fast track method. From the calculation of the project duration using fast track method, the following results are obtained: 1) road improvement project of Samarinda - Anggana calculated with the CPM model with normal duration in the contract time is 210 days, so the project needs to be accelerated by Fast Track method that produces acceleration duration to 171 days, 2) the optimum cost incurred in the normal duration or the project budget plan is Rp.16.677.156.783,43 and costs gained after Fast Track method is Rp. 16.522.297.470,44, 3) the difference in duration between normal time and after fast track is 39 days. While, the difference in cost between normal time and after using Fast Track is Rp.154.859.312,99, it can be concluded that it saves $0.93 \%$ from the normal cost.
\end{abstract}

\section{KEY WORDS}

Efficiency, fast track, project.

As the development of the industrial world goes by as well as the development of transportation facilities, especially roads that are growing rapidly, the difficulty level to manage and run a road project is much higher. The higher the difficulty level, the longer the length of time required to complete the project, (Davidson, 2002). Therefore, it is necessary to have time management which in addition to sharpen priorities, it also tries to improve the efficiency and effectiveness of project management in order to achieve maximum results from available resources, (Zhu et al, 2009). Everything is to achieve the goal of a road improvement project that is success that meets the criteria of time (schedule), as well as cost (budget) and quality, (Akbar, 2002).

In addition to time management, absolutely it also must be followed by the implementation of a good project and in accordance with its planning, (Hellriegel and Slocum, 2006). With good time management and execution, the risk of a road construction project will have a little retardation. This will directly reduce the project cost of the project, and it will ultimately provide its own advantages for contractors as responsible for project implementation. Each construction project typically has a specific implementation plan and implementation schedule: when the project should begin, when it should be completed, how it will be done, and how its resources are provided, (Carayannis et al, 2005). The common impact that often happens is the retardation in project implementation time, besides the increased cost of project implementation. The retardation of project execution generally always has adverse consequences for both owners and contractors because the impact of retardation is conflict and debate about what and who causes, as well as the demands of 
time and added costs. Therefore, it is necessary here to have a time management which in addition to sharpen the priority, it also attempts for efficiency increase.

Project implementation is confronted with three problems: cost, time, and quality, (Söderlund, 2004). These three problems can be interpreted as the targets of the project, which is defined as appropriate cost, appropriate time, and appropriate quality. The success of the project activities is tied to these three objectives, to the extent that the three elements of cost, time, and quality can be met. Time management includes the processes needed to ensure the completion time of the activity. Time management systems concern on whether or not planning and scheduling activities are running. In which in planning time scheduling activities, specific procedures have been provided to complete construction activities more quickly and efficiently. For the sake of the smooth running of a project, management is needed that will manage the project from start to the end of project, specifically project management. The field of project management grows and evolves because of the need in the modern industrial world to coordinate and control complex activities. Project management has a special nature, in which time management work is limited by a predetermined schedule.

Changes in conditions so quickly demand that each of the leaders involved in the project to anticipate the situation, as well as arrange the necessary forms of action. This can be done when there is a mature planning concept and is based on data, information, capabilities, and experience. The success or failure of the implementation is often caused by lack of project plan activities and less effective controls, resulting in inefficient project activities, resulting in retardation, declining quality of work, and increasing implementation costs. The retardation in completion of the project itself is a very undesirable condition as this can cost both parties, both in terms of time and cost. In relation to the time and cost of production, the company must be as efficient as possible in the use of time in each activity, so the cost can be minimized from the initial plan.

In the projects of roads and bridges for example, good management of work scheduling is highly needed, therefore it needs to be handled with careful calculations. A project is considered good if the project completion is efficient in terms of time and cost and it achieves work efficiency, both human and equipment (Badri, 1997). Resource needs for each project activity may be different, so there is a possibility that resource fluctuation occurs. This need fluctuation will affect the budget because there is a moment when resources are not empowered while the costs remain out, in which it is called fixed cost.

In the construction industry, the provisions regarding cost, quality, and timing of the construction work completion are bound within the contract and are set before construction work is realized. As it is known, the completion time needed for the construction work process is always included in the contract document as it will have an important effect on the value of the auction and the financing of its own work. Uncontrolled timing of the construction work will cause the owner to have difficulty in finishing the work of a project, as well as the contractor may incur a cost loss so that the contractor in this case should always try to control the execution time as outlined in the work plan which has been determined,in the process of construction work without neglecting quality control. Time, cost, and quality are inseparable unity. The series in construction activities are sequential and interrelated. In planning a project, a decision maker is often confronted with an option in establishing appropriate resources, such as the number of labor, equipment, method, and technology to realize a construction project activity (Morel et al, 2001).

Each selection of defined activities will lead to time, cost, and quality of a project activity (Coulter, 2004). For construction projects in general, the quality is an element that must be maintained in order to always be in accordance with the planning, whereas if retardation in the execution of the project occurs or because of the request of the owner/project owner to shorten the execution time, it is necessary to accelerate the project execution time, (Williams, 1995). This study specifically discusses the realization of project management on the basis of time acceleration and cost savings on Implementation of Road Improvement Activity in Samarinda-Anggana, East Kalimantan Province. Based on data obtained from East Kalimantan Provincial Planning Office, there are several projects that 
have retarded the implementation period started from the Road Enhancement Pack to the Road Maintenance Package. From this experience, it is necessary to have an appropriate plan, which in this case, depends on the Implementation Method used.

The factors that experience or cause retardation are divided into two parts: 1) technical factors, which are directly related to the implementation of activities. The elements included in this technical factor are as follows: the quality and experience of on-site labor, the availability of on-site equipment, the complexity of the work, the availability of materials at the site, the number of labor in an activity, inter-activity relation, the presence of concerted work, 2) Non-technical factors are factors that include technical issues such as: weather, project location, inter-worker relationship, perpetrator leadership style (Daniels et al, 1999).

In this Samarinda-Anggana Road Improvement Project, there are two main areas of work: Stone Installation Work with mortar and mortar concrete road hardening work. In estimating the time and cost of a project, it is necessary to accelerate the process. Acceleration is usually done to optimize the duration of existing activities and minimize risk but still get optimal results, (Azhar, 2011). One of the ways to achieve time and cost efficiency is by using the method of "Fast Track" with modification of CPM model scheduling on the activities of the critical path. By using this method, it is expected to optimize as well as save time and cost on the improving road project in Samarinda - Anggana.

Based on the description on the background, the present research problems are as follows: 1) how long time duration needed by accelerating the activities that are in the critical path on the project work network?, 2) how is the total cost after Fast Track?, 3) how much the difference of time before and after doing Fast Track?. From these problems, this research aims at: 1) Determining the optimal result with the Fast Track process in the project, 2) Determining the cost plan for the time acceleration, 3) Calculating the difference of the optimal time acceleration of the completion of the road improvement project and the cost by doing acceleration.

\section{METHODS OF RESEARCH}

This research is supported by fast track method. Fast track method is a method of acceleration in development by performing activities in parallel or overlap with faster implementation time and more efficient cost, (Kehlet and Wilmore, 2005). The steps of conducting this research are as follows:

1. Identify the activities involved in the project;

2. Identify the interdependence relationship between activities within the project;

3. Determine the time needed;

4. Build project work network;

5. Determine the critical path;

6. Accelerate with Fast Track on critical paths and have long duration. Fast Track analysis steps are as follows (Tjaturono and Mochtar, 2009):

- Logic activity on the critical path is applied to the principle of parallel system or completion of one activity with another activity.

- Logic activity in the relationship between activities must be rational with empirical conditions and use productivity rill.

- Thoroughly consider the volume, timing of resources, and productivity available on critical path activities.

- Do a Fast Track on a critical path only, especially on activities that have the longest duration.

7. Determine the time that will be accelerated and perform the desired acceleration to speed up the execution time with Fast Track, (Pena-Mora and Li, 2001):

- Determine the critical path on the CPM model, which activity is with the longest time;

- How long it takes to accelerate;

- How much time is possible on other critical trajectory activities; 
- Further acceleration can be done if the above acceleration time still cannot overcome the expected time delay;

- Get a network model with CPM method that has been in Fast Track. so that the goal of time acceleration is obtained;

- Doing Fast Track on activities that pass through critical path, this is done repeatedly until several phases and reach saturation time that is until there is no activity that can be done using Fast Track, calculate time obtained after Fast Track with some phases until Saturation time;

- Calculate the cost that can be from the phases that have been accelerated in time;

- Compare time and cost between several Fast Track phases, then compare it to initial time and cost.

\section{RESULTS AND DISCUSSION}

Analysis of CPM (Critical path method) and Fast Track. This study analyzes the acceleration duration for Samarinda-Anggana Road Improvement Projects along $1.95 \mathrm{~km}$, and costs incurred by acceleration using CPM (Critical Path Method) Fast Track. In the process, this method describes the parts of the work in the project and rearranges them in accordance with the logic of dependence, so that afterwards work network for the project can be made. The calculation uses the time and cost data of each parts of the activities which have been arranged in order obtained from the Provincial Public Works Office of East Kalimantan Province's Highways Division. The total project completion according to the contract for 210 calendar days which its work starts from 20 July 2016 - 08 December 2016 with total project cost is Rp.18.344.872.000,00 including Value Added Tax (VAT).

Table 1 - Job description

\begin{tabular}{|c|l|}
\hline No. & \multicolumn{1}{|c|}{ Description } \\
\hline 1 & Mobilization \\
\hline 2 & Excavation for Drainage Drains and Drainage Canals \\
\hline 3 & Pairs of Rocks with Mortar \\
\hline 4 & Ordinary Excavation \\
\hline 5 & Ordinary stockpiling from excavation sources \\
\hline 6 & Class B Aggregate Footing Layers \\
\hline 7 & Class A Aggregate Footing Layers \\
\hline 8 & Class B Aggregate Footing Layers \\
\hline 9 & Cement Concrete Road Pavement \\
\hline 10 & Footing Layers under Lean Mix Concrete \\
\hline
\end{tabular}

Time Schedule Analysis. From the Time Schedule table that has been made by the contractor, it can be concluded as follows: time Schedule made in the form of work recapitulation and not detail in accordance with the activity dependency; distribution of percentages per week is based on estimation only; the critical activity is unknown which its duration should still be accelerated.

Table 2 - Job description

\begin{tabular}{|l|l|l|l|}
\hline No. & \multicolumn{1}{|c|}{ Job description } & Activity & Duration \\
\hline 1 & Mobilization & A & 24 \\
\hline 2 & Excavation for Drainage Drains and Drainage Canals & B & 70 \\
\hline 3 & Pairs of Rocks with Mortar & C & 94 \\
\hline 4 & Ordinary Excavation & D & 46 \\
\hline 5 & Ordinary stockpiling from excavation sources & $\mathrm{E}$ & 70 \\
\hline 6 & Class B Aggregate Footing Layers & $\mathrm{F}$ & 82 \\
\hline 7 & Class A Aggregate Footing Layers & $\mathrm{G}$ & 70 \\
\hline 8 & Class B Aggregate Footing Layers & $\mathrm{H}$ & 70 \\
\hline 9 & Cement Concrete Road Pavement & $\mathrm{I}$ & 94 \\
\hline 10 & Footing Layers under Lean Mix Concrete & $\mathrm{J}$ & 82 \\
\hline
\end{tabular}


Activity Type Grouping. In order to be more efficient and more optimal in arranging the project work network, it is necessary to group similar or cognate works and to combine the volume of each activity by equalizing the volume, (Stevenson and Hojati, 2007). The principle of equality lies in the ratio of the lowest unit costs and and the biggest unit cost multiple with the work type volume of Samarinda - Anggana road improvement project which consist of:

Table 3 - Currency Works Types of Public Works

\begin{tabular}{|c|l|c|c|c|c|}
\hline No. & \multicolumn{1}{|c|}{ Description } & Unit & Volume & Unit Price (Rp) & $\begin{array}{c}\text { Total Unit Price } \\
(\mathrm{Rp})\end{array}$ \\
\hline 1 & Mobilization & Ls & 1,000 & $205.225 .000,00$ & $205.225 .000,00$ \\
\hline 2 & $\begin{array}{l}\text { Excavation for Drainage Drains and } \\
\text { Drainage Canals }\end{array}$ & $\mathrm{m} 3$ & $1.372,49$ & $86.308,37$ & $118.457 .206,45$ \\
\hline 3 & Pairs of Rocks with Mortar & $\mathrm{m} 3$ & 636,975 & $835.743,65$ & $532.347 .813,48$ \\
\hline 4 & Ordinary Excavation & $\mathrm{m} 3$ & 387,266 & $77.120,63$ & $29.866 .199,23$ \\
\hline 5 & $\begin{array}{l}\text { Ordinary stockpiling from excavation } \\
\text { sources }\end{array}$ & $\mathrm{m} 3$ & $1.657,971$ & $143.893,44$ & $238.571 .139,99$ \\
\hline 6 & Class B Aggregate Footing Layers & $\mathrm{m} 3$ & 405,349 & $678.884,53$ & $275.185 .164,81$ \\
\hline 7 & Class A Aggregate Footing Layers & $\mathrm{m} 3$ & 387,266 & $839.164,89$ & $324.980 .029,67$ \\
\hline 8 & Class B Aggregate Footing Layers & $\mathrm{m} 3$ & $4.368,000$ & $2.671 .542,16$ & $11.669 .296 .155,13$ \\
\hline 9 & Cement Concrete Road Pavement & $\mathrm{m} 3$ & $1.440,000$ & $2.079 .619,03$ & $2.994 .651 .403,08$ \\
\hline 10 & Footing Layers under Lean Mix Concrete & $\mathrm{m} 3$ & 159,00 & $181.4947,62$ & $28.857 .6671,58$ \\
\hline
\end{tabular}

Calculating Volume Per Activity Type. Volume calculation is done at the same time as the activity type equalization. Volume used in the next calculation is the volume of the equalization result, volume calculation is based on the distance of the road improvement.

Arranging Inter-activity Dependence. In determining the relevance or dependence of an activity, it must be in accordance with the method of work completion, so that logical technique is needed in the preparation.

Table 4 - Logic of Interdependence between activities

\begin{tabular}{|c|l|c|c|c|}
\hline No. & \multicolumn{1}{|c|}{ Job description } & Activity & Predecessor & Followers \\
\hline 1 & Mobilization & $\mathrm{A}$ & - & $\mathrm{B}, \mathrm{C}, \mathrm{F}, \mathrm{I}$ \\
\hline 2 & Excavation for Drainage Drains and Drainage Canals & $\mathrm{B}$ & $\mathrm{A}$ & $\mathrm{D}$ \\
\hline 3 & Pairs of Rocks with Mortar & $\mathrm{C}$ & $\mathrm{A}$ & $\mathrm{G}$ \\
\hline 4 & Ordinary Excavation & $\mathrm{D}$ & $\mathrm{B}$ & $\mathrm{E}$ \\
\hline 5 & Ordinary stockpiling from excavation sources & $\mathrm{E}$ & $\mathrm{D}$ & $\mathrm{A}_{2}$ \\
\hline 6 & Class B Aggregate Footing Layers & $\mathrm{F}$ & $\mathrm{A}$ & $\mathrm{H}$ \\
\hline 7 & Class A Aggregate Footing Layers & $\mathrm{G}$ & $\mathrm{C}$ & $\mathrm{E}$ \\
\hline 8 & Class B Aggregate Footing Layers & $\mathrm{H}$ & $\mathrm{F}$ & $\mathrm{G}$ \\
\hline 9 & Cement Concrete Road Pavement & $\mathrm{I}$ & $\mathrm{A}$ & $\mathrm{J}$ \\
\hline 10 & Footing Layers under Lean Mix Concrete & $\mathrm{J}$ & $\mathrm{I}$ & $\mathrm{E}$ \\
\hline
\end{tabular}

Critical Path Determination. Determination of critical path for Samarinda-Anggana Road Improvement Project along $1,95 \mathrm{Km}$ is obtained by using method of CPM (Critical Path Method). To facilitate work network project, list of activities will be made first that precede other activities presented in the form of tables that contain predecessor activities in the sequence of dependence logic. The use of predecessor activity data obtained network for Samarinda-Anggana Road Improvement Project along $1.95 \mathrm{Km}$ which is frolic. Having obtained the numbers of both back and forth calculation, then critical path of the network can be determined, the critical path starting from the initial circle (start circle) to the final circle (finish circle) in which the values of total float (TF) and free (float) from the activities are equal to zero (0). Furthermore, the network of Samarinda-Anggana Road Improvement activities and the acceleration of its critical trajectory are determined.

Fast Track Network Modeling. After the normal time network is arranged in accordance with the activity plan, it is known that the project execution time exceeds the required time of 21 days, while the RAB time is 7 months. So, it needs network modeling to accelerate the work activity using fast track method. Fast track modeling is performed on critical trajectory 
activities that have a long duration of work and is performed until such activity is no longer possible to accelerate.

Table 5 - Time Acceleration in Critical Path Activity

\begin{tabular}{|c|c|c|c|c|c|c|}
\hline No. & Job description & Activity & Duration & $\begin{array}{c}\text { Acceleration } \\
\text { Phase } 1 \text { (days) }\end{array}$ & $\begin{array}{c}\text { Acceleration } \\
\text { Phase } 2 \text { (days) }\end{array}$ & $\begin{array}{c}\text { Acceleration } \\
\text { Phase } 3 \text { (days) }\end{array}$ \\
\hline 1 & Mobilization & $A$ & 24 & 3 & 4 & 6 \\
\hline II & $\begin{array}{c}\text { Excavation for Drainage } \\
\text { Drains and Drainage } \\
\text { Canals }\end{array}$ & B & 70 & 8 & 13 & 16 \\
\hline III & $\begin{array}{l}\text { Pairs of Rocks with } \\
\text { Mortar }\end{array}$ & C & 94 & 0 & 0 & 0 \\
\hline IV & Ordinary Excavation & $\mathrm{D}$ & 46 & 5 & 9 & 11 \\
\hline V & $\begin{array}{l}\text { Ordinary stockpiling } \\
\text { from excavation } \\
\text { sources }\end{array}$ & E & 70 & 8 & 13 & 16 \\
\hline VI & $\begin{array}{l}\text { Class B Aggregate } \\
\text { Footing Layers }\end{array}$ & $\mathrm{F}$ & 82 & 0 & 0 & 0 \\
\hline VII & $\begin{array}{l}\text { Class A Aggregate } \\
\text { Footing Layers }\end{array}$ & G & 70 & 0 & 0 & 0 \\
\hline VIII & $\begin{array}{l}\text { Class B Aggregate } \\
\text { Footing Layers }\end{array}$ & $\mathrm{H}$ & 70 & 0 & 0 & 0 \\
\hline IX & $\begin{array}{c}\text { Cement Concrete Road } \\
\text { Pavement }\end{array}$ & 1 & 94 & 0 & 0 & 0 \\
\hline$x$ & $\begin{array}{l}\text { Footing Layers under } \\
\text { Lean Mix Concrete }\end{array}$ & $\mathrm{J}$ & 82 & 0 & 0 & 0 \\
\hline
\end{tabular}

Table 6 - Duration of Each Acceleration Phase

\begin{tabular}{|c|c|c|c|c|c|c|}
\hline No. & Job description & Activity & Duration & $\begin{array}{c}\text { Fast Track } \\
1\end{array}$ & $\begin{array}{c}\text { Fast Track } \\
2\end{array}$ & $\begin{array}{c}\text { Fast Track } \\
3\end{array}$ \\
\hline I & Mobilization & A & 24 & 3 & 4 & 6 \\
\hline II & $\begin{array}{c}\text { Excavation for Drainage Drains and } \\
\text { Drainage Canals }\end{array}$ & B & 70 & 8 & 13 & 16 \\
\hline III & Pairs of Rocks with Mortar & C & 94 & 11 & 17 & 22 \\
\hline IV & Ordinary Excavation & D & 46 & 5 & 9 & 11 \\
\hline V & Ordinary stockpiling from excavation \\
sources & $\mathrm{E}$ & 70 & 8 & 13 & 16 \\
\hline VI & Class B Aggregate Footing Layers & F & 82 & 9 & 15 & 19 \\
\hline VII & Class A Aggregate Footing Layers & G & 70 & 8 & 13 & 16 \\
\hline VIII & Class B Aggregate Footing Layers & H & 70 & 8 & 13 & 16 \\
\hline IX & Cement Concrete Road Pavement & I & 94 & 11 & 17 & 22 \\
\hline X & Footing Layers under Lean Mix Concrete & J & 82 & 9 & 15 & 19 \\
\hline
\end{tabular}

Project Cost Calculation After Fast Track. Based on the project work plan, the cost is as much Rp.16.677.156.783,43. Implementation of critical activity is done in parallel. There is no increase in the number of labor and the cost of each activity, both the activity on the critical path and the non-critical activity. It is also same as on the use of materials. The use of materials is in line with normal use including the price of the materials. is There is no change in the cost of labor in accordance with the the moment of the research is done. The non-fixed cost is the operational cost incurred by the contractor as much $5 \%$ of the fixed cost of realizing Samarinda-Anggana Road Improvement project. Also, with Fast Track CPM method, it can be seen the results of the acceleration process in this analysis which are optimal cost and time.

The difference is in the indirect costs because the development duration becomes shorter than the planned project duration of 210 days to be 186, 171, and 161 calendar days. Thus, the total cost after Fast Track, it can be concluded that there is indirect cost savings in Fast Track phase 1, that is equal to $0,57 \%$ from normal cost. Then, at the Fast Track phase 
2 , there is a cost optimization of $0.93 \%$ of normal cost. Furthermore, at the Fast Track phase 3 , there is a cost optimization of $1.17 \%$ of the normal cost. So that, Fast Track phase 2 can be selected from the results of cost and optimal time with Fast Track method because besides time has optimal result which leads to indirect costs decreased but it does not also add budget cost.

Table 7 - Comparison of Normal Project Cost after Fast Track

\begin{tabular}{|l|l|l|l|l|}
\hline \multirow{2}{*}{\multicolumn{1}{|c|}{ Information }} & \multicolumn{3}{|c|}{ Actual productivity } \\
\cline { 2 - 5 } & Normal duration & Fast track phase 1 & Fast track phase 2 & Fast track phase 3 \\
\hline Time / Duration (days) & 210 & 186 & 171 & 161 \\
\hline Project Budget (Rp) & Rp.16.677.156.783,43 & Rp.16.677.156.783,43 & Rp.16.677.156.783,43 & Rp.16.677.156.783,43 \\
\hline Fixed Cost (Rp) & Rp.15.843.298.944,5 & Rp.15.843.298.944,25 & Rp.15.843.298.944,25 & Rp.15.843.298.944,25 \\
\hline Variable cost & Rp.833.857.839,17 & Rp.738.559.800,41 & Rp.678.998.526,18 & Rp.639.291.010,03 \\
\hline Total Cost (Rp) & Rp.16.677.156.783,43 & Rp.16.581.858.744,66 & Rp.16.522.297.470,44 & Rp.16.482.589.954,29 \\
\hline Savings (Rp) & Rp - & Rp.95.298.038,76 & Rp.154.859.312,99 & Rp.194.566.829,14 \\
\hline Savings (\%) & 0,00 & 0,57 & 0,93 & 1,17 \\
\hline
\end{tabular}

Table 8 - Fastest Time Output with Cost Savings

\begin{tabular}{|c|c|c|c|c|c|}
\hline No. & Overtime & Time & Acceleration & Total Cost & Cost Savings \\
\hline 1 & Normal & 3005 & 210 & - & Rp18,344,872,461.77 \\
\hline 2 & 1 Hour & 3005 & 186 & 24 & Rp $17,018,427,461.77$ \\
\hline 3 & 2 Hours & 3005 & 171 & 39 & Rp $17,050,625,461.77$ \\
\hline
\end{tabular}

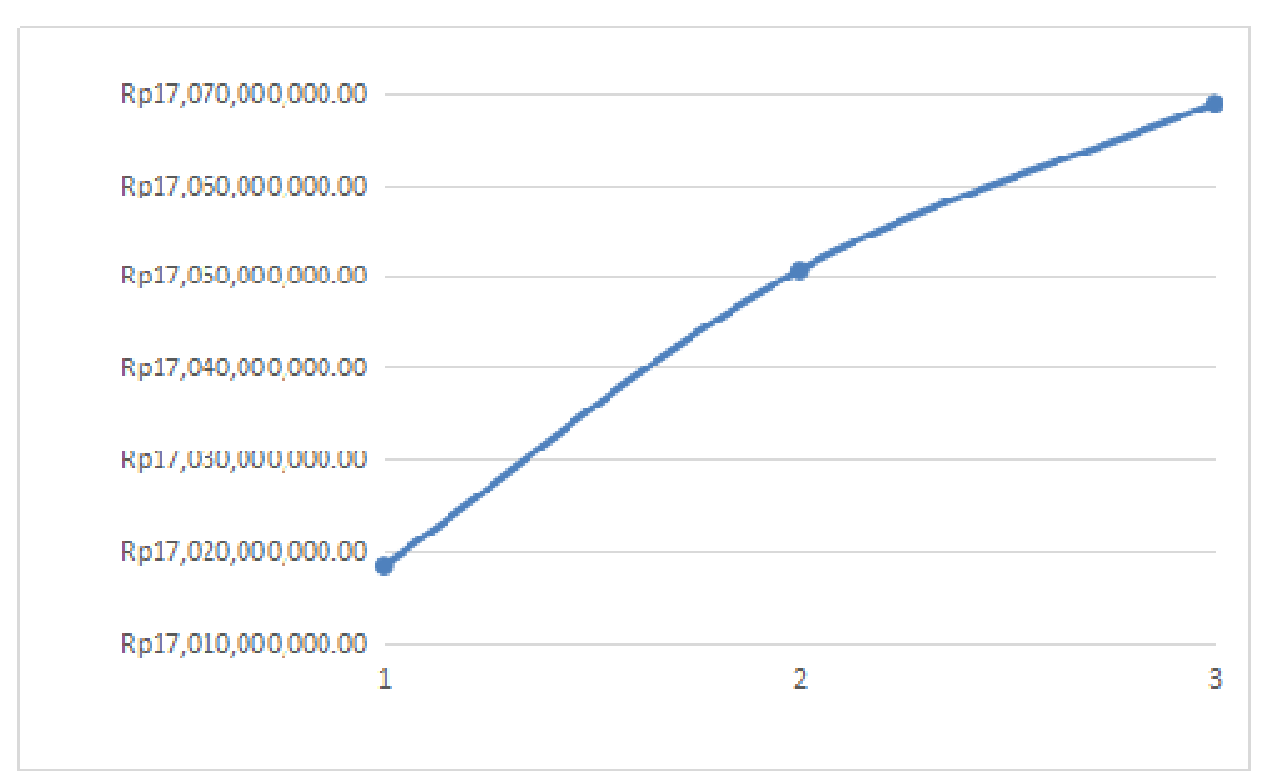

Figure 1 - Relationship between Time and Cost towards Total Project Cost

Based on the above drawings of the project completion time, an effective project completion time with the optimal project cost is chosen. In this case, it is very beneficial in terms of time and cost over the acceleration of some activities obtained on 2-hour overtime alternatives in which all activities are included into critical paths on the 2-hour overtime alternative

\section{CONCLUSION}

From the calculation result of the project duration using fast track method on Samarinda - Anggana Road Improvement Project Implementation in the area of Kutai Lama, the following conclusions are obtained: 
Samarinda - Anggana Road improvement project is calculated with CPM model with normal duration in the contract time of 210 days, so the project needs to be accelerated by Fast Track method that produces acceleration duration to 171 days.

Optimal costs incurred at normal duration or the project budget plan is Rp.16.677.156.783,43 and costs generated after Fast Track method is Rp. 16.522.297.470,44.

The difference in duration between normal time and after fast track is 39 days. While, the difference between the cost of normal time and after using the Fast Track is Rp.154.859.312,99, hence, it can be concluded that savings of $0.93, \%$ of the normal cost.

\section{REFERENCES}

1. Akbar. (2002). Manajemen Kegiatan proyek. Jurnal manajemen, Surabaya.

2. Badri, S. (1997). Dasar-Dasar Network Planning. Jakarta: PT. Rika Cipta.

3. Davidson, J. (2002). Penuntun 10 Menit Manajemen Proyek, Terjemahan dari Ten Minute Guide Project Management, oleh Sisnuhadi. Yogyakarta: Andi.

4. Hellriegel, D., \& Slocum, J. W. (2006). Management des organisations. De Boeck Supérieur.

5. Tjaturono, T., \& Mochtar, I. B. (2009). Pengembangan Metode Fast-Track untuk Mereduksi Waktu dan Biaya Pelaksanaan Proyek Studi Kasus Rumah Menengah di Malang, Jawa Timur. MEDIA KOMUNIKASI TEKNIK SIPIL, 17(1), 39-54.

6. Kehlet, H. (2005). Fast-track surgery. British Journal of Surgery, 92(1), 3-4.

7. Pena-Mora, F., \& Li, M. (2001). Dynamic planning and control methodology for design/build fast-track construction projects. Journal of construction engineering and management, 127(1), 1-17.

8. Williams, G. V. (1995). Fast track pros and cons: Considerations for industrial projects. Journal of Management in Engineering, 11(5), 24-32.

9. Stevenson, W. J., \& Hojati, M. (2007). Operations management (Vol. 8). Boston: McGraw-Hill//rwin.

10. Azhar, S. (2011). Building information modeling (BIM): Trends, benefits, risks, and challenges for the AEC industry. Leadership and management in engineering, 11(3), 241252.

11. Morel, J. C., Mesbah, A., Oggero, M., \& Walker, P. (2001). Building houses with local materials: means to drastically reduce the environmental impact of construction. Building and Environment, 36(10), 1119-1126.

12. Söderlund, J. (2004). Building theories of project management: past research, questions for the future. International journal of project management, 22(3), 183-191.

13. Daniels, G., Ellis, D. R., \& Stockton, W. R. (1999). Techniques for manually estimating road user costs associated with construction projects (Vol. 3). Texas,, USA: Texas Transportation Institute.

14. Carayannis, E. G., Kwak, Y. H., \& Anbari, F. T. (Eds.). (2005). The story of managing projects: an interdisciplinary approach. Greenwood Publishing Group.

15. Coulter, E. D. (2004). Setting forest road maintenance and upgrade priorities based on environmental effects and expert judgment (Doctoral dissertation).

16. Chou, J. S., Peng, M., Persad, K., \& O'Connor, J. (2006). Quantity-based approach to preliminary cost estimates for highway projects. Transportation Research Record: Journal of the Transportation Research Board, (1946), 22-30.

17. Zhu, Y., Ahmad, I., \& Wang, L. (2009). Estimating work zone road user cost for alternative contracting methods in highway construction projects. Journal of Construction Engineering and Management, 135(7), 601-608.

(C) 2017 by the authors. Licensee RJOAS, Orel, Russia. This article is an open access article distributed under the terms and conditions of the Creative Commons Attribution (CC BY) license: http://creativecommons.org/licenses/by/4.0/ 
DOI https://doi.org/10.18551/rjoas.2017-09.20

\title{
COST, TIME, AND QUALITY ANALYSIS OF PRECAST CONCRETE CONSTRUCTION AND IN SITU CONCRETE AT MACRO CHANNEL IN CONTROL OF RUN-OFF: A CASE STUDY OF REGIONAL HARUN NAFSI STREET IN SAMARINDA
}

\author{
Syahrizal Muhammad*, Hidayat Sutanto, Santosa Agus \\ Study Program of Civil Engineering, Concentration of Construction Management, \\ National Institute of Technology, Malang, Indonesia \\ *E-mail: myrizaldii@gmail.com
}

\begin{abstract}
The aims of this study are to calculate the construction cost which is required in the implementation of method of precast and cast concrete construction in its place; calculate the required time in the construction method of precast and cast concrete in its place; analyze the quality of construction of precast and cast concrete method in its place and resulting in the K-250 of quality value. The selection of construction method is important in a construction project work because the right implementation method can provide maximum results, especially when it is viewed in terms of construction cost, time and quality. The construction of comparative cost selection method for In Situ and precast concrete materials uses Office of Highways Analysis 2010 Revision 3, implementation time uses S curve and construction quality uses questionnaire. Based on the result of construction cost plan of In Situ concrete construction of Rp. $109,790,340,000.00$, the budget plan for the construction of precast concrete is Rp. 73.460.740.000.00. The calculation of the need for working time is In Situ concrete construction method needs 2 years 1 month and precast concrete construction method needs 1 year 8 months. The quality of precast concrete construction shows that the precast concrete surface is more neatly, better and more subtle than In Situ concrete. Field dimensions are safer and the quality of precast concrete is guaranteed as the sale of the product which is coupled with the concrete specified from the In Situ.
\end{abstract}

\section{KEY WORDS}

Concrete, cost, time, quality.

Samarinda as the provincial capital, the rapid urbanization and migration from other areas has spurred the residential development that tends to deviate from the concept of sustainable development. The numbers of low areas (swamps, lakes) which initially serves as water reservoir and the riverbanks were turned into residential areas, coupled with the habits of the people who throw garbage into the river further worsen this condition. The topography of Samarinda in which it has many areas below the surface of the elevation of the river makes the reason why flood frequently occurs in Samarinda, but actually not only a topographical issue that needs to know that makes the flood in Samarinda.

Selection of a method is very important in the implementation of a construction project because the right method of implementation can provide maximum results, especially when it is viewed from Construction Costs, Implementation Time, and Construction Quality, (Kulkarni et al, 2008). With the rapid technological advancement in the world of construction, it allows project managers to choose one of the specific construction methods from some alternative existing construction methods, (Pampanin et al, 2001). One of the efforts undertaken by the project manager is to replace the cast concrete in a more modern place that is by the application of precast concrete, (Mirmiran et al, 2001). The use of precast concrete is expected to respond to industrialization challenges that require effective, efficient, quality and economic results.

In general, the use of precast concrete is considered more economical compared to in situ concrete due to the effect of weather with high rainfall and it can also reduce the cost of using formwork and reduce the duration of the project implementation so that the overhead resulted becomes smaller, (Kurama, 2000). In addition, working on the ground surface is 
much easier and safer to do, such as molds, casting, surface hearth, maintenance, and repeated use of formwork, (Ervianto, 2006).

From the above explanation, the researcher attempts to give alternative of choosing the implementation method by researching from the aspect of Construction Cost, Implementation Time, and Construction Quality and to know which one is the most economical betwee the channel installation of pre-cast concrete and In situ concrete.

The purposes of this study are to (i) calculate the cost of construction required in the implementation of precast concrete construction and In situ concrete methods; (ii) calculate the required execution time in the construction method of precast concrete and In situ concrete; (iii) how does the quality of construction in the implementation of precast concrete and In Situ concrete methods result in K-250 quality values.

\section{LITERATURE REVIEW}

Drainage. Drainage is a means of removing undesirable excess water in an area as well as a way to overcome the effects caused by the excess water. The purpose and objective of drainage is to dispose water over excessive soil surface, reduce and maintain water surface rather than puddle, so the negative effect with the existence of puddles and overflow of water can be avoided. (Suhardjono, 1984)

Understanding Precast Concrete. Precast concrete is a construction technology of concrete structures with pre-assembled components, sometimes the components are arranged and pre-assembled, and then it is installed at the installation site. Thus, this precast system will be different from monolith construction, especially in planning aspect which depends on or determined by execution method of fabrication, unification, and installation, and also determined by technical behavior of precast system in the way of connection between component join (Abduh, 2007). Some principles are believed to benefit more from precast concrete technology such as: time, cost, quality, predictability, reliability, productivity, health, safety, environment, coordination, innovation, reusability, and relocatability (Gibb, 1999; Abduh, 2007).

History of Precast System Development. Precast concrete construction has been growing rapidly in the world, including in Indonesia in the last decade, because this system has more advantages than conventional systems. Especially in the field of medium skyscraping buildings, such as Simple Flats, Precast System has been proven to support the development of high-quality, fast and economical housing complexes. The synergy among government, universities, researchers, inventors, research institutes, and industries in this field has resulted in dozens of newly-created and actively-adopted nation-building systems of the nation's generation, (Abduh, 2007).

Development of Precast System in the World. Modern precast system was developed early in European countries. The precast structures were first used as precrete concrete blocks for the Casino in Biarritz, built by Coignet contractor Paris 1891. The reinforced concrete foundation was introduced by a German company, Wayss \& Freytag in Hamburg and began to be used in 1906. In 1912 several skyscraping buildings used Precast system of components, such as walls, columns and floors introduced by John.E.Conzelmann. The structure of prefabricated reinforced concrete components was also introduced in Germany by Philip Holzmann AG, Dyckerhoff \& Widmann G Wayss \& Freytag KG, Prteussag, Loser etc.

Development of Precast System in the World. Indonesia has been familiar with precast system components such as piles, bridge beams, columns, and floor plates since the 1970s. The precast system is growing with the marking of innovations, such as Column Slab System (1996), L-Shape Wall System (1996), All Load Bearing Wall System (1997), Beam Column Slab System (1998), Jasubakim System (1999), Bresphaka (1999), and the T-Cap system (2000). The fundamental issues in the development of precast systems in Indonesia today are:

- The system is relatively new;

- Less socialized types, products and the ability of precast systems that already exist; 
- The absence of official guidance on procedures of analysis, planning and specific level of control for precast system that can be used as guidance for the perpetrators of construction.

Ditch Precast Concrete. U-Ditch is a channel of reinforced concrete with a U-shape cross section and it can also be closed. Commonly it is used as drainage or irrigation channels. The height of these open channels may vary following the needs in the field or the desired channel elevation. The type of joint is a joint plate (embedded plate and joint but male or female joint) where in the meeting part, its connection is sufficient to provide mortar as a grout cover.

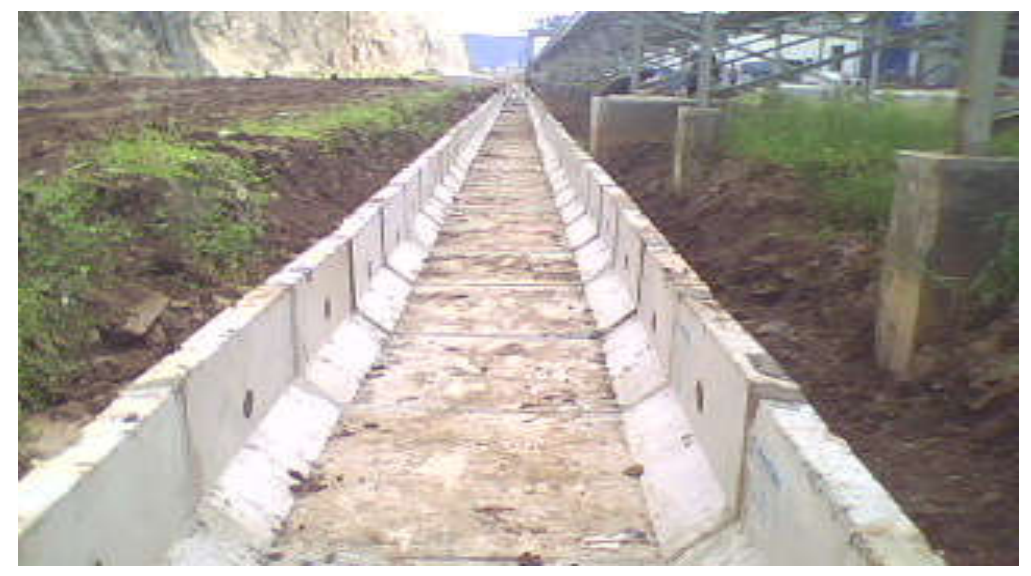

Figure 1 - U-Ditch

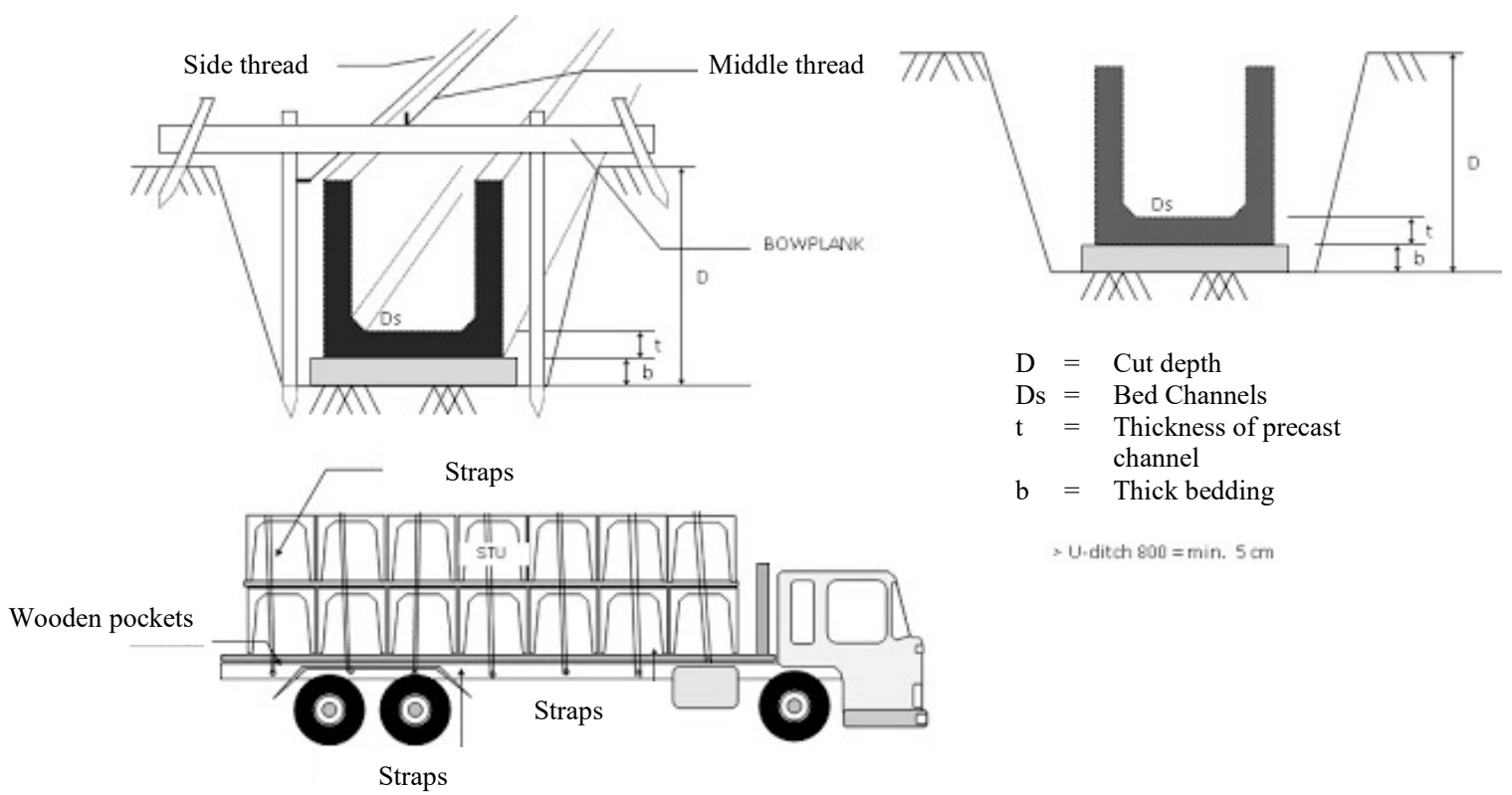

Figure 2 - Transport of U-DITCH

Budget Plan (BP). Activity estimation is one of the main processes in a construction project to answer, "How much money should be reserved for a building?". In general, the cost required in a construction project is large, (Jarkas, 2005). The inaccuracy that occurs in its supply will have a negative effect on the parties involved (Ervianto, 2005). The cost budget of a building or project is a calculation of the amount of costs required for materials and labor wages based on analysis as well as other costs associated with the implementation of work. Ibrahim (2003) states that the cost or the budget itself is the sum of each result of the multiplication of the volume with the unit price of the work. It is concluded that the budget plan of the work is shown in the formula: 


$$
B P=\Sigma(V O L U M E X \text { WORK UNIT PRICE) }
$$

The unit price of materials and labor wages in each region vary. Thus, in determining the calculation and preparation of the budget cost of a work, it should be guided by the price of material units and wages of labor in the market and location of work.

Job Plan Description (Network Planning). The S curve is one of the most commonly used cost control planning methods utilized in a project. The $S$ curve represents the percentage of the cumulative cost plot diagram plotted on a coordinate axis in which the abscissa axis $(X)$ denotes the time of projection and axis $Y$ represents the percent value of the cumulative cost during the life of the project. In the diagram of the $S$ curve, the expenditures spent time units, cumulative cost expenses per unit time, and work progress based on the volume generated in the field can be seen. The way to make the actual S curve is the actual $S$ curve in the plot of the plan curve $S$ in the same way as making the $S$ plan curve. The difference is in the calculation of the labor cost per unit of time which is calculated based on the physical volume generated multiplied by the unit price of the work (the volume generated is circulated from the work of the owner performed by the owner or the representative and the result of the legitimate and accountable re-registration)

The Barchat is a chart containing a chart listing the activities that will be performed, arranged in a downward march where each activity has the required execution time (duration) shown in the form of a timeline (usually a line so that it is like a beam). The length of each line / block indicates the length of time required for each activity as well as the time to start and to end the activity (Soeharto, 1999). While the unit of time can be a day, week, month or a certain time interval. To calculate the percentage of weight of each type of activity, both the cost of each activity and the total cost of the work should be know. The percentage weight calculation for each type of activity is as follows:

$$
\text { Activity weight }=\frac{\text { total activity cost }}{\text { total cost }} \times 100 \%
$$

\section{METHODS OF RESEARCH}

Analysis of Budget Plan. After calculating drainage channel capacity in 2015 condition with 10-year repeat period, then cost budget by using Office of Highways analysis is calculated. Calculation of material prices uses HSBJ City Government 2016. The calculation of budget cost is done by two kinds of calculation with the aim of finding the most economical cost comparison which are: a) calculation of budget plan cost of In Situ concrete method/conventional system, b) calculation of cost budget plan of precast / precast concrete method.

Analyzing Calculation of Time Requirement of workmanship. Using the curve $S$ depiction can be assumed that the cost of each item is evenly distributed over its duration, (Marriott et al, 2009). This condition is not always true because it is possible that a work item with a large material purchase cost (absorbing more than $50 \%$ of the total price of the job) will be absorbed at the beginning of the job and the remaining duration is done for the installation fee.

Quality Analysis. It is done by using a questionnaire with contingency questions. It means that the question form that still goes on. This type of question is possible, but it must be based on the possibility of a certain relationship between one theme with another theme. In addition, answers from respondents to this follow-up question will greatly help to deepen the insights of researchers. The type of research scale used is the Semantic Differential Scale, the semantic difference scale (the science of word meaning) which contains a series of bipolar characteristics (two poles). The semantic differential scheme has three basic dimensions of someone's attitude toward objects: the potential or strength of the object; evaluation or disadvantage or disadvantage of an object; activity or movement level of an object. 


\section{RESULTS AND DISCUSSION}

In the calculation of RAB is obtained results as follows:

- Cost budget plan for In Situ concrete construction method is Rp. 109,790,340,000.00.

- Cost budget plan for precast concrete construction method is Rp. 73.460.740.000,00.

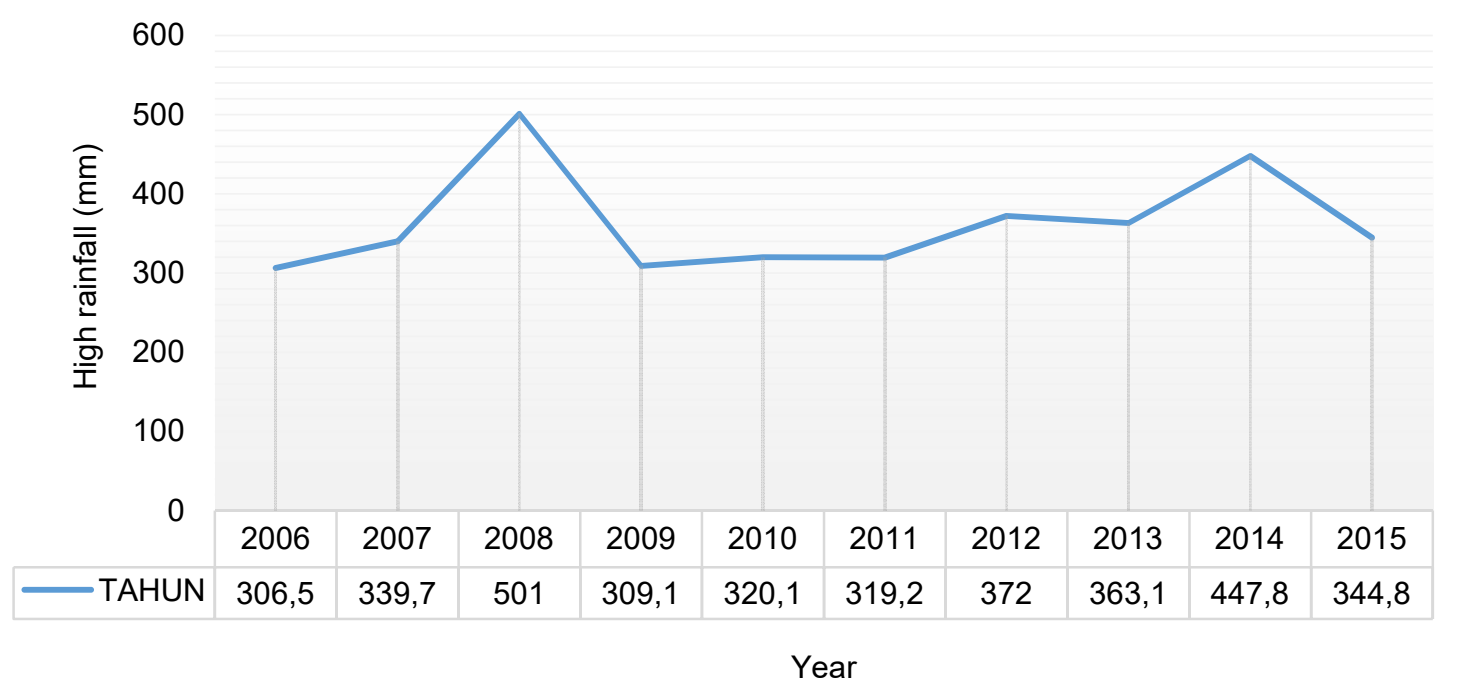

Figure 3 - Monthly Average Rainfall Characteristics of Sta. Temindung

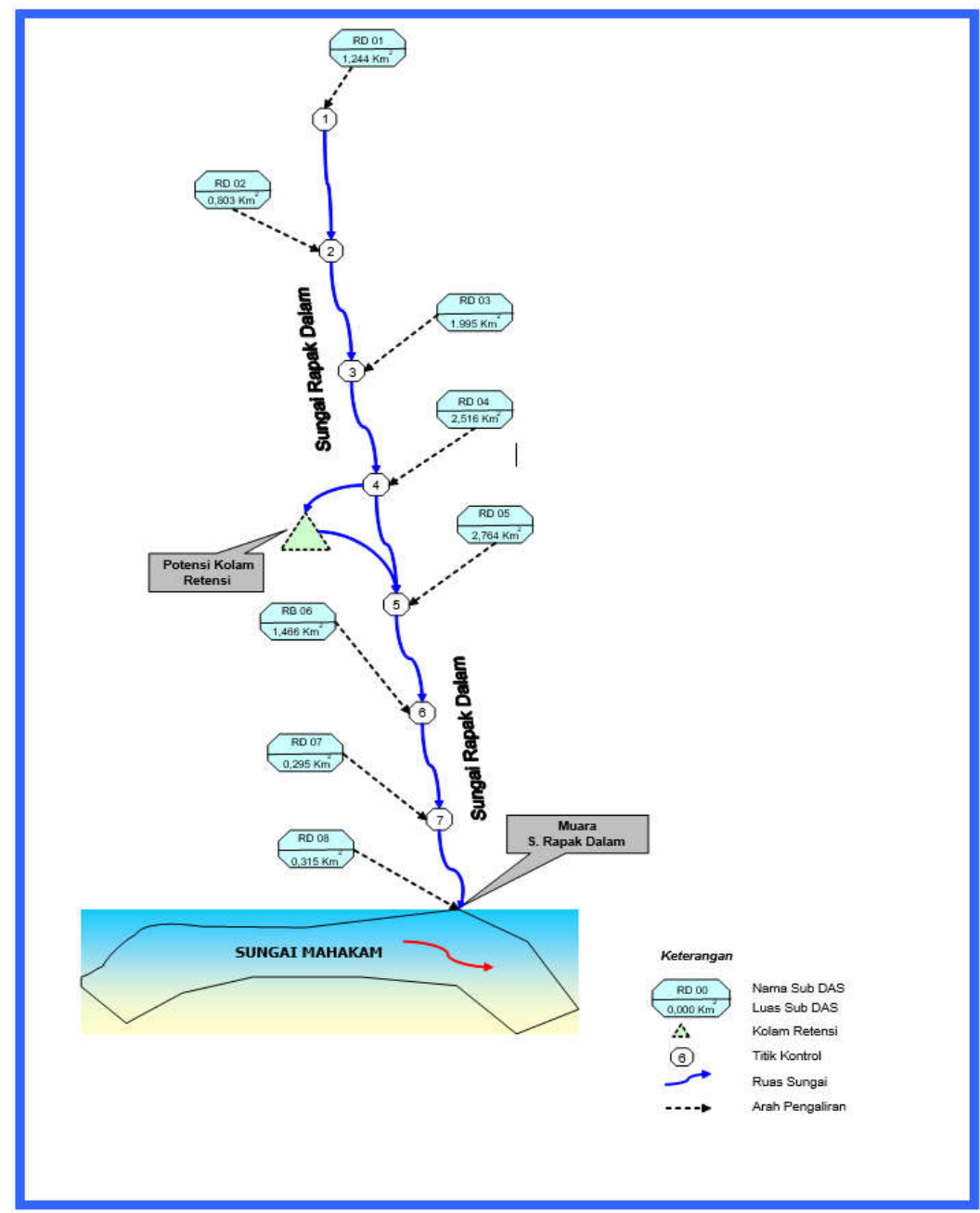

Figure 4 - Rapak Dalam DAS Scheme 
Table 1 - List Quantity in Situ Concrete

\begin{tabular}{|c|c|c|c|c|c|}
\hline $\begin{array}{c}\text { No. } \\
\text { Payment }\end{array}$ & Description & Unit & $\begin{array}{l}\text { Estimated } \\
\text { Quantity }\end{array}$ & $\begin{array}{c}\text { Price } \\
\text { Unit } \\
\text { (Rupiah) }\end{array}$ & $\begin{array}{c}\text { Amount } \\
\text { Prices } \\
\text { (Rupiah) }\end{array}$ \\
\hline$a$ & $\mathrm{~b}$ & C & $\mathrm{d}$ & $\mathrm{e}$ & $f=(D X E)$ \\
\hline \multicolumn{6}{|c|}{ DIVISION 1. GENERAL } \\
\hline 1.2 & Mobilization & LS & 1.00 & $41,500,000.00$ & $41,500,000.00$ \\
\hline \multicolumn{5}{|c|}{ Work Price Total of DIVISION 1 (in Recapitulation of Estimated Price of Work) } & $41,500,000.00$ \\
\hline \multicolumn{6}{|c|}{ DIVISION 2. DRAINAGE } \\
\hline 2.1 & $\begin{array}{c}\text { Digging for Drainage \& Water } \\
\text { Channel }\end{array}$ & $M^{3}$ & 24401.79 & 54027.17 & $1,318,359,496.38$ \\
\hline \multicolumn{5}{|c|}{ Work Price Total of DIVISION 2 (in Recapitulation of Estimated Price of Work) } & $1,318,359,496.38$ \\
\hline \multicolumn{6}{|c|}{ DIVISION 3. GROUND WORK } \\
\hline 3.2. (1) & Landfill & $\mathrm{M}^{3}$ & 964.46 & $149,832.81$ & $144,507,750.25$ \\
\hline \multicolumn{5}{|c|}{ Work Price Total of DIVISION 3 (in Recapitulation of Estimated Price of Work) } & $144,507,750.25$ \\
\hline \multicolumn{6}{|c|}{ DIVISION 7. STRUCTURE } \\
\hline $7.1(5)$ & K-250 Concrete & $\mathrm{M}^{3}$ & 48915.55 & 1432901.85 & $70,091,182,209.30$ \\
\hline $7.1(8)$ & K-125 Concrete & $\mathrm{M}^{3}$ & 2435.15 & $1,075,151.78$ & $2,618,155,865.61$ \\
\hline 7.3 & Reinforcing Steel & $\mathrm{Kg}$ & $1,004,474.93$ & 21095.04 & $21,189,433,752.24$ \\
\hline $7.6(1)$ & $\begin{array}{l}\text { Erection of Ironwood } 10 \times 10-200 \\
\mathrm{~cm}\end{array}$ & $M^{1}$ & 73472.00 & 58600.35 & $4,305,484,915.20$ \\
\hline $7: 11(1)$ & Pipework 1 & "M & 6888.00 & 14630.74 & $100,776,546.30$ \\
\hline
\end{tabular}

Table 2 - The Quantity of Precast Concrete

\begin{tabular}{|c|c|c|c|c|c|}
\hline $\begin{array}{l}\text { No. } \\
\text { Pay- } \\
\text { price }\end{array}$ & Description & Unit & $\begin{array}{l}\text { Estimated } \\
\text { Quantity }\end{array}$ & $\begin{array}{c}\text { Price } \\
\text { Unit } \\
\text { (Rupiah) }\end{array}$ & $\begin{array}{c}\text { Total } \\
\text { Price } \\
\text { (Rupiah) }\end{array}$ \\
\hline$a$ & $\mathrm{~b}$ & $\mathrm{C}$ & $\mathrm{d}$ & $\mathrm{e}$ & $f=(D X E)$ \\
\hline \multicolumn{6}{|c|}{ DIVISION 1. GENERAL } \\
\hline 1.2 & Mobilization & LS & 1.00 & $41,250,000.00$ & $41,250,000.00$ \\
\hline \multicolumn{6}{|c|}{ DIVISION 2. DRAINAGE } \\
\hline 2.1 & $\begin{array}{l}\text { Digging for Drainage \& Water } \\
\text { Channel }\end{array}$ & $M^{3}$ & 26565.39 & 54027.17 & $1,435,252,679.16$ \\
\hline $2.3 a$ & U-ditch $1 \times 1.5$ & $M^{\prime}$ & 225.00 & 42905.56 & 9659390.17 \\
\hline 2.3.B & U-ditch $1.5 \times 2$ & $M^{\prime}$ & 50.00 & $3,783,763.96$ & $851,346,890.17$ \\
\hline 2.3.c & U-ditch $3 \times 2$ & $\mathrm{M}^{1}$ & 500.00 & $5,913,515.83$ & $295,675,791.69$ \\
\hline $2.3 . d$ & U-ditch $4 \times 2$ & $M^{\top}$ & 2022.00 & $7,543,267.71$ & $3,771,633,855.59$ \\
\hline $2.3 . e$ & U-ditch $6 \times 2.5$ & $\mathrm{M}^{\top}$ & 370.00 & $13,802,730.98$ & $5,107,025,442.43$ \\
\hline $2.3 . f$ & U-ditch $7 \times 2.5$ & $M^{1}$ & 1425.00 & $18,807,479.01$ & $26,800,720,764.43$ \\
\hline \multicolumn{5}{|c|}{ Work Price Total of DIVISION 2 in Recapitulation of Estimated Price of Work)) } & $59,842,501,031.62$ \\
\hline \multicolumn{6}{|c|}{ DIVISION 3. GROUND WORK } \\
\hline 3.2. (1) & Landfill & $\mathrm{M}^{3}$ & 996.90 & $118,589.59$ & $118,221,957.54$ \\
\hline \multicolumn{5}{|c|}{$\begin{array}{c}\text { Total Price Work of DIVISION } 3 \text { (in Recapitulation of Estimated Price of } \\
\text { Work) }\end{array}$} & $118,221,957.54$ \\
\hline \multicolumn{6}{|c|}{ DIVISION 7. STRUCTURE } \\
\hline $7.1(8)$ & K-125 Concrete & $\mathrm{M}^{3}$ & 2208.30 & $1,075,151.78$ & $2,374,257,683.52$ \\
\hline $7.6(1)$ & $\begin{array}{l}\text { Erection of Ironwood } 10 \times 10-200 \\
\text { cm }\end{array}$ & $M^{1}$ & 73472.00 & 58600.35 & $4,305,484,915.20$ \\
\hline $7: 11(1)$ & Pipework 1 & "M & 6888.00 & 14630.74 & $100,776,546.30$ \\
\hline
\end{tabular}

Calculation Analysis of Working Time. The working time is made in the curve $\mathrm{S}$, the plan taken from the time calculation of the method of implementation of the work of analysis of Bina-marga Year 2010 Revised.

Implementation Period $=$ Volume $/$ Capacity Production per day 
Table 3 - Calculation Working Time of In situ Concrete

\begin{tabular}{|c|c|c|c|c|}
\hline No & Description & Weight & \multicolumn{2}{|c|}{ Implementation time } \\
\hline 1 & Mobilization & 0,042 & 14 & Days \\
\hline 2 & Digging For Drainage \& Water Channel & 1,321 & 187 & Days \\
\hline 3 & Landfill & 0,145 & 42 & Days \\
\hline 4 & K-250 Concrete & 70.225 & 722 & Days \\
\hline 5 & K-125 Concrete & 2.623 & 22 & Days \\
\hline 6 & Reinforcing Steel & 21.23 & 359 & Days \\
\hline 7 & Erection of Ironwood $10 \times 10-200 \mathrm{~cm}$ & 4.314 & 263 & Days \\
\hline 8 & Pipework 1 & $" .101$ & 50 & Days \\
\hline & Percentage & 100,000 & - & - \\
\hline & Estimated Time plan in accordance with S Curve & - & \multicolumn{2}{|c|}{2 Years 1 Month } \\
\hline
\end{tabular}

Table 4 - Supplies Precast Concrete Working Time

\begin{tabular}{|c|c|c|c|c|}
\hline No & Description & Weight & \multicolumn{2}{|c|}{ Timeimplementing } \\
\hline 1 & Mobilization & 0,062 & 14 & Days \\
\hline 2 & Cut For Drainage \& Water Channel & 2,149 & 204 & Days \\
\hline 3 & U-ditch $1 \times 1.5$ & 1,275 & 45 & Days \\
\hline 4 & U-ditch $1.5 \times 2$ & 0,443 & 12 & Days \\
\hline 5 & U-ditch $3 \times 2$ & 5,648 & 127 & Days \\
\hline 6 & U-ditch $4 \times 2$ & 32,315 & 569 & Days \\
\hline 7 & U-ditch $6 \times 2.5$ & 7,647 & 115 & Days \\
\hline 8 & U-ditch $7 \times 2.5$ & 40,131 & 481 & Days \\
\hline 9 & Landfill & 0,177 & 43 & Days \\
\hline 10 & K-125 Concrete & 3,555 & 20 & Days \\
\hline 11 & Erection of Ironwood $10 \times 10-200 \mathrm{~cm}$ & 6,447 & 263 & Days \\
\hline 12 & Pipework 1 & 0,151 & 50 & Days \\
\hline & Percentage & 100,000 & & \\
\hline & Estimated Time plan in accordance with S Curve & & \multicolumn{2}{|c|}{1 Year 8 Months } \\
\hline
\end{tabular}

Construction Quality Analysis. In general, from the survey results in the form of quality questionnaires with construction methods that occurs in the field for both precast concrete and In Situ concrete, the results of the questionnaire are divided into 4 parts namely pre construction, construction implementation, post construction, and construction quality based on the results of the field are as follows:

Pre-Construction. In Situ Concrete construction method: the executive prepares the K250 concrete jobmix; trial test as a reference of job implementation by using K-250 jobmix data; the precast concrete construction method: factory visit, conduct a random test of precast that will be used in the field, test can be performed with hammer test, core (for thickness) test, concrete tension test, and concrete bending test according to K-250.

Construction Implementation. In Situ Concrete construction method: Implementation of in situ concrete should pay attention that neatness of the installation of formwork must be in accordance with the plan design; the neatness of the reinforcement installation is good in both reinforcement size and reinforcement length; the distance of reinforcement towards the formwork remains to be observed to ensure that a concrete blanket is there; the cleanliness must always be maintained: not workable in a hazard situation even in small intensity; each foundry always provides the test specimen and test slump; conduct the hammer test on the finished channel at least 28 days with K-250 quality.

The precast concrete construction method: always check the U-ditch conditions that come in both basecamp and location and it should not be in a state of damage; conduct a random test of precast U-ditch that comes, the test can be performed by hammer test, core (for thickness), concrete tension test, and bending test of concrete with K-250 quality; not applicable if in a state of intense rainfall.

Post Construction. In Situ Concrete Cast construction method: re-check the straightness of the channel; ensure that all work is in accordance with the quality planned.

The precast concrete construction method: check that the U-ditch condition that is carried out should not be in a defective condition; ensure that all work is in accordance with the quality planned. 
Construction Quality based on Field Results. In the implementation, neatness and construction quality are seen, namely: the dimension size in the field is more assured and precise on precast concrete than In Situ Concrete; the quality of precast concrete is more assured because it is manufactured by the factory coupled with the quality of the concrete that has been determined from the In Situ Concrete.

\section{CONCLUSION AND SUGGESTIONS}

Some things can be concluded in this study, which are:

Costs required in the implementation of construction methods of Precast Concrete and In Situ Concrete are: RAB for In Situ Concrete construction method is Rp. 109,790,340,000.00; $\mathrm{RAB}$ for Precast Concrete construction method is Rp. 73,460,740,000.00.

Cost efficiency is about $33.09 \%$ (Rp. 36,329,625,506.00).

Time required in the implementation of Precast Concrete and In Situ Concrete methods on site are: In Situ Concrete Construction Method is for 2 years and 1 month; Precast Concrete Construction Method is for 1 Year 8 Months; Time Efficiency is about $20.00 \%$ (5 months).

In the implementation, the neatness and implementation quality can be seen as follows: the surface of precast concrete is smoother and tidier than In Situ Concrete; the dimension size of the field is more assured and precise on precast concrete than In Situ Concrete; the quality of precast concrete is more assured because it is manufactured by the factory coupled with the quality of the concrete that has been determined from the In Situ Concrete; questionnaire results toward 30 respondents, $70 \%$ opinion stated that precast concrete is more effective and efficient in the selection of implementation method than In Situ Concrete.

A review is needed in the effectiveness and efficiency of the implementation of the channel length that will be done. In designing the channel, it should be planned according to the standard size produced in the factory. If the location of work is not on the highway, then the creation of access roads following the cost of transportation and others must be considered. For work on the primary channel, the ideal design and the creation of condor channels during the execution of the work should also be considered. It needs to immediately make prevention efforts technically by drafting the master plan of channel / drainage in an integrated and non-technically by doing socialization to related institutions and society.

\section{REFERENCES}

1. Abduh, M. 2007, Technological Innovation and Precast Concrete Systems in Indonesia: A Value Chain Analysis. Seminar and Exhibition of IPR 2007.

2. Ervianto, W. I. (2005). Construction Project Management. Yogyakarta: Andi Publisher.

3. Ervianto, W. I. (2006). Technology Exploration in Precast Concrete Construction Project and beksiting. Yogyakarta: Andi Offset.

4. Gibb, A. G. F. (1999). Off-Site fabrication. John Wiley and Son. New York. USA in

5. Ibrahim, Y.H.M. (2003). Business Feasibility Study, Revised Edition. Jakarta: PT. Rineka Cipata.

6. Jarkas, A.M. (2005). An investigation into the influence of build ability factors on productivity of in situ reinforced concrete construction. An Investigation into the Influence of Build ability Factors on Productivity of in situ Reinforced Concrete Construction.

7. Kulkarni, S.A. (2008). Finite element analysis of precast hybrid-steel concrete connections under cyclic loading. Journal of constructional steel research, 64(2), 190201.

8. Kurama, Y.C. (2000). Unbonded post-tensioned precast concrete walls with supplemental viscous damping. ACI Structural Journal, 97(4), 648-658. 
9. Marriott, D., Pampanin, S., \& Palermo, A. (2009). Quasi-static and pseudo-dynamic testing of unbonded post-tensioned rocking bridge piers with external replaceable dissipaters. Earthquake engineering \& structural dynamics, 38(3), 331-354.

10. Mirmiran, A., Kulkarni, S., Castrodale, R., Miller, R., \& Hastak, M. (2001). Nonlinear continuity analysis of precast, prestressed concrete girders with cast-in-place decks and diaphragms. PCl Journal, 46(5).

11. Pampanin, S., Priestley, M. N., \& Sritharan, S. (2001). Analytical modelling of the seismic behaviour of precast concrete frames designed with ductile connections. Journal of Earthquake Engineering, 5(03), 329-367.

12. Soeharto, I. (1999). Project Management: From Conceptual to Operational, Volume 1. Jakarta: Erlangga.

13. Suhardjono. (1984). Urban Drainage. Malang: UPT Faculty of Engineering Brawijaya.

(C) 2017 by the authors. Licensee RJOAS, Orel, Russia. This article is an open access article distributed under the terms and conditions of the Creative Commons Attribution (CC BY) license: http://creativecommons.org/licenses/by/4.0/ 
DOI https://doi.org/10.18551/rjoas.2017-09.21

\title{
CAPABILITY ASSESSMENT OF SMALL AND MEDIUM ENTERPRISES IN KALIMANTAN TIMUR
}

\author{
Hadjaat Michael*, Za Saida Zainurossalamia, Wahyuni Sri \\ Faculty of Economy and Business, Mulawarman University, Indonesia \\ *E-mail: saida.zainurossalamia.za@feb.unmul.ac.id
}

\begin{abstract}
Economically, Small and Medium Enterprises (SMEs) have contributed to economic growth, but in a development deal with complex problems. The existence of SMEs in the region is expected to provide a significant positive contribution to mitigation efforts such problems. These problems lead to weak business networks, the limited ability of market penetration and market diversification, economies of scale is too small that it is difficult to reduce the cost, the profit margin is very small, and others, and do not have a competitive advantage. At this time, innovation has not been a major driver of economic growth and technological progress in Indonesia, particularly SMEs. The success of building innovation capacity is determined by an existence of markets served carefully, the ability to collect valuable information and learning market information. Implementation of innovation is a complex process that requires the harmonization of policies and strategies from many sectors. If it is met, innovation will occur on an ongoing basis and contribute significantly to economic growth.
\end{abstract}

\section{KEY WORDS}

Innovation, capabilities, cluster, SMEs.

Development of Small and Medium Enterprises (SMEs) became a crucial since SMEs have such an important role for the economic growth of a country, including in the country of Indonesia. In Indonesia, SMEs contribute to the employment of $\pm 99 \%$ and contributed to GDP amounted to $\pm 57 \%$. It shows that SMEs have the ability to strengthen the structure of the national economy. Although economically SMEs have a significant contribution to economic growth, but in a development deal with complex problems are: lack of capital, difficulties in marketing, simple organizational structure with a division of labor that is nonstandard, low- quality management, poor quality and limited human resources, most do not have the financial statements, the legality weak, and poor quality of products and technology.

During these SMEs in the region are often associated with economic and social problems in the region itself, such as high levels of poverty; number huge unemployment, especially for the less educated segments of society; unequal distribution of income; process of uneven development between urban and rural as well as urban problem with all its negative aspects. This means that the presence of SMEs in the region is expected to provide a significant positive contribution to mitigation efforts such problems. These problems lead to weak business networks, the limited ability of market penetration and market diversification, economies of scale is too small that it is difficult to reduce the cost, the profit margin is very small, and others, and do not have a competitive advantage. SMEs have competitive advantages, which are: having a good quality of human resources, optimal use of technology, is able to perform efficiency and increase productivity, improve the quality of products, have access to extensive promotion, have a structured quality management system, resource adequate capital, has extensive business network, and have an entrepreneurial spirit and have the ability to be able to innovate.

Innovation is a process with varying levels of difficulty from simple to complex; and that is certainly dynamic (potentially snow-balling effects). As a process in which there are elements of inter-related driving, where there is an interactive learning so successful innovation in the market. Owner ideas or creations certainly cannot act alone, and in turn interact with the market. Progress of science and technology can now be used in the process to become a product idea, do not always have to be intensive in research and development, 
but rather intensive in to the "science and technology" so readily accepted in the market. Not all owners of ideas have the capacity (including mastery of science and technology) are qualified in the success of innovation, in which case it will be necessary support of "ABG" (Academics, Business, and Government) in synergy. Limitation of innovation system as formulated states that there are vertical and horizontal relationships that form a network to a productive process of learning and diffusion results in best practice. Vertical relationship is reflected in the value chain enterprises (cluster) that may result from innovation, while the more horizontal relationship is a relationship between individuals and between institutions that can succeed innovation. The system itself can be interpreted simply as a bond of some of the elements that have a dependency to one another and interact on a regular basis (regular) in performing a task.

Innovation has not been a major driver of economic growth and technological progress in Indonesia. First, the value of innovation Indonesia only factor of 3.6 in 2012. Second, Indonesia is ranked 108 in the world ranking index of the knowledge -based economy. Third, innovation has not been a major part of economic growth is still dependent on the consumption of around $63 \%$ consists of exports and investment demand. Factors contributing consumption dominant cause of economic growth only reached $6.5 \%$ in 2011 that should be higher if supported also by the lack of innovation. Fourth, innovation does not become the focus of a growing industry in Indonesia, especially in the regions, but more as a secondary raw material or component or assembly plants. The importance of innovation capability as an economic force that drives change in the values of economic offer something new in the markets served. The success of building innovation capacity is determined by the existence of markets served carefully, the ability to collect valuable information and learning market information.

Thus there are two things that are important to be able to build innovation capabilities. First; aspects of learning, where the observed and studied market information into knowledge that has important value in order to build competitiveness. Second; related to the ability to be able to attach the market and stakeholder preferences companies that have relevance values are particularly important to catch the signal - a signal of quality products at competitive standardization. It appears that the implementation of the innovation is a complex process that requires the harmonization of policies and strategies from many sectors. If it is met, innovation will occur on an ongoing basis and contribute significantly to economic growth. According to Pavit (2005) the company must be aware that the success of the companies affected by innovations. Innovation is needed because the environment is always changing. When competitors introduce new products to meet the market demand is there, and then the company must respond to the situation. One way to make innovations in order not to be left by customers.

Potential industry owned by SMEs, some of which became the mainstay commodities. The development of the craft, the recently characterized the emergence of a variety of types and appearances with new designs. That is one of the allure for domestic and foreign consumers. Another problem is also felt in terms of technology introduction and application of various technologies can improve the various weaknesses of small entrepreneurs.

With technology, small businesses can produce precise, accurate, and in a short time in accordance with the order. The development of technology is one of the major forces that control industrial growth. The use and management of new technologies is important for small businesses to improve competition and increase both national and international competition. Many authors state that small businesses are far behind compared to large enterprises in the use of new technologies. Some of the reasons for this are the limited resources of small companies. In addition, a national structure for the production and transfer of new information about the technology adopted for business needs a little small. With the help of human technology tend to have a lot of choices in developing areas of interest. In addition, the technology can be used for the welfare of society or improve the quality of life of man.

Many small companies used to buy equipment and fix it by adding functions. Innovation and new technologies require external information in the development of new ideas facility. 
Basically, regional innovation systems may be developed only when there is a strong desire, pioneering and consistency of Regional Head to build competencies and strengthen the synergistic collaboration of various parties in the region's economic development through policies and instruments policy set. In other words, the key to the successful development of regional innovation systems is the presence of a strong will, pioneering and consistency of both the Regional Heads in setting the policy agenda of regional innovation system development, strengthening the framework of regional innovation system elements, as well as in the provision of regional innovation systems development budget is done with; Carrying capacity of the provider; Absorptive capacity of the user; Institutional linkages interface and the parties mutually beneficial; Specialized infrastructure; Funding / financing of innovation and/or funding/financing risk; and policy support.

The objectives of the study are:

- Identify potential SME sector can be the focus of the development of the innovation capability of SMEs;

- Identify stakeholders both in government, academia, private sector, producers, and society;

- Identify the factors of competitive advantage for formulating SME innovation capability of SME development strategy leading sectors.

Expected benefits can be gained from this study include:

- Material inputs to policy makers at the local government in an effort to empower and development of SMEs;

- Efforts to improve the empowerment of government, academics and the business agent for the community is able to drive the innovation potential synergistic owned achieve the development of SMEs in East Kalimantan.

\section{LITERATURE REVIEW}

Innovation as a management process requires systems and culturally appropriate to achieve the effectiveness of the company. Support intangible assets inherent in man as knowledge is indispensable as a source of value for the company. Intellectual assets that the company is highly dependent on intangible characteristics such as: the ability of innovation, the ability to change, the opportunity to market, development and retention of employees, and the relationship with the customer. Two important dimensions necessary to support innovation of the system is that the technology, structure, and processes as well as a good culture include employee commitment, as well as access to talented employees.

Innovation implemented an innovation opportunity search results. Innovation is not just an outcome but it is a process. Formally, according to Law No. 18 In 2002, innovation is research, development, and or engineering that aims to develop practical application value and context to new knowledge or new ways to apply science and technology existing in the product or production process. Innovation can be said is the mobilization of knowledge and technical skills (diffusion of science and technology) as well as experience in creating new processes and outcomes. Innovation is a key driver of long -term success of a company in today's competitive market. This is because companies with the capacity to innovate will be able to respond to environmental challenges faster and better than companies that do not have the capability for it. Therefore, it is not surprising that the effect of innovation on performance has become a classic in the literature of analysis, with a number of empirical studies provide evidence of the positive effects (Jimenez et al., 2008).

Given the importance of innovation in relation to the competitiveness of the company, a number of studies have tried to identify the major determinants of the capacity of companies to innovate (Damanpour, 1991). These factors consist of internal and external factors as antecedents of innovation. Of internal factors studied include strategy, organizational design, leadership or organizational culture (Damanpour, 1991) and, recently, the learning organization and market orientation (Jimenez et al., 2008). Organizational innovation studied from various disciplines, such as management/strategy, entrepreneurship, political science, and marketing. Innovation is a form of learning and something new. 
Innovation is a means through which an organization responds to a variety of environmental changes. Tushman and Nadler (1986) proposed that innovation refers to, product method new ideas, or services that are applied in the organization. Some researchers define innovation as the implementation of new ideas, methods, or services (Subramanian and Nilakanta, 1996), other researchers assume different innovations. For example, Vigoda-Gadot et al. (2005) view innovation as a multi-dimensional nature of the organization. They define innovation as the organization includes five dimensions: creativity, risk taking, openness to change, future orientation, and pro-activeness. Innovation can be distinguished from creativity and consists of four elements, namely, creativity, strategy, application, and profitability (Li-An Ho, 2011). Pavitt (2005) found at the company level, the process of innovation can be divided into three sub-processes include: Cognitive, namely how companies generate and maintain knowledge to perform tasks; Organization, which is how the company operates internally or in collaboration with other companies and organizations, and Economics, which is how the company determines the internal incentives to ensure the rapid innovation and are in the desired direction.

Strategy of Innovation. Innovation has a dual role as a determinant of economic competitiveness and as a means for liberation (liberation) and socio-cultural backwardness, ignorance, and poverty (Bobb, 2005). Success in today's business is determined by innovation. Innovation is defined as a process within the organization to utilize the skills and resources to develop new products or services or to build a new system of production and operations so as to address the needs of customers (Jones, 2004). Technology, business opportunities, capital, entrepreneurship, regulatory and cultural as well as methodologies are variables that affect the practice of innovation in an organization (Abend, 2005). Innovation on the other hand is also a dilemma for management, organizational survival in the long term requires a commitment to always do the transformation through disruptive growth. However, the facts prove only a few companies that can succeed with this strategy. Innovative organization committed to controlling the environment; organizational structure that gives the freedom to be creative; leadership that encourages organizations to innovate, and a management system that serves the mission of the organization. Natural barriers that are often encountered in efforts to innovation, among others; solid organizational structure (dense), resource constraints, the reluctance to delegate authority, and a high level of internal audit. In order to be sustainable innovation and corporate performance required to support innovation strategy (Terziovski and Marianne, 2004), which classifies the innovation strategy into three groups of radical, incremental, and integrated. Radical is a strategy that refers to the activity of innovation that never existed before; drastically change the establishment, products or new processes that differ from the previous. Incremental is gradually developing strategy; repair the product or an existing business processes with innovative measures. Integrated combine radical and incremental addition to finding new things (invention) integrated strategy also encourages innovation by developing of an existing one. In general, innovation has the meaning adopt something new by anyone who adopt it, and as the process of creating new products. Innovation is a multidimensional concept which consists of four dimensions: leadership orientation towards innovation company (Maldique and Patch, 1988), the type of innovation, the source of innovation (Mansfield, 1988) and the required investment in innovation (Thomson and Ewer, 1989).

Here's an explanation of the dimensions of innovation are:

- Leadership orientation; shows the company's position in the market if the company as a fist to the market, the company as the second player second to the market, or a late entrant. The leader is responsible for determining and formulating a strategy in accordance with the company's position in the market.

- Type of innovation; type of innovation represents a combination of manufacturing innovation, which is a process that is carried out and the products produced by the company. Innovation processes emphasis on new methods in the operation by making new technologies or develop existing technologies. While product innovation is the result of the creation and introduction of radical products or modifications of existing products. Technological uncertainty, lack of support from senior managers, 
lack of resources and poor project management will hamper the achievement of product development (Zahra and Das, 1993). The selection of the type of innovation is affected by the company's investment, and will ultimately affect the performance of the company.

- Source of innovation; describes the implementation of innovation activity, whether the idea of innovation comes from internal or external or both. Internal sources of innovation means that the company entrusted to innovate both in the business process or product on research and development section. While external sources of innovation have a sense that the company will perform innovation by way of purchase, the license agreement, the acquisition of another company or partnership (joint venture) with suppliers, customers or other companies.

- The level of investment; the level of investment includes investment in terms of finance, technology and investment in human resources. Financial investment includes expenditures for research and development projects, and the purchase of an innovation in a product that has been developed elsewhere. Technology investment is the expenditure for equipment, infrastructure, human resources. In the face of an increasingly competitive conditions of competition, the business environment is unpredictable and highly competitive consumer demand, sue the company to seek new solutions in formulating corporate strategy in order to maintain the viability and competitiveness of the company. Particularly in terms of product development innovation strategy needs to be developed and continue to do (never ending innovation). Without innovation companies will die otherwise companies that sustainable innovation or continuously will be able to dominate the market, with the creation, capital, new product appearance.

Economic Clustet. Cluster (cluster) is essentially an attempt to classify interconnected core industry, both supporting industries (supporting industries), industry -related (related industries), supporting services, infrastructure, research, training, education, information infrastructure, technology infrastructure, resources natural resources, and institutions institutions. The cluster is also a way to set some economic development activity. Porter (1990) defines Clusters as "Clusters are geographic concentrations of firms, suppliers, related industries, and specialized institutions that occur in a particular field in a nation, state, or city. Another definition of Clusters industry is the geographical concentration of industries that gain performance advantages through co-location. Clusters can also be defined as "the relationship between the company also provides various complementary services, including consultancy services, education and training providers, financial institutions, professional associations and government institutions".

There are at least three forms Cluster frameworks: Diamond models, flexible specialization and collective efficiency. Flexible models and specialization widely adopted by developing countries. Porter diamond models widely applied in developed countries. Model diamond is considered superior to other models in explaining Clusters are dynamic and have a great role in improving productivity through industrialization process. Cluster approach Porter's model is the development of industrial district or industrial areas developed by Alfred Marshall in 1920. In contrast to Marshall who only focuses on peer companies, Cluster Porter's model does not restrict to just one industry, but more broadly.

Diamond Cluster Model, includes related industries, as well as other companies that have relevance in technology, the same input. By working together in a cluster, then the firms or industry - related industries will benefit from synergies and efficiencies are high compared to those working on their own. According to Porter (1990) Clusters can be formed in the city, the region, and even within a country. Cluster (cluster) is essentially an attempt to classify interconnected core industry, both supporting industries (supporting industries), related industries (related industries), supporting services, infrastructure, research, training, education, information infrastructure, technology infrastructure, resources natural resources, and institutions - institutions. The cluster is also a way to set some economic development activity. Among some very fundamental truth in the concept of industrial clusters and distinguish one concept with other concepts are the dimensions value (value chain). With 
consideration of the value chain dimension, in general there are two (2) industry cluster approach in the literature, namely:

- Some of the literature, especially that developed in advance and further highlights aspects of agglomeration, an approach based on (emphasis on) aspects of similarity (similarity) a set of business activity. In this case for example, industrial centers / business, industrial district, and the like that have a " likeness " of business activity is regarded as an industry cluster;

- Some of the growing literature today, including those emphasized by Porter, an approach highlights the " linkage " (interdependency) or a set of business activities of the value chain. In this view, the central industrial / business and / or industrial district is basically an integral part of the fabric of the value chain as an industry cluster. Assessed value chain approach " more appropriate " especially in the context of increasing competitiveness, innovation systems development (national / local), economic development initiatives knowledge / technology or themes like, and not " just" an attempt to obtain " agglomeration economies " as a similar concentration of business activity. In detail, there are several definitions of the cluster. Porter (1990) defines Clusters as "Clusters are geographic concentrations of firms, suppliers, related industries, and specialized institutions that occurs in a particular field in a nation, state, or city". Another definition of Clusters industry is "the geographical concentration of industries that gain performance advantages through co-location". Clusters can also be defined as "the relationship between the company also provides various complementary services, including consultancy services, education and training providers, financial institutions, professional associations and government institutions.

The Benefits of Clusters. Targeting industrial cluster development program with the industry believed Porter will provide great benefits to economic growth.

The benefits of these clusters are as follows (Porter, 1990):

- Cluster is able to strengthen the local economy industry concentration at a particular location may have an impact on cost savings for companies in the Cluster. The cost savings are known as localization economies. The savings can be derived from the increased availability of specialized input suppliers and services; addition of trained and specialized workforce; public infrastructure investments are done for the needs of specific industries; Financial markets are closely associated with the industry; and the increasing trend of information and technology transfer between the companies.

- Cluster is able to facilitate the reorganization industrial transition from the industrial organization of large companies that produce en masse to a small company that focuses on the specialty production has been well documented. Changes in industry structure occur due to increased global competition and the emergence of new production technologies (eg: computerized production). Cluster is an attractive industrial location for a small company specialized in the production and computerized. Product specialization and the adoption of the latest production technology is more prominent and easy to do for the company in the industrial cluster. The closeness between the company specialized in the production of input suppliers and product markets can increasing the flow of goods through the production system. Readiness for access to market products and inputs also allow the company to adapt to the changes that occur in the market. Thus, the spatial concentration of these companies are able to provide a collection of well-trained workforce that is required by a computerized production technologies.

- Cluster improve networking among companies. Networking is a collaboration between the companies to take advantage of cooperation, develop new markets, integrating activity, or gather resources and knowledge. This cooperation will often occur naturally among cluster members. A survey of manufacturing networks shows that companies that have strong networking benefit from collaboration and transfer of information on marketing, new product development, and technology improvement. 
These companies also increased competitiveness and profitability through cooperation and collaboration between the companies.

- Cluster allows a focus on public resources. Targeting industrial development through cluster allows a region to use the resources of economic development privately held more efficiently. First, industrial cluster allows a region to focus on the recruitment system, maintenance and expansion, as well as small business development programs rather than providing assistance programs for a variety of different types of industries. Planned development efforts such as these provide a clearer identification of the needs of specific industries and allow (with specific spending budget) program providing fewer, but more valuable. Second, because the relationship between companies in the Cluster, programs that support specific business will have a multiplier effect (multiplier effect) is relatively greater to the regional economy. Total employment and income of the form (or retain) Cluster members will exceed total employment and income of the companies of the same amount, but not incorporated in the Cluster.

- Clusters increase productivity and efficiency. With the Clusters then the efficiency will be created in economy. The companies will have access to certain inputs, services performed, labor, information, because it is available in the cluster. Likewise, the coordination between companies in Clusters will be established better and easier. Best practices in Clusters will be faster transmitted so that maximum efficiency will be obtained by many companies.

- Clusters encourage and facilitate innovation. The existence of clusters will increase the ability of members of the Cluster to see opportunities to perform a variety of innovations. Ease of doing experiments with the use of existing resources in the cluster are also other benefits of the ClusterCluster model is very effective for the economy because Cluster provides several benefits. First, an integrative approach Cluster will create coherence of the various activities or projects separate activity. Second, a comprehensive cluster approach, collaboration and cooperation will create synergy in the Cluster. Third, the Cluster will encourage innovation, which in turn will increase productivity.

Clusters vs. Industrial Targeting. Porter stated that what is important is not what is produced in a country or region, but rather how the production productive in increasing growth and competitiveness. Theoretically, any region or country can develop a cluster with competitiveness if they focus on improving productivity. Porter added, "All Clusters matter" (all important Clusters), this opinion may be very surprising for policy makers who are just looking for seed industry (pick the winners). Furthermore, Porter also stressed that "there is no low-tech industry; there is only a low-tech company". In other words, we do not have to do industrial targeting.

Differences between economic developments based on traditional industrial clusters policy. The main difference lies in the first line: if the industrial policy of targeting specific sectors of industrial progress and desired, Cluster approach believe that all Cluster contribute to progress together. The problem, policy analysts just want to know which is more important clusters, targeting the high-tech industry, and it was generally believed that what produced an area (and not how) is vital for the development of strategic policy. This leads to "all Clusters matter" looks like is not part of a strategy. Porter actually believe that traded "Clusters (Cluster export oriented or economic activity) is more important than the "nontraded" Clusters.

In this case, Porter Cluster theory is an extension of the regional economic theory that has been adopted by most local authorities, which "traded Clusters" role as a major driver of economic growth and expanded through forward and backward linkages. Cluster identification generally based on input-output analysis, although this approach is more oriented look backward and forward linkages relations in industrial environments. Porter did not like the input-output analysis. He looked at the relationship between the company, not as a backward and forward linkages relationship, but the relationship technology, expertise, information, marketing and consumer desires, where Porter regard it as a main component to 
create competitiveness and innovation. But Porter also know that the sector is "traded", which is a traded commodity sector, has a major role in development.

Critical Success Factors Clusters. There are several factors that determine the success of a cluster. These factors are the presence of venture capital; the availability of technical infrastructure, the presence of higher education and research institutions, entrepreneurs, networking and quality of linkages, social capital and diversity. Various studies on clusters also found that the cluster that has the competitive environment and their rivalry will be more developed than the cluster that are highly dependent on natural resources, weather and geography.

There are important factors that led to Taiwan succeeded in developing Clusters industry since the 1980s. First, the government's role is very important in the early stages of establishment Clusters by encouraging innovation through research institutions like ITRI and the Institute for Information Industry (III). With the innovation, Clusters grow quickly. The government in the early stages also provide fiscal incentives in the form of income tax-free for 5 years for companies investing in the cluster causes backward and forward linkages of vertical industries, as well as horizontal differentiation. Horizontal differentiation promoting healthy competition and encourages innovation. Scale economies of the electronics industry in Taiwan got a positive distribution in the US market. Availability of reliable labor is also a factor of success Industrial Clusters in Taiwan.

\section{METHODS OF RESEARCH}

Goals to be achieved in the research development innovation capability of SMEs in East Kalimantan include: Maturation of the concept, Doing desk study and collection of data, Perform initial analysis based on the study of literature and secondary data are available, Preparing field study or field survey (direct survey and, holding a series of meetings among others with relevant government agencies, business associations and various other relevant stakeholders in the strip) with the identification of stakeholders and the development of the survey instrument, Carry out a review into the location of the area in a predetermined area and questionnaires, doing further analysis of the results obtained from activities mentioned above by using several methods, both quantitative and qualitative analysis to prioritize potential development, Making the identification and mapping of SME cluster development in the areas concerned, discuss the results of the identification of the various key stakeholders and stakeholder support; and Doing revisions or improvements to the results of the study.

\section{Methods and Analysis Techniques}

a) Descriptive Statistics Descriptive analysis is used to describe a variety of conditions and developments from time to time and updated from a variety of indicators that will be required.

b) Analysis Klassen Typology. Klassen Typology used to determine the image of the pattern and structure of economic growth in each region. Klassen typology divides essentially based on two main indicators, namely regional economic growth and per capita income areas. Through this analysis, there are four characteristics of the economic growth pattern and different structures, namely: the area of fast-forward and fast - growing (high growth and high income), advanced areas but depressed (high income but low growth), rapidly developing areas (high growth but income), and the relatively underdeveloped regions (low growth and low income) (Arsyad, 2010).

c) Overlay Analysis Analysis. Overlay is intended to look at the description of economic activity and growth potential based on the criteria that contribute criteria analysis between MRP and analysis of combinatorial analysis LQ. This overlay technique was formed through the use of overlapping (series) a map, each representing an important environmental factor (Arsyad, 2010).

d) Diamond Cluster Model. Porter (1990) suggests that the cluster is defined as "geographic concentrations of firms, suppliers, related industries, and specialized institutions that occurs in a particular field in a nation, state or city". Another definition of clusters is "the geographical concentration of industries that gain performance advantages through co- 
location". Clusters shows the relationship between the companies that also provide complementary services, including consultancy services, education and training providers, financial institutions, professional associations and government institutions that can be identified are four (4) components, namely: first, the input factor (input factor) which are variables that already exist in the industrial clusters such as human resources (human resources), capital resources (capital resources), infrastructure (physical infrastructure), the infrastructure information (information infrastructure), the infrastructure of science and technology (scientific and technology infrastructure), the infrastructure administration (administrative infrastructure), and natural resources (natural resources). Second, demand conditions (demand condition) associated with sophisticated and demanding local customers. The more advanced a society and increasingly demanding customers in the country, so the industry will always strive to improve the quality of products or innovations in order to meet the high local customer wishes. Third, and related supporting industries (related and supporting industries) for efficiency and synergy in clusters, especially in terms of transaction costs, sharing technology, information, and expertise that can be used by industry or company other woods, which is to improve the competitiveness and productivity.

\section{Data Collection Methods}

Data collection was performed using the following methods: Desk study; held to review the various regulations and policies, review literature related, and secondary data collection related to the potential of SMEs, Survey and Field Observation; Conducted a questionnaire survey to inventory / identify various potential, location of the region / location, type of industry, the type of cluster, and capture the qualitative determination enter the cluster. The survey was conducted using questionnaires, the nature of the closed and open questions, to stakeholders the objectives in this study. Meanwhile, field observations conducted to determine the actual condition of the picture of local economic conditions, depth interviews were conducted to know more about the various existing problems associated with this type of potential economic clusters developed. The discussion was conducted to determine in more depth about the various issues involved in the development of SME innovation capabilities.

\section{RESULTS AND DISCUSSION}

Industrial development Industrial Sector. Industrial development in East Kalimantan province has increased from 15398 units in 2009 to 16574 units in 2013, an increase of 1.176 units, with a growth rate of $1.86 \%$ per year. In line with this growth on the other hand the number of workers absorbed, for the same period increased from 125386153286 persons or people into employment grew an average of $5.28 \%$ per year, as well as for the average investment growth - average 4, 91\% per annum of the nominal Rp.9,09 trillion to Rp. 10.91 trillion. Industrial growth, as above, can be explained in detail, that the business unit of Small and Medium Enterprises (SME) increased from 15268 units in 2009 to 16437 units in 2013 , or an average growth of $1.87 \%$ per year.

Workers absorbed 73326 people in 2009 rose to 89862 people in 2013, with average growth rate-average of $5.31 \%$ per year, while investment of Rp. 2.95 trillion in 2009 to Rp. 5.53 trillion in the year 2013 , with an average growth rate of $19.98 \%$ per year. While the Large Industries in 2009 amounted to 130 business units and business unit increased to 137 in 2013 , with an average growth rate of $1.32 \%$ per year, while the workforce increased from 52060 persons in 2009 to 63424 people in 2013, or an increase average growth of $5.26 \%$ next year for investment decreased from Rp. 6.14 trillion in 2009 to Rp. 5.38 trillion in 2013, an average growth $-1.67 \%$ per annum for the details, the data can be seen in Table 1 .

Potential Regional Featured. In order to develop the industry in East Kalimantan, conducted through commodity development approach, and attention to a variety of commodities are developed, as well as limitations in its development, the more commodities are classified into two (2) categories, namely leading commodity and commodity Focus (potential and prospective). 
Table 1 - Industrial development in Kalimantan Timur

\begin{tabular}{|c|c|c|c|c|c|c|c|c|c|}
\hline \multicolumn{3}{|c|}{ SMEs } & \multicolumn{3}{c|}{ Big Industry } & \multicolumn{3}{|c|}{ Total Industry } \\
\hline Year & $\begin{array}{c}\text { Business } \\
\text { unit }\end{array}$ & Worker & $\begin{array}{c}\text { Investment } \\
\text { (Million } \\
\text { Rp) }\end{array}$ & $\begin{array}{c}\text { Business } \\
\text { Unit }\end{array}$ & worker & $\begin{array}{c}\text { investment } \\
\text { (Million } \\
\text { Rp) }\end{array}$ & $\begin{array}{c}\text { Business } \\
\text { Unit }\end{array}$ & worker & $\begin{array}{c}\text { Investment } \\
\text { (Million } \\
\text { Rp) }\end{array}$ \\
\hline 2009 & 15.268 & 73.326 & 2.949 .966 & 130 & 52.060 & 6.136 .403 & 15.398 & 125.386 & 9.086 .369 \\
\hline 2010 & 15.505 & 75.484 & 2.953 .516 & 131 & 52.814 & 6.643 .663 & 15.636 & 128.298 & 9.597 .179 \\
\hline 2011 & 16.056 & 85.326 & 4.989 .049 & 133 & 61.736 & 4.699 .397 & 16.189 & 147.062 & 9.688 .447 \\
\hline 2012 & 16.218 & 87.995 & 5.529 .820 & 135 & 62.567 & 4.774 .506 & 16.353 & 150.562 & 10.303 .726 \\
\hline 2013 & 16.437 & 89.862 & 5.532 .466 & 137 & 63.424 & 5.382 .185 & 16.574 & 153.286 & 10.914 .651 \\
\hline
\end{tabular}

Source: Disperindagkop \& MSME Kalimantan Timur Province.

Commodities are dominating in 10 districts / Commodities Oil Palm City is shown in Table 2.

Table 2 - Commodities Featured Products Industry Medium Large Kalimantan Timur

\begin{tabular}{|c|c|c|}
\hline 1 & Samarinda City & Fisheries, Tourism, Pepper and Coal \\
\hline 2 & Balikpapan City & Fisheries, Tourism, and Petroleum Refining \\
\hline 3 & Bontang City & Fisheries, Fertilizers and LNG \\
\hline 4 & Tarakan City & Shrimp, Chicken, and Petroleum \\
\hline 5 & $\begin{array}{l}\text { Kabupaten Kutai } \\
\text { Kartanegara }\end{array}$ & $\begin{array}{c}\text { Palm oil, rubber, rice, pepper, Banana, Pineapple, Fishing,Tourism, Coal, Gas } \\
\text { and HTI. }\end{array}$ \\
\hline 6 & Kabupaten Kutai Timur & Palm Oil, bananas, corn, rubber, coal and timber plantations. \\
\hline 7 & Kabuapten Kutai Barat & Palm Oil, Rubber, Durian, Rambutan, freshwater fishing,Coal and Gold. \\
\hline 8 & Kabupaten Pasir & $\begin{array}{l}\text { Palm Oil, rubber, rice, bananas, Fisheries, Coal and HTI. } \\
\text { Seaweed. }\end{array}$ \\
\hline 9 & $\begin{array}{l}\text { Kabupaten Penajam } \\
\text { Paser Utara }\end{array}$ & Fisheries, Pepper, Palm Oil, Durian, Rubber and HTI \\
\hline 10 & Kabupaten Berau & Oil Palm, Rubber, Rice, Soybean, Fisheries, Oil, Tourism, and Coal. \\
\hline 11 & Kabupaten Bulungan & Palm Oil, Durian, Cocoa, Fishing, Cempedak, Methanol, andHTI. \\
\hline 12 & Kabupaten Malinau & Cocoa, oil palm, pineapple, Cempedak, HTI, and Coal \\
\hline 13 & Kabupaten Nunukan & $\begin{array}{l}\text { Cocoa, Palm Oil, Fisheries, Rice Adan (Bario), Corn, Chicken Nunukan, } \\
\text { Petroleum, Industrial Plantation Forest (HTI) and Salt Mount }\end{array}$ \\
\hline 14 & $\begin{array}{l}\text { Kabupaten Tanah } \\
\text { Tidung }\end{array}$ & Palm Oil, Durian, Cocoa, Fishing, Cempedak, Methanol, and HTI. \\
\hline
\end{tabular}

Table 3 - Commodities Featured Products Industry Medium Large Kalimantan Timur

\begin{tabular}{|c|c|c|}
\hline 1. & Kayu Lapis (plywood), Mdf & Samarinda,Balikpapan,PPU,Tarakan,Kukar \\
\hline 2. & Udang Beku & Balikpapan,Tarakan,Nunukan,Kukar \\
\hline 3. & $\begin{array}{l}\text { Ind. Pengolahan } \\
\text { Kayu/sawmill }\end{array}$ & $\begin{array}{c}\text { Samarinda,Balikpapan, Tarakan,Nunukan, } \\
\text { Kukar,Berau,Bulungan,Pasir,Kutim }\end{array}$ \\
\hline 4. & Crude Palm Oil & Samarinda,Kutai,Pasir,Kutim \\
\hline 5. & Galangan Kapal & Kukar,Pasir,Samarinda,Balikpapan \\
\hline 6. & Pupuk urea \& Amoniak & Bontang \\
\hline 7. & Moulding & Samarinda,Balikpapan,Tarakan, Nunukan,Kukar \\
\hline 8. & Gas Methanol & Bulungan \\
\hline 9. & Methanol & Bontang \\
\hline 10. & Hexamethylene Tetramine & Bontang \\
\hline 11. & Melamine & Bontang \\
\hline 12. & Ind. Lem & Samarinda, Bontang \\
\hline 13. & Ind. Minyak Kelapa & Nunukan \\
\hline 14. & Pulp & Berau \\
\hline 15. & Bengkel Service & Samarinda, Balikpapan, Kubar, Kukar \\
\hline 16. & Ind. Pengolahan Rotan & Pasir, Balikpapan \\
\hline 17. & Kulit Buaya & Samarinda \\
\hline 18. & Kain Tenun Ulap Doyo & Kutai Kartanegara \\
\hline 19. & Garmen & Balikpapan \\
\hline
\end{tabular}

Commodities focus is a commodity that is used as a development candidate based on an assessment conducted in sub-criteria to consider aspects of the advantages, the interest rate comparison, merging the advantages and value of pair wise comparisons. In this focus commodities determined 5 main commodities that can be developed prospectively and any 
potential, i.e. wood, coal, oil palm, cocoa and rubber. Potential medium large industrial commodity products in Kalimantan Timur can be seen in Table 3.

Industry Centers. Center of Small and Medium Industries in East Kalimantan were recorded until the year 2013 as many as 206 centers consisting of 2,653 business units, employment reaching 8,352 people, with an investment of Rp. 73.686 billion. State of the medium and small industries is still dominated by the food industry as much as 91 industrial centers, as in Table 4.

Table 4 - State Central Small Industries of Kalimantan Timur (According to the Industrial Branch)

\begin{tabular}{|c|l|c|c|c|c|c|c|}
\hline $\mathrm{n} / \mathrm{n}$ & \multicolumn{1}{|c|}{ Cabang Industri } & Sentra & UU & TK & Investasi Rp. 000 & $\begin{array}{c}\text { Produksi } \\
\text { Rp. 000 }\end{array}$ & $\begin{array}{c}\text { BB/BP } \\
\text { Rp.000 }\end{array}$ \\
\hline 1. & Pangan & 91 & 1,033 & 2,797 & $9,663,255$ & $13,728,648$ & $12,699,431$ \\
\hline 2. & Sandang dan Kulit & 8 & 117 & 201 & $1.643,925$ & $1,432,196$ & $1,196,111$ \\
\hline 3. & Kimia dan Bahan Bangunan & 23 & 301 & 1,432 & $6,068,164$ & $5,592,199$ & $2,687,562$ \\
\hline 4. & Kerajinan & 47 & 500 & 1,144 & $8,904,436$ & $7,646,781$ & $1,852,148$ \\
\hline 5. & Logam & 21 & 440 & 1,307 & $39,240,574$ & 7.432 .741 & $4,694,115$ \\
\hline 6. & Hasil Hutan & 16 & 262 & 1,471 & $8,165,787$ & $3,524,082$ & $1,839,762$ \\
\hline \multicolumn{2}{r}{ Total } & 206 & 2,653 & 8,352 & $73,686,141$ & $37,329,020$ & 24.969 .129 \\
\hline
\end{tabular}

Source: Disperindagkop \& MSME Kalimantan Timur Province.

Industrial Area (Industrial Estate). East Kalimantan Industry Concentration is generally done by establishing industrial zones. In Concentration Industrial Area is known as an industrial estate. Industrial Estate which is a region where the concentration of the industry which is equipped with infrastructure that includes land and strategic location as well as other facilities such as electricity, water, telephone, roads and landfills. Concentration of industrial area aims to provide a positive impact for the development of the industry itself. The existence of an industrial area industry which facilitate activities will eventually encourage the growth of the industry. In general, the concept of industrial concentration region forming aims to create a special infrastructure of concentration in a limited area so as to reduce costs; to be able to attract new business by providing an integrated infrastructure in one location; to keep industries from urban areas as well as trying to reduce the environmental and social impacts of industrial use; to provide local environmental control specifically for the needs of the industrial area.

Kariangau Industrial Area (KIK). The area planned for the Industrial Zone Kariangau (CIC) located in the coastal city of Balikpapan, the characteristics of the basis for planning the area is primed to develop an urban area that is conducive to the balance of the coastal environment and as a new growth center of the base of industrial activity. Currently, in the area already in some companies, but most of the area is still a wilderness, reeds, weeds and the like so that communities do not benefit economically because they use the land as shifting cultivation.With great location and strategic and after the enactment of Law No. 32 and 34 in 2004, the local government intends to develop the area into an industrial area with the name Industrial Estate Kariangau ( $\mathrm{CIC}$ ) for the livelihoods of our people. Kariangau planned industrial area of 5,000 hectares located in the Village of West Balikpapan Kariangau subdistrict. The first phase of the development of an area is 1989.54 hectares while the rest will be developed later. In the development of this area, the local government to divide the different functions such as port with an area of 56.5 hectares, an industrial area with 399288 hectares wide and means of support (housing, education, entertainment, and sports facilities) covering an area of 339267 hectares. At this time has issued licenses to several companies, among others: PT. Kencana Indonesia dock; PT. Andalas Earth bloom; Container Port; PT.Kutai Chip Mill; PT. Green Forestra Lestari; PT. Prosperity Paradigm; PT. Kaltim Kariangau Industry; PT. Kariangau Power; PT. Primary Mighty dock; PT. Petrosea.

Kariangau industrial area located on the edge of the regional arterial roads leading to the bridge crossing the bay Balikpapan Balikpapan, access to reach it can be done in several ways, with varying travel time. The travel time is only 60 minutes Sepinggan. It takes 45 minutes dar Balikpapan city center with regional arterial roads Balikpapan-Samarinda at 
kilometer 12.9. Only 15 minutes by speedboat from the Port of Kampung Baru, Balikpapan. Investment in the Industrial Zone will be a very important advantage because the location is very strategic Balikpapan and also supported by adequate infrastructure and the commitment of the entire the ranks of the city government to make the city the best city to invest Balikpapan.

Industrial Area Maloy (Maloy Kipi). East Kalimantan, the country is rich in natural resources, attempting to shift the superiority of coal which currently dominates the export figures in that area. The development of agriculture-based industries through the International Port and Industrial Zone (Kipi) Maloy reinforced by Presidential Instruction No. $1 / 2012$ become desperate to shift the coal empire. Target of 1 million hectares of oil palm in 2013 established East Kalimantan Governor Awang Ishak Faroek already realized and planned to be increased to 2.4 million hectares. Land area is certainly going to make the province of East Kalimantan as a producer of crude palm oil (CPO) in Indonesia. Therefore, the existence of Kipi Maloy seems to be a way to replace the natural resources which are updated as a source of regional economic growth. Kipi Maloy has two development concepts build oleo chemical industry cluster and processing of international scale plantations. This is in order to increase value added, employment and business opportunities as well as providing industrial areas with high competitiveness with the support of incentives and various facilities. The plan, the total investment needed in the industrial area reached $\mathrm{Rp}$ 4.77 trillion, with total area of 5305 hectares.

However, for the development of the first phase of 1,000 acres of land in advance with the status of truly prepared covers 577 hectares. The land area of 577 hectares of land which is located is in the appropriate conditions. The rest, a mangrove area of land that will not be disturbed because of the development will not interfere with existing ecosystems around the area which is close to the bay. Later, the region will be built olein industry, aluminum smelting industry, stearin and PFAD (palm fatty acid distillate), fatty acid industry, the biodiesel industry and cooking oil. Besides supporting the region such as ports, power plant $2 \times 100$ $\mathrm{MW}$, railways and coal terminals. In the industrial area okeokimia built CPO port with the ability diatas 100.000 DWT. On the land side was built on an area of 115.38 hectares with office facilities, workshops, fire house and a storage tank 19 units with a capacity of 3,000 tons each per unit. Noted there are 19 potential investors have already interested in investing in these locations. However, the Management Board has not been able to offer the Kipi Maloy and directing potential locations to investors.

\section{CONCLUSION}

Small and medium enterprises (SMEs) occupy an important place in the strategic and economic growth and equitable development in all countries, both developed and developing countries. SME as an economic powerhouse has been taking place by having a percentage of $90 \%$ of the total companies in most countries around the world. SMEs are the driving force behind a large number of innovations and contribute to national economic growth through job creation, investment and exports. Potential of SMEs is often not realized because of the common problems associated with size, isolation, market opportunities, standards / quality, supply chain, logistics and technology innovation. To obtain small profit margins, small entrepreneurs in developing countries do not choose to innovate products and processes as their growth strategy and improvement in the long run. The strategies used to increase SMEs in this study are develop Industrial commodity based on local resources in the context of building a sustainable industrial competitiveness and environmentally friendly through the industry cluster approach; increasing the competitiveness of local industry through a major commodity, industrial core competency areas and populist economic empowerment; develop industry that relies on potential areas of sustainable and environmentally friendly, especially agro-industrial by prioritizing the development of small industries; develop Commodities with industrial cluster development approach based commodity and prospective; strengthen linkages at all levels of the value chain in the cluster industries concerned; increase the value-added products / results and resources used industrial industry; improving supervision 
of industrial products in order to control the $\mathrm{SNI}$; the increase in small and medium industries based social economy; improved facilities and infrastructure industry; cultivate a business environment that is comfortable and conducive.

Concentration of industrial area aims to provide a positive impact for the development of the industry itself. The existence of an industrial area which facilitates activities will eventually encourage the growth of the industry. In general, the concept of industrial concentration region forming aims to create a special infrastructure of concentration in a limited area so as to reduce costs; to be able to attract new business by providing an integrated infrastructure in one location; to keep industries from urban areas as well as trying to reduce the environmental and social impacts of industrial use; to provide local environmental control specifically for the needs of the industrial area.

\section{REFERENCES}

1. Abend, C.J, (2005), In Search of Innovation Synthesis, Ideas for a Unified Innovation Theory, Technology Transfer Society.

2. Arsyad, L. (2010). Ekonomi Pembangunan, Edisi Kelima. UPP STIE YKPN, Yogyakarta

3. Bobb, K.I, (2005). Duality of Innovation: Liberation and Economic Compentitiveness, Georgia Institute of Technology.

4. Damanpour, F. (1991), Organizational innovation: a meta-analysis of effects of determinants and moderators.Acad. Mgmt. J.34: 555.90.

5. Jimenez-Jimenez, D. (2008), Fostering innovation: the role of market orientation and organizational learning; European Journal of Innovation Management, 3(11): 389-412.

6. Jones G.B, (2004), Organizational Theory, Design, and Change, Prentice Hall.

7. Li-An Ho, (2011), Meditation, learning, organizational innovation and performance; Industrial Management \&DataSystems, Vol.111, 1: 113-131.

8. Light, P. (1998), Sustaining Innovation: Creating nonprofit and Government Organizations That Innovation Naturally, Jossey-Bass Publishing.

9. Maldique, M., \& Patch, P, (1988), Corporate Strategy and Technological Policy in Reading in the Management of Innovation, Ballinger Publishing Company, Cambridge.

10. Mansfield, E. (1988) The Speed \& Cost of Industrial Innovation in Japan and United States; Journal Management Science, 10:1157-1188.

11. Pavitt, K, (2005), Innovation processes, in Fagerberg, J., Mowery, D.C. and Nelson, R.R. (Eds), The Oxford Handbook of Innovation, Oxford University Press, Oxford, 86-114.

12. Porter, M.E, (1990), The Competitive Advantage of Nations, The Free Press, New York

13. Robey, Daniel, Maria C. B, Gregory M. Rose, (2000), Information Technology and Organizational Learning: A Review and Assesement of Research; Accounting, Management and Information Technology, 10: 125-156.

14. Subramanian, A. (1996), Organizational innovativeness: exploring the relationship between organizational determinant of innovation, types of innovations and measures of organizational performance.International Journal of Management Science, 24(6): 631-47.

15. Terziovski, Mile, \& Marianne, Gloet. (2004), Exploring the relationship between knowledge management practices and innovation performance; Journal of Manufacturing Technology Management, Volume 15, Number 5, 402-409.

16. Thomson, J.H., \& Ewer, S.R, (1989), How Should R\&D Report and Expwnditures; Research and Development, 31, 174-176.

17. Tushman, M.(1986) Organizing for innovation; California Management Review, 28:74-92.

18. Vigoda Gadot, A. Shoham, Nitza Schwabsky \& A Ruvio, (2005), Public Sector Innovation For Europe; A Multinational Eight Country Exploration of Citizens Perspectives; Journal Compilations, Public Administration, Vol 86, 2: 307-329.

19. Zahra. S.A. (1994), Innovation Strategy and Financial Performance in Manufacturing Companies: An Empirical Study; Production and Operation Management, 2, 1: 15-23. 
DOI https://doi.org/10.18551/rjoas.2017-09.22

\title{
МОДЕРНИЗАЦИОННАЯ РОЛЬ ЗАРАБОТНОЙ ПЛАТЫ В ПРЕДПРИНИМАТЕЛЬСКОЙ ДЕЯТЕЛЬНОСТИ \\ MODERNIZATION ROLE OF WAGES IN ENTREPRENEURIAL ACTIVITY
}

\author{
Графов А.В.*, доктор экономических наук \\ Grafov A.V. Doctor of Economic Sciences \\ Милованов Е.А., Немиров В.Н., кандидаты экономических наук \\ Milovanov E.A., Nemirov V.N., Candidate of Economic Sciences \\ Виноградова Е.А., магистрант \\ Vinogradova E.A., Graduate student \\ Российская академия народного хозяйства и государственной службы \\ при Президенте России, Москва, Россия \\ Russian Academy of National Economy and Public Administration \\ under the President of Russia, Moscow, Russia \\ *E-mail: grafav@mail.ru
}

\begin{abstract}
АННОТАЦИЯ
Заработная плата играет важную роль в развитии предпринимательской деятельности, увеличения благосостояния народа. Заработная плата является важным рычагом материального стимулирования роста и совершенствования производства. Чтобы производство непрерывно развивалось и совершенствовалось, необходимо создавать материальную заинтересованность работников в результатах труда. В статье рассмотрены проблемы совершенствование системы заработной платы в контексте эффективной реализации её важнейших функций как фактора ускорения социальноэкономического развития.
\end{abstract}

\section{ABSTRACT}

Wages play an important role in the development of entrepreneurial activities, increasing the welfare of the people. Wages are an important lever for material stimulation of growth and improvement of production. In order to continuously develop and improve production, it is necessary to create a material interest of workers in the results of labor. The article discusses the problems of improving the wage system in the context of the effective implementation of its most important functions as a factor in accelerating social and economic development.

\section{КЛЮЧЕВЫЕ СЛОВА}

Заработная плата, мотивация, социальная политика, предпринимательство.

\section{KEYWORDS}

Wages, motivation, social policy, entrepreneurship.

Экономическая цель развития хозяйствующих субъектов любого уровня и, в первую очередь, предприятий малого и среднего бизнеса - получение прибыли, которая является основой формирования как явных, так и нечетко обозначенных фондов, а именно резервного фонда, фонда развития производства, фонда социального развития коллектива и фонда материального поощрения.

При этом основным фактором, определяющим уровень социального обеспечения работников предприятия, является размер их заработной платы, в то время как размер премий из прибыли является дополнительным, но не главным фактором роста их социального уровня. Следует отметить, что законодательно регламентируется только минимальный размер оплаты труда (МРОТ), на который как на нижнюю границу должен ориентироваться менеджмент предприятия, в то время как верхняя граница и 
заработной платы, и размера премий из прибыли (фонд материального поощрения) никакими нормативами не ограничиваются.

Из вышеизложенного следует, что экономической основой формирования качества жизни работников предприятия являются заработная плата (фонд заработной платы) и прибыль (фонд материального поощрения).

Модернизация экономики предполагает коренное обновление всех сторон функционирования общественного организма. Для решения этой глобальной задачи важен поиск фракторов и резервов, использование которых будет способствовать решению этой задачи. Одним из таких фракторов модернизации является совершенствование системы заработной платы в контексте эффективной реализации её важнейших фрункций.

Современные экономисты рассматривают заработную плату как категорию, фрормирующуюся на рынке труда. Оплата труда является результатом продажи наемным работником своей способности к труду и покупки ее работодателем. Условия данной купли-продажи закреплены в трудовом договоре. Заработная плата это, стоимость рабочей силы. Кроме того заработная плата может быть определена для работодателя как издержки, составляющие одну из основных статей расхода в себестоимости производимых товаров и услуг. В этой трактовке издержки на рабочую силу включают прямую заработную плату, которая связана с участием работника в производственном процессе, оплату отпуска, праздничных дней, дней нетрудоспособности, социальные взносы и налоги, связанные с использованием рабочей силы.

Заработная плата выступает в качестве многогранного явления. Будучи, по сути, интегральным френоменом, она выполняет несколько важных фрункций. Функции заработной платы в конечном итоге обусловливают ее структуру.

В ряду фрункций заработной платы выделяют социальную, регулирующую, воспроизводственную, стимулирующую (мотивационную), распределительную, ресурсно-разместительную, статусную фрункции, а также фуункцию фрормирования платежеспособного спроса населения. Все присущие заработной плате функции находятся в диалектическом единстве и лишь в совокупности позволяют правильно понять сущность и содержание заработной платы, её роль в модернизации воспроизводственного процесса, противоречия и проблемы, возникающие в процессе совершенствования ее организации. Каждая функция есть часть единого целого (заработной платы), предполагающая не только существование других функций, но и содержащая в себе их элементы.

Социальная функция заработной платы, в основном, заключается в обеспечении реализации принципа социальной справедливости при установлении условий оплаты труда. Представляется, что при этом из всего многообразия понимания термина «социальный» подразумевается тот, который показывает на проявление заботы об индивидах как членах общества.

Регулирующая функция заработной платы проявляется в ее воздействии на соотношение между спросом и предложением рабочей силы, на формирование персонала, численность работников и уровень их занятости. Зарплата выступает рычагом регулирования трудового отношения работник - работодатель (отношения между индивидуальными способностями работника и потребностями работодателей в соответствующей рабочей силе).

Воспроизводственная фрунция заработной платы, с позиции экономики труда, реализует экономические интересы работника, который заинтересован в том, чтобы его заработная плата носила постоянный характер, гарантируя регулярный приток денежных средств, обеспечивающих не только удовлетворение основных, базисных, потребностей работника и членов его семьи, но и поддержание уровня жизни, считающегося в данном обществе приемлемым.

Стимулирующая (мотивационная) функция заработной платы - это ее свойство направлять интересы работников на достижение требуемых результатов труда (большего их количества, более высокого качества и т.д.) за счет обеспечения 
взаимосвязи размеров вознаграждения и трудового вклада. Это выражается в том, что работодатель стремится установить и прямую, и косвенную зависимость размера заработной платы от количества, качества и результатов труда.

Между функциями заработной платы возможны противоречия. Одним из важнейших противоречий является противоречие между регулирующей и стимулирующей функциями заработной платы. Ведь регулирующая функция заработной платы позволяет добиваться сокращения в неравенстве доходов. Стимулирующая функция же, наоборот, порождает данное неравенство за счет материального поощрения работников, работающих наиболее качественно и производительно. На наш взгляд, данное противоречие должно быть устранено государством, которое при регулировании вопросов заработной платы должно стремиться обеспечивать реальное денежное содержание заработной платы. В частности, надо установить величину минимального размера оплаты труда (MPOT), соотносимую с реальной стоимостью потребительской корзины в данном регионе, а также проводить разумную налоговую политику, чтобы работодатель и работник были заинтересованы соответственно в начислении и получении выплат стимулирующего характера при оптимальном их налогообложении. В настоящее время МРОТ в РФ установлен на уровне 7800 рублей, или 132 дол. США, что меньше прожиточного минимума составляющего на 2017 год 10600 рублей. Это означает, что работающий человек не имеет возможности не только содержать семью, но и элементарно удовлетворять свои минимальные потребности.

Наши либеральные экономисты (А. Кудрин и др.) увязывают низкую заработную плату в России с недостаточным уровнем производительности труда по сравнению с развитыми странами. Но, например, по производительности труда Россия отстаёт от той же Франции примерно в 2,5-3 раза. А как же французский уровень МРОТ?

Минимальная зарплата во Франции обозначается аббревиатурой SMIC - Le Salaire minimum interprofessionnel de croissance. Ставка минимальной зарплаты распространяется на всех работников, независимо от того, оплачивается ли их труд за отработанные часы, за эффрективность, за выполненные задания и т. д, работают ли они на полную ставку или на неполную. Единая минимальная зарплата гарантирует нормальную покупательную способность работникам, получающим самые низкие зарплаты на рынке труда.

Таблица 1 - Среднемесячная заработная плата в субъектах Центрального федерального округа РФ в 2016 г. в руб. и дол. США (1\$= 59,00 по курсу Банка России на 14 февраля 2017 г.)

\begin{tabular}{|c|c|c|}
\hline Субъекты Российской Федерации & $\begin{array}{c}\text { Среднемесячная } \\
\text { зарплата, тыс. руб. }\end{array}$ & $\begin{array}{c}\text { Среднемесячная } \\
\text { зарплата, \$ }\end{array}$ \\
\hline Российская Федерация & 36,20 & 613,55 \\
\hline ЦФО РФ & 43,78 & 742,03 \\
\hline Белгородская область & 27,28 & 462,37 \\
\hline Воронежская область & 26,07 & 441,86 \\
\hline Курская область & 22,77 & 385,93 \\
\hline Липецкая область & 24,64 & 417,62 \\
\hline Московская область & 42,46 & 719,66 \\
\hline Тамбовская область & 21,45 & 363,55 \\
\hline Орловская область & 16,83 & 285,25 \\
\hline г. Москва & 66,88 & 1133,55 \\
\hline
\end{tabular}

Также как и в России, МРОТ во Франции законодательно устанавливается с начала года. C 1 января 2016 года ставка SMIC составляет 9,61€ в час, или 1448,52 € в месяц до уплаты налогов. Минимальная зарплата в месяц рассчитывается исходя из 35 рабочих часов в неделю. Работодателям, выплачивающим зарплаты ниже минимального уровня, грозит штрафр в размере до 1500 евро за каждого работника. То есть в России МРОТ ниже фрранцузского в 11-12 раз.

МРОТ лежит в основе и среднемесячной заработной платы, уровень которой в РФ также не выдерживает критики. Как видно из таблицы 1 даже в Центральном 
федеральном округе РФ наблюдается существенный разрыв в уровне средней заработной платы, от 16830 в Орловской области до 66880 руб. в г. Москве, то есть около 4 раз. Если же сравнить Орловскую область с Московской областью, то и здесь разница составит более 2,5 раз. Что касается Липецкой области, то разрыв в уровне среднемесячной зарплаты с аналогичным показателем по Центральному федеральному округу составляет 1,77 раза, а по отношению к Москве- 2,7 раза. При этом трудно предположить, что различия в уровне производительности труда в столичном регионе и в провинции столь существенны. Причина всё-таки видимо в том, что в России отсутствует продуманная социальная политика в контексте её региональной составляющей в целом и заработной платы в частности.

Сравнительный анализ средней заработной платы по регионам России попрежнему показывает углубляющуюся тенденцию к увеличению разрыва между центром и провинцией: деньги практически оседают в Москве и в меньшей степени второй неофициальной столице РФ - Санкт-Петербурге. По нашим оценкам деформация фринансовых потоков в РФ привела к тому, что примерно 70\% объёма фринансовых ресурсов сосредоточено в Москве, около 20\% в Петербурге ну а остатки (10\%) в остальных регионах страны.

Таблица 2 - Среднемесячная заработная плата в странах СНГ и других странах мира в 2016 году ( $1 \$=59,00$ по курсу Банка России на 14 феевраля 2017 г.)

\begin{tabular}{|c|c|c|}
\hline Страны мира & $\begin{array}{c}\text { Среднемесячная } \\
\text { зарплата, \$ }\end{array}$ & $\begin{array}{c}\text { Среднемесячная } \\
\text { зарплата, руб. }\end{array}$ \\
\hline Норвегия & 4650 & 274000 \\
\hline США & 4460 & 263000 \\
\hline Германия & 4150 & 244000 \\
\hline Франция & 1448 & 85000 \\
\hline Польша & 1440 & 84000 \\
\hline Эстония & 1240 & 73000 \\
\hline Словакия & 1050 & 61000 \\
\hline Румыния & 660 & 38000 \\
\hline Россия & 613 & 36000 \\
\hline Казахстан & 370 & 21000 \\
\hline Беларусь & 350 & 20000 \\
\hline Украина & 200 & 11800 \\
\hline
\end{tabular}

В 2016 году зарплаты россиян заметно выросли по сравнению с 2015 годом, в среднем по стране они повысились на $12 \%$. Впрочем, это касается только номинала в национальной валюте - российском рубле. Если взять аналогичный показатель в долларах США, здесь наблюдается дальнейшее проседание. Средняя зарплата россиян по-прежнему значительно меньше, чем у соседних стран Прибалтики и бывшего соцлагеря, где оплата труда, например, в Эстонии, Словакии и Польше уже в разы больше, чем в России, хотя экономический потенциал этих стран не сравним с российским (см. таблицу 2). Как результат, в настоящее время из-за низкой реализации фуннций заработной платы, и прежде всего её стимулирующей (мотивирующей) функции, более 50 \% работников реального сектора экономики в РФ еле сводят концы с концами, практически живут впроголодь. Именно поэтому работники не в полной мере реализуют свой физический и интеллектуальный потенциал в процессе трудовой деятельности, что конечно не способствует высокой производительности труда.

Что же в этом контексте предпринимается нашим правительством. Незначительное укрепления рубля в последнее время, подвигло Правительство РФ выдвинуть идею о деноминации национальной валюты, которую с воодушевлением поддержал наш Центральный банк. Решается вопрос лишь о её размерах. Безусловно, реализация этой идеи приведёт к очередному падению реальной заработной платы и как следствие снижению уровня жизни в стране.

Также необходимо отметить влияние уровня заработной платы на развитие важнейших отраслей национальной экономики. На примере строительной отрасли 
можно сделать вывод о том, что низкий уровень средней заработной платы не дает возможности большинству населения приобретать в собственность квартиры или строить индивидуальные жилые дома. Ситуацию в сфере обеспечения населения собственным жильем усложняют также высокие процентные ставки по ипотечным кредитам и высокая цена за квадратный метр. К перечисленным фракторам необходимо добавить и то, что низкий темп роста объемов строительства жилых и производственных объектов не дает возможности развиваться предприятиям производящим строительную продукцию. Многие предприятия производящие строительную продукцию находятся в неустойчивом фринансовом состоянии из-за недостаточных объемов строительства и продаж готового индивидуального жилья. Похожая ситуация и в сельском хозяйстве. Несмотря на то, что сфера сельского хозяйства находиться на втором месте по тем роста уровень заработных плат в данной сфрере очень низкий и требует кардинального изменения.

Кардинальные изменения в подходах к расчёту МРОТ в России является одним из существенных резервов экономического роста, модернизации экономики и повышения производительности труда, повышения уровня жизни населения. Вместо введения системы различных социальных пособий малоимущим, например введения продовольственных карточек, чем ещё озаботилось наше правительство в последнее время, нужно платить работающим людям реальную заработную плату соответствующую их трудовому вкладу, цивилизационным нормам потребления, мотивирующую высокопроизводительный труд. А пока во многих случаях действует известный принцип «они делают вид, что нам платят, ну а мы делаем вид что работаем».

\section{БИБЛИОГРАФИЯ}

1. Графова Г.Ф., Графов А.В., Шахватова С.А. Использование методов регрессионного анализа при оценке бизнеса // Аудитор. 2014. №12 (238). С. 72-77.

2. Докукина И.А., Полянин А.В. Формирование стратегического управления затратами на инновационное развитие в условиях повышения конкурентоспособности региона // Среднерусский вестник общественных наук. 2014. №2. С. 219-225.

3. Инновационно-инвестиционная деятельность предприятий/ Аврашков Л.Я., Графова Г.Ф., Графов А.В., Шахватова С.А. // Липецкий фрилиал Российской академии народного хозяйства и государственной службы при Президенте Российской Федерации. Москва, 2015.

4. Инновационно-инвестиционное развитие предприятий металлургического комплекса: теория и практика: монография / Аврашков Л.Я. и др. // Москва, 2010.

5. Полянин А.В. Концептуальная модель региональной инновационной системы // В сборнике: Фундаментальные и прикладные исследования в области экономики и финансов. Международная научно-практическая конференция: материалы и доклады, 2015. С. 10-13.

6. Экономика организаций (фрирмы) / Аврашков Л.Я., Графрова Г.Ф., Графров А.В., Шахватова С.А.// Учебное пособие для магистров / Москва, 2014.

7. Шахватова С. А., Аврашков Л. Я., Графова С. А. К вопросу о взаимосвязи показателей экономического и социального развития предприятий // Аудитор. 2014. №10 (236). С. 86-90.

8. Экономические основы фрормирования производственной инфраструктуры / Макарова Ю.Л., Полянин А.В., Суровнева В.А.Орел, 2016.

9. Evrokatalog.eu, SIA Alliance Media

10. Средняя зарплата в 2016 году по регионам России и другим странам мира, сайт bslife.ru 
DOI https://doi.org/10.18551/rjoas.2017-09.23

\title{
PROFILE OF PLASTIC WATER BOTTLES WASTES PROCESSING BUSINESS UNIT FOR WASTE PICKERS
}

\author{
Herijanto Pudji*, Fiernaningsih Nilawati \\ Department of Business Administration, Politeknik Negeri Malang, Indonesia \\ Widjanarko \\ Department of Mechanical Engineering, Politeknik Negeri Malang, Indonesia
}

*E-mail: pakherijanto@gmail.com

\begin{abstract}
Used plastic water bottles waste pickers can be categorized as one of the informal sector's component. They work for themselves by picking up used water bottles and selling them to the waste collectors. The problem to be solved in this research is How the Most Appropriate Used Plastic Water Bottles Business Model for Waste Pickers Is that enables them to be categorized as formal sector. From the result of the interview with 120 waste pickers, 96 results were qualified to be analyzed. The interview was located in several waste collectors, which were visited by waste pickers at certain hours. The data were analyzed descriptively based on six business aspects. Specifically for production facilities, Quality Function Deployment (QFD) and Value Engineering (VE) analysis were performed. The results of the analysis indicate that the business is practicable for waste pickers and has the potential to enable them run a formal business sector.
\end{abstract}

\section{KEY WORDS}

Informal sector, plastic waste, processing, business.

Waste pickers can be categorized as one of the informal sector's component. Siregar (2013) defines informal sector as a small-scale business unit which produces and distributes goods and services with creating job opportunities and income for themselves as the main purposes and physical capital and human resources as the main obstacles. A used plastic water bottles waste picker is definitely one of them. They work for themselves in picking up wastes, and then sell the wastes to waste collectors to get income.

Used plastic water bottles waste pickers also have the weaknesses commonly found in informal sector. The weaknesses include society judgment towards informal sector as a burden that pollutes the beauty and cleanliness of the city, failing to compete in both domestic and export markets, and lacks of product diversification (Hermawani, 2013).

Plastic water bottles waste processing is now widely operated since processed products have a high economic value. By being processed into plastic shreds, the price of the wastes can be at least doubled. Indeed, various supporting aspects are extremely needed to run this business. According to Prabowo (2012) and Kristiyono (2014), there are 6 aspects determining the feasibility of the establishment and/or development of plastic chopper factories, i.e. market, technical, legal and environmental, human resource management, and financial aspects. Although both of the researchers conducted the study at industrial level, the result of their findings could be applied to the informal sector such as waste pickers by considering their conditions.

The problem to be solved in this research is: How the Most Appropriate Used Plastic Water Bottles Business Model for Waste Pickers Is that enables them to be categorized as formal business sector. Thus, the aim of the research based on the problem is to describe the most appropriate used plastic water bottles business profile for waste pickers. 


\section{LITERATURE REVIEW}

Informal Sector. Informal sector is defined as a small-scale business unit which produces and distributes goods and services with the ultimate goal of creating job opportunities and income for themselves and the main constraints are physical capital and human resources (Siregar, 2013).

Some of the advantages of informal sector are: (a) Labor-intensive, generally informal sector is a labor-intensive small business; (b) Durability, the crisis proves that informal sector does not only survive, but also grow rapidly; (c) Special (Traditional) Expertise, the products they make are generally simple and need no formal education, but require special skills (traditional skill); (d) Capital, most entrepreneurs in informal sector depend on their own money (savings), or loan funds from informal sources (outside the banking / financial sector) for their capital needs.

Business Feasibility. Referring to the findings of Prabowo's (2012) and Kristiyono's (2014) studies, there are six aspects determining the feasibility of establishment and/or business development, i.e. market, technical, legal, environmental, human resources and financial aspects.

Market aspects assess existing market opportunities to run a potential business. It is done by comparing the amount of supply and demand. If demand is still higher and the quantity is quite economical, it means the market opportunity still exists.

Technical aspects relate to things that technically support the business. These aspects include at least land ownership, factory arrangement, technological mastery, and production process mastery. These points will ensure the production process run effectively and efficiently.

Legal aspects pertain to the legality of business actors and business units. Business actor must be a legal citizen with a legal residence. A business unit must have a license from the relevant department to be included as a formal business unit.

Environmental aspects concern the impact of a business towards the economic and social conditions of business actors and their environment. A good business certainly not only gives a positive impact on the business actors, but also has a positive impact on the environment.

Human resource management aspects deal with business actors' management. Business actors need to have minimum requirements for running a business, while their management is minimally accommodated in an organization with clear task structure and responsibilities.

The financial aspect measures the financial performance of a business. Sucipto, Oktaviani, and Rizal (2015) calculate financial performance with two measures, i.e. Return on Assets (ROA) and Return on Sales (ROS). ROA is ratio between net profits earned by total assets owned by the company while ROS is ratio of total profit earned by the company. ROA is a form of profitability ratio to measure a company's ability to generate profits by using the total existing assets and after the capital costs (the costs used to fund the assets) are excluded from the analysis (Margaretha, 2011). ROS measures how effectively sales made to provide income.

Quality Function Deployment (QFD). QFD is an analytical tool to describe customer needs, evaluate products or services systematically about its ability to meet those needs. The analysis is done by knowing the attributes the customer requires, customer satisfaction levels and comparison with customer satisfaction levels to other products (Adriantantri, 2008). Furthermore, Rahman \& Supomo (2012) state that QFD is usually used as a planning tool to meet the expectations and the needs of consumers, in which QFD is utilized to interpret the specific needs of the customer into engineering directions and measures.

Value Engineering. Pontoh (2013) concludes that value engineering intends to provide an optimal amount of the money spent by using systematic techniques to analyze and control the total product costs. Value Engineering will help distinguish and separate between necessity and alternative, so an option which meets the needs (and leaves the unnecessary) can be developed at the lowest cost. 


\section{METHODS OF RESEARCH}

This research is an explorative descriptive research that aims to describe the model of water bottles wastes chopping business for waste pickers. Data was collected through structured interviews with 120 waste pickers. Once verified, there were only 96 interviews that were qualified for analysis. The analysis was done descriptively to describe the business model as mentioned above.

\section{RESULTS OF STUDY}

Table 1, 2, and 3 illustrate the overview of the respondents based on age, gender, and interest in entrepreneurship.

Table 1 - Overview of Respondents by Age

\begin{tabular}{|c|c|c|c|}
\hline No. & Age & Total & $\%$ \\
\hline 1 & $15-20$ & 12 & $13 \%$ \\
\hline 2 & $21-26$ & 12 & $13 \%$ \\
\hline 3 & $27-32$ & 18 & $19 \%$ \\
\hline 4 & $33-38$ & 27 & $28 \%$ \\
\hline 5 & $39-44$ & 21 & $22 \%$ \\
\hline 6 & $45-50$ & 6 & $6 \%$ \\
\hline- & Total & 96 & $100 \%$ \\
\hline
\end{tabular}

Table 2 - Overview of Respondents by Gender

\begin{tabular}{|c|c|c|c|}
\hline No. & Gender & Total & $\%$ \\
\hline 1 & Female & 8 & 9 \\
\hline 2 & Male & 88 & 91 \\
\hline- & Total & 96 & 100 \\
\hline
\end{tabular}

Interest in Entrepreneurship. Several reasons of the respondents who are interested in this business include:

a. Providing working capital, i.e. as assets or business to create a better job.

b. Having known the business before.

c. Increasing income, that is processed plastic water bottles wastes have higher selling price than unprocessed bottles. Thus, it will be able to supplement their income.

Whereas the non-interested respondent has several reasons, i.e.:

a. Having no land. This is the most dominant reason of $38 \%$ of non-interested respondents.

b. Having inadequate knowledge about chopper tools or machines

c. Difficulty in finding the materials

d. Having no funds.

Table 3 - Interest in Entrepreneurship of Plastic Wastes Processing

\begin{tabular}{|c|c|c|c|}
\hline No. & Interest & Total & $\%$ \\
\hline 1 & Interested & 58 & 61 \\
\hline 2 & Not interested & 34 & 35 \\
\hline 3 & Abstain & 4 & 4 \\
\hline & Total & 96 & 100 \\
\hline
\end{tabular}

Source: Questionnaire (being processed).

Of 20 waste collectors state that the accommodated number of wastes is unlimited. Any amounts dropped by waste pickers will be accepted. On the other hand, waste pickers find it difficult to deposit in larger quantities due to the technical deliveries to the collectors. Waste pickers only place the bottles in the sack. Thus, despite the large volume of the sacks, they weigh very little. The survey results find that waste pickers averagely deposit 2.5 sacks per day, weighing about $1 \mathrm{~kg} / \mathrm{sack}$. 
Table 4 - Land Ownership

\begin{tabular}{|c|c|c|}
\hline Ownership & $\mathrm{n}$ & $\%$ \\
\hline Own & 42 & $44 \%$ \\
\hline Rent & 6 & $6 \%$ \\
\hline No ownership & 48 & $50 \%$ \\
\hline Total & 96 & $100 \%$ \\
\hline
\end{tabular}

In relation to the size of land owned, the majority of waste pickers have only a narrow remaining land, or even no more land left, which cause them to keep the wastes in the house temporarily. Furthermore, the landless waste pickers can be grouped into two, i.e. which still live together with parents or live with the relatives or friends.

Table 5 - Ownership of Motorcycles

\begin{tabular}{|c|c|c|}
\hline- & n & $\%$ \\
\hline Own & 72 & 75 \\
\hline No motor & 24 & 25 \\
\hline Total & 96 & 100 \\
\hline
\end{tabular}

Table 6 - Motorcycle Type

\begin{tabular}{|c|c|c|}
\hline- & $\mathrm{n}$ & $\%$ \\
\hline Automatic & 30 & 42 \\
\hline Regular & 42 & 58 \\
\hline Total & 72 & 100 \\
\hline
\end{tabular}

Table 7 - Machine Maintenance Capability

\begin{tabular}{|c|c|c|}
\hline- & $\mathrm{n}$ & 0 \\
\hline Major Damage & 0 & 0 \\
\hline Minor Damage & 63 & 98 \\
\hline Unable & 12 & 9 \\
\hline
\end{tabular}

Table 8 - Mastery of the Production Process

\begin{tabular}{|c|c|c|}
\hline- & $\mathrm{n}$ & $\%$ \\
\hline Have no understanding & 45 & 54 \\
\hline Have understanding & 24 & 28 \\
\hline Be able to & 15 & 18 \\
\hline Total & 84 & 100 \\
\hline
\end{tabular}

Referring to the input of waste pickers, the desired specifications of processed products are approximately $2 \mathrm{~mm}$ chopped outcome and more preferably in a clean condition.

The expected machine specification is a relatively small-sized machine which does not occupy many spaces, because the majority of them have no adequate land size to set up a factory. The machine should be portable enough to be carried by motorcycles because almost all waste pickers have one. The compact machine also eases the waste pickers in chopping the plastic bottles, instead of carrying them in large volumes.

Table 9 - Daily Income

\begin{tabular}{|c|c|c|}
\hline No & Income Level (in thousands) & $\mathrm{n}$ \\
\hline 1 & $25-35,5$ & 34 \\
\hline 2 & $>35,5-46$ & 14 \\
\hline 3 & $>46-56,5$ & 15 \\
\hline 4 & $>56,5-67$ & 22 \\
\hline 5 & $>67-77,5$ & 9 \\
\hline 6 & $>77,5-88$ & 2 \\
\hline \multicolumn{2}{|c|}{ Total } & 96 \\
\hline
\end{tabular}


The above incomes data is the total revenue from waste picking result. The results obtained from selling plastic water bottles wastes can be determined from the deposited bottles from waste pickers to waste collectors. As discussed in the business aspect, waste pickers averagely deposit 2.5 sacks, which is equivalent to $2.5 \mathrm{~kg}$. Price per $\mathrm{kg}$ is $\mathrm{Rp} 7,500,-$, so their income is Rp 18,750, -.

The earned income will be different if waste pickers initially sort the water bottles wastes because the prices of each part are different. A bottle is usually divided into four parts, i.e. the cap, the bottle neck, the body and the bottom of the bottle. The bottle cap costs Rp 3000, - / kg, the body is Rp 8.500, - / kg, and the neck and bottom can reach $R p$ 9,500, -. Similarly, for glasses wastes, it should be separated between the upper (thicker) circular parts with the body and bottom parts. Table 10.

Once being sorted, the price of $1 \mathrm{~kg}$ of bottles wastes can be calculated as seen from

Table 10 - Price After Sorting Process

\begin{tabular}{|c|c|c|c|c|c|}
\hline No & Part & $\%$ & $\mathrm{Kg}$ & $\mathrm{Rp} /$ piece & Rp sold \\
\hline 1 & Cap & 10 & 0,10 & 3000 & 300 \\
\hline 2 & Neck and Bottom & 15 & 0,15 & 9.500 & 950 \\
\hline 3 & 75 & 0,75 & 8.500 & 6.375 \\
\hline \multicolumn{3}{|c|}{ Price/Kg } & 8.100 \\
\hline \multicolumn{3}{|c|}{ Price without sorting process } & 7.500 \\
\hline
\end{tabular}

The results of waste picking enable $57 \%$ of waste pickers to have savings, as presented in Table 11.

Table 11 - Daily Savings

\begin{tabular}{|c|c|c|c|}
\hline No & Savings (in thousands) & $\mathrm{n}$ & $\%$ \\
\hline 1 & 0 & 41 & 43 \\
\hline 2 & 5 & 6 & 6 \\
\hline 3 & 10 & 14 & 15 \\
\hline 4 & 15 & 16 & 17 \\
\hline 5 & 20 & 11 & 11 \\
\hline 6 & 25 & 6 & 6 \\
\hline 7 & 30 & 2 & 2 \\
\hline \multicolumn{2}{r|}{} & 96 & 100 \\
\hline
\end{tabular}

Daily work pattern of $72 \%$ waste pickers is to work on their own, while the remaining $28 \%$ work in groups of 3 to 7 people. Their group is an informal group based on friendship and family relationships, causing them to have no formal organizational structure. Distance of the residential location between members is in one house or different houses in one urban village.

Table 12 - Waste Pickers' Educational Level

\begin{tabular}{|c|c|c|}
\hline Educational Level & $\mathrm{n}$ & $\%$ \\
\hline Elementary & 43 & 45 \\
\hline Junior High School & 44 & 46 \\
\hline Senior High School & 9 & 9 \\
\hline Total & 96 & 100 \\
\hline
\end{tabular}

The work ethic of waste pickers is generally very high to meet personal and / or family needs. In general, family dependents include daily needs fulfillment for children, wife / husband, and parents and the educational needs of their children. This is in line with their high work ethics which aims to improve the welfare by increasing income and working more easily.

Some waste pickers with ID cards do not have a permanent residence because they are non-native Malang or they still stay with parents or relatives. 
Table 13 - Family Dependents

\begin{tabular}{|c|c|c|}
\hline Dependent (person) & $n$ & $\%$ \\
\hline 0 & 13 & 14 \\
\hline 1 & 8 & 8 \\
\hline 2 & 32 & 33 \\
\hline 3 & 18 & 19 \\
\hline 4 & 12 & 13 \\
\hline 5 & 9 & 9 \\
\hline 6 & 4 & 4 \\
\hline Total & 96 & 100 \\
\hline
\end{tabular}

Table 14 - Ownership of ID card

\begin{tabular}{|c|c|c|}
\hline- & $\mathrm{n}$ & $\%$ \\
\hline Own & 90 & 94 \\
\hline No & 6 & 6 \\
\hline Total & 96 & 100 \\
\hline
\end{tabular}

Table 15 - Residence

\begin{tabular}{|c|c|c|}
\hline- & $n$ & $\%$ \\
\hline Permanent & 81 & 84 \\
\hline Non-Permanent & 15 & 16 \\
\hline Total & 96 & 100 \\
\hline
\end{tabular}

Table 16 - Socio-Economic Aspects

\begin{tabular}{|c|c|c|c|}
\hline Socio-Economic Aspects & Yes & No & Abstain \\
\hline Increase family economy & $91 \%$ & - & $9 \%$ \\
\hline Improve social status & $81 \%$ & - & $19 \%$ \\
\hline Reduce social problems & $75 \%$ & $6 \%$ & $13 \%$ \\
\hline
\end{tabular}

All respondents have no business documents because they are still informal economy actors.

\section{DISCUSSION OF RESULTS}

Market Aspects. From the results of the research, it can be concluded that waste collectors offer limitless demands, while the ability of waste pickers to meet the demand is still limited. By comparing the demand of unlimited number of wastes by waste collectors and supply from waste pickers, the market opportunity is still widely open.

Technical Aspects. In terms of land ownership, most waste pickers do not have enough area to run the business. From the data of motorcycle ownership, almost all waste pickers have motorcycles. Considering that the size of the plastic chopper machine is only $70 \mathrm{~cm} \mathrm{x}$ $45 \mathrm{~cm}$, this unit is transportable on a motorcycle. Thus, it enables the landless waste pickers to run plastic wastes chopper business, even without land ownership.

From the ability to repair motorcycle engine damage, $88 \%$ waste pickers are able to repair minor damage. Since the chopper machine working system is almost the same as a motorcycle engine, waste pickers will be able to minimally perform maintenance of the machine.

From the understanding of production process, $54 \%$ of waste pickers do not understand the process. Thus, to be able to run the plastic wastes chopping business, waste pickers need to be trained. It can be taken with a group effort, where there is at least one person familiar with the production process in each group.

Referring to the results of interviews with one of the waste collectors who have a chopper machine, the production process of plastic chopping is quite simple. For bottles, the process includes: 1) Separate the cap, neck, body parts, and the bottom of the bottle. 2) Separate the lid and put the body, neck and bottom together. 3) Chop the parts separately according to the group. Then for glasses, firstly the upper circle of the glass and body are 
separated. In chopping process, the top circle of glasses can be mixed with the neck and bottom parts of the bottles, then the glasses' body parts are put together with the body parts of the bottles.

The results are sold separately because each product has different price. The price figure is presented in table 10 .

From the description of technical aspects, the required facilities to run this business are motorcycle, chopper machine, and maintenance equipment for minor service. Accordingly, the value of the assets required to conduct the business is as follows:

Table 17 - Asset Value Calculation

\begin{tabular}{|c|c|c|c|c|c|}
\hline No & Description & $Q$ & Unit & $\begin{array}{c}\text { @Rp } \\
(000)\end{array}$ & $\begin{array}{c}\text { Rp Total } \\
(000)\end{array}$ \\
\hline 1 & Motorcycle & 0,4 & piece & 15.000 & 6.000 \\
\hline 2 & Machine & 1 & piece & 5.000 & 5.000 \\
\hline 3 & Tolls kit & 1 & set & 100 & 100 \\
\hline \multicolumn{7}{|c|}{ Total Asset Value } \\
\hline
\end{tabular}

Financial Aspects. Daily income from collecting plastic water bottles wastes after being sorted is Rp 8.100, -. The price will be doubled for chopped bottles. Then, the daily income will be as follows:

Table 18 - Monthly Income After Being Chopped

\begin{tabular}{|c|c|c|c|c|c|}
\hline No & Part & $\mathrm{Kg}$ & Rp/ Part & * & Rp Sold \\
\hline 1 & Cap & 0,10 & 3000 & 2 & 1.200 \\
\hline 2 & Neck and Bottom & 0,15 & 9.500 & 2 & 1.800 \\
\hline 3 & Body & 0,75 & 8.500 & 2 & 12.750 \\
\hline \multicolumn{5}{|c|}{ Price $/ \mathrm{Kg}$} & 15.750 \\
\hline \multicolumn{5}{|c|}{ Income / day with $2.5 \mathrm{~kg}$ results } & 39.375 \\
\hline \multicolumn{5}{|c|}{ Results Per month with 6 working days } & 945.000 \\
\hline \multicolumn{5}{|c|}{ Annual Gross Income } & 11.340 .000 \\
\hline
\end{tabular}

Source: Table 10 (processed, 2017).

To obtain the above results, the monthly operating costs are:

Table 19 - Monthly Operating Costs

\begin{tabular}{|c|c|c|c|c|c|}
\hline No & Description & Q & Unit & @Rp & Total Rp \\
\hline 1 & Raw material & 2,5 & $\mathrm{~kg}$ & 0 & 0 \\
\hline 2 & Labor & 1 & orang & 5000 & 5.000 \\
\hline 3 & Partiality & 1,5 & liter & 7500 & 10.850 \\
\hline \multicolumn{4}{|r|}{ Daily Operating Costs } \\
\hline
\end{tabular}

Therefore, the calculation of annual operating costs is:

Table 20 - Monthly Operating Costs

\begin{tabular}{|c|c|c|c|c|c|}
\hline No & Description & Q & Unit & $@ R p$ & Total Rp \\
\hline 1 & Monthly Operating Cost & 12 & month & 380.400 & 4.564 .800 \\
\hline 2 & Annual Depreciation & 1 & year & 1.000 .000 & 1.000 .000 \\
\hline 3 & Machine Maintenance & 1,5 & year & 500.000 & 500.000 \\
\hline \multicolumn{2}{|r|}{ Total Annual Operating Cost } & 6.064 .800 \\
\hline
\end{tabular}

From Table 18 and Table 20, the net income / year is Rp 11,340,000 - Rp 6,064,800 = Rp 5,275,200, -.

Referring to the previous data, the analysis of financial performance of this business is: 


\begin{tabular}{|c|c|c|c|c|}
\hline \multirow[b]{2}{*}{$\mathrm{ROA}=$} & $5,275,200$ & \multirow[b]{2}{*}{$x$} & \multirow[b]{2}{*}{$100 \%=$} & \multirow[b]{2}{*}{$47.96 \%$} \\
\hline & 11,000,000 & & & \\
\hline \multirow[b]{2}{*}{$\mathrm{ROS}=$} & $5,275,200$ & \multirow[b]{2}{*}{$x$} & \multirow[b]{2}{*}{$100 \%=$} & \multirow[b]{2}{*}{$46.52 \%$} \\
\hline & 11.340 .000 & & & \\
\hline
\end{tabular}

From the calculation of ROA and ROS, it can be seen that the capitals invested in this business can generate profits of $47.96 \%$ of the investment. Besides, it means that the business profit is $46.52 \%$ of total sales value. Thus, based on the value of ROA and ROS, this business can be financially categorized well.

Aspects of Organization and Human Resources. The daily work patterns of the waste pickers are $72 \%$ waste pickers working on their own, while the remaining $28 \%$ working in groups of 3 to 7 people. They have family relationships and friendships. They inhabit in one area of the urban village. From the conditions mentioned above, the most appropriate organization for them is individual organizations and individual alliances.

Educational level of waste pickers ranges from elementary to high school. Referring to the Indonesian National Qualification Framework, the qualification of primary and secondary graduates are operators, causing them to have no managerial ability. Consequently, establishment of a formal organization is not yet possible. Siagian (1996: 63) argues that "Managerial skills are the skill of moving others to work well." Referring to the above opinion, there will be "elder figures" in every social group, who will usually be the role models of the group. This will certainly appear also in the waste pickers group. Thus, even though their formal educations reach a maximum of high school, it is possible for them to establish formal organizations.

The work ethic of waste pickers is very high to meet personal and / or family needs. They have similar work ethics. It is also one of the supporting factors in establishing an organization which is having the same purpose.

Legal Aspects. Of ownership of ID card, $96 \%$ of waste pickers have ID card. In addition, they also have a permanent residence. This is a general requirement to conduct formal activities, including opening a formal business and conducting business-related activities such as credit application to the bank.

Socio-Economic Aspects. The number of respondents who agree that this business will increase the family economy is $91 \%$. The family economy will be improved due to the increasing income from selling chopped plastic wastes. Moreover, they also have a business capital in the form of chopper machine which facilitates their work processes.

Furthermore, $81 \%$ respondents believe that running a plastic bottles chopping business will improve their status. They can be self-supporting and not depend anymore on the waste collectors. In addition, they can even be the waste collectors for their friends who do not have a machine yet.

Finally, $75 \%$ waste pickers argue that having a chopping business will reduce social problems. Some argue that they will be able to provide jobs for their unemployed friends. In addition, they also feel involved in maintaining the cleanliness of the environment by processing plastic wastes into plastic pieces.

\section{CONCLUSION}

From the results of the discussion, it can be concluded that Plastic Water Bottles Wastes Processing Business Unit for Waste Pickers is feasible to run, with the profile of business aspects as follows:

The market opportunity is still widely open, as demand from waste collectors is unlimited and supply from waste pickers is limited.

Technically, plastic chopping units are designed mobile on motorcycles, so waste pickers can directly execute the production process in the field. Then, the result is directly stored to the waste collectors. This is also supported by waste picker's ability to repair minor 
damage in the chopper machine. The capability of waste pickers' production process still needs to be improved, with the training model or apprenticeship to waste pickers who already have the understanding and ability in the production process. The production process needs to be separated based on the thickness of the plastic because they have different prices.

Financially, this business can be categorized well, because it provides $47.96 \%$ profit from the money invested, or $46.52 \%$ of total sales value.

The organization of this business can be in the form of individual organizations and individual alliances. Although their education is high school graduates at the highest, managerial traits will always be found in an organization based on family relationship and friendship.

Legally, waste pickers have become good citizens by having an ID card and a permanent residence.

From the socio-economic aspect, this business will increase the waste pickers' income, improve the status of the waste pickers, and reduce social problems.

\section{REFERENCES}

1. Siregar, Padang Rihim, 2013, Profil Sektor Informal (Studi Pedagang Kaki Lima di Jalan Hang Tuah Kota Tanjungpinang), riset.umrah.ac.id, hal $249-258$.

2. Hermawani, May, 2013, Strategi Bertahan Pedagang Kaki Lima Di Sekitar Kampus Universitas Sumatera Utara, Undergraduate Thesis, repository.usu.ac.id.

3. Kristiyono, Fitra; Bakar, Abu; \& Yuniar, 2014, Analisis Kelayakan Pendirian Pabrik Pencacah Plastik Acrylonitrile Butadiene Stryrene (ABS), Reka Integra ISSN: 2338-5081 - Jurusan Teknik Industri Itenas - No.03 - Vol.01 - Januari 2014.

4. Margaretha,Farah.2011.Manajemen Keuangan.Erlangga.Jakarta

5. Prabowo, Hartiwi, 2012, Kelayakan Investasi Perluasan Pabrik Penggilingan Plastik Pd Xyz, BINUS BUSINESS REVIEW Vol. 3 No. 2 November 2012: 803-818.

6. Anggraeni, Mutiara; Desrianty, Arie; \& Yuniar, 2013, Rancangan Meja Dapur Multifungsi Menggunakan Quality Function Deployment (QFD), Reka Integra ISSN: 2338-5081 Jurusan Teknik Industri Itenas - No.02 - Vol.01 - Oktober 2013.

7. Suarmawan, Kadek, Agus, 2015, Analisis Faktor-Faktor Yang Mempengaruhi Keberhasilan Usaha Mikro Dan Kecil (Studi Pada Usaha Kerajinan Ingka Di Desa Bulian, Kec. Kubutambahan), Jurnal Jurusan Pendidikan Ekonomi (JJPE) - Volume: 5 Nomor:1 Tahun: 2015, Hal.: 1 - 10.

8. Adriantantri, Emmalia; 2008, Aplikasi Metode Quality Function Deployment (Qfd) dalam Usaha Memenuhi Kepuasan Pelanggan Terhadap Produk Aqua Gelas 240 Ml Pada Pt. Tirta Investama Pandaan, Prosiding Seminar Nasional Teknoin 2008 Bidang Teknik Industri.

9. Rahman; Abdul \& Supomo, Heri, 2012, Analisa Kepuasan Pelanggan pada Pekerjaan Reparasi Kapal dengan Metode Quality Function Deployment (QFD), JURNAL TEKNIK ITS Vol. 1, No. 1(Sept. 2012) ISSN: 2301-9271.

10. Siagian, Sondang P., (1996), Manajemen Sumber Daya Manusia, Bumi Aksara, Jakarta.

11. Sucipto, Edi. Oktaviani, Rina. \& Rizal. 2015. The effects of partnership and entrepreneurship toward business performance of oyster mushroom (pleurotusostreatus). Indonesian Journal of Business and Entrepreneurship, Vol. 1 No.1, January 2015, Page $32-41$.

(C) 2017 by the authors. Licensee RJOAS, Orel, Russia. This article is an open access article distributed under the terms and conditions of the Creative Commons Attribution (CC BY) license: http://creativecommons.org/licenses/by/4.0/ 
DOI https://doi.org/10.18551/rjoas.2017-09.24

\title{
THE ROLE OF FINANCIAL LITERACY IN CREATIVE INDUSTRY GROWTH: WOMEN ENTREPRENEUR STUDY OF DONGGALA WOVEN FABRIC INDUSTRY
}

\author{
Tallesang Mukhtar*, Rossanty Niluh Putu Evvy, Darman \\ Faculty of Economics, Tadulako University, Indonesia \\ *E-mail: $\underline{\text { m.tallesang@gmail.com }}$
}

\begin{abstract}
Having a financial literacy is vital to get a prosperous life. Proper financial management supported by good financial literacy is expected to increase the standard of living. This term is applied to every income level as no matter how much someone's income level is, without having good financial management, it is surely hard to achieve financial security. This study aims to (1) analyze factors affecting women entrepreneur financial literacy of Donggala woven fabric creative industry player, (2) analyze the role of financial literacy in creative industry growth. The object of this study was 34 women entrepreneur selected randomly. The data were analyzed using multiple regression analysis. The result shows that the factor of education (sig. 0.883), age (sig. 0.494), and the length of business (0.383) has no significant influence on the level of women entrepreneur financial literacy of Donggala woven fabric creative industry player ( $\alpha$ : 0.05). Except for training financial factor (sig. 0.002), it has a significant influence on the level of women entrepreneur financial literacy. The same goes to the financial literacy (sig. 0.001) having significant influence over the creative industry growth of Donggala woven fabric in Central Sulawesi-Indonesia.
\end{abstract}

\section{KEY WORDS}

Creative industry, financial literacy, women entrepreneur, donggala woven fabric.

Arranging an effective financial decision and understanding how to manage money is a key skill to enjoy financial in the future. However, there are many individuals and families who do not have an understanding required to make a good financial decision (Braunstein et al., 2002). Financial distress is influenced not only by earned income, but also mismanagement. Understanding financial literacy is vital to get a prosperous life. Proper financial management supported by good financial literacy is expected to increase the standard of living. This term is applied to every income level as no matter how much someone's income level is, without having good financial management, it is surely hard to achieve financial security.

A research on financial literacy at SMEs (Usaha Kecil Menengah or UKM) in Ghana finds that financial literacy is essential to encourage SMEs sector (Nunoo et al., 2012). The result shows that financial literacy has a positive influence over the SMEs performance. George Lucas Educational Foundation (2013) proposes that financial literacy is essential to enable individual to make a financial decision, to discuss financial issues and the future plan.

One of the SMEs passed down over the generation by the community of Donggala district is the creative industry of Donggala woven fabric. This traditional woven fabric is really unique since made of natural silk fibers with various colors and pattern which is truly interesting and typical and is weaved by the ingenious hand of rural women using traditional equipment called balida (traditional loom). However, nowadays, the creative industry of Donggala woven fabric suffers in a downturn and even feared extinct. One of the causes is the women of Donggala woven fabric creative industry player still have a limitation of knowledge and financial management.

Considering the importance of financial literacy to the community, especially women entrepreneur, as well as the importance of preserving Donggala woven fabric in Central Sulawesi, it is important to analyze factors affecting financial literacy and the role of financial literacy in creative industry business growth of Donggala woven fabric. 


\section{LITERATURE REVIEW}

Greenspan (2002) states that financial literacy helps individual to understand financial knowledge needed to arrange household budget, to start saving the plan, and to make a strategic investment decision. The right application will help an investor to fulfill his/her financial obligation through thoughtful training and resources allocation can decrease maximum utility. Lusardi and Mitchell (2007) define financial literacy as the financial knowledge and ability to apply it. Additionally, The President's Advisory Council of Financial Literacy (2008) also defines financial literacy as the ability to function knowledge and ability to manage financial resources to achieve prosperously.

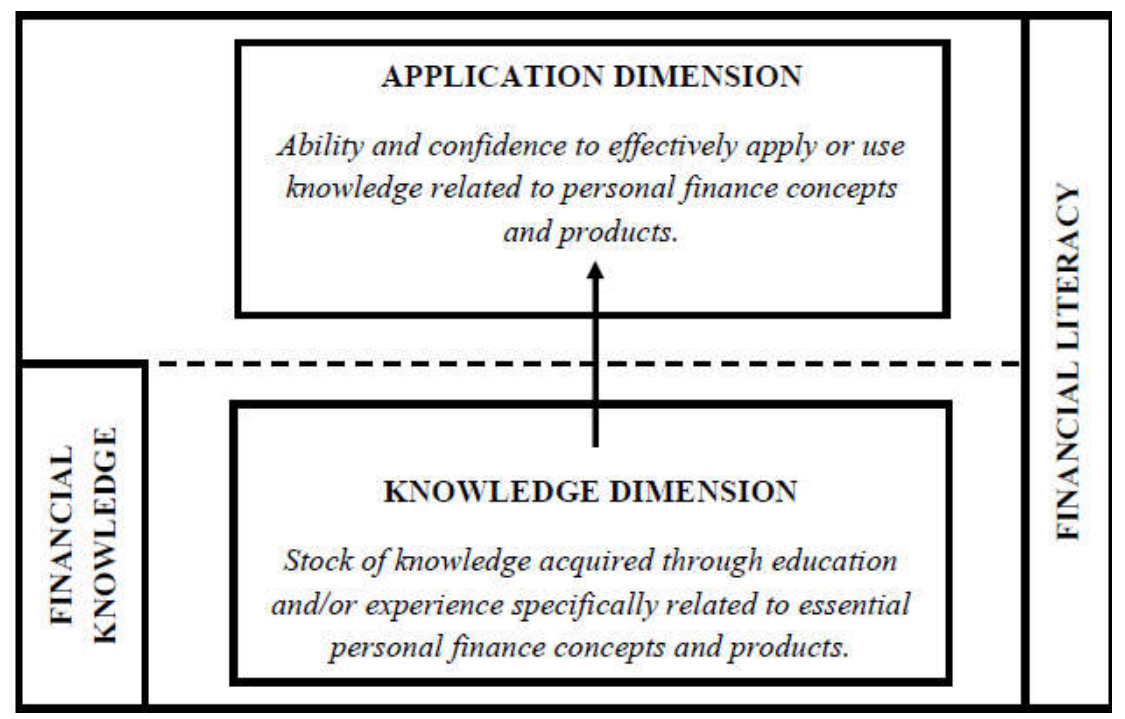

Figure 1 - Financial Literacy Concept (Hutson, 2011)

Huston (2010) proposes that financial literacy can be defined as the measurement how well an individual is to understand and use information related to the financial. Financial literacy needs not only knowledge dimension but also additional dimension-that is, application dimension that requires individual to have an ability and self-confidence of financial literacy owned to be used in the financial decision making. Such literacy concept is illustrated in figure 2.1.

Chen and Volpe (1998) define financial literacy as the ability to manage finance to get a prosperous life in the future. There are four aspects of financial literacy, firstly General Personal Finance Knowledge covering to an understanding of several things related to the basic knowledge of financial. Secondly, Savings and Loans, these cover to knowledge related to the savings and loans. Thirdly, insurance, it covers to insurance basic knowledge and basic insurance. Fourthly, Investments covering to knowledge on investment and investment risk. Additionally, Remund (2010) states that there are 4 most common things in financial literacy, that is: unemployment, savings, loans, and investment. Financial literacy involves not only knowledge and ability to overcome a problem but also a non-cognitive attribute.

According to the Financial Services Authority (Otoritas Jasa Keuangan or OJK) (2013), literacy is defined as the ability to understand, thus financial literacy is the ability to manage fund owned to get a more prosperous life in the future. OJK states that the important mission of financial literacy program is to educate the community to manage financial smartly and to overcome the low financial literate in order to achieve more prosperous life. For that matter, OJK launches three main pillars of financial literacy, that is: Pillar 1, education and national campaign on financial literacy. Pillar 2, reinforcement of financial literacy infrastructures. Pillar 3, financial services and products development. The performance of those three pillars is expected to be able to realize Indonesian society having high financial literacy so they will have financial knowledge and apply it to increase prosperous. 


\section{METHODS OF RESEARCH}

This was quantitative descriptive research using survey methods. The object of this study was Donggala woven fabric creative industry in Central Sulawesi-Indonesia. While the analysis unit of this study was the women of Donggala woven fabric creative industry player, 34 of them were chosen randomly as the sample. Analysis methods used was consisted of 2 stages, namely:

Identifying factors influencing women financial literacy of Donggala woven fabric creative industry player. The data was analyzed using inferential statistic in form of multiple regression analysis (Algifari, 1997) using SPSS 16 statistics.

$$
Y=a+b 1 \times 1+\ldots b n \times n+e
$$

Where: Y - Financial Literacy (dependent variable); a - Intercept variable; b1...bn Regression coefficient; $x 1$...xn - Influencing factors (independent variable); e - error.

Identifying the role of financial literacy in creative industry growth of Donggala woven fabric. Creative industry growth uses an indicator of selling growth, capital growth, asset growth, and profit growth (Musran, 2010).

$$
Y(\text { Creative industry growth })=a+b \text { Financial Literacy }+e
$$

\section{RESULTS AND DISCUSSION}

The result of data processing using multiple regression linear analysis aiming to know factors influencing the level of women entrepreneur financial literacy of Donggala woven fabric craftsmen is as follow:

Table 1 - Value for R-squared model

\begin{tabular}{|c|c|cc|}
\hline Model & $\mathrm{R}$ & Adjusted R-squared \\
\hline 1 & $.881^{\mathrm{a}}$ & & .767 \\
\hline a. Predictors: (Constant), Training, Age, Education, Long Business & \\
\hline
\end{tabular}

Source: Processed Data, 2017.

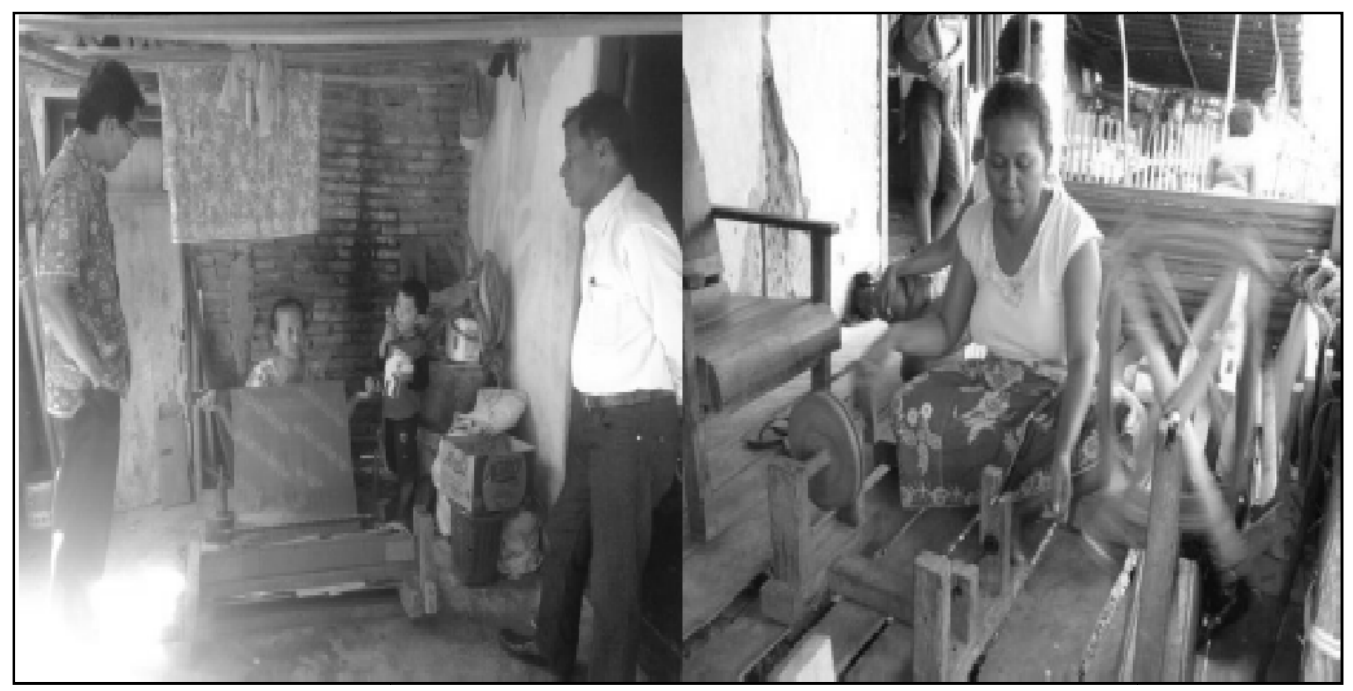

Figure 2 - Women Entrepreneur of Donggala Woven Fabric Creative Industry Player

Factor influence testing of financial training, age, education, and the length of business results in the value of $R$ by 0.881 . It shows that the relationship between financial training, age, education, and long business and the level of women entrepreneur financial literacy is categorized as strong. Moreover, the existence of Adjusted-R Squared value by 0.767 
indicating that the variable factor of financial training, age, education, and the length of business is able to explain the level of women entrepreneur financial literacy by 76.7 percent, while 23.3 is explained by other factors out of the model.

According to the model reliability of Table 1 above, thus performed testing between the independent variable (financial training, age, education, and long business) and the dependent variable (financial literacy level).

The result of data processing is seen from Table 2.

Table 2 - Data processing Result of Influencing Factors Women Entrepreneur Financial Literacy

\begin{tabular}{|c|c|c|c|c|c|c|}
\hline \multirow{2}{*}{\multicolumn{2}{|c|}{ Model 1}} & \multicolumn{2}{|c|}{ Unstandardized Coefficients } & \multirow{2}{*}{$\frac{\text { Standardized Coefficients }}{\text { Beta }}$} & \multirow{2}{*}{$\mathrm{t}$} & \multirow{2}{*}{ Sig. } \\
\hline & & $\mathrm{B}$ & Std. Error & & & \\
\hline \multirow{5}{*}{$\mathrm{n} / \mathrm{n}$} & (Constant) & .338 & .878 & & .385 & .703 \\
\hline & Education & .019 & .131 & .024 & .148 & .883 \\
\hline & Age & .111 & .161 & .113 & .693 & .494 \\
\hline & Long Business & .124 & .140 & .148 & .885 & .383 \\
\hline & Financial Training & 1.022 & .292 & .560 & 3.498 & .002 \\
\hline \multicolumn{6}{|c|}{ a. Dependent Variable: Financial Literacy ( $\alpha$ : 0.05) } & \\
\hline
\end{tabular}

Source: Processed Data, 2017.

According to the result of data processing, it shows that the factor of education (sig. 0.883), age (sig. 0.494), the business (0.383) has no significant influence on the level of women entrepreneur financial literacy of Donggala woven fabric creative industry player. Except for training financial factor (sig. 0.002), it has a significant influence on the level of women entrepreneur financial literacy.

Education factor has no significant influence over the women entrepreneur financial literacy level. It is caused by the low educational background of women entrepreneur of Donggala woven fabric creative industry player. Educational background of women entrepreneur is not graduate primary school ( $<S D$ ) by 23,5 percent, graduate SD by 47.1 percent, graduate Junior High School (SMP) by 20.6 percent, and graduate Senior High School (SMA) by 8.8 percent. This indicates that most women entrepreneur of Donggala woven fabric creative industry player have a low educational background so never had a lesson about financial knowledge formally.

Age has no significant influence over the women entrepreneur financial literacy level. The age of women entrepreneur ranging from 20-35 years old is 23.5 percent, 36-45 years old by 26.5 percent, and above 46 years old by 50 percent. This indicates that the majority of women entrepreneur of creative industry player is elderly. Commonly, women entrepreneur are a housewife who not only does housework but also manages a business to get more income.

The length of a business factor also has no significant influence on the level of women entrepreneur financial literacy. The length of time of Donggala woven fabric creative industry less than 5 years is 25.5 percent, while those which have been running for $6-15$ years are 27.5 percent, and those above 15 years are 47.1 percent. This indicates that, generally, Donggala woven fabric creative industry has been managed for a long time and passed down from the generation by women entrepreneur, but its financial management suffering in stagnancy.

Financial training factor has a significant influence on the level of financial literacy of women entrepreneur. Training on business financial management held by local government along this time actually plays an important role in the level of women entrepreneur financial literacy of Donggala woven fabric creative industry player. However, it is only sub-section of women entrepreneur who gets training on business financial management. Survey result indicates that women entrepreneur who gets financial training is only 17.6 percent, while the 82.4 percent do not participate yet.

Moreover, data processing was done to find out the role of financial literacy in creative industry growth of Donggala woven fabric. The result of data processing is depicted from Table 3. 
Table 3 - Data Processing Result of Financial Literacy Role in Creative Industry Growth

\begin{tabular}{|c|c|c|c|c|c|c|}
\hline \multicolumn{2}{|c|}{ Model 1 } & \multicolumn{2}{c|}{ Unstandardized Coefficients } & Standardized Coefficients & \multirow{2}{*}{$\mathrm{t}$} & \multirow{2}{*}{ Sig. } \\
\cline { 3 - 6 } & B & Std. Error & Beta & 2.803 & .009 \\
\hline \multirow{2}{*}{$\mathrm{n} / \mathrm{n}$} & (Constant) & .814 & .291 & .536 & 3.594 & .001 \\
\cline { 2 - 7 } & Financial Literacy & .621 & .173 & & & \\
\hline \multicolumn{2}{|l|}{ a. Dependent Variable: Growth of age }
\end{tabular}

Source: Processed Data, 2017.

Table 3 above indicates that financial literacy (sig. 0.001) has a significant influence on the creative industry growth of Donggala woven fabric in Central Sulawesi-Indonesia. This indicates that financial literacy in form of financial basic knowledge, knowledge of savings and loan, knowledge of assurance, and knowledge of investment very influences the sustainability of Donggala woven fabric creative industry which is the cultural heritage of Central Sulawesi community-Indonesia.

\section{CONCLUSION}

According to the explanation above, it concludes that financial training delivers values to the level of women entrepreneur financial literacy of Donggala woven fabric creative industry player. Additionally, financial literacy in form of basic knowledge of financial, knowledge of savings and loans, knowledge of assurance, and knowledge of investment has a big influence over the sustainability of Donggala woven fabric creative industry which is the cultural heritage of Central Sulawesi community-Indonesia. For that matter, women entrepreneur are expected to increase their financial literacy and contribution to the related sides, especially the local government to perform efforts to increase the financial literacy of creative industry player, especially financial training administration.

\section{REFERENCES}

1. Algifari, 1997. Analisis Statistik Untuk Bisnis; Dengan Regresi, Korelasi dan Nonparametrik, Yogyakarta: BPFE

2. Braunstein, Sandra and Carolyn Welch, 2002. Financial Literacy: An Overview of Practice, Research and Policy. Federal Reserve Bulletin, Federal Reserve Board.

3. Chen, H. \& Volpe, R. P. 1998. An analysis of personal financial literacy among college students, Financial Services Review, 7(2): 107-128.

4. George Lucas Educational Foundation, 2013. How Financial Literacy Yields Success.

5. Greenspan, A., 2002. A Tool for Economic Progress, the Futurist, 4(36): 37- 41.

6. Huston, S. J., 2011. Measuring Financial Literacy, Rochester: SSRN Paper Series.

7. Huston, S.J., 2010. Measuring Financial Literacy, Journal of Consumer Affairs, 2(44).

8. Lusardi, A., Mitchell, O. S., 2007. Financial Literacy and Retirement Planning: New Evidence from the Rand American Life Panel, JEL classification: D91

9. Musran, T. M., 2010. Pengaruh Faktoe Eksternal dan Internal Kinerja UKM di Sulawesi Selatan, Jurnal Manajemen dan Kewirausahaan, Vol 12 No.1: 33-41.

10. Nunoo dan Andoh, 2012. Sustaining Small and Medium Enterprises through Financial Service Utilization: Does Financial Literacy Matter?

11. Otoritas Jasa Keuangan, 2013. Financial Customer Care, Majalah Edukasi Konsumen, Edisi Agustus 2013, Th. I.

12. Remund, D L., 2010. Financial Literacy Explicated: The Case For A Clearer Definition In An Increasingly Complex Economy. Journal of Consumer Affairs, Volume 44 Issue 2.

13. The President's Advisory Council of Financial Literacy, 2008. Annual Report to the President, Executive Summary.

(c) 2017 by the authors. Licensee RJOAS, Orel, Russia. This article is an open access article distributed under the terms and conditions of the Creative Commons Attribution (CC BY) license: http://creativecommons.org/licenses/by/4.0/ 
DOI https://doi.org/10.18551/rjoas.2017-09.25

\title{
PROBLEMS OF FORMATION OF LABOR POTENTIAL IN RUSSIAN SMALL TOWNS AND RURAL SETTLEMENTS: A STUDY ON THE EXAMPLE OF THE PRIMORSKY REGION, RUSSIA
}

\author{
Krasova E.V., Candidate of Economic Sciences \\ Vladivostok State University of Economics and Service, Vladivostok, Russia \\ E-mail: elena krasova@rambler.ru
}

\begin{abstract}
Development of small towns and rural settlements is an actual subject of Russian scientific researches, along with the regional and branch economics. The main scientific and practical problem of the article is reduction of labor potential in Russian small towns and rural settlements. The purpose of the article is to actualize the problems of formation of labor potential in small towns and rural settlements by the example of Primorsky Region. Methodological basis of the study are the theses of modern economic theory, theory of small towns, economic geography, the concept of rational distribution of population and labor resources. These theses are applied in the article through the systematic approach and statistical analysis. The article proves the relevance of declared subject, considers distribution of the population in Primorsky Region, and studies the main problems of formation of labor potential in small towns and rural settlements. The author points such problems as narrow economic specialization of the settlements, backwardness of small towns and rural settlements in terms of quality of habitat, unclaimedness of highly skilled workers and the demographic decline in the settlements.
\end{abstract}

\section{KEY WORDS}

Labor potential, small cities, rural settlements, Primorsky Region, socio-economic development, unclaimedness of labor force, demographic decline.

Small towns and rural settlements are very important elements of Russian population's resettlement scheme, especially in the Far East. Throughout the history of development of the Far East, urban and rural settlements were the most widespread populated localities. Unlike the western part of Russia, where the main functional purpose of the settlements was the maintenance of agricultural production, formation and development of the Far Eastern settlements were conformed to important political and economic tasks: extraction and processing of natural resources, location of significant industrial facilities, implementation of Russian military and political interests in the Far East. That is why the growth rates of small towns and rural settlements in the region in the 1960s, 1970s and 1980s were higher than the rates of development of large cities (Belskaya, 2005). The total number and structure of modern settlements in Primorsky Region are presented in tables 1, 2.

Table 1 - The number of settlements in Russia and Primorsky Region by types, 2016

\begin{tabular}{|c|c|c|c|c|}
\hline $\begin{array}{c}\text { Number of } \\
\text { municipalities }\end{array}$ & $\begin{array}{c}\text { In Russia as a } \\
\text { whole, units }\end{array}$ & $\begin{array}{c}\text { In Russia, } \\
\text { percentage share }\end{array}$ & $\begin{array}{c}\text { In Primorsky } \\
\text { Region, } \\
\text { units }\end{array}$ & $\begin{array}{c}\text { In Primorsky Region, } \\
\text { percentage share }\end{array}$ \\
\hline Total, including: & 22406 & 100,0 & 158 & 100,0 \\
\hline Municipal districts & 1788 & 8,0 & 22 & 13,9 \\
\hline City districts & 852 & 3,8 & 12 & 7,6 \\
\hline Urban settlements & 1592 & 7,1 & 14,6 \\
\hline Rural settlements & 18177 & 81,1 & 101 & 63,9 \\
\hline
\end{tabular}

Source: Federal State Statistics Service of Russia.

There are many examples of rapidly developing territories in Primorsky Region: small cities of Arsenyev, Dalnegorsk, Bolshoy Kamen, and their adjacent agricultural areas. 
Through the small cities and settlements, rather high potential of human resources was formed in Primorsky Region in Soviet period. This potential is high in its quantitative parameters and qualitative characteristics.

Table 2 - Distribution of population in Primorsky Region by types of settlements, for 01.01.2017

\begin{tabular}{|c|c|c|c|c|c|}
\hline $\begin{array}{c}\text { Type of } \\
\text { settlements }\end{array}$ & $\begin{array}{c}\text { Population in } \\
\text { municipal } \\
\text { districts }\end{array}$ & $\begin{array}{c}\text { Population in } \\
\text { urban } \\
\text { settlements }\end{array}$ & $\begin{array}{c}\text { Population in } \\
\text { rural settlements }\end{array}$ & $\begin{array}{c}\text { Population in } \\
\text { city districts }\end{array}$ & $\begin{array}{c}\text { Population in } \\
\text { villages of city } \\
\text { type }\end{array}$ \\
\hline $\begin{array}{c}\text { Population, } \\
\text { thousand people }\end{array}$ & 498,4 & 171,4 & 326,9 & 1325,2 & 158,0 \\
\hline $\begin{array}{c}\text { Share in } \\
\text { population of the } \\
\text { Region }\end{array}$ & $25,8 \%$ & $8,9 \%$ & $16,9 \%$ & $68,7 \%$ & $8,2 \%$ \\
\hline
\end{tabular}

Source: Federal State Statistics Service of Russia.

\section{RESULTS AND DISCUSSION}

At the present time, the main problem of formation and development of labor potential in small towns and rural settlements is the gap between accumulated human capital and the low level of socio-economic development in these areas. This problem has the systematic nature and manifests itself in a number of aspects, the most important of which are the following.

1. The most of small towns and rural settlements are monofunctional according to the established economic specialization. A narrow production orientation forms a very one-sided labor market of the monopsonistic type. There is the strong dependence of employment, incomes and living standards of people from one particular enterprise or from exclusively development of agriculture. In the situation of decline in the financial stability of such enterprises and farms, the burden of grievous consequences lays on inhabitants and local governments (Tokarev, 2007). In addition, the special features of this type of labor market are low labor mobility, growth of the share of informal employment, decline of the quality and safety of labor, inefficient of the state regulation.

2. Lag of small towns and rural settlements in terms of quality of habitat from the big cities and central territories of Russia. In general, in Russia only $20 \%$ of small towns and settlements reach the normative indicators of urban development, and in rural settlements such indicators are much lower. The acute problem of Russian rural territories is the insufficient level of development of the socio-cultural infrastructure, its incompleteness (Mayakova, 2004). First of all the problem concerns the education, health care, housing and communal services, cultural and leisure infrastructure. Often in small towns and rural settlements you can see the neglect of territories, the old rural way of life.

A special factor that influences to quality of the environment is remoteness of the settlements from regional center, transport and communication isolation of the settlements from the main economic, scientific and cultural centers and market infrastructure. On average, $75 \%$ of Russian small towns and rural settlements are located at the distance of more than $80 \mathrm{~km}$ from the regional centers (Mayakova, 2004). In the Far East and Primorsky Region this indicator is several times higher (table 3).

Numerous scientific studies show that the more remoteness of a settlement from regional center, the higher migration outflows from the settlement and the weaker development of labor potential. A specificity of organization of the settlements in Russian Far East should be noted here: their great remoteness from the regional center promotes increase of their role as separate, independent centers of management, economic and cultural services in big part of the Region's territory. However, at the present time, the economic and managerial potential of the territories has been weakened, and migration outflows from the most of the far areas can grow soon without significant investments to development of strategic projects (Krasova and Ma, 2015). 
Table 3 - Remoteness of small towns and rural centers of Primorsky Region from the regional center Vladivostok

\begin{tabular}{|c|c|c|c|c|}
\hline $\begin{array}{c}\text { Place in population } \\
\text { rating }\end{array}$ & $\begin{array}{c}\text { Small towns and rural } \\
\text { centers }\end{array}$ & $\begin{array}{c}\text { Population, } \\
\text { people }\end{array}$ & $\begin{array}{c}\text { Distance to the regional } \\
\text { center, km }\end{array}$ & $\begin{array}{c}\text { Share in } \\
\text { population } \\
\text { of the region }\end{array}$ \\
\hline 1 & Vladivostok & 606653 & 0 & $31,4 \%$ \\
\hline 2 & Ussuriysk & 168598 & 98 & $8,7 \%$ \\
\hline 3 & The find & 153581 & 479 & $8,0 \%$ \\
\hline 4 & Artem & 105338 & 239 & $2,5 \%$ \\
\hline 5 & Arsenyev & 53083 & 223 & $2,2 \%$ \\
\hline 6 & Spassk-Far & 41539 & 109 & $2,0 \%$ \\
\hline 7 & Big Stone & 38718 & 167 & $1,9 \%$ \\
\hline 8 & Partizansk & 37470 & 362 & $1,9 \%$ \\
\hline 9 & Lesozavodsk & 36027 & 491 & $1,8 \%$ \\
\hline 10 & Dalnegorsk & 35405 & 409 & $1,4 \%$ \\
\hline 11 & Dalnerechensk & 26378 & 424 & $0,8 \%$ \\
\hline 12 & Kavalerovo & 14525 & 188 & $0,7 \%$ \\
\hline 14 & Chernigovka & 13046 & 181 & $0,6 \%$ \\
\hline 15 & Slav & 12314 & 316 & $0,6 \%$ \\
\hline 16 & Chuguevka & 12171 & 176 & $0,6 \%$ \\
\hline 17 & The King & 10860 & 133 & $0,5 \%$ \\
\hline 18 & Pokrovka & 10360 & 196 & $0,5 \%$ \\
\hline 19 & Frontier & 10215 & 281 & $0,2 \%$ \\
\hline 20 & Yakovlevka & 4480 & 438 & $0,2 \%$ \\
\hline 21 & Olga & 3625 & 662 & $0,2 \%$ \\
\hline
\end{tabular}

Source: Federal State Statistics Service of Russia.

3. The unclaimedness of highly skilled labor force, the lack of conditions for the qualitative self-realization of human capital. As a rule, development of human capital in small towns and rural settlements is hampered by stable, low-paid and narrow-profile work and limited range of high-quality jobs. Studies of many Far Eastern scientists show that the main reasons for migration outflows of youth from the settlements of the Far East are the following: low perspectives in professional growth; unpromising real estate market; uncomfortable public transport; high level of goods' prices; low demand for specialists with high level of human capital and high innovative activity in the business environment of the settlements (Latkin and Grivanov, 2014).

The scientists note that the last factor is the most important when young people choose a model of their migratory behavior.

4. Constant demographic decline of small towns and rural settlements. The sociodemographic situation is characterized not only by fall of population, but also by deformation of age structure of the population, decrease in the share of young people and employable persons, and increase in the share of pensioners. Small towns and rural settlements in Russia are the main donors for regional centers: researches for more than 100-year period show that the population consistently migrates to cities with population with more than 500 thousand people, where the relatively high quality of urban environment is formed (Yurasov and Goryachev, 2015). In particular, increase in the population of Vladivostok is mainly due to the migration component, namely by means of migration from the territories of Primorsky Region and the whole Far East. Also the higher mobility of modern population should be taken into account here: less than earlier people are attached to the territory, to their parents' home, their small homeland. Modern people focus their attention on a perspective work, quality of life, opportunities to spend leisure and travel interestingly. Therefore, most of young people who were born in 1990s and in 2000s, are going to leave the small towns and rural settlements. According to report of the Ministry of Economic Development of Russia, in 2010s the outflows of population from the periphery to large cities can achieve 20 to 40 million people (Bondarskaya and Yuriev, 2014). 
Reduction of quantity of human resources, deterioration of their structure and quality lead to delay in the socio-economic development, debilitation of entrepreneurial and social initiatives in small towns and rural settlement.

\section{CONCLUSION}

What measures should be taken in this situation? According to the author's opinion, two main ways are necessary, without which development of human capital cannot take place.

1. Creation and development of industrial facilities in the territory of urban and rural settlements. The human resource is special resource: it is the essential condition for economic activity, but it requires some special conditions for its development. In big cities there are many opportunities for formation of labor potential because of large consumer demand for various goods and services, much higher developed market infrastructure. But in small towns and rural settlements realization of human capital requires a certain center of entrepreneurial activity. Such centers can be created on the base of the shipbuilding complex "Zvezda» in Bolshoy Kamen, the helicopterbuilding complex "Progress» in Arsenyev and other significant industrial facilities on various territories of Primorsky Region (Sapunov and Krasova, 2012).

2. More effective state management of agriculture in Primorsky Region. In each rural area the following facilities must be created: social and engineering systems and infrastructures; life support systems and infrastructures: roads, transport, construction, resource supply, communication capacities; social infrastructure: public services, household services, catering, trade, health, education, culture, sports, personnel development, incentives and wages, skills development; development of entrepreneurship: financial opportunities, consulting and insurance; government support, innovative development and commodity markets.

It's necessary to take into account the specificity of market infrastructure for different sectors of economy (large business, medium, small and micro business) (Gorobets, Mayakova and Osipov, 2014).

However, creation of only industrial, transport-logistic or agro-industrial infrastructure is not enough to save the labor potential in rural settlements. Industrial development of agricultural areas is urgently required (Kuzubov and Shashlo, 2017). The distribution of areas by gross agricultural output shows that the main factors of development are: proximity to big cities, creation of demand for agricultural products (in Nadezhdinsky, Mikhailovsky and Partizansky districts), and location in rice cultivation areas with developed melioration and acceptable climatic conditions (in Khankai, Kirovsky, Spassky, Khorolsky, Anuchinsky, Chernigovsky districts).

Also it must be said that Primorsky Region is the territory with extreme conditions of agriculture, floods, and small land resources. $90 \%$ of precipitation falls in summer. The intensity of precipitation can be $80-100 \mathrm{~mm}$ and more per day, so floods and waterlogging of soils can last 7-10 days. For cereals, excluding rice, the flooding period more than 1-2 days is disastrous. For vegetables and potatoes such disastrous period is 3-4 days (Nosovsky, 2006). Obviously, irrigation and flood control are necessary conditions for the development of agriculture in Primorsky Region.

\section{REFERENCES}

1. Belskaya E.E. (2005). Small cities: socio-economic and demographic problems and development prospects: author's abstract. diss. ... cand. geogr. sciences. Irkutsk. -26 p.

2. The population of the Russian Federation for municipalities on January 1, 2016 [Electronic resource] // Federal State Statistics Service of Russia. - URL: http://www.gks.ru/wps/wcm/connect/ rosstat_main / rosstat / en / statistics / publications. 
3. Tokarev V.V. (2007). The development of Human Capital at the sub-regional level (in small towns of Russia): monograph / Ministry of Agriculture of Russian Federation, Michurinsky State Agrarian University, Michurinsk-naukograd.

4. Mayakova A.A. (2004). Modern understanding of the problem of effective development of small towns and rural settlements // Reports of the Far Eastern State Technical University. № 138. P. 91-95.

5. Krasova E.V., Ma Y. (2015). Free Port of Vladivostok: Development Conditions, Prospects, Risks // Economic and Social Changes: Facts, Trends, Forecast. No. 6 (42). P. 108-122.

6. Latkin A.P., Grivanov R.I. (2014). Innovative component as a key factor in the development strategy of the Russian Far East and its integration to the economic system of the APR // Economics and Management of Management Systems. № 4. P. 79-86.

7. Yurasov I.A., Goryachev I.N. (2015). The human capital in cities of subjects of Privolzhsky federal district // Izvestiya of the Saratov university. New episode. Series: Sociology. Political science. T. 15. № 1. P. 9-14.

8. Bondarskaya TA, Yuriev V.M. (2014). Creative human capital as a factor in the economic growth of small cities // Proceedings of the VII annual All-Russian scientific-practical conference «Problems of socio-economic development of Russia at the present stage». P. 20-27.

9. Sapunov A.V., Krasova E.V. (2012). Historical and economic review of the most important investment projects between Russia and the Republic of Korea in Primorsky Region // Territory of new opportunities. Bulletin of the Vladivostok State University of Economics and Service. № 1. P. 74-83.

10. Gorobets Y.V., Mayakova A.A., Osipov V.A. (2014). Organization of management in development of the regional production cluster in modern conditions. Vladivostok: Dalynauka. - $181 \mathrm{p}$.

11. Kuzubov A.A., Shashlo N.V. (2017). Implementation of the monitoring subsystem in the regulation system of the agro-food sector on the regional level // Russian Journal of Agricultural and Socio-Economic Sciences. T. 62. № 2. P. 33-41.

12. Nosovsky V.S. (2006). Economics of melioration: theory, practice and strategy. Moscow: «Rosin-formagrotekh». $-300 \mathrm{p}$. 
DOI https://doi.org/10.18551/rjoas.2017-09.26

\title{
EMPIRICAL ANALYSIS COMPANY SIZE, CORPORATE GOVERNANCE AND AUDIT QUALITY TO EARNING MANAGEMENT IN INDONESIA
}

\author{
Mawardi Rizal \\ Faculty of Economics and Bussiness, Airlangga University, Indonesia \\ E-mail: rizal.mawardi@gmail.com
}

\begin{abstract}
In the preparation of accrual basis accounting financial statements are selected because it can reflect the company's financial condition directly. Policymakers provide flexibility for management to be able to choose the accounting standards applied to the company. Management takes advantage of the freedom of selection of certain accounting policies in order to provide good earnings reporting in the financial statements. This study aims to analyze the effect of firm size and good corporate governance (GCG) to earnings management with moderation variables that is audit quality. This research is a quantitative research using secondary data. The sample selection was done by purposive sampling method and the data processing method using hypothesis analysis and multigroup analysis. The data used is obtained from Indonesia Stock Exchange and processed by using Smart PLS. The results showed that firm size variables did not significantly influence positively to earnings management but the variable of Good Corporate Governance (GCG) had a significant positive effect on earnings management. Audit quality can not moderate the effect of firm size on earnings management. The researchers hope that the results of this study will provide new insights for academics and practitioners regarding the relationship between Corporate Size, Good Corporate Governance (GCG) and Audit Quality to Profit Management.
\end{abstract}

\section{KEY WORDS}

Company, size, corporate governance, profit, management.

Profit is the company's main goal in undergoing operations that take place in each period. Practically operational, earnings can be seen in the financial statements of each company, according to (Agustia, 2013). The financial statements are one of the important things for some external parties as well as internal parties. In the financial statements contain a collection of information concerning the financial position, performance, change of a company's financial position, and beneficial to economic decision-making. Profit information is a major concern for assessing performance or management presentations.

In the preparation of financial statements, accrual-based accounting is chosen because it can reflect the company's financial condition directly. In general, management will take advantage of the freedom of selection of certain accounting policies in order to provide good earnings reporting in the financial statements. This allows management to perform accounting practices with profit-oriented numbers that will result in low quality reported earnings resulting in errors in decision making (Barus \& Setiawati, 2015).

According Sunandar et. al., (2014) states the actions of managers will impact on the quality of earnings that will result in lower financial statements. The low quality of this information served by the management is due to the practice of earnings management as the impact of agency problems. Accounting practices undertaken by management that also impacts the size of the company in the eyes of the parties shareholders and ownership of the company.

Researchers are interested to examine whether firm size is influential in implementing earnings management practices and researchers are interested in examining whether good corporate governance (GCG) affects earnings management practices Where the use of audit quality variables as moderating variables is based on the role of the auditor as an independent party in giving opinion on reports Finance. 
Research Questions. Based on the background of the research described earlier, then in this study formulated problems in the research questions as follows:

- Does corporate size have a significant effect on earnings management?

- Does Good Corporate Governance (GCG) significantly affect earnings management?

- Does corporate size have a significant effect on earnings management with audit quality as a moderating variable?

- Does Good Corporate Governance (GCG) significantly affect earnings management with audit quality as a moderating variable?

Research Purpose. From the above explanation, the purpose of this research is to know:

- The effect of Company Size on Profit Management;

- The influence of Good Corporate Governance (GCG) on earnings management;

- The effect of firm size on earnings management with audit quality as a moderating variable;

- The influence of Good Corporate Governance (GCG) on earnings management with audit quality as a moderating variable.

\section{LITERATURE REVIEW AND HYPOTHESIS}

Theoretical Framework:

Agency Theory. Agency Theory in Sari Kartika Rini et al. (2013), is the basic theory in running the company's business practices so far. The main principle of this theory states the existence of a working relationship between the authorizer (prisipal) ie the investor with the party who receives the authority (agent) ie manager, in the form of work contract.

The shareholder is the principal who forms the contract to maximize his or her wellbeing with ever-increasing profitability. The agency problem arises because of the opportunistic nature of the agent that is the management behavior to maximize its own wellbeing by contradicting the pricipal interests. Managers have a strong impetus to choose and apply accounting methods that can show good market reactions that are merely aimed at getting a prestigious bonus (Rahadi and Asyik Fadjrih Nur 2014).

Earning Management. Earnings management is a fraud committed by the management on the financial statements presented deliberately overstate profits or lower profits with the aim of getting a bonus clean. According to Alvin Arens et al. (2011: 372), states "the case of fraud in the financial statements involves an attempt to overstate income whether by overstatement of assets and revenues or by removing liabilities and expenses, companies also deliberately reducing the present profits." Fraudulent financial statements are aimed at exaggerating or degrading net income even though this is not entirely wrong in managing earnings management.

So, earning management is the effect of some motivations. Motivation according to Bismark et al. (2015), to conduct earnings management that is: a) Meet the target within the company. Fully targets will affect the quality of the company; b) Attract the sympathy of investors who have invested or who want to invest their capital into the company; c) Establish or smooth out earnings; d) 'Good Looking' the financial statements to make it easier to get loans from banks or loans from other parties.

Firm Size. Rowland et al (2015), states the size of a company can be measured by total assets. The measurement is often used to identify the size of a company because the greater the assets owned by the company, the higher the capital invested. The larger the size of the company, the more valid the information available to investors in decision-making in relation to investment investment in the company's stock is more and more.

Company size is the grouping of companies into several groups, among large, medium and small enterprises. According Kodriyah (2015). Large companies will be more concerned with the community so they will be more careful in doing financial reporting, so that the impact of the company reported the condition more accurately. The larger the company and the extent of the business, will result in the owner can not manage his own company directly. 
Therefore the emergence of agency problems. Large companies tend to take less profit management measures than small firms. Due to the big companies often get stronger pressure in presenting the financial statements.

Corporate Governance. Corporate Governance is one way of entity policy to restore investor confidence in order to strengthen legislation and policies to reduce potential fraud in the entity (Wagimin 2015: 50). According to Hery (2016: 252) corporate governance is highly relied upon for internal auditors to handle the development and maintain the effectiveness of internal control systems, ensure the implementation of risk management, and ensure the creation of the possibility and failure in the organization.

According to Tunggal Widjaja Amin (2016: 44-48) said the importance of the accountant's role is significantly involved in the implementation activities of the principles of Good Corporate Governance (GCG), namely fairness, accountability, transparency, responsibility.

Quality Audit. Audit quality can be seen from running the profession. Auditors are required to be independent in detecting possible irregularities or fraud behaviors committed by the management in preparing financial statements according to the results of research (Doan and Erwin 2013).

According to Wiryadi Arri and Sebrina Nurzi (2013) quality is defined a word that is used universally and has become a determinant in business success. While the audit is a systematic process by ensuring the information that has been presented in the financial statements of the company's operational activities are truly objective, reliable, and reliable. The conclusions of the process are presented in the form of audit reports communicated to stakeholders. Therefore, the audit quality of an auditor plays an important role to assess the professional's results of a person's auditor in handling or detecting the client's financial statements.

Hypothesis Development:

Company Size to Earning Management. According to Doan and Erwin (2013) that company size affects earnings management. The existence of the description that large companies that have a lot of assets that will be more likely to dare to use capital from loans (debt financing) in buying all assets, whether fixed assets or current assets that can be used to expand the business, compared with small size companies.

However, inversely proportional to the research Lestiyana Fita (2014) that the size of the company has no effect on earnings management by the management.

H1: The size of the firm significantly affects earnings management.

Good Corporate Governance to Earning Management. The concept of good corporate governance, it can be concluded that a good application will generate shareholder rights to obtain information about the company's overall internal conditions and management obligations to disclose all information related to the company so as to reduce the practice of earnings management by the company (Kadek, 2014 ).

According to the research of Rahadi Pricilia Hana (2013) the mechanism of good corporate governance includes the size of the board of directors and the size of the board of commissioners to earnings management that the size of the board of directors affect the earnings management and the size of the board of commissioners does not affect earnings management.

H2: Good corporate governance significantly affects earnings management.

Company Size to Profit Management with Audit Quality As Moderation Variables. According to research (Sari, 2014) KAP big four or non big four can minimize earnings management practices, the management manipulates earnings to increase company size and avoid costs incurred by the company. Manipulation tends to be done by small and large companies in order to have a good performance performance.

According to research (Marjani and Endah, 2013) say firm size has a significant influence in handling earnings management practices.

H3: Audit quality is able to moderate the effect of firm size on earnings management.

Good Corporate Governance to Profit Management With Audit Quality As Moderation Variable. According to Sari et al (2013) study the practice of earnings management has a 
significant impact on Good Corporate Governance (GCG) although with audit quality as a moderating variable. Profit can be seen in the financial statements, the resulting profits must be qualified in order to increase investor confidence. Trust that is the benchmark how good the company in minimizing earnings management practices. Audit quality should be supported by the implementation of GCG value in the hope of supporting the company in reducing earnings management practices. Good earnings quality is proven after the audit by public accounting firm big four and non big four. Thus the investors are more interested and believe to invest their shares into the company. Good quality must go hand in hand with the application of GCG to the company, to ensure equality of information owned by investors and management.

H4: Audit quality is able to moderate the influence of Good Corporate Governance (GCG) on earnings management.

\section{Dependent Variable:}

Earning Management. In this study, the dependent variable used is earnings management proxied by discretionary accrual. Research literature by Hana (2014) states that earnings management has been modified based on research conducted by Dechow et al. (1995) the change of accounts receivable can be included in the model assuming that all credit sales are due to the practice of earnings management, because it is more easily engineered Compared to cash. This modified Jones model can be believed to have a better impact than other models. To measure the discretionary accruals, first calculate the total accrual for each firm $i$ in year $t$ with the Jones modification method that is:

$$
\text { DACCit }=\text { TACCit/Ait }- \text { NDACCit }
$$

To search for Total Accruals (TACC) the following models are used:

$$
\text { TACCit }=\text { Niit }- \text { CFOit }
$$

Where: TACCit $=$ Total accruals; Niit $=$ Net Income; CFOit $=$ Cash Flow Operation . follows:

The total accrual value (TACC) is estimated using the OLS regression equation as

$$
\text { TACCit } / \text { Ait-1 }=\beta 1(1 / \text { Ait-1 })+\beta 2(\Delta \text { Revt/Ait-1 })+\beta 3(P P E t / A i t-1)+e
$$

By using the above regression coefficient, the non discretionary accrual (NDACC) value can be calculated by the formula:

$$
N D A C C i t=\beta 1(1 / \text { Ait-1 })+\beta 2(\Delta R e v t / \text { Ait-1- } \Delta \text { Rect/Ait-1 })+\beta 3(P P E t / A i t-1)
$$

Where: DACCit $=$ discretionary Accruals of firm $\mathrm{i}$ in period $\mathrm{t}$; NDACCit $=$ non Discretionary Accruals firm i in period $t$; TACCit $=$ total accruals of firm $i$ in period $t$; Niit $=$ company's net profit $\mathrm{i}$ in period $\mathrm{t}$; CFOit $=$ cash flows from company's operating activities $\mathrm{i}$ in period $\mathrm{t}$; Ait-1 = total assets of firm i in period $t-1 ; \Delta$ Revt $=$ change of company earnings $i$ in period $t$; PPEt $=$ fixed assets of the company in period $\mathrm{t}$; $\Delta$ Rect $=$ change of receivables of company $\mathrm{i}$ in period $\mathrm{t} ; \beta=$ regression coefficient; $\mathrm{e}=$ errors.

\section{Independent Variables:}

Company Size (UP). Company size according to Kodriyah (2015) can affect the management of the company in the management of profit, because the greater the company the more information available to users of financial statements in decision making. Company size can be measured from the logarithm of total assets owned by the company..

Good Corporate Governance (PK). Sari et al. (2013), suggests that Good Corporate Governance (GCG) or governance is one of the key elements in improving economic 
efficiency, which includes a combination of corporate management, board of commissioners, shareholders and other stakeholders.

Ratio Independent CEO (UD). According to Agustia Dian (2013) the role of board of commissioners is to monitor the policies of directors who are expected to minimize agency issues that arise between the board of directors and shareholders. The number of independent commissioners shall represent at least $30 \%$ and the total number of commissioners in the board of commissioners (BAPEPAM -KL Regulation No. IX.I.5). The proportion of independent board of commissioners is calculated using the percentage of independent commissioners compared to the total number of commissioners.

Board Size (KA). According Hana (2014) states that the size of the board of directors is the number of members of the board of directors in the company. The existence of a board of directors is called to serve as the primary internal control mechanism to monitor the managers of the company, the size of the board of directors is measured using the indicator of the number of members of the board of directors of a company.

Moderation Variable (MA). Audit Quality An auditor plays an important role in assessing the outcome of one's auditor's personality in handling or detecting clients' financial statements (Wiryadi Arri and Sebrina Nurzi 2013).

According to Sudjatna Indiferent and Muid Dul (2015) audit quality can be categorized into 2 things ie companies that are audited by KAP Big 4 and non Big 4 companies. Audit quality is expressed in dummy variables based on external KAP used by the company. Code 1 is provided if the company uses the Big-four services to audit its company, and code 0 if the company uses Non Big 4 external audit services.

Data collection technique:

The population in this study used 101 companies listed on the Indonesia Stock Exchange (IDX) in the period 2014-2015 with the following criteria:

1. A manufacturing company issuing financial statements for the period 2014-2015.

2. Those companies whose shares are actively traded in the Indonesia Stock Exchange (BEI).

3. Complete company data is in Indonesia Stock Exchange (BEI).

4. Companies that publish financial statements and annual reports on the company website or BEI website during the period 2014-2015 and expressed in rupiah (Rp) so that the value is not affected by the fluctuation of the rupiah against the dollar.

Sampling technique used is to use purposive sampling that is a particular consideration technique (Sugiyono 2013: 392). Therefore, the number of samples from the entire population that has been determined criteria, this study using a sample of 101 manufacturing companies at the time period financial statements of 2014 to 2015. Data sources can be obtained from the Indonesian Capital Market Directory (ICMD).

\section{Research Model:}

Descriptive Statistics. Descriptive statistics are statistics that describe the phenomenon or characteristics of the data under study. These statistics provide frequency values, measurement of control tendencies, and measure of shapes (Jogiyanto, 2007: 166).

Moderated Regression Analysis (MRA). Imam Ghozali (2012: 229) Moderated Regression Analysis (MRA) is different from sub-group analysis, because it uses an analytic approach that maintains the integrity of the sample and provides a basis for controlling the influence of moderator variables. To use an MRA with one predictor variable $(X)$, then we have to compare three regression equations to determine the moderator variable type. The two equations are:

$$
\begin{gathered}
Y i=\alpha+\beta 1 X i+e \\
Y i=\alpha+\beta 1 X i+\beta 2 Z i+\beta 3 X i^{*} Z i+e
\end{gathered}
$$

If the equation (Equation Two) The variable $Z$ is the pure moderator variable, then the equations (First Equation) and (Second Equation) are different $(\beta 2=0 ; \beta 3 \neq 0)$. 
The regression equation model developed in this study based on Moderated Regression Analysis (MRA) is as follows:

$$
\begin{gathered}
M A=\alpha+\beta 1(U P)+e \\
M A=\alpha+\beta 1(G C G)+e \\
M A=\alpha+\beta 1(U P)^{*}(K A)+e \\
M A=\alpha+\beta 1(G C G)^{*}(K A)+e
\end{gathered}
$$

Where: MA - discretionary accruals; $\alpha$ - Constants; $\beta$ - The variable coefficients; UP Company Size; GCG - Proportion of board of commissioners and number of directors; e Error term.

Test Validity Model PLS. Konstuk validity is to show how well the results obtained from the use of a measurement fit the theories used to define a construct (Hartono, 2008a). Results Outer loadings (measurement model) or convergent validity are used to test the unidimensionality of each construct. The strong correlation between the construct and the question items and the weak relationship with other variables is one way to test the convergence validity and discriminant validity.

Test of PLS Model Reliability. In addition to the validity test, PLS also performs a reliability test to measure the internal consistency of the measuring instrument. Reliability demonstrated accuracy, consistency, and accuracy of a measuring instrument in measuring (Hartono, 2008a). Reliability test in PLS can use two methods, namely Cronbcach's alpha and Composite realibility.

Cronbach's alpha for measuring the reliability of a construct limit value with a minimum 0.6 and Composite realibility was rated better in estimating the internal konsistensu a construct should be greater than 0.7 according to the study (Salisbury, Chin, Gopal, and Newsted, 2002).

\section{RESULTS OF STUDY}

Descriptive Statistics. Company Size as measured by Total Assets, the average total assets for 202 companies in the Indonesia Stock Exchange 2014-2015 is Rp. $9,081,972,716,300.00$. While the standard deviation for total assets is Rp. 3.703.103.309.737,00. Companies that have the least total assets are PT. Semen Baturaja Persero Tbk. In the year 2014 of Rp. 29.263.600.000,00 while which has the largest total assets is PT. Champion Pasific Indonesia Tbk in 2015 amounting to Rp. 38.353.493.604.000,00.

From 202 companies in BEl during 2014-2015, it is observed that the variable of good corporate governance is firstly the average size of proportion of commissioners measured through independent commissioner divided by total commissioner of $38.36 \%$ with standard deviation of $13.876 \%$. While the second is the size of directors as measured by the number of directors owned by each company, with the average number of directors owned is 4.8713 or rounded to 5 people and whereas the standard deviation of 2.35278 or 2 people.

The sample of companies that have been taken and studied the average audit quality listed in Indonesia Stock Exchange is 33\% of companies audited partner / use the services of Public Accountant Firm (KAP) Big Four and the remaining 67\% of companies do not partner on / Not using the services of Big Four Public Accountant Firm (KAP) with standard deviation of $47.19 \%$.

It can be concluded that the results of this study show that earnings management is measured using discretionary accruals, with an average of 202 companies in Indonesia Stock Exchange 2014-2015 amounted to 73.90, with the lowest value of 0.00 and the highest of 10,876. In the research (Rahadi Pricilia Hana, 2014) that this can be in the indication of earnings management with the pattern of increasing income. 
Moderated Regression Analysis (MRA)

Table 1 - Path Coeffecient Konstata

\begin{tabular}{|c|c|c|c|c|c|c|c|c|c|c|c|}
\hline \multicolumn{4}{|c|}{ Sebelum di moderasi } & \multicolumn{4}{c|}{ KAP Big 4 } & \multicolumn{4}{c|}{ KAP Non Big 4 } \\
\hline- & GCG & MA & UP & - & GCG & MA & UP & - & GCG & MA & UP \\
\hline GCG & - & 0.214 & - & GCG & - & 0.070 & - & GCG & - & 0.112 & - \\
\hline MA & - & - & - & MA & - & - & - & MA & - & - & - \\
\hline UP & - & 0.203 & - & UP & - & 0.241 & - & UP & - & 0.351 & - \\
\hline
\end{tabular}

Source: Output Smart PLS 2.0.

Table 2 - Path Coeffecient Standar Error

\begin{tabular}{|c|c|c|c|}
\hline \multirow{2}{*}{-} & \multicolumn{3}{|c|}{ Standard Error (STERR) } \\
\cline { 2 - 4 } & Sebelum di moderasi & KAP Big 4 & KAP Non Big 4 \\
\hline GCG -> MA & 1.308542 & 0.081779 & 0.116536 \\
\hline UP -> MA & 0.984018 & 0.111521 & 0.143982 \\
\hline
\end{tabular}

Source: Output Smart PLS 2.0.

Based on the results of regression output above, to determine a variable is a moderation variable, the test results that have been described whether audit quality is a variable that can moderate the relationship between company size and good corporate governance to earnings management practices. Comparing the four equations is:

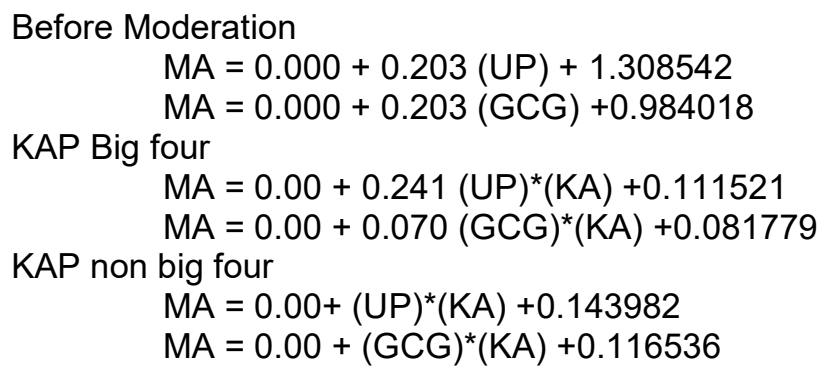

Model Measurement Test (Outer Model):

Validity tests. Figure 1 shows the value of outer loading in each variable above 0.5 in each variable so it can be said valid. While the regression coefficient is owned by the variable size of the company of 0.203 and good corporate governance of 0.214 .

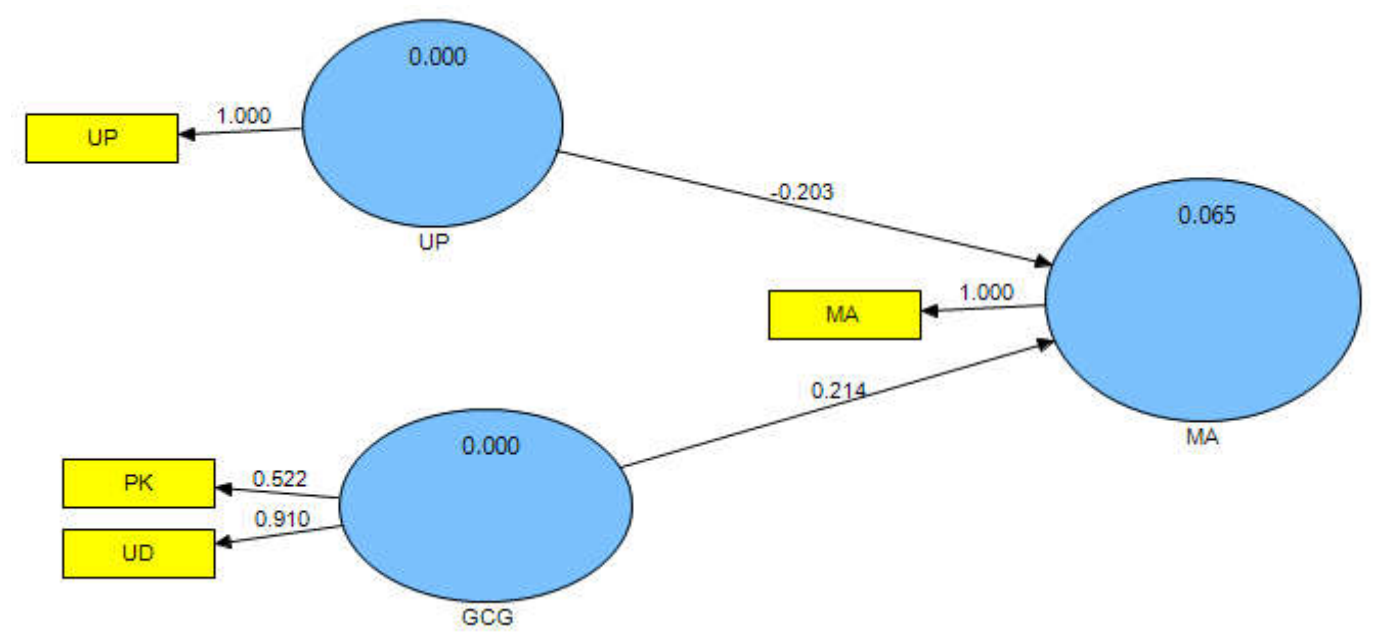

Figure 1 - Company Size and Good Corporate Governance (GCG) on Profit Management Source: Output Smart PLS 2.0 


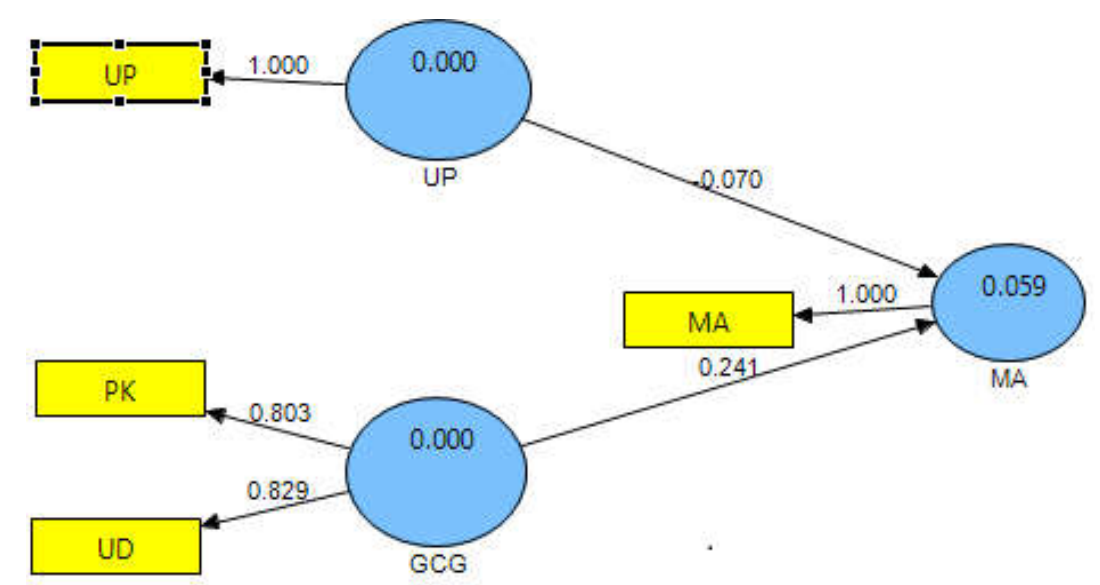

Figure 2 - Company Size and Good Corporate Governance (GCG) on Profit Management with moderate variables Audit Quality of Big-four Source: Output Smart PLS 2.0

Figure 2 shows the value of outer loading in each variable above 0.5 in each variable so it can be said valid. While the regression coefficient is owned by the variable size of the company of 0.070 and good corporate governance of 0.241 .

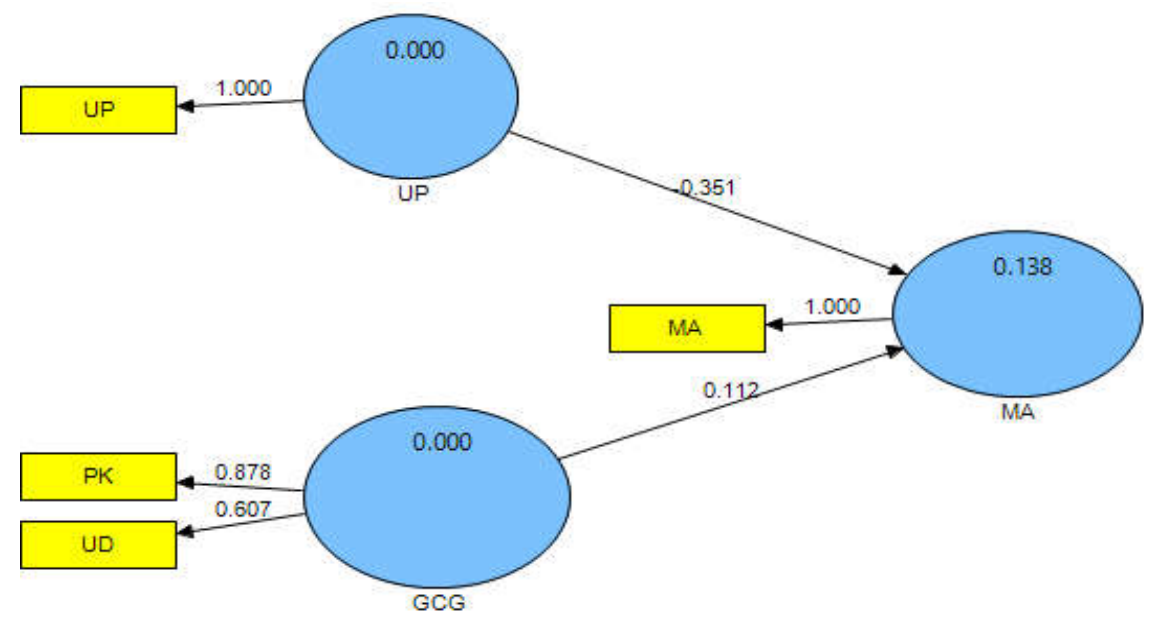

Figure 3 - Company Size and Good Corporate Governance (GCG) on Profit Management with moderate variables Quality Audit KAP-Non BigFour Source: Output Smart PLS 2.0

Figure 3 shows the value of outer loading in each variable above 0.5 in each variable so it can be said valid. While the regression coefficient is owned by the variable size of the company of 0.361 and good corporate governance of 0.112 .

Table 3 - Outer Loading

\begin{tabular}{|c|c|c|c|c|c|c|c|c|c|}
\hline \multicolumn{4}{|c|}{ Sebelum Moderasi } & \multicolumn{3}{c|}{ KAP BIG 4 } & \multicolumn{3}{c|}{ KAP NON BIG 4 } \\
\hline- & GCG & MA & UP & GCG & MA & UP & GCG & MA & UP \\
\hline MA & - & 1 & - & - & 1 & - & - & 1 & - \\
\hline PK & 0.522 & - & - & 0.803 & - & - & 0.878 & - & - \\
\hline UD & 0.910 & - & - & 0.829 & - & - & 0.607 & - & - \\
\hline UP & - & - & 1 & - & - & 1 & - & - & 1 \\
\hline
\end{tabular}

Source: Output Smart PLS 2.0

All indicators in the constructs in the study have the value of outer loading above 0.50 in table 4.3. This explains that all the indicators that exist in all constructs in this study meet the requirements of convergent validity. 
Table 4 - Average Variance Extraced dan Communality Value

\begin{tabular}{|c|c|c|c|c|c|c|}
\hline \multirow{2}{*}{-} & \multicolumn{2}{|c|}{ Before Moderating } & \multicolumn{2}{c|}{ KAP BIG 4 } & \multicolumn{2}{c|}{ KAP NON BIG 4 } \\
\cline { 2 - 7 } & AVE & Communality & AVE & Communality & AVE & Communality \\
\hline GCG & 0.55079 & 0.55079 & 0.50716 & 0.50716 & 0.5693 & 0.5693 \\
\hline MA & 1 & 1 & 1 & 1 & 1 & 1 \\
\hline UP & 1 & 1 & 1 & 1 & 1 & 1 \\
\hline
\end{tabular}

Source: Output Smart PLS 2.0

Meanwhile, the AVE and Communality values generated by all constructs in this study satisfy the convergence validity requirement of $>0.50$ which means to meet the requirements of convergent validity.

Table 5 - Cross Loading

\begin{tabular}{|c|c|c|c|}
\hline \multicolumn{4}{|c|}{ Before Moderating } \\
\hline- & GCG & MA & UP \\
\hline MA & 0.16242 & 1 & -0.1486 \\
\hline PK & 0.52243 & 0.07427 & -0.0077 \\
\hline UD & 0.9103 & 0.15298 & 0.29818 \\
\hline UP & 0.25296 & -0.1486 & 1 \\
\hline \multicolumn{4}{|c|}{ KAP BIG 4 } \\
\hline- & GCG & MA & UP \\
\hline MA & 0.19443 & 0.01357 & -0.0384 \\
\hline PK & 0.5381 & 0.19489 & 0.23151 \\
\hline UD & 0.99762 & -0.0384 & 0.25717 \\
\hline UP & 0.27133 & KAP NON BIG 4 & 1 \\
\hline \multicolumn{5}{|c|}{ MA } & UP \\
\hline MA & GCG & 1 & -0.3546 \\
\hline PK & 0.1226 & 0.11179 & -0.1589 \\
\hline UD & 0.8775 & 0.06747 & 0.19905 \\
\hline UP & 0.60712 & -0.3546 & 1 \\
\hline
\end{tabular}

Source: Output Smart PLS 2.0

In table 4.5 it can be seen that every variable before and after moderation qualify because cross loading above 0.50. Discriminant in this study meets the requirement of discriminant validity that is $>0.50$ which means to fulfill discriminant validity requirement.

Table 6 - Correlation of Latent Variable and Average Variance Extracted

\begin{tabular}{|c|c|c|c|c|c|c|}
\hline \multicolumn{7}{|c|}{ Before Moderating } \\
\hline- & GCG & MA & UP & & AVE & $\sqrt{\text { AVE }}$ \\
\hline GCG & 1 & - & & GCG & 0.55079 & 0.74215 \\
\hline MA & 0.16242 & 1 & & MA & 1 & 1 \\
\hline UP & 0.25296 & -0.1486 & 1 & UP & 1 & 1 \\
\hline \multicolumn{7}{|c|}{ KAP BIG 4} \\
\hline- & GCG & MA & UP & & AVE & VAVE \\
\hline GCG & 1 & & & GCG & 0.50716 & 0.71215 \\
\hline MA & 0.1226 & 1 & & MA & 1 & 1 \\
\hline UP & -0.0312 & -0.3546 & 1 & UP & 1 & 1 \\
\hline \multicolumn{7}{|c|}{ KAP NON BIG 4} \\
\hline - & $\overline{G C G}$ & $\mathrm{MA}$ & UP & & AVE & VAVE \\
\hline GCG & 1 & - & & GCG & 0.5693 & 0.75452 \\
\hline MA & 0.19443 & 1 & & MA & 1 & 1 \\
\hline UP & 0.27133 & -0.0384 & 1 & UP & 1 & 1 \\
\hline
\end{tabular}

Source: Output Smart PLS 2.0

Table 5 can be seen that the square root value of AVE is greater than the correlation value between the latent construct in the same column. This explains that all constructs in this research model meet the requirements of discriminant validity. 
Table 7 - Cronbcach's alpha dan Composite Realibility Value

\begin{tabular}{|c|c|c|c|c|c|c|c|c|}
\hline \multicolumn{3}{|c|}{ Before Moderating } & \multicolumn{4}{c|}{ BIG 4 } & \multicolumn{3}{c|}{ NON BIG 4 } \\
\hline- & $\begin{array}{c}\text { Cronbachs } \\
\text { Alpha }\end{array}$ & $\begin{array}{c}\text { Composite } \\
\text { Reliability }\end{array}$ & - & Cronbachs Alpha & $\begin{array}{c}\text { Composite } \\
\text { Reliability }\end{array}$ & - & $\begin{array}{c}\text { Cronbachs } \\
\text { Alpha }\end{array}$ & $\begin{array}{c}\text { Composite } \\
\text { Reliability }\end{array}$ \\
\hline GCG & 0.61842 & 0.69557 & GCG & 0.6 & 0.7 & GCG & 0.6 & 0.7 \\
\hline MA & 1 & 1 & MA & 1 & 1 & MA & 1 & 1 \\
\hline UP & 1 & 1 & UP & 1 & 1 & UP & 1 & 1 \\
\hline
\end{tabular}

Source: Output Smart PLS 2.0

The value of cronbachs alpha and composite reliability generated in this study is $>0.60$ so it can be said that all constructs can be said reliable. The result of reliability test in this research can be seen in table 7 .

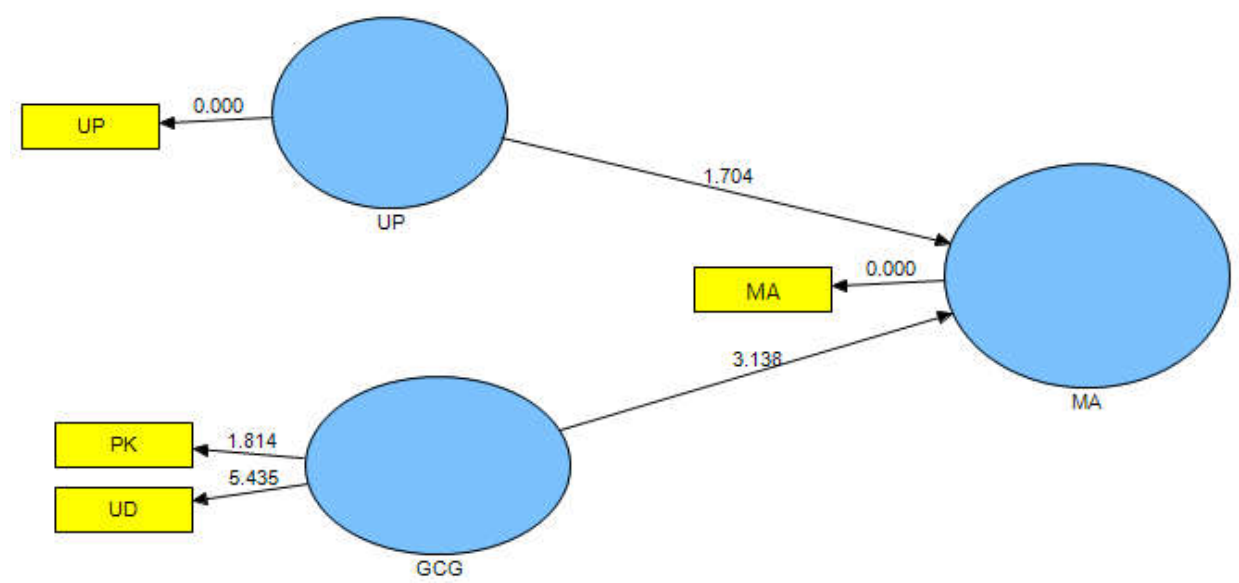

Figure 4 - Company Size and Good Corporate Governance (GCG) on Profit Management Source: Output Smart PLS 2.0

Figure 4 shows that company size has a value of 1.704 while the value of Good Corporate Governance (GCG) is 3.136, which indicates that firm size does not affect earnings management period 2014-2015.

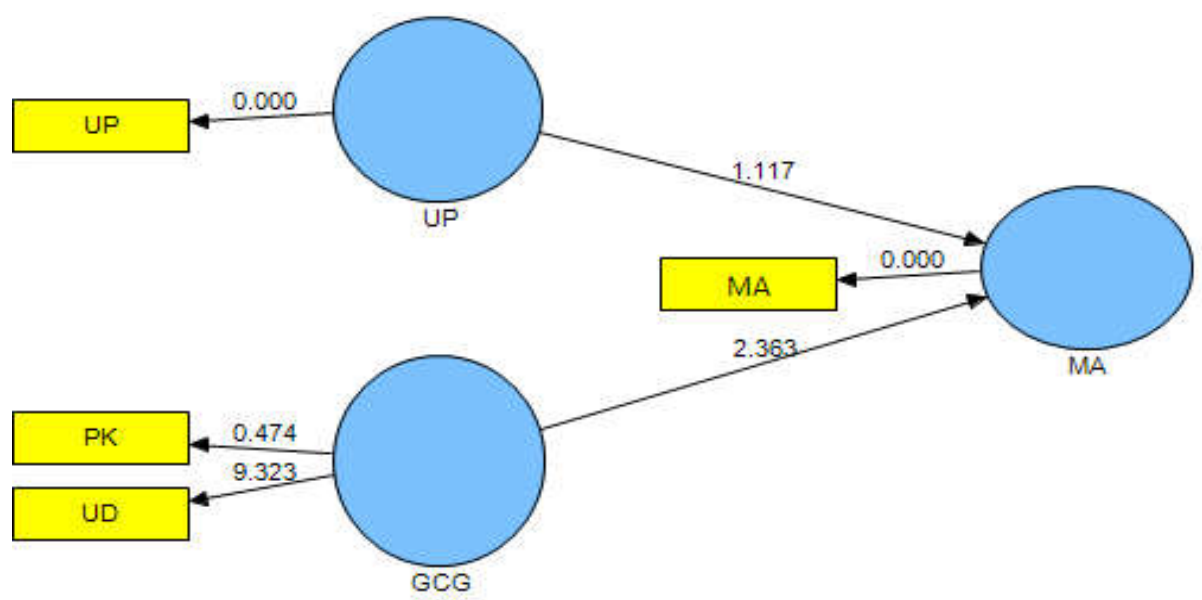

Figure 5 - Company Size and Good Corporate Governance (GCG) on Profit Management with moderate variables Audit Quality of BigFour Source: Output Smart PLS 2.0

Judging from the figure 4.6 that audit quality is audited by public accountant big four on company size variable with value 1,117 whereas value of variable of Good Corporate Governance (GCG) is 2,363 , indicating that firm size does not affect earnings management in period 2014-2015. 


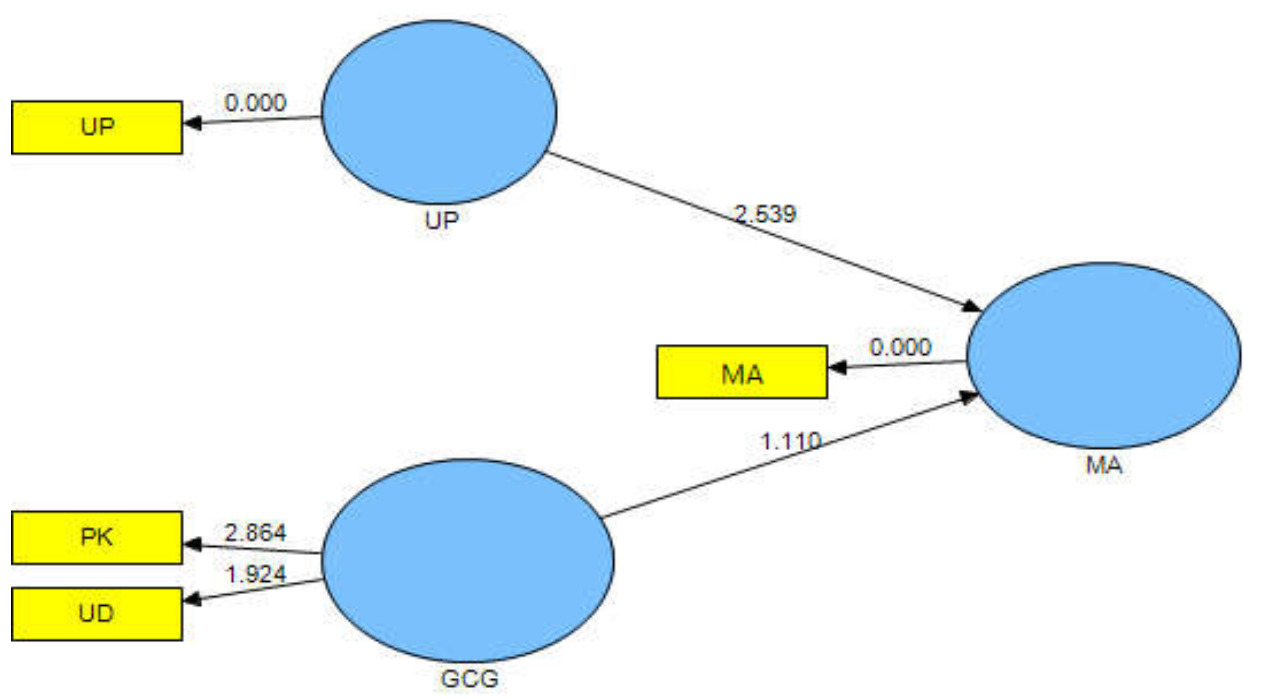

Figure 6 - Company Size and Good Corporate Governance (GCG) on Profit Management with moderation variables Audit Quality NON BigFour Source: Output Smart PLS 2.0

It can be seen from the figure 4.6 that after the firm size and good corporate governance variables in moderation with the quality of non-big four audit the size of the company has a value of 2,539 while the value of Good Corporate Governance (GCG) variable is 1,110 , which indicates that firm size affects earnings management in the period $2014-2015$.

Multigroup Hypothesis. The calculation of multigroup hypothesis is calculated to find out the final result $t$ statistic after firm size and good corporate governance to earnings management in moderation with audit quality ie big four or non big four. In order to conclude in detail whether firm size and good corporate governance to earnings management with audit quality as a moderation variable, then its calculation as follows:

Company Size:

$$
\begin{aligned}
& \text { UP } \\
& B 1=-0.110626 \\
& \mathrm{~B} 2=-0.326 \\
& \mathrm{~m}=63 \\
& \mathrm{t} \text {-value }(\mathrm{BIG} 4)=1.241516 \\
& \text { SE 1 }=0.079295 \\
& \text { SE 2 }=0.1382 \\
& n=199 \\
& \mathrm{t}-\text { Value }(\text { non BIG 4)= } 2.539416 \\
& t=\frac{\text { Path }_{\text {sample }_{1}}-\text { Path }_{\text {sample }_{2}}}{\left[\sqrt{\frac{(m-1)^{2}}{(m+n-2)} * S \cdot E 1^{2}+\frac{(n-1)^{2}}{(m+n-2)} * S \cdot E 2^{2}}\right] *\left[\sqrt{\frac{1}{m}+\frac{1}{n}}\right]} \\
& t=\frac{-0.110626-(-0.326)}{\left[\sqrt{\frac{(63-1)^{2}}{(63+199-2)} * 0.079295^{2}+\frac{(199-1)^{2}}{(63+199-2)} * 0.1382^{2}}\right] *\left[\sqrt{\frac{1}{63}+\frac{1}{199}}\right]}
\end{aligned}
$$

Good Corporate Governance:

GCG

$B 1=2.1891$

$\mathrm{B} 2=0.0972$

$\mathrm{m}=63$

$$
\begin{gathered}
\text { SE } 1=0.090121 \\
\text { SE } 2=0.100604 \\
n=199
\end{gathered}
$$




$$
\begin{gathered}
t=\frac{\text { Path }_{\text {sample }_{1}}-\text { Path }_{\text {sample }_{2}}}{\left[\sqrt{\frac{(m-1)^{2}}{(m+n-2)} * S . E 1^{2}+\frac{(n-1)^{2}}{(m+n-2)} * S . E 2^{2}}\right] *\left[\sqrt{\frac{1}{m}+\frac{1}{n}}\right]} \\
t=\frac{2.1891-0.0972}{\left[\sqrt{\frac{(63-1)^{2}}{(63+199-2)} * 0.090121^{2}+\frac{(199-1)^{2}}{(63+199-2)} * 0.100604^{2}}\right] *\left[\sqrt{\frac{1}{63}+\frac{1}{199}}\right]}
\end{gathered}
$$

\begin{tabular}{|c|c|c|}
\hline The Hypothesis in Proposed & Hypothesis Results & Conclusion \\
\hline $\begin{array}{l}\text { H1: Company size has a positive effect on earnings } \\
\text { management practices }\end{array}$ & 1.704 & $\begin{array}{c}\text { Not significantly positive } \\
\text { because below t-table } 1.96 \text {. }\end{array}$ \\
\hline $\begin{array}{l}\text { H2: Good Corporate Governance (GCG) negatively } \\
\text { affects earnings management practices. }\end{array}$ & 3.138 & $\begin{array}{c}\text { Significantly positive due to the } \\
\text { above t-table } 1.96 \text {. }\end{array}$ \\
\hline $\begin{array}{l}\text { H3: Audit quality is able to moderate the effect of firm } \\
\text { size on earnings management }\end{array}$ & 0.862 & $\begin{array}{c}\text { Not significantly positive due to } \\
\text { below t-table } 1.96 \text {. }\end{array}$ \\
\hline $\begin{array}{l}\text { H4: Audit quality is able to moderate the influence of } \\
\text { Good Corporate Governance (GCG) on earnings } \\
\text { management }\end{array}$ & 0.656 & $\begin{array}{l}\text { Not significantly positive } \\
\text { because below t-table } 1.96 \text {. }\end{array}$ \\
\hline
\end{tabular}

Table 8 - T-test Result

Source: Output Smart PLS 2.0

Model Evaluation. The structural model is assessed by looking at the R-Squares value for each endogenous latent variable as the predictor force of the structural model. The results of R-Squares using Smart PLS can be seen in the table below:

Table 9 - R Square

\begin{tabular}{|c|c|c|c|}
\hline \multirow{2}{*}{-} & Before Moderating & KAP BIG 4 & KAP NON BIG 4 \\
\cline { 2 - 4 } & R Square & R Square & R Square \\
\hline GCG & & & 0.13816 \\
\hline MA & 0.06481 & 0.04678 & \\
\hline UP & & & \\
\hline
\end{tabular}

Source: Output Smart PLS 2.0

Based on the test results in table 4.4 then obtained $\mathrm{R}$ amounted to 0.064813 before moderation and after moderated 0.04678 at big four and 0.13816 KAP with non four big audit quality. $R$ shows the correlation between two variables to earnings management. $R$ value ranges from 0 to 1 . If the value is close to 1 , then the relationship gets closer. Conversely, if close to 0 , then the relationship is weak. This shows under the weak relationship. This shows that there is a weak relationship between company size and good corporate governance to earnings management with audit quality as a moderating variable.

\section{DISCUSSION OF RESULTS}

The size of the Company Affects Profit Management. The results of this study indicate that firm size does not positively affect earnings management with the value of $t$-count 1,704 below 1.96, thus $\mathrm{H} 1$ is not accepted.

The reasons that support the results of this study is that each company can make earnings management, because by applying earnings management companies can maximize profits so it can be concluded that to apply earnings management does not have to be based on the size perusahaan. Hasil research is in line with research AT Marjani (2013) Stated that firm size has no positive effect on earnings management.

Good Corporate Governance (GCG) Affects against Profit Management. The results of this study indicate that Good Corporate Governance (GCG) has a significant positive effect on earnings management with t count is 3.138 above 1.96, thus $\mathrm{H} 2$ accepted. 
This research is supported by previous research that this is because many number of board of commissioner tend to do earnings management (Kodriyah, 2015). From this result, it can be concluded that the more internal board of commissioners know the level of profitability of a company for the benefit of a group (commissioner) coupled with the lack of efficient supervisory power because of the many interventions even in the eyes of the public as the level of supervision of the commissioner is very effective but the efficiency and effectiveness must Go hand in hand for better corporate.

The Effect of Audit Quality in Moderating The Influence Of Company Size To Profit Management. These results indicate that the audit quality used in the big four or non big four can not demodulate the effect of the size of manufacturing firms in Indonesia to the practice of earnings management with $\mathrm{t}$ counts of 0.862 below 1.96 , thus $\mathrm{H} 3$ is not accepted.

As for the reasons that support the outcome is the litigation risk against big four KAP in Indonesia is quite low. A legal environment that is still not good with the lack of lawsuits that could damage the reputation of big four KAP caused the low litigation risk. Large KAPs become the impetus for earnings management in client companies.

Supported by Yasar Alplasan (2013) research that there is no difference in quality of KAP big four audit or KAP non big four in preventing earnings management practice.

The Effect of Audit Quality in Moderating the Influence of Good Corporate Governance (GCG) to Profit Management. These results indicate that the audit quality used by the big four or non big four can not moderate the influence of good corporate governance of manufacturing in Indonesia to the practice of earnings management with $t$ count is 0.656 below 1.96, thus $\mathrm{H} 4$ is not acceptable.

As for the reasons that support the results are manufacturing companies in this study did not pay attention to the big four or non big four KAP will audit their companies in detecting earnings management, but the main thing for the company is how the KAP can produce quality audit reports. Supported by research Lestiyani Fita (2014) that the quality of audits generated not only measured by big four or non big four KAP but from audit reports and auditor independence.

\section{CONCLUSION}

Based on the results of the test analysis then obtained the following conclusions: the size of the firm has no significant positive effect on earnings management; Good Corporate Governance (GCG) has a significant positive effect on earnings management; Quality Audit can not moderate the effect of firm size on earnings management; Quality of audit can not moderate Good Corporate Governance (GCG) to earnings management.

In this research finding can give implication that is:

Contributing company size and good corporate governance to earnings management with audit quality as a moderating variable and providing additional knowledge and information related to firm size and good corporate governance to earnings management with audit quality as moderation variable;

Provide insight and insight and add reference to auditing. Especially about company size and good corporate governance to earnings management with audit quality as moderation variable;

Become an understanding of the quality of information as a reference by the parties investors, shareholders, creditors in decision-making.

The researcher gives recommendation for limitation from this research is the following:

Expand the object of research so that the results obtained can reflect the manufacturing company in general and provide more useful conclusions;

Adding other variables that are expected to affect earnings management, such as ROA, share value and audit committee. Thus it can be found more variances of variables affecting earnings management;

Extend the observation period so that more amount of data is used. It is expected that the results will be more accurate. 


\section{REFERENCES}

1. Abdillah Willy, Jogiyanto. 2015. Partial Least Square.Yogyakarta. Andi.

2. Agustia Dian. 2013. Pengaruh Faktor Good Corporate Governance, Free Cash Flow dan Leverage terhadap Manajemen Laba. Surabaya. Jurnal Akuntansi dan Keuangan Vol 15 No 1.

3. Asyraf Afthanorhan, Nazim, A., \& Ahmad, S. 2014. A Parametric Approach to Partial Least Square Structural Equation Modelling of Multigroup Analysis (PLS-MGA). International of Economics, Commerce and Management United Kingdom, II (10), 1-15.

4. AT, M., \& Puspitosarie, E. 2013. Jurnal Manajemen dan Akuntansi Volume 2.

5. Anggana, G. R., \& Prastiwi, A. 2013. Analisis Pengaruh Corporate Governance of (Studi pada Perusahaan Manufaktur di Indonesia). Diponegoro Jurnal of Accounting, 2, 1-12.

6. Anugerah Rita 2014. Peranan Good Corporate Governance Dan Fraud.

7. Alvin. A. Arens, Randal J. Elder, Mark S. Beasley, Amir Abadi Jusuf, (2011), Audit dan Jasa Assurance: Pendekatan Terpadu (Adaptasi Indonesia), Jakarta: Penerbit Salemba Empat.

8. Barus, A. C., \& Setiawati, K. 2015. Pengaruh Asimetri Informasi, Mekanisme Corporate Governance, dan Beban Pajak Tangguhan Terhadap Manajemen Laba, 5, 10.

9. Bismark, R., Pasaribu, F., Kowanda, D., Firdaus, M., \& Ummah, R. N. 2015. Mekanisme Good Corporate Governance, Ukuran Perusahaan, Struktur Kepemilikan Manajerial Dan Perbankan Di Bursa Efek Indonesia, 1-22.

10. Effendi, S. 2013. Pengaruh Corporate Governance Dan Kualitas Audit Terhadap Manajemen Laba, 2, 1-14.

11. Febriyanti Dewi, Made, N., \& Metha, Made, I. 2014. Pengaruh Masa Perikatan Audit, Rotasi KAP, Ukuran Perusahaan Klien, dan Ukuran KAP Pada Kualitas Audit. E- Jurnal Akuntansi Universitas Udayana, 2, 503-518.

12. Ghozali. (2010). Aplikasi Analisis Multivariate dengan Program SPSS. Cetakan V. Semarang: Badan Penerbit Universitas Diponegoro.

13. Hery. (2016). Auditing dan Asuransi. Jakarta. Grasindo

14. Kristiani, Emi, K., Sulindawati, Erni, Gede, Luh, N., \& Herawati, Trisna, N. 2014. Pengaruh Mekanisme Corporate Governance dan Ukuran Perusahaan, 1(1).

15. Mustika, G., Sari, Nelly, R., \& L, Azhar, A. (2014). Pengaruh Pengungkapan Corporate Social Responsibility Terhadap Manajemen Laba, 3(9), 1-16.

16. Kodriyah. 2015. Pengaruh Kepemilikan Institusional, Ukuran Perusahaan,Leverage dan Good Corporate Governance Terhadap Manajemen Laba((Studi Empiris Perusahaan Manufaktur yang terdaftar di BEI 2009-2012). Jurnal Akuntansi Vol 2 No 1 Juli 2015. Jurnal Akuntansi Vol 2 No 1 Juli 2015.

17. Sunandar, Farida Ida, Alfin Muhammad. 2014. Pengaruh Kualitas Audit dan Ukuran Komite Audit terhadap Manajemen Laba. Surabaya. Jurnal Bisnis dan Manajemen Vol 2, No.2.

18. Tunggal Widjaja Amin. 2016. Teknik-Teknik Pencegahan Kecurangan Karyawan dan Manajer Haraido

19. Wind, Ajeng. 2014. Forensic Accounting. Jakarta Timur: Dunia Cerdas.

20. Wiryadi, A., \& Sebrina, N. 2013. Pengaruh Asimetri Informasi, Kualitas Audit, dan Struktur Kepemilikan terhadap Manajemen laba, 1(2), 155-180.

21. Www.idx.co.id, di akses maret 2016

22. Yasar, A. (2013). Big Four Auditors' Audit Quality and Earnings Management: Evidence from Turkish Stock Market Department of Accounting and Finance, 4(17), 153-163. 
DOI https://doi.org/10.18551/rjoas.2017-09.27

\title{
OPENING UP FAMILY SUCCESSION AND BUSINESS CONTINUITY IN INDONESIA: THE CASE OF LOMBOK POST-INDONESIA
}

\author{
Iqbal Mohammad*, Putra Irfan Kharisma, Arifin Zainul \\ Graduate School of Business Administration, Faculty of Administrative Science, \\ University of Brawijaya, Indonesia \\ *Email: iqbal07@ub.ac.id
}

\begin{abstract}
This study employs a business exit concept of a family-owned business and provides a deeper understanding on the success of the business. Furthermore, this study aims to determine the process of family succession prior to the continuity of the business owned by family members. This study is a qualitative study, employing case study design which sources were obtained from the CEO of Lombok Post-Indonesia. The data of this study were obtained through interviews and observation. The results showed that managing FOBs is a complicated and demanding task to do, especially within the event of choosing particular candidate for future succession since not every family member is intrested to engage in family-owned entreprises. Furthermore, FOBs does not always have any objectives to pass on the leadership to the family member unless they are ready and well- prepared with sufficient knowledge to take over the business.
\end{abstract}

\section{KEY WORDS}

Family-owned business, succession, business continuity.

The development global business keeps shifting dramatically. Intense competition and dynamic business environment require companies to be aggressive and competitive. One category of enterprises included in the development of the global business is family-owned businesses (FOB). Substantial challenge in the business environment necessiattes FOBs to become more competitive and agile in planning and implementing their strategies. Almost every global and leading companies at the present time was established from small scale enterprises founded by families. Donnelley (2002) in his article suggests that an organization can be said to be a family-owned business (FOB) and an organization when there are more than two family members who work together and share the same goal.

Several world-class companies which are family-controlled, were able to sustain their strategies and established themselves as 'distinctive' family businesses as written in Fortune Global 500 with 19 percent share. Based on the McKinsey-Bloomberg Company Report, the 'top ten' family-owned business was not merely dominated by the Western economy, but also Asian. In general, every country is characterised by the involvement of family-owned businesses in their economic development. Whilst it is true that these companies are publicly listed, the definition of family business is not yet clear.

As defined in many literature in the domain of entrepreneurship and family business, FOB is defined as an organisation that is managed and owned by family members (HilburtDavis \& Dyer 2003). Whether or not an owner releases the whole or partial portion of the business ownership is not yet determined in the literature of FOB. This is due to the modest and narrow definition of FOB suggested by scholars which made it difficult to state a concise and agreed definition of FOB (Astrachan \& Shanker 2003). Nonetheless, the study of McKinsey-Bloomberg Company report in 2014 has provided the list of large family-founded companies and has made an assumption that a business is still perceived as an FOB if it is indicated by major ownership that founders' hold despite its publicly-listed status. Thus, we would argue that any definition of FOB is applicable to any contextual basis which is relevant to a certain research objectives. 
Ever since its first discussion appeared on prominent academic journals two decades ago, ${ }^{1}$ research on FOB topics have started to grow significantly until present. The discussion on FOBs continues to gain awareness among scholars as well as professional consulting groups due to its uniqueness. Indeed, an FOB is different compared to non family-owned business. The different nature between both types of businesses has been a concern in numerous studies as stated by (Kelly, Athanassiou \& Crittenden 2000). In their article, Kelly et al (2000) explain that family-owned and non-family owned businesses are different due to their different patterns of influence, organizational climate and processes. Furthermore, an FOB is generally more stable yet it has more conservative attitude (Kelly et al 2000; Donkels \& Frohlick 1991). Despite the tendency to dichotomize between family-owned and non-family owned businesses, to some extent an FOB could be more flexible in making speedy decisions, due to the nature that family members controls both: the ownership and management. Thus, FOB appears as a unique phenomena for its characteristics of having both advantages and disadvantages. Moreover, regarding to Kelly et al's (2000) explanation, FOBs are engine ignition of a nation's economy as proven by various evidences related to successful businesses in the world.

Table 1 - List of Large Family-Owned Businesses

\begin{tabular}{|c|c|c|c|}
\hline Company & Country (founded) & Industry & Revenue, 2013, (US\$ bn) \\
\hline Walmart & United States (1962) & Retail & 476.3 \\
\hline Vokswagen & Germany (1937) & Automotive & 261.7 \\
\hline Glencore & Anglo-Swiss (1974) & Commodities & 232.7 \\
\hline Samsung & South Korea (1969) & Electronics & 209 \\
\hline EXOR & Italy (1927) & Finance/Indutrial & 151.1 \\
\hline Ford & United States (1903) & Automotive & 146.9 \\
\hline Lukoil & Russia (1991) & Oil & 141.4 \\
\hline MsKesson & United States (1833) & Pharmaceuticals & 137.6 \\
\hline FoxConn & Taiwan (1974) & Electronics & 109.9 \\
\hline
\end{tabular}

Source: McKinsey—Bloomberg Company Report 2014 (cited in http://economist.com).

In developing economies such as Indonesia, prominent and dominant businesses are being controlled and owned by family groups, similar to any other countries in the Eastern and Southeast Asia (Carney \& Gedajlovic 2003). Moreover, Indonesia has the highest percentage of family business groups among any other country in the Southeastern region (Carney \& Gedajlovic 2003). According to a survey on family businesses conducted by IBFC, FOBs account for more than $60 \%$ of all the listed companies In the Southeast Asian region, where they frequently outperform non-family controlled companies (IBFC 2014). In Indonesia, the existence of FOBs that later held the status as 'conglomerate groups' such as Salim group, Astra Group, Sinar Mas, Lippo Group, Gudang Garam, Djarum as well as several other dominant FOBs in the country were politically supported by the Indonesian government to build the industrial fundamental during the post-war era (Sato 1993; Carney 2005). In fact, Mursitama (2006) highlighted that sales of the top 100 private business groups represent approximately $20 \%$ of Indonesia's gross product for the top 200 private business groups in 1993 that had not only cover a quarter of the Indonesian national economy, but also the size of the business groups that exceeded the size of Indonesian state-owned enterprises (Sato 2003). Thus, FOBs are dominant in the economic development since the post-world war era, whereby business groups established and grown by families are undoubtedly important entities. It is noteworthy that the discussion of FOBs does not merely focus on the survival, growth and the performance of such business, but also to some extent ways in which businesses started to prepare an event of leadership succession.

Business succession is not only regarded as a mechanism to switch ownership, but it can also be regarded as an entrepreneurial recycling process (Mason \& Harrison 2006; DeTienne 2010) whereby founders' of a business to somepoint in their lives must depart from

\footnotetext{
${ }^{1}$ Dyer and Handler's (1994) exploration the connection between families and entrepreneurial dynamics; Brockhaus's historical view of entrepreneurship and the future for family business' research (Entrepeneurship: Theory \& Practice, 1994).
} 
the firm they have created and pass the torch of leadership to their inheritors as an avenue to refresh as well as enhance the sustainability of the FOB. In the context of FOBs, Nordqvist et al (2013) suggest that succession should be seen as a complex process which is influenced by personal goals of owners, family structure, ability and ambitions of potential successors and legal and financial issues. Furthermore, survival is underlined as a critical component in the post-stage of successions. Whereas, it is indicated that only $30 \%$ of FOBs have survived the transition between generations in the second generation, while only $12 \%$ were able to survive the third generation and only $3 \%$ were able to develop to the fourth generation (Hall et al 2001). Hence, it neccessitates an attention to the process of succession in FOBs as well as critical aspects that drives the continuity of the business once successors' undertake the management control and the ownership (Collins et al 2016). It has been mentioned in previous studies that succession is a cumbersome issue to cope with. In fact, many FOBs could not survive once the second generation have taken the torch of leadership. As an evidence in the Indonesian context, an FOB inherited by Rahman Tamin failed to keep developing due to conflict of interests that occurred among family members (Panglaykim, 1984). It triggers a question: why do FOBs often face difficulties that results in the discontinuance of the FOB? Is it merely due to the management issues, conflicts between family members or are there any dilematic issues that the founder failed to solve during the succession process?

Based on those questions, researchers aim to highlight some relevant aspects (1) the importance of managerial roles that involves the family; (2) Family dynamics prior to select an incumbent's successor; and, (3) the design of the firm founder-successor relationship within the management of FOBs. The researchers specofied the focus of thi study to Lombok-Post, a media company under the management of Jawa Pos News Network (JPNN)-Indonesia. Presently, JPNN is the largest newspaper network in Indonesia with 171 print media companies, established mostly via mergers and acquisitions with local newspapers across the country (Nugroho, Putri \& Laksmi 2012). In Indonesia, media companies started to expand dramatically in the aftermath of the Indonesia's political reform in 1998. The acceleration of this industry has reached to the point where conglomerates controls most of media channels in Indonesia (Nugroho et al 2013). Moreover, highlighting the facts of Indonesian newspaper industry, contradictory finding have indicated that despite the profit that increases overtime for newspaper key players (such as: Kompas and Jawa Pos) the industry is starting to get left behind, not literally dead, but it is on a life support (Nugroho et al 2013). The Indonesian media industries are mostly privatey-owned (family groups), hence, their sustainability are at the crossroads, especially for conventionally operated printed media. Thus, companies of any business field, hold the urgency to ensure the continuity of their businesses. For FOBs, ensuring the continuity of the business also means extending the family values generating traditions (Salvato, Chirico, Sharma 2010). On the other hand, losing the business will contribute to the loss of socioemotional wealth, family identity, ability to strengthen the family's influence as well as the continuation of the family dynasty (Gómez-Mejía et al 2007; DeTienne, McKelvie \& Chandler 2015). Hence, exploring family succession in the media industry in Indonesia is necessary, not only due to the uniqueness of the FOBs characteristics, but also the domination of media industry within nations' economy and costs associated that cause businesses fail to sustain.

\section{LITERATURE REVIEW}

Closer Look on Family Owned Business (FOB). Since the discussion of the FOB phenomenon is quite extensive as it intersects with multiple disciplines, different contexts, as well as different unit levels of analysis being employed, we need to emphasize more on the process and the arts of managing dynamics and paradox rather than solely focusing on the success or failures, although success and failures often can be associated with how FOBs progress with their entrepreneurial continuum. In an attempt to consolidate the literature of FOBs, Sharma (2004) reviewed 217 scholarly written articles following her (Sharma 2004) review of the previous work by Sharma, Chrisman and Chua $(1997,1998)$. Further, Sharma 
(2004) noted that regardless of the attempted objective to provide an overview of the FOB literature and the scope of the study, previous argument made by Sharma et al $(1997,1998)$ lacked of detail prescriptions of individual studies and comprehensive listing of the scholarly work published. Hence, Sharma (2004) has provided a much clearer assessment on the FOB literature by providing fruitful insights on: (a) the domain of the field; (b) the level of the analysis of the study; and, (c) the strategies employed to obtain knowledge and dissemination. An FOB prepares itself on the basis of family and business even though both are distinct institutions which have different purposes and values even if they are regarded a unity in the family company (DeTienne \& Chirico 2013). The main functions of family are related to the family care and education of members, while the function of a business is related to the production and distribution of goods and services (DeTienne 2010).

Defining the FOB from a strategic management viewpoint, Sharma et al (1997) define FOB as "a business governed and/or managed on a sustainable, potentially crossgenerational, basis to shape and perhaps pursue the formal or implicit vision of the business held by members of the same family or a small number of families" (p.2). Furthermore, these authors (Sharma et al 1997) contend that in the context of strategic management, FOBs are assumed to have threshold of goals to pursue, a strategy to accomplish certain goals, and mechanisms to implement the strategy and control the firm's progress toward the achievement of its goals. The work done by Sharma (2004) over than a decade ago had strengthened up our understanding on FOBs holistically, rather than solely focusing on the distinction between a family and a non-family ones. Indeed, the involvement of the founder's family in the ownership, governance and management has formed characteristics of family businesses different from the non-family ones (Klein, Astrachan, \& Smyrnios, 2005; Astrachan 2010). Nonetheless, FOBs are stereotypically known for conservative planning and organic expansion that might narrow their growth compared to non-FOBs (Astrachan 2010).

In a previous study, Choi, Zahra, Yoshikawa and Han (2015) noted that research on FOB have indicated that family owners who control a firm's management are prominent in the developed countries and developing countries where the corporate control by markets is weak. Moreover, FOBs tend to assign family members as CEOs or holding other top tier managerial positions as the consequence of non-financial motives such as a need for belonging, preserving family wealth, nurturing the social status and maintaining family traditions (Gómez-Mejía et al., 2007; Zellweger \& Astrachan, 2008; Salvato et al 2010; Choi et al 2015). FOB's are often exposed to failure, mainly caused by the inability to establish professional leadership. A previous study done by Stewart and Hitt (2012) has highlighted some important caveats on why FOBs often fail to professionalize (Yildirim-Öktem \& Üsdiken 2010) as well as the possibility of principal conflicts occurred in private FOBs.

The Continuity of FOB's. Continuity of FOBs is a conflicting issue that may trigger anxious feelings among the founders' of the firm. This is due to strong emotional attached to the firm, anxiety of loosing accumulated and socioemotional wealth (DeTienne et al 2015). It needs a lot of commitment for family members to ensure the continuity of the FOB. According to Salvato et al (2010), commitment is a psychological state that forces an individual to conduct a particular action of relevance. FOBs are by far committed-intensive entities as family members are emotionally attached to the business (Salvato et al 2010). Commitment to grow and sustain FOBs is often being associated with the family member's responsibility in maintaining not only the performance but also the ownership structure of the firm. Nonetheless, planning and nurturing the FOB's continuity do not occur without challenges. In an article, Ward (1997) has identified that there are at least six crucial challenges that threat the continuity of FOBs: (1) Maturing business life cycles and increasing competition; (2) Limited capital to fund both family needs and business growth needs; (3) Weak next-generation business leadership; (4) Inflexibility and resistance of the Entrepreneurial leaders to change; (5) Conflicts among sibling successors; and, (6) Disparate family goals, values, and needs (p.325). Thus, success and continuity of FOBs are followed by various problems. To overcome these confronting issues, FOBs must design some strategies in mind and strategic actions to sustain. The notion that FOBs must 
formulate, implement and control strategies to achieve particular goals had sometimes turned out to neglect the strategic importance itself, since family interests and values are incorporated into the goals and objectives arranged for the firm (Sharma et al 1997).

Business Succession: A Founder's Choice. While it is true that FOBs engage themselves in family ties, emotional and psychological wellbeing of the family to the firm, in a certain moment, a founder will sooner or later leave the business (DeTienne 2010). Business succession is very crucial in maintaining the continuity of the family enterprise and thus, taking a leave is a strategic mechanism to ensure the continuity of the firm. Furthermore, founder's centrality is believed to have an impact on firm's strategy and decision making (Sharma et al 1997) which includes founder's role in selecting future successor as well as identifiying the potency for the entrepreneur to be engaged after leaving as a trusted family member, advisor, board member, or finance caretaker (Neubauer, 2003). Hence, Sharma et al (1997) contend that an organization can be characterized as authoritarian, centralized, lacking in trust, delegation and planning, impulsive; and, highly dependent on power due to the firm's centrality or closeness to the founder. Nonetheless, dependencies of FOBs on their founders especially when emotions are attached could be a possible threat to the continuity of the firm unless the firm attempts to overcome it by performing a strategic approach as part of their value. The strategic approach that an FOB possesses depends on its ability to preceed succession planning as part of it.

Succession Planning is the most vulnerabe part that causes failures in family firms due to some problems that are often faced by family firms, should they fail to execute. Sudden retirement of a founder/CEO's firm (e.g. illness, death) will disrupt the firm massively (Sharma et al 2003), especially when there is no safeguard mechanism such as succession planning being prepared prior to the founder's leave. Thus, preparing succession plan in mind is an avenue to mitigate unprecedented disruption. Regardless of that, planning for a respected founder's leave is never an easy process, particularly if he/she is somewhat resistant, resulting in an avoided and postponed succession process (Liu, Eubanks \& Chater 2015). Moreover, as mentioned by Liu et al (2015), founder's choice to involve family member will be more likely result in a smoother transition to a new CEO. This is due to the fact that involving family member to takeover the firm would in some ways seem "easier" because of the familiarity with the business and being regarded as a "trusted entity" to the CEO and key stakeholders (Liu et al 2015).

\section{METHODS OF RESEARCH}

This research employed a qualitative research method (Miles, Hubermen \& Saldana 2013) since the researchers attempted at describing the phenomena of the succession of family-owned business related to the sustainability of the business. In examining the business exit happended to Jawa Pos News Network and Lombok post, the researchers focused on gaining perspectives by administering in-depth interviews with the CEO/Owner of Lombok Post and the successors. In their article on family business, De Massis and Kotlar (2014) noted, "family business is a heterogeneous field that encompasses multiple theoretical approaches and levels of analysis, and we believe that diversity can and should be reflected in the way in which case studies are used" (p.15). Case study is particularly helpful in understanding the process deployed in family firms, an area which is often being neglected (De Massis \& Kotlar 2014). Hence, following the guideline proposed by De Massis and Kotar (2014), we investigated the necessity to conduct this research under the case study design, particularly in exploring features and dimensions that determine family firms' behaviours and processes within the context of family succession.

\section{RESULTS AND DISCUSSION}

Founder's-Successor's Perspective on Family Succession. The founder and successors' perspectives on their experience in conducting the transition are found to be relevant and fruitful to the understanding of the family succession at Lombok Post. Founder's 
response as presented in Table 4.1 gives an interesting view that initially the founder had no intention to inherit the business the his son. Nonetheless, realizing the necessity to bring succession comes in mind when the founder was anxious about the future of the firm due to his limited capacity in running the business in the future. Possible reasons to explain why anxiety arises are: (1) physical state of the founder due to aging condition; (2) limited capability to overcome environment dynamics and uncertainty compared to the younger gnenerations; and, (3) maintaning the business as part of the family value. Moreover, AY as the successor felt that it is necessary for FOBs to pass on the business to the family members regardless of the changing nature, objectives and directions of the firm in the future whether or not to inherit the firm to the third generation.

It has been the nature that often a founder realizes the necessity to pass on the firm to his/her inheritors not only by means of maintaining the kinship and the accumulated wealth, but also, as a learning process for his/her inheritors. Moreover, trustworthiness to family members are often distinct compared to non-family members at the firm, although, there are still possibilities to prepare a succesion for non-family members who are capable of running the firm in the future. Failure of a succession does not only leave a firm in jeopardy, but it also leaves the founder's family less option in sustaining and continuing the entrepreneurial journey of the family and its tradition. Thus, we found that for both: founder and successor clearly need a succession for a continued success of the firm and familiness.

Tabel 2 - Respondents' Perspectives on Family Succession

\begin{tabular}{|c|c|}
\hline $\begin{array}{c}\text { Key } \\
\text { Informant }\end{array}$ & Responses \\
\hline \multirow{3}{*}{ IH 1} & $\begin{array}{l}\text { "It has never been my intention and obsession to pass on the business to my children, but as I age } \\
\text { and find myself becomes limited in terms of my capacity and capability as well as the fact that the } \\
\text { dynamics have changed, it is a good option. Not all capabilities possessed in the past will be able to } \\
\text { be utilized, and I think passing on my business to my family becomes an important objective at the } \\
\text { end" }\end{array}$ \\
\hline & $\begin{array}{l}\text { "In my opinion, the second generation need to take control of the family firm to maintain the business } \\
\text { as a realistic change, without leaving the firm's loyalists and those who have the capacity to sustain } \\
\text { the firm" }\end{array}$ \\
\hline & $\begin{array}{l}\text { "I started the succession process to my son at the age of } 54 \text {. It was not an easy process to convince } \\
\text { him because he had planned to work outside media industry, but as time pass by he started to grow } \\
\text { interests in working in this field" }\end{array}$ \\
\hline AY 1 & $\begin{array}{l}\text { "In my opinion, leadership succession in FOB must be passed on to the next generation especially } \\
\text { family members of the second generation, although, the direction and objectives may change once } \\
\text { the second generation takes over and may or may not be passed on to the third generation" }\end{array}$ \\
\hline
\end{tabular}

Succession Planning at Lombok Post. The second focus of this study was the question of "How do you view succession planning and how was it done in your firm?" Responses from both: the founder $(\mathrm{IH})$ and the successor $(\mathrm{AY})$ were consistent. IH mentioned, related to his experience of succession, he summarized that what had been undertaken in his firm was both: planned and unplanned. It was unplanned since the founder had no intention at the beginning to leave his firm. Some aspects may be able to explain why the succession was unplanned: (1) no interests of the future successor to run the firm, especially when the founder still holds full control and forces family members to continue the business; or, (2) future successors decline to take the throne due to their different carreer orientation.

The planning of succession sometimes becomes problematic for firm founders. Socioemotional aspect is often the case, particularly during the process of choosing a suitable candidates. IH as a founder had planned the succession for a long period of time and had been willing to relinquish his tittle and select the eldest member of the family to take over the firm. IH eventually gave his position to his heir considering the educational background of his successor which is relevant to the business. The succession process is a planned action regarding to the fact that the successor was sent to obtain formal education related to the field. AY as a successor was sent to boarding school and university in order to obtain formal education related to human capital development. Moreover, AY was willing to take over the leadership, not only because the firm is a FOB, but he also had the confidence 
to run the firm since he already obtained adequate skill related to the field. As the founder, IH had chosen his eldest son instead of his other children because the other heirs had low interests in the firm. In fact, the other chidren preferred establishing their career as accounting consultants; eventhough later on they were hired as the treasurer of the firm and strategic business manager of Lombok TV.

Another fact that is revealed from the interview is the fact that Lombok Post had not prescribed any certain criteria in determining the successor, as there was only one strong candidate. IH only had $\mathrm{AY}$ in mind due to the fact that his sisters chose different career path, even though they eventually joined the firm. Thus, it becomes an interesting insight as AY was chosen not only because he was well-educated and had adequate experience, but also because he is the eldest child in the family. In the cultural context, hierarchy and gender are important aspects to consider. Eldest sons usually have a greater responsibility since they are regarded as the representation of the father as a leader of the family.

Table 3 - Interview Responses on the Succession Planning

\begin{tabular}{|c|l|}
\hline $\begin{array}{c}\text { Key } \\
\text { Informant }\end{array}$ & \multicolumn{1}{c|}{ Response } \\
\hline \multirow{5}{*}{ IH 2} & $\begin{array}{l}\text { "Basically, the succession process that I undertook was both: planned and unplanned. I never } \\
\text { planned the succession before because I gave my children the freedom of their own whether or not } \\
\text { to continue the business. The fact that my son is interested to take over (the firm), I started thinking } \\
\text { to prepare him for the leadership succession. I needed to have control on the succession plan for } \\
\text { the continuity of the business and to minimize risks" } \\
\text { "I have chosen my eldest child because the others had chosen different career paths outside this } \\
\text { business" }\end{array}$ \\
\hline \multirow{5}{*}{ AY 2 } & $\begin{array}{l}\text { "Succession can be well prepared if we are able to predict the business' future, it would be different } \\
\text { if it happens to the first generation (founder). The family succession in my opinion is particularly } \\
\text { necessary for the third generation because usually the third generation are inherited with luxuries } \\
\text { and privileged with a well established firm, unlike the second generation who experiences the } \\
\text { struggle of his/her parents when working with the business" }\end{array}$ \\
\cline { 2 - 3 } & $\begin{array}{l}\text { "The succession plan was quite challenging because my father prepared the process from the basic } \\
\text { step: education in which he sent me to attend a boarding school and University majoring } \\
\text { Communication" }\end{array}$ \\
\cline { 2 - 3 } & $\begin{array}{l}\text { "When I joined the firm, I did not have the luxury to be directly employed in a strategic position, } \\
\text { rather I was hired as a journalist and I was involved in various roles and duties. I took around five } \\
\text { years of learning before I gained full trust to lead the firm" }\end{array}$ \\
\hline
\end{tabular}

\section{CONCLUSION}

Succession is often problematic due to some non-technical issues and high emotional content during the process. If the succession fails in the management, the succession planning will fail often, which later may cause big failure for the FOB itself. Most people think that if the corporate strategy is properly implemented, everything will go smoothly. Yet, the fact shows different things. If the founder is excellently managing $F O B$, he/she will become irreplaceable. Appropriate management applied in the FOB is not merely about winning the business strategies, but also in the quest of preparing a successor in order to ensure the continuity of the firm.

It is important to note that succession and leadership in FOBs are two crucial elements of how firms' objectives and kinship are able to encounter the dynamic environment. Furthermore, when the owner and the family begin to focus on succession planning, there will be many options and considerations in developing the next generation. Challenges and financial issues usually occur in preparing the next generation to take over the business. Various efforts should be done to help seniors in dealing with emotional and financial challenges that will be experienced by the next stage owner. Aging also one of the reasons of founders' retirement plan until the heirs are ready to take over the firm. Problems usually arise from the owners who often consider next generation too young to make a choice, giving the next generation a dilemmatic choice.

In the context of this study, business succession in an FOB was necessary. Considering the dynamic environment of the industry, succession option should not be taken 
for granted. Owners must consider other alternatives such as positioning the family under the patronages of parents' business partners who serve to support the welfare of the family. More importantly, the values believed in the family help them building a succesfull business. Values and beliefs shared in a firm support the continuity of the business and provide good long-term thoughts related to the firm. This transition model also helps to provide competitive feeling as the successor feel that they are selected due to their leadership capacity and their own achievements.

Some interesting facts about the context of FOB have been found in this study, yet we believe that this study can be extended to involve cultural aspects and family identity as the determinants of the success of business succession. In addition, we believe that the theories of family business that we used in this study suffer from some weaknesses. Since this study is a qualitative research, researchers are unable to generalize the finding of this study to other context. Therefore, we recommend that future researcher explore this issue through other research method conducted to multiple family business companies to obtain more interesting findings.

\section{REFERENCES}

1. Astrachan, J.H. and Shanker, M.C., 2003. Family businesses' contribution to the US economy: A closer look. Family business review, 16(3), pp.211-219.

2. Astrachan, J.H., 2010. Strategy in family business: Toward a multidimensional research agenda. Journal of Family Business Strategy, 1(1), pp.6-14.

3. Carney, M. and Gedajlovic, E., 2003. Strategic innovation and the administrative heritage of East Asian family business groups. Asia Pacific Journal of Management, 20(1), pp.526.

4. Carney, M., 2005. Corporate governance and competitive advantage in family-controlled firms. Entrepreneurship theory and practice, 29(3), pp.249-265.

5. Choi, Y.R., Zahra, S.A., Yoshikawa, T. and Han, B.H., 2015. Family ownership and R\&D investment: The role of growth opportunities and business group membership. Journal of Business Research, 68(5), pp.1053-1061.

6. Collins, L., Grisoni, L., Tucker, J., Seaman, C., Graham, S., Fakoussa, R. and Otten, D., 2016. The modern family business: Relationships, succession and transition. Springer.

7. De Massis, A. and Kotlar, J., 2014. The case study method in family business research: Guidelines for qualitative scholarship. Journal of Family Business Strategy, 5(1), pp.1529.

8. DeTienne, D.R., 2010. Entrepreneurial exit as a critical component of the entrepreneurial process: Theoretical development. Journal of Business Venturing, 25(2), pp.203-215.

9. DeTienne, D.R. and Chirico, F., 2013. Exit strategies in family firms: How socioemotional wealth drives the threshold of performance. Entrepreneurship Theory and Practice, 37(6), pp.1297-1318.

10. DeTienne, D.R., McKelvie, A. and Chandler, G.N., 2015. Making sense of entrepreneurial exit strategies: A typology and test. Journal of Business Venturing, 30(2), pp.255-272.

11. Donckels, R. and Fröhlich, E., 1991. Are family businesses really different? European experiences from STRATOS. Family business review, 4(2), pp.149-160.

12. Donnelley, R.G., 1988. The family business. Family Business Review, 1(4), pp.427-445.

13. Gómez-Mejía, L.R., Haynes, K.T., Núñez-Nickel, M., Jacobson, K.J. and MoyanoFuentes, J., 2007. Socioemotional wealth and business risks in family-controlled firms: Evidence from Spanish olive oil mills. Administrative science quarterly, 52(1), pp.106137.

14. Hall, A., Melin, L. and Nordqvist, M., 2001. Entrepreneurship as radical change in the family business: Exploring the role of cultural patterns. Family Business Review, 14(3), pp.193-208.

15. Hilburt-Davis, J. and Dyer, W.G., 2003. Consulting to family businesses. A practical guide to contracting, assessment, and implementation. San Francisco, CA: J osseyBass/Pfeifler. 
16. Kelly, L.M., Athanassiou, N. and Crittenden, W.F., 2000. Founder centrality and strategic behavior in the family-owned firm. Entrepreneurship Theory and Practice, 25(2), pp.2742.

17. Klein, S.B., Astrachan, J.H. and Smyrnios, K.X., 2005. The F-PEC scale of family influence: Construction, validation, and further implication for theory. Entrepreneurship Theory and Practice, 29(3), pp.321-339.

18. Liu, C., Eubanks, D.L. and Chater, N., 2015. The weakness of strong ties: Sampling bias, social ties, and nepotism in family business succession. The Leadership Quarterly, 26(3), pp.419-435.

19. Mason, C.M. and Harrison, R.T., 2006. After the exit: Acquisitions, entrepreneurial recycling and regional economic development. Regional Studies, 40(1), pp.55-73.

20. Miles, M.B., Huberman, A.M. and Saldana, J., 2013. Qualitative data analysis. Sage.

21. Mursitama, T.N., 2006. Creating relational rents: The effect of business groups on affiliated firms' performance in Indonesia. Asia Pacific Journal of Management, 23(4), pp.537-557.

22. Neubauer, H., 2003. The dynamics of succession in family businesses in western European countries. Family Business Review, 16(4), pp.269-281.

23. Nordqvist, M., Wennberg, K. and Hellerstedt, K., 2013. An entrepreneurial process perspective on succession in family firms. Small Business Economics, 40(4), pp.10871122.

24. Nugroho, Y., Putri, D.A. and Laksmi, S., 2012. Mapping the landscape of the media industry in contemporary Indonesia. Jakarta: Creative Common.

25. Panglaykim, J., 1984. Bisnis keluarga: perkembangan dan dampaknya (The Family Business: Development and Implication). Andi Offset.

26. Salvato, C., Chirico, F. and Sharma, P., 2010. Understanding exit from the founder's business in family firms. In Entrepreneurship and Family Business(pp. 31-85). Emerald Group Publishing Limited.

27. Sato, Y., 1993. The Salim group in Indonesia: the development and behavior of the largest conglomerate in Southeast Asia. The Developing Economies, 31(4), pp.408-441.

28. Sharma, P., 2004. An overview of the field of family business studies: Current status and directions for the future. Family business review, 17(1), pp.1-36.

29. Sharma, P., Chrisman, J.J. and Chua, J.H., 1997. Strategic management of the family business: Past research and future challenges. Family business review, 10(1), pp.1-35.

30. Stewart, A. and Hitt, M.A., 2012. Why can'ta family business be more like a nonfamily business? Modes of professionalization in family firms. Family Business Review, 25(1), pp.58-86.

31. Ward, J.L., 1997. Growing the family business: Special challenges and best practices. Family Business Review, 10(4), pp.323-337.

32. Yildirim-Öktem, Ö. and Üsdiken, B., 2010. Contingencies versus external pressure: professionalization in boards of firms affiliated to family business groups in late-industrializing countries. British Journal of Management, 21(1), pp.115-130.

33. Zellweger, T.M. and Astrachan, J.H., 2008. On the emotional value of owning a firm. Family Business Review, 21(4), pp.347-363. 
DOI https://doi.org/10.18551/rjoas.2017-09.28

\title{
РАЗВИТИЕ ОРГАНИЗАЦИОННО-ЭКОНОМИЧЕСКОГО МЕХАНИЗМА ВОСПРОИЗВОДСТВА ПРОИЗВОДСТВЕННО-РЕСУРСНОГО ПОТЕНЦИАЛА ПРЕДПРИЯТИЙ АПК \\ DEVELOPMENT OF THE ORGANIZATIONAL AND ECONOMIC MECHANISM FOR THE REPRODUCTION OF PRODUCTIVE AND RESOURCE POTENTIAL OF THE AGRO-INDUSTRIAL COMPLEX'S ENTERPRISES
}

\author{
Кузубов А.А., кандидат экономических наук \\ Владивостокский государственный университет экономики и сервиса, \\ Владивосток, Россия \\ Vladivostok State University of Economics and Service, Vladivostok, Russia \\ E-mail: alexceyk@gmail.com
}

\begin{abstract}
АННОТАЦИЯ
В статье обоснована актуальность и выявлены фракторы, которые усложняют развитие организационно-экономического механизма воспроизводства производственноресурсного потенциала аграрных предприятий. Определены методологические подходы к его развитию на основе теории использования ресурсов как основных фракторов производства, цикличности ресурсопользования и производства. Особое внимание было уделено перспективам применения с целью расширенного воспроизводства производственно-ресурсного потенциала с учетом косвенной государственной поддержки и макроэкономического регулирования.
\end{abstract}

\section{ABSTRACT}

The article substantiates the urgency and identifies factors that complicate the development of the organizational and economic mechanism for the reproduction of the productive and resource potential of agricultural enterprises. Methodological approaches to its development are determined on the basis of the theory of using resources as the main factors of production, the cyclical nature of resource use and production. Particular attention was paid to the prospects of using the productive and resource potential of agro-formations with the aim of expanded reproduction, taking into account indirect state support and macroeconomic regulation.

\section{КЛЮЧЕВЫЕ СЛОВА}

Производственно-ресурсный потенциал, аграрные предприятия, организационноэкономический потенциал, фракторы производства, земельные ресурсы, инновации, государственная поддержка, управление.

\section{KEY WORDS}

Production and resource potential, agricultural enterprises, organizational-economic potential, production factors, land resources, innovation, government support, management.

Формирование социально ориентированной аграрной политики в России, осуществление эфрфективных реформ по организации сельских территорий и улучшения жизненного уровня сельского населения возможно только при условии эфффективного воспроизводства производственно-ресурсного потенциала в аграрной сфрере экономики. Однако отсутствие действенных мер по улучшению организационноэкономического механизма воспроизводства, в т.ч. в составе комплексных национальных, региональных и местных программ развития сельских территорий, существенно тормозит этот процесс. Как следствие, ухудшается рентабельность сельскохозяйственных предприятий, благополучие их работников и эфрфективность фрункционирования аграрной отрасли в целом. 
Проведя теоретические исследования научных трудов, ведущих ученых экономистов по обозначенной проблематике, таких, как Д.А. Шайдаева [1], Д.М. Матвеев [2], Ю.Т Фаринюк [3], В.М. Подгорный [4], Н.В. Шашло [5], Н.А. Куриленко [6], Н.П. Шилова [7], Е.В. Коцюк [8], Д.Г. Исаева [9], О.Ю. Ермаков [10], Н.В. Гусанов [11] и других, необходимо заметить, что актуальным вопросом на современном этапе развития субъектов хозяйствования аграрной сферы экономики является формирование единых методологических подходов по совершенствованию механизма эфффективного воспроизводства производственно-ресурсного потенциала сельскохозяйственного производства.

В экономической теории, экономике аграрных предприятий известны различные подходы относительно трактовки экономической категории «воспроизводство фракторов производства в рыночных условиях хозяйствования». Большинство из них подобны и отличаются между собой только частично, на уровне отдельных составляющих. Так ученые, которые изучали и изучают вышеупомянутую проблему, определяют воспроизводство фракторов производства как совокупность мероприятий по возобновлению личных (трудовые ресурсы) и вещественных (земельные, материальные, нематериальные ресурсы) элементов процесса производства с целью их эффрективного использование [12]. Указанное понимание сущности процесса воспроизводства фракторов производства обусловливает направления эволюции соответствующей теории. В целом она предусматривает развитие двух из них, а именно:

- теории воспроизводства (улучшения) первичной, или основной, составляющей ресурсного потенциала (труд и земля) ;

- теории воспроизводства (улучшения) вторичной составляющей (капитал, отражающий результат влияния труда на природные ресурсы и предпринимательство).

Кроме этого, целесообразно отметить, что теории воспроизводства первичной (трудовых и земельных ресурсов) и вторичной (ресурсы в фрорме капитала и предпринимательской деятельности) составляющих производственных фракторов основываются на обеспечении и учете условий развития научно-технического прогресса, в своевременном предоставлении и использовании информации о деятельности аграрных предприятий и обеспечении их устойчивого экологического и социально-экономического состояния, принятии обоснованных управленческих решений тактического и стратегического характера.

Так наиболее весомыми по воспроизводству фракторов производства были разработки представителей марксистской и маржиналистской экономических теорий (Ф. Энгельс, К. Маркс, А. Маршалл, У. Пети, Д. Рикардо, А. Смит и др). Ученые трактовали прежде всего производственные фракторы как важные элементы, или объекты, которые могут решающим образом повлиять на эффрективность функционирования и доходы любого хозяйствующего субъекта. Также такой подход предполагает оценку влияния отношений собственности на эфффективность воспроизводства фракторов производства. То есть все вышеуказанные подходы ученых направлены на одновременное воспроизведение всех ключевых производственных фракторов благодаря дифференцированным мерам.

Только в таком случае обеспечивается наибольший синергическое влияние на воспроизводство производственных ресурсов как основных фракторов аграрного производства.

Определено, что организационно-экономический механизм общественного воспроизводства аграрных ресурсов - это система связанных между собой форм, рычагов и методов социально-экономического воздействия на сельскохозяйственных товаропроизводителей с целью активизации производственной, фринансовоинвестиционной деятельности и насыщения аграрных рынков конкурентоспособной продукцией [13]. Учитывая вышеуказанную дефиницию, мы обосновали основные составляющие организационно-экономического механизма общественного воспроизводства производственных аграрных ресурсов. 
Речь идет об организационной (организация производства и бизнес-процессов, отношения собственности, система управления на всех направлениях хозяйственной деятельности, реструктуризация и проч.) и экономической (ценообразования, налогообложения, планирования и прогнозирования финансово-хозяйственной деятельности, экономическое стимулирование предприятий, формы их инвестирования и кредитования, мотивация к рационального ресурсопользования и тому подобное) составляющих. Они взаимосвязаны между собой, особенно на конечном этапе применения через анализ и контроль за использованием ресурсов на всех уровнях хозяйствования, предоставление необходимой информации владельцам или руководителям основных показателей и индикаторов деятельности сельскохозяйственных предприятий с целью оптимизации ресурсного воспроизводства.

Важное значение имеет определение фракторов, которые влияют на воспроизводство производственных ресурсов как факторов сельскохозяйственного производства. Они имеют как общеэкономический характер, так и проявляются на уровне субъектов аграрного хозяйствования, являются субъективными или объективными.

Прежде всего, это общественно-политические (геополитическая ситуация, социально-экономическое положение в стране, уровень социально-экономической стабильности, социологические настроения в обществе); социально-экономические (совершенство институтов и институций, состояние и уровень развития аграрной сфреры экономики и рынка труда, рентабельность и доходность сельскохозяйственных предприятий; уровень материального и социально-психологического стимулирования работников и тому подобное); особенности и приоритеты государственной аграрной политики; эффективность и качество использования сельскохозяйственных земель и других ресурсов, его проблемы и тенденции; природно-климатические условия территорий размещения аграрных предприятий (плодородие почв, температурные показатели, водная и ветровая эрозия, стихийные бедствия и др.); сезонность производства (весенне-осенние полевые работы и др), уровень производительности труда и эфффективность других ресурсов; энерго - $и$ ресурсоемкость сельскохозяйственного производства, уровень ресурсосбережения; внедрение инновационных технологий, органического земледелия, мелиораций.

Следовательно, все вышеуказанные фракторы имеют решающее влияние на воспроизводства производственно-ресурсного потенциала аграрной сферы экономики. Также воспроизводства трудовых ресурсов должно базироваться на оптимизации демографической ситуации, мотивации аграрной труда, обеспечении доходов и уровня жизни сельскохозяйственных работников и жителей на основе принципов социальной справедливости. С другой стороны, фрормирование эффрективного и конкурентоспособного аграрного производства, что обеспечивает потребности населения в продуктах питания, высоких доходах, что удовлетворяет спрос предприятий перерабатывающих отраслей, a также нужды экспорта сельскохозяйственной продукции и стабильность аграрных рынков, что является сегодня стратегической целью аграрной политики государства и направлено на оптимальное использования и воспроизводства производственно-ресурсного потенциала.

В условиях ухудшения качества, нарушений, деградации природных систем жизнеобеспечения, незавершенности рыночных рефрорм, нестабильности социальноэкономической ситуации в стране, проблема воспроизводства аграрного производственно-ресурсного потенциала приобретает особую актуальность, но и одновременно отходит на второстепенный план из-за макроэкономических кризисных явлений и процессов. Сложность ее решения обусловлена также несовершенством национального законодательства, регулирующего эколого-экономические фракторы производства недостаточно комплексным подходом к осуществлению рыночных рефрорм и непоследовательностью аграрной политики. Поэтому на современном этапе развития аграрных фоомирований необходимо совершенствовать методологические 
подходы к определению организационно-экономического механизма воспроизводства аграрного производственно-ресурсного потенциала.

Материально-технические ресурсы сельскохозяйственных предприятий подразделяются на основные и оборотные средства. Основные средства, кроме стоимости земли, содержат еще и стоимость машин и оборудования, транспортных средств, зданий и сооружений, рабочего и продуктивного скота, многолетних насаждений и др. От их состава в значительной мере зависит возможность своевременного качественного выполнения технологических операций производственного процесса. Именно материально-техническая база и особенно ее активная часть (машины и оборудования) определяют масштабы и направления развития аграрного производства, его доходность, фринансово-экономическую устойчивость, конкурентоспособность и эфффективность.

Длительный неэквивалентный обмен сельскохозяйственной и промышленной продукции привел к значительному росту степени износа основных средств, снижение темпов внедрения инновационных технологий, других достижений научно-технического прогресса В агроформировании. У многих, особенно малых и средних сельскохозяйственных предприятиях износ зданий и сооружений составляет более $60 \%$, машин и оборудования - около $70 \%$. Формально же стоимость основных средств растет из-за их индексации без дополнительного ввода новых ресурсов. Более половины парка тракторов, уборочных комбайнов и грузовых автомобилей отработали свой амортизационный срок. В следствии расходы на ремонт и техническое обслуживание составляют почти $70 \%$ от суммы средств на приобретение новой техники, до 40\% машин простаивают по техническим причинам.

В большинстве сельскохозяйственных предприятий снижаются ресурсообеспеченность и уровень экономической эффективности использования материально-технических ресурсов, исключается переход на высокоэффективные ресурсоемкие технологии производства [14]. Сейчас только агрохолдинги и крупные сельскохозяйственные предприятия благодаря инвестициям могут обеспечить выполнение производственных процессов высокопроизводительными и качественными машинами и оборудованием при условии и с целью использования инновационных технологий на больших земельных площадях.

Однако стремление получать сверхприбыли за счет выращивания коммерческих энергоемких продовольственных и технических культур, истощающих землю, требует немедленного принятия на законодательном уровне мер по рациональному использованию земель сельскохозяйственного назначения, внедрение в практику новых технологий обработки почвы и других агротехнических мероприятий, направленных на сохранение и повышение плодородия почв, борьбу с эрозионными процессами. Необходимым считаем выведение из интенсивного возделывания малопродуктивных и деградированных земель. Все это требует значительных инвестиций для обеспечения непрерывности в наращивании производственной деятельности. Без государственной поддержки и повышения доходности сельского хозяйства на других предприятиях невозможно восстановление материальнотехнической базы, внедрение прогрессивных технологий, производство конкурентоспособной продукции $[15,16]$.

В аграрном производстве воспроизводственные циклы тесно связаны с биологическими законами, переплетаясь с естественными. Особенностью сельскохозяйственного воспроизводства является сезонный характер производственных процессов (в первую очередь, в растениеводстве, но и в животноводстве сезонные колебания могут быть весьма существенными). Этим фрормируется отличный от большинства промышленных отраслей порядок создания оборотного капитала и воспроизводства рабочей силы, поскольку технологический процесс производства и реализации сельскохозяйственной продукции занимает несколько месяцев.

Следовательно, обеспечить нормативы использования оборотных средств за счет собственных источников не только невозможно, но и экономически неоправданно. 
Излишек оборотных средств, образуемый в межсезонье, обесценивает капитал и создает предпосылки для нецелевого или неэффективного использования временно свободных средств. В следствии зависимости производственного процесса от природных условий обеспечить непрерывность воспроизводства в аграрной сфере возможно через экономическую составляющую организационно-экономического механизма воспроизводства, совокупность управленческих и регулирующих мер в сфрере воспроизводственных циклов как самого аграрного предприятия, так и государства.

Последние проявляют свое влияние при использовании горизонтальных экономических связей сельского хозяйства с машиностроением, энергетикой, химической промышленностью, строительством и другими отраслями экономики; через вертикальные экономические связи в сельском хозяйстве, обеспечивая взаимодействие живого труда и всех остальных ресурсных факторов производства. В результате такие ее составляющие, как сельскохозяйственные угодья и биологическая группа средств производства, ежегодно циклически расширено воспроизводятся в пределах отрасли и каждого отдельного аграрного предприятия. Если сельскохозяйственные культуры и поголовья животных воспроизводятся не только количественно, но и качественно, то воспроизведение земель происходит только в качественном содержании, путем улучшения плодородия почв.

Воспроизводство производственно-ресурсного потенциала зависит от комплекса условий, способных ускорять этот процесс. Их можно объединить в следующие группы: природно-биологическая, фринансово-инвестиционная, инфрормационная, кадровая, управленческая и инновационная. Все вышеприведенные факторы, которые определяют производственно-ресурсный потенциал сельскохозяйственных предприятий, тесно переплетаются и взаимосвязаны между собой и влияют на эфрфективность использования каждого вида ресурсов.

Определяющая роль в ресурсном обеспечении их устойчивого экономического развития, как и национальной экономики в целом, принадлежит человеческому капиталу, который как ресурс аграрного производства фрормируется прежде всего в среде сельского населения. Требования к качеству последнего возрастают в связи с повышением технологического уровня сельскохозяйственного производства и необходимостью усиление его конкурентоспособности. Сейчас же профессиональноквалификационный уровень аграриев, которые в подавляющем большинстве работают с отрывом от содержания современных инновационных технологий в растениеводстве и животноводстве, является низким.

Вышеприведенные проблемы, которые наблюдаются сегодня в ресурсном обеспечении аграрной сферы экономики, требующие, как уже отмечалось, последовательной государственной поддержки, в ведущих рыночных экономиках выполняет стабилизирующую и стимулирующую функции в обеспечении устойчивого развития субъектов аграрного хозяйствования. Системная государственная аграрная политика должна направляться на повышение эфффективности использования и воспроизводства, задействованного в сельскохозяйственном производстве производственно-ресурсного потенциала, что позволит аграрной сфере страны быть «точкой роста» и фрундаментом дальнейших модернизационных преобразований экономики страны в целом.

Одним из приоритетных направлений такой поддержки должно стать фрормирование благоприятного финансово-кредитного среды через обеспечение сельскохозяйственных товаропроизводителей необходимыми объемами финансовых ресурсов для расширенного воспроизводства и инновационного развития, финансовой стабильности и конкурентоспособности на внутреннем и внешнем аграрных рынках.

Выводы и перспективы дальнейших исследований. Перспективным фрактором и элементом организационно-экономического механизма регулирования процесса воспроизводства производственно-ресурсного потенциала сельскохозяйственных предприятий является организация и развитие сельских территорий путем расширения собственных полномочий и возможностей сельских общин в осуществлении контроля и 
стимулирования рационального ресурсопользования домохозяйств и малых предприятий; привлечению инвестиций в производственную, экологическую и социальную сферы села общественными организациями, волонтерами и меценатами. Улучшить финансово-инвестиционное состояние сельскохозяйственных товаропроизводителей как основного фактора воспроизводственных процессов ресурсопользования может государственное регулирование интервенционных реализационных цен на сельскохозяйственную продукцию и предоставление кредитов для воспроизводства материально-технических ресурсов. Субсидирование части банковского процента (стоимости) инвестированного капитала даст возможность получателям кредитов сократить денежные расходы за пользование заемными средствами. Это будет способствовать укреплению фринансово-экономической устойчивости сельскохозяйственных предприятий, повышению их инвестиционной привлекательности. Достаточно важным в механизме регулирования процессов воспроизводства производственно-ресурсного потенциала на перспективу является снижение процента платы за пользование лизинговым имуществом. Значительную роль в нем играет субсидирование строительства хозяйственных и других объектов на инновационной основе, реконструкция и техническое переоснащение действующих производств. Такое строительство можно рассматривать как инновационный процесс, результатом которого является нововведение в аграрное производство и воспроизводство его ресурсопользования.

\section{БИБЛИОГРАФИЯ}

1. Шайдаева Д.А. Экономический потенциал агропромышленного предприятия: сущность и структура / Д.А. Шайдаева // Проблемы развития АПК региона. - 2012. №12. - С. 165 - 174.

2. Матвеев Д.М. Повышение эффрективности государственной поддержки технического переоснащения сельского хозяйства/Матвеев Д.М., Стадник А.Т., Крохта М.Г.//Вестник НГАУ. -2012. -Том -3 -№24. -С132-136.

3. Фаринюк Ю.Т., Глебова А.Г. Организационно-экономические условия инновационного развития аграрного производства: монографрия. Тверь: АгросферА, 2011. $158 \mathrm{c}$.

4. Подгорный В.М. Государственное регулирование инвестиционной деятельности АПК. / В.М. Подгорный/ автореферат диссертации на соискание ученой степени кандидата экономических наук / Воронеж. гос. аграр. ун-т им. императора Петра I. Воронеж, 2012, 26 с.

5. Шашло Н.В Идентификация и развитие компетенций агропромышленных предприятий. // В сборнике: Актуальные проблемы экономической теории и практики. Сборник научных трудов. Под редакцией В.А. Сидорова. Краснодар, 2012. C. 84-90.

6. Куриленко Н.А. Оценка инвестиционной привлекательности сельскохозяйственной отрасли региона // Вестник Белорусской государственной сельскохозяйственной академии. 2016. №4. С.19-22

7. Шилова Н.П. Организационно-экономические аспекты развития интегрированных агропромышленных формирований. Воронеж: Воронежский ГАУ, 2013. 244 с.

8. Коцюк Е.В. Оценка эфффективности использования основных средств и пути снижения затрат за счет улучшения агротехники / Е.В. Коцюк, Н.В. Ежакова // Ученые записки Крымского инженерно-педагогического университета - 2016. - №1 (51) - C. 60-67.

9. Исаева Д.Г. Проблемы технического и технологического переоснащения сельскохозяйственных предприятий // Проблемы развития АПК региона. 2015. Т. 2. №2 (22). C. 120-124.

10. Ермаков А. Ю. Формирование экономически устойчивого производственного потенциала сельскохозяйственных предприятий: монографрия / О. Ю. Ермаков, В. В. Нагорный. - М.: Компринт, 2015 - 294 с. 
11. Гусанов Н. В. Пути улучшения использования основных производственных фондов. // АПК: экономика, управление.- 2014.- №12.- С. 96-97.

12. Краснова Н.А. Прогнозирование и бюджетирование производственнохозяйственной деятельности инновационного предприятия // Novalnfo.Ru. 2014. №27. C. 44-62.

13. Старикова М.С. Оценка конкурентоспособности продукта в условиях отсутствия прямых аналогов // Успехи современной науки. 2015. №1. С. 51-55.

14. Хватов К.Ю. Формирование стратегии создания новой продукции. Монография. Воронеж, 2006. - 180c.

15. Печатнова А.П. Методы оценки инвестиционных проектов // Молодой ученый. 2014. - №17. - С. 316-318.

16. Кузубов А.А. Анализ рисков для государства, обусловленные мотивациями иностранных инвесторов // Экономика: теория и практика. 2017. №2 (46). С. 70-75.

(C) 2017 by the author. Licensee RJOAS, Orel, Russia. This article is an open access article distributed under the terms and conditions of the Creative Commons Attribution (CC BY) license: http://creativecommons.org/licenses/by/4.0/ 
DOI https://doi.org/10.18551/rjoas.2017-09.29

\title{
DETERMINANT FACTORS OF AGRICULTURAL EXTENSION COMPETENCE IN THE IMPLEMENTATION OF GOOD AGRICULTURAL PRACTICES IN BANGKA, BELITUNG PROVINCE
}

\author{
Agustina F.* \\ Department of Agribusiness, Faculty of Agriculture, Bangka Belitung University, \\ Bangka, Indonesia \\ Zahri I., Yazid M., Yunita \\ Department of Agribusiness, Faculty of Agriculture, Sriwijaya University, \\ Palembang, Indonesia \\ *E-mail: fournitaagustina@gmail.com
}

\begin{abstract}
The application principles of Good Agricultural Practices (GAP) in plant cultivation must be guarded well by the Agricultural Extension Workers in order to make sure that the implementation completely in accordance with the provisions to produce good product. The amount of demand for good and healthy food product as well as friendly environment is something that cannot be inevitable. The implementation process of agricultural extension can be run properly if it is supported by the professional and reliable extension workers, extension materials flown constantly, correct counseling implementation system and proper counseling method of the polyvalent extension management. The purpose of this study was to determine the factors that affect the competence of agricultural extension on the implementation of GAP. In this study, survey method and sampling are used that is conducted probability, i.e. stratified random sample (stratified random sampling) with a total sample of 125 agricultural extension workers and 100 farmers built by agricultural extension. The data collected is then analyzed using SEM (Structural Equation Model) with the program LISREL (Linear Structural Relationships). The results showed that exogenous latent variable characteristics of the educator, motivational counselor, educator attitudes, knowledge and skills extension educator clearly influenced on improving the competence of agricultural extension. The effect of each latent variable exogenous to the extension of competence (endogenous latent variable) appears on its merits extension competence in planning outreach programs, utilizing local resources, organize agricultural extension, build networks and capacity extension in the field of technical expertise
\end{abstract}

\section{KEY WORDS}

Agricultural extension, good agricultural practices, competencies extension.

Food and Agriculture Organization world (FAO) who shelter under the United Nations, stated in the world meeting that there are three main challenges agriculture today, namely: (1) increasing food security, livelihoods and incomes of the rural population, (2) reaching the demand in increasing the variety need of safe food products (3) preservation of natural resources and the environment (FAO, 2003).

By seeing the agricultural developments, it is necessary to take a strategic step in agriculture, especially in Indonesia, to answer those three challenges. The government has been aware of this, so that at the beginning of the administration of President Susilo Bambang Yudhoyono emerged a revitalization program of Agriculture, Fisheries and Forestry (RPPK) and Revitalization of Agricultural Extension (RPP). RPP program received strong legal umbrella with the issuance of Law No. 16 of 2006 on the Extension System of Agriculture, Fisheries and Forestry (SP3K). Revitalization Program is focused on several sub-programs, namely the institutional arrangement of agricultural extension, increasing the quantity and quality of agricultural extension, an increase in institutional and leadership of 
farmers, improvement of the organization of agricultural extension systems, and the development of cooperation between agriculture and agri-extension system (Sumardjo et al. 2010).

Policies and general strategies taken in the implementation of RPPK itself is the reduction of poverty, improvement of competitiveness and the preservation and utilization of the environment and sustainable natural resources. Increasing competitiveness, productivity, added value and self-reliance among others by good agriculture practices (GAP = Good Agricultural Practices). The application of the principles of Good Agricultural Practices (GAP) in the cultivation of plants must be guarded well by the Agricultural Extension Workers (PPL) for the implementation completely in accordance with the provisions and produce good product.

The passing of Law No. 16 of 2006 on "Extension System of Agriculture, Fisheries and Forestry" the momentum of rise in the Indonesian education system. The law is legal certainty, which set the start of the extension system, institutional, FEA, counseling implementation, infrastructure, financing, up guidance and supervision in counseling, but on the other hand also leaves fundamental issues such as the preparation of human resources extension. Reliable human resource will be able to improve the performance of the public service.

The process of implementation of agricultural extension can be run properly if it is supported by the FEA professionals, institutional extension reliable, extension materials are constantly flowing, system counseling implementation correct and counseling methods appropriate management and counseling polyvalent (Warya 2008).

In terms of meaning agribusiness agricultural extension is a source of information for farmers to improve their farming both upstream subsystems, subsystem farming, downstream subsystem (processing) and supporting subsystems. Unfortunately, the condition of the field illustrates that the level of competence of agricultural extension in implementing the stewardship of agricultural extension is still not as expected farmers.

Agriculture extension is the cornerstone for the success of agricultural development. Therefore, It is always required for carrying out a duty to serve and fight for the interests of farmers and the fore is visionary, creative, productive, disciplined and independent. Increased insight and expertise extension needs to be improved so that conducive to the development potential as a professional educator.

The purpose of this study was to determine the factors that affect the competence of agricultural extension on the implementation of GAP. This study is expected to strengthen the architecture of competence theory in the context of agricultural extension and the expected results of this study can be a reference to the policy-making both by the central government and the local governments.

\section{METHODS OF RESEARCH}

This research was conducted in Bangka Belitung Province, namely in three districts of 7 districts / cities in Bangka Belitung province. Locations were selected purposively namely Bangka, Bangka Regency of Central and South Bangka Regency with the consideration that the district has established appropriate institutional counseling Law No. 16 of 2006 and has the largest extension in Bangka Belitung. Collecting data in the field is carried out from February to August 2014.

The unit of analysis is all the existing agriculture extension Bangka, Bangka Regency of Central and South Bangka Regency whose population is 144 extension workers and farmers who cultivated horticultural extension agent. Based on the formula solving with an error rate of five percent is derived sample of 125 people extension taken by stratified random sampling and horticultural farmers (100 people). This study uses a survey through questionnaires which supported the interview. The data collected is then analyzed using SEM (Structural Equation Model) with the program LISREL (Linear Structural Relationships). 


\section{RESULTS AND DISCUSSION}

Hypothetical model proposed includes 29 indicators derived from six independent variables and the dependent variable. After the estimation of variables that affect the competence of agricultural extension, structural competence discovered agriculture extension models that show the influence between variables with the results of SEM conformance criteria as follows:

Table 1 - Results of the conformance criteria SEM Model

\begin{tabular}{llll}
\hline \multicolumn{1}{c}{ Goodness-of-Fit } & Cutt-off-Value & Result & Description \\
\hline GFI(Goodness of Fit) & $\geq 0,90$ & 0.96 & Good Fit \\
RMR(Root Mean Square Residual) & $\leq 0.1$ & 0.08 & Marginal Fit \\
RMSEA(Root Mean square Error of Approximation) & $\leq 0,08$ & 0.02 & Close Fit \\
AGFI(Adjusted Goodness of Fit Index) & $\geq 0,90$ & 0.95 & Good Fit \\
CFI (Comparative Fit Index) & $\geq 0,90$ & 1.00 & Good Fit \\
\hline
\end{tabular}

Hypothesis 1: "A characteristic aspect counselor, educator motivation, attitude extension, extension of knowledge, skills extension have real effect on improving the competence of agricultural extension in the development of GAP in Bangka Belitung. How to test the hypothesis 1 is done by comparing the value of t-test and t table for each variable. The direct effect of the study variables are presented in the table below.

Table 2 - Effect directly between research variables and coefficients of influence

\begin{tabular}{|c|c|c|c|c|c|c|}
\hline \multicolumn{3}{|c|}{ Between Variables Influence } & \multicolumn{4}{|c|}{ Influence Coefficient } \\
\hline Free variable $(X)$ & & $\begin{array}{l}\text { Variables } \\
\text { Bound }(\mathrm{Y})\end{array}$ & Directly & Total & $\begin{array}{c}\text { Value } t \text { on } \\
\alpha=0,05\end{array}$ & $\mathrm{R}^{2}$ \\
\hline $\begin{array}{l}\text { Characteristics } \\
\text { Extension }\end{array}$ & $\rightarrow$ & & 0,44 & 0,44 & 7,00 & \\
\hline $\begin{array}{l}\text { Motivation Extension } \\
\text { Attitude Extension } \\
\text { Knowledge Extension } \\
\text { Skills Extension }\end{array}$ & $\begin{array}{l}\rightarrow \\
\rightarrow \\
\rightarrow\end{array}$ & $\begin{array}{l}\text { competence } \\
\text { Extension } Y_{1}\end{array}$ & $\begin{array}{l}0,47 \\
0,46 \\
0,58 \\
0,67\end{array}$ & $\begin{array}{l}0,47 \\
0,46 \\
0,58 \\
0,67\end{array}$ & $\begin{array}{c}6,44 \\
8,07 \\
14,03 \\
11,35\end{array}$ & 0,9 \\
\hline Extension System & $\rightarrow$ & & $-0,58$ & $-0,58$ & $-3,18$ & \\
\hline
\end{tabular}

Source: Primary Data Processed, 2014.

Table 2 shows the direct influence of the variable characteristics of extension, extension motivation, attitude extension, extension of knowledge, skills extension and extension system in agriculture extension competencies are significantly different at the 0.05 level. A mathematical equation structural model of agricultural extension competencies are:

$$
Y 1=0,44{ }^{*} X 1+0,47^{*} X 2+0,46 * X 3+0,58 * X 4+0.67^{*} X 5-0: 58^{*} X 6
$$

Where: $\mathrm{Y} 1$ is an extension of competence; $\mathrm{X} 1$ extension characteristics; $\mathrm{X} 2$ motivation extension; $X 3$ attitude extension; $X 4$ extension of knowledge; $X 5$ and $X 6$ skills extension agricultural extension systems. Collectively the six variables influence the competence of agricultural extension by 90 percent real on $\alpha=0.05$ so the hypothesis is accepted. This can be explained that:

The characteristics of direct extension have real effect on the competence of agricultural extension, it means that each increase of one unit of the characteristic extension 0,44 units.

The results showed that the variables directly affect the characteristics of real competence agricultural extension. This means that the extension characteristics also determine whether the poor competence agricultural extension coefficient of 0.44 real influence on á $=0.05$. Effect of extension on competence characteristics visible on its merits 
extension educator competencies in planning outreach programs, utilizing local resources, organize counseling, networking and capacity building areas of technical expertise.

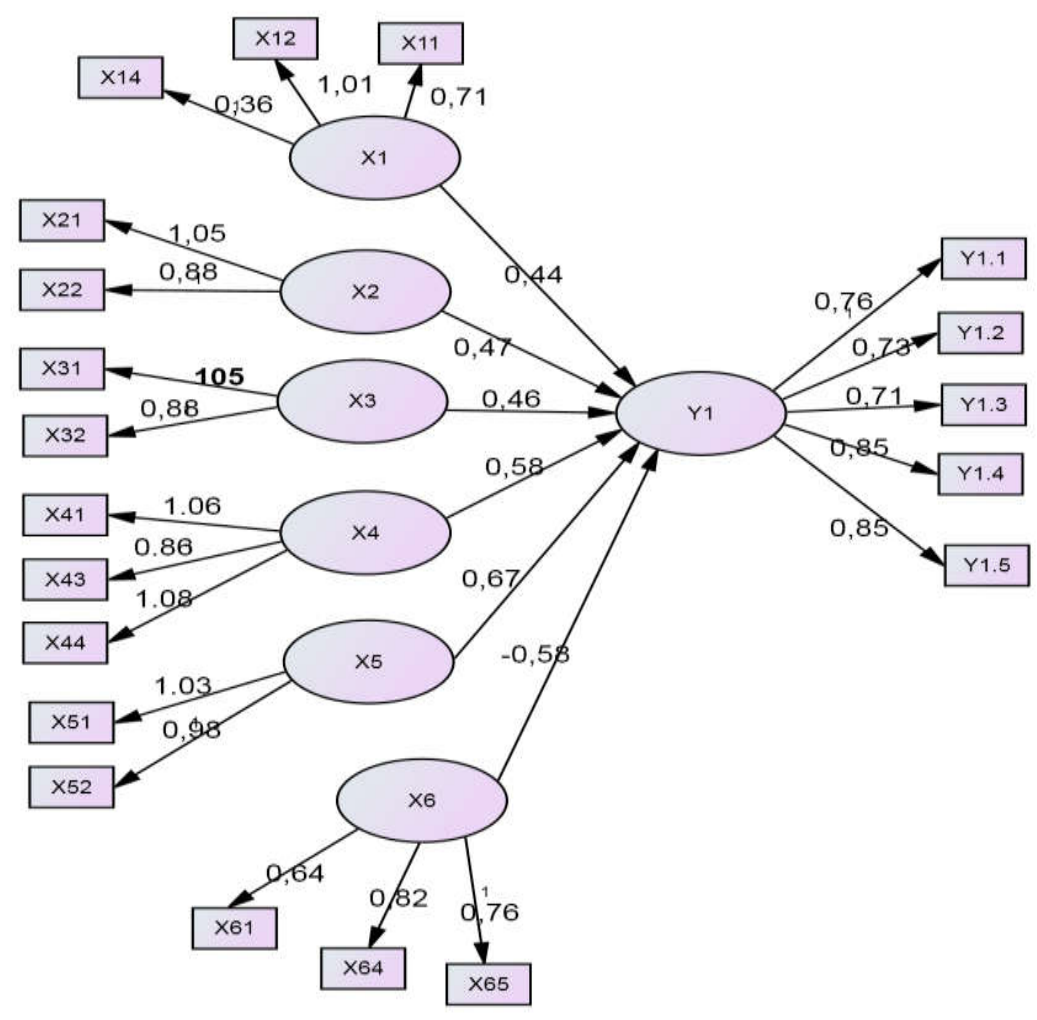

Notes: $X 1=$ Characteristics Extension; $X 1.1$ (Age), $X 1.2$ (Tenure) and X1.4. (Technical training); $X 2=$ Motivation Extension; X2.1 (need for achievement), X2.2. (need for affiliation); $X 3=$ Attitude extension; X3.1. (Ability to cooperate), X3.2. (Analyzing the problem); $X 4=K$ nowledge; $X 4.1$ (Understanding the potential of the region), X4.3. (Access to information resources), X4.4. (Technical horticultural cultivation); X5 = Skills Instructor; X5.1 (communicate effectively), X5.2 (building networks); $X 6$ = Extension System; X6.1 (government support); X6.4 (support means), $X 6.5$ (extension methods); $Y 1$ = Competence agricultural extension; $Y 1.1$ (planned extension program), Y1.2 (utilizing local resources), Y1.3 (organizing counseling); Y1.4 (building networks), Y1.5 (technical expertise).

Figure 1 - Structural Model of determinant factors of agricultural extension competence in Bangka Belitung

The real effect of the characteristics of agriculture extension educator at competencies reflected by the observed variables (manifest), the dimensions of age, years of service, and technical training followed by extension. Circumstances age extension in Bangka Belitung province ranged from 22 to 56 years old and mostly aged $26-45$ years $(80.8 \%)$. This means most of the extension of childbearing age, so the impact on the improvement of the competence of extension. According to Klausmeier and Goodwind (1975) in Yunita 2010, age is one of the important characteristics relating to the efficiency and effectiveness of learning, individuals who are in the productive age will more readily accept change, new ideas and innovation. The tenure of the extension in Bangka Belitung province ranged between 1 and 32.tahun. Most of the work period of $5-10$ years $(48 \%)$. this suggests that agricultural extension in Bangka Belitung generally young (juniors) so that they are eager to find information and technological innovation will be the agricultural extension materials, these conditions have an impact on improving the competence of extension.

Technical training and functional extension followed by the agricultural extension is still relatively low, yet still have an impact on improving the competence of extension for extension has not felt saturated with the training provided and encouraged to seek new information or The results of this study are also consistent with the results of Bryan and Glenn (2004) concluded that, work experience have a positive effect relatively new 
extension, while the extension is already longer work showed low levels of client satisfaction. Havelock (1969) in Yunita (2010) states that a person's experiences affect the tendency to require and ready to accept new knowledge. Results of research jahi Kurniawan $R$ and $A$ (2005) concerning the competence of agricultural extension in seven districts in Bekasi, West Java, which concluded that despite their diverse characteristics, the instructor showed high agreement in rank eighth kinds of competencies that they need.

The study provides information that the extension characteristics such as age, years of training can be a real influenced on improving the competence of extension. Thus this study can be used as a reference for the government in managing agricultural extension educator with due regard to age, years of service and extension training. In the recruitment system to consider the age of the prospective counselor and educator who had long tenure need to be improved abilities through training related to the development of innovation. Training extension workers need to be scheduled well and adapted to the needs of farmers. This will facilitate the extension in serving farmers auxiliaries.

Motivation direct extension have real effect on the competence of agricultural extension, means that each increase of one unit will increase the motivation of extension agricultural extension competence of 0.47 units.

The results showed that the variables of motivation educator real effect on the competence of agricultural extension. This means motivation will determine whether the poor competence of extension coefficient of 0.47 real influence on á $=0.05$. Extension motivational effect on the competence of extension appears in planning outreach programs, utilizing local resources, organize counseling, networking and capacity building areas of technical expertise.

Dimensions motivation extension are closely linked to agricultural extension competence is reflected by two variables observed (manifest), namely (1) the need for achievement that includes encouragement for excel or achievement. and (2) the need for affiliation which includes the desire to be accepted by others in the neighborhood extension work or residence. The need for achievement is the most powerful indicator reflects the motivation variable $(\lambda=1.06)$. Thus the effect of outstanding educator needs great potential to increase the competence of extension.

The results of this study are consistent with the results of the study Marius AJ (2007) concerning the competence development of agricultural extension in East Nusa Tenggara province, which concluded that the aspects of motivation is a big influence on the dimensional extension of competence $(0.628 \%)$.

Theoretically this research direction of the Achievement proposed by McClelland (1961), states that there are three important things to be human needs, namely:

- Need for achievement (need for achievement) in this case the urge to excel, or

Achievement:

- Need for affiliation (the need for social relationships / almost equal to its social need Maslow) in this case the urge to build social relationships;

- Need for Power (the urge to organize) in this case the urge to dominate or manage other people.

Based on the research results and the above theory, the results of this study showed a noticeable effect with competence motivation extension of dimensions need for achievement and affiliation needs. Thus the results of research can help local governments improve motivation extension of the dimensions of need for achievement and the need to involve counselors affiliated with the various races, increased levels of formal and non formal education, as well as reward to the agents who excel and provide the facilities and infrastructure extension.

Attitude extension directly real effect on the competence of agricultural extension, means that each increase of one unit of attitude extension will increase the competence of 0.46 units of agricultural extension.

The results showed that the real effect on the attitude variable competence agricultural extension. This means that attitudes determine whether the poor competence extension agricultural extension coefficient of 0.46 real influence on $\alpha=0.05$. 
Influence the attitude of extension in agricultural extension appears competence in planning outreach programs, utilizing local resources, organize counseling, networking and capacity building areas of technical expertise.

Dimensions attitude extension which is closely related to the competence of the agricultural extension reflected by variables observed (manifest), namely (1) the attitude of working together synergistically fellow educator and farmer is measured by the attitude to accept other people's opinions and attitudes towards a group / team, (2). attitude to the problems faced by farmers. Variables observed (manifest) the most powerful extension reflects the attitude is the attitude of working together $(\lambda=1.06)$. Thus the effect of attitudes educator who can develop an attitude in working together potentially the most to improve the competency of agricultural extension.

Theoretically this study in line with the opinion Sumardjo (2006) which explains that competency is the ability and authority possessed by a person to do a job that is based on the knowledge, skills and attitudes in accordance with the specified performance. Further Roger (1983) suggested that an extension is said to be competent if he managed to carry out a series of duties that include: (1) the willingness and ability of extension workers to build relationships directly or indirectly with the targeted community; (2) the willingness and ability to be an intermediary educator / mediator between the sources of innovation with the government, institutions and community extension target; and (3) the willingness and ability to customize activities to do with the needs that can be perceived by the government or agency counselors and targeted community.

Based on the research results and the above theory, the research revealed a real influence on the attitude of the educator competency dimension in working attitude and problem analysis. Thus the results of research can help local governments to increase the competence of extension educator with attention attitude in collaborating and problem analysis.

Knowledge extension directly real effect on the competence of agricultural extension, means that each increase of one unit of knowledge extension will increase the competence of agricultural extension was 0.58 units.

The results showed that there are significant variables knowledge competence agricultural extensions. This means knowledge extension determine whether the poor competence agricultural extension coefficient 0,58 real influence on á $=0.05$ Effect of knowledge extension on competence extension appears in planning outreach programs, utilizing local resources, organize counseling, build networks and ability areas of technical expertise.

Dimensional extension of knowledge are closely linked to agricultural extension competence eis reflected by the observed variables (manifest), is (1) an understanding of the potential extension work areas include understanding the potential of natural resources, leading commodities and farmers' efforts auxiliaries. (2) knowledge extension of access to information resources that includes knowledge of the benefits and how to use computers and internet media, (3) knowledge of horticulture cultivation techniques ranging from soil preparation to the marketing. In connection with the competence of agricultural extension, technical knowledge horticultural cultivation is an observed variable (manifest) that reflects the knowledge of the most powerful extension $(\lambda=1.08)$. Thus the effect of extension of knowledge to develop technical knowledge horticultural cultivation greatest potential to improve the competency of agricultural extension.

Theoretically this study in line with the opinion of the opinion Sumardjo (2006) which explains that competency is the ability and authority possessed by a person to do a job that is based on the knowledge, skills and attitudes in accordance with the specified performance.

Based on the research results and the above theory, the research revealed a real influence on the competency of knowledge extension agricultural extension educator understanding of the dimensions of the potential work areas, access to information resources and technical knowledge to the horticultural cultivation. Thus the results of research can help local governments to increase the competence of extension workers by enhancing knowledge of extension workers through the provision of facilities and infrastructure 
extension, extension to include the various training and improvement of the administrative system of extension services to help farmers increase their productivity.

Skills direct extension real effect on the competence of agricultural extension, means that each increase of one unit of skills trainers will increase the competence of 0.67 units of agricultural extension.

The results showed that the real effect on the variable skills competency agricultural extension. This means the skills of counselors determine whether the poor competence agricultural extension coefficient of 0.67 real influence on á $=0.05$.

Influence skills extension educator at competencies visible in planning outreach programs, utilizing local resources, organize counseling, networking and capacity building areas of technical expertise.

Dimensions of the agents whose skills are closely related to the competence of the agricultural extension reflected by the observed variables (manifest), are (1) the skills to communicate effectively which includes the preparation of extension materials, packaging in the form of multimedia message later skill in conveying the message to the various extension methods. (2) Skills to build networks include skills in negotiating with partners in making business deals. Variables observed (manifest) that has great potential in agriculture extension competency is communicating effectively $(\lambda=1.03)$. Thus the effect of the agents whose skills can develop the skills to communicate effectively the greatest potential to improve the competency of agricultural extension.

Theoretically this study in line with the opinion Sumardjo (2006) which explains that competency is the ability and authority possessed by a person to do a job that is based on the knowledge, skills and attitudes in accordance with the specified performance.

Based on the research results and the above theory, the research revealed a real influence on the competency skills extension agricultural extension of dimensional skills to communicate effectively and build networks. Thus the results of the research can be used as a reference for local government in making policies to increase the competence of extension workers with training that is associated with the ability to plan extension outreach programs and counseling implementation and provide facilities and infrastructure extension

The extension system is directly significant effect on the competence of agricultural extension, means that any reduction in one unit will increase the competence of extension system of agricultural extension was 0.58 units.

The results showed that the variables extension system real effect on the competence of agricultural extension. This means the system determines whether the poor competence extension agricultural extension with a coefficient of -0.58 real influence on ó $=0.05$. Effect of extension system in the apparent extension of competence in planning outreach programs, utilizing local resources, organize counseling, networking and capacity building areas of technical expertise.

Dimensional extension system is factors beyond the individual agents whose influence its behavior in performing the task. Extension system that is closely linked to agricultural extension competence is reflected by three variables observed (manifest), is (1). government policy covering government budgeted funds for extension activities and the existence of a stand-alone extension agency; (2). the support means includes availability and publication, (3). pattern of leadership includes the distribution division of authority and the attitude of the leadership in the decision-making considerations. Support is forming a powerful tool against latent variable extension system. Thus the great potential to improve the competency of agricultural extension.

SEM analysis results indicate that the effect of the extension system coefficient is negative. This means that the extension system negatively affect the competence of agricultural extension. In general, extension system, including the category of being. Likewise, if viewed from the observed variables (manifest) included in the category of being. These findings indicate that the extension system which runs currently not running optimally. Agricultural extension facilities although equipped with two-wheeled vehicles but not supported with adequate operational costs will certainly affect the counseling process. Aside from the publication received only limited extension beam farmer magazine. 


\section{CONCLUSION AND SUGGESTIONS}

Based on the analysis and discussion, it can be concluded that the extension characteristics, motivation extension, extension attitude, knowledge and skills of extension, the extension system real effect on improving the competence of extension. Competence extension appears in planning outreach programs, utilizing local resources, organize counseling, and build networks and capacity extension in the field of technical expertise.

The following suggestions were formulated based on the results of the above conclusions: Agricultural Extension Policy makers need to improve the competence and performance of extension agents to develop the implementation of Good Agricultural Practices (GAP) in Bangka Belitung; It should be further research on the potential extension budget and empowerment strategies in order to develop GAP in Bangka Belitung.

\section{REFERENCES}

1. DT and Glenn Bryan, 2004. Agent and Customer Satisfaction. Journal of Extension, number 6 Volume 42 December 2004. Http://www.joe.org/joe/2004 december / a4.php.

2. FAO, 2003 Report Of The Expert Consultation on a Good Agricultural Practices (GAP) aproach, Proceedings of the Expert Consultation Good Agricultural Practices, 10 to 12 November 2003. FAO, Rome. 3-5

3. Ferdinand, Augusty (2002). Structural Equation Modelling, research management, Agency Publisher Diponegoro University, Semarang.

4. Ghozali and Fuad. 2008. SEM. Theories and Concepts by LISREL 8.80 program. Semarang: BP-Undip.

5. Minister of Manpower and Transmigration Republic of Indonesia NUMBER: KEP. 29 / MEN / III / 2010 On Establishment of the Draft National Competence Indonsesia Agriculture Agricultural Extension field womanly National Competence Indonesia. Jakarta.

6. Kurniawan $\mathrm{R}$ and jahi, 2005. Competence Agricultural extension workers in seven districts in Bekasi, West Java. Journal of Counseling Volume 1 No. 1, September 2010.

7. Marius AJ. 2007. pengembanagan competence extension in East Nusa Tenggara. Dissertation at the Department of Communication and Community Development Program Graduate Institute Pertanian Bogor. Bogor.

8. Notoatmodjo, S. 1993. Introduction to Health Education and Behavioral Sciences, Andi Offset, Yogyakarta

9. Nuryanto, B.G, 2008. "Competence Extension in Agricultural Development". Dissertation, Bogor: the Graduate School of Bogor Agricultural Institute.

10. Robbins PS. 1996. Organizational Behavior. Indonesian edition of Volume I. Jakarta: Prenhallindo

11. Sumardjo, 2006. "Competence Extension" Paper presented at the Treasury Office meeting with the Ministry of Agriculture in Batam in April 2006

12. Sumardjo et al. 2010. Guidance Towards Development of Human Capital and Social Capital In delivering Social Welfare. Scientific Oration Professor in the framework of IPB Anniversary 47th. Bogor. Bogor Agricultural Institute

13. Warya Adang, 2008 paper on Event Day Seminar Workshop Pulpit Farmers se Tidore Islands. Jakarta. Pusbangluhtan-Department of Agriculture.

14. Yunita, 2010. Capacity Building Strategy Irrigated Rice Lebak Household Food Security towards Ogan Ogan Ilir in South Sumatra province. Dissertation at the Graduate Program of Bogor Agricultural Institute.

(C) 2017 by the authors. Licensee RJOAS, Orel, Russia. This article is an open access article distributed under the terms and conditions of the Creative Commons Attribution (CC BY) license: http://creativecommons.org/licenses/by/4.0/ 
DOI https://doi.org/10.18551/rjoas.2017-09.30

\title{
СТОИМОСТНАЯ ТЕОРИЯ ЭФФЕКТИВНОСТИ КАК ИНСТРУМЕНТ ДИАГНОСТИКИ ЭКОНОМИЧЕСКОЙ УСТОЙЧИВОСТИ ПРЕДПРИЯТИЙ АГРОПРОМЫШЛЕННОГО КОМПЛЕКСА \\ EFFICIENCY VALUE THEORY AS A DIAGNOSTIC TOOL OF THE ECONOMIC STABILITY OF THE AGRO-INDUSTRIAL COMPLEX'S ENTERPRISES
}

\author{
Шашло Н.В., кандидат экономических наук \\ Shashlo N.V., Candidate of Economic Sciences \\ Владивостокский государственный университет экономики и сервиса, \\ Владивосток, Россия \\ Vladivostok State University of Economics and Service, Vladivostok, Russia \\ E-mail: ninelllsss@gmail.com
}

\begin{abstract}
АННОТАЦИЯ
В статье представлен теоретико-методический подход к диагностике экономической устойчивости предприятия АПК с использованием стоимостной теории эффективности. Выявлено, что базисом стоимостной теории является необходимость учета расходов на капитал в условиях ограниченности традиционных показателей устойчивости. Аналитический фокку концентрируется на выявлении значимых причинных фракторов, влияющих на перманентность процесса оценки уровня экономической устойчивости предприятия АПК.
\end{abstract}

\section{ABSTRACT}

In the article theoretical and methodical approach to diagnostics of economic stability of the agrarian and industrial complex enterprise with use of the cost theory of efficiency is presented. It is shown that basis of the cost theory is necessity of accounting of expenses on the capital in the conditions of limitation of traditional indicators of stability. Analytical focus concentrates on identification of the significant causal factors influencing permanence of the assessment process of the economic stability level of the agrarian and industrial complex enterprise.

\section{КЛЮЧЕВЫЕ СЛОВА}

Экономическая устойчивость, стоимостная теория эфффективности; предприятие, рентабельность, ликвидность, устойчивое состояние, неустойчивое состояние, переходное состояние, кризисное состояние.

\section{KEY WORDS}

Economic stability, cost theory of efficiency, enterprise, profitability, liquidity, stable state, unstable state, transition state, crisis state.

Оценка экономической устойчивости предприятий АПК вызывает интерес как с научной, так и с практической точек зрения, поскольку выступает информационным конструктором для принятия взвешенных управленческих решений. Фундаментальной основой всех научных подходов к количественному измерению экономической устойчивости выступают фринансовые индикаторы деятельности предприятий и их соотношения, которые обычно определяются на основе учетной аналитической модели. Исследования в данном направлении отражены в работах таких ученых как Б.Н. Герасимов [1], В.В. Бочаров [2], Э.А. Козловская [3], О.С. Черемных [4], О. Чернозуб [5], М.А. Якубович [6], С.Н. Яшин [7], В.В. Ковалев [8], Д.А. Буряков [9], В.Г. Кандалинцев [10], С.И., Крылов [11], Г.М. Харисова [12] и др. Данный подход исключает учет инвестиционных рисков и требуемой нормы доходности, что приводит к необходимости трансформации подходов в соответствии с достижениями теории корпоративных фринансов, основанной на принципах экономической прибыли $[13$, с. 
115-123; 14, с. 11-19]. Стоимостная модель бизнеса не отрицает традиционные показатели устойчивости, но акцентирует внимание на их ограниченности [15, с. 28-30] и отражает необходимость учета расходов на капитал. Таким образом, развитие инструментария экономической оценки процессов и явлений актуализирует потребность в их имплементации на проблематику научных исследований устойчивость предприятий. Обоснование теоретико-методического подхода к оценке экономической устойчивости на основе стоимостной модели, вызывает необходимость в формализации уровня экономической устойчивости в соответствии с потребностями современной экономической диагностики и реального бизнеса.

Целью данной статьи является разработка теоретико-методического подхода к оценке экономической устойчивости предприятий АПК с использованием инструментария стоимостной теории, а именно, стоимостной модели, которая является аналитической инновацией и позволяет формализовать уровни и состояния экономической устойчивости в соответствии с потребностями современной экономической диагностики и реального бизнеса.

Е. П. Кочетков считает, что обеспечение устойчивости - цель новой парадигмы управления бизнесом, которая придет на смену парадигмы ценностноориентированного управления, разрушение стоимости - следствие потери финансовоэкономической устойчивости предприятия [16, с. 451]. Разделяя мнения ученых в указанном научном направлении, предложим собственное видение использования потенциала стоимостной аналитической модели как поликритериальной методической основы диагностики уровня и состояний экономической устойчивости предприятия.

Одним из имманентных свойств устойчивости предприятия является способность сохранять параметры, отражающие нормальное состояние функционирования бизнеса. С точки зрения современных теорий эфффективности (результативности, производительности) деятельности предприятия, «финансовое здоровье» определяется на основе способности компании управлять денежными средствами [17, с. 54]. Традиционные оценки на основе учетной аналитической модели расширяются инновациями в современной бизнес-аналитике, которые заключаются в:

- дополнении традиционной системы фринансовых показателей совокупностью нефинансовых индикаторов;

- расширении спектра аналитических показателей от учетных к финансовым, то есть таких, как прибыль до выплаты процентов (EBIT, Earnings before interest and tax), налогов и начисления амортизации (EBITDA, earnings before interest, tax, depreciation and amortization), чистый денежный поток от операционной деятельности (FOCF, free operating cashflow), чистый денежный поток компании (FCFF, free cashflow to the firm);

- построении системы финансовой аналитики на базе индикаторов, логически связанных с формированием стоимости бизнеса.

Результаты систематизации базиса теории фринансово-экономического оценивания позволяют говорить о том, что ученые и бизнес-аналитики в рамках стоимостной аналитической модели «фринансовое здоровье» предприятия диагностируют по трем проекциям:

- проекция текущей экономической эффрективности деятельности. В традиционной (учетной) аналитической модели интерпретировалась как «проекция доходности (доходности)», поскольку в основу большинства методик были заложены показатели прибыли. В этой проекции оценивается уровень эфффективности использования ресурсов, то есть происходит сопоставление затрат и ресурсов с результатами от их использования. В стоимостной аналитической модели наполнение проекции эффрективности осуществляется в соответствии с оценкой эфффективности на основе проекций учетной модели, содержащей такие аспекты, как: уровень финансовой зависимости / независимости от внешних инвесторов и кредиторов, обеспеченность запасов собственными оборотными средствами, уровень ликвидности и платежеспособности с точки зрения обеспечения своевременного удовлетворения требований кредиторов, уровень рациональности (оптимальности) структуры капитала, 
совокупность показателей деловой активности, инвестиционной привлекательности и т.д.

- Проекция ликвидности (или жизнеспособности), которая связана с анализом способности предприятия к генерированию денежных потоков и возможности выполнять обязательства перед инвесторами, кредиторами и собственниками капитала. Основой формирования проекции ликвидности бизнеса в рамках применения стоимостной аналитической модели является поток свободных денежных средств (FCFE, free cashflow to equity). Логика формирования FCFE определяет потоки денежных средств, которые остаются после определения инвестированного капитала, необходимого для реализации стратегии и выплат кредиторам, то есть характеризует финансовую способность покрывать инвестиционные и текущие потребности в фринансировании хозяйственной деятельности, а также уровень кредитоспособности.

- Проекция сбалансированности роста бизнеса предполагает оценку капитала и диагностирует целесообразность наращивания деятельности. Наиболее известными моделями оценки устойчивого роста являются: модели, основанные на определении роста, которые обеспечиваются собственными источниками фринансирования (модель сбалансированного роста («золотое правило экономики предприятия»)); модель устойчивости роста (SGR, Sustainable Growth Rate), основанная на расчете коэфффициента устойчивости роста; модель внутреннего роста Р. Хиггинса (Model of Optimal Growth Strategy), модели стоимостного роста, представленные в публикациях Г. Арнольда, Ю. Бригхема, С. Валдайцев, А. Дамодарана, С. Росса, К. Уолша и др.

Обозначенная систематизация аналитических моделей роста является условной. В рамках нашего исследования акцент на них проецируется только с позиций фрормирования аналитического инструментария, который будет эфрфективным с точки зрения практики использования в процессах оценки состояния экономической устойчивости предприятий.

Диагностику состояний экономической устойчивости целесообразно осуществлять в проекции современной аналитической VBM-модели. В современных научных исследованиях наиболее популяризованными VBM-моделями являются модели: экономической добавленной стоимости (EVA, Economic Value Added), окончательной прибыли (RI, Residual Income), рыночной добавленной стоимости (MVA, Market Value Added), акционерной добавленной стоимости (SVA, Shareholder Value Added), добавленной денежной стоимости (CVA, Cash Value Added) и модифицированной добавленной денежной стоимости (MCVA, Modified Cash Value Added), денежной рентабельности инвестиций (CFROI, Cash Flow Returnon Investment), внутренней нормы доходности (IRR, Internal Rate of Return), добавленной стоимости для стейкхолдеров (STVA, Stakeholder Value Added). Каждая из указанных моделей предусматривает расчет набора показателей, которые сигнализируют о состоянии «финансового здоровья» компании в пределах проекций «Эффрективность» «Ликвидность» - «Рост» и в дальнейшем трансфрормируются в пирамиду аналитических индикаторов, выступающих ориентирами для достижения целей. Сорормируем логику применения указанных моделей в процессе диагностики и идентификации состояний экономической устойчивости предприятия.

Модель окончательной прибыли (RIM, Residual Income Model) построена на принципах концепции экономической прибыли А. Маршалла [18], а фрормирование самой модели связывают с научными трудами П. Белла, Э. Эдвардса, М. Миллера, Ф. Модильяни, Е. Фамы. Основой фрормирования RIM являются следующие факторы: величина инвестированного капитала на момент оценивания, фрактический и ожидаемый уровень доходности на инвестированный капитал, устойчивость спрэда результатов. В контексте RIM выделяют два направления: операционное, который базируется на концепции операционной окончательной прибыли (ReOI, Residual Operation Income) и капитальное, основой которого является чистая окончательная прибыль (RE, Residual Earnings). Показатель окончательной операционной прибыли, введенный в научный оборот С. Пенменом, является аналогом показателя экономической прибыли в версии консалтинговой компании McKinsey\&Co. 
Информационная направленность $R e O I$ фрокусируется на операционных эфрфектах деятельности предприятия, что обусловило в расчете (формулы 1 - 2) [19, с. 10] под инвестициями использовать балансовую величину чистых активов (NA, NetAssets).

$$
\begin{aligned}
& R e O I=E B I-N A \times W A C C \\
& \operatorname{Re} O I=N A \times\left(R O A-k_{\text {wacc }}\right)
\end{aligned}
$$

где ROA - уровень рентабельности чистых активов, рассчитанный на основе чистой прибыли к уплате процентов; $\mathrm{k}_{\text {wасc }}$ - ставка средневзвешенных затрат на капитал.

Становление показателя окончательной чистой прибыли (формулы 3 - 4) [7, с. 11] связано с П. Белл и Е. Эдвардсом, а также широко используется консалтинговой компанией Marakon Associates. RE- модель довольно часто встречается в научных публикациях как модель Эдварда - Белла - Олсона (Edvards - Bell - Oh/son (EBO) valuation Model):

$$
\begin{aligned}
& R E=N I-k_{E} \times E \\
& R E=E \times\left(R O E-k_{E}\right)
\end{aligned}
$$

где ROE - уровень рентабельности собственного капитала по чистой прибыли («финансовая рентабельность» предприятия); $k_{E}$ - ставка затрат на собственный капитал.

Показатель $R E$ характеризует чистые эффректы результатов деятельности предприятия непосредственно с позиций акционеров. Поэтому инвестициями является величина собственного капитала, результатом - чистая прибыль, а уровень ожидаемой доходности измеряется на основе затрат на собственный капитал.

Ученые выделяют проблему по наполнению аналитических проекций показателями, характеризующими «финансовое здоровье» предприятия. В зависимости от интересов двух групп носителей капитала (кредиторов и собственников) по-разному фрормируются контуры аналитических проекций и их интерпретация, а также разграничиваются учетная (бухгалтерская) модель, ориентированная на учет интересов кредиторов, и стоимостная, в которой отражаются интересы владельцев капитала. Однако стоит отметить, что указанные аналитические модели органично дополняют друг друга в зависимости от конечной цели диагностирования проблемы.

Обеспечение экономической устойчивости предприятия является процессом перманентным [20], а ее состояние можно идентифицировать как «нормальное переходное - кризисное». Если за базовый критерий идентификации состояния экономической устойчивости принять чистую окончательную прибыль, то уровень

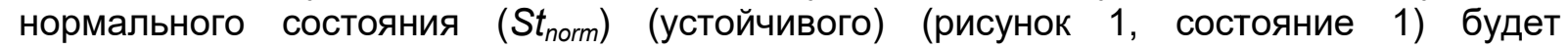
идентифицирован положительными абсолютными значениями $R E$, генерирующими функционирующий капитал.

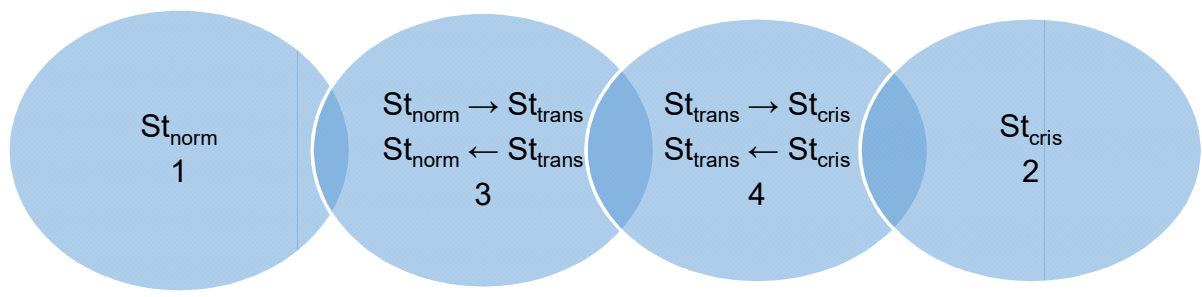

условные обозначения: St norm - нормальная ситуация (normal state); St trans- переходное состояние (transition state); $S t_{\text {cris }}$ кризисное состояние (crisis state).

Рисунок 1 - Идентификация состояний экономической устойчивости предприятия АПК Источник: разработано автором 
Отрицательная величина RE будет означает переход от устойчивого к неустойчивому состоянию, которое может быть идентифицировано как переходное (Sttrans) (рисунок 1 состояние 3 - 4) или кризисное (Stcris) (рисунок 1, состояние 2). Отрицательные значения $R E$ определяются отрицательным значением спрэда производительности (доходности) собственного капитала (Spred Equity), который формируется двумя фракторами: доходностью собственного капитала и уровнем его затратности. Положительную величину спрэда получают когда уровень финансовой рентабельности превышает затраты на собственный капитал (формулы 5, 6):

$$
\begin{aligned}
& \operatorname{Spred}_{\text {Equity }} \geq 0 \text {, если ROE } \geq k_{E} \\
& \operatorname{Spred}_{\text {Equity }}<0 \text {, если ROE }<k_{E} \text { или } N I \leq 0
\end{aligned}
$$

По этой логике можем сформировать первое базовое условие обеспечения устойчивого состояния предприятия АПК, сущность которого заключается в том, что уровень фринансовой рентабельности должен превышать затраты на собственный капитал ( $R O E>k E$ ) (таблица 1). Отрицательное значение спрэда производительности собственного капитала может быть либо результатом убыточности деятельности (тогда предприятие может находиться, либо в зоне 2, или 4 (рисунок 1), или недостаточности уровня финансовой рентабельности для покрытия ставки затрат на собственный капитал (зона 3, рисунок 1). Тенденция роста спрэда производительности собственного капитала ( $\left.T_{\text {sped. equity }}\right)$ (таблица 1 , критерий 1.2$)$ будет обеспечиваться при более высоких темпах роста уровня финансовой рентабельности ( $\left.T_{R O E}\right)$ (таблица 1 , критерий 1.3) по сравнению с ростом ставки затрат на собственный капитал $\left(T_{k .} E\right)$ (фрормула 7) и наоборот (формула 8):

$$
\begin{aligned}
& T_{\text {spred equity }} \geq 1,0, \text { если } T_{R O E} \geq T_{k_{E}} \\
& T_{\text {spred equity }}<1,0, \text { если } T_{R O E}<T_{k_{E}}
\end{aligned}
$$

Уровень фринансовой рентабельности определяется доходностью реализации продукции $\left(\right.$ Prof $\left._{\text {sales }}\right)$, производительностью функционирования активов (Product $\left.t_{\text {ass }}\right)$ и уровнем фринансового риска, который в классической DuPont-модели измеряется на

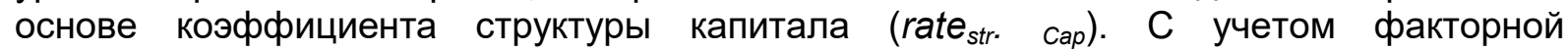
интерпретации финансовой рентабельности фрормула спрэда производительности собственного капитала приобретает вид (формула 9):

$$
\text { Spred }_{\text {Equity }}=\text { Prof }_{\text {sales }} \times \text { Product }_{\text {ass }} \times\left(1+\text { rate }_{\text {strCap }}\right)-k_{E}
$$

Модифицированная формула спрэда производительности собственного капитала позволяет определить критическое значение рентабельности реализации (Prof fales $)$ по

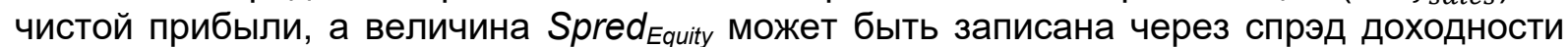
реализации (Spred $d_{\text {prof. sales }}$ ) (форомулы 10 - 12):

$$
\begin{aligned}
& \text { Spred }_{\text {Equity }}=\text { Product }_{\text {ass }} \times\left(1+\text { rate }_{\text {strCap }}\right) \times\left(\operatorname{Prof}_{\text {sales }}-\operatorname{Prof}_{\text {sales }}^{\text {crit }}\right) \\
& \text { Spred }_{\text {prof.sales }}=\text { Prof }_{\text {sales }}-\text { Prof }_{\text {sales }}^{\text {crit }} \\
& \text { Spred }_{\text {Equity }}=\text { Product }_{\text {ass }} \times\left(1+\text { rate }_{\text {strCap }}\right) \times \text { Spred }_{\text {prof.sales }}
\end{aligned}
$$

Динамика спрэда реализации является ключевым фрактором Spred Equity и определяется не только уровнем эффективности внутренних бизнес-процессов компании, но и ее конкурентными позициями на рынках. Поэтому стабильность положительной динамики этого показателя выступает критерием идентификации 
состояния экономической устойчивости (таблица 1, критерий 1.4). Согласно логике формирования Spred Equity индикатором его изменений является производительность активов и уровень рациональности структуры капитала.

Таблица 1 - Критерии и показатели идентификации состояния экономической устойчивости / неустойчивости предприятий

\begin{tabular}{|c|c|c|c|c|c|c|}
\hline \multirow{4}{*}{$\begin{array}{c}\text { Критериии } \\
\text { показатели } \\
\text { идентифрикации }\end{array}$} & \multicolumn{6}{|c|}{ Состояния экономической устойчивости / неустойчивости } \\
\hline & \multirow{2}{*}{ Устойчивый } & \multicolumn{5}{|c|}{ Неустойчивый } \\
\hline & & \multicolumn{4}{|c|}{ Переходный } & Кризисный \\
\hline & $S t_{\text {norm }}$ & $S t_{\text {norm }} \rightarrow S t_{\text {trans }}$ & $S t_{\text {norm }} \leftarrow S t_{\text {trans }}$ & $S t_{\text {trans }} \rightarrow S t_{\text {cris }}$ & $S t_{\text {trans }} \leftarrow S t_{\text {cris }}$ & $S t_{\text {cris }}$ \\
\hline \multicolumn{7}{|c|}{ 1. Стратегический уровень диагностики } \\
\hline \multirow{3}{*}{$\begin{array}{l}1.1 \text { Спрэд } \\
\text { продуктивности } \\
\text { собственного капитала, } \\
\%\end{array}$} & \multirow{3}{*}{$\begin{array}{l}\text { Spred } \\
\text { Equity }>0\end{array}$} & \multicolumn{5}{|c|}{ Spred $_{\text {Equit }}<0$} \\
\hline & & \multirow{2}{*}{\multicolumn{2}{|c|}{$\begin{array}{c}R I>0 \\
R O E>0 \\
R O E<0\end{array}$}} & \multirow{2}{*}{\multicolumn{3}{|c|}{$\begin{array}{l}R I<0 \\
R O E<0\end{array}$}} \\
\hline & & & & & & \\
\hline $\begin{array}{l}1.2 \text { Темп роста } \\
\text { спрэдапродуктивности } \\
\text { собственного капитала }\end{array}$ & & $\begin{array}{l}T_{\text {spred.equity }}< \\
1,0\end{array}$ & $T_{\text {spred.equity }}>1,0$ & \multirow{2}{*}{$T_{R O E}<T_{k E}$} & \multirow{4}{*}{ - } & \multirow{3}{*}{ - } \\
\hline $\begin{array}{l}1.3 \text { Темп роста } \\
\text { финансовой } \\
\text { рентабельности }\end{array}$ & \multirow{2}{*}{$\begin{array}{l}\text { 1) } T_{R O E}>T_{k . E} ; \\
\text { 2) } T_{R O E} \leq \\
T_{k . E} T_{\text {spred. }} \\
\text { sale } \\
>1,0\end{array}$} & $T_{R O E} \leq T_{k . E}$ & 1) $T_{R O E}>T_{k . E}$ & & & \\
\hline $\begin{array}{l}1.4 \text { Темп роста } \\
\text { спрэда реализации }\end{array}$ & & $T_{\text {spred.sale }} \leq 1,0$ & $\begin{array}{l}\text { 2) } T_{R O E}<T_{k . E} \\
T_{\text {spredsale }}>1,0\end{array}$ & $T_{\text {spred.sale }} \leq 1,0$ & & \\
\hline $\begin{array}{l}1.5 \text { Свободные } \\
\text { потокиденежных } \\
\text { средств }\end{array}$ & $F C F>0$ & $F C F<0$ & $\begin{array}{l}\text { 3) } T_{R O E}<T_{k . E} \\
T_{\text {sped.sale }} \leq 1,0 \\
F C F>0\end{array}$ & $F C F<0$ & & $\begin{array}{l}\mathrm{FCF}<0 \\
\mathrm{~T}_{\mathrm{FCF}} \leq 1,0\end{array}$ \\
\hline \multicolumn{7}{|c|}{ 2. Тактический уровень диагностики } \\
\hline $\begin{array}{l}2.1 \text { Коэфрфициенты } \\
\text { ликвидности и } \\
\text { платежеспособности }\end{array}$ & \multirow{4}{*}{\multicolumn{2}{|c|}{ не влияет на решение }} & $\mathrm{k}_{\text {liq }} \in \mathrm{k}_{\text {norm }}$ & $\mathrm{k}_{\text {liq }} \notin \mathrm{k}_{\text {norm }}$ & & $\begin{array}{c}\mathbf{k}_{\text {liq }} \notin \mathbf{k}_{\text {nom }} \\
\mathrm{T}_{\text {liq }} \leq 1,0\end{array}$ \\
\hline $\begin{array}{l}2.2 \text { Коэфффициенты } \\
\text { структуры капитала }\end{array}$ & & & $\mathrm{k}_{\text {str.cap }} \in \mathrm{k}_{\text {nom }}$ & $\mathrm{k}_{\text {str.cap }} \notin \mathrm{k}_{\mathrm{norm}}$ & & $\mathrm{k}_{\text {str.cap }} \notin \mathrm{k}_{\text {norm }}$ \\
\hline $\begin{array}{l}2.3 \text { Уровень } \\
\text { обеспеченности } \\
\text { запасов собственными } \\
\text { оборотными } \\
\text { средствами }\end{array}$ & & & $\begin{array}{l}\text { не влияет на } \\
\text { решение }\end{array}$ & $\begin{array}{c}F(x)=\{0,0 \\
0\}\end{array}$ & $\begin{array}{l}\mathrm{F}(\mathrm{x}) \neq\{0 \\
0,0\}\end{array}$ & $\begin{array}{c}F(x)=\{0 \\
0,0\}\end{array}$ \\
\hline $\begin{array}{l}2.4 \text { Показатели деловой } \\
\text { активности }\end{array}$ & & & \multicolumn{4}{|c|}{$\begin{array}{c}\text { Динамика изменений показателей, объясняет тенденции } \\
\text { происходят в контуре уровней } 2.1 \text { - 2.3. }\end{array}$} \\
\hline
\end{tabular}

Источник: разработано автором.

Основой разграничения устойчивого / неустойчивого состояний выбран критерии

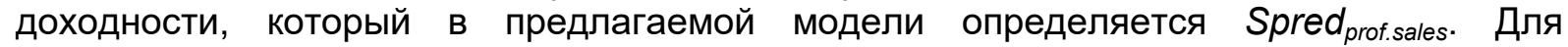
конкретизации типов неустойчивого состояния и шкалы состояний устойчивости, критерии производительности активов и эфффективности фрормирования структуры капитала будут использованы в соответствии с логикой фрормирования $R E$-модели. Попытка сорормировать аналитические параметры для определения «Переходного состояния» обусловила потребность в детализации аналитической шкалы, поскольку иерархия критериев и возможных комбинаций показателей значительно больше, чем при идентифрикации «нормального» и «кризисного» состояний. Для конкретизации «переходного» состояния и с целью адаптации разрабатываемой методики к потребностям бизнес-практики считаем целесообразным определять такие «переходные» состояния:

- переход с «нормального» к «переходному» состоянию - «St $t_{\text {norm }} \rightarrow S t_{\text {trans }}$;

- переход с «переходного» к нормальному» состоянию -«St $\mathrm{t}_{\text {trans }} \rightarrow \mathrm{St}_{\text {norm }}$;

- переход с «переходного» к «кризисному» состоянию - «St $\mathrm{trans} \rightarrow \mathrm{St}_{\text {cris }}$;

- переход с «кризисного» к «переходному» состоянию - «St $\mathrm{St}_{\text {cris }} \rightarrow \mathrm{St}_{\text {trans }}$.

Условия видовой идентификации переходного состояния в соответствии с стратегически значимыми критериями отражены в таблице 1.

В процессе использования разработанного теоретико-методического подхода не предусматривается установление фиксированных шкал и определение жестких формализованных ограничений для идентификации состояний экономической устойчивости предприятия АПК. Аналитический фокус концентрируется на выявлении 
значимых причинных фракторов, влияющих на перманентность процесса оценки уровня экономической устойчивости. При этом содержательное построение критериев и показателей идентификации состояний устойчивости вполне подчиняется логике формирование VBM-модели. Предлагаемая нами шкала состояний экономической устойчивости / неустойчивости предприятия АПК может изменяться в зависимости от целей диагностики и потребностей пользователей. Вариативной является приоритетность критериев, которые заложены в основу идентификации состояний, однако общая идея оценивания должна заключается в способности экономически устойчивого предприятия агропромышленного комплекса обеспечивать формирование положительных потоков добавленной стоимости бизнеса.

\section{БИБЛИОГРАФИЯ}

1. Герасимов Б.Н. Теория управления: монография. - Самара: НОАНО ВПО СИБиУ, 2012.- 404 C.

2. Бочаров В.В., Самонова И.Н., Макарова В.А. Управление стоимостью бизнеса: учеб. пособие. СПб.: СПбГУЭФ, 2009. 124 с.

3. Козловская Э.А., Демиденко Д.С., Яковлева Е. А., Гаджиев М.М. Стоимостной подход к управлению инновационным процессом на предприятии: учебник. СПб.: СПбГПУ, 2010. 205 с.

4. Черемных О.С. Стратегический корпоративный реинжиниринг: процессностоимостной подход к управлению бизнесом. М.: Финансы и статистика, 2005.736 с.

5. Чернозуб О. Стоимостной подход к управлению частной компанией. М.: Альпина Паблишер, 2009. 290 с.

6. Якубович М.А. Финансовые показатели эффрективности функционирования предприятий // Планово-экономический отдел. 2005. № 9. С. 36-39.

7. Яшин С.Н., Кошелев Е.В., Макаров С.А. Анализ эфффективности инновационной деятельности: учеб. пособие. СПб.: БХВ-Петербург, 2012. 288 с.

8. Ковалев В.В. Управление денежными потоками, прибылью и рентабельностью/ В.В. Ковалев.-М.: Проспект, 2007 - 336с.

9. Буряков Д.А. Экономическая безопасность и фринансовая устойчивость предприятий / Д.А. Буряков, М.А. Велькович, А.В. Самойлов. - СПб. : СанктПетербургский государственный университет аэрокосмического приборостроения, 2011. - 375 c

10. Кандалинцев В.Г. Инновационный бизнес: применение сбалансированной системы показателей / В.Г. Кандалинцев. - М. : Дело, 2010. - 172 с.

11. Крылов С.И. Развитие методологии анализа в сбалансированной системе показателей / С.И. Крылов. - М. : Финансы и статистика, 2010. - 149 с.

12. Харисова Г.М. Стоимостной подход к управлению инвестиционно-инновационной деятельностью региональных интегрированных образований в реальном секторе экономики (на примере Республики Татарстан) - Казань:, КГАСУ,2011, -145с.

13. Ивашковская И. В. Финансовые измерения корпоративных стратегий. Стейкхолдерский подход: монография / И. В. Ивашковская. - М.: ИНФРА-М,2013. C. 115-123.

14. Grant R.Shareholder value maximization: Rehabilitatinga "dumb idea" / R.Grant // Competitive Strategy Newsletter. - 2010. - 4 (1). - P. 9-11.

15. Pettit, J. Strategic Corporate Finance / J. Pettit. -2 nd ed.JohnWiley\&Sons: NJ. - 2007. - P. 28-30.

16. Кочетков Е. П. Финансово-экономическая устойчивость организации: диагностика угрозы утраты на ранних стадиях как один из фракторов экономического роста России (стоимостной аспект) / Е. П. Кочетков // Труды Вольного экономического общества России, работы победителей конкурса научных работ молодежи «Экономический рост России». - 2012. - Т. 161. - С. 447 - 466.

17. Теплова Т. В. Инновации в финансовой аналитике / Т. В. Теплова, А. Н. Рассказова // Модернизация. Инновации. Развитие. - 2012. - Т. 12. - № 4. - С. 54 - 61. 
18. Маршалл А. Принципы политической экономии / А. Маршалл. - Пер. с англ. Р. И. Столпера, общ. ред. С. М. Никитина - М.: Издательство Прогресс, 1983г. - 416 с.

19. Волков Д. Л. Показатели результатов деятельности: использование в управлении стоимостью компании / Д. Л. Волков // Российский журнал менеджмента. - 2005. Том. 3. - № 2. - C. 3-42.

20. Vorozhbit O.Yu., Shashlo N.V. Integration Processes and a Common Agricultural Market under the Conditions of the Eurasian Economic Union // International Business Management. Том: 10 Часть: 19. С.4635 - 4643.

cc) (i) 2017 by the author. Licensee RJOAS, Orel, Russia. This article is an open access article distributed under the terms and conditions of the Creative Commons Attribution (CC BY) license: http://creativecommons.org/licenses/by/4.0/ 
DOI https://doi.org/10.18551/rjoas.2017-09.31

\title{
ОЦЕНКА ЭФФЕКТИВНОСТИ НОВЫХ ПРОДУКТОВ ПИТАНИЯ С УЧЕТОМ ИСПОЛЬЗОВАНИЯ ИННОВАЦИЙ \\ EVALUATION OF THE EFFECTIVENESS OF NEW FOOD PRODUCTS TAKING INTO ACCOUNT THE USE OF INNOVATIONS
}

\author{
Лоза А.А., научный сотрудник \\ Loza A.A., Researcher \\ Санкт-Петербургский национальный исследовательский университет \\ информационных технологий, механики и оптики, Санкт-Петербург, Россия \\ St. Petersburg National Research University of Information Technologies, Mechanics and \\ Optics, St. Petersburg, Russia \\ E-mail: projecttechnic@mail.ru
}

\begin{abstract}
АННОТАЦИЯ
Нейронные сети успешно применяются в экономике, бизнесе, технике, физике. С их помощью можно решать задачи прогнозирования, классификации или управления и, в более широком плане, задачи распознавания образов. Нейронные сети нелинейны по своей природе. В задачах, где линейная аппроксимация неудовлетворительна, линейные модели работают плохо. Нейронные сети учатся на примерах. Пользователь нейронной сети подбирает представительные данные, а затем запускает алгоритм обучения, который автоматически воспринимает структуру данных. Сравнительно простые нейронные сети, которые строит система, например, ST Neural Networks или NeuroShell 2, являются мощным инструментом в арсенале специалиста по прикладной статистике. В работе рассмотрен с названных позиций рынок продуктов питания, имеющие сбалансированные рецептуры.
\end{abstract}

\section{ABSTRACT}

The neural networks are successfully used in economics, business, engineering and physics. They can be used to solve the problems of prediction, classification and management, and generally, the problems of pattern recognition. The neural networks are non-linear in nature. The models do not work well in the problems where the linear approximation is not satisfactory. The neural networks learn by the examples. The user of neural network selects representative data, and then runs a learning algorithm which automatically accepts the data structure. Rather simple neural network, which is building the system, for example, ST Neural Networks or NeuroShell 2, is a powerful tool in the arsenal of an expert in the applied statistics. From the named position in this article we consider the food market with balanced formulas.

\section{КЛЮЧЕВЫЕ СЛОВА}

Нейронные сети, продукты питания, распознавание образов.

\section{KEY WORDS}

Neural networks, food, pattern recognition.

Современная индустрия продуктов питания, как и другие отрасли, реальной экономики стремится производить продукцию, удовлетворяющую как можно более широкому спектру потребителей, но с наименьшими производственными издержками. Специфика этой отрасли состоит в том, что ее продукция должна удовлетворять еще одному важному требованию - максимально соответствовать здоровому образу жизни.

Одним из наиболее апробированных путей решения такой задачи является выпуск продуктов питания сбалансированных по основным питательным веществам. 
Пусть некоторая фрирма, разрабатывающая и производящая новые продукты питания, имеющие необходимые для жизни человека пищевые вещества, такие как белки, жиры и углеводы вводит в их состав некоторые витаминные добавки.

Учитывая конкуренцию на рынке, целесообразно создать некоторую экономикоаналитическую систему, которая поможет продавать продукцию этой фирмы.

Стоимость продуктов питания в регионе, где работает фрирма, относительно высока, и можно надеяться, что новые рецептуры продуктов питания существенно сэкономят деньги покупателей. Разрабатываемая система, должна предсказывать ежедневную стоимость продуктов питания, которые продает фрирма, при условии удовлетворения запроса потребителя на отдельные группы пищевых веществ в зависимости от калорийности.

После того, как принято решение о цели прогноза, нужно решить, какие переменные следует принять во внимание для осуществления такого предсказания. Очевидно, что на стоимость продуктов питания потребленных за день, влияет несколько факторов, в том числе количество жиров, количество белков, количество углеводов и т.д. При первой попытке построить систему, например, на основе нейронной сети задача остается простой, поэтому можно использовать в качестве наиболее важной переменной среднее количество жиров потребляемых за день, для предсказания дневной стоимости продуктов питания одним потребителем.

Заметим, что до того, как решиться использовать нейронную сеть, необходимо рассмотреть возможность использования регрессионного анализа. В рассматриваемом случае один момент делает построение линейной модели сложным: если содержание жиров лежит в диапазоне от 32 до $45 \%$, то он весной и летом такие продукты питания плохо потребляются, поэтому дневная стоимость потребляемых продуктов питания нелинейна [1].

После того, как принято решние, о цели прогнозирования и составе переменных используемых для такого предсказания, можно приступить к использованию экономико-аналитической системы на базе нейронной сети.

Наиболее просто построить такую систему можно с помощью программы NeuroShell 2.

Обычный порядок действий для создания приложения в NeuroShell 2 состоит в последовательном переходе от значка к значку слева направо, сверху вниз.

В процессе введения начальных данных необходимо набрать данные за прошлый год. В рассматриваемом случае необходимо вводить ежедневные отчеты стоимости проданных продуктов питания за год, рассортированные в порядке от самой низкой до самой высокой стоимости.

Для успешного построения системы нужно проинформировать NeuroShell 2 о том, какие из столбцов являются входами, а какие - выходами.

Можно обозначить столбец "Среднее содержание жиров" как вход, І, а столбец "Стоимость/день" как столбец, который сеть пытается предсказать (выход, А).

Следующим шагом является ввод минимального и максимального значений для каждой переменной в строках Минимум и Максимум. Поскольку нейронные сети требуют перевода переменных путем масштабирования в диапазоны от 0 до 1 или от 1 до 1, сети необходимо знать истинный диапазон значений переменной. В этом модуле можно ввести минимальное и максимальное значения для каждой переменной, которая должна использоваться сетью, или можно вычислить диапазон автоматически из введенных данных, вызывая пункт «Расчет мин/макс» меню «Установки». Выбор этого пункта меню также приводит к вычислению среднего и стандартного отклонения для каждой переменной [2].

В общем случае, нужно использовать диапазон, границы которого вплотную примыкают к данным. (Можно указать значения минимума и максимума, которые будут чуть меньше и чуть больше соответствующих значений в фрайле данных, чтобы предусмотреть более широкий диапазон для будущих предсказаний, или можно предпочесть выбрать диапазон более узкий, чтобы исключить выбросы, которые могут повлиять на точность работы сети.) Если не установить значения минимума и 
максимума вплотную к данным, сеть может потерять способность отслеживать мелкие различия в данных.

Деле следует перейти к тренировке сети, щелкая дважды по значку «Обучение», чтобы вызвать модуль тренировки. При появлении этот модуль уже должен знать о количестве входов и выходов из.MMX-фрайла (созданного в модуле «Выбор входов/выходов»). Тем не менее, есть еще несколько параметров, которые необходимо задать, прежде чем начать тренировку. Во-первых, нужно указать сложность задачи, щелкнув по одному из переключателей в левой верхней части экрана. Можно решить, что имеющиеся данные очень просты. Тогда следует щелкнуть мышью по кнопке «Очень простые». Следует обратить внимание, что при этом значения скорости обучения и момента автоматически устанавливаются равными 0,6 и 0,9 .

Затем следует установить количество скрытых нейронов. Щелчок по кнопке вычисления по умолчанию вызывает вычисление количества по встроенной фрормуле NeuroShell 2, которая дает хорошее начальное приближение для будущих задач.

Можно использовать случайный порядок представления данных сети, так как данные отсортированы в порядке от низких стоимостей к высоким, а это позволяет сети хорошо предсказывать результат при всех стоимостях.

Для первого сеанса тренировки следует устанавливать интервал «Калибровки» равным 0, хотя это мощный инструмент, который следует использовать для большинства задач.

Основной статистический показатель тренировки - это внутренний средний "показатель ошибки". Предварительно вычислить или точно воспроизвести этот средний показатель на тренировочном наборе невозможно, да это и совершенно не нужно. Тем не менее, это среднее по всем примерам значение квадрата ошибки всех выходов, вычисленных в пределах внутреннего интервала NeuroShell 2. Значение этого числа само по себе бесполезно. Полезно в процессе тренировки видеть, улучшается ли качество сети, т.к. по мере улучшения сети показатель уменьшается.

Можно посмотреть, хорошие ли результаты дает построенная сеть. Нужно дважды щелкнуть по значку «Применение» к файлу и выбирать пункт «Начать» применение из меню «Работа». По умолчанию флажки "Вычислять R квадрат и т.д.", "Включать выходы в.OUT-фрайл" и "Включать в.OUT-файл разности между выходами и ответами сети" включены.

Модуль «Применение» по умолчанию обрабатывает.РАТ-файл, который представляет собой первый введенный набор данных. Количество потребляемых жиров каждого дня (вход) обрабатывается натренированной сетью, которая вычисляет стоимость продуктов питания за этот день. На экране отображаются статистические показатели, измеряющие точность работы натренированной сети [3].

Натренированная сеть дает значение R квадрат на.РАТ-фрайле около 0,95. Нужно записать значение $\mathrm{R}$ квадрат, чтобы сравнивать эту сеть с другими, которые можно создать позже.

$\mathrm{R}$ квадрат, коэфффициент множественной детерминации, - это статистический индикатор, обычно используемый при анализе методом множественной регрессии. Он сравнивает точность модели с точностью тривиальной реперной модели, для которой предсказание представляет собой просто среднее по всем примерам. При безупречном совпадении предсказаний с желаемыми значениями $R$ квадрат будет равен 1, при хорошем совпадении - близок к 1 , а при очень плохом совпадении близок к 0. Если предсказания построенной нейросетевой модели хуже, чем можно было бы предсказать, просто используя среднее значение выхода по всем примерам, значение $\mathrm{R}$ квадрат будет равно 0.

Теперь нужно просмотреть.OUT-файл, в котором показаны реальные значения стоимости за день, которые вводились в фрайл первоначально, предсказания сети (ее выход) и разница между ними. Можно дополнительно осуществить "приписывание" выходного файла к исходному файлу данных, чтобы видеть исходный фрайл данных вместе с предсказаниями сети. Модуль «Приписывание» выходного фрайла сделает 
это, создавая при этом новый -OUT-фрайл. Для вызова этого модуля можно щелкнуть по значку «Приписывание» выходного файла. Поскольку вероятно, нужно контролировать результаты работы сети рядом со значениями входной переменной, следует щелкнуть по значку «Приписать файл сбоку».

Теперь можно оценить.OUT-фрайл с помощью заполненной Таблицы, дважды щелкнув по значку «Просмотр данных».

Таблица не является электронной таблицей коммерческого класса, и при загрузке больших фрайлов работает довольно медленно. Если использован очень быстрый компьютер, то это не причинит неудобств, в противном случае необходимо использовать программу работы с электронными таблицами [4-5].

Можно оценить качество модели предсказания стоимости продуктов питания другим способом, не использующим R квадрат.

Это можно сделать, например, посмотрев на данные в графической форме.

Видно, что модель на основе нейронной сети близко следует реальным данным. Предположим, что ответы недостаточно хороши. Что следует делать в этом случае? Самое простое - это попробовать другие архитектуры сети из модуля «Нейронные сети для профессионала».

С другими архитектурами можно получить несколько лучшие результаты, но на практике, вероятно, необходимо сделать что-то из того, что перечислено ниже в порядке убывания вероятности положительного эффекта:

1. Использовать «Калибровку». NeuroShell 2 использует «Калибровку» для оптимизации сети путем применения текущей сети в процессе тренировки к независимому тестовому набору. Можно создать тестовый набор данных автоматически, используя модуль «Выделения» тестового набора. «Калибровка» позволяет найти оптимальную сеть для данных в тестовом наборе, (что означает, что сеть способна хорошо обобщать, и дает хорошие результаты на новых данных).

При использовании «Калибровки» это делается путем вычисления среднего квадратичного отклонения между реальными и предсказанными значениями для всех выходов по всем примерам. При «Калибровке» вычисляется квадратичное отклонение для каждого выхода в данном примере, они суммируются, и затем вычисляется среднее значение этой величины по всем примерам в тестовом наборе [6-8].

Для сетей с обратным распространением ошибки сеть сохраняется всякий раз при достижении нового минимума средней ошибки (или среднего квадратичного отклонения). Чтобы использовать «Калибровку», необходимо установить интервал проверки «Калибровки», т.е. как часто производится оценка на тестовом наборе. Можно устанавливать его в диапазоне от 50 до 200. В этом случае также целесообразно выбрать "Автоматическую запись сети при наилучшем результате на тестовом наборе".

2. Включить в рассмотрение переменные, которые лучше предсказывают то, что сеть пытается предсказать. Другим выходом являются лучшие способы представления переменных, которые уже есть. Можно получить лучшие результаты, включив в рассмотрение переменную для количества минеральных добавок в продукте питания. Увеличение этого показателя непосредственно влияет на калорийность продукта, возможность использования его в качестве лечебно-профилактического и т.д.

Если бы у сети было большое количество входов, возможно, стоило бы преобразовать некоторые входы в отношения. Это дает больше информации при меньшем количестве переменных. Нейронные сети похожи на людей: чем проще сделать входы, которые они должны выучить, тем легче сети выучить задание. Отношения служат этой цели.

3. Подойти заново к вопросу о том, что именно нужно предсказать. Для некоторых вещей это сделать проще, чем для других. Иногда можно получить более высокую точность, предсказывая процентное изменение стоимости продуктов питания, а не саму стоимость.

4. Можно собрать более качественный набор исторических данных или более представительный тестовый набор. Убедитесь в том, что выбранные переменные 
нормированы, если это необходимо. Иногда это означает необходимость убедиться в том, что уровни, характерные для ситуации несколько лет назад, переведены в тот же диапазон, что и сегодняшние. В научной области нормировка может означать многие другие вещи. Если нет возможности нормировать данные, придется предъявить сети гораздо большее количество примеров, с соответствующим увеличением времени обучения.

5. Следует подобрать скорость обучения, момент и количество скрытых нейронов и посмотрите, не получатся ли сети более высокого качества. Можно использовать Turboprop, который не требует установки скорости обучения и момента. Этот метод включен в модуль «Проектирования» в системе для профессионала и работает для сетей с обратным распространением ошибки.

Описанный подход построения системы экономико-аналитического анализа стратегии поведения фрирмы-производителя на рынке продуктов питания не исчерпывает возможностей применения приемов нечеткой логики в экономических целях.

Не менее эффективным в некоторых случаях являются подходы построения многомерных моделей с помощью модуля Fuzzi Logic пакета программ Mathlab или MathCad. В этом случае удается проанализировать комплексное влияние на выбранную целевую функцию сразу нескольких изменяемых параметров.

Органолептические оценки можно рассматривать как лингвистические переменные теории нечетких множеств, что позволяет одновременно в одной серии экспертных исследований оптимизировать биотехнологические и экономический параметр продукта. В результате органолептической оценки дегустаторами продукта были получены две матрицы оценок.

Таблица 1 - Результаты органолептической оценки продукта

\begin{tabular}{|c|c|c|c|c|c|c|c|c|}
\hline Обозначение матриц & Показатели & \multicolumn{5}{|c|}{ Средние арифметические величины показателей } \\
\hline \multirow{2}{*}{$\mu 1^{\text {-матрица ингредиента 1 }}$} & Содержание мг/100 г, g & 20 & 21.4 & 23 & 25 & 27.2 & 28.6 & 30 \\
\cline { 2 - 9 } & Средние оценки экспертов & 0.12 & 0.32 & 0.68 & 0.88 & 0.82 & 0.38 & 0.06 \\
\hline \multirow{2}{*}{$\mu 2^{\text {- матрица цены }}$} & Цена руб/100 г, h & 3.5 & 4 & 5 & 6 & 10 & 20 & 30 \\
\cline { 2 - 9 } & Средние оценки экспертов & 1 & 1 & 1 & 1 & 0.64 & 0.35 & 0 \\
\hline
\end{tabular}

Такого рода экономико-аналитические системы часто оказываются эффрективны в практике работы пищевых производств и используются для обучения и повышения профессиональной квалификации менеджеров крупных фрирм-производителей [9-12].

\section{БИБЛИОГРАФИЯ}

1. Алексеев Г.В, Аксенова О.И. Использование нечеткой логики в пищевых производствах [Текст] / Сборник материалов докладов IV международной научно практической конференции «Фундаментальная наука и технологии - перспективные разработки». Северный Чарльстон. США, 2014. - С. 4-8.

2. Алексеев Г.В. Основы теории решения изобретательских задач // учеб. пособие / Г.В. Алексеев, Н.Б. Жарикова; Федер. агентство по образованию, Гос. образоват. учреждение высш. проф. образования С.-Петерб. гос. ун-т низкотемператур. и пищевых технологий. СПб., 2004.

3. Алексеев Г.В., Бриденко И.И Виртуальный лабораторный практикум по курсу «механика жидкости и газа».Учебное пособие / Саратов, 2013.

4. Алексеев Г.В., Верболоз Е.И., Кондратов А.В.Возможности управления процессом измельчения путем изменения структурно-механических свойств пищевой смеси. Известия санкт-петербургского государственного университета низкотемпературных и пищевых технологий. 2008. № 4. С. 54-58.

5. Арет В.А. Реологические основы расчета оборудования производства жиросодержащих пищевых продуктов. Учеб. пособие для студентов вузов, обучающихся по направлению подгот. бакалавров и магистров 551800 - "Технол. машины и оборуд." для дисциплины "Технол. оборуд. при пр-ве жировой продукции" 
/ Федер. агентство по образованию, Гос. образоват. учреждение высш. профр. образования С.-Петерб. гос ун-т низкотемператур. и пищевых технологий. СПб., 2004

6. Алексеев Г.В., Аксенова О.И. Использование математического моделирования для ресурсосберегающих пищевых производств / Процессы и аппараты пищевых производств - № 3 - 2014.

7. Аксенова О.И., Шубенкова В.А. Проектирование многокомпонентных продуктов с использованием теории нечетких множеств / Сборник трудов II заочной Международной научно-практической конференции «Техника и технологии: роль в развитии современного общества». Краснодар. 2013. - С. 34-3.

8. Аксенова О.И., Шубенкова В.А. Составление рецептурной смеси проектируемых продуктов при неопределенности структурных факторов показателей качества / Сборник трудов Международной научно-технической конференции «Инновационные технологии в пищевой промышленности: наука, образование и производство». Воронеж. 2013. - С.816-820.

9. Арет В.А., Кулаев Д.Х., Малявко Д.П., Морозов Е.А. О подготовке учебных материалов для обучения инженеров в интернете Научный журнал НИУ ИТМО. Серия: Процессы и аппараты пищевых производств. 2006. № 1. С. 20-25.

10. Арет В.А., Байченко Л.А., Байченко А.А. Применение нечеткой логики в управлении предприятием пищевой промышленности // Научный журнал НИУ ИТМО. Серия: Экономика и экологический менеджмент / Санкт-Петербургский национальный исследовательский университет информационных технологий, механики и оптики, 2014. - Вып. 15. - № 2. - URL: http://economics.inbt.ifmo.ru/file/article/10476.pdf

11. Арет В.А., Байченко Л.А., Арет Г.М., Байченко А.А. Рост численности населения Земли и эволюция продовольственных технологий. Научный журнал НИУ ИТМО. Серия: Экономика и экологический менеджмент / Санкт-Петербургский национальный исследовательский университет информационных технологий, механики и оптики, - 2010. - Вып. март 2010. - URL: http://economics.openmechanics.com/articles/169.pdf.

12. Арет В.А., Пирогов А.Н., Полякова Г.В., Шокальская Л.П. К интенсификации технологических процессов формования на основе распознавания реологических образов // Межвузовский сборник научных работ "Интенсификация существующих и разработка новых технологических процессов в пищевой промышленности. Москва, 1978.

(C) 2017 by the author. Licensee RJOAS, Orel, Russia. This article is an open access article distributed under the terms and conditions of the Creative Commons Attribution (CC BY) license: http://creativecommons.org/licenses/by/4.0/ 
DOI https://doi.org/10.18551/rjoas.2017-09.32

\title{
RICE PRICE VOLATILITY IN EAST JAVA
}

\author{
Wati Rustida Yulivia Eko* \\ Graduate School, Faculty of Agriculture, University of Brawijaya, Indonesia
}

Anindita Ratya, Setiawan Budi

Department of Socio Economics, Faculty of Agriculture, University of Brawijaya, Indonesia

*E-mail: rustida.yulivia@gmail.com

\begin{abstract}
The purpose of the research is analyzing the volatility and volatility spillover of monthly price of paddy at the level of farmers and consumers in 2010-2016. ARCH/GARCH used to analyze volatility and GARCH BEKK-model is used to analyze the volatility spillover. The results of the analysis show that price volatility at the farmer level is very high (extremely high volatility), price volatility at the consumer level is low (low volatility), and volatility spillover does not occur between the farmers and the consumers market. The need to guarantee an effective floor price as well as information disclosure related to the market commodity prices so that the pattern of prices transmission among interrelated markets can be symmetrical.
\end{abstract}

\section{KEY WORDS}

Price, volatility, rice, market.

Nominal prices of agricultural commodities are generally more volatile than nonagricultural commodities (Tomek and Robison, 1990). The cause was a shock on production due to natural factors such as climate change, pests, and diseases (Banterle and Vandone, 2013) as well as supply and demand in the short term that is inelastic (Demeke et al., 2012). FAO et al., (2011), explained that the onset of price volatility or price variations will not be a problem when the price moves subtly and price trend shows a typical seasonal pattern. However, the variation of the price will be a problem when the price variations occurred too large and could not be anticipated by the market (Donmez and Magrini, 2013).

There are several factors that can be varying the prices of rice. On the demand side, price variations are caused by ups and downs of people's income (Gilbert and Morgan, 2011) and the price of fuel oil (Demeke and Balie, 2016). On the supply side, the availability of rice stocks affects the occurrence of the price variations are generally caused by natural shock factors such as weather and an uncertain climate, pests and diseases, and natural disasters (Kalkuhl et al., 2013).

The fluctuated price condition of rice led to higher risks and uncertainties faced by farmers or consumers (Assefa et al., 2015). From the consumer side, the high rice prices and volatile became a threat for the poor especially in the developing countries (Serra and Gil, 2012) such as Indonesia are predominately consuming rice as a major commodity in meet the needs of calories (Badan Penelitian dan Pengembangan Pertanian, 2012). When the price of rice goes up, then the purchasing power of society in meeting the needs of calories will decrease (Badan Pengkajian dan Pengembangan Kebijakan Perdagangan, 2015). So, fluctuation faced in the high level of price will automatically be able to increase the number of poverty rates.

Irawan (2007) explained that price fluctuations can harm the farmers because the lack of sales management to get a more favorable selling price in the right time. Prices at the farmers level are likely to be determined by the tradesman or middleman because farmers have low bargaining positions in determining price and only acts as a recipient of the price (price takers) (Jamal et al., 2006). Farmers often have limited access information about the price movement in the market. 
The price received by the farmers is directly proportional to the income that he received. Low grain prices and volatile impact on the decrease of well-being level of farmers. Without adequate welfare, farmers as producers will lose the incentive to produce because of the magnitude of the risks faced by farmers due to the uncertainty of the price. So the farmers as producers can eventually reluctant to plant rice or even switching production to other commodities which are more profitable. This condition can interfere with the level of food availability and food security in the future. Thus, the purpose of the research was to analyze the present price volatility of farmers and consumers, as well as analyze the volatility spillover between the consumer market and farmers market.

\section{MATERIALS AND METHODS}

The data used is the price of harvested dry grain at the level of farmer and rice price at the level of consumer from January 2010 until December 2016 in Jember District, Malang District and Kediri District to represent the production of East Java based on the use of irrigation technical (surplus area), the technical and not technical irrigation (balance area), as well as not technical irrigation (deficit area). The following methods are used to analyze volatility and volatility spillover:

1. Stationary Test, selection of the best ARMA order and the test of ARCH:

Time series data that will be analyzed must be stationary (Ajija et.al, 2011). Data that has been stationary for each subsequent price variable being estimated or prediction Autoregressive Moving Average (ARMA) model using the method of trial error. The best model of ARMA has criteria, among others, all significant parameters coefficients (probability $<0.05$ ) with the smallest value of the standard error of a regressor (Ekananda, 2016). Having obtained the best model of ARMA, the next step is testing the presence of $A R C H$. Test of ARCH (ARCH effect) can be done with ARCH-LM test (Connor and Keane, 2011). This test is done to make sure that the value of the variance of the error does not have the same variance (heteroskedasticity).

2. Volatility Analysis:

Behavior of Volatility Analysis. A new method used in analyzing the data time series well-known as Autoregressive Conditional Heteroskedasticity (ARCH) model. The ARCH model allows the occurrence of shocks in the future period to influence the current volatility positively. While the GARCH model generalizes ARCH model which the GARCH model does not only allow the previous shocks, but also the previous volatility that affects current volatility (Connor and Keane, 2011).

$$
\begin{aligned}
& \sigma^{2} P P=\alpha_{0}+\alpha_{1} \varepsilon^{2} P P_{t-1}+\beta_{1} \sigma^{2} P P_{t-1}+\varepsilon_{t} \\
& \sigma^{2} C P=\alpha_{0}+\alpha_{1} \varepsilon^{2} C P_{t-1}+\beta_{1} \sigma^{2} C P_{t-1}+\varepsilon_{t}
\end{aligned}
$$

Where, $\sigma^{2}$ is the response variable (dependent) at time $(t)$ or current residual diversity; $\alpha_{0}$ is a constant, $\varepsilon_{t-1}^{2}$ is the ARCH/Volatility in the previous period; $\alpha_{1}, \beta_{1}$ is a coefficient of estimation; $\sigma_{t-1}^{2}$ is $\mathrm{GARCH} /$ residual diversity of the previous period; $P P$ is the price of harvested dry grain at the level of farmers, $C P$ is the price of rice at the consumer level; and $\varepsilon_{t}$ is a the error term factor in period to $t$.

According to Lipetit (2011), the sum of the estimated coefficients $\alpha_{1}+\beta_{1}$ on each model indicates the level of volatility. So, the volatility can be known by looking at the values $\alpha_{1}+\beta_{1}$. In this case, $\alpha$ is the value of ARCH and $\beta$ is the value of GARCH. Where $\alpha_{1}+\beta_{1}<1$ shows that the volatility is low (low volatility), $\alpha_{1}+\beta_{1}=1$ shows the volatility that occurred is high (high volatility) and $\alpha_{1}+\beta_{1}>1$ shows the volatility that occurred is very high (extremely high volatility).

The Measurement of Annualized Volatility. Here's how to calculate the annualized volatility according to Kant (2011), Ledebur and Schmitz (2012); and Singh and Kumar (2015). 


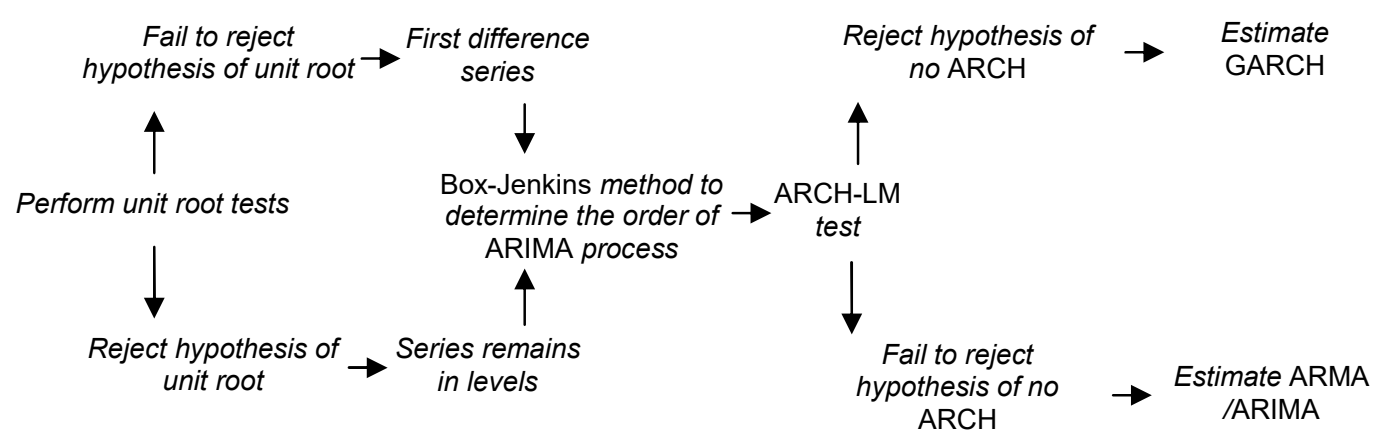

Figure 1 - Flowchart of methodology of calculating conditional volatility

(Moledina et al., 2004)

Measuring price changes in the market by calculating the log of a ratio $\left(P h_{j}\right)$ on the price $\left(P_{2}\right)$ of the current price $(t)$ to the previous price $\left(P_{1}\right)$.

$$
\mathrm{Ph}_{\mathrm{j}}=\ln \left(\frac{P_{2}}{P_{1}}\right)
$$

Calculate the "average variance" from the average. The calculation of "average variance" can be measured using standard deviation:

$$
\overline{\mathrm{SD}}=\sqrt{\frac{\sum(X-X)^{2}}{n}}
$$

Calculate the annualized volatility:

$$
\text { Annualized volatility }=S D^{*} \sqrt{12}
$$

Analysis of Volatility Spillover. In analyzing the volatility spillover used the GARCH BEKK-models to uncover the volatility spillover between prices at the level of farmers and consumers. The following GARCH BEKK- model used to analyze price volatility in the level of the farmer and price at the consumer level:

$$
\mathrm{hCP}, \mathrm{PP}_{\mathrm{t}}=\mathrm{CCP}, \mathrm{PP}+\alpha_{C P, P P}^{2} v_{C P_{t}-1}^{2} v_{P P_{t}-1}^{2}+\beta_{C P, P P}^{2} \mathrm{hCP}, \mathrm{PPt}-1
$$

Where, $h C P, P P t$ is the conditional covariance relationship between the price of rice at the consumer level and the price of harvested dry grain at the farm level at the time $(t) ; C$ is a constant; $\alpha, \beta$ is the estimation of parameter; $h C P, P P-1$ is the conditional covariance relationship between the price of rice at the consumer level and the price of harvested dry grain at the farm level at a previous period; $v_{C P_{t}-1}^{2} v_{P P_{t}-1}^{2}$ is the squared residual between the price of rice at the consumer level and the price of harvested dry grain at the farm level at a previous period; $P P$ is a variable of price at farmer level; and $C P$ is the consumer price variable. The interrelated market volatility spillover can be known from the squared residual value $\left(v_{P P_{t}-1}^{2} v_{C P_{t}-1}^{2}\right)$ (Rapsomanikis, 2011). If the value of $v_{P P_{t}-1}^{2} v_{C P_{t}-1}^{2}<0$ (negative), It didn't occur volatility spillover between the price of rice at the consumer level and harvested dry grain at the level of the farmer. And If the value of $v_{P P_{t}-1}^{2} v_{C P_{t}-1}^{2}>0$ (positive), then there is volatility spillover between the price of rice at the level of consumers and the price of harvested dry grain at the farm level.

\section{RESULTS AND DISCUSSION}

Result of Price Volatility. The analysis of price volatility is used to indicate the degree of variation of the ups and downs of the price of harvested dry grain at the farmers level and 
rice prices at the consumer level in East Java. Based on table 1, price data at the farmers level and consumers in Jember, Malang, and Kediri has a value of $t_{\text {statistic }}<$ test critical value. This means that the data on the level of the farmer and the consumer are stationary level. Thus, it can be said that the time series data does not contain spurious regression and unit root.

Table 1 - Stationary Test Results of Price Data at the Level of Farmers and Consumers

\begin{tabular}{cccccc}
\hline \multirow{2}{*}{ Variable } & \multirow{2}{*}{ Level } & \multicolumn{4}{c}{ ADF Test } \\
\cline { 3 - 6 } & & Test Critical Value $(\alpha=5 \%)$ & $t_{\text {statistic }}$ & Prob & Stationarity \\
\hline Farmer's price in Jember & Level & $-2,897223$ & $-10,16557$ & 0,0000 & stationary \\
Consumer's Price in Jember & Level & $-2,897223$ & $-9,227915$ & 0,0000 & stationary \\
Farmer's price in Malang & Level & $-2,897223$ & $-6,056026$ & 0,0000 & stationary \\
Consumer's Price in Malang & Level & $-2,898145$ & $-4,641213$ & 0,0003 & stationary \\
Farmer's Price in Kediri & Level & $-2,897223$ & $-9,706081$ & 0,0000 & stationary \\
Consumer's Price in Kediri & Level & $-2,897223$ & $-6,683464$ & 0,0000 & stationary \\
\hline
\end{tabular}

Source: Secondary data (re-make), 2017.

Error tolerance $(\alpha)$ 5\%.

After the data was stationary, the next step was the selection of the most suitable ARMA order based on its tentative model. Based on table 2. The result of the best ARMA order of price at the farmers level in Jember, Malang, and Kediri in a row were the order of ARMA (1.1), the order of ARMA (3.3) and the order of ARMA (3.3). While the results of the best order of ARMA on consumer prices in Jember, Malang, and Kediri in a row were the order of ARMA (3.3), the order of ARMA (3.2) and the order of ARMA (2.2). The result of the best order of ARMA on the prices at the farmers level and consumers will be used in subsequent analysis, i.e. ARCH effect test.

Price variable that is containing $\mathrm{ARCH}$ effect is consumer price variable in Jember and farmer price in Kediri. This was because the value of obs* $\mathrm{R}$-squared on both variables is smaller than $F_{\text {statistic }}$ and the probability is less than 0.05 . Thus, of the six variables of price data that can be analyzed using ARCH / GARCH were the only variable price of rice at the consumer level in Jember and harvested dry grain at the farmer level in Kediri because of $\mathrm{ARCH}$ effect indicates that data is heteroskedasticity and the effect occurred price volatility.

Table 2 - Results of the Best ARMA Order Selection

\begin{tabular}{|c|c|c|c|c|c|c|}
\hline Variable & $\begin{array}{l}\text { ARMA } \\
\text { Model }\end{array}$ & Parameterr & $\begin{array}{l}\text { Parameter } \\
\text { Coefficient }\end{array}$ & $\begin{array}{c}\mathrm{P}- \\
\text { value }\end{array}$ & Significancy & $\begin{array}{c}\text { Standard Error of } \\
\text { Regressor }\end{array}$ \\
\hline Farmer's price Jember & $(1,1)$ & $\begin{array}{c}\mathrm{C} \\
\mathrm{AR}(1) \\
\mathrm{MA}(1)\end{array}$ & $\begin{array}{c}0,001945 \\
0,683907 \\
-0,979948 \\
\end{array}$ & $\begin{array}{l}0,0000 \\
0,0000 \\
\end{array}$ & $\begin{array}{l}\text { Significant } \\
\text { Significant }\end{array}$ & 0,028711 \\
\hline $\begin{array}{l}\text { Consumer's price } \\
\text { Jember }\end{array}$ & $(3,3)$ & $\begin{array}{c}C \\
\text { AR (3) } \\
\text { MA (3) }\end{array}$ & $\begin{array}{c}0.002153 \\
-0,870587 \\
0,960148\end{array}$ & $\begin{array}{l}0,0000 \\
0,0000\end{array}$ & $\begin{array}{l}\text { Significant } \\
\text { Significant }\end{array}$ & 0,016413 \\
\hline Farmer's price Malang & $(3,3)$ & $\begin{array}{c}\mathrm{C} \\
\mathrm{AR}(3) \\
\mathrm{MA}(3)\end{array}$ & $\begin{array}{c}0,002651 \\
-0,459152 \\
0,560647\end{array}$ & $\begin{array}{l}0,0042 \\
0,0016 \\
\end{array}$ & $\begin{array}{l}\text { Significant } \\
\text { Significant }\end{array}$ & 0,022384 \\
\hline $\begin{array}{l}\text { Consumer's price } \\
\text { Malang }\end{array}$ & $(3,2)$ & $\begin{array}{c}C \\
\text { AR (3) } \\
M A(2) \\
\end{array}$ & $\begin{array}{c}0,003088 \\
0,272074 \\
-0,259027 \\
\end{array}$ & $\begin{array}{l}0,0145 \\
0,0216 \\
\end{array}$ & $\begin{array}{l}\text { Significant } \\
\text { Significant }\end{array}$ & 0,015348 \\
\hline Farmer's price Kediri & $(3,3)$ & $\begin{array}{c}C \\
\text { AR (3) } \\
M A(3)\end{array}$ & $\begin{array}{c}0,003080 \\
-0,846097 \\
0,934638 \\
\end{array}$ & $\begin{array}{l}0,0000 \\
0,0000\end{array}$ & $\begin{array}{l}\text { Significant } \\
\text { Significant }\end{array}$ & 0,033637 \\
\hline $\begin{array}{c}\text { Consumer's price } \\
\text { Kediri }\end{array}$ & $(2,2)$ & $\begin{array}{c}C \\
\text { AR (2) } \\
\text { MA (2) }\end{array}$ & $\begin{array}{c}0,002879 \\
-0,435462 \\
0,973440\end{array}$ & $\begin{array}{l}0,0000 \\
0,0000\end{array}$ & $\begin{array}{l}\text { Significant } \\
\text { Significant }\end{array}$ & 0,012318 \\
\hline
\end{tabular}

Source: secondary data (re-make), 2017.

Error tolerance (a) $5 \%$. 
Table 3 - The Result of ARCH Effect Test

\begin{tabular}{cccccc}
\hline Variable & Obs ${ }^{*} R$-squared & Prob & $F_{\text {statistic }}$ & Prob & Arch Effect \\
\hline Farmer price in Jember & 1,983875 & 0,1590 & 1,983470 & 0,1629 & No ARCH effect \\
Consumer price in Jember & 6,107806 & 0,0135 & 6,452009 & 0,0131 & ARCH effect exists \\
Farmer price in Malang & 1,926555 & 0,1651 & 1,924719 & 0,1693 & No ARCH effect \\
Consumer price in Malang & 2,581211 & 0,1081 & 2,600842 & 0,1109 & No ARCH effect \\
Farmer price in Kediri & 12,01234 & 0,0005 & 13,80778 & 0,0004 & ARCH effect exists \\
Consumer price in Kediri & 0,002639 & 0,9590 & 0,002573 & 0,9597 & No ARCH effect \\
\hline
\end{tabular}

Source: secondary data (re-make), 2017.

Error Tolerance (a) $5 \%$.

Value of $\alpha$ is representing an $A R C H$ value, while $\beta$ is the value of the GARCH. The results of the estimation of GARCH model (1.1) in table 4 shows that the price of harvested dry grain at the level of farmers in Kediri with a very high price volatility (extremely high volatility) proven by the value of volatility greater than 1 which the value of $\alpha+\beta>1$, namely 1.356754. While rice price at the consumer level in Jember has a low price volatility (low volatility) proven by the value of volatility that is less than 1 in which the values of $\alpha+\beta<1$, i.e. 0.829743 .

Table 4 - Result of Behavior of Volatility using $\operatorname{GARCH}(1,1)$

\begin{tabular}{|c|c|c|c|c|c|c|c|}
\hline Variable & $C$ & $\alpha$ & Prob & $\beta$ & Prob & $\alpha+\beta$ & Volatility \\
\hline $\begin{array}{c}\text { Farmer price in } \\
\text { Jember }\end{array}$ & - & - & - & - & - & - & $\begin{array}{l}\text { Volatility doesn't } \\
\text { occur }\end{array}$ \\
\hline $\begin{array}{c}\text { Consumer price in } \\
\text { Jember }\end{array}$ & 0,000125 & 0,906381 & 0,0021 & $-0,076637$ & 0,2090 & 0,829743 & Low volatility \\
\hline $\begin{array}{c}\text { Farmer price in } \\
\text { Malang }\end{array}$ & - & - & - & - & - & - & $\begin{array}{c}\text { Volatility doesn't } \\
\text { occur }\end{array}$ \\
\hline $\begin{array}{c}\text { Consumer price in } \\
\text { Malang }\end{array}$ & - & - & - & - & - & - & $\begin{array}{l}\text { volatility doesn't } \\
\text { occur }\end{array}$ \\
\hline $\begin{array}{c}\text { Farmer price in } \\
\text { Kediri }\end{array}$ & 0,000149 & 1,253428 & 0,0003 & 0,103326 & 0,2672 & 1,356754 & $\begin{array}{c}\text { Extremely high } \\
\text { volatility }\end{array}$ \\
\hline $\begin{array}{c}\text { Consumer price in } \\
\text { Kediri }\end{array}$ & - & - & - & - & - & - & $\begin{array}{c}\text { Volatility doesn't } \\
\text { occur }\end{array}$ \\
\hline
\end{tabular}

Source: secondary data (re-make), 2017.

Error tolerance (a) $5 \%$.

The price of harvested dry grain at the farmer's level every month and years was fluctuation. The fluctuation cycle of the price with the same tends to occur each year. In addition, the pattern of grain prices that farmers received inversely proportional to the grain production pattern produced by the farmers. When the grain production is high, the price of grain decreased. And conversely, the low production of grain makes the prices highly increased. These conditions led to high price volatility on the harvested dry grain prices at the level of farmers.

The high price volatility of harvested dry grain also allegedly as the impact of uneffectiveness government policy related to government purchase prices (floor price). This is because the percentage of cases the under minimum grain purchase prices by the Government was still quite high (Arjayanti, 2010). In addition, procurement of rice by Bulog and the determination of cost of goods purchase has not done at the right time. In this case, Bulog would instead perform the lowest amounts of procurement at the time of the harvest months. While the highest procurement precisely in facing famine. Meanwhile, related to the time setting of floor price is precisely done after the great harvest passed so that the determination of the floor price could not be effective because farmers generally have done the harvesting.

Meanwhile, rice prices that were in low volatility could indicate that rice prices at the consumer level tend to be stable. Stability of rice prices may occur due to a pricing policy instrument that was formed by the Government to protect the consumer-level price. A pricing policy instrument of the Government among other things, distributing subsidized rice to the 
poor (Raskin), perform a buffer stock of rice through the purchase of rice yield both produce domestics and imports, and controlling during the turmoil of the market price through the rice price stabilization operations (OSBH) (Prastowo et al., 2008).

The average annualized volatility of the rice price at the consumer level price variations has a smaller value than the variation value at price of dry grain at the level of farmers. This condition indicates that the rice price was more relatively stable than the price of harvested dry grain at the farmer level indicates that the price volatility of rice at the consumer level is low. Rice prices relatively stable occurred because the Government often conducts market operations directly to the consumer market than the farmers market, so high price fluctuations could be directly addressed.

Table 5 - The Development of Annualized Price Volatility at the Farmer Level

\begin{tabular}{ccccccc}
\hline Year & $\begin{array}{c}\text { Farmer price } \\
\text { in Jember }\end{array}$ & $\begin{array}{c}\text { Consumer price } \\
\text { in Jember }\end{array}$ & $\begin{array}{c}\text { Farmer price } \\
\text { in Malang }\end{array}$ & $\begin{array}{c}\text { Consumer price } \\
\text { in Malang }\end{array}$ & $\begin{array}{c}\text { Farmer price } \\
\text { in Kediri }\end{array}$ & $\begin{array}{c}\text { Consumer price } \\
\text { in Kediri }\end{array}$ \\
\hline 2010 & 43,02 & 12,63 & 37,63 & 19,95 & 44,22 & 23,17 \\
2011 & 26,72 & 19,10 & 22,19 & 22,09 & 37,72 & 20,04 \\
2012 & 14,97 & 7,64 & 4,88 & 6,39 & 25,01 & 8,76 \\
2013 & 20,15 & 7,21 & 10,92 & 3,80 & 29,61 & 2,86 \\
2014 & 28,14 & 17,60 & 12,11 & 7,47 & 12,01 & 11,76 \\
2015 & 21,28 & 18,44 & 23,59 & 12,20 & 22,71 & 4,84 \\
2016 & 16,33 & 7,45 & 16,47 & 7,99 & 19,37 & 5,46 \\
\hline Mean & 24,37 & 12,87 & 18,24 & 11,41 & 27,24 & 10,98 \\
\hline
\end{tabular}

Source: secondary data (re-make), 2017.

Result of Volatility Spillover. On the analysis of the previous price volatility, that the price data which has the effect of $\mathrm{ARCH}$ was the harvested dry grain price data at the level of farmers in Jember and rice prices at the consumer level in Kediri. While the harvested dry grain price data at the level of farmers in Jember and Malang, as well as data of rice price at the consumer level in Malang and Kediri, does not contain the ARCH effects and it could not be analyzed using GARCH-BEKK model. So the volatility spillover analysis can only be analyzed between rice prices at the consumer level in Jember and harvested dry grain prices at the level of farmers in Kediri.

Results of Analysis in table 6, shows that the value of $v_{C P_{t}-1}^{2} v_{P P_{t}-1}^{2}$ as much as $(-0.57)$ with the negative sign means that the volatility spillover does not occur between rice prices at the consumer level in Jember and prices of the harvested dry grain at the level of farmers in Kediri. So when the trend changes in the price volatility of rice at the consumer level in Jember will not be followed by a change of harvested dry grain price volatility at the level of farmers in Kediri.

In the short term, the dynamics of rice price at the consumer level commonly has the same pattern with rice price dynamics at the level of farmers because the demand faced by the farmers in farmer's level is a derivative of the demand in the area of consumer (Harianto and Sari, 2011). If the rice price increase in the level of the consumer caused by the high demand so traders will continue rising the rice prices to farmers. So the price at the level of farmers or peasants is also experiencing an increase.

Meanwhile, the conditionals correlation between consumer prices and farmers negatively shows that rates transmission from consumer level to the level of the farmer occurred imperfectly and asymmetric. This condition is caused arising of rice price at consumer level followed by the rise of the price continues to the farmers slowly and imperfectly. So price fluctuations in farmer level higher than price fluctuations in the level of the consumer.

The price transmission occurs from the consumer market to the farmers market happens imperfectly and asymmetric, it can be indicators of the existence of oligopsony or monopsony power on the marketing agencies such as the middleman and merchant. When market traders have oligopsony or monopsony power, then the trader will be able to control the purchase price obtained from farmers so that although rice prices at the consumer level are relatively constant. 
Table 6 - The Result of Annualized Price Volatility Spillover at the Farmer and Consumer Level

\begin{tabular}{ccccc}
\hline Variable & $\mathrm{C}$ & $v_{C P_{t}-1}^{2} v_{P P_{t}-1}^{2}$ & $\begin{array}{c}\mathrm{hCP}, \mathrm{PP} \text { t- } \\
1\end{array}$ & $\begin{array}{c}\text { Volatility spillover } \\
\text { analysis }\end{array}$ \\
\hline $\begin{array}{c}\text { Vol. Consumer price in Jember } \rightarrow \text { Vol. } \\
\text { Farmer price in Jember }\end{array}$ & - & - & - & $\begin{array}{c}\text { Un-analyzed volatility } \\
\text { spillover }\end{array}$ \\
\hline $\begin{array}{c}\text { Vol. Consumer price in Jember } \rightarrow \text { Vol. } \\
\text { Farmer price in Malang }\end{array}$ & - & - & - & $\begin{array}{c}\text { Un-analyzed spillover } \\
\text { volatility }\end{array}$ \\
\hline $\begin{array}{c}\text { Vol. Consumer price in Jember } \rightarrow \text { Vol. } \\
\text { Farmer price in Kediri }\end{array}$ & 0,000098 & $-0,57$ & $-0,10$ & $\begin{array}{c}\text { volatility spillover } \\
\text { doesn't occur }\end{array}$ \\
\hline $\begin{array}{c}\text { Vol. Consumer price in Malang } \rightarrow \text { Vol. } \\
\text { Farmer price in Malang }\end{array}$ & - & - & - & $\begin{array}{c}\text { Un-analyzed volatility } \\
\text { spillover }\end{array}$ \\
\hline $\begin{array}{c}\text { Vol. Consumer price in Malang } \rightarrow \text { Vol. Farmer } \\
\text { price in Jember }\end{array}$ & - & - & - & $\begin{array}{c}\text { Un-analyzed volatility } \\
\text { spillover }\end{array}$ \\
\hline $\begin{array}{c}\text { Vol. Consumer price in Malang } \rightarrow \text { Vol. Farmer } \\
\text { price Kediri }\end{array}$ & - & - & - & $\begin{array}{c}\text { Un-analyzed volatility } \\
\text { spillover }\end{array}$ \\
\hline $\begin{array}{c}\text { Vol. Consumer price in Kediri } \rightarrow \text { Vol. Farmer } \\
\text { price in Kediri }\end{array}$ & - & - & - & $\begin{array}{c}\text { Un-analyzed volatility } \\
\text { spillover }\end{array}$ \\
\hline $\begin{array}{c}\text { Vol. Consumer price in Kediri } \rightarrow \text { Vol. Farmer } \\
\text { price in Jember }\end{array}$ & - & - & - & $\begin{array}{c}\text { Un-analyzed volatility } \\
\text { spillover }\end{array}$ \\
\hline $\begin{array}{c}\text { Vol. Consumer price in Kediri } \rightarrow \text { Vol. Farmer } \\
\text { price in Malang }\end{array}$ & - & - & - & $\begin{array}{c}\text { Un-analyzed volatility } \\
\text { spillover }\end{array}$ \\
\hline
\end{tabular}

Source: secondary data (re-make), 2017.

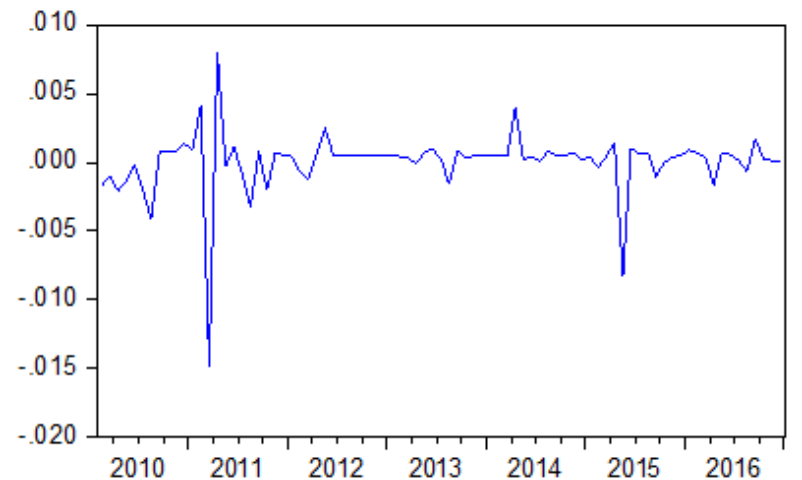

Figure 2 - Chart of Conditional Covariance

Spillover Volatility of rice price at the consumer level in Jember and harvested dry grain price at the farmer level in Kediri

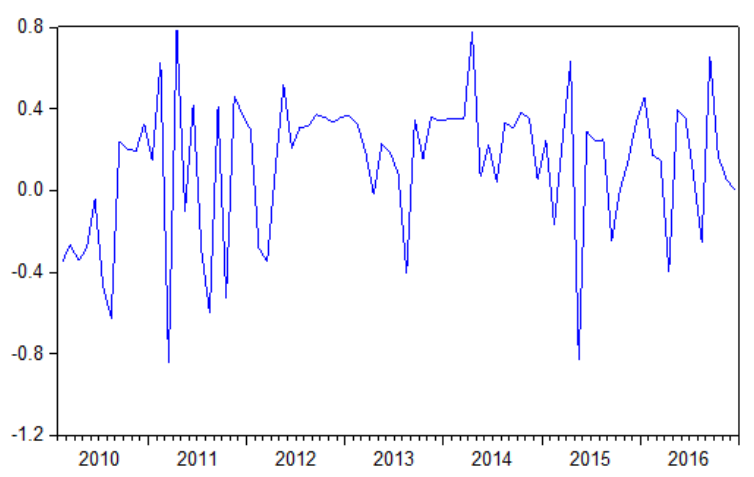

Figure 3 - Chart of Conditional Correlation price Volatility of rice at the consumer level in Jember and price of harvested dry grain at the farmer level in Kediri

But the middleman or trader can press the purchase price from the farmers to maximise its profits (Irawan, 2007). And vice versa, when rising prices at the consumer level, the trader or the middleman or trader keep the prices up imperfectly to the farmers so as to increase the price received by the farmers is lower to be compared with the increase of the price that occurs at the consumer level.

\section{CONCLUSION AND RECOMMENDATIONS}

Based on the results of the research, the conclusions of this study, that price volatility of harvested dry grain are included an extremely high volatility (price volatility is very high) category. While the price volatility of rice at the consumer level are included in the low volatility (low volatility) category. In addition, the volatility spillover does not occur between the consumer market and farmers market because the results of the analysis show that squared residual marked negatively.

In order to cope with the onset of price volatility in the level of the farmer and the consumer, the need for a balanced policy between the farmers and the consumers in a way guaranteeing the effective price floor and market information disclosure related to the commodity prices in order to make the pattern of price transmission of interrelated market symmetrical. 


\section{REFERENCES}

3. Arjayanti, Syam. 2010. Analisis Kebijakan Stabilisasi Harga Gabah/Beras di Tingkat Petani di Propinsi DIY. Volume 15 Nomor 2. Jurnal Kebijakan dan Administrasi Publik. Jogjakarta.

4. Assefa, Tsion Taye; Meuwissen, Miranda P.M.; dan Lansink, Alfons G.J.M. Oude. 2015. Does Price Volatility Matter? An Assessment along EU Food Chains. International Conference of Agricultural Economist. Italia.

5. Badan Penelitian dan Pengembangan Pertanian. 2012. Dinamika Produksi dan Harga Beras di Indonesia. Kementrian Pertanian.

6. Badan Pengkajian dan Pengembangan Kebijakan Perdagangan. 2015. Analisis Dampak Kebijakan Pemerintah Terhadap Inflasi dan Kemiskinan. Kementrian Perdagangan. Jakarta.

7. Banterle, Alessandro; dan Vandone, Daniela. 2013. Price Volatility and Risk Management: The Case of Rice. Universität Bonn-ILB Press, Bonn. Jerman.

8. Connor, O. Declan; dan Keane, Michael. 2011. Empirical Issues Relating to Diary Commodity Price Volatility. Spinger Science+Business Media, LLC. USA.

9. Demeke, Mulat; Dewe, David; Tefft, James; Ferede, Tadele; dan Bell, Winnie. 2012. Stabilizing Price Incentives for Staple Grain Producers in the Context of Broader Agricultural Policies. ESA Working Paper No. 12-05. Food And Agriculture Organization of the United Nations.

10. Demeke, Mulat dan Balie, Jean. 2016. Assessment of National Policies in Developing Countries to Combat and Mitigate Effect of Agricultural Markets' Excessive Price Volatility. Routledge Taylor \& Francis Group. London and New York.

11. Donmez, Ayca dan Magrini, Emiliano. 2013. Agricultural Commodity Price Volatility and its Macroeconomic Determinats. JRC Thechnical Reports.

12. Ekananda, Mahyus. 2016. Analisis Ekonometrika Time Series, Edisi 2. Mitra Wacana Media. Jakarta.

13. FAO, IFAD, IMF, OECD, UNCTAD, WFP, World Bank, dan WTO. 2011. Price Volatility in Food and Agricultural Markets: Policy Responses. Diakses http://g20india.gov.in/hindi/pdfs/2011-B-June-Joint-Report-on-Food-Price.pdf.

14. Gilbert, C.L dan Morgan, C. W. 2010. Food Price Volatility. Royal Society.

15. Harianto dan Lianita, Dina Sari. 2011. Pola Spread Harga Gabah dan Beras di Indonesia: Suatu Indikasi Efektivitas Perubahan Kelembagaan Bulog. Departemen Agribisnis Fakultas Ekonomi dan Manajemen, Institut Pertanian Bogor. Bogor.

16. Irawan, Bambang. 2007. Fluktuasi Harga, Transmisi Harga dan Pemasaran Sayuran dan Buah. Analisis Kebijakan Pertanian. Volume 5 No. 4: 358-373. Bogor.

17. Jamal, Erizal; Noekman, N. Khairina; Hendiarto; Ariningsih, Ening; dan Askin, Andi. 2006. Analisis Kebijakan Penentuan Harga Pembelian Gabah. Pusat Analisis Sosial Ekonomi dan Kebijakan Pertanian. Departemen Pertanian.

18. Kalkuhl, Mathias; Kornher, Lukas; Kozicka, Marta; Boulanger,Pierre; dan Torero, Maximo. 2013. Conceptual Framework on Price Volatility and its Impact o Food and Nutrion Security in the Short Time, Foodsecure working paper No. 15. Interdisciplinary Research Project to Explore the Future of Global Food and Nutrion Security.

19. Kant, Ravi Jain. 2001. Putting Volatility to Work. Active Trader.

20. Ledebur, Von O. dan Schmitz, J. 2012. Price Volatility and Farm Income Stabilisation, Modelling Outcomes and Assessing Market and Policy Based Responses. Paper prepared for the 123rd EAAE Seminar. Dublin.

21. Lipetit, Plot Isabelle. 2011. Price Volatility and Price Leadership in the EU Beef and Pork Meat Market. Spinger Science+Business Media, LLC. USA.

22. Moledina, A. Amyaz; Roe, L. Terry; dan Shane, Mathew. 2004. Measuring Commodity Price Volatility and the Welfare Consequences of Eliminating Volatility. Working Paper, USDA/ERS and the Economic Development Center. University of Minnesota. 
23. Prastowo, Joko Nugroho; Yanuarti, Tri; dan Depari, Yoni. 2008. Pengaruh Distribusi Dalam Pembentukan Harga Komoditas dan Implikasinya Terhadap Inflasi. Working Paper. Bank Indonesia.

24. Rapsomanikis, George. 2011. Price Transmission and Volatility Spillovers in Food Markets, Chapter 8. Food and Agriculture Organization of the United Nations. Rome.

25. Serra, Teresa dan Gil, José M. 2012. Price Volatility in Food Markets: Can Stock Building Mitigate Price Fluctuations?. International Association of Agricultural Economists (IAAE) Triennial Conference. Brazil.

26. Singh, Ranjit; dan Kumar,Amit. 2015. Stock Trading Strategy Based on Daily Stock Volatility. IJCST Vol. 6, Iss ue 1 Spl- 1.

27. Tomek, G. William dan Robinson, L. Kenneth. 1990. Agricultural Product Price. Cornel University Press. New York. 
DOI https://doi.org/10.18551/rjoas.2017-09.33

\title{
ASSESSMENT OF SEVERAL AMPHIBIAN RICE VARIETIES IN THE CENTER OF RICE PRODUCTION IN LAMONGAN REGENCY OF EAST JAVA PROVINCE
}

\author{
Sudaryono Tri, Researcher \\ Assessment Institute for Agricultural Technology, Malang, Indonesia \\ Email: tri sdr@yahoo.com
}

\begin{abstract}
Climate change due to global warming has brought wide impact on various aspects of life; one of the most serious impacts is in agriculture sector. One of the ways to overcome the situation is to provide several varieties of amphibian rice to be planted in less-water condition. To accelerate the spread of amphibian varieties to users, an assessment was carried out by applying Integrated Approach to Crop . The purpose of this assessment was to determine the growth and production performance of several amphibian rice varieties, so the VUB can substitute and anticipate drought to overcome crop failure in long dry season (elnino phenomenon). The assessment was conducted in Maduran Village, Maduran District, Lamongan Regency from August to November 2015. The study used Inpago 5, Inpago 8, Inpago 9, Inpari 10, Situ Patenggang, and Ciherang varieties as comparison with total area of 10 ha. The study was done using Randomized Block Design with four (4) replications. The parameters observed included growth component, pest attack, and production. The results showed that the treatment on amphibian varieties had significant effect on plant height and number of tillers. Of the 5 (five) amphibian varieties studied, Inpago 9 production was higher (8.31 $\mathrm{t} / \mathrm{ha}$ ) than the other four varieties.
\end{abstract}

\section{KEY WORDS}

Amphibian rice variety, integrated approach to crop, wetland rice.

The government is targeting rice self-sufficiency and sustainable rice self-sufficiency with a production target of 73.40 million tons by 2015 . East Java as the main producer of rice contributes to national rice production $\pm 20 \%$ is generated from \pm 1.62 million ha/year with average productivity of $53 \mathrm{qu} / \mathrm{ha}$. The target achievement scenario is mostly pursued through productivity improvement of 63.23 qu/ha [1]. In 2013, rice production reached 12,049,342 tons, with the contribution of East Java Province to national rice production as much as $16.90 \%$ [2]. It is expected that by 2015 the rice production target will reach 12.86 million tons [3].

Climate change due to global warming has brought wide impact on various aspects of life. Agriculture is the most seriously affected sector. Changes in rainfall patterns, increased extreme climatic events, and rising temperatures and sea levels have led agricultural production, especially the food crop sub-sector, to decline significantly. It is estimated that agricultural productivity will continue to decline in line with global temperature rise.

In the midst of the world food crisis triggered by climate change, the government still targets to increase the productivity of food crops, especially rice. To achieve the target, integrated and comprehensive work is required as well as coordination among all stakeholders, both at the central and regional levels, in policy, programming, and technology implementation, especially in the anticipation and mitigation of climate change threats. To that end, the Ministry of Agriculture has developed the Climate Change Research and Development Consortium.

The role of technology in improving agricultural production and the welfare of farmers has been widely recognized. In the past 25 years, the Body for Agricultural Research and Development has been instrumental in agricultural development through the creation of superior varieties technology, efficient cultivation system, pest and disease control, harvest and post-harvest technology, and the use of agricultural tools and machinery. In order to 
increase the productivity and efficiency of food crop, an Integrated Approach to Crop and resource management has been developed [4].

In principle, the increase in rice production and productivity is still possible since there is a gap between potential yields and actual yields. This is because of (i) the use of high yield seed varieties is low, only around $53 \%$, (ii) unbalanced and inefficient use of fertilizers, (iii) the unpopular use of organic fertilizers, and (iv) location-specific cultivation has not yet been developed. Through the program established by the Ministry of Agriculture, East Java Province strives to encourage and accelerate the increase of food production by implementing technological innovation, IP enhancement, and integrated site-specific resource management in order to achieve the established production target.

Adaptation to climate change is an urgent priority for Indonesia. All ministries and national planning need to consider climate change in their programs regarding issues such as poverty reduction, community empowerment, food security, disaster management, disease control, and urban planning. However, this is not a mere central government task; it should be a national effort involving local governments, the general public, and all nongovernmental organizations, as well as UNDP private parties [5].

Technology of Agricultural Research Agency in anticipation of drought for rice commodity is available. However, hardening in the form of assessment, facilitation, and socialization of the resulting technology needs to be disseminated in drought-prone locations in the form of assessment of varieties to recommend the use of site-specific superior varieties.

The purpose of the assessment is to determine the growth and production performance of some amphibian rice varieties, so VUB can substitute and anticipate drought to overcome crop failure in long dry season (EI Nino phenomenon).

\section{METHODS OF RESEARCH}

The assessment was conducted in Maduran Village, Maduran District, Lamongan Regency from August to November 2015 at MK-2. Site selection was the drought-prone, but still allowed for some water. Varieties of amphibian rice used as treatment were Inpago 5, Inpago 8, Inpago 9, Inpari 10, and Situ Patenggang; Ciherang variety was used as comparison, with a total area of 10 ha. The component of Integrated Crop Management applied was the seed quality certified as class FS derived from BB Rice Sukamandi; the planting of young seedlings < 20 HSS; $2-3$ seeds/hole; planting system of tanam jajar legowo 2:1 $(20 \mathrm{~cm} \times 12.5 \mathrm{~cm} \times 40 \mathrm{~cm}$ ); fertilization according to the Decree of Minister of Agriculture; organic fertilizer $5 \mathrm{t} / \mathrm{ha}$; intermittent watering; pest-disease control with IPM. Assessment was done using Randomized Block Design with four (4) replications. Parameters observed included growth components such as plant height, tiller number, and yield components such as panicle number, panicle length, grain contents, and empty grains per panicle, and yield. The data were analyzed in a variety of ways, and the effect of the treatment was tested using Duncan at $5 \%$ degree of confidence.

\section{RESULTS AND DISCUSSION}

Characteristics of the Assessment Area. Geographically, Maduran Village, Maduran District, lies in the south latitude and east longitude. The village is about $6 \mathrm{~m}$ above sea level. It has an area of approximately 193.5 ha, consisting of 13 ha of settlements, 156 ha of paddy fields, 16 ha of plantation, 6.5 ha of home garden, and offices, parks and others cover the rest 35 ha. Rainfall average is $2400 \mathrm{~mm} /$ year, with the most rainfall occurs in December to reach $405.04 \mathrm{~mm}$, which has been the highest rainfall during the period 2000 to 2010 [6].

Results of Assessment. The study of amphibian new varieties in MK 2 was done in cooperation with the Institute of Agricultural Technology Assessment (IATA) East Java with Indonesian Center for Rice Research (ICRR) Sukamandi. At the time of assessment, Ciherang variety was the one mostly grown by farmers, due to its high production and 
productivity, and high selling value, making it the preference of the intermediaries. Based on this, Ciherang variety was used as a comparison in this study.

The result of observation on vegetative growth at the age of 45 days after planting from each variety can be seen in Table 1 . Table 1 shows that the highest rice plant was from Situ Patenggang variety $(105.33 \mathrm{~cm})$, then Inpago $9(99 \mathrm{~cm})$, and Inpago $5(75.89 \mathrm{~cm})$. However, the height of Situ Patenggang did not produce many tillers, only 15.67 , or the lowest, while the number of tillers of other varieties was around 18 to 20. Observation of growth in the productive phase was carried out in rice plants aged 93 days after planting (DAP). The highest rice plant was produced from Inpari 10, then Ciherang, Situ Patenggang, Inpago 9, Inpago 8, and Inpago 5. The highest productive tillers were for Inpago 9 of 29 tillers, followed by Inpago 5 of 20 tillers. The number of tillers for the other varieties was relatively evenly distributed, around 12 to 17 (Table 1). From the observation of plant height in the productive phase, it was close to the description of VUB Rice [7], except Inpago 5, as the plant height was lower than its description of $132 \mathrm{~cm}$.

Table 1 - Average plant height and number of tillers of several rice varieties at 45 and 93 days after planting (Lamongan 2015)

\begin{tabular}{|c|c|c|c|c|}
\hline \multirow{2}{*}{ Variety } & \multicolumn{2}{|c|}{ Height $(\mathrm{cm})$} & \multicolumn{2}{c|}{ Tiller } \\
\cline { 2 - 5 } & $45 \mathrm{DAP}$ & $93 \mathrm{DAP}$ & $45 \mathrm{DAP}$ & $93 \mathrm{DAP}$ \\
\hline Inpago 5 & $\left.75.89 \mathrm{a}^{*}\right)$ & $91.67 \mathrm{a}$ & $20.78 \mathrm{~b}$ & $20.00 \mathrm{~b}$ \\
Inpago 8 & $85.75 \mathrm{ab}$ & $101.56 \mathrm{ab}$ & $18.75 \mathrm{ab}$ & $17.56 \mathrm{ab}$ \\
Inpago 9 & $99.00 \mathrm{c}$ & $109.89 \mathrm{~b}$ & $18.89 \mathrm{ab}$ & $29.56 \mathrm{c}$ \\
Inpari 10 & $87.72 \mathrm{~b}$ & $142.78 \mathrm{~d}$ & $19.33 \mathrm{ab}$ & $12.22 \mathrm{a}$ \\
Situ Patenggang & $105.33 \mathrm{c}$ & $123.11 \mathrm{c}$ & $15.67 \mathrm{a}$ & $12.56 \mathrm{a}$ \\
Ciherang & $86.44 \mathrm{ab}$ & $130.44 \mathrm{c}$ & $19.78 \mathrm{ab}$ & $14.89 \mathrm{ab}$ \\
\hline
\end{tabular}

*) Figures followed by the same letter in the same column show no significant difference at the 5\% Duncan multiple test range.

Table 2 - The average panicle number, panicle length, grain contents, and empty grains per panicle (Lamongan 2015)

\begin{tabular}{|c|c|c|c|c|}
\hline Variety & Panicle number & Panicle length & Grain content per panicle & Empty grain per panicle \\
\hline Inpago 5 & $8.56 \mathrm{a}$ & $25.09 \mathrm{~b}$ & $176.33 \mathrm{c}$ & $19.22 \mathrm{a}$ \\
Inpago 8 & $8.33 \mathrm{a}$ & $25.97 \mathrm{~b}$ & $120.67 \mathrm{ab}$ & $16.33 \mathrm{a}$ \\
Inpago 9 & $8.67 \mathrm{a}$ & $26.97 \mathrm{~b}$ & $181.50 \mathrm{c}$ & $31.17 \mathrm{a}$ \\
Inpari - 10 & $9.44 \mathrm{a}$ & $29.50 \mathrm{~b}$ & $115.67 \mathrm{a}$ & $142.17 \mathrm{~b}$ \\
Situ Patenggang & $10.44 \mathrm{a}$ & $25.51 \mathrm{~b}$ & $167.44 \mathrm{bc}$ & $16.67 \mathrm{a}$ \\
Ciherang & $13.44 \mathrm{~b}$ & $13.56 \mathrm{a}$ & $121.67 \mathrm{ab}$ & $171.11 \mathrm{~b}$ \\
\hline
\end{tabular}

*) Figures followed by the same letter in the same column show no significant difference at the $5 \%$ Duncan multiple test range.

Based on the observation flowering (63 days after planting), visually the varieties having flowered included Situ Patenggang (75\%) and Inpari $10(80 \%)$, while others were only 30\% (Inpago 5), $15 \%$ (Inpago 8), 15\% (Inpago 9), and 20\% (Ciherang). Observation on pests and diseases was done every week, to anticipate pest explosion. Pests found during observation were false white pests, golden snails, and rats. Overall, at the time of observation of rice cropping, the rice varieties were relatively good, although the golden snail still attacked at 45 DAP, but it was not expected to affect production because the plants were strong enough.

Farmers are commonly afraid of pest attract in the generative phase such as rats, stem borer, and blast disease. However, these did not occur because the pest and disease attacks were relatively low-rats attacked about $5 \%$, golden snail $3 \%$, and fake white lice $5 \%$ at 45 DAP. Natural enemies of predators were found at the time of observation, such as Paederus fuscifes with the most populations found in the variety of Situ Patenggang on an average of 12.67 , and 1.33 to 2.67 for other varieties. Another predator is Coccinella sp. with an average population of 1 to 2 .

The results of observation on the components of panicle number, panicle length, grain contents, and empty grains per panicle can be seen in Table 2 . The highest number of 
panicles per clump is from Ciherang variety-it was different from other varieties, yet it had the lowest panicle length. The highest grain content per panicle was shown by Inpago 9, which was not different from Inpago 5 and Situ Patenggang. The lowest empty grain per panicle was found in Inpago 8, which was not significantly different with Inpago 5, Inpago 9, and Situ Patenggang.

The results of observations on the production of Dried Unhulled Rice can be seen in Table 3. The highest rice yield was for Inpago 9 variety of $8.31 \mathrm{t} / \mathrm{ha}$. Based on discussions with farmer groups during field meeting, this variety was the most favored for its long grain, bright grain color, unlined grain, clear rice color, and compact grain. The production achieved by Inpago 9 approaches the potential yield of $8.4 \mathrm{t} /$ [7]. The production of other varieties (Inpago 5, Inpago 8, Situ Patenggang, and Inpari 10) was equivalent to Ciherang variety as the comparison (Table 3).

Table 3 - The productivity of amphibian varieties (Lamongan 2015)

\begin{tabular}{|c|c|c|}
\hline Variety & Yield (t/ha) & Weight of 1000 grains $(\mathrm{g})$ \\
\hline Inpago 5 & $7.56 \mathrm{c}$ & 28.64 \\
Inpago 8 & $5.17 \mathrm{a}$ & 32.42 \\
Inpago 9 & $8.31 \mathrm{~d}$ & 30.33 \\
Inpari - 10 & $7.22 \mathrm{c}$ & 32.77 \\
Situ Patenggang & $5.78 \mathrm{ab}$ & 30.50 \\
Ciherang & $5.92 \mathrm{~b}$ & 30.20 \\
\hline
\end{tabular}

*) Figures followed by the same letter in the same column show no significant difference at the $5 \%$ Duncan multiple test range.

\section{CONCLUSION}

Inpago 5, 8, 9, Situ Patenggang, and Inpari 10 showed positive response to plant growth (plant height and number of tillers). The high growth is also supported by the use of high organic material (5 tons/ha), because farmers usually only use organic material at 500 $\mathrm{kg} / \mathrm{ha}$. The highest Dried Unhulled Rice production was for Inpago 9 variety $(8.31 \mathrm{t} / \mathrm{ha}$ Dried Unhulled Rice). With the existence of amphibian rice varieties suitable for drought conditions, crop failure can be avoided.

\section{REFERENCES}

1. Dinas Pertanian Provinsi Jawa Timur, 2014. Program Pembanguan Pertanian Tanaman Pangan 2013. Disampaikan dalam Acara Sinkronisasi Program Pertanian, Surabaya.

2. Dinas Pertanian Provinsi Jawa Timur. 2013. Program Pembangunan Pertanian Tanaman Pangan 2013. Disampaikan dalam Acara Sinkronisasi Program Pertanian, Surabaya.

3. Dinas Pertanian Provinsi Jawa Timur, 2015. Program Pembangunan Pertanian Tanaman Pangan 2015. Disampaikan dalam Acara Sinkronisasi Program Pertanian, Surabaya.

4. Badan Penelitian dan Pengembangan Pertanian, 2014. Petunjuk Pelaksanaan Sosialisasi Katam Terpadu (Kalender Tanam Terpadu). Badan Litbang Pertanian. Jakarta.

5. UNDP, 2007. Sisi Lain Perubahan Iklim: Mengapa Indonesia harus beradaptasi untuk melindungi rakyat miskinnya. United Nation Development Programme Indonesia. UNDP Indonesia Country Office. Jakarta.

6. Anonim. 2015. Monografi Desa. Profil Desa Maduran. Kec. Maduran Lamongan.

7. Mejaya, MJ, Satoto, P. Sasmita, Y. Baliadi, A. Kuswara dan Suharna. 2014. Deskripsi Varietas Unggul Baru Padi. Balitbangtan.

(c) 2017 by the author. Licensee RJOAS, Orel, Russia. This article is an open access article distributed under the terms and conditions of the Creative Commons Attribution (CC BY) license: http://creativecommons.org/licenses/by/4.0/ 
DOI https://doi.org/10.18551/rjoas.2017-09.34

\title{
THE CORRELATION OF VEGETATIVE AND GENERATIVE CHARACTERS OF DUKU (LANSIUM DOMESTICUM CORR.) ACCESSION IN BANYUASIN REGENCY, SOUTH SUMATRA
}

\author{
Susilawati ${ }^{*}$, Ammar Muhammad, Priadi Dwi Putro, Robiartini Lucy, Irmawati \\ Department of Agronomy, Faculty of Agriculture, University of Sriwijaya \\ Juan Fitra \\ Department of Agroekoteknologi, Faculty of Agriculture, University of Sriwijaya \\ *E-mail: susilawati@fp.unsri.ac.id
}

\begin{abstract}
The development of duku plantation in other regencies is required to enrich duku germplasms in South Sumatra. Banyuasin Regency in South Sumatra was chosen as research location for this study since many duku plantations are located in this area.This research was aimed to observe the correlation of vegetative and generative characters of duku accession in Banyuasin Regency. The research was conducted for 10 months in 2017 located in three areas of Banyuasin Regency, which are Banyuasin $1\left(B_{1}\right)$, Banyuasin 2 $\left(\mathrm{BA}_{2}\right)$ and Banyuasin $3\left(\mathrm{BA}_{3}\right)$ with 5 plants per area resulting in total 15 plants. Purposive sampling method was used to determine the samples. Variability analysis and the calculation for correlation among vegetative and generative characters then were performed. Results showed that the characters of duku accessions indicated positive and negative correlation. Fruit sweetness level, however, did not show any correlation with either vegetative or generative characters.
\end{abstract}

\section{KEY WORDS}

Duku, plantations, fruits, characters, plants.

Indonesia with its tropical weather provides a favorable environment for growth and development of various fruit commodities, including for local Indonesian fruits. However, unfortunately, the local fruit is mostly not properly cultivated and well utilized. Fruit production in Indonesia increases year by year following the increasing demand of fruit consumption. Indonesian fruit consumption per capita was $23.56 \mathrm{~kg}$ in 2006 increasing to $32.59 \mathrm{~kg}$ in 2010 . Nevertheless, this number is still far below the reccommended standard of Food Agricultural Organization (FAO) which is $65 \mathrm{~kg}$ per capita per year.

Duku (Lansium domesticum Corr.) is a fruit tree originated from Indonesia and has been widely distributed across Indonesia with the production center located in Sumatra island (South Sumatra, West Sumatra, and Jambi), Java island (Central Java and Jakarta), and Kalimantan island (West Kalimantan) (Directorate General of Horticulture, 2015). Duku fruit is considered to have a high commercial value and competitive to other fruit commodities. It is favorited due to its sweet taste and odorless smell and it also has fairly nutrient content. In every $100 \mathrm{~g}$, it contains $42 \mathrm{cal}, 0.7 \mathrm{~g}$ protein, $13 \mathrm{~g}$ carbohydrate, $13.0 \mathrm{mg}$ calcium, $20.0 \mathrm{mg}$ phosphorus, $3.2 \mathrm{~g}$ fiber, $0.06 \mathrm{mg}$ vitamin $\mathrm{B} 1,3.8 \mathrm{mg}$ vitamin $\mathrm{C}$ and $0.9 \mathrm{mg}$ Zinc (Mayanti, 2009). Yet, duku production in Indonesia is recently in the decreasing trend. The production in $2012-2014$ in respectively was 258,$453 ; 233,118 ; 208,424$ ton per ha per year (Central Bureau of Statistic, 2015).

South Sumatra Province is one of germplasm center of various fruit commodities, especially duku plant. South Sumatra duku production was 10,457 ton contributing in $5.02 \%$ of national duku production (Central Bureau of Statistic, 2015). Duku originated from South Sumatra is very popular and even has its own trade mark in the national market with the nickname of "Duku Palembang", while in the local South Sumatra market is known as 
"DukuKomering". Therefore, South Sumatra government has determined duku as mascot flora in the province (Deroes and Wijaya, 2010).

Duku plants in South Sumatra are mostly grown along the river basins of Komering, Ogan, Lematang, and MusiRiver distributed in seven regencies which are Ogan Komering Ulu (OKU), OganKomeringllir (OKI), Banyuasin, Musi Banyuasin, Muaraenim, Musi Rawas and Lahat. Duku plant from each regency has different phenology in both vegetative and generative (fruit quality) growth. Duku of OKU has been determined as variety based on the Decree of Agricultural Ministry No. 31/Kpts/tp.240/95 stating that Rasuan cultivar and Palembang cultivar were appointed as two national duku varietiesoriginated from South Sumatra (Seed Inspection and Certification Center of South Sumatra, 1999). However, both cultivars are most known in national market as Duku Palembang. The characteristics of Duku Palembang are the sweet taste and thin fruit peel (Uji, 2007).Duku cultivation is potential to be developed commercially due to the high demand of duku fruit for either freshly consumption or fruit drink ingredients. Furthermore, duku price is relatively higher compared to other similar commodities. This condition should be used as a great opportunity for increasing the income and welfare of duku farmers and duku related stakeholders (Pane, 2011).

The development of duku plantation in other regencies is required to enrich duku germplasms in South Sumatra. BanyuasinRegency in South Sumatra was chosen as research location for this study since there are many duku plantations in this area. Kusandaryani and Luthfy (2006) stated that the efforts to anticipate plant gene erosion by conserving the genetic materials were needed to be performed, either through exploration, characterization, rejuvenation, or documentation.

The inventory activities in several locations in Banyuasin was conducted to collect the data of duku accession in these areas. The activities included exploration and identification (Yuniarti, 2011). Plant morphological identification was carried out by observing the leaves, stems, flowers, fruits, roots and other morphological characteristics. The characteristic that could be used as anatomy marker is leaf stomata (Damayanti, 2007). Physiological characteristics such as nitrogen content, leaf chlorophyll and leaf sucrose were essential to indicate photosynthesis process in plant. Hanumet al. (2013) stated that the characters of morphology, anatomy and physiology were affected by both environment and genetic. Environmental difference will result in varied characters in plant creating many accessions in some locations. Morphological variation in duku plants are shown in the trees, leaves and fruits.

Thus, the study was conducted to observe the correlation among vegetative and generative characters of duku accession in Banyuasin Regency. The data obtained could further utilized as a base information for Banyuasin duku position as duku germplasm resource in South Sumatra.

\section{MATERIALS AND METHODS OF RESEARCH}

Materials used in this study consisted of: duku plant samples, aceton $80 \%$, sticky tape, filter paper, plastic bag, labelling paper, nail polish, transparent plastic, plastic rope, munsell color chart of plant tissue, cooling box, scissors, hygrometer, canon camera PowerShot SX $520 \mathrm{HS}$, compass, laser portable leaf area meter-1-202, microscope celettron-screen, ruler, gauge, manual of leaf architecture, analytical balance, electric oven, spectrophotometerUNICO 1100, aluminum ladder, calipers, and refractometer. The research was conducted for 10 months in 2017 located in three areas of Banyuasin Regency, which are Banyuasin $1\left(\mathrm{BA}_{1}\right)$, Banyuasin $2\left(\mathrm{BA}_{2}\right)$ and Banyuasin $3\left(\mathrm{BA}_{3}\right)$.

Methods used were survey and literature study. Sampling was performed by using purposive sampling method. Five plant samples were observed in each location resulted in total 15 plant samples. Research steps included survey, research sites determination, and purposive sampling. Vegetative characters were observed in stems and leaves, while fruits were observed for the generative characters. The observation in stem morphology consisted of the parameters of plant height, stem girth and branching type. The analysis of leaf 
morphology, leaf anatomy and leaf physiology was carried out in the laboratory of Plant Physiology, Department of Agronomy, Faculty of Agriculture, University of Sriwijaya.

Leaf chlorophyll was analyzed by soaking $2 \mathrm{~cm} \times 2 \mathrm{~cm}$ of fresh leaf samples into $10 \mathrm{ml}$ of ethanol $80 \%$ for about 48 hours in dark room. The absorbance then was determined using spectrophotometer with 650 and $665 \mathrm{~nm}$ of wavelength (Hall and Rao, 1987). Antrone method was used to determine leaf sucrose. $2 \mathrm{~g}$ of fresh leaf was added with $15 \mathrm{ml}$ of ethanol then crushed in the mortar. Another $10 \mathrm{ml}$ of ethanol then was added to the crushed leaf samples. It was then filtered and heated in $70{ }^{\circ} \mathrm{C}$ temperature for 30 minutes. After cooling down, $0.2 \mathrm{ml}$ of sample solution was added with $6 \mathrm{ml}$ antrone $(0.25$ antrone +177.5 $\mathrm{ml} \mathrm{H}_{2} \mathrm{SO}_{4}+72.5 \mathrm{ml}$ of water). The solution was heated until it changed into blue-ish color. After cooling down, the absorbance was determined using spectrophotometer with $600 \mathrm{~nm}$. Leaf nitrogen was determined by using Kjeldahl method. $0.1 \mathrm{~g}$ of dry samples added with strong sulphate acid was heated in the acid room. Destillation process then was performed by using Borax acid and indicator. The solution then was titrated with $0.01 \mathrm{~N}$ of sulphate acid until the color changed into red (Lorenz, 1978).

Data resulted then were descriptively analyzedand calculated for the correlation among characters. Phenotypic variance analysis and deviation standard were used to determine the range (large or narrow) of the observed characters' variability. Deviation standard and phenotypic variance were also calculated. Characters variability was determined based on Daradjat (1987) method. Large variability was occurred when the variance was bigger than twice of deviation standard $\left(\sigma_{f}^{2}>2 . S \mathrm{~d} \sigma_{f}^{2}\right)$, and narrow variability when the variance is less than twice of deviation standard.All collected data were presented in form of tables and figures.

\section{RESULTS AND DISCUSSION}

Vegetative Characters. The characters of morphology, anatomy and physiology were observed as the vegetative characters. Morphological characters then were divided into quantitative and qualitative morphology.
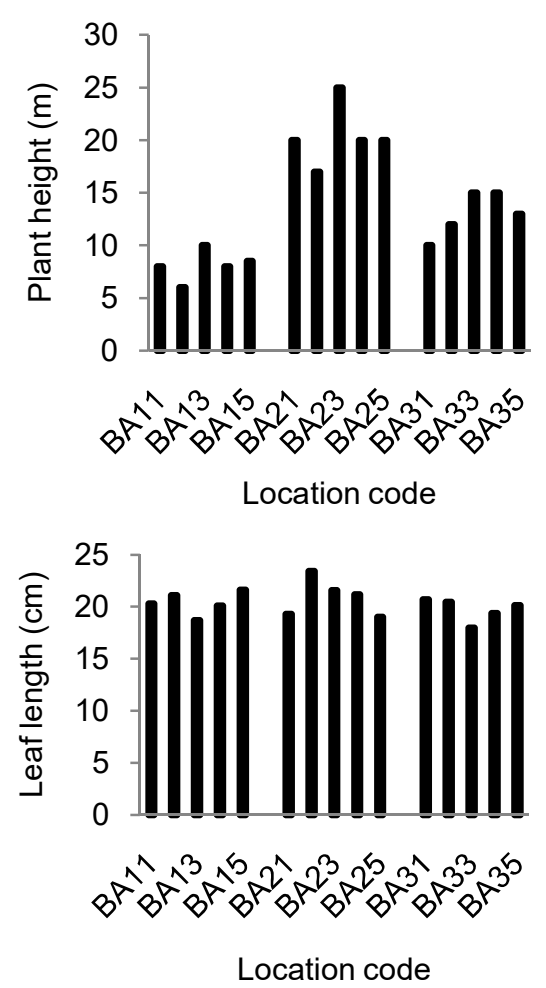
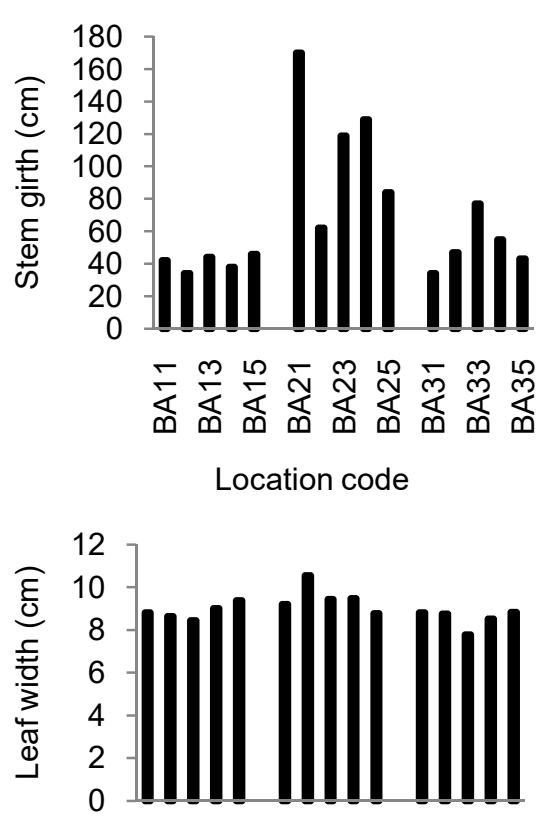

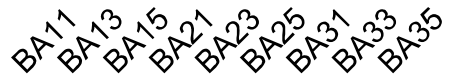

Location code

Figures 1-4 - Vegetative Characters 
Quantitative morphology then was used as phenotypic variability analysis. The observation for quantitative morphology obtained the data of plant height, stem girth and leaf width.

The tallest tree was found in $\mathrm{BA}_{23}$ location with $25.0 \mathrm{~m}$ and the lowest was in $\mathrm{BA}_{12}$ with $6.0 \mathrm{~m}$. The largest stem girth was $\mathrm{BA}_{21}$ with $170 \mathrm{~cm}$ and the smallest was in $\mathrm{BA}_{12}$ and $\mathrm{BA}_{31}$ with $34 \mathrm{~cm}$. The longest and widest leaf was found in the same location in $\mathrm{BA}_{22}$ with $23.43 \mathrm{~cm}$ and $10.55 \mathrm{~cm}$ respectively. However, the shortest and narrowest leaf was from different location. The shortest leaf was in $\mathrm{BA}_{13}$ with $18.71 \mathrm{~cm}$ and the narrowest leaf was in $\mathrm{BA}_{33}$ with $7.78 \mathrm{~cm}$. The difference in leaf morphology was due to the difference in temperature, humidity, and light intensity intercepted by the leaves (Pompelliet al., 2010; Sholikhahet al. 2015)(Figure 1-4).

The qualitative morphology based on Munsell Colour Book and Manual of Leaf Architecture (Ash et al., 199)showed the similarity for all the observed characters in all locations.The branching type was monopodial with an obvious main stem which was bigger and taller compared to the branches. The branches direction was also tend to go upward.Leaf shape was elliptic with 1.5-2 : 1 of comparison between leaf length and leaf width while leaf petiole was on the lamina.Leaf margin was entire with thin segment and no fiber layer. Leaf base shape was complex and leaf tip was acuminate, while leaf venation type was a pinnate with single leaf vein. Leaf greeness level was 3/4 7.5 GY (data not shown).

Both quantitative and qualitative data for leaf anatomy were obtained through microscopic observation. Quantitative data includednumber of abaxial and adaxial stomata, and stomata shape was as qualitative data. The number of abaxial stomata was relatively higher than adaxial stomatafor about 20.75 - 29.50 in which the highest was found in $\mathrm{BA}_{25}$ and the lowest was in $\mathrm{BA}_{11}, \mathrm{BA}_{23}$ and $\mathrm{BA}_{31}$, while adaxial stomata was around $5.75-$ 9.25 where the highest was in $\mathrm{BA}_{14}$ and the lowest was in $\mathrm{BA}_{32}$ (Figure 5). Stomata number was counted in each microscopic viewing with $40 \times 10$ magnification.According to Yuliasmara and Ardiyanti (2013), leaf would tend to have more number of leaf stomata on the under surface of the leaf compared to the leaf surface. The higher number of stomata, the higher stomata density. Yulianti et al. (2010) stated that stomata density could be determined as the character identifying plant disease resistancy.

Result showed that stomata shape was anomocytic shapecharacterizedby the guard cell surrounded by five or more epidermic cells so that the shape would look like a pentagon. Based on stomata position, duku leaf was identified as an amphystomatic type (data not shown). It is a type of leaf that has stomata in both sides of the leaf (Rushayati and Maulana, 2005).

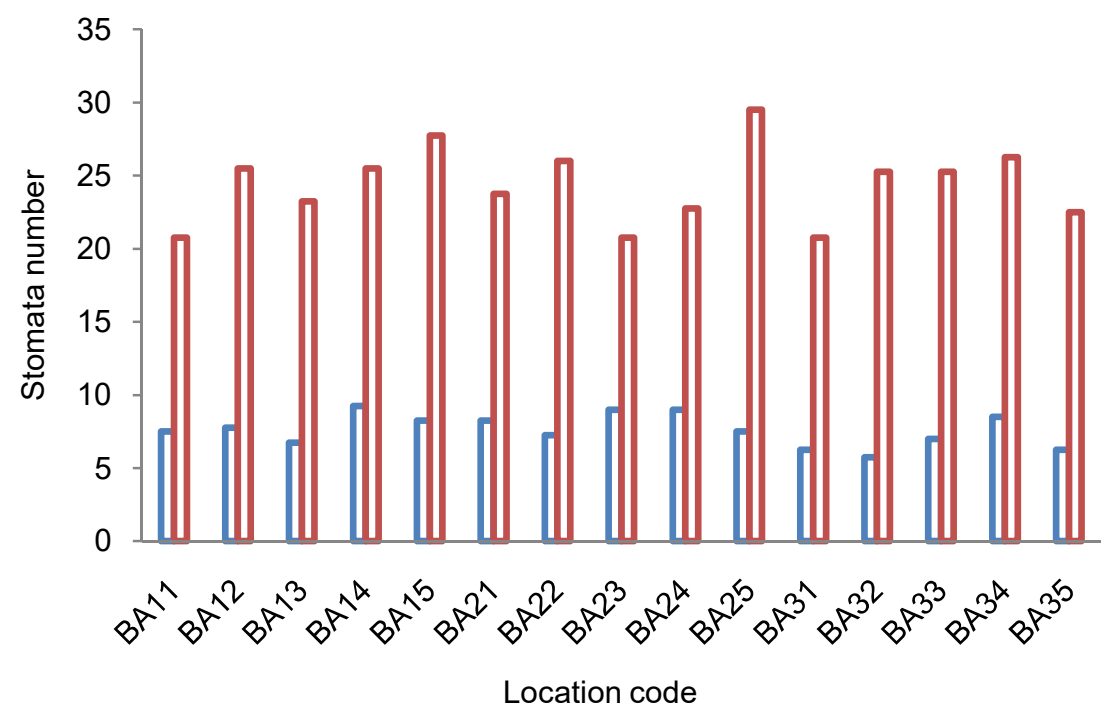

Figure 5 - Adaxial and abaxial stomata of duku accession in Banyuasin Regency 
Leaf chlorophyll was analized in the laboratory resulting in $10.54-30.45 \mathrm{mgg}^{-1}$ of chlorophyll content. The highest was resulted in location $\mathrm{BA}_{13}$ and the lowest was in $\mathrm{BA}_{14}$ (Figure 6). Leaf nitrogen was around $0.28-1.68 \%$ and leaf sucrose was $0.03-0.44 \%$. The highest nitrogen was from $B A_{31}$ and the lowest was from $B A_{21}$, while for sucrose the highest was $B_{21}$ and the lowest was $B_{13}$ (Figure 7). Ai Song and Banyo (2011) stated that leaf chlorophyll was influenced by environmental factors such as light intensity and $\mathrm{H}_{2} \mathrm{O}$. Leaf nitrogen could be used as an indicator for photosynthesis activity since nitrogen is one the constituent elements of chlorophyll required for carbohydrate formation in photosynthesis (Hernita et al., 2012). Anggarwulan et al. (2008) added that leaf nitrogen was also influenced by $\mathrm{H}_{2} \mathrm{O}$. Leaf sucrose resulted a varied data which might be caused due to either environmental (such as ground water content) or genetical factor by SUT gene expression or sucrose transporter (Novita et al., 2007).

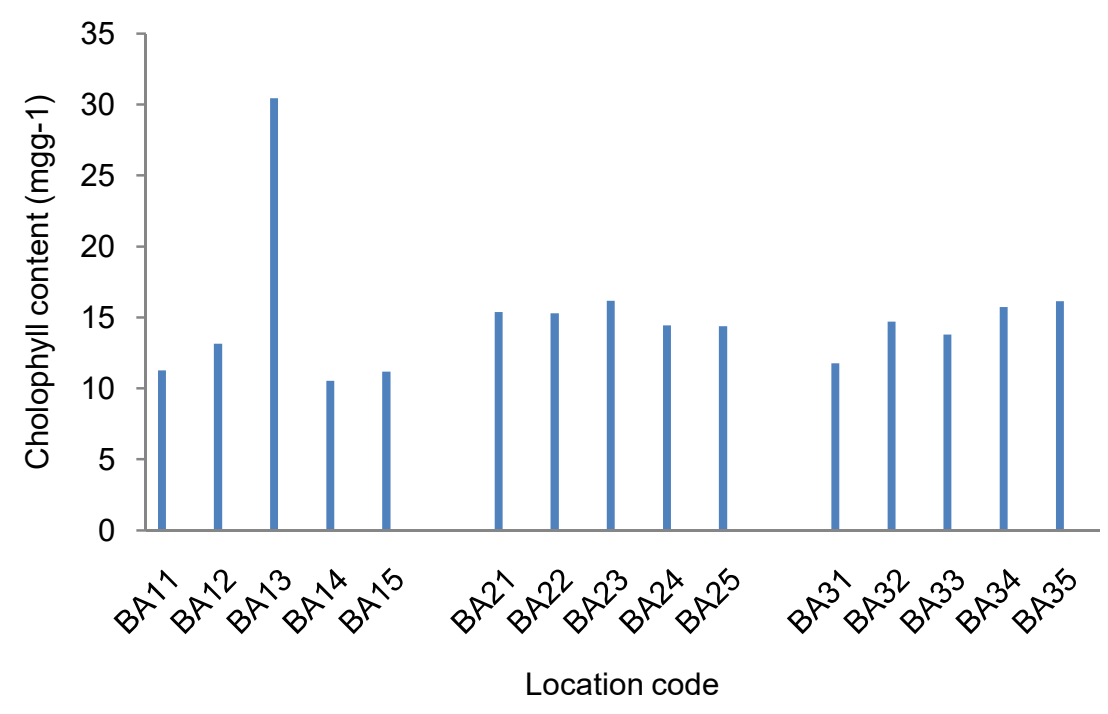

Figure 6 - Leaf chlorophyll of duku accession in Banyuasin Regency

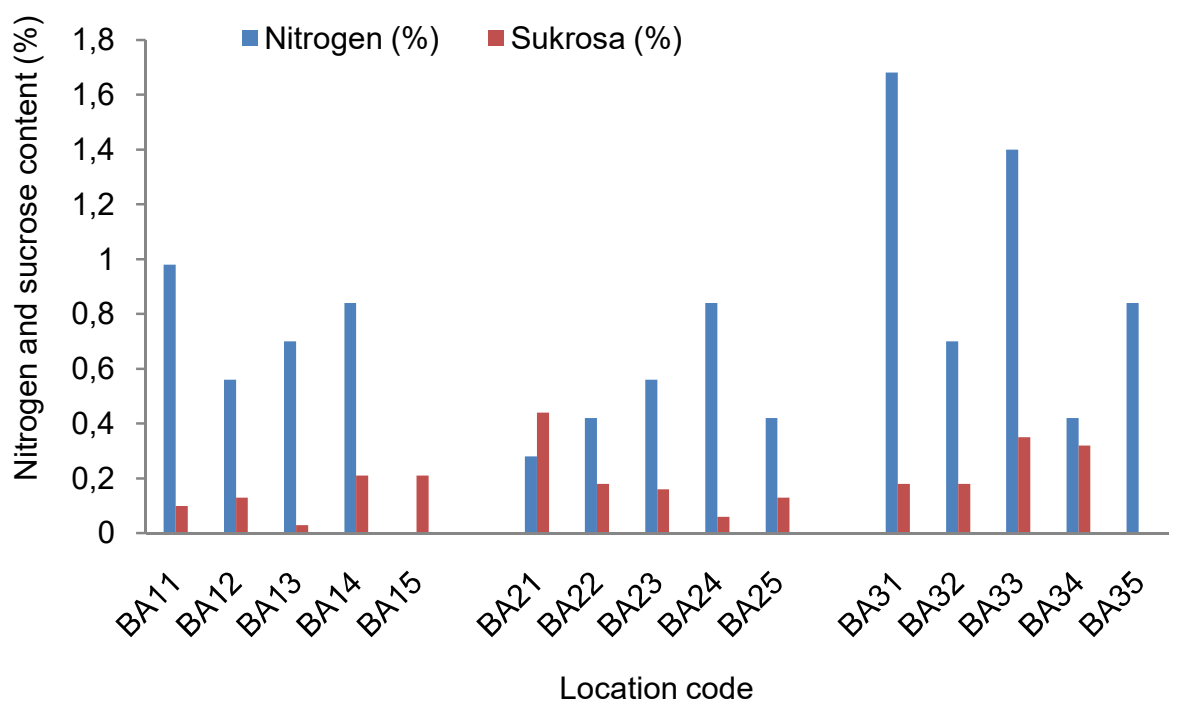

Figure 7 - Leaf and sucrose content of duku succession in Banyuasin Regency

Generative Characters. The obtained data of generative characters consisted of fruit length $(\mathrm{cm})$, fruit diameter $(\mathrm{cm})$, fruit peel thickness $(\mathrm{g})$, fruit weight $(\mathrm{g})$, number of slices per fruit, number of seed per fruit and sweetness level ( ${ }^{\circ}$ brix). Fruit length was around $2.70-$ $3.46 \mathrm{~cm}$ where the longest fruit was resulted from location $\mathrm{BA}_{25}$ and the shortest was in $\mathrm{BA}_{22}$. 
Fruit diameter was around $2.18-2.71 \mathrm{~cm}$ where the largest was in $\mathrm{BA}_{12}$ and the smallest was in $\mathrm{BA}_{33}$. Fruit peel thickness was around $0.15-0.23 \mathrm{~cm}$ where the thickest was in two locations $\mathrm{BA}_{25}$ and $\mathrm{BA}_{34}$, while the thinnest was in $\mathrm{BA}_{22}$ (Figure 8).

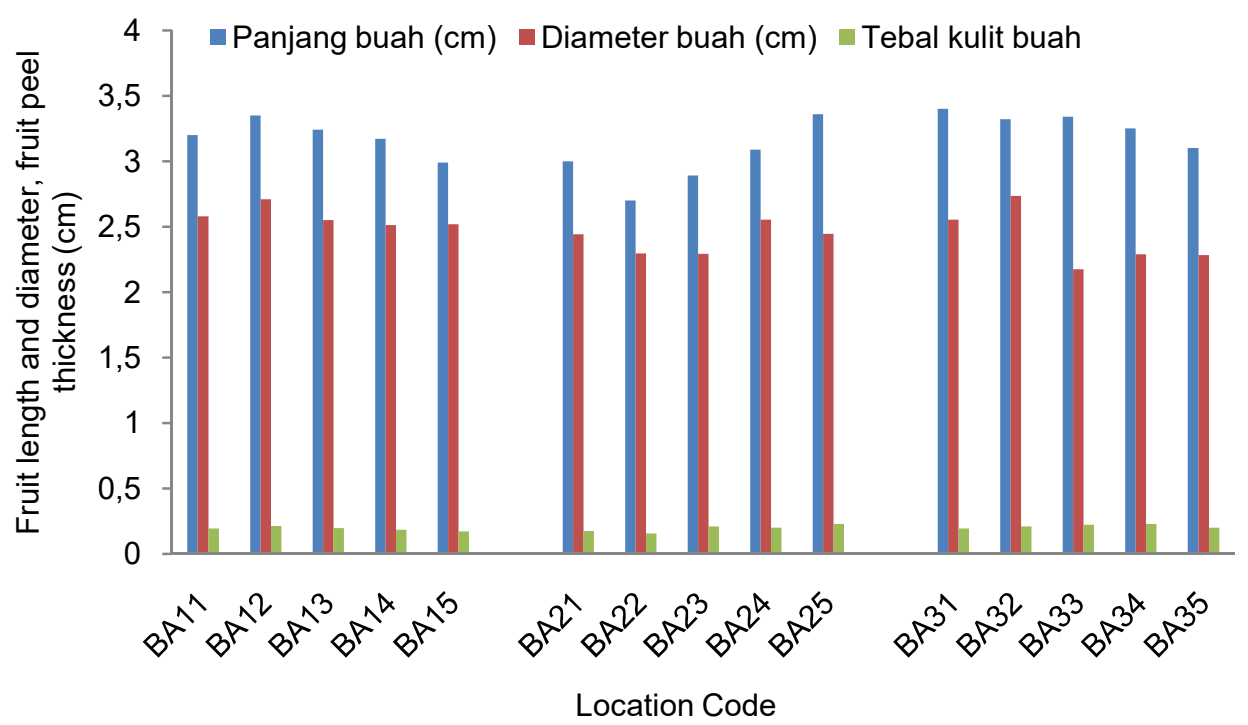

Figure 8 - Fuit length, diameter and fruit peel thickness of duku accession in Banyuasin Regency

Fruit weight was around $9.26-16.10 \mathrm{~g}$ where the heaviest was in $\mathrm{BA}_{12}$ and the lightest was resulted from two locations $\mathrm{BA}_{21}$ and $\mathrm{BA}_{31}$ (Figure 9). Number of slices per fruit was around $4.67-5.00$ where the highest number was resulted from 4 locations: $\mathrm{BA}_{12}, \mathrm{BA}_{13}$, $\mathrm{BA}_{14}$ and $\mathrm{BA}_{22}$. While the lowest number was in $\mathrm{BA}_{34}$ (Figure 10). Seed number per fruit was around $0.00-0.83$ where the highest was in $\mathrm{BA}_{11}$ and the lowest was in $\mathrm{BA}_{21}$ (Figure 11). Sweetness level was around $18.82-22.28{ }^{\circ}$ brix. The highest was in $\mathrm{BA}_{25}$ and the lowest was in $\mathrm{BA}_{34}$ (Figure 12).

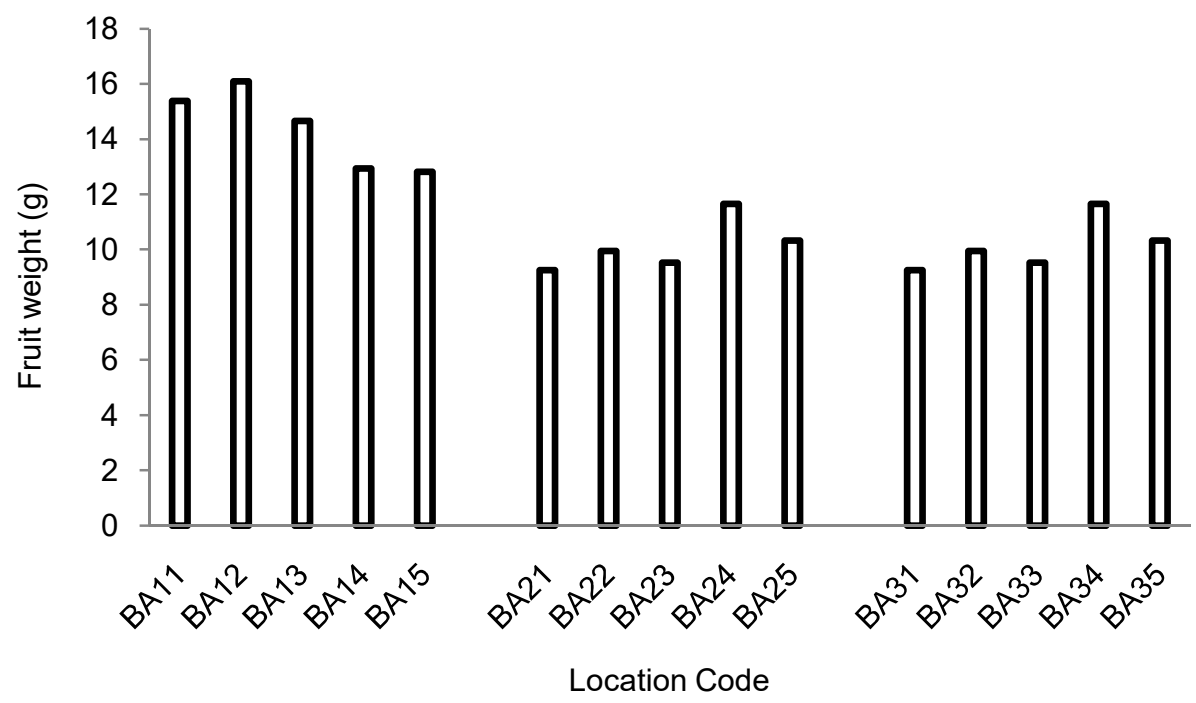

Figure 9 - Fruit weight of duku accession in Banyuasin Regency

Analysis of Variability and Correlation among Characters. Phenotypic variability analysis was performed based on the characters of quantitative morphology, quantitative anatomy and physiology. Results showed that both wide (varied) and narrow (similar) variability were found in the accession of duku in Banyuasin Regency (Table 1). 


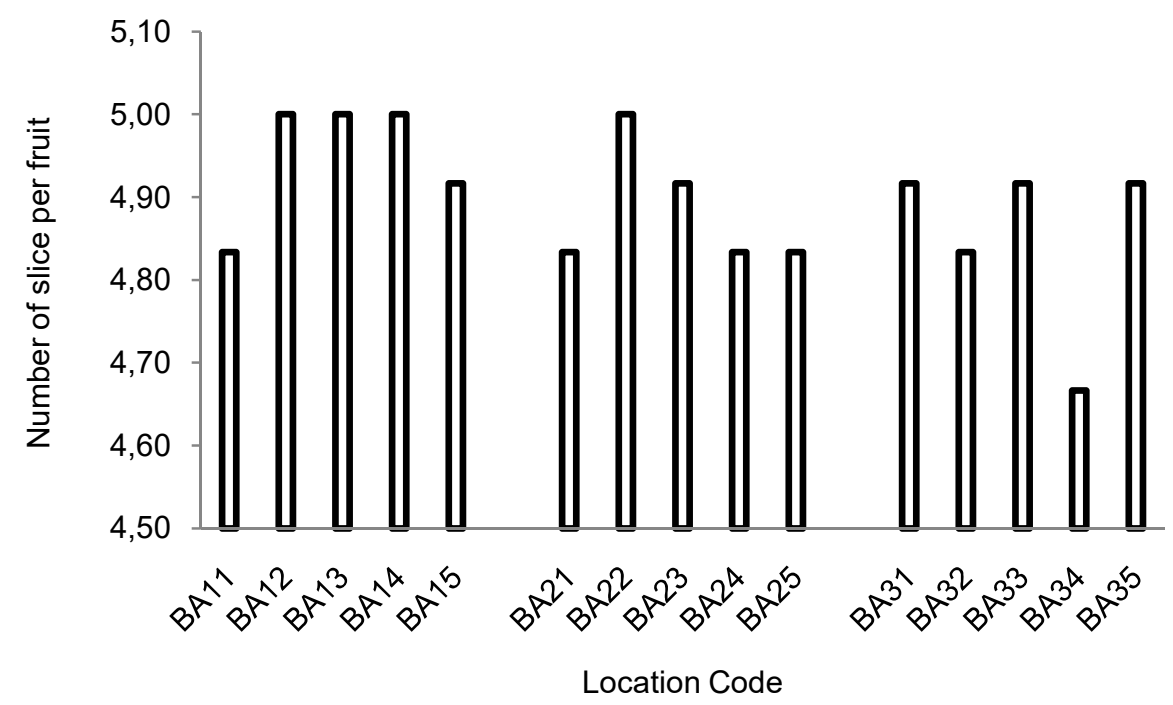

Figure 10 - Number of slice per fruit of duku accession in Banyuasin Regency

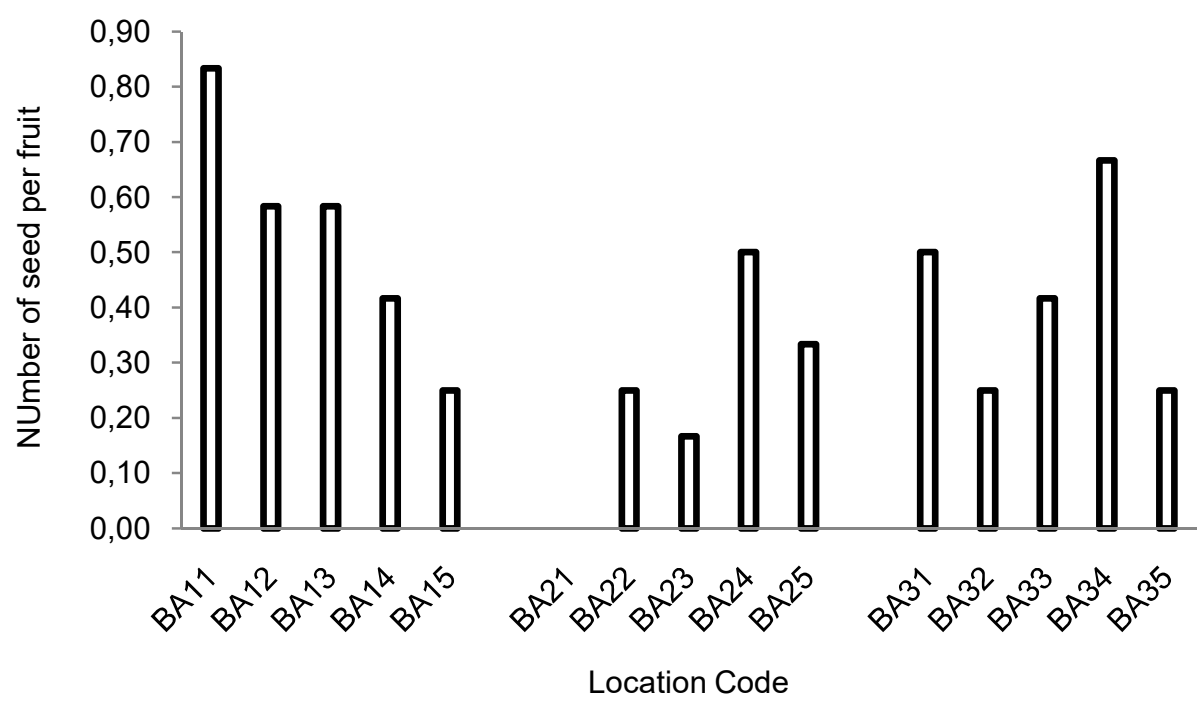

Figure 11 - Number of seed per fruit of duku accession in Banyuasin Regency

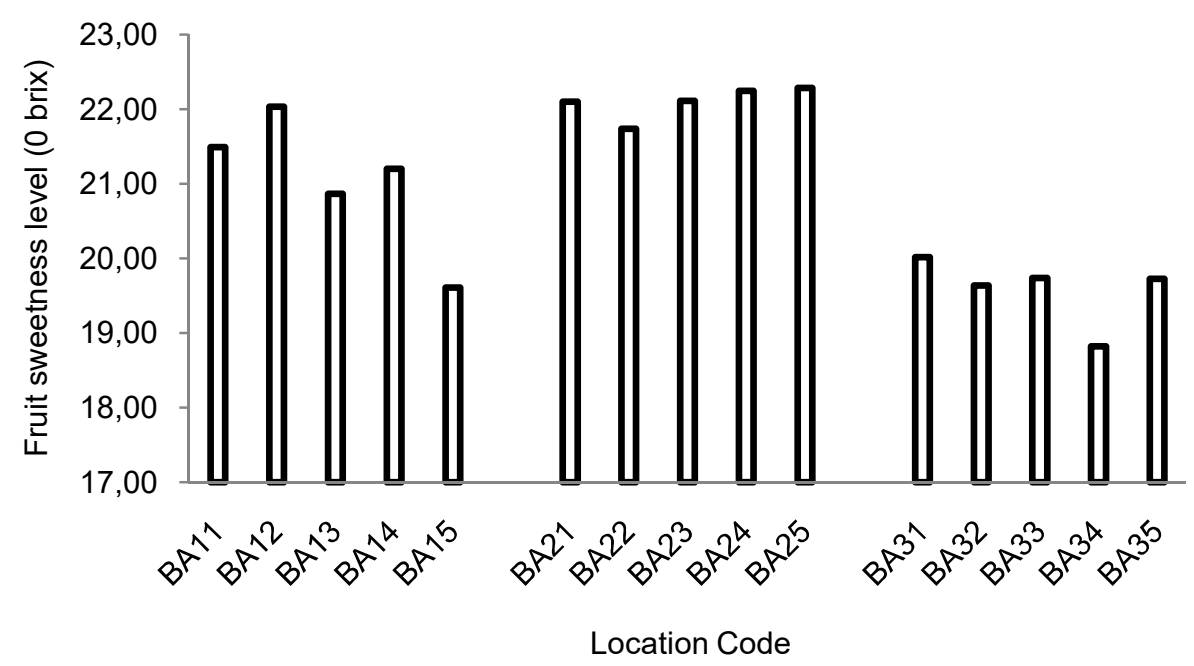

Figure 12 - Fruit sweetness level of duku accession in Banyuasin Regency 
Table 1 - Variability analysis of duku accession in Banyuasin Regency

\begin{tabular}{llll}
\hline Characters & Variance & Deviation standars & Variability \\
\hline Tree height $(\mathrm{m})$ & 38.34 & 1.68 & Wide \\
Stem girth $(\mathrm{cm})$ & 1514.45 & 26.61 & Wide \\
Leaf length $(\mathrm{cm})$ & 0.35 & 1.27 & Narrow \\
Leaf width $(\mathrm{cm})$ & 0.48 & 0.62 & Narrow \\
Number of adaxial stomata & 0.58 & 0.69 & Narrow \\
Number of abaxial stomata & 0.10 & 3.81 & Narrow \\
Leaf chlorophyll $\left(\mathrm{mgg}^{-1}\right)$ & 0.22 & 0.71 & Narrow \\
Leaf nitrogen $(\%)$ & 0.06 & 0.28 & Narrow \\
Leaf sucrose $(\%)$ & 0.004 & 0.45 & Narrow \\
Fruit weight $(\mathrm{g})$ & 3.484 & 1.866 & Narrow \\
Fruit length $(\mathrm{cm})$ & 0.019 & 0.137 & Narrow \\
Number of slice per fruit & 0.003 & 0.051 & Narrow \\
Number of seed per fruit & 0.020 & 0.140 & Narrow \\
Fruit peel thickness $(\mathrm{cm})$ & 0.000 & 0.011 & Narrow \\
Fruit sweetness $\left({ }^{0}\right.$ Brix $)$ & 1.589 & 1.260 & \\
\hline
\end{tabular}

Note: variability determined using the method of Daradjat (1987).

Large variability was resulted when the variance was more than twice of deviation standard, while if the variance was less than twice of deviation standard, narrow variability was resulted. Large variability was resulted from the characters of tree height and stem girth, while other characters resulted a narrow variability. The difference of variability might be caused by envionmental factor (phenotypic variability) and genetic factor (genetic variability). According to Ruchjaningsih et al. (2002), a character with narrow variability indicated a relatively simiar population so that it was rather impossible to carry out a selection for character improvement. Furthermore, Alnopri (2004) added that large variability was considered as one of selection requirements for certain desired character.

Table 2 - Correlation among vegetative and generative characters of duku accession

\begin{tabular}{|c|c|c|c|c|c|c|c|c|c|c|c|}
\hline Characters & $\mathrm{TH}$ & SG & LL & LW & $\mathrm{FL}$ & FD & FW & SLPF & SDPF & FPT & $\overline{S L}$ \\
\hline $\mathrm{TH}$ & 1 & $0.823^{\star *}$ & 0.040 & 0.325 & -0.426 & $-0.533^{*}$ & $-0.673^{* *}$ & -0.332 & $-0.524^{*}$ & 0.201 & -0.080 \\
\hline SG & & 1 & -0.070 & 0.262 & -0.387 & -0.274 & $-0.465^{\star}$ & -0.305 & $-0.531^{*}$ & 0.028 & -0.075 \\
\hline LL & & & 1 & $0.861^{* *}$ & $-0.659^{\star *}$ & 0.136 & 0.002 & 0.295 & -0.187 & $-0.625^{\star *}$ & 0.088 \\
\hline LW & & & & 1 & $-0.849^{* *}$ & -0.033 & -0.180 & 0.196 & -0.410 & $-0.723^{* *}$ & 0.023 \\
\hline $\mathrm{FL}$ & & & & & 1 & 0.382 & 0.213 & -0.203 & $0.503^{*}$ & $0.672^{\star *}$ & -0.087 \\
\hline FD & & & & & & 1 & $0.513^{*}$ & 0.100 & 0.262 & -0.078 & 0.065 \\
\hline FW & & & & & & & 1 & 0.225 & $0.680^{* *}$ & -0.028 & -0.039 \\
\hline SLPF & & & & & & & & 1 & -0.147 & -0.489 & 0.377 \\
\hline SDPF & & & & & & & & & 1 & 0.280 & -0.284 \\
\hline FPT & & & & & & & & & & 1 & -0.198 \\
\hline SL & & & & & & & & & & & 1 \\
\hline
\end{tabular}

Note: $T H=$ tree height; $S G=$ stem girth; $L L=$ leaf length; $L W=$ leaf width; $F L=$ fruit length; $F D=$ fruit diameter; $F W=$ fruit weight; SLPF = number of slice per fruit; SDPF = number of seed per fruit; FPT = fruit peel thickness; $S L=$ sweetness level. ${ }^{*}=$ significant in 0.05 level; ${ }^{* *}=$ significant in 0.01 level.

Based on the correlation analysis of vegetative and generative charaters, it was found that tree height had significant positive correlation with stem girth and significant negative correlation with fruit diameter and number of seed per fruit, and also had significant correlation with fruit weight. Stem girth showed a significant negative correlation with number of seed per fruit. While leaf length had significant positive correlation with leaf width and significant negative correlation with fruit length and fruit peel thickness. Leaf width showed significant negative correlation with fruit length and fruit peel thickness. Fruit length had significant positive correlation with number of seed per fruit and fruit peel thickness. Fruit diameter showed siignificant positive correlation with fruit weight, and fruit weight was positively correlated with number of seed per fruit significantly. 


\section{CONCLUSION}

Based on the obtained results, it was concluded that postive correlation was resulted among vegetative characters and also among generative characters, while vegetative and generative characters were negatively correlated.

\section{REFERENCES}

1. Ai Song A., and Y. Banyo. 2011. Chlorophyll Concentration as the Indicator of Water Deficit in Plant. J. IImiah Sains 11(2):167-173.

2. Alnopri. 2004. The Genetic Variability and Heritability of Seedling Growth Traits of Seven Genotypes Robusta-Arabica Coffee. JurnallImu-ilmuPertanian Indonesia. Volume 6(2): 91-96.

3. Anggarwulan E, Solikhatun, Widya M. 2008. Physiological characters of kimpul (Xanthosomasagittifolium(L.)Schott) in various of light intensity (shading) and water availability. Biodiversitas 9(4):264-268.

4. Ash, A., B. Ellis., L.J. Hickey., K. Johnson., P. Wilf., dan S. Wing. 1999. Manual of leaf architecture. Morphological description and categorization of dicotyledonous and netveined monocotyledonous angiosperms. Smithsonian institution. Washington.

5. Central Bureau of Statistic. 2015. The Statistic of Indonesian Fruit Production..www.bps.go.id (accessed on June 19, 2016).

6. Damayanti, F. 2007. The Analysis of Chromosome Number and Stomata Anatomy in Several Banana (Musa sp.) Germplasms Originated from East Kalimantan. Bioscientiae. 4(2): 53-61.

7. Daradjat, A.A. 1987. Genotype Adaptation Variability of Wheat Plants on Different Planting Environment in Indonesia .University of Padjajaran. Bandung.

8. Deroes, K.Mand A. Wijaya. 2010. Current Condition and Opportunity for Duku(Lansium Domesticum Corr) Development. J. Pembangunan Manusia 4 (11) : 1-7.

9. Directorate General of Horticulture. 2015. The Information of Horticultures and Other Various Plants. Directorate General of Horticulture. Jakarta. (In Indonesian)

10. Hanum, L., R.S. Kasiamdari., Santosaand Rugayah. 2013. The Character of Macromorphology and Micro-morphology of Duku, Kokosan, Langsatin Determining Taxonomy Status in the Category of Intra-species.JurnalBiospecies Vol. 6 (2): 23-29.

11. Hall, D.O., K.K. Rao. 1987. Photosynthesis. 4thed King's college, University of London, London.

12. Hernita, D., R. Poerwanto., A.D. Susila and S. Anwar. 2012. The Determination of Nutrient Status on Duku Seedlings. J. Hort. 22(1): 29-36.

13. Irawan, B. and K. Purbayanti. 2008. The Characterization and Genetic Relation of Local Rice Cultivar in Rancakalong, Sumedang.PTTI National Seminar,October 21-23, 2008.

14. Kusandaryani, Y. and Luthfy, 2006. The Characterization of Kangkung Germplasms. Buletin plasma nutfah. 12 ( ): $30-33$

15. Lorenz, O.A. 1978. Potential nitrate level in edible plant parts. P. 201-219. In D.R Nielsen J.G. MacDonald (Eds) Nitrogen in The Environment. Academic Press, New York.

16. Novita, H., Sumadi., D.P. Restanto., T.A. Siswoyoand B. Sugiharto. 2007. The Isolation and Characterization of Gene Expression for Protein Sucrose Transporter in Sugarcane. JurnalllmuDasar. 8(2): 118-127.

17. Pane, N., R. Gintingand H. Hasyim. 2009. Farming Business Analysis of Duku(LansiumdomesticumCorr.)Plantation. J. Agroekoteknologi3(2): 92-98.

18. Pompelli, M.F., S.C.V. Martins., E.F. Celin., M.C. Ventrella., dan F.M. DaMatta. 2010. What is the influence of ordinary epidermal cells and stomata on the leaf plasticity of coffe plants grown under full-sun and shady conditions?.Braz. J. Biol., 70(4): 1083-1088.

19. Rohlf, F.J. 1998. NTSys-pc. Numerical Taxonomy and Multivariate Analysis System. Version 2.02. Exerter Software. New York. 
20. Rushayati, S.B., and R.Y. Maulana. 2005. Growth Response and Anatomy of Canary (Canarium commune L.) Leaf and Acacia (Acacia mangiumWilld.) to Vehicle Gas Emission. Media Konservasi.X (2): Desember 2005: 71-76.

21. Ruchjaningsih A., Imaraman, Thamrin M., Kanro M.Z. 2002. Phenotypic Performance of Several Genetic Parameter of Eight Ground Nut Cultivars Grown in Paddy Field. Zuriat 11(1): 110.

22. Seed Inspection and Certification Center of South Sumatra. 1999. The Determination of Fruit Parent Trees. Seed Inspection and Certification Center of South Sumatra, Palembang.

23. Sholikhah, U., D.A. Munandar and A. Pradana. 2015. Physiological Characters of Robusta Coffee Clone BP 358 at Different Shading Types. Agrovigor . 8 (1) : 58-67.

24. Yuniarti. 2011. The Inventory and Morphological Characterization of Durian (DuriozibethinusMurr.) in Tanah DatarRegency. J. Plasma nutfah. 1 1) : 1-7.

25. Yulianti, H., D. Siswanto., and J. Purnomo. 2010. The Study of Stomata Density in the Sensitive and Tolerant Cultivar to Leaf Rust PucciniaarachidisSpeg.) in Ground Nut (Arachishipogaea L.). Basic Science national seminar proceeding. Malang. 20 februari 2010. 1-5.

26. Yuliasmara, F and F. Ardiyanti. 2013. Morphology, physiology and anatomy of pakupicisan (Drymoglossumphyloselloides) and its influence on the cocoa tree. Pelita Plantation. 29 (2): 128-141.

(c) 2017 by the authors. Licensee RJOAS, Orel, Russia. This article is an open access article distributed under the terms and conditions of the Creative Commons Attribution (CC BY) license: http://creativecommons.org/licenses/by/4.0/ 
DOI https://doi.org/10.18551/rjoas.2017-09.35

\title{
CONTAMINATION OF COLIFORM, ESCHERICHIA COLI, AND LEAD IN VEGETABLES SOLD AT TRADITIONAL MARKET IN PALEMBANG CITY PROVINCE OF SOUTH SUMATRA
}

\author{
Yani Ade Vera*, Hasbi, Priyanto Gatot, Pambayun Rindit, Wijaya Agus \\ Faculty of Agriculture, University of Sriwijaya, Indonesia \\ *E-mail adeverayani@yahoo.com
}

\begin{abstract}
This study aims to identify the number of contaminantion of coliform, Escherichia coli and lead contained in lettuce, tomato and carrots at the level of traditional market in Palembang city. There were 27 total samples selected from four traditional markets. Microbial analysis was determine based on AOAC (1984) method, lead analysis by using AAS (Shimatzu type AA 700). The data were expressed as mean \pm standard deviation was calculated using Microsoft Excel 2007 program. All research work conducted in triplicate. The results showed that all vegetables contained coliform and lead contamination while Escherichia coli was not detected.
\end{abstract}

\section{KEY WORDS}

Coliform, Escherichia coli, plumbun, lettuce, tomato, carrot.

Currently consumption of fresh vegetables is increasing. The Food and Drug Administration (FDA) and the World Health Organization (WHO) recommends consuming 5-9 servings of vegetables daily because it can reduce the risk of certain diseases (Weldezgina and Muleta, 2016; Ignarro et al., 2007; Liu, 2003). Lettuce, tomatoes, and carrots are vegetables that are often consumed fresh (raw).

Although it has health benefits, raw vegetables need to be taken into consideration of their safety level because it is suspected that vegetables have been contaminated due to improper treatment at all stages during pre and post harvest techniques (De Roever, 1999; Lund et al., 2000; Amoah et al., 2006). Types of contaminants commonly found ini vegetables include pathogenic microbial contaminants and chemical contaminants.

Many epidemics in many countries are caused by the consumption of fresh vegetables contaminated with microbes (Beuchat, 2002; FAOMHO, 2008). Pathogenic microbes commonly detected in fresh vegetables are coliform bacteria and Escherichia coli (Tambekar and Mundhada, 2006).

In developing countries, the use of waste water and fertilizers for vegetable production is a contributing factor to the contamination of vegetables (Johannessen et al., 2002; AdeOluwa and Cofie, 2012). Coliform is used as an indicator of microbiological quality of water and food (Chaturvedi et al., 2013). The presence of coliform contamination in vegetables indicates that vegetables are contaminated by human and animal feces (Cornish et al., 1999). Microbiological contamination of pathogens originating from irrigation water contaminated with waste, soil or manure used as fertilizer characterized by the presence of Escherichia coli (Purba et al., 2012).

Several studies have revealed the presence of pathogenic microbial contamination in vegetables that harm consumers (D'Mello, 2003; Zandstra and De Kryger, 2007). In the USA there is an outbreak of E.coli O157: $\mathrm{H} 7$ contained on the lettuce from the Taco Bell restaurant in the northern United States (CDC, 2015).

The International Commission on Microbiological Specification for Foods (ICMSF) (1996) recommends vegetables to be consumed raw containing Escherichia coli less than $10^{3} \mathrm{CFU} / \mathrm{g}$. Directorate General of Food and Drug Control of the Republic of Indonesia (1989), requires maximum consumed vegetables containing Escherichia coli $10^{2} \mathrm{CFU} / \mathrm{g}$.

Contaminants of other harmful chemicals found in vegetables are heavy metals such as lead $(\mathrm{Pb})$ which pollute many environments and are harmful to human health 
(Widaningrum et al., 2007; Notohadiprawiro, 1995). The source of heavy metal contaminants comes from excessive exhaust fumes, fertilizers or pesticides that exceeds the prescribed safe dose (Singh, 2004). Winarti and Miskiyah (2010), showed that the content of lead contaminats $(\mathrm{Pb})$ in carrots was $0.10-0.21 \mathrm{ppm}$. While the content of $\mathrm{Pb}$ on lettuce is not detected.

The presence of pathogenic microbial contaminants and heavy metals in fresh vegetables indicates inadequate handling during planting, harvesting, distribution and transportation to marketing. Traditional market sanitation conditions are generally inadequate, this can be seen from the dirty environment, muddy, unpleasant smell, uncomfortable. This situation allows bacteria to move from one place to antoher or cross contamination (Mujianto, 2008).

Research purposes. Generally, this study aims to assest coliform, E.coli and lead contaminantion in vegetables those are sold at the traditional market in Palembang city.

Hypothesis. The hypothesis of the study was fresh vegetables those sold in traditional marketed in Palembang city contained coliform, E.coli and lead.

\section{METHODS OF RESEARCH}

The Scope of Research. The scope of research was identification of Coliform, E.coli and Lead contamination in fresh vegetables marketed in Palembang city, Indonesia. The execution of research work were four traditional markets which represent marketing area, namely Jakabaring (JK), Perumnas (PM), Alang-Alang Lebar (AAL) and Km 5 (K5).

Random sampling was adopted to collects sample vegetables. There were 27 total samples selected from four traditional markets. The vegetables investigated were lettuce, tomato and carrot as those vegtetables commonly consumed freshly. All research work conducted in treplicate.

Analysis Method. Microbial analysis was determine based on AOAC (1984) method, lead analysis by using AAS (Shimatzu type AA 700). The data were expressed as mean \pm standard deviation was calculated using Microsoft Excel 2007 program.

\section{RESULTS AND DISCUSSION}

Coliform. This research is to know the amount of microbial contamination of pathogenic coliform and E. coli in lettuce, tomatoes, and carrots. Test result showed that coliform contaminants on lettuce, tomatoes, and carrots at the level of traditional market in the city of Palembang ranged from $(9.62 \pm 4.65) \times 10^{2} \mathrm{CFU} / \mathrm{g}$ up to $(10.43 \pm 4.97) \times 10^{2} \mathrm{CFU} / \mathrm{g}$ for lettuce; $(4.73 \pm 1.45) \times 10^{2}$ up to $(5.97 \pm 3.96) \times 10^{2}$ for tomatto; and $(9.13 \pm 5.31) \times 10^{2}$ up to $(13.04 \pm 8.67) \times 10^{2}$ for carrot.

Table 1 - Coliform contamination

\begin{tabular}{lccc}
\hline \multirow{2}{*}{ Traditional Market } & \multicolumn{3}{c}{ Coliform (CFU/g) } \\
\cline { 2 - 4 } & Lettuce & Tomatto & Carrot \\
\hline Jaka Baring & $(10.43 \pm 4.97) \times 10^{2}$ & $(5.38 \pm 2.49) \times 10^{2}$ & $(11.75 \pm 4.32) \times 10^{2}$ \\
Km 5 & $(10.03 \pm 5.03) \times 10^{2}$ & $(4.78 \pm 1.54) \times 10^{2}$ & $(10.68 \pm 4.81) \times 10^{2}$ \\
AAL & $(9.87 \pm 4.91) \times 10^{2}$ & $(5.97 \pm 3.96) \times 10^{2}$ & $(9.13 \pm 5.31) \times 10^{2}$ \\
Perumnas & $(9.62 \pm 4.65) \times 10^{2}$ & $(4.73 \pm 1.45) \times 10^{2}$ & $(13.04 \pm 8.67) \times 10^{2}$ \\
\hline
\end{tabular}

Data were expressed in mean \pm standar deviation based on triplicate readings $(n=3)$.

Based on Table 1, among of the three vegetables, carrot was the most contaminated, followed by lettuce, and tomatoes. Test result also showed that all vegetables involved have level of coliform contamination exeeded the limit of recommended by WHO and the International Commission on Microbiological Specifications for Food i.e. $10-10^{2} \mathrm{CFU} / \mathrm{g}$ (Benti's run et al., 2014). Coliform in vegetables is an indication of contamination that comes from human and animal faecal (Cornish et al., 1999). 
These results correlated with the source of contamination during growth, namely soil, organic fertilizer and water sources (Heaton and Jones, 2008). The carrot is a kind of vegetable that is directly in contact with the ground, lettuce is belong to growing low above the ground while tomatoes are relatively far away from the land where the growing. The application of manure from animal waste, watering with contaminated domestic waste water, post-harvest handling unhygienic by farmers is a potential source of contamination (Chaturvedi et al., 2013; Amoah et al., 2005; Mensah et al., 2002; Halablah et al., 2011; Johannessen et al., 2002). In addition, the use of fresh manure without drying used for vegetable production potentially to produce total coliform fecal matter with a high number of (Drechsel et al., 2000). The presence of coliform is more an indication of the condition of prosessing or inadequate sanitation (anonymous, 2008). But the number of coliform is not necessarily indicates a microbial pathogen (Nguz et al., 2005).

Pathogenic microbial contamination on agricultural products occurs at some point, starting from the production, harvesting, processing, packaging, distribution and marketing in traditional markets (Sapers, 2001). Sanitary condition of traditional market also influences the presence of coliform contamination on vegetables, tomatoes, lettuce and carrots.

Jaka Baring market is a wholesale market that have fair sanitation conditions, where each commodity are separated, and the vegetables are sold in large quantities for retailer. This contrasts with other market such as market Perumnas and $\mathrm{Km} 5$ where vegetables were sold in small quantities and spread on plastic layer on the ground. It is the circumstance which allows the bacteria move from one place to another or cross-contamination (Mujianto, 2008).

In addition the vegetables displayed were often touched by many hands. Handling is often done by hand which is not hygienic are factors that contribute to high levels of microbes. Dusty environment, a lively street, coupled with the quality of the water used to sprinkle vegetables to keep it stay fresh is a supporting factor that can help the survival and multiplication of microorganisms on the surface of vegetables (Chaturvedi et al., 2013).

Escherichia coli. Escherichia coli is one of the members of the coliform group found in human waste. Escherichia coli is often referred as coliform faecal (Fardiaz, 2011). In addition Escherichia coli is one of the microbes used as terms of the quality of microbial impurities contained in the standard specification for horticulture. There are some outbraeks caused by Escherichia coli. Year 2011 poisoning outbreaks occurring caused by E. coli O157: H7 in some States in the United States caused from consuming romaine lettuce. In year 2012, there was a remarkable incident caused by $\mathrm{E}$. coli O157: H7 associated with the consumption of organic spinach, the year 2013 unusual poisoning is also caused by $\mathrm{E}$. coli O157: H7 in ready eat salad, the year 2014 there was outbraek caused by E. coli 0121 on raw clouver sprouts (www.cdc.gov, accessed on September 5, 2016).

Based on the test results analysis, the amount of contaminant Escherichia coli on all vegetable lettuce, tomatoes and carrots marketed in a few traditional in the city of Palembang were $<2$ MPN $/ 100 \mathrm{ml}$. The value of $<2$ MPN (most probable Number) $/ 100 \mathrm{ml}$ indicates that none of the positive test tubes containing Escherichia coli. This mean that all vegetables tested meet the $\mathrm{E}$. coli contamination requirement set by Food and drugs adminstration of Republic Indonesia (2004) which require the limit for Escherichia coli on vegetables are $0-10^{3} \mathrm{CFU} / \mathrm{g}$ (BPOM, 2004).

The levels of $E$ coli on the vegetables is influenced by the location of the cultivation and post-harvest treatment. Most vegetable like lettuce, tomato, and carrot come from area where the water for irrigation during the process of cultivation is derived from well water and rain water. In addition the site of cultivation are no aquaculture enclosures for livestock as source of potential microbial contamination on the vegetables produced. The use of manure derived from chicken manure could be made only at the time of the preparation of the soil prior to planting so as to minimize the occurrence of Escherichia coli contamination.

Escherichia coli in vegetables indicates poor environmental sanitation. Escherichia coli is a bacteria indicator for sanitation. The absence of Escherichia coli on all vegetables tested pointed out that environmental sanitation around the cultivation of market environment classified as good. Vegetables can be contaminated by pathogenic bacteria from 
contaminated irrigation water, soil, sewage or animal waste used as fertilizer. However, postharvest handling like washing with clean water in planting location and sorting by manufacturer, farmer, wholesaler and retailers can reduce pathogenic bacteria, except bacteria spore-forming (Djaafar and Rahayu, 2007).

Soil and water is the habitat of many microbes including Coliform, Ee. coli, S. aureus and Bacillus cereus spore-forming bacteria and (Baird-Parker, 2000). To reduce the occurrence of microbial contamination in vegetable, washing done prior to marketing at the level of farmers and traders in a traditional market.

The traditional market is a great place to meet the seller and the buyer. The building consists of stalls and kiosk, most of which is sold daily necessities. Sanitary condition of traditional markets is generally very bad, it can be seen from the environment is dirty, muddy, smell unpleasant, uncomfortable. It is the circumstance which allows the bacteria move from one place to another or cross-contamination (Mujianto, 2008).

Based on interviews with farmers, the vegetables were cleaned in advance directly after harvest before being sold to wholesaler, including cleaning of residual soil or sand and washing to keep vegetables clean and fresh. Vegetables which have been harvested and collected should be cleaned of all dirt that clings to the surface of the skin, either in the form of dust, splashing on the ground, as well as the remains of the pesticides and fertilizers that is sprayed on leaves when the plant maintenance. The dirt when not cleaned immediately would constitute a source of contamination from a wide range of pathogens that can accelerate damage and lower the quality (Kartasapoetra, 2008).

Heavy metal Lead $(P b)$. Lead contamination in lettuce, tomatoes and carrot can be found in Table 2.

Table 2 - Lead contamination in lettuce, tomatoes and carrot marketed in Palembang city

\begin{tabular}{lccc}
\hline & \multirow{2}{*}{ Market } & \multicolumn{3}{c}{ Lead $(\mathrm{ppb})$} & Carrot \\
\cline { 2 - 4 } & Lettuce & Tomato & $18 \pm 6$ \\
Jaka Baring & $26 \pm 5$ & $11 \pm 2$ & $15 \pm 3$ \\
Km 5 & $25 \pm 5$ & $10 \pm 2$ & $14 \pm 3$ \\
AAL & $21 \pm 6$ & $13 \pm 2$ & $15 \pm 3$ \\
Perumnas & $22 \pm 4$ & $12 \pm 2$ & \\
\hline
\end{tabular}

Data were expressed in mean \pm standard deviation based on triplicate readings $(n=3)$.

Heavy metals lead $(\mathrm{Pb})$ is one of a wide variety of heavy metal pollution in major cities. Heavy metals lead $(\mathrm{Pb})$ goes into the plant through the roots and leaves of the mouth (stomata). Test results showed that lead content on lettuce, tomatoes and carrots were varies in each market. Based on Table 2, lead content $(\mathrm{Pb})$ in lettuce, tomatoes and carrot were below the treshold which specified in the standard heavy metal contamination in foods that is $0.5 \mathrm{ppm}$ (SNI 7387: 2009). Low levels of lead on the vegetables due to land used for cultivation of vegetables are far away from the highway and in addition there was no pesticide used during cultivation. This means that the lead in the vegetables predominantly come from the soil and the plant itself as well as a small portion comes from smoke the rest of the results of fuel combustion in motor vehicles. According to Sari et al. (2011) the lower density of vehicles passing on the road, the lower levels of lead found in the vegetable. Plants contain lead $(\mathrm{Pb})$ fairly high when planted near a highway. This is caused by dust and smoke contamination of vehicle fuel that contains lead.

Pollution of lead $(\mathrm{Pb})$ may occur in the air, water, or soil. Lead $(\mathrm{Pb})$ content in the soil is average of $16 \mathrm{ppm}$, but for certain areas could reach thousands of ppm (Fardiaz, 1992). The concentration of lead $(\mathrm{Pb})$ in a densely populated urban air traffic could be 5 up to 50 times compared with the mountain air (Sunu, 2001). Lead (Pb) content in plants of agricultural or plantation located adjacent to the highway is higher compared to agricultural or plantation located far from the highway. This shows that the pollution of lead $(\mathrm{Pb})$ that potential comes from a motor vehicle. However, in addition to the distance of the plant with the highway, the levels of lead $(\mathrm{Pb})$ in plants are also affected by the traffic density, the time the process of 
planting, the mileage from the location to the area of marketing, the contribution of lead from soil, physiology and morphology of plants and also the direction of the wind.

Lead $(\mathrm{Pb})$ is largely accumulated by plant organ, i.e., leaf, stem, root and root tubers for example carrots. The transfer of lead from soil to plant depending on composition and $\mathrm{pH}$ of soils. High lead concentrations (100 to $1000 \mathrm{mg} / \mathrm{kg}$ ) will lead to toxic influences on the process of photosynthesis and growth. Lead affects only the plant when its concentration is high (Charlena, 2004). The plant can absorb metals $\mathrm{Pb}$ upon condition of fertility and low soil organic matter content. In this situation of heavy metals $\mathrm{Pb}$ will be detached from the bonds of the soil and in the form of ions that move freely in the soil solution. If other metals are not capable of inhibiting its existence, then it will be absorbed by plant roots. Lead is a highly toxic heavy metals, it can be detected in all the inanimate objects in the environment and in the entire biological system. The main source of lead is food and drink. This component is toxic to all aspects of life. Lead showed toxic on the nervous system, hemetologic, hemetotoxic and affect the work of the kidneys.

Lead $(\mathrm{Pb})$ is very dangerous to humans because it is a toxic substances that can not be destroyed or changed in shape. Heavy metals can enter into the environment due to the weathering of rocks containing heavy metals in the ground, the use of natural materials for fertilizers and waste disposal plant and household waste. Heavy metal does not harm the surroundings of life beings but heavy metals harmful when entering into the system the metabolism of living beings in amounts exceeding the threshold.

\section{CONCLUSION}

The results of the study show that there are contaminants coliform in lettuce, tomatoes and carrots on the level of market traders Jaka Baring, Perumnas, Km 5, Alang-Alang Lebar. Highest coliform contaminants found in carrots ranged from $(1304 \pm 8.67) \times 10^{2} \mathrm{CFU} / \mathrm{g}$, followed by lettuce and tomatoes ranged $(10.43 \pm 4.97) \times 10^{2} \mathrm{CFU} / \mathrm{g}$, and tomato $(5.97 \pm 3.96)$ $\times 10^{2} \mathrm{CFU} / \mathrm{g}$. While the contaminant Escherichia coli not found on all vegetable samples test. The highest lead contaminants are present in the lettuce of $26 \pm 5$ ppb followed by carrot $18 \pm 6$ $\mathrm{ppb}$ and tomato $13 \pm 2 \mathrm{ppb}$.

\section{REFERENCES}

1. AdeOluwa, O.O., and Cofie, O. 2012. Urine as an Alternative Fertilizer in Agriculture: Effects in Amaranths (Amaranthus caudatus) Production in Nigeria. Renew. Agric. Food Syst. 27(4):287-294.

2. Amoah, P., Drechsel, P., Abaidoo, C. 2005. Irrigated Urban Vegetables Production in Ghana: Sources of Pathogen Contamination and Health Risk Elimination. Irrig. Drainage 54:49-61.

3. Amoah, P., Drechsel, P., Abaidoo, R,C. 2006. Pesticide and Microbiological Contamination of Vegetables in Ghana's Urban Markets. Arch. Environ. Contam. Toxicol (AECT) 50:1-6.

4. Anonim, 2008. Food Microbiology Testing. InfoPOM.9(2)

5. Food and Drug Supervision Agency. 2004. Regulatory Status of Impurities in Food Products. Food Safety Bulletin, 6. p.4-5.

6. Centers for Disease Control and Prevention (CDC), "Food borne outbreak online database", 2015, http://www.outbreakdatabase. com/details/taco-bell-restaurants-lettuce2006

7. Chaturvedi, M., Kumar, V., Singh, D. and Kumar, S. 2013. Assesment of Microbial Load of Some Common Vegetables Among Two Different Socioeconomic Groups. International Food Research Journal 20(5):2927-2931

8. Cornish, G.A., Mensah, E., Ghesquière, P. 1999. Water Quality and Peri-urban Irrigation. An Assessment of Surface Water Quality for Irrigation and Its Implications for Human Health in the Peri-Urban Zone of Kumasi, Ghana. Report OD/TN 95. HR Wallingford Ltd, Wallingford, UK. 
9. D’Mello, J.P.F., 2003. Food Safety: Contaminants and Toxins. CABI Publishing, Wallingford, Oxon, UK, Cambridge, MA. p. 480

10. De Roever., C. 1999. Microbiological Safety Evaluations and Recommendations on Fresh Produce. Food Control 9:321-347.

11. Djaafar, T.F and Siti Rahayu. 2007. Microbial Impurities on Agrculutural Products, Disease and Prevention. Journal of Agriculutural, 26 (2).

12. Drechsel, P., Abaidoo, R,C., Amoah, P., Cofie, OO. 2000. Increasing Use of Poultry Manure in and Around Kumasi, Ghana: Is Farmers' Race Consumers' Fate. Urban Agric. Mag. 2:25-27.

13. Food and Agriculture Organization (FAO)Morld Health Organization (WHO). 2008. Microbiological Risk Assessment Series: Microbiological Hazards in Fresh Fruit and Vegetables. Available at http://www.who.int/foodsafety

14. Halablab, M, A., Sheet, I.H. and Holail, H,M. 2011. Microbiological Quality of Raw Vegetables Grown in Bekaa Valley, Lebanon. American Journal of Food Technology 6:129-139

15. Heaton, J.C., Jones, K. 2008. Microbial Contamination of Fruit and Vegetables and the Behaviour of Enteropathogens in the Phyllosphere: A Review. J. Appl. Microbiol. 104:613-626.

16. Ignarro, L. J., Balestrieri, M. L., and Napoli, C. 2007. Nutrition, Physical Activity, and Cardiovascular Disease: an Update. Cardiovascular Research, 73(2), 326-340.

17. Johannessen, G.S., Loncarevic, S and Kruse, H. 2002. Bacteriological Analysis of Fresh Produce in Norway. International Journal of Food Microbiology. 77: 199-204.

18. Liu, R. H. 2003. Health Benefits of Fruit and Vegetables are From Additive and Synergistic Combinations of Phytochemicals. American Journal of Clinical Nutrition, 78(3):517-520.

19. Lund, B.M, Baird Parker T.C, Gould G.W. 2000. The Microbiological Safety and Quality of Food. Vol. II. Aspen Publisher, Inc. Gathersburg, Maryland.

20. L. R. Beuchat. 2002. Ecological Factors Influencing Survival and Growth of Human Pathogens on Raw Fruits and Vegetables. Microbes and Infection, 4 (4):413-423

21. Mensah, P., Yeboah-Manu D., Owusu-Darko K. and Ablordey A. 2002. Street Foods in Accra, Ghana: How Safe Are They? Bulletin WHO 80: 546-554.

22. Nguz. K., Shindano, J., Samapundo, S., Huyghebaghebaert, A. 2005. Microbiological Evaluation of Fresh-Cut Organic Vegetables Produced in Zambia. J. Food Contr. 16:623628.

23. Notohadiprawiro, T., 1995. Heavy Metals in Agriculture. Journal of Human and Environment, 2 (7): 3-12.

24. Sapers, G.M. 2001. Efficacy of Washing and Sanitizing Methods for Disinfection of Fresh Fruit and Vegetable Products. Food Technol. Biotechnol. 39(4):305-311.

25. Tambekar, D.H. and Mundhada, R.H. 2006. Bacteriological Quality of Salad Vegetables Sold in Amravati city (India). Journal of Biological Science 6: 28-30.

26. Winarti, $C$ and Miskiyah, 2010. The Status of Contaminants in Vegetables and His Efforts in Indonesia. Journal of Innovation Development of Agriculture. 3(3):227-237.

27. Widaningrum, 2007. The Danger of Contamination of Heavy Metals in Vegetables and Alternative Impurities Prevention. Bulletin.Technology Postharvest. 3, 16-27.

28. Weldezgina. 2016. Bacteriological Contaminants of Some Fresh Vegetables Irrigated with Awetu River in Jimma Town, Southwestern Ethiopia. Research Article. Hindawi Publishing Corporation Advances in Biology Volume 2016, Article ID 1526764, 11 pages

29. Yong, R.N., A.M.O. Mohamed, and S.P. Warkenting 1992. Principles of Contaminant Transport in Soil Development in Geoteknikal Eengineering, 73. Elsevier.

(C) 2017 by the authors. Licensee RJOAS, Orel, Russia. This article is an open access article distributed under the terms and conditions of the Creative Commons Attribution (CC BY) license: http://creativecommons.org/licenses/by/4.0/ 
DOI https://doi.org/10.18551/rjoas.2017-09.36

\title{
ОСОБЕННОСТИ ИСПОЛЬЗОВАНИЕ ПУЛЛОРНОГО ЭРИТРОЦИТАРНОГО АНТИГЕНА: СПЕЦИФИЧНОСТЬ РЕАКЦИИ \\ PECULIARITIES OF THE USE OF A PURULENT ERYTHROCYTE ANTIGEN: SPECIFICITY OF THE REACTION
}

\author{
Бурлаков С.В. ${ }^{*}$, начальник отдела \\ Burlakov S.V., Chief of the Department \\ Отдел оценки и анализа рисков, Всероссийский государственный центр \\ качества и стандартизации лекарственных средств для животных и кормов, \\ Москва, Россия \\ Department of Veterinary Risks Assessment and Risk-Based Prediction, All-Russian State \\ Center for Quality and Standardization of Veterinary Drugs and Feed, Moscow, Russia
}

\author{
Капустин А.В., Лаишевцев А.И., научные сотрудники \\ Kapustin A.V., Laishevtcev A.I., Researchers \\ Всероссийский научно-исследовательский институт экспериментальной \\ ветеринарии имени Я. Р. Коваленко, Москва, Российская Федерация \\ All-Russian Research Institute of Experimental Veterinary Medicine \\ named after Y.R. Kovalenko, Moscow, Russia \\ *E-mail: s.burlakov@crarf.ru
}

\begin{abstract}
АННОТАЦИЯ
Быстрое и точное диагностирование сальмонеллеза является первым и основным элементом своевременной профилактики и борьбы с данным заболеванием среди сельскохозяйственных животных, в т.ч. птиц. Диагностика сальмонеллёзов животных и птиц подразумевает анализ эпизоотологических данных, клинических признаков и патоморфологических изменений, на основании которых устанавливается предварительный диагноз с последующим обязательным подтверждением его методами лабораторной диагностики. Среди лабораторных тестов для установления диагноза существуют экспресс-методы, позволяющие выявлять антиген или специфические к нему антитела в крови больной птицы: полимеразная цепная реакция (ПЦР), иммуноферментный анализ (ИФА), кровекапельная реакция непрямой гемагглютинации с цветным комплексным пуллорным антигеном (ККРНГА) для диагностики пуллороза-тифа кур. Окончательный диагноз ставится на основании лабораторных исследований с выделением возбудителя и его видовой и/или серовариантной идентификации. Для птицефабрик обязательным условием является контроль поголовья на пуллороз, для диагностирования которого используется эритроцитарный пуллорный антиген. Однако, при проведении мониторингов латентных инфекций среди птицепоголовья, в том числе и сальмонеллёзов, нами были выявлены случаи, когда в благополучном по пуллорозу предприятии ККРНГА была положительной при полном отсутствии клинических признаков и отрицательном заключении микробиологического исследования. В ходе проведения бактериологического исследования положительно и сомнительно реагирующих на сальмонеллёз птиц нами был выделен ряд представителей условно-патогенной микрофлоры, которые в последующем были использованы как биологический материал для воспроизведения экспериментальной инфекции у кур с целью выявления возбудителей, вызывающих неспецифическую реакцию с пуллорным антигеном. В качестве дополнительного метода для оценки специфичности ККРНГА эти же сыворотки были проверены на наличие антител к сальмонеллам методом иммуноферментного анализа. В результате проведенного исследования выявлено наличие неспецифических реакций антигена пуллорного эритроцитарного с кровью птицы, экспериментально заражённой несколькими видами бактерий: Proteus vulgaris,
\end{abstract}


Morganella morganii u Escherichia coli, при отсутствии положительного результата в ИФА.

\section{ABSTRACT}

Rapid and accurate diagnosis of salmonellosis is the first and essential element for timely prevention and combating the disease among farm animals, including poultry. Diagnosis of animals and bird's salmonellosis involves the analysis of epizootic data, clinical signs and pathological changes, on the basis of which a preliminary diagnosis with the subsequent mandatory confirmation of his methods of laboratory diagnostics. Laboratory test for diagnosis there are rapid tests that can identify a specific antigen or antibodies there to in the blood of sick poultry: polymerase chain reaction (PCR), enzyme-linked immunosorbent assay (ELISA), blood-drop indirect hem-agglutination reaction with a color complex antigen pullorum for the diagnosis pullorosis-typhoid chickens. The final diagnosis is based on laboratory research with abjection and its species and/or serovariants identification. For poultry farm is obligatory to control livestock on the pullorosis, the diagnosis of which is used pullorosis erythrocyte antigen. However, during the monitoring of latent infections among poultry, including salmonellosis, we have identified cases when successful on pullorosis the company of (blood-drop indirect hem-agglutination reaction with a color complex antigen pullorum) was positive in the absence of clinical signs and negative opinion of microbiological research. During the bacteriological examination is positive and questionably reacting to the salmonellosis of the birds we were allocated a number of representatives of conditionally pathogenic microflora, which were subsequently used as biological material to reproduce experimental infection in chickens with the aim of identifying pathogens that cause nonspecific reaction with the antigen pullorum. As an additional method to assess the specificity of (blood-drop indirect hem-agglutination reaction with a color complex antigen pullorum) the same serum was tested for presence of antibodies to the Salmonella enzyme immunoassay. In the result of the study revealed the presence of nonspecific reactions pullinga erythrocytic antigen with the blood of birds experimentally infected with multiple species of bacteria: Proteus vulgaris, Morganella morganii and Escherichia coli, in the absence of a positive result in the ELISA.

\section{КЛЮЧЕВЫЕ СЛОВА}

Сальмонеллёз, пуллороз, диагностика, мониторинг, анализ-рисков, специфичность диагностикумов, эритроцитарный антиген, иммуноферментный метод, безопасность продукции птицеводства.

\section{KEY WORDS}

Salmonellosis, pullorosis, diagnostics, monitoring, analysis, risks, specificity of antigens, erythrocyte antigens, immunoassay method, the safety of poultry products.

Лабораторная диагностика инфекционных болезней является не только необходимой мерой для своевременного предотвращения падежа животных, но и реальным средством спасения людей от возникновения и развития массовых заболеваний $[2,3,11]$. Поэтому при выборе средств диагностики предпочтение должно отдаваться методам, которые минимизируют получение ложноположительных и ложноотрицательных результатов $[8,9,10]$. На примере серологической диагностики пуллороза кур можно сравнить два метода, имеющих важную значимость, но различную степень достоверности получаемых результатов:

1. Крове-капельная реакция непрямой гемагглютинации - является легко воспроизводимым, дешёвым методом экспресс диагностирования пуллороза кур непосредственно на территории производства. Постановка реакции осуществляется благодаря использованию коммерческого пуллорного эритроцитарного антигена и может быть воспроизведена любым ветеринарным работником или иным персоналом птицефабрики. Процесс постановки реакции занимает не более 5 минут, вместе с взятием пробы крови. 
2. Иммуноферментный анализ является более сложно воспроизводимым, достаточно дорогим (на фроне эритроцитарного диагностикума), требующим достаточно дорогого оборудования и высококвалифицированного оператора. Процесс постановки достигает 4-5 часов с учётом времени необходимого для получения сыворотки крови. Для реализации данного метода исследования птицепоголовья на пуллороз на территории Российской Федерации имеются в продаже апробированные наборы зарубежного производства: BioChek Ck117, Ck 218 и IDEXX SE Ab Test, а так же отечественный «Набор для выявления антител к бактериям рода Salmonella серогрупп B и D в сыворотках крови кур иммунофрерментным методом при тестировании сывороток в одном разведении», изготавливаемый ВНИИЗЖ $[4,6]$.

Стоит отметить, что ранее для серологической диагностики сальмонеллёза применялись методы иммунофлюоресценции (РИФ) и реакция латекс агглютинации (РЛА), но в данный момент наборы для ветеринарной практики не производятся. Тем не менее, ввиду того, что РИФ и РЛА нацелены на выявление не антител, а антигенов, существует возможность использования для постановки этих реакций медицинских диагностических средств. Оба приведённых серологических метода востребованы и обладают определённой специфичностью в отношении возбудителя $[1,5,7]$.

Цель исследования - определение специфичности пуллорного эритроцитарного антигена в кровекапельной реакции непрямой гемагглютинации (ККРНГА) при экспериментальных инфекционных болезнях кур в сравнении с ИФА.

\section{МАТЕРИАЛЫ И МЕТОДЫ ИССЛЕДОВАНИЙ}

Экспериментальная часть исследования проводилась на базе ФГБНУ «Всероссийский научно-исследовательский институт экспериментальной ветеринарии имени Я. Р. Коваленко», а так же на базе Вышневолоцкого фрилиала ВИЭВ с опытной базой (о. Лисий). Мониторинг латентных инфекций птиц проводился в частных птицеводческих предприятий Кировской, Тамбовской и Орловской областях в течение 2016 года.

При проведение микробиологического исследования в рамках выполнения скрининга инфекционных болезней в скрытой форме использованы следующие питательные среды: агар Эндо, МакКонки, агар Сабуро, бульон Сабуро, мясопептонный агар (МПА), мясопептонный бульон (МПБ), MRS-агар, колумбия агар основа для кровяного агара, цитратный агар, висмут-сульфитный агар, SS-aгap, XLDагар, хромогенный агар cm 1007, среда Раджа-Ханса, основа бульона с бромкрезоловым пурпурным M284 Himedia. Все используемые среды являются коммерческими, приготовление их производиться в полном соответствии с инструкцией производителя, которыми являются «Oхоid» и «Himedia». Биохимическая идентификация выделенных культур проведена с использованием следующих тестов и наборов: RapID ${ }^{\mathrm{TM}}$ ANA II, RaplD ${ }^{\mathrm{TM}}$ NF Plus, RapID ${ }^{\mathrm{TM}}$ ONE, Microbact 12e, API 20E, ENTEROtest 24N, HiStaph, набор для биохимической идентификации стафилококков и HiStrep Набор для идентификации стрептококков. Для изучения дополнительных сахаролитических свойств использованы среды Гисса с углеводами: адонит, арабиноза, галактоза, D-глюкоза, дульцит, инозит, инулин, ксилоза, мальтоза, маннит, манноза, рафффиноза, рамноза, салицит, сорбит, сахароза, трегалоза, фруктоза, целлобиоза. Заражение птиц контрольной группы проведено с использованием музейного штамм Salmonella pullorum № 16 из коллекции микроорганизмов ФГБНУ ВИЭВ им. Я.Р. Коваленко.

Обоснованием для проведения данного исследования стало то, что при серологическом исследовании в благополучном по сальмонеллезу птицеводческом хозяйстве у вновь введенного поголовья кур-молодок были выявлены случаи, когда клинически здоровая и не имеющая признаков сальмонеллёза птица положительно реагировала в ККРНГА с пуллорным эритроцитарный антигеном. При этом после проведенного в диагностических целях убоя и бактериологического исследования, не 
было получено подтверждения наличия сальмонелл в материале. Наиболее часто в патологическом материале обнаруживали следующие виды микроорганизмов: Bacillus cereus, Enterobacter cloacae, Escherichia coli, Klebsiella oxytoca, Morganella morganii, Proteus vulgaris, Staphylococcus aureus, Staphylococcus saprophyticus, Streptococcus faecalis, другие виды бактерий выявлялись в единичных случаях. Для выявления бактериального антигена, провоцирующего получение ложного результата ККРНГА, было проведено экспериментальное инфицирование выделенными изолятами бактерий птицы с последующим исследованием её на наличие антител в ККРНГА и ИФА.

В ходе выполнения работы было произведено экспериментальное заражение различными культурами бактерий девяти групп птиц в возрасте 170 дней по 3 головы в каждой. В качестве положительного контроля была инфрицирована группа птиц бактериями вида Salmonella pullorum, в качестве отрицательного оставлены чистые не инфрицированные птицы. Во время проведения опыта вся птица содержалась раздельно. Взятие крови для постановки реакции ККРНГА и получения сыворотки для ИФА проводилось в течение месяца после заражения 6 раз с экспозицией 5 дней.

\section{РЕЗУЛЬТАТЫ И ИХ ОБСУЖДЕНИЕ}

Проведение исследования позволило определить, что экспериментальное заражение птицы бактериями видов Bacillus cereus, Enterobacter cloacae, Klebsiella oxytoca, Staphylococcus aureus, Staphylococcus saprophyticus и Streptococcus faecalis не вызывало образования антител, дающих положительную реакцию с пуллорным антигеном в кровекапельной реакции и при исследовании полученных от них сывороток в иммуноферментном анализе в течение всего срока наблюдения (30 дней). При этом антигены Escherichia coli, Morganella morganii, Proteus vulgaris и Salmonella pullorum провоцировали проявление положительной и сомнительной реакции с различной степенью в течение всего опыта. Контрольная отрицательная группа демонстрировала негативный результат при воспроизведении обоих серологических методов. Результаты изучения специфичности эритроцитарного пуллорного антигена при экспериментальном воспроизведении инфекции приведены в таблице 1.

Таблица 1 - Результаты проведения крове-капельной реакции непрямой гемагглютинации при экспериментальном заражении

\begin{tabular}{|c|c|c|c|c|c|c|c|c|c|c|c|c|c|}
\hline \multirow{2}{*}{ Срок инфр-ия } & \multirow{3}{*}{$\begin{array}{l}\text { Реакция } \\
\text { гицы }\end{array}$} & \multicolumn{12}{|c|}{ Вид возбудителя } \\
\hline & & \multicolumn{3}{|c|}{ Escherichia coli } & \multicolumn{3}{|c|}{ Morganella morganii } & \multicolumn{3}{|c|}{ Proteus vulgaris } & \multicolumn{3}{|c|}{ Salmonella pullorum } \\
\hline Номер птицы & & №1 & №2 & №3 & №1 & №2 & №3 & №1 & №2 & №3 & №1 & №2 & №3 \\
\hline \multirow{2}{*}{ До инф-ия } & ККРНГА & - & - & - & - & - & - & - & - & - & - & - & - \\
\hline & ИФА & - & - & - & - & - & - & - & - & - & - & - & - \\
\hline \multirow{2}{*}{5 день } & ККРНГА & ++ & ++ & + & - & + & + & ++ & ++ & ++ & +++ & +++ & +++ \\
\hline & ИФА & - & - & - & - & - & - & - & - & - & $《+»$ & «+» & $《+»$ \\
\hline \multirow{2}{*}{10 день } & ККРНГА & +++ & +++ & ++ & - & ++ & ++ & ++ & ++ & ++ & ++++ & ++++ & ++++ \\
\hline & ИФА & - & - & - & - & - & - & - & - & - & $《+»$ & $《+»$ & $《+»$ \\
\hline \multirow{2}{*}{15 день } & ККРНГА & ++ & + & + & - & - & + & + & + & - & ++++ & ++++ & ++++ \\
\hline & ИФА & - & - & - & - & - & - & - & - & - & $《+»$ & «+» & $《+»$ \\
\hline \multirow{2}{*}{20 день } & ККРНГА & ++ & + & + & - & - & - & - & - & - & ++++ & ++++ & ++++ \\
\hline & ИФА & - & - & - & - & - & - & - & - & - & $《+»$ & $《+»$ & $\|+»$ \\
\hline \multirow{2}{*}{25 день } & ККРНГА & + & - & - & - & - & - & - & - & - & ++++ & ++++ & ++++ \\
\hline & ИФА & - & - & - & - & - & - & - & - & - & $《+»$ & «+» & $《+»$ \\
\hline \multirow{2}{*}{30 день } & ККРНГА & - & - & - & - & - & - & - & - & - & ++++ & ++++ & ++++ \\
\hline & ИФА & - & - & - & - & - & - & - & - & - & $\langle+\rangle$ & «+» & $《+»$ \\
\hline
\end{tabular}

- отрицательная реакция ККРНГА; + сомнительная реакция ККРНГА; ++ сомнительная реакция ККРНГА; +++ положительная реакция ККРНГА; ++++ положительная реакция ККРНГА; «+» положительная реакция ИФА.

Анализируя полученные данные по специфичности пуллорного антигена при экспериментальной инфекции культурами, не относящимся к роду Salmonella spp. 
можно утверждать, что перекрёстную реакцию вызывал один из изолятов $E$. coli, отнесенный при серологической идентифрикации к серогруппе О138. Другие изоляты эшерихий, в том числе широко распространённых и признанных возбудителями эшерихиоза кур серогрупп О2 и О78, не вызывали образования антител, выявляющихся в ККРНГА. После проведенного заражения кур E. coli образование антител наблюдалось уже на 5 сутки и сохранялось вплоть до 25 дня с момента инфицирования. Положительная реакция постепенно исчезает к 30 дням. В отношении сомнительной реакции вызванной Morganella morganii стоит обратить внимание, что реакция была менее выражена, чем в группе положительного контроля, а также у кур, инфицированных эшерихиями серогруппы О138. При этом нарастание титра антител продолжалось в течение 10 дней, а затем постепенно снижалось и к 20 дню наблюдения у кур, инфрицированных $M$. morganii уже не фриксировались даже сомнительные реакции. Аналогичная ситуация наблюдалась и при инфекции, вызванной Proteus vulgaris: наибольший титр в кровекапельной реакции наблюдался уже через 5 дней. При этом положительная реакция на выявление титров антител к сальмонеллам группы D методом ИФА у всех кур, инфицированных эшерихиями, протеем и морганеллами, отсутствовала.

В группе птиц положительного контроля, инфицированных штаммом S. pullorum, титры антител были зафиксированы в течение всего периода наблюдения с 5 по 30 день после инфицирования с высокой оценкой. Также у птиц этой группы наблюдалось проявление расстройство фрункции кишечника, синюшность гребня, потеря аппетита, угнетенное состояние, постепенно нарастающее истощение.

Наличие неспецифической реакции пуллорного антигена с кровью кур, не инфицированных сальмонеллами, можно считать следствием наличия близких антигенов у энтеробактерий, в частности E. coli, M. morganii, P. vulgaris и S. pullorum, что подтверждается фрилогенетической связью между ними.

При проведении периодических обследований поголовья птиц в подопытных хозяйствах установлено, что неспецифические реакции с пуллорным антигеном в большинстве случаев происходят только у птиц, вновь введенных в стадо (как правило, это куры-молодки, ежегодно сменяющие часть выбывающей переярой птицы). У птицы, находящейся в стаде более месяца наличие неспецифических реакции не наблюдалось. Это можно объяснить тем, что введённая в поголовье птица продуцирует антитела к возбудителям, циркулирующим на территории хозяйства. Ввиду того, что возбудители являются условно-патогенными, развитие клинических признаков и проявление патологического процесса не наблюдается.

Кроме того, как видно из таблицы №1 имеются особи, не проявляющие положительный результат в кровекапельной реакции. Такую ситуацию мы наблюдаем у птицы №1 инфицированную $M$. morganii, что в свою очередь говорит об индивидуальной чувствительности птицы.

Заключение. В соответствии с действующей инструкцией по применению эритроцитарного антигена для диагностики пуллороза-тифра птиц по кровекапельной реакции непрямой гемагглютинации, положительно и сомнительно реагирующая птица изолируется и отправляется на убой. В случаях, если реакция оказывается неспецифической, это приводит к необоснованной выбраковке здоровой, не представляющей опасность для заражения людей, птицы, что влечет серьезные экономические потери. Потому, при получении достаточно большого количества выявляемой методом ККРНГА положительно реагирующей птицы, а также подтверждении отсутствия циркуляции в хозяйстве у птицепоголовья сальмонеллезной инфекции, целесообразно проводить исследование методом ИФА. Это позволит обезопасить потребителей от риска заражения сальмонеллами, а также предотвратит экономические потери у производителей птицеводческой продукции. Так же нецелесообразно использовать пуллорный эритроцитарный антиген для диагностики в хозяйствах, где подтверждена циркуляция бактерий видов M. morganii, P. vulgaris и E. coli серогруппы O138. 


\section{БИБЛИОГРАФИЯ}

1. Belimenko V.V. Prospects for the use of geographic information systems for risk-based monitoring of natural focal diseases of animals and humans.//Russian Journal of Agricultural and Socio-Economic Sciences. 2016. T. 56. № 8. C. 22-25.

2. Burlakov S.V. Tasks of veterinary service to ensure the biological safety of poultry products in the Russian federation: analysis and assessment of risks.// Russian Journal of Agricultural and Socio-Economic Sciences. 2016. T. 59. № 11. C. 181-185.

3. Laishevtcev A.I. Microbial profile of the digestive canal of budgerigars (Melopsittacus Undulatus)//Russian Journal of Agricultural and Socio-Economic Sciences, 2016; 5(53):76-82.

4. Pimenov N.V. Perfection of means and methods of combating salmonellosis of birds//Veterinary and feeding, 2012. 4:32-34.

5. Tatarenko Y.S. The study of pathogenic properties of enterobacterial flora of clinically healthy quails for possible detection of bacteriocarrier.// Russian Journal of Agricultural and Socio-Economic Sciences. 2016. T. 56. № 8. C. 67-73.

6. Гулюкин М.И. Методические рекомендации по расчету годовой потребности в биопрепаратах для проведения профилактических и противоэпизоотических мероприятий в хозяйствах всех форм собственности.// Ветеринарный консультант. 2007. № 21-22. С. 9-15.

7. Найманов А.Х. Практическое пособие по мониторингу бруцеллеза, туберкулеза, паратуберкулеза и лейкоза крупного рогатого скота: организационнохозяйственные, ветеринарно-санитарные и зоогигиенические аспекты профилактики и ликвидации этих инфекций.// ВИЭВ имени Я.Р. Коваленко, Москва, 2014.

8. Татаренко Я.С. Выявление бактерионосительства перепелов частного сектора в Московской, Тульской и Рязанской областях.// Ветеринария, зоотехния и биотехнология. 2016. № 9. С. 48-52.

9. Шабейкин А.А. Эпизоотологические геоинформационные системы. Возможности и перспективы.// Ветеринария. 2016. № 7. С. 21-24.

10. Юров К.П. Методические рекомендации по расчету годовой потребности в биопрепаратах для проведения профилактических и противоэпизоотических мероприятий в хозяйствах всех форм собственности.// Ветеринарный консультант. 2007. № 21-22. С. 9-15.

11. Шорохов В.В., Ленев С.В., Капустин А.В. Пуллорный эритроцитарный антигендиагностикум для пуллороза-тифа птиц // В книге: Разработка и освоение производства нового поколения лекарственных средств для животных и их применения В ветеринарной практике Всероссийская научно-практическая конференция: тезисы докладов. 2000. С. 18-19. 
DOI https://doi.org/10.18551/rjoas.2017-09.37

\title{
ОЦЕНКА КОЛЛЕКЦИОННОГО МАТЕРИАЛА СОИ ВСЕРОССИЙСКОГО ИНСТИТУТА РАСТЕНИЕВОДСТВА ИМЕНИ Н.И. ВАВИЛОВА В ТУЛЬСКОЙ ОБЛАСТИ EVALUATION OF THE SOYBEAN COLLECTION OF THE ALL RUSSIAN INSTITUTE OF CROP PLANTING NAMED AFTER N.I. VAVILOV IN CONDITIONS OF THE TULA REGION
}

Дятлова Н.А.* , старший научный сотрудник Dyatlova N.A., Senior Researcher

Тульский научно исследовательский институт сельского хозяйства, Тульская область, Россия

Tula Research Institute of Agriculture, Tula Region, Russia

Сальникова Н.Б., научный сотрудник

Salnikova N.B., Researcher

ФГБУ «Россельхозцентр», Москва, Россия

$\mathrm{FSBI}$ «Rosselhozcenter», Moscow, Russia

*E-mail: tniisx@mail.ru

\section{АННОТАЦИЯ}

В работе представлены результаты изучения в 2013-2016 годах сои из мировой коллекции Всероссийского института растениеводства имени Н.И. Вавилова. Проведен анализ сортообразцов по морфобиологическим признакам, показателям элементов продуктивности, содержанию белка и жира, устойчивости к болезнями вредителям.

\begin{abstract}
The paper presents the results of the study in 2013-2016 of soybean from the world collection of the All-Russian of Crop Planting named after N.I. Vavilov. The analysis of varieties for morphobiological features, indicators of productivity elements, protein and fat content, resistance to pests was conducted.
\end{abstract}

\section{КЛЮЧЕВЫЕ СЛОВА}

Соя, образец, вегетационный период, агрометеорологические условия, продуктивность.

\section{KEY WORDS}

Soybean, sample, cropping season, agro-meteorological conditions, productivity.

Изменение климата страны в последние десятилетия требует адаптации растениеводства к меняющимся условиям. Одним из путей решения этой проблемы может стать расширение ареала возделывания более теплолюбивых и более урожайных культур, обеспечивающих интенсификацию сельскохозяйственного производства, в числе которых важное место отводится соe (Glycine max.(L) Merr.) высокобелковой зернобобовой культуре $[1,2]$. Необходимость внедрения культуры сои в структуру посевных площадей центральных районов Нечерноземной зоны РФ связана с потребностями кормопроизводства в высокопротеиновых и качественных кормах, позволяющих сокращать расходы на производство животноводческой продукции на $20-25 \%$ [3].

Среди всех зернобобовых культур соя имеет наиболее разнообразное использование: она является кормовой, продовольственной и технической культурой [4]. В целом в семенах сои находится в 3-5 раз больше белка, чем в зерне пшеницы, ячменя, кукурузы, риса, а по содержанию незаменимых аминокислот разница составляет 8-9 раз [5]. При этом важно отметить, что белок сои полноценен по 
содержанию аминокислот, по этой характеристике он приближается к яичному, т.е. стоит на одном уровне с белком животных. Он положительным образом влияет на здоровье людей: уменьшает количество холестерина в крови, препятствует накоплению потенциальных канцерогенов в организме, влияет на гормональный обмен, препятствует развитию опухолей [6]. Спрос на соевые продукты в мире постоянно возрастает. Высоко ценится соевое масло, содержащее такие незаменимые жирные кислоты, как линолевая и линоленовая, которые выполняют функции витаминов, но не синтезируются в организме [7].

Приведенные выше аргументы свидетельствуют о важной роли соевого белка и жира, ради которых выращивают сою. Поэтому в производственных условиях нужно стремиться к максимальному их сбору с единицы площади.

Для условий Центрального Федерального Округа РФ соя - новая нетрадиционная культура. За последние 15 лет динамика роста посевных площадей под соей имеет тенденцию к увеличению и выросла более чем в 66 раз. По данным Росстата основным производителем сои в стране является Дальневосточный ФО $(47,1 \%)$ [8]. В Тульской области площади, занятые этой культурой, составили в 2012 г. - 1950 га, в 2013 г. - 4037 га, в 2014 г. - 14567 га, в 2015 г. - 16800 га. Посевные площади, занятые соей, по данным статистических сборников [9-12], стремительно увеличиваются.

Ареал сои чрезвычайно обширен, но приспособляемость ее сортов весьма ограничена. При перенесении фрорм сои из одной местности в другую рост ее угнетается. Климатические изменения вредным образом отражаются не только на урожайности сои, но также и на ее качестве. Поэтому степень приспособленности видов и сортов растений к местным условиям выступает в качестве основополагающего фактора $[13,14]$.

\section{МАТЕРИАЛЫ И МЕТОДЫ ИССЛЕДОВАНИЙ}

Полевые опыты проводились на базе существующего при институте отдела первичного семеноводства в 2013-2016 годах. Работа проводилась согласно методик государственного сортоиспытания сельскохозяйственных культур [15] и «Международного классификатора сои СЭВ» [16]. Лабораторные исследования образцов сои проведены в лаборатории ЦКП Орел ГАУ «Генетические ресурсы растений и их использование».

Материалом для исследований послужили 15 образцов сои из 300 полученных из коллекции ВИР: к-11004, Свапа (Орловская область); к-9959, Окская (Рязань); к-11115, Мелета (Рязань); к-11042, М-134 (Московская область); к-10973, Березина (Беларусь); к-9984, Ольса (Белорусь); к-4480, Молдавская 65 (Молдова); к-5230, Herb 610 (Румыния); к-5582, 840-2-7 (Швеция); к-6778, Mutante Stamm 54/145 (Германия); к-7082, Красноградская (Украина); к-11301, Алиса (Украина); к-9442, Primanordia (Польша); к10623, Мадева (Чувашия); к-10852, INRA 597-9-2 (Франция).

Опыт проводился на чернозёмных средневыщелоченных среднемощных среднесуглинистых почвах в полевом севообороте с использованием традиционных агротехнических мероприятий. Опыт однофакторный мелкоделяночный краткосрочный. Предшественник картофель.

Осенняя обработка почвы состояла из лущения и ранней зяблевой вспашки. Весенняя обработка почвы включала боронование зяби и две последующие культивации с боронованием в агрегате, для лучшего выравнивания почвы. Посев проводили в разные сроки: 01.06.2013 г., 13.05.2014 г., 08.05.2015 г., 28.05.2016 г. с междурядьями 45 см ручной сеялкой СР-1М на глубину 3-4 см. Закладка опытов проведена при устойчивом прогревании посевного слоя почвы до $12-14^{\circ} \mathrm{C}$.

Уход за посевами сои включал прикатывание до и после посева, междурядные обработки до смыкания рядков.

Урожайность пересчитана на стандартную влажность и 100\% чистоту. Структура урожая определялась по методу прямого подсчета у 20 растений (количество бобов, семян в бобе, семян с растения). Определение содержания белка и жира проводили с 
помощью прибора Jnfratek 1241, который позволяет в целых семенах, т.е. без размола, определить содержание этих веществ. Статистическую обработку урожайных данных проводили методом дисперсионного и корреляционного анализов по Б.А. Доспехову [17].

\section{РЕЗУЛЬТАТЫ ИССЛЕДОВАНИЙ И ИХ ОБСУЖДЕНИЕ}

Погодные условия в годы исследований были контрастными (рис. 1). Если 2014 год характеризовался дефицитом влаги, осадков выпало за вегетационный период $49,5 \%$ от среднемноголетних данных, то в 2016 году с мая по август выпала практически двойная норма осадков. 2013 и 2015 годы - промежуточные: май, сентябрь 2013 и июнь 2015 отличались обильными осадками.

Средняя температура воздуха была близка к среднемноголетней или отличалась незначительно от 0,6 до $4,8^{\circ} \mathrm{C}$. Благоприятные условия для посева сои складываются во второй декаде мая, когда почва прогревается на глубину заделки до $14-16^{\circ} \mathrm{C}$.

Мировая коллекция сои ВИР им. Н.И.Вавилова содержит многообразные сорта этой культуры и служит ценнейшим источником исходного материала. В условиях полевого опыта в Тульском НИИСХ в 2013 году из 300 образцов были выделены 98 по срокам созревания. В 2014 году из 98 отобраны 32 образца сои по технологичности, в 2015 году из 32 образцов выделены 15 по устойчивости к болезням и вредителям. В 2016 году проведена сравнительная оценка 15 образцов сои по содержанию белка и жира. Выделенные образцы являлись среднеспелыми. Период вегетации составил 100-118 дней.
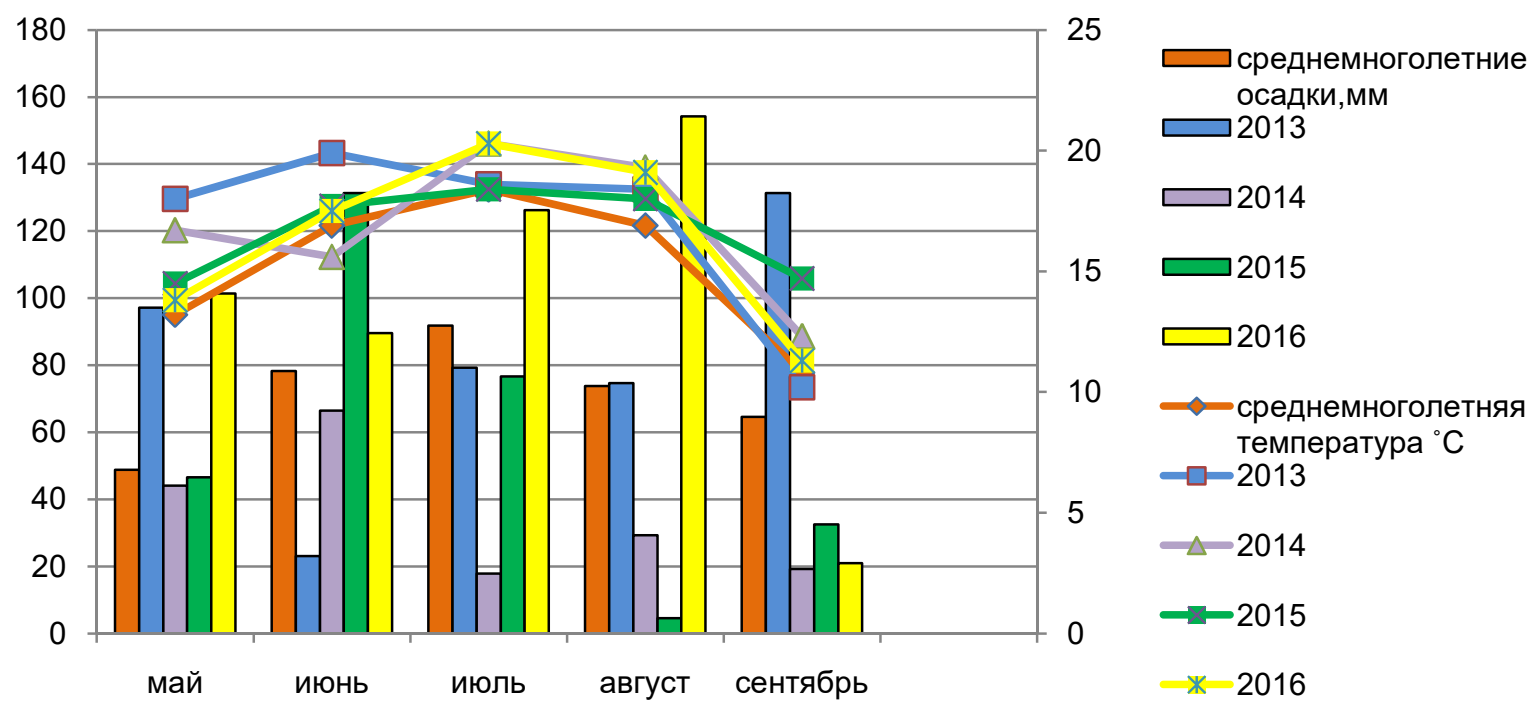

Рисунок 1 - Агрометеорологические условия вегетационного периода 2013-2016 гг.

Проведена комплексная оценка фенотипической и генотипической изменчивости образцов по признакам: длина стебля; высота прикрепления нижнего боба; количество бобов на растении, масса 1000 семян, масса семян с 1 растения (табл. 1,2).

«Длина стебля - отвечает за характер роста растений, определяется генотипом растения, условиями его развития, а также влияет на повышение технологичности уборки и полегаемость. За все годы исследований длина стебля колебалось от 45,6 до 98,3 см. В более влагообеспеченном 2016 году все образцы отличались большей длиной главного побега $(61,5$ - 98,3 cм), а в годы с низкой влагообеспеченностью (2013-2014 гг.) образцы имели меньшую длину - 45,6-72,5 см. Все образцы среднестебельные. Для создания оптимальной модели сорта нового поколения наиболее пригодны среднестебельные образцы. 
Таблица 1 - Высота прикрепления нижнего боба, длина стебля, 2013-2016 гг., см

\begin{tabular}{|c|c|c|c|c|c|c|c|c|c|c|c|}
\hline \multirow{2}{*}{$\begin{array}{c}\text { №n/ } \\
\text { п }\end{array}$} & \multirow{2}{*}{$\begin{array}{c}\text { №по } \\
\text { каталог } \\
\text { у ВИР }\end{array}$} & \multirow{2}{*}{ Название } & \multirow{2}{*}{$\begin{array}{c}\text { Страна } \\
\text { происхождени } \\
\text { я }\end{array}$} & \multicolumn{4}{|c|}{$\begin{array}{c}\text { Высота прикрепления } \\
\text { нижнего боба, см }\end{array}$} & \multicolumn{4}{|c|}{ Длина стебля, см } \\
\hline & & & & $\begin{array}{c}201 \\
3 \\
\end{array}$ & $\begin{array}{c}201 \\
4 \\
\end{array}$ & $\begin{array}{c}201 \\
6\end{array}$ & $\begin{array}{c}\text { Средня } \\
\text { я }\end{array}$ & $\begin{array}{c}201 \\
3\end{array}$ & $\begin{array}{c}201 \\
4 \\
\end{array}$ & $\begin{array}{c}201 \\
6 \\
\end{array}$ & $\begin{array}{c}\text { Средня } \\
\text { я }\end{array}$ \\
\hline 1. & 11004 & Свапа & Россия & 10,0 & 14,3 & 15,1 & 13,1 & 76,2 & 68,1 & 93,9 & 79,4 \\
\hline 2. & 9959 & Окская & Рязань & 11,1 & 12,1 & 16,3 & 13,2 & 62,1 & 67,0 & 89,5 & 72,9 \\
\hline 3. & 11115 & Мелета & Рязань & 11,2 & 12,5 & 16,1 & 13,3 & 63,4 & 46,2 & 85,7 & 65,1 \\
\hline 4. & 10973 & Березина & Беларусь & 14,7 & 16,3 & 18,4 & 16,5 & 82,1 & 51,1 & 87,6 & 73,6 \\
\hline 5. & 4880 & Молдавская 65 & Молдова & 15,4 & 12,4 & 15,6 & 14,5 & 70,1 & 65,2 & 82,0 & 72,4 \\
\hline 6. & 5230 & Herb 610 & Румыния & 12,2 & 11,7 & 12,0 & 12,0 & 67,2 & 73,0 & 65,3 & 68,5 \\
\hline 7. & 5582 & $840-2-7$ & Швеция & 12,1 & 12,7 & 13,2 & 12,7 & 65,4 & 45,6 & 71,6 & 60,2 \\
\hline 8. & 6778 & $\begin{array}{c}\text { Mutante } \\
\text { Stamm54/145 }\end{array}$ & Германия & 12,4 & 16,8 & 19,1 & 16,1 & 91,2 & 65,4 & 72,1 & 76,2 \\
\hline 9. & 7082 & $\begin{array}{c}\text { Красноградска } \\
\text { я }\end{array}$ & Украина & 13,7 & 14,3 & 15,0 & 14,3 & 62,3 & 56,7 & 59,7 & 59,6 \\
\hline 10. & 9442 & Primanordia & Польша & 14,2 & 15,2 & 14,0 & 14,5 & 65,2 & 71,6 & 73,0 & 69,9 \\
\hline 11. & 9984 & Ольса & Беларусь & 12,7 & 12,3 & 13,1 & 12,7 & 71,4 & 58,3 & 78,9 & 69,5 \\
\hline 12. & 10623 & Мадева & Чувашия & 17,2 & 12,4 & 14,5 & 14,7 & 75,2 & 52,4 & 72,2 & 66,6 \\
\hline 13. & 10852 & INRA 597-9-2 & Франция & 14,8 & 14,2 & 14,6 & 14,5 & 74,2 & 72,5 & 71,2 & 72,6 \\
\hline 14. & 11042 & $\mathrm{M}-134$ & Россия & 15,2 & 12,4 & 10,1 & 12,6 & 65,4 & 58,1 & 65,3 & 62,9 \\
\hline 15. & 11301 & Алиса & Украина & 10,2 & 16,2 & 11,5 & 12,6 & 98,3 & 61,3 & 61,5 & 73,7 \\
\hline
\end{tabular}

«Высота прикрепления нижнего боба» - первостепенный, технологический признак, снижающий потери семян сои во время уборки прямым комбайнированием. Он обусловлен общим числом междоузлий на растении, их расстоянием (особенно с 4го, 5-го), так как на их уровне закладываются первые продуктивные узлы между корневой шейкой и клювиком боба. За годы исследований значение признака варьировало от 10 до 19,1см. Большая часть образцов характеризовалась значительно более низким прикреплением нижнего боба в 2014 и более высоким в 2016 г. У трёх образцов сои этот показатель был стабилен на протяжении всех лет: к5230, Herb 610 (Румыния) - в среднем 12,0 см; к-5582, 840-2-7 (Швеция) - 12,7 см; к9984, Ольса (Беларусь) - 12,7см. Наибольшей высотой прикрепления нижнего боба отличились образцы к-10973, Березина (Беларусь) - 18,4 см и к-6778, Mutante Stamm54/145 (Германия) - 19,1 см. Остальные образцы показали различную высоту прикрепления нижнего боба.

Семенная продуктивность - сложный признак, который зависит от составляющих её элементов структуры урожая, являющихся основой при моделировании нового морфотипа и залогом эфффективности широкого возделывания в производстве будущих сортов. Количество бобов на растении - один из важных элементов продуктивности. За все годы исследований число бобов варьировало от 19 до 100 шт. В 2016 году самое большое их количество отмечено у образца к-9442, Primanordia (Польша) - 100 шт. и к-11042, M - 134 (Москва) 91 шт. Причём этот же Московский образец и в 2013 году дал максимальное число бобов с растения (62 шт.).

Масса 1000 семян также является одним из важных компонентов продуктивности, и как показатель качества, имеет большое значение в семеноводстве сои. В 2013 году максимальную массу 1000 семян имел один образец к-4880, Молдавская 65 (Молдова) - 192,3г. В более благоприятный для сои 2014 год максимальное (> 191г) значение имели образцы к-4880, Моладвская (223 г); к-5230, 65 Herb (223 г); к-9984, Ольса (220 г); к-5582, 610 840-2-2 (196г); к-11301, Алиса (192 г). В 2016 году - к-6778, Mutante Stamm 54/145 (280 г); к-9984, Ольса (251 г); к-10623, Мадева (202 г).

Масса семян с растения - основной показатель, по которому оценивают сорта. У испытуемых образцов по годам этот показатель варьировал от 8,0 до 36,4 г. Только два образца, в условиях мелко деляночного опыта, - к-6778, Mutante Stamm 54/145 и к9984, Ольса показали стабильную продуктивность на протяжении всех лет исследований - 17,5 г и 23,9 г., соответственно.

Исследуемые 15 образцов сои были проанализированы на содержание белка и жира - основных показателей качества семян. В таблице 3 приведены данные о содержании белка и жира. Интервал варьирования содержания белка 33,7-39,0\%, содержание жира колебалось от 17,8 до $23,2 \%$. Наибольшее значение содержания 
белка у сорта к-7082, Красноградская (Украина) - 39,0\%, а содержание жира у образца к-10852, INRA597-9-2 (Франция) - 23,2\%.

Таблица 2 - Элементы продуктивности сои, 2013-2016гг.

\begin{tabular}{|c|c|c|c|c|c|c|c|c|c|c|c|c|c|}
\hline \multirow[t]{2}{*}{ №n/П } & \multirow{2}{*}{$\begin{array}{c}\text { №по } \\
\text { каталогу } \\
\text { ВИР }\end{array}$} & \multicolumn{4}{|c|}{$\begin{array}{l}\text { Количество бобов } \\
\text { на } 1 \text { растении, шт. }\end{array}$} & \multicolumn{4}{|c|}{ Масса 1000 семян, г } & \multicolumn{4}{|c|}{ Масса семян с 1 растения, г } \\
\hline & & 2013 & 2014 & 2016 & Средняя & 2013 & 2014 & 2016 & Средняя & 2013 & 2014 & 2016 & Средняя \\
\hline 1. & 11004 & 43 & 47 & 30 & 40,0 & 100,0 & 156 & 157 & 137,7 & 14,6 & 21,9 & 10,4 & 15,6 \\
\hline 2. & 9959 & 26 & 33 & 28 & 29,0 & 140,0 & 151 & 168 & 153,0 & 15 & 13,4 & 10,5 & 13,0 \\
\hline 3. & 11115 & 36 & 43 & 33 & 37,3 & 180,0 & 153 & 167 & 166,6 & 19,5 & 25,0 & 12,2 & 18,9 \\
\hline 4. & 10973 & 48 & 54 & 31 & 44,3 & 152,2 & 136 & 120 & 136,1 & 30 & 19,8 & 9,5 & 19,8 \\
\hline 5. & 4880 & 38 & 35 & 19 & 30,6 & 192,3 & 223 & 165 & 193,4 & 27 & 18,7 & 14,2 & 20,0 \\
\hline 6. & 5230 & 35 & 66 & 41 & 47,3 & 161,4 & 223 & 159 & 181,1 & 18 & 35,4 & 15,4 & 22,9 \\
\hline 7. & 5582 & 43 & 31 & 25 & 33,0 & 179,2 & 196 & 167 & 180,7 & 22 & 17,6 & 12,0 & 17,2 \\
\hline 8. & 6778 & 36 & 30 & 27 & 31,0 & 110,0 & 190 & 280 & 193,3 & 18 & 17 & 17,5 & 17,5 \\
\hline 9. & 7082 & 47 & 48 & 27 & 40,7 & 158,6 & 180 & 145 & 161,2 & 17 & 36,4 & 8,0 & 20,4 \\
\hline 10. & 9442 & 49 & 31 & 100 & 60,0 & 171,0 & 123 & 183 & 159,0 & 21 & 8,7 & 23,2 & 17,6 \\
\hline 11. & 9984 & 24 & 53 & 43 & 40,0 & 150,0 & 220 & 251 & 207,0 & 24 & 24,6 & 23,3 & 23,9 \\
\hline 12. & 10623 & 27 & 29 & 47 & 34,3 & 148,0 & 185 & 202 & 178,3 & 14 & 16,6 & 23,5 & 18,0 \\
\hline 13. & 10852 & 62 & 28 & 33 & 41,0 & 188,0 & 166 & 173 & 175,7 & 34 & 9,2 & 12,7 & 18,6 \\
\hline 14. & 11042 & 62 & 31 & 91 & 61,3 & 177,2 & 190 & 180 & 182,4 & 27 & 14,1 & 12,4 & 17,8 \\
\hline 15. & 11301 & 21 & 56 & 44 & 40,3 & 120,0 & 192 & 152 & 154,7 & 14 & 33,5 & 13,9 & 20,5 \\
\hline
\end{tabular}

Таблица 3 - Содержание жира и белка в семенах сои, 2016 г.

\begin{tabular}{|c|c|c|c|c|c|c|c|}
\hline \multirow[b]{2}{*}{$\begin{array}{l}\text { № } \\
\Pi / \Pi\end{array}$} & \multirow[b]{2}{*}{$\begin{array}{c}\text { №по каталогу } \\
\text { ВИР }\end{array}$} & \multirow[b]{2}{*}{ Название } & \multirow[b]{2}{*}{ Страна происхождения } & \multicolumn{2}{|c|}{ Белок, \% } & \multicolumn{2}{|c|}{ Жир, \% } \\
\hline & & & & & $\begin{array}{c}\text { +/- к } \\
\text { стандарту }\end{array}$ & & $\begin{array}{c}\text { +/- к } \\
\text { стандарту }\end{array}$ \\
\hline 1 & 11004 , st & Свапа & Россия & 35,9 & - & 22,7 & - \\
\hline 2 & 9959 & Окская & Рязань & 36,1 & $+0,2$ & 20,8 & $-1,9$ \\
\hline 3 & 11115 & Мелета & Рязань & 36,8 & $+0,9$ & 22,3 & $-0,4$ \\
\hline 4 & 10973 & Березина & Беларусь & 37,2 & $+1,3$ & 21,2 & $+1,5$ \\
\hline 5 & 4880 & Молдавская 65 & Молдова & 38,4 & $+2,5$ & 19,4 & $-3,3$ \\
\hline 6 & 5230 & Herb 610 & Румыния & 37,8 & $+1,9$ & 17,8 & $-4,9$ \\
\hline 7 & 5582 & $840-2-7$ & Швеция & 32,1 & $-3,8$ & 19,5 & $-3,2$ \\
\hline 8 & 6778 & Mutante Stamm54/145 & Германия & 36,4 & $+0,5$ & 20,0 & $-2,7$ \\
\hline 9 & 7082 & Красноградская & Украина & 39,0 & $+4,1$ & 18,1 & $-4,6$ \\
\hline 10 & 9442 & Primanordia & Польша & 34,5 & $-1,4$ & 19,9 & $-2,8$ \\
\hline 11 & 9984 & Ольса & Беларусь & 35,6 & $-0,3$ & 21,9 & $-0,8$ \\
\hline 12 & 10623 & Мадева & Чувашия & 38,5 & $+2,6$ & 20,4 & $-2,3$ \\
\hline 13 & 10852 & INRA 597-9-2 & Франция & 33,7 & $-2,2$ & 23,2 & $+0,5$ \\
\hline 14 & 11042 & $\mathrm{M}-134$ & Россия & 34,9 & $-1,0$ & 23,0 & $+0,3$ \\
\hline 15 & 11301 & Алиса & Украина & 34,7 & $-1,2$ & 21,4 & $-1,3$ \\
\hline
\end{tabular}

Таблица 4 - Урожайность сортов сои, 2016 г.

\begin{tabular}{|c|c|c|c|c|}
\hline $\begin{array}{l}\text { № } \\
\text { ח/ח }\end{array}$ & №nо каталогу ВИР & Название & Страна происхождения & Урожайность, т/га \\
\hline 1 & 11004 & Свапа & Россия & 2,3 \\
\hline 2 & 9959 & Окская & Рязань & 1,5 \\
\hline 3 & 11115 & Мелета & Рязань & 2,0 \\
\hline 4 & 10973 & Березина & Беларусь & 2,1 \\
\hline 5 & 4880 & Молдавская 65 & Молдова & 1,5 \\
\hline 6 & 5230 & Herb 610 & Румыния & 1,9 \\
\hline 7 & 5582 & $840-2-7$ & Швеция & 2,1 \\
\hline 8 & 6778 & Mutante Stamm54/145 & Германия & 2,4 \\
\hline 9 & 7082 & Красноградская & Украина & 2,1 \\
\hline 10 & 9442 & Primanordia & Польша & 2,7 \\
\hline 11 & 9984 & Ольса & Беларусь & 2,5 \\
\hline 12 & 10623 & Мадева & Чувашия & 2,6 \\
\hline 13 & 10852 & INRA 597-9-2 & Франция & 1,8 \\
\hline 14 & 11042 & $\mathrm{M}-134$ & Россия & 1,6 \\
\hline \multirow[t]{2}{*}{15} & 11301 & Алиса & Украина & 2,4 \\
\hline & $\mathrm{HCP}_{0,05}$ & - & - & 0,2 \\
\hline
\end{tabular}

Данные об урожайности в 2016 году представлены в таблице 4. Интервал варьирования от 1,5 т/га до 2,7 т/га. По результатам урожайности наибольшую 
показали образцы: к-9442, Primanordia, Польша (2,7 т/га), к-10623, Мадева, Чувашия (2,6 т/га), к-9984 Ольса, Беларусь (2,5 т/га).

\section{ЗАКЛЮЧЕНИЕ}

На основе полученных данных при проведении полевого опыта изучения образцов сои различного эколого-географического происхождения в условиях Тульской области в 2013-2016 годах из 300 образцов мировой коллекции ВИР были выделены 15 сортообразцов адаптированных к местным условиям, обладающих общими признаками скороспелости, технологичности и устойчивостью к болезням и вредителям. Выделились образцы с высоким содержанием белка к-7082, Краснодарская (Украина) - 39,0\% и жира к-10852, INRA597-9-2 (Франция) - 23,2\% в качестве источников для дальнейшей селекционной работы. Отмечено два образца имеющих стабильную урожайность на протяжении всего срока испытаний: к-6778, Mutante Stamm 54/145 (Германия) и к-9984, Ольса (Беларусь).

\section{БИБЛИОГРАФИЯ}

1. Адаптация сельского хозяйства России к глобальным изменениям климата http://www.dssercat.com.

2. Папцов А.Г. Адаптация сельского хозяйства России к глобальным изменениям климата // М: ВНИИ экономики сельского хозяйства, 2015. - 42 с.

3. Устюжин А.П. Стратегия развития соевого комплекса России // Земледелие. - 2012. - №2. - C.3-6.

4. Шпаков А. С. Основные направления развития и научное обеспечение полевого кормопроизводства в современных условиях // Кормопроизводство. - 2007. - №5. C. 8-11.

5. Гаврилин Д.С. Сравнительная оценка сбора белка и масла у сортов сои отечественной селекции при разных сроках посева в условиях Тамбовской области // Зернобобовые и крупяные культуры. - 2014. - №1 (9). - С. 30-35.

6. Гуреева Е.В. Источники хозяйственно ценных признаков для селекции сои в Рязанской области / Е.В. Гуреева, Т. А. Фомина //

7. Клыков А. П. Вопросы акклиматизации и агротехники сои в Нечерноземной зоне / А. П. Клыков // Соя: сборник статей. - М.: Изд-во сельскохозяйственной литературы, журналов и плакатов, 1963. - С.277-290.

8. Жученко А.А. Ресурсный потенциал производства зерна в Росси (теория и практика) // М., Издательство Агрорус. - 2004. - 1110с.

9. Посевные площади сельскохозяйственных культур по категориям хозяйств Тульской области. Статистический сборник ФСГС. - Тула, 2012 - 94с.

10. Посевные площади сельскохозяйственных культур по категориям хозяйств Тульской области. Статистический сборник ФСГС. - Тула, 2013 - 96с.

11. Посевные площади сельскохозяйственных культур по категориям хозяйств Тульской области. Статистический сборник ФСГС. - Тула, 2014 - 94с.

12. Посевные площади сельскохозяйственных культур по категориям хозяйств Тульской области. Статистический сборник ФСГС. - Тула, 2015 - 92с.

13. Буряков Ю.П. Соя. Интенсивная технология // М.: ВО Агропромиздат, 1988. - 47с.

14. Летова У. Соя выходит в фравориты // Защита растений. - 2016. - №1 - - С. 6-9.

15. Методика государственного сортоиспытания сельскохозяйственных культур. - М: Колос, 1989. - 35 с.

16. Международный классификатор СЭВ. - Ленинград: ВИР, 1990. - 39 с.

17. Доспехов Б.А. Методика полевого опыта // М., Агропромиздат. - 1985. - 351с.

(C) 2017 by the authors. Licensee RJOAS, Orel, Russia. This article is an open access article distributed under the terms and conditions of the Creative Commons Attribution (CC BY) license: http://creativecommons.org/licenses/by/4.0/ 
DOI https://doi.org/10.18551/rjoas.2017-09.38

\section{ОСОБЕННОСТИ РОСТА И РАЗВИТИЯ МУСКУЛАТУРЫ ТУШ БЫЧКОВ ЧЕРНО- ПЕСТРОЙ ПОРОДЫ И ЕЕ ПОМЕСЕЙ С АБЕРДИН-АНГУССКОЙ И ШАРОЛЕЗСКОЙ CHARACTERISTICS OF GROWTH AND DEVELOPMENT OF CALVES' CARCASSE MUSCLES OF BLACK-MOTLEY BREED AND ITS HYBRIDS WITH ABERDEEN-ANGUS AND CHAROLAIS}

Прохоров И.П., доктор сельскохозяйственных наук

Prokhorov I.P., Doctors of Agricultural Sciences

РГАУ-МСХА имени К.А. Тимирязева, Москва, Россия

Russian State Agrarian University - Moscow Timiryazev Agricultural Academy, Moscow, Russia

E-mail: iprohorov@rgau-msha.ru

Пикуль А.Н., кандидат сельскохозяйственных наук

Pikul A.N., Candidate of Agricultural Sciences

Тульский научно исследовательский институт сельского хозяйства, Тульская область, Россия

Tula Research Institute of Agriculture, Tula Region, Russia

E-mail:anzpikul@mail.ru

\section{АННОТАЦИЯ}

В статье рассмотрено влияние промышленного скрещивания на особенности формирования мясной продуктивности помесных бычков. Изучены характер и интенсивность роста и развития отдельных мускулов и их функциональных групп у бычков черно-пестрой породы и ее помесей с абердин-ангусской и шаролезской. Установлено, что генотип животных оказал существенное влияние на интенсивность роста мускулатуры туш.

\section{ABSTRACT}

The article considers the influence of industrial crossing on the peculiarities of the meat production of crossed bull-calves. The nature and intensity of growth and development of individual muscles and their functional groups in black-motley bull-calves and its hybrids with Aberdeen-Angus and Sharolese breeds were studied. It was established that the genotype of animals had a significant effect on the intensity of musculature growth in the carcasses.

\section{КЛЮЧЕВЫЕ СЛОВА}

Помеси, мускулатура, гормоны, рост, развитие.

\section{KEY WORDS}

Hybrids, muscles, hormones, growth, development.

Интенсивность и характер роста скелетной мускулатуры туш животных в постнатальном онтогенезе, начиная со становления локомоции новорожденных телят до достижения ими дефинитивной организации мышечного комплекса, определяются закономерными и последовательными изменениями напряженности ростовых процессов тканей и органов их организма. Эта периодичность роста и развития мускулатуры сопряжена с последовательными дифференцировками и в значительной степени обусловлена возрастными изменениями уровня половых стероидов [8, 9, 13].

Знания о периодичности роста органов и тканей, в частности, мышечного компонента туш животных позволяют в определенной степени воздействовать на интенсивность их роста, а, следовательно, регулировать процессы фрормирования мясной продуктивности. Однако для управления этими закономерностями необходимы 
углубленные исследования влияния различных фракторов на характер и интенсивность роста мускулатуры.

Результатами многих исследований установлено, что на рост соматической мускулатуры влияют фактор кормления [2, 6, 7], генотип животных [5, 12], половые гормоны [8-10, 13, 14], фрункциональные нагрузки на мускулатуру [2, 13, 15].

Однако до настоящего времени остается неизученным влияние промышленного скрещивания на особенности формирования мясной продуктивности помесных бычков.

Настоящая работа посвящена изучению характера и интенсивности роста и развития отдельных мускулов и их функциональных групп у бычков черно-пестрой породы и ее помесей с абердин-ангусской и шаролезской.

\section{МАТЕРИАЛЫ И МЕТОДЫ ИССЛЕДОВАНИЙ}

Для изучения особенностей роста и развития мускулатуры черно-пестрых и помесных бычков при интенсивном их выращивании и откорме были отобраны и сформированы 3 группы животных по 15 голов в каждой. Формирование групп проводили методом пар-аналогов с учетом происхождения, возраста и массы при рождении. В первую (контрольную) группу были включены бычки черно-пестрой породы, во вторую и третью (опытные) группы - соответственно бычки 1/2 кровности от скрещивания коров указанной породы с абердин-ангусскими и шаролезскими быками. Животные всех групп находились в одинаковых условиях кормления и содержания. Содержание животных было стойловое, до 6 месяцев групповое в клетках в последующие возрастные периоды - на привязи. Опыты проводили от рождения до 18 месячного возраста. Уровень кормления подопытного молодняка был интенсивным и рассчитан в соответствии для получения среднесуточных приростов $1000-1100$ г. и достижения живой массы в возрасте 18 месяцев 550-600 кг. Учет потребленного корма проводили ежедекадно путем взвешивания заданных кормов и их остатков. Кормление и условия содержания по группам не различались.

Прирост живой массы бычков контролировали путем ежемесячного взвешивания. Контрольные убои были проведены на Подольском мясокомбинате. При рождении было убито по 1 бычку из каждой группы, в возрасте 6 и 12 месяцев - по 3 головы, в 15 месяцев - по 5 бычков. После проведения контрольных убоев в 15 месячном возрасте, был продолжен откорм оставшихся бычков (по 3 головы в каждой группе). При этом ставилась задача изучить характер и интенсивность роста и развития основных тканей туш.

Для определения закономерностей возрастных изменений массы мускулатуры производили послойное препарирование и определение массы каждой мышцы (с точностью до 1 г.) левой полутуши. На основе абсолютных данных о массе мускулов была высчитана их средняя для каждой группы, а также относительная масса мускулов (масса, выраженная в процентах ко всей массе исследованной мускулатуры). Общую массу мускулатуры анатомических областей определяли суммированием массы каждой мышцы, входящей в эту группу. Для группировки мышц по анатомическим отделам использовали классификацию П.А. Глаголева [3] и А.И. Акаевского [1].

\section{РЕЗУЛЬТАТЫ ИССЛЕДОВАНИЙ И ИХ ОБСУЖДЕНИЕ}

Интенсивное выращивание и откорм животных в течение опытного периода обеспечили высокую интенсивность роста бычков всех групп. Шаролезские помеси обладали повышенной энергией роста и в возрасте 12, 15 и 18 месяцев живая масса

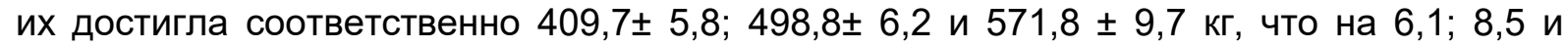
$11,8 \%$ ( $\mathrm{P}<0,05-\mathrm{P}<0,001)$ больше, чем у сверстников материнской породы. Различия в величине указанного показателя между животными 1 и 2 групп были незначительны.

Генотип животных оказал существенное влияние на рост мышечной массы туш (рис. 1). Высокий уровень кормления способствовал наиболее полной реализации наследственного потенциала шаролезских помесей. Так, при практически одинаковой 
массе мускулатуры туш новорожденных бычков сравниваемых групп (13742-14400 г) величина этого показателя у шаролезских помесей в возрасте 12, 15 и 18 месяцев

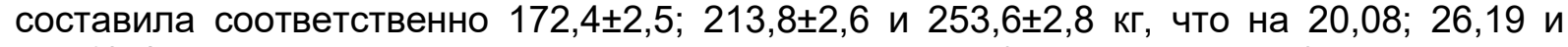
$31,5 \%$ больше, чем у сверстников материнской породы $(\mathrm{P}<0,01-\mathrm{P}<0,001)$.

Различия в абсолютной массе мускулатуры туш между бычками контрольной группы и абердин-ангусскими помесям в указанные возрастные периоды были незначительны и находились в пределах 4,0 - 5,3 кг.

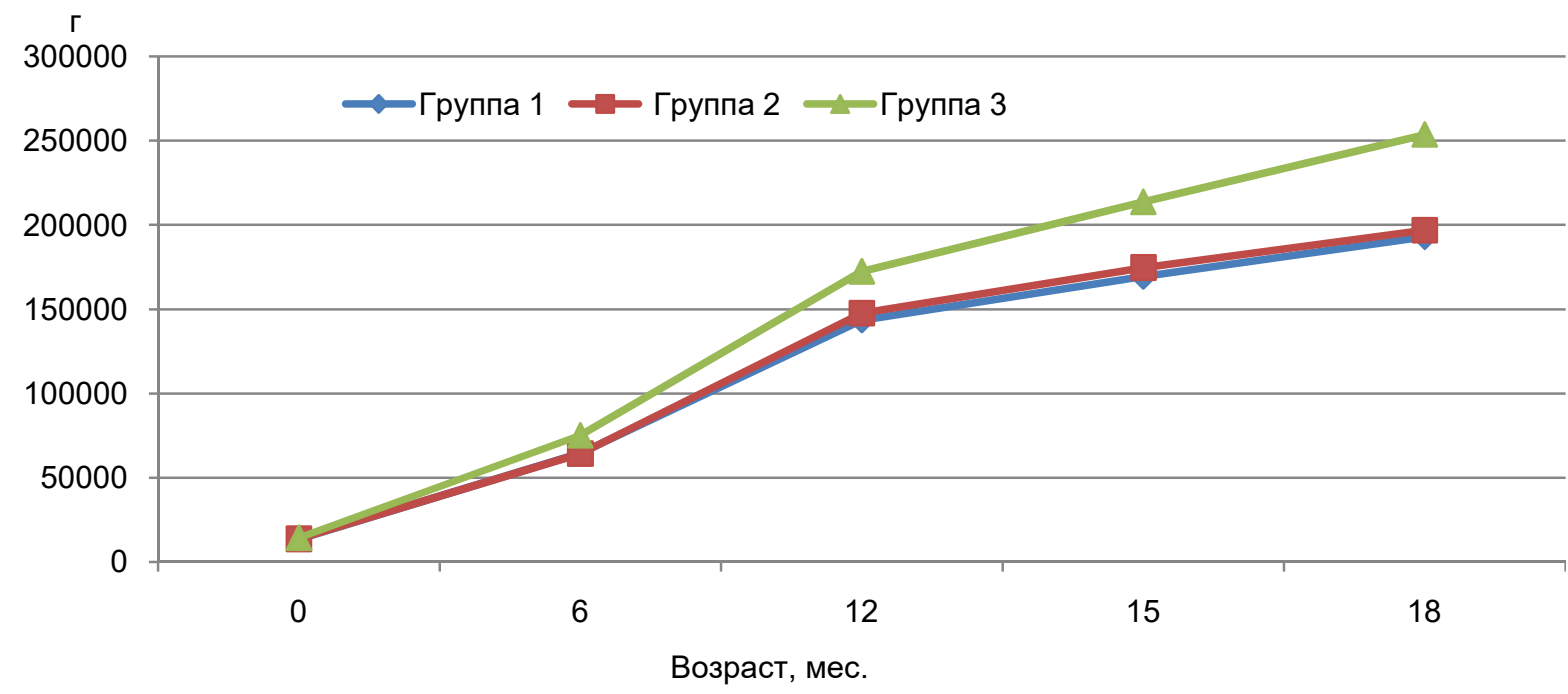

Рисунок 1 - Динамика общей массы мускулатуры туш подопытных бычков

При определении среднесуточных приростов мускулатуры было установлено, что величина указанного показателя до 6-месячного возраста была относительно низкой (266 - 322 г), затем она к 12-месячному возрасту у шаролезских помесей возросла до 520 г, а у сверстников 1 и 2 групп - соответственно до 432 и 456 г. После годовалого возраста установлено значительное снижение интенсивности роста мускулатуры туш подопытных бычков. Так, абсолютная скорость роста соматической мускулатуры к 15месячному возрасту составила по группам в порядке возрастания их номеров 284, 298 и 456 г, а к концу опытного периода - 256, 244 и 438 г.

Значительное снижение уровня среднесуточных приростов мускулатуры у бычков 1 и 2 групп после 12-месячного возраста, по-видимому, связано с переориентацией синтетических процессов в сторону усиления отложения жира в их теле.

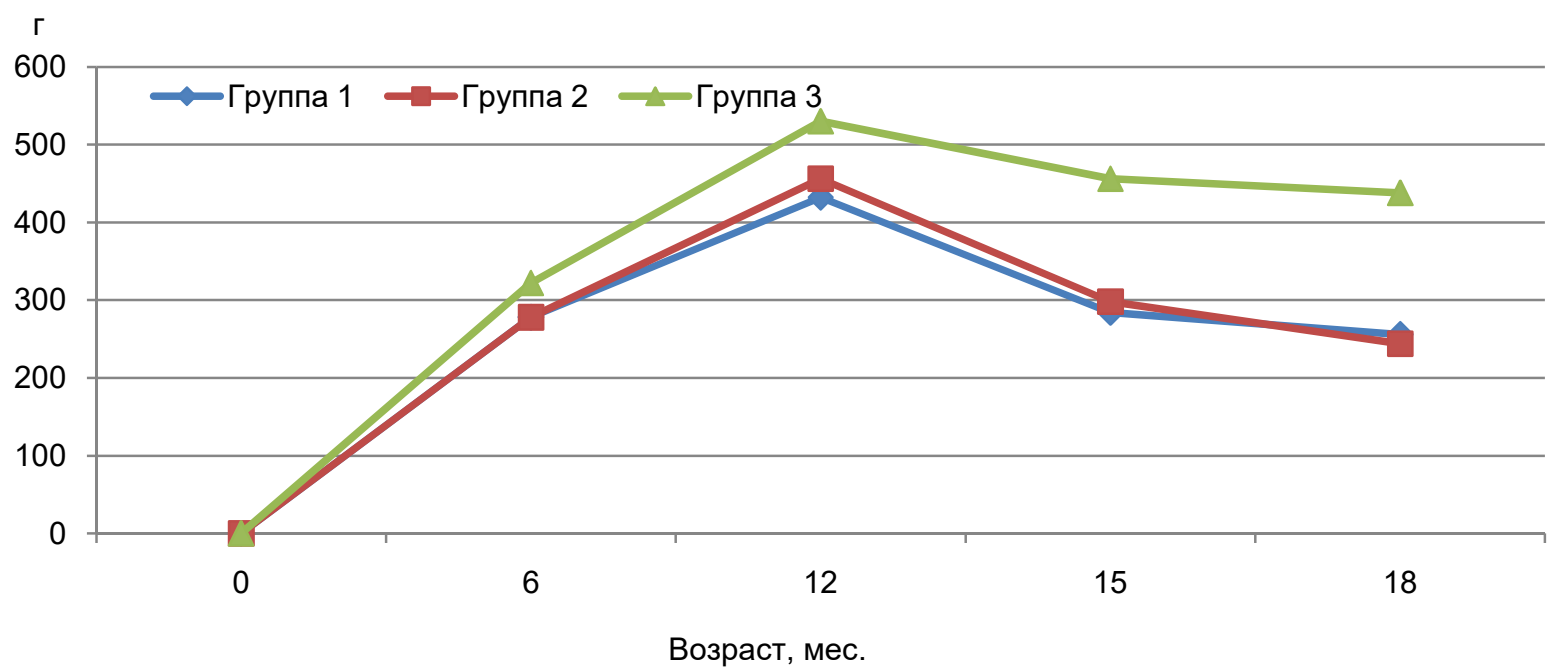

Рисунок 2 - Динамика среднесуточных приростов мускулатуры туш подопытных бычков 
Известно, что на интенсивность роста мускулатуры влияют функциональная нагрузка, генотип животных, фрактор кормления, а также уровень и соотношение гормонов. По данным многих исследователей $[4,8,9,13]$ на интенсивность роста мускулатуры бычков значительное влияние оказывают андрогены. В связи с этим следует отметить, что период наиболее интенсивного роста мускулатуры совпал с началом становления и созревания половой фрункции бычков. Известно, что в этот возрастной период усиливается функция гонад и в крови возрастает концентрация андрогенов, которые обладают мощным анаболическим эфффектом $(8,9,10,13,14)$. Но основное влияние андрогенов на ростовые процессы опосредованы посредством стимуляции соматотропной функции гипофриза. Гормон роста стимулирует синтез в печени, мышцах и других периферийных тканях инсулиноподобный фактор роста (IGF1), который, как и инсулин, облегчает проникновение аминокислот и глюкозы через плазматическую мембрану внутрь мышечных клеток.

Влияние СТГ на синтез белка в мышцах на первых этапах осуществляется посредством стимулирующего действия на транспорт аминокислот и глюкозы через плазматические мембраны мышечных клеток, а также усиления процессов трансляции в рибосомах. Кроме этого, гормон роста, обладая жиромобилизующим эффектом, обеспечивает энергетику синтеза мышечных белков [8].

Из этого можно заключить, что мощный рост мускулатуры в возрастной период от 6 до 12 месяцев можно рассматривать как результат опосредованного действия тестостерона через другие анаболические гормоны.

Снижение интенсивности роста скелетной мускулатуры к концу опытного периода, по-видимому, связано с тем, что по мере полового созревания бычков в их крови возрастает концентрация андрогенов, которые уже оказывают ингибирующее влияние на соматотропную функцию гипофиза. Можно предположить, что высокая концентрация тестостерона в крови животных является пусковым фрактором для торможения ростовых процессов активных тканей туш.

Поскольку каждый анатомический отдел состоит из комплекса мышц разной интенсивности роста, внутреннего строения и питательной ценности, важно иметь представление о соотношении массы мышечного компонента анатомических областей. В таблице 1 представлена абсолютная масса мускулатуры различных анатомических отделов туш.

Таблица 1 - Абсолютная масса мускулатуры анатомических отделов туш подопытных бычков в возрасте 18 месяцев (в каждой группе $\mathrm{n}=3$ )

\begin{tabular}{|l|c|c|c|c|c|c|}
\hline \multirow{2}{*}{ Мускулатура } & \multicolumn{2}{c|}{1 группа } & \multicolumn{2}{c|}{2 группа } & \multicolumn{2}{c|}{3 группа } \\
\cline { 2 - 7 } & г & $\%$ & г & $\%$ & \multicolumn{1}{c|}{ г } \\
\hline Общая связывающая & 36983 & 19,18 & 37824 & 19,21 & 48014 & 18,93 \\
\hline Позвоночного столба & 33493 & 17,37 & 36249 & 18,41 & 44463 & 17,53 \\
\hline Грудной клетки & 9795 & 5,08 & 10435 & 5,30 & 13316 & 5,25 \\
\hline Брюшной стенки & 15348 & 7,96 & 14354 & 7,29 & 19885 & 7,84 \\
\hline Грудного пояса & 11974 & 6,21 & 11302 & 5,74 & 14229 & 5,61 \\
\hline Области плеча & 10354 & 5,37 & 10416 & 5,29 & 13646 & 5,38 \\
\hline Предплечья & 5187 & 2,69 & 5415 & 2,75 & 6062 & 2,39 \\
\hline Тазового пояса & 12899 & 6,69 & 13133 & 6,67 & 17552 & 6,92 \\
\hline Области бедра & 44214 & 22,93 & 45484 & 23,10 & 59808 & 23,58 \\
\hline Области голени & 8387 & 4,35 & 8230 & 4,18 & 11388 & 4,49 \\
\hline Подкожная & 4242 & 2,20 & 4056 & 2,06 & 5276 & 2,08 \\
\hline Общая & 192866 & 100,00 & 196900 & 100,78 & 253639 & 100,00 \\
\hline
\end{tabular}

Из таблицы видно, что шаролезские бычки по абсолютной массе мускулатуры анатомических отделов полутуш значительно превосходили сверстников двух других групп. Так, различия в массе мышечного компонента позвоночного столба, области бедра, общей связывающей мускулатуры между шаролезскими помесями и бычками материнской породы составили соответственно 10910; 15594 и 11031 г, или 32,7; 35,3 и $29,8 \%$ в пользу помесей. Наименьшие межгрупповые различия установлены по массе мускулатуры области плеча (16,8\%). 
Шаролезские и абердин-ангусские помеси отличались лучшим развитием мускулатуры области бедра, они превосходили сверстников материнской породы, как по абсолютной, так и по относительной массе мускулатуры области бедра.

Определение коэффрициентов роста мускулатуры различных анатомических отделов туш позволило установить различия в характере и интенсивности роста и развития мышечного компонента этих отделов (рис. 3).

Поскольку характер роста и развития мускулатуры одноименных анатомических отделов туш животных сравниваемых групп был сходным, приведены данные только по шаролезским помесям, отличавшимся наиболее интенсивным ростом мускулатуры.

Для сравнительного анализа интенсивности роста мышечной массы анатомических отделов туш в качестве средней была принята интенсивность роста общей массы мышечного компонента туш. По отклонениям коэфффициентов роста мускулатуры анатомических отделов в большую или меньшую сторону относительно таковых общей массы мускулатуры туш судили об интенсивности роста той или иной мышечной группы.

Анализ данных об интенсивности роста мускулатуры анатомических отделов туш показал, что таковая мышечного компонента, связывающего туловище с передней конечностью, позвоночным столбом и областью бедра, которые в значительной степени определяют уровень мясной продуктивности животных, была достаточно высока. Так, коэффицциенты роста мускулатуры указанных отделов в порядке их перечисления при проведении заключительного убоя у шаролезских помесей составили 19,79; 19,42 и 15,95 против 17,61 мышечного компонента туш. Приведенные данные свидетельствуют о более интенсивном росте общей связывающей мускулатуры и мышечной массы позвоночного столба и относительно низкой напряженности роста мышечного комплекса области бедра, по сравнению с таковой с мышечным компонентом туш.

Следует отметить, что в общую связывающую мускулатуру входят такие крупные мускулы, как зубчатый вентральный, глубокий грудной, широчайший спины, увеличение массы которых в значительной степени и определяет более интенсивный рост данного мышечного комплекса.

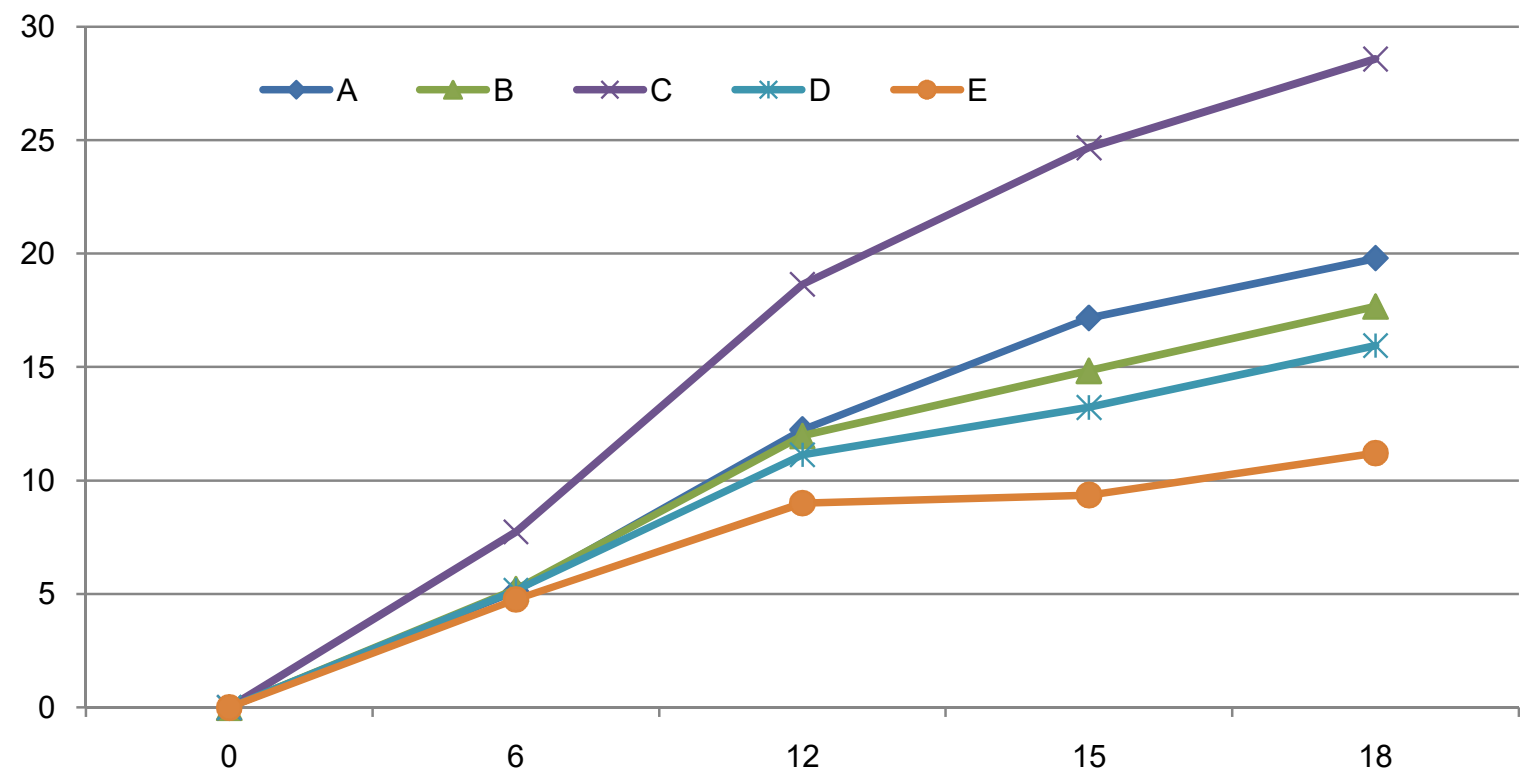

Возраст, мес.

Рисунок 3 - Коэффициенты роста мускулатуры анатомических отделов туш (А - общая связывающая мускулатура; В - мускулатура туш; C - брюшной отдел; D - область бедра; E - область голени) 
Интенсивный рост зубчатого вентрального мускула объясняется прогрессивно нарастающей функциональной нагрузкой, оказываемой подвешенным на передних конечностях телом, которое под действием гравитационной силы стремится опуститься вниз, в силу чего основная нагрузка массы тела ложится на мышцы плечевого пояса. Значительное увеличение живой массы с возрастом бычков, особенно передней трети их туловища, приводит к возрастанию нагрузки, что и способствует интенсивному росту и увеличению массы и мощности этих мышц. Кроме этого, грудная часть зубчатого вентрального мускула противодействует провисанию туловища и принимает участие в протягивании туловища вперед между передними конечностями. Таким образом, наибольшая масса зубчатой вентральной мышцы и ее мощность в значительной степени обусловлены увеличением массы животных, повышением антигравитационного действия и участием ее в пропульсии туловища вперед. Широчайшая мышца спины, кроме протягивающей функции туловища вперед, противодействует, как и зубчатая вентральная мышца, провисанию туловища и способствует разгибанию локтевого сустава. Основной функцией глубокой грудной мышцы является пропульсия туловища. Таким образом, интенсивность роста последних трех мускулов в значительной степени, обусловлена функциональной нагрузкой, оказываемой при локомоции, и гравитацией.

Выше было отмечено, что на рост мускулатуры, кроме функциональной нагрузки, мощное влияние оказывают уровень и соотношение гормонов в крови животных. Однако следует иметь в виду, что гормоны могут влиять на интенсивность роста тканей и органов в том случае, если они чувствительны к воздействию этих гормонов. А чувствительность тканей возможна при наличии в них рецепторов этих гормонов и их активизации.

В связи с этим следует отметить, что в период полового созревания в крови бычков значительно возрастает концентрация андрогенов, которые способствуют образованию и активизации рецепторов тестостерона в мышечной ткани. Вследствие этого отдельные мышцы, расположенные в области шеи и входящие в мускулатуру, связывающую туловище с передней конечностью, становятся более чувствительными к воздействию андрогенов. В результате свободного проникновения биологически активного тестостерона внутрь клетки и взаимодействия его с соответствующими рецепторами образуются лигандные комплексы, способные реализовать гормональные эффректы в клетке, прежде всего процессы транскрипции. Ростовой эффект тестостерона наиболее полно проявляется в пуберантный период, когда он избирательно стимулирует рост мускулатуры передней трети туловища.

Наибольшая энергия роста характерна для мускулатуры брюшной стенки. Ее масса, по сравнению с таковой новорожденных бычков, в конце опытного периода возросла в 28,57 раза. Функциональная нагрузка, оказываемая на мускулатуру брюшного отдела, является основным фрактором, определяющим интенсивность ее роста. Мускулатура брюшного отдела относится к поздноразвивающейся мышечной системе, поскольку телята в период утробного развития и сразу после рождения не испытывают достаточно сильного давления внутренних органов и пищеварительного тракта, так как последние имеют незначительный объем и массу. Однако с ростом животных и становлением рубцового пищеварения в постнатальный период объем и масса внутренних органов, особенно преджелудков, значительно увеличивается, следовательно, повышается и нагрузка на мышцы брюшной стенки. Известно, что только за первые 5 месяцев жизни телят объем рубца увеличивается в 89 раз.

Общий паттерн влияния фуункциональной нагрузки на значительный рост мышечной массы брюшной стенки можно представить следующим образом: по мере увеличения массы и объема внутренних органов и преджелудков в период становления рубцового пищеварения мышцы брюшной стенки испытывают возрастающую гравитационную нагрузку.

Необходимо иметь в виду, что реакция на любое достаточно сильное воздействие как внутренней, так и внешней среды, обеспечивается системой, специфически реагирующей на данный раздражитель. В ответ на воздействие 
раздражителя на определенном этапе онтогенеза в организме формируется фрункциональная доминирующая система, которая для сохранения равновесия этой системы на данном этапе посредством подчинения всех исполнительных органов, координирует функции нервной, эндокринной, ферментной, кровеносной, мышечной систем (11).

Известно, что в организме поддерживается равновесие между уровнем развития мышц и функциональной нагрузкой, оказываемой на них. При усилении гравитационной нагрузки на брюшные мышцы нарушается вышеупомянутое равновесие. Для адаптации к возросшей гравитационной нагрузке система способствует росту и усилению мощности мускулатуры брюшной стенки за счет расширения кровеносных сосудов и поступления пластического материала в достаточном количестве. Следует отметить, что отдельные гормоны, в том числе СТГ и инсулин существенно влияют на интенсификацию белкового обмена и вызывают увеличение массы мускулатуры за счет интенсификации синтеза белка в них посредством усиления активности ферментной системы, повышения синтеза фрерментов и обеспечения проницаемости аминокислот и глюкозы через плазматические мембраны мышечных клеток. Лабильность мышечной системы способствует ее адаптации к оказываемому давлению со стороны внутренних органов и преджелудков за счет усиления интенсивности роста мышечной массы. При установлении равновесия между гравитационной нагрузкой, оказываемой внутренними органами, и антигравитационным действием брюшных мышц система также возвращается в привычное для нее равновесие.

В отличие от мышечной системы брюшной стенки развитие мускулатуры конечностей, особенно их дистальных отделов, в пренатальный период онтогенеза должно быть завершено в такой степени, чтобы сразу после рождения они были способны выполнять свойственные им функции движения для выживания новорожденных телят. Достаточно развитая мускулатура конечностей позволяет телятам бегать за матерью, принимать устойчивое положение для сосания.

Интенсивность роста мускулатуры конечностей, по сравнению с таковой брюшной стенки, позвоночного столба, связывающей туловище с передней конечностью, несколько ниже. Следует также отметить, что чем дистальнее расположена мускулатура конечностей, тем ниже интенсивность ее роста. Так, например, коэффрициенты роста мускулатуры отделов плеча и бедра шаролезских помесей в конце опытного периода составили соответственно 16,17 и 15,95, а предплечья и голени - 11,21 и 11,18.

\section{ЗАКЛЮЧЕНИЕ}

На основании проведенных исследований было установлено, что генотип животных оказал существенное влияние на интенсивность роста мускулатуры туш. Мышечная масса туш у шаролезских помесей в возрасте 12, 15 и 18 месяцев

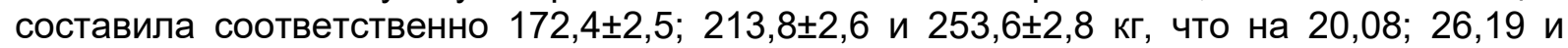
$31,5 \%$ больше, чем у сверстников материнской породы $(P<0,01-P<0,001)$. Различия в величине указанного показателя между бычками 1 и 2 групп были незначительны.

Шаролезские помеси в конце опытного периода существенно превосходили сверстников материнской породы по абсолютной массе мускулатуры всех анатомических отделов, за исключением таковой предплечья и голени. Помеси 2 и 3 групп отличались лучшим развитием мускулатуры области бедра, они превосходили сверстников материнской породы, как по абсолютной, так и по относительной массе мускулатуры указанного анатомического отдела.

Анатомические отделы туш по интенсивности роста мускулатуры были распределены в следующем убывающем порядке: брюшная стенка, грудная клетка, общая связывающая, позвоночного столба, тазового пояса, грудного пояса, области плеча, области бедра, области предплечья, области голени. 


\section{БИБЛИОГРАФИЯ}

1. Акаевский А. И. Анатомия домашних животных // М.: Колос, 1968. - 608 с.

2. Берг Р.Т. Мясной скот: концепция роста (пер. с англ.) // М.: Колос. - 1979. - 280 с.

3. Глаголев П.А. Анатомия сельскохозяйственных животных с основами гистологии и эмбриологии // М.: Колос, 1977. - 450 с.

4. Држевецкая И.А. Основы фризиологии обмена веществ и эндокринной системы / И.А. Држевецкая // М.: Высшая школа, 1977 - 256 с.

5. Прохоров И.П. Формирование мясной продуктивности молодняка у крупного рогатого скота при промышленном скрещивании // Автореф. дисс. д-ра с.-х. наук. M. - 2013. $-33 \mathrm{c}$.

6. Прохоров И. П. Сравнительная оценка продуктивных качеств бычков черно-пестрой породы и ее помесей с герефордами и лимузинами / И.П. Прохоров // Известия Тимирязевской сельскохозяйственной академии. - 2011. - № 3. - С. 129-138.

7. Прохоров И.П., Возрастные изменения показателей обмена веществ черно-пестрых и помесных бычков // Зоотехния. - 2012. - № 10. - С. 9-10.

8. Розен В.Б. Основы эндокринологии // М., Высшая школа,1984. - 336 с.

9. Сонькин В.Д. Развитие мышечной энергетики и работоспособности в онтогенезе / В.Д. Сонькин, Р.В. Тамбовцева // М.: Книжный дом «Либроком», 2011. - 368 с.

10. Тамбовцева Р.В. Развитие мышечной ткани в онтогенезе / Р.В. Тамбовцева // Новые исследования. - 2010. - № 2. - С. 81-94

11. Ухтомский А.А. Доминанта // М.: Наука, 1966. - 273 с.

12. Эртуев М.М. Мясная продуктивность и морфологические особенности туш бычков при различных вариантах промышленного скрещивания комбинированных пород с мясными / М.М. Эртуев // Известия ТСХА. - 1980. - вып.1. - С.126-135.

13. Armstrong N. Aerobic fitness and anaerobic performance during childhood and adolescence International Council of Physical Activity and Fitness Re-search. Symposium // Acta Kinesiologiae Un / Tartuensis/ - 2002. - P. 13-19

14. Boisseau N., Delamarche P. Metabolic and hormonal responses to exercise in children and adolescents // Sports Med. - 2000. - 30 (6). - P. 405-422

15. Hinriksson L.K. Frieden J. Distribution of fibre sizes in human skeletal muscle. An enzyme Histochemical stady in m. tibial anterior.// Acta Physiol Scand. - 1985. - v.123. pp. 171-177.

(C) 2017 by the authors. Licensee RJOAS, Orel, Russia. This article is an open access article distributed under the terms and conditions of the Creative Commons Attribution (CC BY) license: http://creativecommons.org/licenses/by/4.0/ 
DOI https://doi.org/10.18551/rjoas.2017-09.39

\title{
ЭФФЕКТИВНОСТЬ ПРИМЕНЕНИЯ И ВЛИЯНИЕ БЕЛКОВОГО ГИДРОЛИЗАТА НА КАЧЕСТВО ПРОДУКЦИИ КРОЛИКОВОДСТВА EFFECTIVENESS OF APPLICATION AND INFLUENCE OF PROTEIN HYDROLYSATE ON QUALITY OF THE RABBITS PRODUCTION
}

\author{
Василевич Ф.И., доктор ветеринарных наук, профессор, академик РАН \\ Vasilevich F.I., Doctor of Veterinary Sciences, Professor, Academician of the Russian \\ Academy of Sciences \\ Бачинская B.M*., кандидат биологических наук, доцент \\ Bachinskaya V.M., Candidate of Biological Sciences, Associate Professor \\ Дельцов А.А., доктор ветеринарных наук, доцент \\ Deltsov A.A., Doctor of Veterinary Sciences, Associate Professor \\ Московская государственная академия ветеринарной медицины и \\ биотехнологии - МВА имени К.И. Скрябина, Москва, Россия \\ Moscow State Academy of Veterinary Medicine and Biotechnology - \\ MVA named after K.I. Skryabin, Moscow, Russia \\ *E-mail: bachinskaya1980@mail.ru
}

\begin{abstract}
АННОТАЦИЯ
Применение кроликам белкового гидролизата, внутрь в дозе 1 мл/кг в течении 14 суток, способствует увеличению живой массы животных на 3,5\% по отношению к контролю, активации эритропоэза, что проявляется в увеличении содержания гемоглобина на $1,6 \%$ и количества эритроцитов на $6,6 \%$ к концу опыта. Применение препарата не оказывает отрицательного влияние на показатели безопасности мяса кроликов, а по дегустационной оценке мяса и бульона было установлено, что в опытной группе мясо отличалось от контроля более высокими вкусовыми свойствами, имело ярко выраженный аромат и вкус, нежную и сочную консистенцию, а бульон был прозрачным и наваристым.
\end{abstract}

\section{ABSTRACT}

Application to rabbits of protein hydrolyzate, inside in a dose of $1 \mathrm{ml} / \mathrm{kg}$ within 14 days, promotes increase in alive mass of animals by $3,5 \%$ in relation to monitoring, activation of an erythrogenesis that is shown in increase in a hemoglobin content by $1,6 \%$ and quantities of erythrocytes by $6,6 \%$ by the end of experience. Use of medicine does not exert the negative impact on indicators of safety of meat of rabbits, and by tasting assessment of meat and broth was established that in experienced group meat differed from monitoring in higher flavoring properties, had pronounced aroma and taste, gentle and rich consistence, and broth was the transparent and rich.

\section{КЛЮЧЕВЫЕ СЛОВА}

Кролиководство, белковые гидролизаты, качество, безопасность.

\section{KEY WORDS}

Rabbit breeding, protein hydrolyzates, quality, safety.

Основной проблемой в кролиководстве является огромное влияние стрессовых ситуаций, в результате чего происходит: 1) потеря мясной продуктивности, 2) возникновение заболеваний (повышение радикалов и усиление пероксидного окисления липидов в мембранах клеток), обусловленных повреждением различных органов и тканей, 3) ухудшение воспроизводительной способности. Стресс факторами могут, является: нарушение норм содержания, соблюдение санитарных правил, полноценное кормление. 
Давно установлено, что введение в рацион молодняка кроликов микроэлементных подкормок способствует более интенсивному приросту живой массы животных. В настоящее время для этих целей используются как минеральные соли эссенциальных микроэлементов (сульфаты, хлориды и пр.), так и их органические соединения (хелаты, коллоидные растворы).

Минеральные соединения имеют довольно много недостатков. Они взаимодействуют с веществами корма, плохо усваиваются, могут вызвать поражения желудочно-кишечного тракта, при хранении в смесях нестабильны. Хелатные соединения микроэлементов (глюконаты, аминоаты, комплексонаты и др.) при отсутствии этих недостатков имеют высокую стоимость и не устраняют проблемы конкуренции ионов металлов за определённые рецепторы в желудочно-кишечном тракте.

Препараты фрерментативного растительного (соевого белка) гидролизата, к которым относится препарат «Абиопептид» (производства ООО Фирма «А-БИО», РФ), содержащий все незаменимые и заменимые аминокислоты а также низшие пептиды, представляют наибольшую перспективность в развитии кролиководства.

Также при использовании, каких либо препаратов (добавок) в продуктивном животноводстве необходимо учитывать их возможное отрицательное воздействие на показатели качества и безопасности продуктов убоя.

Вопросы эффективности применения препарата «Абиопептид» в кролиководстве и ветеринарно-санитарной экспертизе продуктов убоя кроликов в доступной литературе освещены недостаточно, поэтому данная тема является актуальной.

Цель нашей работы являлось изучение биологического действия препарата «Абиопептид» на кроликах и определение качественных показателей получаемой продукции, на основании органолептических, бактериологических, фризико-химических, гистологических и токсико-биологических показателях.

\section{МАТЕРИАЛЫ И МЕТОДЫ ИССЛЕДОВАНИЙ}

Биологическое действие препарата «Абиопептид» изучали на 20 кроликах породы российский горностаевый. Животных распределили на две группы по принципу аналогов, по 10 голов в каждой, кроликам первой группы «Абиопептид» задавали орально по 1 мл/кг живой массы животных каждый день в течение двух недель, а вторая группа животных служила контролем и находилась на стандартном рационе. Кролики содержались в аналогичных условиях содержания, кормления и ухода в индивидуальных клетках. Ежедневно проводили клинический осмотр животных. Послеубойный ветеринарно-санитарный осмотр тушек кроликов проводили по общепринятой методике, согласно «Правилам ветеринарного осмотра убойных животных и ветеринарно-санитарной экспертизы мяса и мясопродуктов» (1983г., с дополнениями и изменениями от 1988г.). Органолептические исследования проводили согласно ГОСТ 20235.0-74 «Мясо кроликов. Методы отбора образцов. Органолептические методы оценки качества».

Также образцы мяса кроликов опытной и контрольной групп исследовали на соответствие требованиям СанПиН 2.3.3.1078-01 «Гигиенические требования к безопасности и пищевой ценности пищевых продуктов», пп. 1.1.1, 1.1.1.1 на содержание в них микроорганизмов, антибиотиков, токсичных элементов, пестицидов и радионуклидов. Эти исследования проводили в испытательной лаборатории пищевой продукции, продовольственного сырья и кормов ГНУ ВНИИ Ветеринарной санитарии, гигиены и экологии в соответствии с нормативной документацией на методы испытаний.

\section{РЕЗУЛЬТАТЫ И ИХ ОБСУЖДЕНИЕ}

За период проведения экспериментальных исследований препарата все животные опытной и контрольной были клинически здоровы, все показатели 
фризиологические показатели находились в пределах нормы и изменялись незначительно. Результаты исследований крови кроликов представлены в таблице 1.

Из данных представленных в таблице 1 следует, что количество гематокрита, гемоглобина, эритроцитов и лейкоцитов у опытной группы кроликов достоверно не отличалось на начало эксперимента от контрольной группы.

В группе кроликов получавших препарат «Абиопептид», в 80-дневном возрасте количество гемоглобина повышается на 1,6\%, что свидетельствует о положительном влиянии препарата «Абиопептид» на синтез гемоглобина.

Таблица 1 -Динамика гематологических показателей под влиянием препарата «Абиопептид»

\begin{tabular}{|c|c|c|c|c|}
\hline Показатели & Ед. измерения & Возраст, дней & Опыт & Контроль \\
\hline \multirow{2}{*}{ Эритроциты } & \multirow{2}{*}{ Млн/мкл } & 60 & $5,9 \pm 0,18$ & $5,8 \pm 0,11$ \\
\hline & & 80 & $6,4 \pm 0,24^{*}$ & $6,0 \pm 0,14$ \\
\hline \multirow{2}{*}{ Лейкоциты } & \multirow{2}{*}{ Тыс/мкл } & 60 & $8,22 \pm 0,17$ & $8,27 \pm 0,15$ \\
\hline & & 80 & $8,18 \pm 0,15^{*}$ & $7,82 \pm 0,19$ \\
\hline \multirow{2}{*}{ Гемоглобин } & \multirow{2}{*}{ г/л } & 60 & $125,7 \pm 1,8$ & $129,8 \pm 2,1$ \\
\hline & & 80 & $132,2 \pm 1,4^{*}$ & $130,1 \pm 1,6$ \\
\hline \multirow{2}{*}{ Гематокрит } & \multirow{2}{*}{$\%$} & 60 & $39,9 \pm 0,10$ & $39,6 \pm 0,04$ \\
\hline & & 80 & $40,6 \pm 0,08$ & $40,3 \pm 0,17$ \\
\hline
\end{tabular}

* $-P \leq 0,05$

На начало эксперимента количество эритроцитов в крови кроликов опытной и контрольной групп находилось в пределах 5,9 млн/мкл - 5,8 млн/мкл. В 80-дневном возрасте содержание эритроцитов в первой группе получавших препарат «Абиопептид» на 6,6\% выше. Исходя из полученных данных, можно сделать вывод что препарат «Абиопептид» стимулируют эритропоэз в период технологических стрессов.

Определение количества лейкоцитов, показало, что у кроликов контрольной группы этот показатель на конец опыта снизился на $5,4 \%$, а у кроликов опытной группы на $0,5 \%$ от первоначального уровня. Кролики контрольной группы оказываются более чувствительными к воздействию стрессов, тогда как у кроликов получавших препараты «Абиопептид» данный показатель изменяется незначительно, что свидетельствует о снижении влияния технологических стрессов.

Уровень гематокрита кроликов опытной и контрольной групп находился на начало и на конец опыта в пределах физиологических норм, характерных для данного вида животных.

Таблица 2 - Динамика биохимических показателей крови под влиянием препарата «Абиопептид»

\begin{tabular}{|c|c|c|c|c|}
\hline Показатели & Ед. измерения & Возраст, дней & Опыт & Контроль \\
\hline \multirow{2}{*}{ АЛТ } & \multirow{2}{*}{$U / L$} & 60 & $46,4 \pm 0,03$ & $39,6 \pm 0,11$ \\
\hline & & 80 & $39,6 \pm 0,09$ & $38,8 \pm 0,10$ \\
\hline \multirow{2}{*}{ ACT } & \multirow{2}{*}{$U / L$} & 60 & $97,6 \pm 0,14$ & $99,1 \pm 0,09$ \\
\hline & & 80 & $98,3 \pm 0,04$ & $98,3 \pm 0,05$ \\
\hline \multirow{2}{*}{ Мочевина } & \multirow{2}{*}{ Ммоль/л } & 60 & $6,9 \pm 0,04$ & $7,9 \pm 0,06$ \\
\hline & & 80 & $6,2 \pm 0,05$ & $7,1 \pm 0,11$ \\
\hline \multirow{2}{*}{ Креатинин } & \multirow{2}{*}{ Ммоль/л } & 60 & $108,4 \pm 0,16$ & $107,2 \pm 0,13$ \\
\hline & & 80 & $106,2 \pm 0,24$ & $104,6 \pm 0,17$ \\
\hline \multirow{2}{*}{ Щелочн. фоосфатаза } & \multirow{2}{*}{$U / L$} & 60 & $8,7 \pm 0,03$ & $9,3 \pm 0,03$ \\
\hline & & 80 & $7,9 \pm 0,11$ & $9,1 \pm 0,09$ \\
\hline \multirow{2}{*}{ Глюкоза } & \multirow{2}{*}{ Ммоль/л } & 60 & $5,2 \pm 0,01$ & $5,1 \pm 0,03$ \\
\hline & & 80 & $5,14 \pm 0,08$ & $5,0 \pm 0,12$ \\
\hline
\end{tabular}

$P \leq 0,05$

По результатам биохимических исследований крови было установлено, что достоверных различий в показателях опытной и контрольной групп животных не установлено, все исследуемые биохимические показатели находились в пределах фризиологической нормы и изменялись незначительно. Это говорит об отсутствии 
негативного действия препарата «Абиопептид» на обмен веществ у животных. Результаты исследований представлены в таблице 2.

По результатам проведенных исследований было установлено, что применение препарата «Абиопептид» способствовало увеличению живой массы кроликов на 3,5\% по отношению к контролю и составило в контрольной группе 3230 г, а в контроле 3120г.

При проведении послеубойного ветеринарно-санитарного осмотра тушек и внутренних органов опытной и контрольной групп кроликов каких-либо видимых патологоанатомических изменений не обнаружено, степень обескровливания хорошая, тушки имеют характерный светло-розовый цвет, подкожная и внутренняя жировая ткань желтовато-белого цвета. Установлено, что на поверхности тушек кроликов опытной и контрольной группы после созревания своевременно образуется корочка подсыхания бледно-розового цвета, серозная оболочка грудной и брюшной полостей сохраняется определённое время влажной и блестящей. Мышцы на разрезе слегка влажные (не оставляют влажного пятна на фрильтровальной бумаге), бледно-розового цвета с красноватым оттенком, консистенция плотная, упругая, при надавливании пальцем образующаяся ямка быстро выравнивается, запах специфический, свойственный свежему мясу кроликов, бульон прозрачный, ароматный. При микроскопии мазков - отпечатков исследуемого мяса кроликов, в глубоких слоях мускулатуры не обнаружено кокков или палочек и не наблюдалось распада мышечной

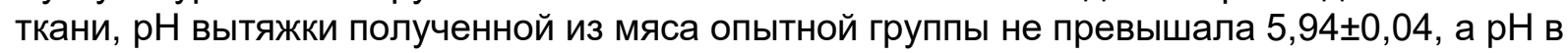

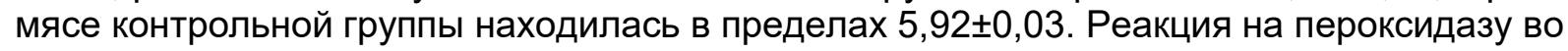
всех случаях была положительной, мясная вытяжка приобретала сине-зеленый цвет который в течение 1,5 мин переходил в буро-коричневый эти показатели соответствуют, показателям мяса полученного от здоровых животных.

Таблица 3 - Результаты дегустации бульона из мяса кроликов

\begin{tabular}{|c|c|c|c|}
\hline \multirow{2}{*}{ Показатели качества } & \multicolumn{3}{|c|}{ Группы кроликов } \\
\cline { 2 - 4 } & Ед. измерения & І группа (опыт) & II группа (контроль) \\
\hline \multirow{2}{*}{ Внешний вид / цвет } & Балл & 8 & $7,5 \pm 0,57$ \\
\cline { 2 - 4 } & $\%$ & 106,7 & 100 \\
\hline \multirow{2}{*}{ Аромат } & Балл & 8 & $7,25 \pm 0,5$ \\
\cline { 2 - 4 } & $\%$ & 110,3 & $7,5 \pm 0,57$ \\
\hline \multirow{2}{*}{ Вкус } & Балл & $7,75 \pm 0,5$ & 100 \\
\cline { 2 - 4 } & $\%$ & $7,5 \pm 0,57$ & 100 \\
\hline \multirow{2}{*}{ Наваристость } & Балл & 100 & $7,4 \pm 0,5$ \\
\hline \multirow{2}{*}{ Общая оценка } & $\%$ & 7,8 & 100 \\
\cline { 2 - 4 } & Балл & 105,4 & \\
\hline
\end{tabular}

По результатам проведенной комиссионной дегустационной оценки мясного бульона было установлено, что в опытной группе бульон был, прозрачным и имел более насыщенный аромат и вкус по отношению к контрольной группе.

Таблица 4 - Результаты дегустации вареного мяса кроликов

\begin{tabular}{|c|c|c|c|}
\hline \multirow{2}{*}{ Показатели качества } & \multicolumn{3}{|c|}{ Группы кроликов } \\
\cline { 2 - 4 } & Ед. измерения & I группа (опыт) & II группа (контроль) \\
\hline \multirow{2}{*}{ Запах / аромат } & Балл & $7,25 \pm 0,5$ & $6,25 \pm 0,5$ \\
\cline { 2 - 4 } & $\%$ & 116 & 100 \\
\hline \multirow{2}{*}{ Вкус } & Балл & $7,75 \pm 0,5$ & $7,25 \pm 1$ \\
\cline { 2 - 4 } & $\%$ & 106,9 & $7,25 \pm 0,5$ \\
\hline \multirow{2}{*}{ Нежность - жесткость } & Балл & $1,5 \pm 0,57$ & 100 \\
\hline \multirow{2}{*}{ Сочность } & Балл & $7,5 \pm 0,57$ & 100 \\
\cline { 2 - 4 } & $\%$ & 111,1 & $7,5 \pm 0,57$ \\
\hline \multirow{2}{*}{ Внешний вид } & Балл & $7,75 \pm 0,5$ & 100 \\
\hline \multirow{2}{*}{ Общая оценка } & $\%$ & 103,3 & $7,25 \pm 0,57$ \\
\cline { 2 - 4 } & Балл & $7,55 \pm 0,5$ & 100 \\
\hline
\end{tabular}


При реакции с сернокислой медью, фрильтрат оставался прозрачным, что свидетельствует об отрицательной пробе на продукты первичного распада белков и соответствует свежему мясу.

Была проведена закрытая дегустация бульона и мяса кроликов, оценку проводили по 8-ми бальной шкале. Бульон оценивали по показателям: внешний вид / цвет, аромат, вкус, наваристость (Табл. 3). Оценка вареного мяса: Запах / аромат, вкус, нежность - жесткость, сочность, внешний вид (Табл. 4). Для дегустации были предоставлены бульон и мясо кроликов опытной и контрольной групп.

Данные представленные в таблице 4, свидетельствуют об улучшении качественных показателей мяса кроликов экспериментальной группы. Общая оценка вареного мяса опытной группы на $4,1 \%$ преобладала над контролем. Так же дегустаторами было отмечено, что мясо кроликов I группы отличалось по вкусовым качествам, имело более нежную и сочную консистенцию, ярко выраженный аромат и вкус.

Таблица 5 - Результаты испытаний образцов мяса кроликов по показателям безопасности

\begin{tabular}{|c|c|c|c|c|}
\hline \multirow{2}{*}{$\begin{array}{c}\text { Наименование } \\
\text { определяемых } \\
\text { показателей }\end{array}$} & \multicolumn{2}{|c|}{ Фактический результат } & \multirow[b]{2}{*}{ Нормы по НД } & \multirow[b]{2}{*}{ НД на метод испытаний } \\
\hline & Опытная группа & $\begin{array}{l}\text { Контрольная } \\
\text { группа }\end{array}$ & & \\
\hline $\begin{array}{l}\text { Микробиологические } \\
\text { показатели: } \\
\text {-КМАФАНМ, КОЕІг }\end{array}$ & $6,0 \times 102$ & $5,8 \times 102$ & $1,0 \times 103$ & ГОСТ 10444.15-94 \\
\hline -БГКП (колиформы) в 0,1 г & Не обнаружено & Не обнаружено & Не допускается & ГОСТ 50474-93 \\
\hline $\begin{array}{c}\text {-патогенные м/о, в т.ч. } \\
\text { сальмонеллы в } 25 \text { г }\end{array}$ & Не обнаружено & Не обнаружено & Не допускается & ГОСТ 50480-93 \\
\hline -L. monocitogenesB 25r & Не обнаружено & Не обнаружено & Не допускается & ГОСТ P 51921-2002 \\
\hline $\begin{array}{c}\text { Антибиотики, мг/кг: } \\
\text {-левомицетин } \\
\text {-тетрациклиновая группа } \\
\text {-гризин } \\
\text {-бацитрацин } \\
\end{array}$ & $\begin{array}{l}\text { Не обнаружено } \\
\text { Не обнаружено } \\
\text { Не обнаружено } \\
\text { Не обнаружено } \\
\end{array}$ & $\begin{array}{l}\text { Не обнаружено } \\
\text { Не обнаружено } \\
\text { Не обнаружено } \\
\text { Не обнаружено } \\
\end{array}$ & $\begin{array}{l}\text { Не допускается } \\
\text { Не допускается } \\
\text { Не допускается } \\
\text { Не допускается } \\
\end{array}$ & MУ 3049-84M3 РФ \\
\hline $\begin{array}{c}\text { Токсичные элементы, } \\
\text { мг/кг: } \\
\text {-свинец } \\
\text {-кадмий } \\
\text {-мышьяк } \\
\text {-ртуть } \\
\end{array}$ & $\begin{array}{c}0,24 \\
0,01 \\
0,04 \\
\text { менее } 0,002\end{array}$ & $\begin{array}{c}0,27 \\
0,01 \\
0,04 \\
\text { менее } 0,002\end{array}$ & $\begin{array}{c}0,5 \\
0,05 \\
0,1 \\
0,03\end{array}$ & $\begin{array}{l}\text { ГОСТ 30178-96 } \\
\text { ГОСТ 30178-96 } \\
\text { ГОСТ 26930-86 } \\
\text { ГОСТ 26927-86 } \\
\end{array}$ \\
\hline $\begin{array}{c}\text { Пестициды, мг/кг: } \\
\text {-гХЦГ ( } \alpha-, \beta-\text { и ү-изомеры) } \\
\text {-ДДТ и его метаболиты }\end{array}$ & $\begin{array}{l}\text { менее } 0,001 \\
\text { менее } 0,005\end{array}$ & $\begin{array}{l}\text { менее } 0,001 \\
\text { менее 0,005 }\end{array}$ & $\begin{array}{l}0,1 \\
0,1\end{array}$ & $\begin{array}{c}\text { МУ по определению } \\
\text { остаточного содержания } \\
\text { макроколичеств пестицидов в } \\
\text { продуктах питания, кормах и } \\
\text { внешней среде. } \\
\end{array}$ \\
\hline $\begin{array}{c}\text { Радионуклиды, Бк/кг: } \\
\text {-цезий-137 }\end{array}$ & 10,2 & 10,4 & 200 & МУК 2.6.1.1194 \\
\hline
\end{tabular}

По результатам исследований представленных в таблице 5 безопасности мяса кроликов опытной и контрольной групп установлено, что мясо обеих групп соответствовало требованиям СанПиН 2.3.3.1078-01, а так же в исследуемых образцах не было обнаружено патогенной и условно-патогенной микрофлоры, а также содержание токсичных элементов, радионуклидов, пестицидов и антибиотиков находилось ниже допустимого уровня.

Заключение. Полученные результаты исследований свидетельствуют, что применение белкового гидролизата «Абиопептид» в кролиководстве способствует увеличению прироста живой массы на 3,5 \%, стимулирует эритропоэз животных. А также по результатам проведенных исследований ветеринарно-санитарной экспертизы мяса было отмечено, что применение препарата «Абиопептид» способствует улучшению вкусовых качеств мяса кроликов, поскольку оно обладает более нежной и сочной консистенцией и имеет ярко выраженный аромат и вкус. 


\section{БИБЛИОГРАФИЯ}

1. Антипов, А.А. Влияние энтеральных лекарственных препаратов железа на клиническое состояние крыс и морфологию кишечника в эксперименте по изучению острой токсичности / А.А. Антипов, А.А. Дельцов // Российский ветеринарный журнал. Сельскохозяйственные животные - 2014. - №1. - С. 16-19

2. Антипов, А.А. Сравнительное морфологическое исследование влияния на печень крыс энтеральных лекарственных препаратов с различной химической природой соединений железа / Антипов А.А., Дельцов А.А., Уразаев Д.Н. // Актуальные вопросы ветеринарной биологии-2014.-№3. - С. 59-64

3. Бачинская, В.М. Качество и безопасность козьего молока при применении «Абиопептида плюс» / В.М. Бачинская, 3.Н. Меньшикова, А.А. Дельцов // Проблемы ветеринарной санитарии, гигиены и экологии. - 2017. №2. - С. 23-27.

4. Бачинская, В.М. Качество мяса кроликов после применения препаратов седимин$\mathrm{Se}+$ и седимин-Fe+ / В.М. Бачинская, А.А. Дельцов // Ветеринария, зоотехния и биотехнология. - 2016. - №1. - С 63-67.

5. Бачинская, В.М. Определение безопасности мяса кроликов при использовании в рационе препарата «Био-железо с микроэлементами» / В.М. Бачинская, А.А. Дельцов // Ветеринария -2014.-№4. С. 54-55

6. Бачинская, В.М. Органолептические показатели и общая ценность мяса кроликов, получавших препарат «Био-железо с микроэлементами» / В.М. Бачинская, А.А. Дельцов // Ветеринария -2014.-№ 10 С. 52-54

7. Боровков, М.Ф. Ветеринарно-санитарная экспертиза с основами технологии и стандартизации продуктов животноводства: Учебник / М. Ф. Боровков, В.П. Фролов, С. А. Серко: под ред. проф. М. Ф. Боровкова. - СПб.: Издательство «Лань», 2007. C. 448.

8. Василевич, Ф.И. Безопасность мяса кроликов после обработки препаратом Феранимал-75М / Ф.И. Василевич, В.М. Бачинская, А.А. Дельцов // Ветеринария.2015.-№6.-C.57-59.

9. Василевич, Ф.И. Применение Гидропептон-плюс® в кролиководстве и изучение влияния его на показатели качества мяса / Ф.И. Василевич, В.М. Бачинская, А.А. Дельцов, Д.В. Гончар // Проблемы ветеринарной санитарии, гигиены и экологии. 2017. №2. - C. 20-22.

10. Громова А.В., Ноздрин Г.А., Леляк А.А., Показатели качества мяса кроликов при применении кормовой пробиотической добавки Велес 6.59 // Вестник НГАУ. - 2014. №3 (32). С. - 91-94.

11. Дельцов, А.А. Изучение острой токсичности Седимина-Fe+ и Седимина-Se+ / A.A. Дельцов, С.Н. Варнавский, Д.Н. Уразаев // Ветеринарная медицина. - 2010.-№34.-C.70-72.

12. Дельцов, А.А. Оксидативный статус крови телят при профилактике железодефицитной анемии в зоне радиации / А.А. Дельцов, Ц.Ц. Содбоев, С.Г. Чупраков, М.В. Щукин // Ветеринария. -2011.- №12.- С.13-16

13. Дельцов, А.А. Анализ сферы обращения лекарственных средств для ветеринарного применения / А.А. Дельцов, И.В. Косова // Ремедиум. Журнал о российском рынке лекарств и медицинской технике. - 2014.-№7-8.- С. 29-31

14. Дельцов, А.А. Морфологические изменения печени и почек поросят при железодефицитной анемии /А.А. Дельцов, А.А. Антипов // Ветеринария. -2013.№4. - С. 46-49

15. Егоров, И. Абиопептид в кормлении бройлеров / И. Егоров, Е. Андрианова, Л. Присяжная и др. // Птицеводство .- 2009 .-№3.- С.25-26.

16. Кочиш, И.И. Эффективность применения иммуностимулирующего препарата Баксин-вет в птицеводстве / И.И. Кочиш, М.С. Найденский, М. Э. Тотоева // Птица и птицепродукты. 2008. - № 5. -С. 29-31. 
17. Панин, А.Н. Товароведение, стандартизация и контроль качества ветеринарных препаратов /А.Н. Панин, Б.В. Уша, В.И. Родин, В.П. Яремчук - М.: КолосС, 2010. $343 \mathrm{c}$.

18. Петрова Ю.В. Ветеринарно-санитарная характеристика мяса цыплят-бройлеров кросса кобб-500 при применении в рационе Абиопептида и Ферропептида / Ю.В. Петрова, С.В. Редькин, И.И. Кочиш, Ю.Г. Исаев // Проблемы ветеринаной санитарии, гигиены и экологии. - 2016. №4. С. 16-21.

19. Плотников, В.Г. О тенденциях развития кролиководства в мире / В. Г. Плотников // Кролиководство и звероводство. - 2003. - №2. - С. 13.

20. Уразаев, Д.Н. Основные аспекты и пути совершенствования фрармацевтического синтеза железодекстрановых препаратов (научная статья) / Д.Н. Уразаев, А.А. Дельцов, А.Ю. Парасюк// Аграрная наука. - 2013. - № 8. - С. 24-25.

21. Уразаев, Д.Н. Биологическая роль железа. Применение железосодержащих препаратов в ветеринарной медицине (монография) / Д.Н. Уразаев, А.А. Дельцов, Л.П. Парасюк, Р.Д. Уразаева// М.: «Колос», 2010. -104 с. Тираж 1000 экз.

22. Adebowala E. A., Naxachima Y. Rumen degradation of some Leguminosae and Graminae roughages: effect of chemical pretreatment with or without cellulase preparation on dm matter and cell wall disappearance. // Anim. Feed. Sci and Technol.1992.-v. 38., №2-3, - p. 219-235

23. lenkins K. I., Hidroglou M. Effects of Clevated iodine in milk replacer on calt performance // i. Dairy Sci.-1990. -v.-73. № 3. - p. 804.

24. Roy C. Iron homeostasis: new tales from the crypt / C. Roy, C. Enns // Blood. 2000. - Vol. 96. - p. 4020.

25. Valce B.L. - Jn. Mineral Metabolism. Vol.2, part B. The elements. New-Jork-London. Acad.Press. - 1962. - p.443-482. 
DOI https://doi.org/10.18551/rjoas.2017-09.40

\title{
QUALITY LOSS ANALYSIS OF CAPTURE FISHERIES IN THE GULF OF TOMINI REGION, INDONESIA
}

\author{
Miru Sulaeman*, Suparman \\ Faculty of Economics, University of Tadulako, Indonesia \\ *E-mail: sulaimanmiru@yahoo.co.id
}

\begin{abstract}
The post-harvest fish loss in Indonesia is relatively high or about 30 percent. Even Food and Agriculture Organization (FAO) states that the post-harvest fish loss in Indonesia reaches up to 30 percent per year. This study aims to analyze quality loss of capture fisheries in the Gulf of Tomini region-Indonesia. This research used a survey method through direct observation to the fish caught by fishermen. In order to assess the fish loss, organoleptic testing based on the supply chain was done, the sample is four fish. Organoleptic characteristics observation was done through providing an assessment based on the parameter of SNI 012346-2006. The result shows that there is a quality loss of capture fisheries in the Gulf of Tomini region after the fish on the fishing boats (9.0) and landed at the fish port (7.8), fish terminal (6.8), and fish market (5.0). This is caused by the fish catch handling which is still traditional and simple so that fishermen get a loss benefit financially.
\end{abstract}

\section{KEY WORDS}

Post-harvest fish loss, organoleptic, supply chain, Gulf of Tomini.

The post-harvest fish loss in Indonesia is relatively high or about 30 percent. Even Food and Agriculture Organization (FAO) states that the post-harvest fish loss in Indonesia reaches up to 35 percent per year. Looking at the data of Indonesia's fisheries capture in 2014 by 5.8 million tons or about Rp 99 trillion (US $\$ 75$ billion ) so that the value of fish loss reached up to Rp 30 trillion (Expert Assistant to the Indonesian Minister of Marine Affairs and Fisheries, Achmad Poernomo, 2015). The fish loss is a desperate phenomenon which needs special and urgent treatment as able to affect national economic and food defense (The Head of Research and Development of Marine Affairs and Fisheries Ministry, 2015). Ward and Jeffries (2000) states that fish loss covers to physical loss, quality loss, and market loss.

Fish loss condition is also experienced by the community around the Gulf of Tomini since the handling is still traditional. In particular, the Gulf of Tomini has a big potential of capture fisheries, considering the Gulf of Tomini is the largest gulf around the equator area with $\pm 59.500 \mathrm{~km} 2$ length or \pm 6 million hectares and its covers to 4 autonomous regions in Central Sulawesi. The amount of the potential is inversely proportional with the percentage of the poor community in Central Sulawesi reaching up to 13.61 percent, which is the highest number in Sulawesi Island (Central Statistics Body or BPS, 2014). For that matter, an analysis of capture fisheries quality is important to do to know how much the rate of fish loss based on the supply chain, started from fishing until marketing.

\section{LITERATURE REVIEW}

Post-harvest Fish Loss is a total loss value after harvest as a result of physical damage and decline in quality started from the fish was caught until landed at the customer's hand. According to Ward and Jeffries (2000), fish loss explains time period when fish is separated from its living medium. Fish loss consists of several types, namely physical loss, quality loss, and market loss.

Physical loss is the number/weight of fish which is lost or wasted. Physical loss can be caused by several factors, among other, fish damage, attacked by insects, eaten by other animals, over supply and less buyer so fish wasted, stolen and wasted cause of caught (Ward and Jeffries, 2000). 
Quality loss is the discrepancy of the best and worst fish quality value. All the process will fall into decay. Ward and Jeffries (2000) states that the damaged fish will be sold at a low price since its quality has been degraded. Fish categorized damaged are not sold at the same price as fresh fish but will be sold at different market or for another purpose. This layer of fish and ice is not allowed to exceed $50 \mathrm{~cm}$. If it is over, the lowest fish will get a pressure so causes damage or loss weight. Murniyati and Sunarman, 2000).

Market force losses are the most difficult fish loss to be measured. Market losses can be influenced by supply/demand/season and much more. Quality does not fully influence fish price. During harvest moon, the first quality of fish will have a cheap price. Meanwhile, during a hard time, low-quality fish will be more expensive. Losses might happen during the catch, such as the fish fall down from the net or the handling causing a contusion, not using ice during the landed, attacked by insects during the processing and material delay (Ward and Jeffries, 2000).

The fish loss was explored based on the fish supply chain. The main focus of Supply Chain Management (SCM) is to reach the improvement of product quality and efficiency through Supply Chain (SC) of integration (Chin et al., 2006). Effective distribution management has been a key issue in the business known as SCM, which is the latest approach to integrate distribution and production, as one of the concepts of most well-known management in the logistic field (Kiefer and Novack, 1999; Ballou, 2007). SCM is the easiest way to enhance business value by limiting waste through low operational cost (Chasem 1998; Ballou, 2007). By the same token, SCM also can be understood as the management philosophy (Tan et al., 2002, Chan and Qi, 2003). For instance, Lummus and Vokurka (in Ellram and Cooper: 1993) defines SCM as the philosophy combining the management of total expenditures of distribution chain from the supplier to the customer. SCM has been illustrated in many terms; supplier integration; partnerships; main supply management, supplier alliance, supply chain balance (Tan et al., 2002); network path; supplier pipe path management; and value chain management (Croom et al., 2000; Romano and Vinelly, 2001); and as a demand chain (Kotzab and Otto, 2004 in Blackwell and Blackwell, 1999).

Supply Chain Management is an integrated approach philosophy to set total chain from distribution chain of the supplier to the main customer (Ellram dan Cooper, 1990). This management is to connect both upstream and downstream of their operations with suppliers and customers to deliver value to key customers for less cost as an overall supply chain (Martin, 1998; Weber, 2002). An effective supply chain strategy aims to create competitiveness range around the accuracy of goods and services assignments which are competitive, quality, affordable and involving right business partner (Hewitt, 1994; Hobbs et al., 1998; Easton, 2002). Supply Chain Management is a concept which is relatively new in the business world aiming to reach an efficiency at all operational function through the supply in the uncertainty external environment. In several kinds of literature, supply chain management involves a lot of disciplines which simplifies regulation coordination of material and information and the initial supplier to the final user.

\section{METHODS OF RESEARCH}

This research was done with survey method through direct observation to the fish caught by fishermen in the Gulf of Tomini region Indonesia which is the largest Gulf in the equator area with $\pm 59.500 \mathrm{~km} 2$ length or \pm 6 million hectares. The object of this study was fishermen who catch fish in the Gulf of Tomini region.

Fish loss assessment was tested using organoleptic based on the supply chain of 4 samples of fish. Organoleptic characteristic observation was done by giving an assessment based on the parameter of SNI 01-2346-2006 with the weight of 1-9, they were; eyes, gills, body slime surface, meat, smell, and texture ( National Standardization Agency, 2006). 


\section{RESULTS AND DISCUSSION}

Organoleptic assessment of fisheries capture is based on the condition of eyes, gills, body slime surface, meat, smell, and texture. The organoleptic assessment was conducted at 4 points namely, on the fishing boats, fish port, fish terminal, and fish market.

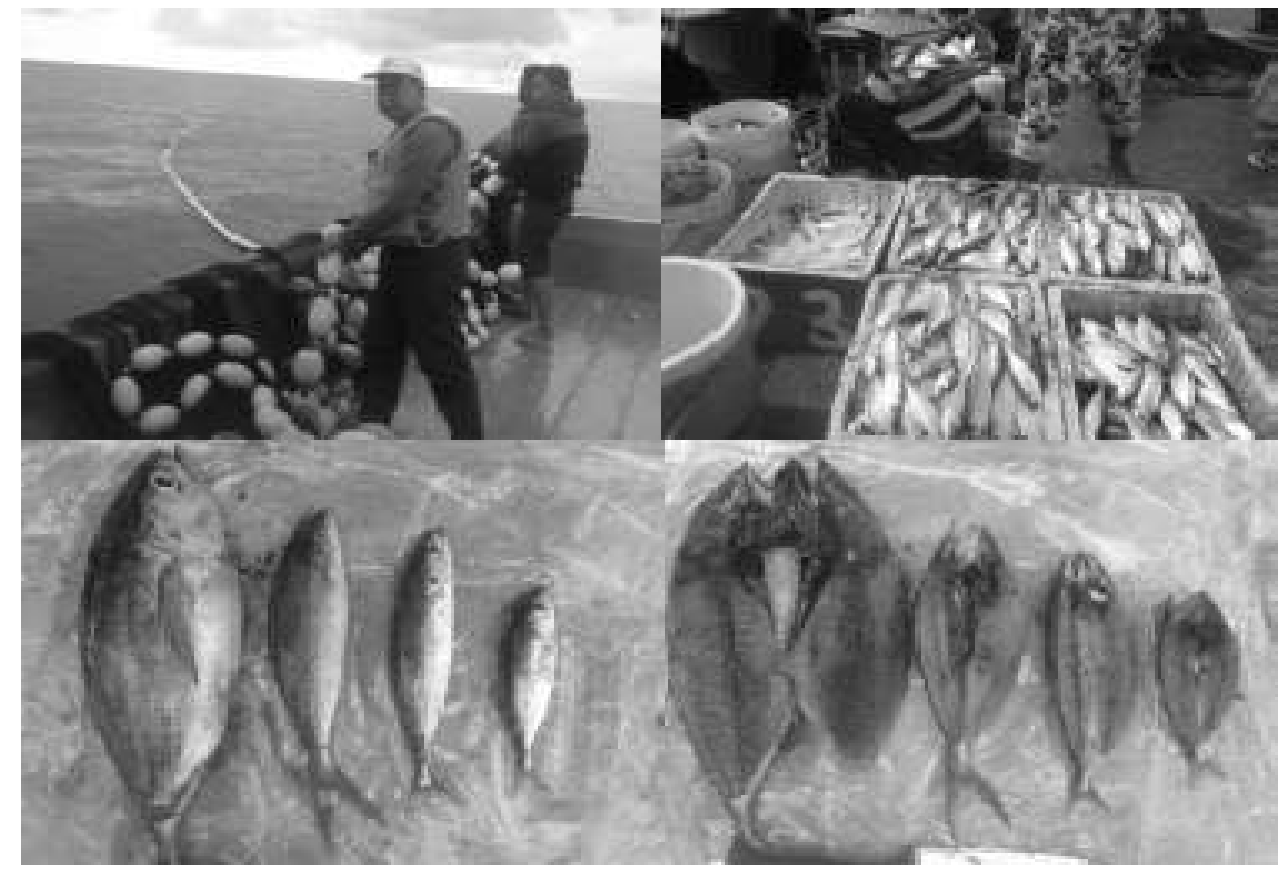

Figure 1 - Capturing Fish in the Gulf of Tomini, Indonesia Source: Survey data, 2017.

Figure 2 illustrates the result of quality loss assessment through organoleptic testing in the fish eyes. According to the data, it can be shown that the average value of the fish on the fishing boats is 9 . This indicates that the fish is truly fresh, having clear eyes, featured eye ball, and clear corneum. Later on, the average value of fish at the fish port, fish terminal and fish market is $8,7,5$ respectively. This condition shows that there is a quality loss from fishing boats to the fish market amounting to 4 or eye ball is slightly concave, grayish pupil, and less clear corneum.

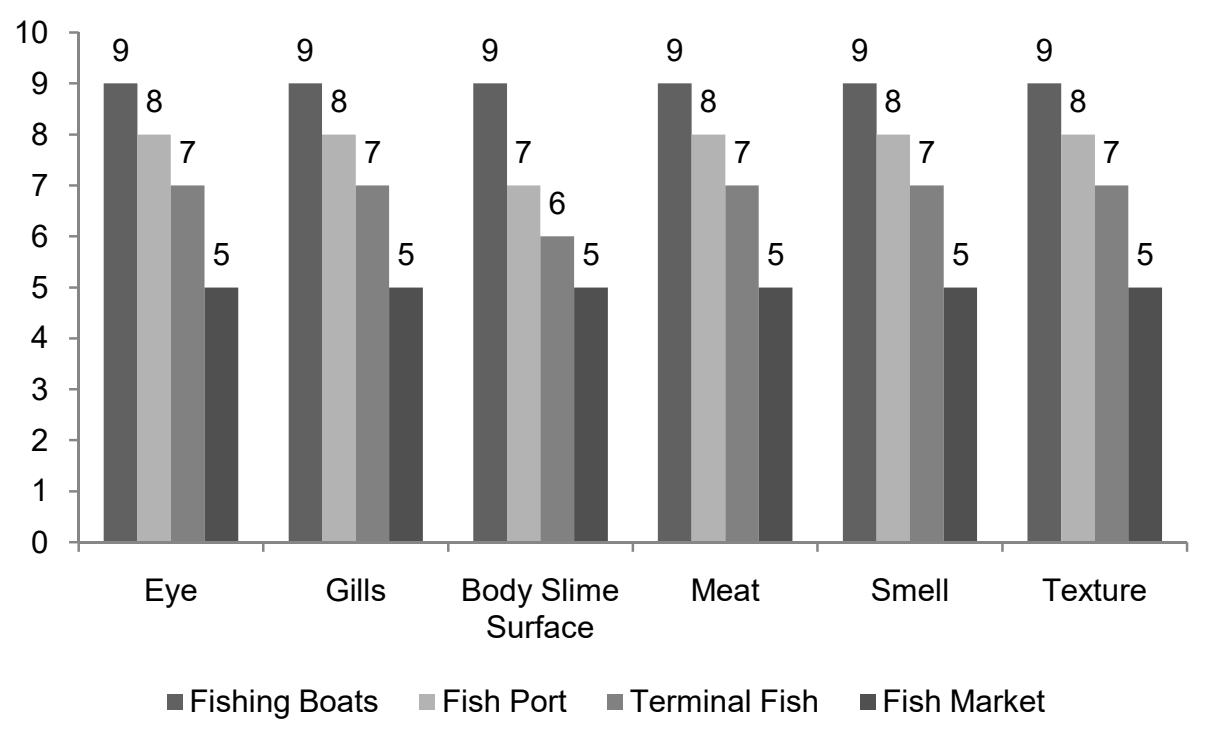

Figure 2 - The Average Value of Organoleptic Testing Result Source: Survey data, 2017. 
The average value of organoleptic testing provided to the gills on the fishing boats is 9 . This indicates that the fish are still fresh since having red brilliant gills without slime. Later on, the average value of fish at the fish port, fish terminal and fish market is 8, 7, 5 respectively. Such this condition shows that there is a quality loss from fishing boat to the fish market amounting to 4 or gills' color changed into brown red and produced slime.

The average value of organoleptic testing provided to the body slime surface on the fishing boats is 9 . This indicates that fish are still fresh since having clear slime layer, transparent, and glossy. The average value of fish when landed at fish port, fish terminal, and fish market is 7, 6, 5 respectively. This indicates that there is a quality loss amounting to 4 from fishing boat to fish market or the slime is dense, the color changes into white and muddy.

The average value of organoleptic assessment conducted to the meat on the fishing boats is 9 . This indicates that fish are truly fresh, having a clear fillet, specific in type, there is no redness along the backbone, the abdominal wall is still in one piece. Later on, the average value of fish at the fish port, fish terminal and fish market is $8,7,5$ respectively. This condition indicates that there is a quality loss from the fishing boat until fish market amounting to 4 or the fish fillet is going to be fade, redness along the backbone, and the abdominal wall is slightly soft.

Organoleptic assessment of fish smell results in an average value of fish on fishing boats by 9 . This indicates that the fish is truly fresh since having a very fresh smell and specific in type. Later on, the average value of fish at the fish port, fish terminal and fish market is $8,7,5$ respectively. This condition shows that there is a quality loss from the fishing boat until fish market amounting to 4 or been smelled ammonia and sour smell of the fish.

The average value of organoleptic assessment of fish texture on fishing boats is 9 . This indicates that the fish are still very fresh, they have a dense texture, elastic if pressed with fingers, hard to tear the meat from the backbone. Later on, the average value of fish at the fish port, fish terminal and fish market is $8,7,5$ respectively. This condition shows that there is a quality loss from fish on fishing boats to fish market by 4 or fish texture is tender, less elastic if pressured with fingers, easy to tear the meat from the backbone.

According to the organoleptic testing above, then the assessment of the weight of each specification (eyes, gills, body slime surface, meat, smell) is accumulated. The result of organoleptic assessment accumulation of fisheries capture in the Gulf of Tomini region is as follows.

Table 1 - Organoleptic Assessment Accumulation of Capture Fisheries

\begin{tabular}{|c|c|c|c|c|c|}
\hline \multirow{2}{*}{ Specification } & \multirow{2}{*}{ Weight } & \multicolumn{4}{|c|}{ Value (Score X Weight) } \\
\cline { 3 - 6 } & & Fishing Boats & Fish Port & Fish Terminal & Fish Market \\
\hline Eye & $16 \%$ & 1.44 & 1.28 & 1.12 & 0.8 \\
\hline Gills & $16 \%$ & 1.44 & 1.28 & 1.12 & 0.8 \\
\hline Body Slime Surface & $16 \%$ & 1.44 & 1.12 & 0.96 & 0.8 \\
\hline Meat & $16 \%$ & 1.44 & 1.28 & 1.12 & 0.8 \\
\hline Smell & $20 \%$ & 1.8 & 1.6 & 1.4 & 1.0 \\
\hline Texture & $16 \%$ & 1.44 & 1.28 & 1.12 & 0.8 \\
\hline Total & $100 \%$ & 9.0 & 7.8 & 6.8 & 5.0 \\
\hline
\end{tabular}

Source: Processed data, 2017

Table 1 above indicates that the fish quality on the fishing boats is truly fresh (9.0), but then the quality losses occurred when fish landed on the fish port (7.8), fish terminal (6.8), and fish market (5.0). This is caused by the fish catch handling which is still traditional and simple so that fishermen get a loss benefit financially.

\section{CONCLUSION}

Quality loss of fisheries capture in the Gulf of Tomini region happened after the fish was caught on the fishing boats (9.0) and landed at the fish port (7.8), fish terminal (6.8), and 
fish market (5.0). This is caused by the fish catch handling is still traditional and simple so that fisherman gets a loss benefit financially. For that reason, it needs an advanced analysis to overcome the fish loss, thus able to reduce financial loss got by fishermen in the Gulf of Tomini region.

\section{REFERENCES}

1. Achmad P. 2015. Susut Hasil Perikanan Tangkap Rp.30 Triliun, Kompas, http://cdn.assets.print.kompas.com/baca/2015/11/12/Susut-Hasil-Perikanan-Tangkap-Rp30-Triliun

2. Ballou, R.H. 2007. The Evolution and Future Of Logistics And Supply Chain Management, European Business Review, Vol. 19 No. 4, pp. 342-8.

3. Blackwell, R. and Blackwell, K. 1999. The Century of The Consumer: Converting Supply Chains Into Demand Chains, Supply Chain Management Review, Fall, pp. 22-3, available at: www. manufacturing.net/scm/index.asp?layout1 4articleWebzine\&articleid 14 CA154949

4. Badan Standarisasi Nasional, 2006. Petunjuk Pengujian Organoleptik dan atau sensori, Jakarta

5. BPS. 2014. Kemiskinan, Jumlah Penduduk dan Persentase Penduduk Miskin di Sulawesi Tengah, http://sulteng.bps.go.id/frontend/Subjek/view/id/23\#subjekViewTab3/accordiondaftar-subjek1

6. Chan, F.T.S. and Qi, H. 2003. An Innovative Performance Measurement Method For Supply Chain Management, Supply Chain Management: An International Journal, Vol. 8 No. 3, pp. 209-23.

7. Chase, C.W. Jr. 1998. The Role Of The Demand Planner In Supply Chain Management, Journal of Business Forecasting, Vol. 17 No. 3, pp. 2-24.

8. Chin, K.S., Yeung, I.K. and Pun, K.F. 2006. Development Of An Assessment System For Supplier Quality Managemen, International Journal of Quality \& Reliability Management, Vol. 23 No. 7, pp. 743-65.

9. Croom, S., Romano, P. and Giannakis, M. 2000. Supply Chain Management: An Analytical Framework for Critical Literature Review, European Journal of Purchasing \& Supply Management, Vol. 2000 No. 6, pp. 67-83.

10. Easton, R. 2002. Seizing The Supply Chain Opportunity In Asia, Ascet, Vol. 4.(The) Economist (1992), April 18, p. 67.

11. Ellram, L.M. and Cooper, M.C. 1990. Supply Chain Management Partnerships And The Shipper-Third Party Relationship, International Journal of Logistics Management, Vol. 1 No. 2, pp. 1-10.

12. Ellram, L.M. and Cooper, M.C. 1993. The Relationship between Supply Chain Management And Keiretsu, The International Journal of Logistics Management, Vol. 4 No. 1, pp. 1-12.

13. Hewitt, F. 1994. Supply Chain Redesign, The International Journal of Logistics Management, Vol. 5 No. 2, pp. 1-9.

14. Hobbs, J.E., Kerr, W.A. and Klein, K.K. 1998. Creating International Competitiveness Through Supply Chain Management: Danish Pork, Supply Chain Management: An International Journal, Vol. 3 No. 2, pp. 68-78.

15. Kepala Badan Penelitian dan Pengembangan Kementerian Kelautan dan Perikanan. 2015. KKP-FAO Kaji Fenomena Penyusutan Pascapanen Perikanan, http://villagerspost.com/todays-feature/kkp-fao-kaji-fenomena-penyusutan-pasca-panenperikanan/

16. Kiefer, A.W. and Novack, R.A. 1999. An Empirical Analysis of Warehouse Measurement Systems in The Context Of Supply Chain Implementation, Transportation Journal, Vol. 38 No. 3, pp. 18-27.

17. Kotzab, H. and Otto, A. 2004. General Process-Oriented Management Principles To Manage Supply Chains: Theoretical Identification 
18. Lummus, R. and Vokurka, R.J. 1999. Defining Supply Chain Management: A Historical Perspective And Practical Guidelines, Industrial Management \& Data Systems, Vol. 99 No. 1, pp. 11-17.

19. Martin, C. 1998 Logistics and Supply Chain Management: Strategies for Reducing Cost and Improving Service, Pitman Publishing, London.

20. Murniyati, S.A., Sunarman. 2000. Pendinginan, Pembekuan dan Pengawetan Ikan . Kanisius, Yogyakarta

21. Romano, P. and Vinelli, A. 2001. Quality Management In A Supply Chain Management Perspective, International Journal of Operations \& Production Management, Vol. 21 No. 4, pp. 446-60.

22. Tan, K.C., Lyman, S.B. and Wisner, J.D. 2002. Supply Chain Management: A Strategic Perspective, International Journal of Operations \& Production Management, Vol. 22 Nos 5/6, pp. 614-31.

23. Ward, A.R. and Jeffries, D.J. 2000. A Manual For Assessing Post Harvest Fisheries Losses. Natural Resources Institute, Chatham, UK. vii + 140 pp. English

24. Weber, M.M. 2002. Measuring Supply Chain Agility In The Virtual Organisation, International Journal of Physical Distribution \& Logistics Management, Vol. 32 No. 7, pp. 577-90.

(c) 2017 by the authors. Licensee RJOAS, Orel, Russia. This article is an open access article distributed under the terms and conditions of the Creative Commons Attribution (CC BY) license: http://creativecommons.org/licenses/by/4.0/ 
DOI https://doi.org/10.18551/rjoas.2017-09.41

\title{
DISTRIBUTION, DENSITY AND IDENTIFICATION OF GIANT CLAMS IN COASTAL AREA OF NEGERI MORELLA, THE DISTRICT OF LEIHITU, CENTRAL MALUKU REGENCY, INDONESIA
}

\author{
Widyasari Ferliana, Arafat Gulam, Robiandi, Setiadi Didik, Rahmat Syahid, \\ Latulanit M. Nasrul, Fahlevi Arif Reza, Arisandy Kiki Riski \\ The Division of Coastal and Marine Resources Management, Sorong, Indonesia
}

\author{
Sayuti Mohammad* \\ Polytechnic of Marine and Fisheries, Sorong, Indonesia
}

*E-mail: mohsayut@gmail.com

\begin{abstract}
Giant clams are protected biota both nationally and internationally. The coastal area of Negeri Morella, the District of Leihitu, Central Maluku Regency, Maluku is one of the areas as the habitat of these giant clams. This study aims to identify the types of clams, conduct ecological studies covering density, diversity index of Tridacninae shells in Central Maluku, especially in Negeri Morella. Implementation of the clam population survey is conducted by using UVC (Underwater Visual Census). The results show that ofthe ten (10) samples in the observation station, 91 individuals of giant clams under the type of Tridacna squamosa and Tridacna crocea. The giant clams found in the coastal waters of Negeri Morella has a small size; in the depth of 1-5 m, 87 giant clams were found in various sizes with a length of 2-30 $\mathrm{cm}$, and in the depth of $5-10 \mathrm{~m}$, only four (4) giant clams with a length of $11-30 \mathrm{~cm}$. The population density obtained was 45.5 individuals/ha, the value of Diversity Index $\left(\mathrm{H}^{\prime}\right)$ was 0.69 , the Uniformity Index (E) ranged from 0-1, and the Dominance Index (D) of 0.505.
\end{abstract}

\section{KEY WORDS}

Density, Diversity Index, Giant Clams, Morella, Tridacna, UVC

Giant clams (Bivalvia, Cardiidae) are marine mollusks that live in coral reefs in the Indo-Pacific region. They come in two genera (Tridacna and Hippopus) with nine species, seven species of which are found in Indonesia. Geographically, these shells have limited distribution in the tropical region of Indo-Pacific, from the Red Sea to the Pacific Islands of Tuamotu (Yusuf et al., 2009). Tridacninae shells live in shallow waters, at a depth of 1 to 20 m (Hernawan, 2011). Tridacninae shells ecologically are biota which act as a natural bio filter, as they are able to filter ammonia and nitrate dissolved in seawater for the need of zooxanthellae of nitrogen for growth process (Braley, 1985). Tridacninae is known to have an important economic value because apart from being a source of food, the shells can be used as decoration materials and jewels. In addition, the shells are so much sought for jewelry and for the industry of terrazzo tiles, leading to the decreasing population of the species (Nontji, 2002).

Giant clams are protected biota both nationally and internationally. Internationally all types of clams included in the II CITES Appendix since 1985. Nationally, the giant clams are protected under Government Regulation Number 7 of 1999 that includes seven types of clams living in the waters of Indonesia. Their status are protected animals, where all forms of exploitative utilization (poaching and trade) are not permitted, excluding the results of cultivation, and after being given the status for game hunting (in accordance with Government Regulation Number 8 of 1999).

One of the coastal areas in Indonesia as the home of giant clams is the coastal area of Negeri Morella, the District of Leihitu, Central Maluku Regency, Maluku. The majority of the people here are farmers and fishermen. Along the coastal area are the home of giant clams, and the place of recreation and fish capture. 


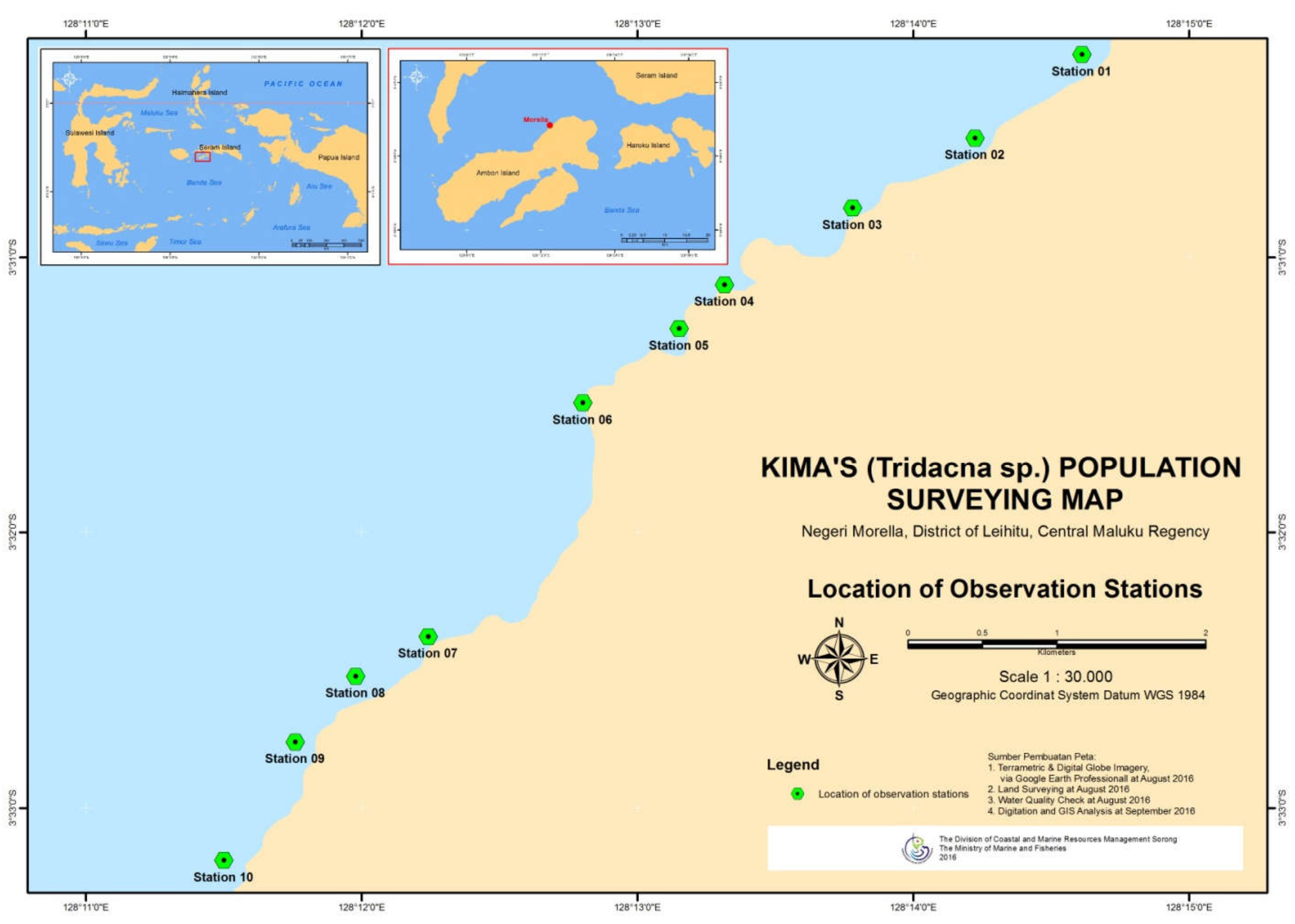

Figure 1 - Survey Sites (Observation Stations) 
The giant clams here are used as a food source traditionally. The local people call the giant clams as "biagaru". The use of the giant clams as a food source and jewelry has been done for generations. This also has caused the population of the giant clams to decrease.

Scientific information for types of Tridacninae in the region of Central Maluku, especially in the waters of Negeri Morella is not available; therefore the research aims to identify the types of clams through an ecological study which includes examination on the density and diversity index of Tridacninae.

\section{MATERIALS AND METHODS}

Population Survey Method. Clam population survey is conducted using UVC (Underwater Visual Census). There are two teams, each of two (2) people plus one (1) boat driver. These monitoring resources at least have an A1 diving license or equivalent and have good understanding of UVC method and types of clams. The boat drivers are fishermen of good knowledge about the locations potential for clams in the territorial waters of Negeri Morella and have the ability to use GPS (Global Positioning System). To estimate the population of giant clams, sampling is ten (10) observation stations representing the entire territory of the coastal area of Negeri Morella with a coastline of $\pm 10.7 \mathrm{~km}$. Each station represents a one-kilometer coastline, with a hundred-meter transect at two depths. If the reef is steep in the stations, two repetitions with the same depth are done.

The procedure for giant clam survey is as follows:

1. Determine the location and number of monitoring stations starting from the shoreline as the 0 point. Mount the peg as a marker and record the coordinates;

2. Expand the rope starting from the point $0,100 \mathrm{~m}$ parallel to the shoreline to a depth of 3-15 m;

3. Write down all the individuals and types of clams found under the transect line and as far as $5 \mathrm{~m}$ of the observation area for each observer so that the total range of both observers is $10 \mathrm{~m}$. The total area of observation is $10 \mathrm{~m} \times 100 \mathrm{~m}$ or $1,000 \mathrm{~m}^{2}$;

4. Record all types of clam found in the observation area. Measure the shell width using stainless ruler. All data is recorded into the observation sheet (slate or waterproof paper) for further processing;

5. Record other information such as coastal vegetation, the slope of the reef, conditions (sand and rubble), and if possible record the former bomb and coral bleaching due to rising sea surface temperatures or predation by Achantasterplancii.

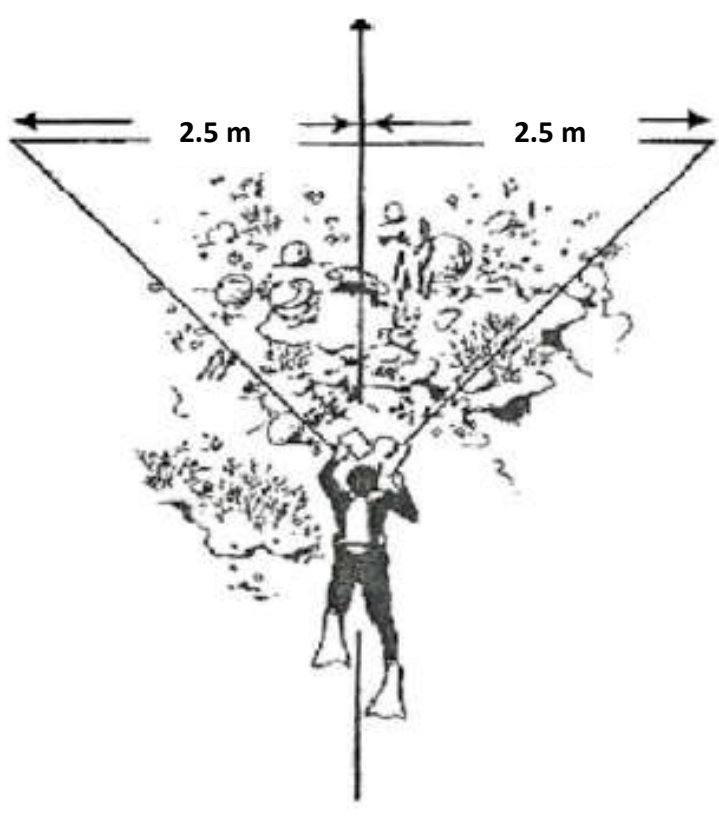

(a)

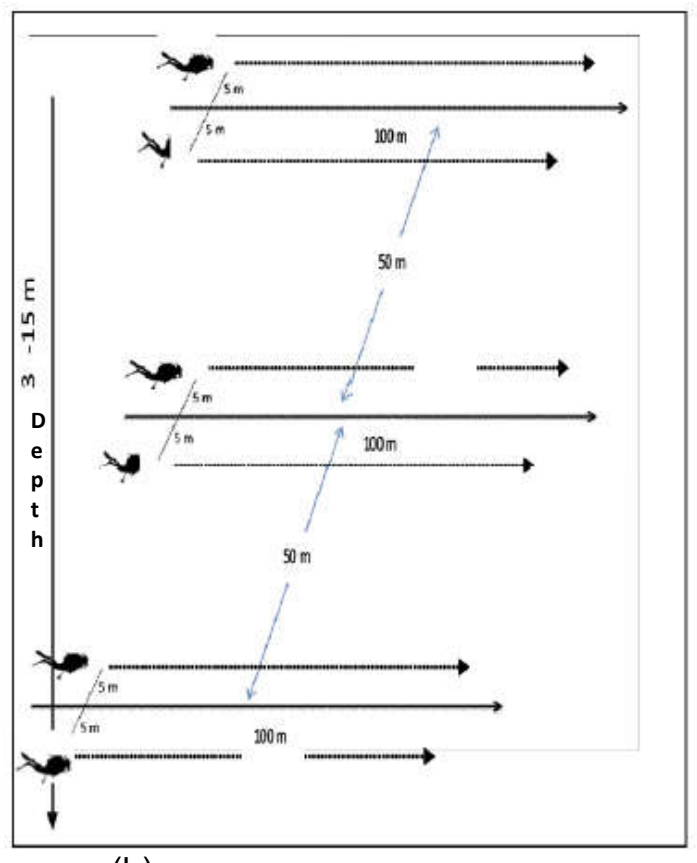

(b)

Figure 1 - (a) Range of observation of an observer; (b) UVC Method 
Calculating the Density and Diversity Index of the Giant Clams:

Density. Density refers to the number of individuals per unit area of each station.

$$
\mathrm{X}=\frac{\Sigma \mathrm{x}}{\mathrm{n}}
$$

Where: $X=$ the average number of clams per unit area; $\Sigma x=$ number of clams in unit number $\mathrm{I} ; \mathrm{N}=$ the width of unit number $\mathrm{i}$.

Diversity Index. Diversity index refers to a structure of organism communities to ease analysis on information about the type and number of species. The more types of biota in waters, the higher diversity of the waters is. Diversity index calculation is done using the Shannon-Wiener formula (Magurran, 2004) as follows:

$$
\mathrm{H}^{\prime}=-\left(\sum \frac{n t}{N} \ln \frac{n t}{N}\right)
$$

Where: $H^{\prime}=$ diversity index; $n_{1}=$ number of each individual of each type; $n=$ total number of all individuals of all types.

Based on the formula of diversity index, the diversity is categorized as follows:

$$
\begin{gathered}
H^{\prime}<1=\text { low diversity } \\
1<H^{\prime}<3=\text { medium diversity } \\
H^{\prime}>3=\text { high diversity }
\end{gathered}
$$

Evenness Index. Evenness expresses how evenly the individuals in a community are distributed among the different species (Odum, 1971). Index is obtained by comparing the diversity index to the maximum value as follows:

$$
\mathrm{E}=\frac{\mathrm{H}^{\prime}}{\mathrm{H}^{\prime} \text { maks }}
$$

Where: $E=$ evenness index; H'max $=\ln \mathrm{s} ; \mathrm{S}=$ the number of biota.

The value ranges between 0 to 1 . The smaller the value of $E$, the less even the biota is. This shows that the distribution of each type is different and there is a possibility that a type of biota dominates the population. In contrast, the bigger the value of $\mathrm{E}$, then the higher the evenness of the biota is. This shows that the number of individual of each type is the same, in which a type of biota does not dominate the population.

Dominance Index. Using the dominance index by Simpson (Krebs, 1989) as follows:

$$
D=\sum_{i=1}^{\infty}\left[\frac{N i}{N}\right]^{2}
$$

Where: $\mathrm{D}=$ Simpson dominance index; $\mathrm{Ni}=$ the number of individual number $\mathrm{I} ; \mathrm{N}=$ the total number of individuals; $S=$ the type number.

The domination index is classified as follows:

$$
\begin{gathered}
0<D \leq 0.05 \text { low dominance } \\
0.5<D \leq 0.75 \text { medium dominance } \\
0.75<D \leq 1.00 \text { high dominance }
\end{gathered}
$$

\section{RESULTS AND DISCUSSION}

Population of Giant Clams. To know the population of giant clams in the waters of Negeri Morella, sampling has been done in ten (10) observation stations representing all the waters in Morella with a coastline of \pm 10.7 kilometers with a coordinate of observation station 1 at $128^{0} 14^{\prime} 38.40^{\prime \prime} \mathrm{EL}, 3^{0} 30^{\prime} 15.80^{\prime \prime} \mathrm{SL}$; station 2 at $128^{\circ} 14^{\prime} 13.20^{\prime \prime} \mathrm{EL}, 3^{0} 30^{\prime} 34.02^{\prime \prime} \mathrm{SL}$; station 
3 at $128^{0} 13^{\prime} 48.00^{\prime \prime} \mathrm{EL}, 3^{0} 30^{\prime} 49.25^{\prime \prime} \mathrm{SL}$; station 4 at $128^{0} 13^{\prime} 19.20^{\prime \prime} \mathrm{EL}, 3^{0} 31^{\prime} 5.99^{\prime \prime} \mathrm{SL}$; station 5 at $128^{0} 13^{\prime} 8.40^{\prime \prime} \mathrm{EL}, 3^{0} 31^{\prime} 15.60^{\prime \prime} \mathrm{SL}$; station 6 at $128^{0} 12^{\prime} 46.80^{\prime \prime} \mathrm{EL}, 3^{0} 31^{\prime} 31.76^{\prime \prime} \mathrm{SL}$; station 7 at $128^{0} 12^{\prime} 14.40^{\prime \prime} \mathrm{EL}, 3^{0} 32^{\prime} 22.74^{\prime \prime} \mathrm{SL}$; station 8 at $128^{\circ} 12^{\prime} 00.00^{\prime \prime} \mathrm{EL}, 3^{0} 32^{\prime} 31.38^{\prime \prime} \mathrm{SL}$; station 9 at $128^{\circ} 11^{\prime} 45.60^{\prime \prime} \mathrm{EL}, 3^{0} 32^{\prime} 45.67^{\prime \prime} \mathrm{SL}$; and station 10 at $128^{0} 11^{\prime} 31.20^{\prime \prime}$ ELdan $3^{0} 33^{\prime} 11.45^{\prime \prime} \mathrm{SL}$. The population of giant clams is presented in Table 1.

Table 1 - Number and Type of Giant Clam Population in Morella

\begin{tabular}{|c|c|c|c|c|c|c|c|c|c|c|c|}
\hline \multirow{2}{*}{ Type of Giant Clam } & \multicolumn{10}{|c|}{ The Number of Giant Clam Population at Station } & \multirow{2}{*}{ Total } \\
\hline & $\mathrm{I}$ & II & III & IV & $\mathrm{V}$ & $\mathrm{VI}$ & VII & VIII & IX & $\mathrm{X}$ & \\
\hline Tridacna squamosa & 8 & 8 & 1 & 1 & 2 & 10 & 8 & 8 & 0 & 4 & 50 \\
\hline Tridacna crocea & 0 & 1 & 0 & 0 & $\overline{1}$ & 12 & 15 & 6 & 5 & 1 & 41 \\
\hline Amount & 8 & 9 & 1 & 1 & 3 & 22 & 23 & 14 & 5 & 5 & 91 \\
\hline
\end{tabular}

During observation, 91 giant clams were found. The highest number was in station 7 , as many as 23 giant clams, followed by station 6 , as many as 22 clams, and the lowest was in station 3 and 4 , as many as 1 clam.

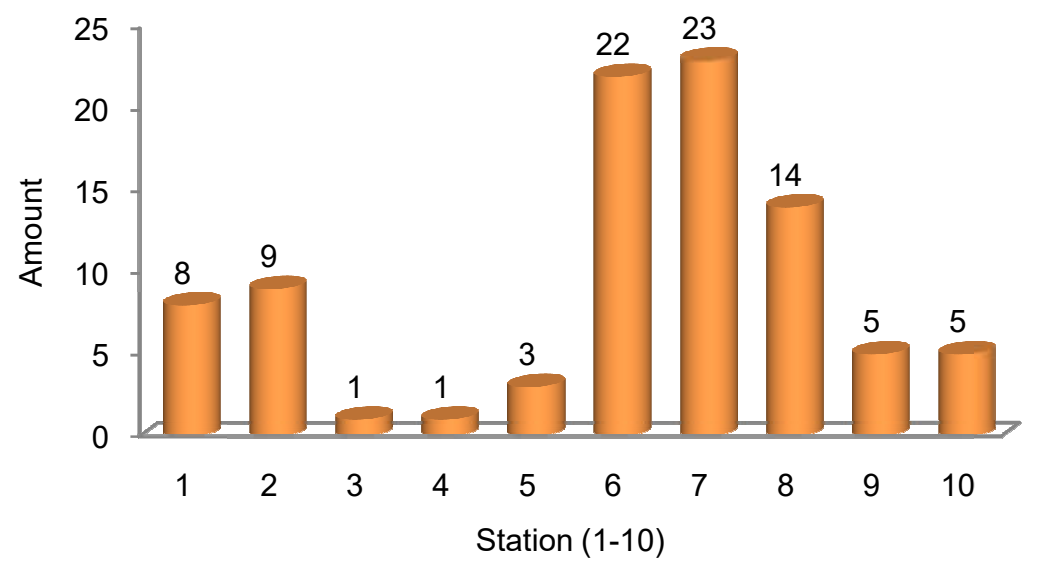

Figure 3 - The number of giant clams per station

During the observation using visual census, two types of clams i.e. Tridacna squamosa, as many as 50 individuals, and Tridacna crocea, as many as 41 individuals, were found. The percentage of the two types of giant clams can be seen in the image below:

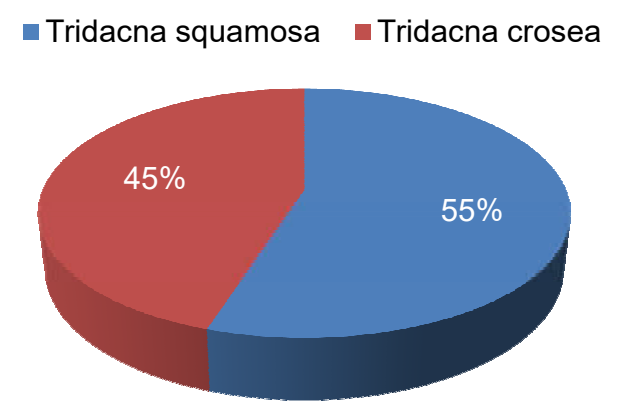

Figure 4 - Percentage of Giant Clams

The giant clams Tridacna squamosa $L$ have a symmetrical shell and wavy shell opening. The upper valvehas flattish folds that interlock at the margin with similar folds on the lower valve so that they can clamp together and the shell can close tightly. The mantle usually brownish color, and may be various mixtures of black and white, as well as orange, yellow, or often with brilliant blue or green lines depending on the symbiotic algae. Tridacna squamosa found during the survey have a size range of $4-30 \mathrm{~cm}$, and this is consistent with 
the statement that the clamshell is able to grow to the size of $40 \mathrm{~cm}$ length. The people in Morella utilize these clams as a food source and they take the clams during the low tide (Wells, 1997).

The giant clams Tridacna crocea begin to cling on the substrate surface in the form of hard rock while still a juvenile form with a size of 4-20 mm (Kawaguti, 1983; Suzuki, 1998). A piece of mantle tissue that comes out of the openings in the byssus at the bottom shell serves as a permanent adhesive. The mantle tissue at the base of the shell also produces a weak acid that can soften or dissolve limestone $(\mathrm{CaCO} 3)$ that over time hard coral surface begins to form a hole. After a hole is formed, the giant clams continue to issue a weak acid to soften the lime around the shell (Hedley, 1921). The mechanical movement to open and close the shell will erode the already fragile coral part that the hole grows even larger (Yonge, 1936; Hamner and Jones, 1976). The size of Tridacna crocea found during the survey was in a range of $2-10 \mathrm{~cm}$. Tridacna crocea has the slowest growth rate in comparison with other types of clams. Shell size increases only 1-2 mm per month.

Population based of the Number and Size of Clamps. The giant clams found during observations consisted of a variety of lengths, the largest size with a length of $30 \mathrm{~cm}$, and the smallest size with a length of $2 \mathrm{~cm}$. The average size mostly found was with the length below or equal to $10 \mathrm{~cm}$, as many as 70 individuals. Clam population based on the number and size of clams is presented in the following figure.

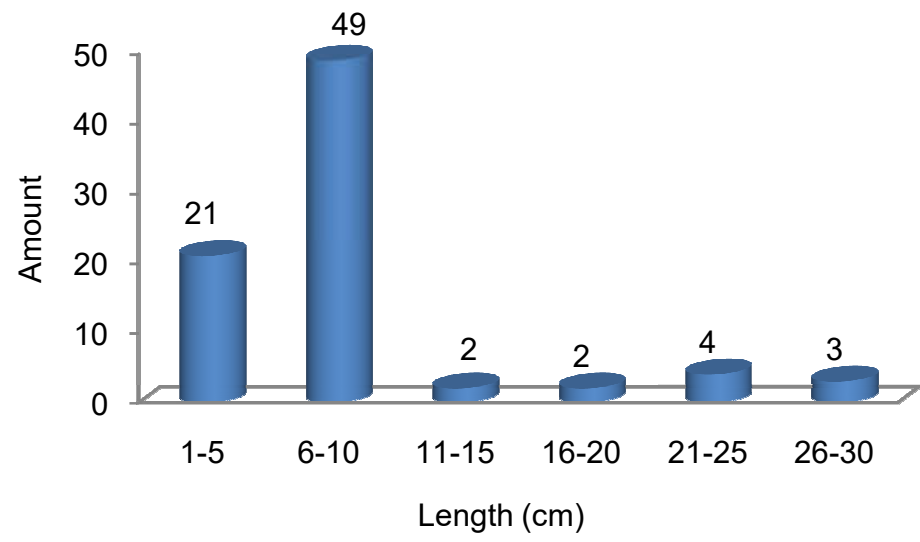

Figure 5 - The Length of the Giant Clams Found

The giant clams found in the territorial waters of Negeri Morella have a small size. In the depth of $1-5 \mathrm{~m}$, clams were found in various sizes with a length of $2-30 \mathrm{~cm}$ by 87 individuals, and in the depth of 5-10 m, clams found were only four (4) with a length of 11-30 $\mathrm{cm}$.

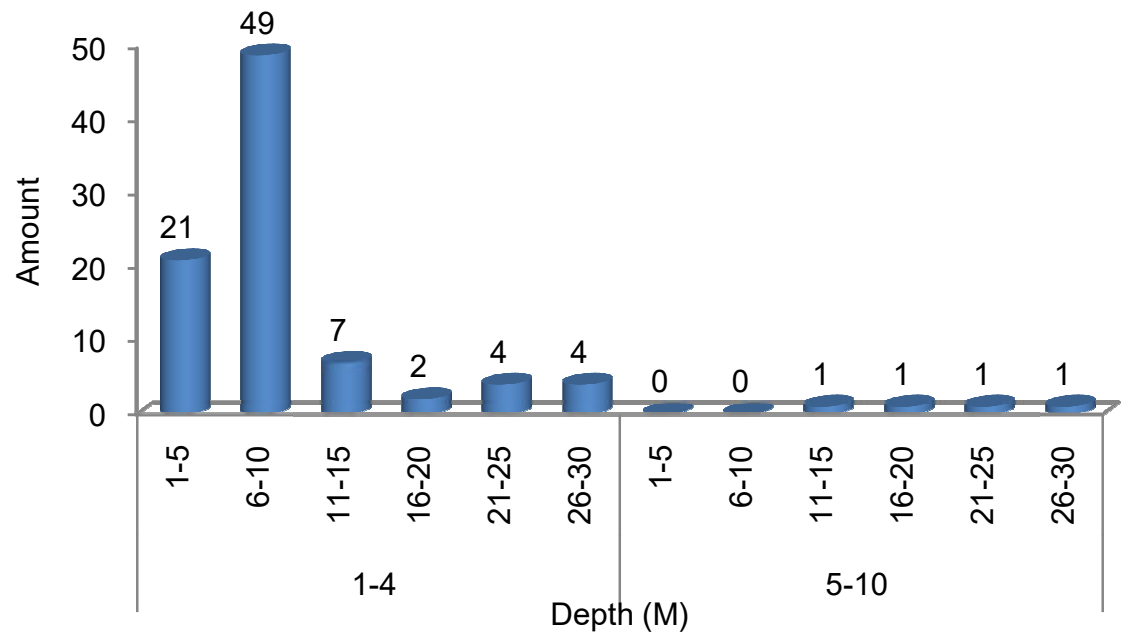

Figure 6 - Distribution of the Giant Clams' Length based on Depth 
Distribution of the Giant Clams' Length based on Depth. The small-sized clams were mostly found in shallow waters, while the large-sized clams were found in a depth of more than $5 \mathrm{~m}$.

Distribution of the Giant Clams' Number based on Depth. In the depth of 1-4 $\mathrm{m}$, there were 89 clams found in 10 stations with a percentage of $97.8 \%$, while in the depth of $5-10 \mathrm{~m}$, there were four (4) clams found in 3 stations with a percentage of $4.39 \%$.

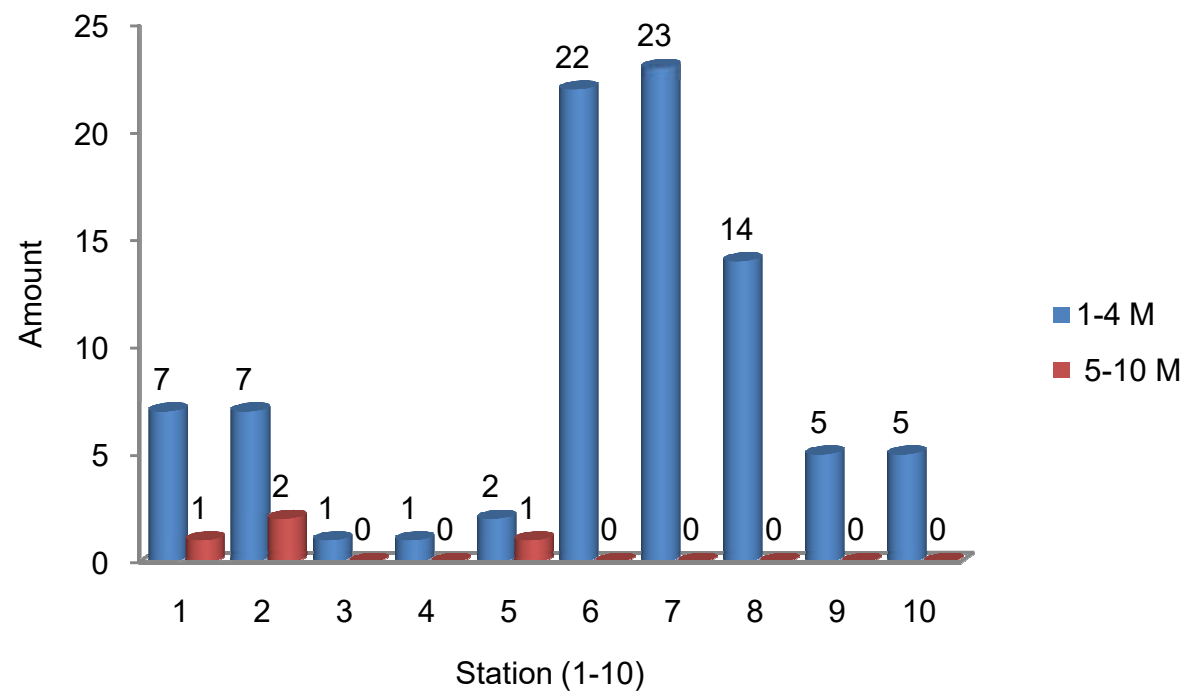

Figure 7 - The Number of the Giant Clams Found based on Depth

Density, Diversity Index, Evenness, and Dominance. The results of calculation on the density of clams in Negeri Morella produces a value of 0.0045 individuals $/ \mathrm{m}^{2}$ or 45.5 individuals/ha. The highest individual density of Tridacna squamosa $L$ is 0.0025 individuals $/ \mathrm{m}^{2}$ or 25 individuals/ha, while the density of Tridacna crocea is 0.002 Individual $/ \mathrm{m}^{2}$ or 20.5 individuals/ha.

Table 2 - Density, Diversity Index, Evenness, and Dominance

\begin{tabular}{cccccccc}
\hline No & Type & Number & $\mathrm{X}(\mathrm{ha})$ & $\mathrm{X}\left(\mathrm{m}^{2}\right)$ & $\mathrm{H}^{\prime}$ & $\mathrm{E}$ & $\mathrm{D}$ \\
\hline 1 & Tridacna squamosa & 50 & & & 0.33 & & 0.302 \\
2 & Tridacna crocea & 41 & & & 0.36 & 0.203 \\
\hline & & 45.5 & 0.0045 & 0.69 & 0.99 & 0.505 \\
\hline
\end{tabular}

Note: $X=$ Density; $H^{\prime}=$ Diversity Index; $E=$ Evennes Index; $D=$ Dominance Index.

Based on the above table, the diversity index produced is 0.69 ; this indicates a low level of diversity, as according to Shannon Wiener (Magurran, 2004) the diversity index in which $\mathrm{H}^{\prime}<1$ indicates a low level of diversity. This is understood as there were only two types of clams found in Negeri Morella, i.e. Tridacna squamosa L and Tridacna crocea. The biodiversity of waters is highly dependent on the number of species in the community, meaning that the more species found, and then the higher the diversity is (Wilhm and Doris, 1986). The low diversity index can be influenced by biotic and abiotic factors; biotic factors will influence directly or indirectly the presence, density, and distribution of species (McNaughton and Wolf, 1973). The abiotic factors affecting the distribution and diversity index of marine organisms, especially Tridacna, are temperature, substrate, and dissolved oxygen (Nybakken, 2001).

Based on observations, the evenness index $(\mathrm{E})$ obtained is 0.99 . Evenness expresses how evenly the individuals in a community are distributed among the different species (Odum, 1971). E value obtained belongs to the high category meaning that the population is highly even, or the number of individuals of each kind is the same. 
The dominance index (Krebs, 1989) shows a value of five (5), indicating a low dominance, i.e. the population is not dominated by other organisms.

\section{CONCLUSION}

There are two (2) types of giant clams found in Negeri Morella, i.e. Tridacna squamosa and Tridacna crocea, with population density of 45.5 individuals $/ \mathrm{Ha}$, diversity index $\left(\mathrm{H}^{\prime}\right)$ of 0.69 , evenness index (E) between 0-1, and dominance index (D) of 0.505.

\section{REFERENCES}

1. Braley, R.D. 1985. Serotonin-induced spawning in giant clams (Bivalvia: Tridacnidae). Aquaculture, 47 (4): 321-325.

2. Hamner, W.M. and M.S. Jones. 1976. Distribution, burrowing, and growth rates of the clam Tridacna crocea on interior reef flats. Oecologia, 24 (3): 207-227.

3. Hedley, C. 1921. A revision of the Australian Tridacna. Rec. Aust. Mus., 13, pp.163-172.

4. Hernawan, U.E. 2011. Taxonomy of Indonesian Giant Clams (Cardiidae, Tridacninae). Bonorowo Wetlands.

5. Kawaguti, S. 1983. Metamorphosis of the boring clam, Tridacna crocea. Proceedings of the Japan Academy, Series B, 59 (4): 67-70.

6. Krebs, C.J. 1989. Ecology Methodology. Harper and Row Publisher. New Yok: 224 pp

7. Magurran, A.E. 2004. Measuring biological diversity. Malden, Blackwell Pub. VIII+256 pp.

8. McNaughton, S.J. and Wolf, L.L. 1973. General Ecology. Holt, Rinehart \& Winston: New York.

9. Nontji, A. 2002. Laut Nusantara. penerbit Djambatan, Jakarta.

10. Nybakken, J.W. 2001. Marine biology: an ecological approach (Vol. 5). San Francisco: Benjamin Cummings.

11. Odum, E.P. 1971. Fundamental of Ecology. W.E. Sounders, Philadelphia: 574 pp.

12. Suzuki, Y. 1998. Preliminary studies of locomotion and burrowing by juvenile boring clam, Tridacna crocea. Naga, The ICLARM Quarterly, 21 (1):31-35.

13. Wells, S. 1997. Giant clams: Status, Trade and Mariculture, and the Roles of CITES Management. IUCN, Gland, Switzerland and Cambridge, UK.77 pp.

14. Wilhm, J. And L. Doris. 1986. Biological indicators of pollution, in B.A Whitton (Ed) River Ecologi Blackwell Scientifice Publication, Oxpord. London

15. Yonge, C.M. 1936. Mode of life, feeding, digestion, and symbiosis with zooxanthellae in the Tridacnidae (pp. 283-321). London: British Museum.

16. Yusuf, C., Ambariyanto, and R. Hartati. 2009. Abundance of Tridacna (Family Tridacnidae) at Seribu Islands and Manado Waters, Indonesia. Jurnal IImu Kelautan Universitas Diponegoro (UNDIP). Semarang, 14 (3):150-154. 


\section{ABOUT JOURNAL}

Russian Journal of Agricultural and Socio-Economic Sciences (ISSN 2226-1184) is an interdisciplinary open access journal of agriculture and socio-economic studies. Topical coverage includes: agriculture and rural development, agricultural economics, management, agribusiness, agrarian policy, information systems, social economy and rural sociology.

The electronic publication is registered by the Federal Service for Supervision of Communications and Mass Media of Russian Federation. Registration certificate EI No. FS 77-51446 of October 19, 2012.

Since December 1, 2015 RJOAS is considered to be included in the List of peer-reviewed scientific publications in which should be published basic scientific results of dissertations for the degree of Candidate of Science, for the degree of Doctor of Science (http://vak.ed.gov.ru/87) by the Order of the Ministry of Education and Science of the Russian Federation on July 25, 2014 №793, as amended by the Order of the Ministry of Education and Science of the Russian Federation on June 3, 2015 № 560 (registered by the Ministry of Justice of the Russian Federation on August 25, 2014, registration number 33863).

\section{Editor-in-Chief:}

- Researcher, Candidate of Agricultural Sciences Sergey Plygun (All-Russian Research Institute of Phytopathology, http://www.vniif.ru, Moscow Region, Russia).

Editorial Board:

- Scientific officer, Doctor in biology Andrei Orlinski (European and Mediterranean Plant Protection Organization (EPPO/OEPP), http://www.eppo.int, Paris, France);

- Prof. Dr. Wilhelm Windisch (TUM Technische Universitat Munchen, http://lte.wzw.tum.de, Freising, Germany);

- Professor, Dr. Sait Engindeniz (Ege University, http://www.ege.edu.tr, Bornova-Izmir, Turkey);

- Professor, Russian Federation Honored Scientist Vasily Lobkov (Orel State Agrarian University, http://www.orelsau.ru, Orel, Russia);

- Professor, Russian Federation Honored Scienitist Anatoly Stifeev (Kursk State Agricultural Academy, http://www.kgsha.ru, Kursk, Russia);

- Professor Yuri Kirichenko (Moscow State Mining University, http://www.msmu.ru, Moscow, Russia);

- Professor Nikolai Pimenov (Moscow State Academy of Veterinary Medicine and Biotechnology named after K.I. Skryabin, http://www.mgavm.ru, Moscow, Russia);

- Dr. Vikash Pratap Singh Bhadauria (Eshan college of Engineering, http://www.eshancollege.com, 28-B Ramchandra Puri, India);

- Dr. Rab Nawaz Lodhi (Institute of Business and Management, University of Engineering and Technology, http://www.uet.edu.pk, Sahiwal, Pakistan);

- Researcher Mohammad Ali Shariati (Islamic Azad University, http://www.azad.ac.ir, Tehran, Iran);

- Researcher Alexey Glinushkin (All-Russian Research Institute of Phytopathology, http://www.vniif.ru, Moscow Region, Russia);

- Researcher Andrey Polukhin (All-Russian Research Institute of Agricultural Economics, http://www.vniiesh.ru, Moscow, Russia);

- Associate Professor Igor Podkovyrov (Volgograd State Agricultural Academy, http://www.volgau.com, Volgograd, Russia);

- Associate Professor Dmitry Neuymin (Michurinsk State Agrarian University, http://www.mgau.ru, Michurinsk, Russia);

- Associate Professor Tatiana Sabetova (Voronezh State Agrarian University named after Peter the Great, http://www.vsau.ru, Voronezh, Russia).

Official sites: http://www.rjoas.com, http://www.rjoas.ru

Current indexing includes: AGRIS (International Information System for the Agricultural Sciences and Technology); DOAJ (Directory of Open Access Journals); CAB Abstracts; Open Access Infrastructure for Research in Europe (OpenAIRE); Research Papers in Economics (RePEc); Bielefeld Academic Search Engine (BASE); EBSCOhost; AgroKnow Stem; OCLC WorldCat; Russian Science Citation Index; Cyberleninka; ELS of Publishing House "Lan"; ELS of Publishing House "InfraM"; ELS "IPRbooks"; GlobalF5; SocioNet. 
OPEN

ACCESS 


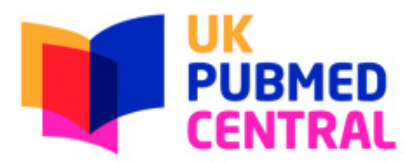
ukpmc.ac.uk
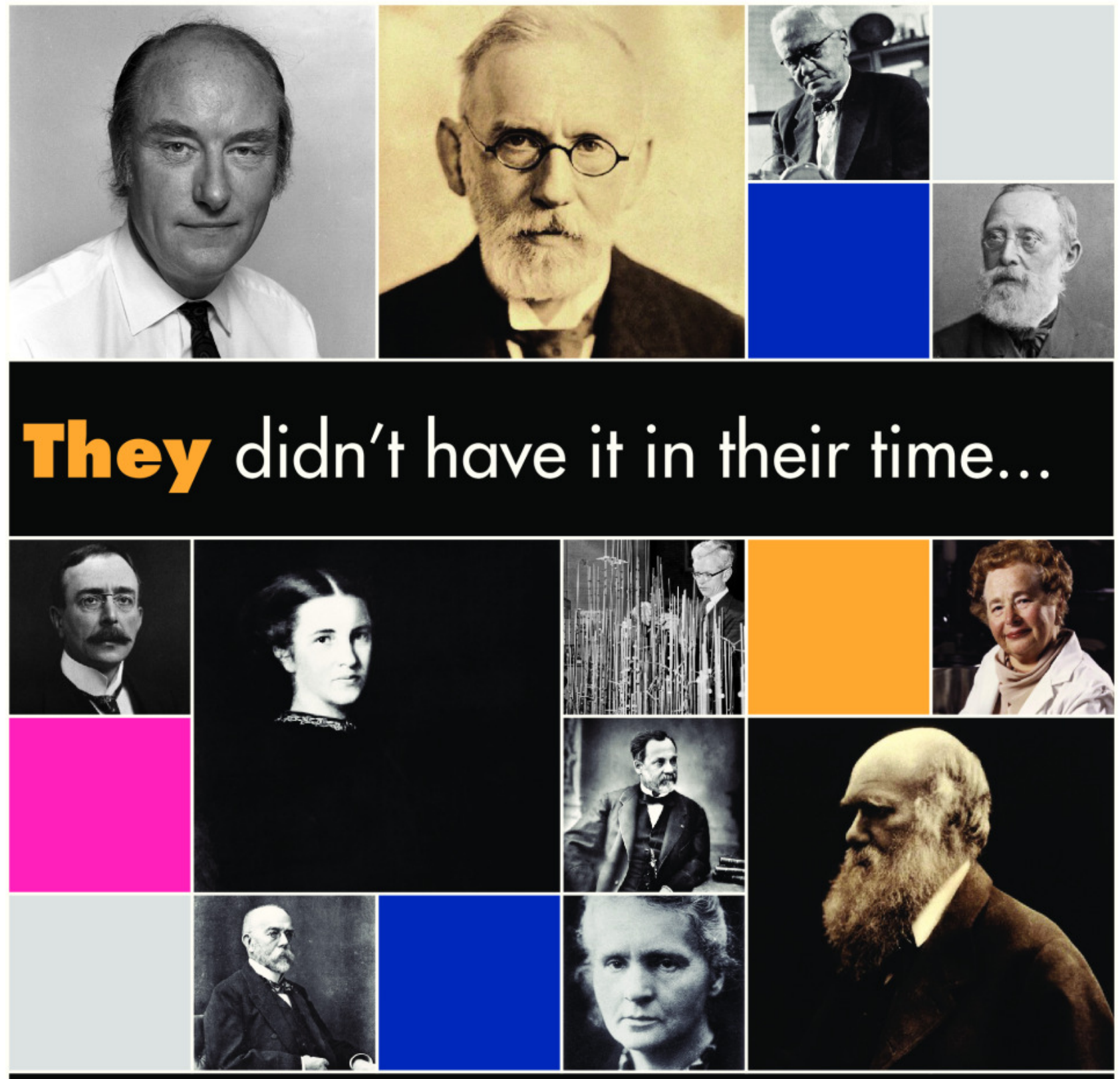

...imagine what y०u could achieve with it now

Images of Francis Crick and John Kendrew courtesy of MRC Loboratory of Molecular Biology. All other images courtesy of Wellcome Library, London

\section{UK PubMed Central}

A unique, free, information resource for biomedical and health researchers ukpmc.ac.uk

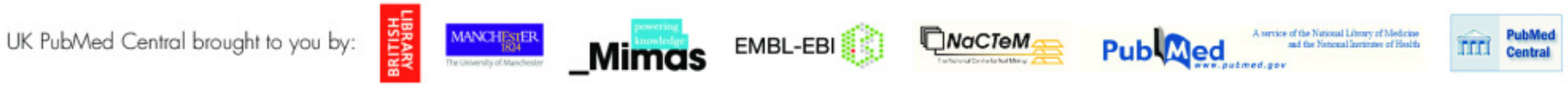

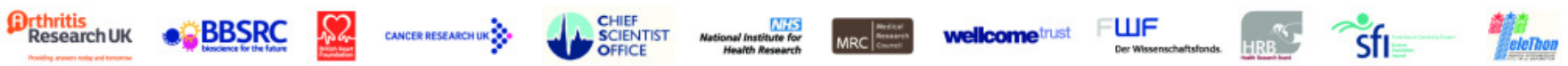

